

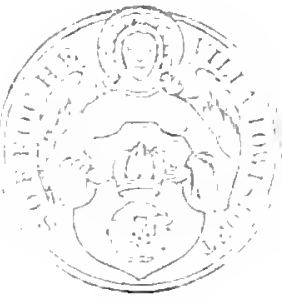

Borongh of Comestort

PUBIIC LIBRARY

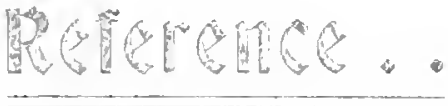

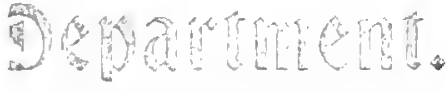


This Volume is presented by the Lords Commissioners of His Majesty's Treasury

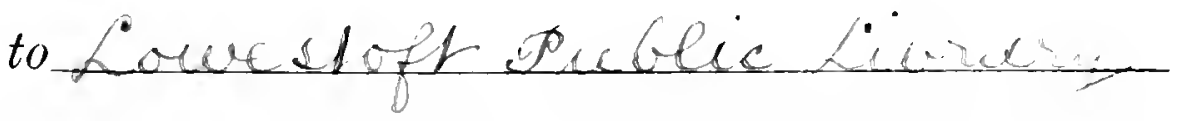
and will, in the event of the Library being broken up, be returned to the Controller of His Majesty's Stationery Office, Westminster. 
Wido

myln.

310
12 
CHRONICLES AND MEMORIALS OF GREA'T BRITAIN AND IRELAND

DURING

\section{T'HE MIDDLE AGES。}





\title{
THE CHRONICLES AND MEMORIALS
}

\author{
$\mathrm{OF}$
}

\section{GREAT BRITAIN AND IRELAND}

DURING THE MIDDLE AGES.

ON the 26th of January 1857, the Master of the Rolls submitted to the Treasury a proposal for the publication of materials for the History of this Country from the Invasion of the Romans to the Reign of Henry VIII.

The Master of the Rolls suggested that these materials should be selected for publication under competent editors without reference to periodical or chronological arrangement, without mutilation or abrilgment, preference being given, in the first instance, to such materials as were most scarce and valuable.

He proposed that each chronicle or historical document to be edited should be treated in the same way as if the editor were engaged on an Editio Princeps; and for this purpose the most correct text should be formed from an accurate collation of the best MSS.

To render the work more generally useful, the Master of the Rolls suggested that the editor should give an account of the MSS. employed by him, of their age and their peculiarities; that he should add to the work a brief account of the life and times of the author, and any remarks necessary to explain the chronology; but no other note or comment was to be allowed, except what might be necessary to establish the correctness of the text. 
The works to be published in octavo, separately, as they were finished; the whole responsibility of the task resting upon the editors, who were to be chosen by the Master of the Rolls with the sanction of the Treasury.

The Lords of Her Majesty's Treasury, after a careful consideration of the subject, expressed their opinion in a Treasury Minute, dated February 9, 1857, that the plan reconimended by the Master of the Rolls "was well calculated for the accomplishment of this important national object, in an effectual and satisfactory manner, within a reasonable time, and provided proper attention be paid to economy, in making the detailed arrangements, without unnecessary expense."

They expressed their approbation of the proposal that each chronicle and historical document should be edited in such a manner as to represent with all possible correctness the text of each writer, derived from a collation of the best MSS., and that no notes should be added, except, such as were illustrative of the various readings. They suggested, however, that the preface to each work should contain, in addition to the particulars proposed by the Master of the Rolls, a biographical account of the author, so far as authentic materials existed for that purpose, and an estimate of his historical credibility and value.

Rolls House,

December 1857. 


\title{
LETTERS AND PAPERS
}

\author{
illustrative of tile:
}

REIGNS OF RICIIARD III. AND HENRY VII. 

Nand 

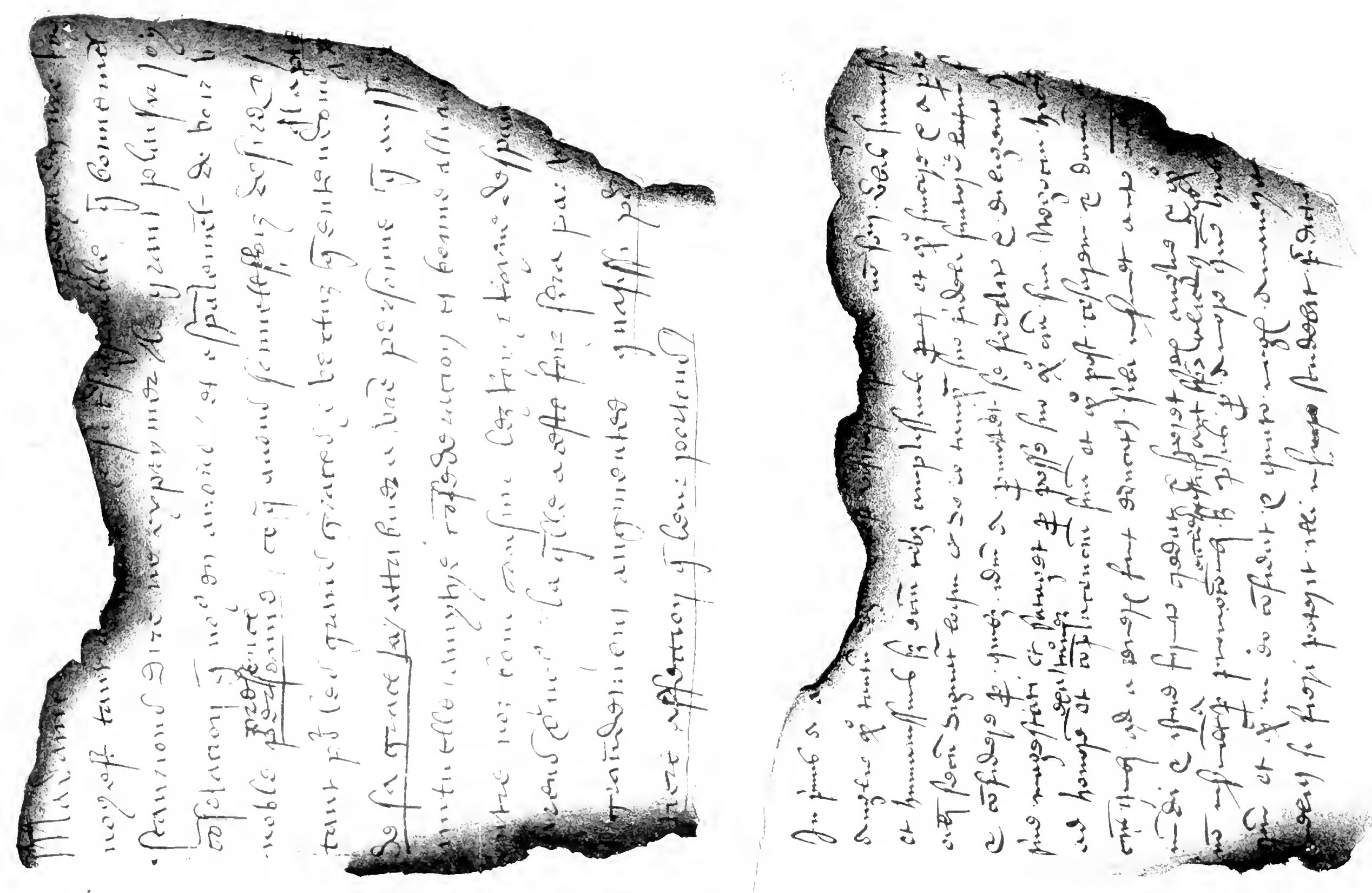


\title{
LETTERS AND PAPERS
}

\author{
ILLUSTRATITE: OT \\ THE REIGS \\ OF \\ E D ITE D \\ LY \\ J A IES GAIRDNER.
}

PUDLISIED BY THE AUTHORTY OF TIHE LORDS COMMISSIONERS OF HER MAESTY' TREASURY, UNDER THE DIRECTION OH THE MIASTER OF THE ROLIS.

$$
\text { VOL. I. }
$$

$$
\text { LONDON : }
$$

LONGMAN, GREEN, LONGMAN, AND ROBER'IS

1501. 
Printcel by

GYRe anl SPOTIISWOODE, Her IIajesty's Printel's, For Her Majesty's Stationcry Office. 


\section{TABLE OF CONTENTS.}

Preface
Chronologichl Sumidiy





\section{PREFACE.}





\section{PREFACE.}

In the Preface to a former Volume of this Series, Special imthe Editor had occasion to speak of the extreme paucity portance of and meagreness of contemporary narratives of the reign where of Henry VII. The information derived from these torical maamounts to little more than a mere outline of events, terials are and requires in a peculiar degree the collateral light of documents. It appeared, therefore, to be an object of some importance to collect in one publication whatever fragments of unedited correspondence the period might be found to yield.

Such materials are for the most part unknown, Difficulty and where known are not easily consulted. Im- of knowing portant original letters have lain buried among the sulting confused and long neglected stores of the Chapter House at Westminster; others, no less important, have been turned into mere shreds and fragments, if not totally destroyed, by the disastrous fire in the Cottonian Library; others have been, too evidently, separated at times from the collections to which they originally belonged, to enrich private libraries and, in the course of time, to be sold at auctions as curious autographs. There is no clue to their lurking places, even where they are most accessible. In the best known collection of all, that of Sir Robert Cotton, things are heaped together with little or no arrangement, and many important papers, imperfectly or inaccurately catalogued, are certain to escape the diligence of the most studious inquirer. 
'Their places of deposit.

Documents, such as we should call State papers, were in early times preserved in the treasury of the Exchequer. Of those which were once kept there a large number of the most interesting are now in the Cottonian library. But the great bulk is still in the original collection, till lately kept in the Chapter House at Westminster, and now in the General Repository of the Public Records. The principal contents of this volume relating to the reign of Henry VII., are de rived from these two sources.

For the age preceding Henry VII. this country does not afford any great store of similar materials; but there is a very valuable register of the correspondence of Richard III., from which hitherto only extracts and single letters have been printed. By transcribing this so far as it has not been published, we lave been able to bring together papers both of Richard III. and Henry VII., in which it will be seen that the historic interest of the two reigns is inseparable. For though the battle of Bosworth, which placed Henry on the throne, is one of the most marked eras in English history, the events which immediately led to it, and have a most important bearing on the whole of Henry's reign, date from the death of Edward IV.

Insecurity The chief point illustrated by the papers here colof the lected,--the great fact that pervades nearly every one shown by of them, is the insecurity of the throne, both in letters of the period. Richard's time and in Henry's. This may perhaps be attributed to the circumstance that neither of these sovereigns had a legitimate right; but in truth it was hard to tell in that age wherein legitimate right consisted. According to the view which posterity has sanctioned, such right did not belong originally to the house of Lancaster, and if it had accrued to them by long possession, it was finally lost by weakness and misgovernment. It might be thought to have rested with the house of York, but it was forfeited by internal dissension, cruelty, and usurpation. Much certainly was 
done to establish it by the union of the two dynasties, but for some time that union was precarious, and not altogether free from objection. Divine right had not yet been invented to tell men where allegiance was due. It could not have been recognized in such an age.

In truth, this celebrated doctrine has scarcely had Different justice done to its historical significance. Its extrava- which regance has been made the theme of well merited satire gulated the by many great writers, and it is now so generally indifferent viewed as an exploded alosurdity that it may seem ages. strange to speak of it as an abiding eonstitutional truth. Yet such it undoubtedly is, and the principle, though no longer spoken of by name, is practieally operative still. By a modified theory of divine right the king never dies, nor requires his Parliament to ratify his title. It was otherwise in early times. Before the 17th century we look in vain for anything like that clear recognition of a definite hereditary principle which governs the sueeession in our own days. Under the old Saxon and Norman kings, when the throne fell vacant, the power of nominating a suceessor was exereised by the witan or lords of the couneil. But the English respect for birth, proceeding from a strong belief in the virtue of blood and lineage, which practically limited the elective principle, operated gradually to weaken and annul it. In the days of the later Plantagenets the erown was clearly looked upon as an inheritance, but the question from whom it was derived oceasioned eivil war. Under the Tudors it was anxionsly sought to establish a clear principle, but in vain; the many marriages of Henry VIII. served only to eomplicate the difficulty whieh, it seems, they were intended to remove. A Protestant faction attempted to prevent the suecession of Mary; the Jesuits thought the title of Elizabeth indefensible. Some conceived that Mary queen of Seots was the rightful queen of England. Some expected on the death of Elizabeth 
a bloody competition for the crown. ${ }^{1}$ Conspiracies to dethrone that queen produced a strong popular reaction, and a sanctity was ascribed to royalty which it had never known before. The rights of the crown must be above all question, whether of pope or parliament. James I. succeeded accordingly by divine right alone; there was no other principle on which his claim could be vindicated. His succession was in distinct opposition to more than one Act of Parliament, ${ }^{2}$ but there

1 In 1594, nine years before James's Accession, Parsons the Jesuit published " $\Lambda$ Conference " about the next succession to the

"Crown of Ingland." In this work he entered very minutely into the history of the succession, and pointed ont the claims which might be advaneed on the death of Nlizabeth by many different families descended from Edward III., claims which there was some danger might even be disputed with bloodshed. Owing to various acts of bastardy, attainders, and other statutes, the question of law was extremely perplexing. Parsons himself, after reviewing the arguments for and against each possible competitor, comes to no definite conclusion. When the question came to be decided the practical good sense of the nation at once adopted a principle which cleared it of all legal subtleties.

2 In fact, the legislation upon the subject had overshot the mark, and tended rather to increase than to diminish uncertainty. On the fall of Anne Boleyn, a flaw was discovered in her marriage with Henry VIII., so that Elizabeth was declared illegitimate, as Mary had been before. Parliament, there- fore, in 1536 , limited the succession to such legitimate issue as the king should have by Jane Seymom or any other ; and in defiult of such issne gave IIenry himself power to dispose of the crown by will (Stat. 28 Men. VIII, c. 7.) $\Lambda$ few years later, when it appeared evident that Henry wonld leave no legitimate issne except Fdward, he obtained the concurrence of parliament (Stat. 35 Hen. VIII., c. 1), to an arrangement that if Edward should die without issue, Mary should succeed, and if she died without issue, Elizabeth. And in the contingency which actually happened of Elizabeth also dying without issne, it was again enacted that the descent should be as Henry should think fit to order in his will. It was a strong proof of confidence in the king, but a bad precedent, especially as it encouraged Edward VI. to think he, too, might will away the crown, even without an Act of Parliament, which was the occasion of very sad events. However, by the Statute Henry's will was law, and Henry willed that on his son and his two daughters all dying without issue, the crown should go to the descendants of his younger 
could be no roubt it was for the peace of England. Haply would it have lieen for this combry if the new doctrine could lave been at once accepted in the sime moderate form in which it is accepted now. We need not recall further how sadly it was mistaken,--how civil war again broke loose,-how royalty erred and suffered, and a new dymastic rivalry was created. Thank God, all these controversies have long been ended, anr are not be revived.

The politic rule of the Tudors generally, and of Doubts reHenry VIT. in particular, did much to secure for garding it Fingland the blessings of domestic peace In the latter VII.'stime. part of Henry's reign we find men debating the ehances of the succession in a manner which shows that even then the true principle of descent had not been sufficiently determined. "It is not long sithens," said Sir" Hugh Conway, "his highmess was sick, and lay then " in his manor of Wamstead. It happened the same " time me to be amongst many great personages, the "which fell into conmmnication of the king's grace, "and of the world that should be after him if his "grace happened to depart. Then, he said, that some " of them spoke of my lord of Buckingham, saying" "that he was a noble man and would be a royal "ruler. Other-there were that spake, he said, in like " wise of your traitor Edmund De la Pole, but none of "them, he said, that spake of my lord prince." I It would appear that those personal qualities which com-

sister Mary, passing over those of his elder sister Margaret Queen of Scots, from whom James 1. was deseended. This arrangement was confirmed by another atet on the succession of Flizabeth (Sitat. 1., Eliz. c. 3), and moquestionably during tle greater part of Elizalbeth's reign there was no desire for a stewart's suecessiom. Tt might have been questioned, also, whether James was not excluded by the Sitatute 17 Eliz. c. 1., which enacted that any attempt against the Cueen in behalf of one who mignt have a juspective title to the Crown, barred the pretendere's claim for ever after.

$$
1 \text { lage es:3. }
$$


mand the respect of the multitude might tempt any nobleman of the blood royal to aspire to the crown. The father of the duke of Buckingham above mentioned did so and suffered for it in the reign of Richard III. ; he himself did so and suffered for it in the reign of Henry VIII. ; and the great dramatist who has made every one familiar with the story of his arrest and execution, paints also the sympathy of the populace with his fallen greatness, and makes the king himself bear witness to his personal accomplishments. ${ }^{2}$

Harl, MS. The register of Richard III.'s correspondence, of which 433. mention las been made above, is contained in MS. 433 of the Harleian Collection in the British Museum. The volume appears to have been a docket book kept by Russell, bishop of Lincoln, of all the letters and documents that passed through his hands in his official capacity as Chancellor during the reigns of Edward V. and Richard III. It may be considered as divided into two sections. The larger consists of copies or minutes of formal documents, such as the grants and warrants which passed the Great Seal, the Privy Seal, or the king's Signet; the other is a letter book, containing copies of the correspondence of Richard with foreign sovereigns, instructions to ambassador's, proclamations, and other papers relating to affairs of state. It is from this latter portion only that our gleanings have been made.

The historical importance of such a MS. requires no comment. The volume is well known and has been often referred to by historical writers, though few of the entries have hitherto been printed entire. It is said to have belonged to the great lord Burleigh ; at a later period it was the property of Strype. It is

\footnotetext{
1 By his own confession to Mor- I have no doubt his rebellion was ton, though his subsequent rebellion aninated by that hope only. was ostensibly in favour of Rich- " Shakespeare's Henry VIII., Act mond, he at first entertained a hope i., Scene ii. of obtaining the crown himself.
} 
described by Wanley in the Marleian Catalogue at much greater length than any other MS. of the collection. Several of the letteis it contains will be found in Rymer; some in Ellis, and other more recent publications. Mr. Nichols has edited for the Camden Society such of its contents as belong to the Reign of Edward $V$. But many of the most important papers of Richard the Third's time have not been printed till now, some having apparently escaped notice altogether. The interest of No. xii. especially is so peculiar that there can be no donbt the French hand in which it is written has been the only cause why it has not been quoted.

None of the entries in the second or letter-book part of the volume belong to the reign of Edward $V$. The earliest in the first part is dated 5th of May 148.3, the day after that young king's arrival in London. About that time or shortly after, Russell was appointed Chancellor: For nine years previously he had been keeper of the Privy Seal, and he is mentioned in More's History of Richard III. as "a wise man and " a good, and of much experience, and one of the " best learned men, undoubtedly, that England had in " his time." It is important in many respects that the character of Richard's chancellor' is vouched for on such good anthority.

On1 volume commenees with an account, derived Funeral of from a MS. in the Herald's College, of the funcral Edward rites of Edward the Fourth. It is characteristic of the olden time that pageants were so minutely and cirefully recorded, while events of such awful moment as the coup d'état of the 13th of Jume, when the Protector suddenly ordered Hastings to the block, the excentions of Rivers, Vaughan, and Grey, the usupation of Richard III., and the death of his nephews, are so slightly noticed in contemporary letters and narratives, that doubts have been raised as to every eiremmstance comnected with them. Yat wo cament comsider this she 
so much to any general indifference to crime, as to the high importance then attached to whatever was visible and tangible. Pageants were not only regarded with an interest as mere shows for which the world has now grown too old, but were in themselves afiairs of state of some importance. It must also be considered that the act of writing was not then so natural and spontaneous as it is with us. Private letters in the fifteenth century were almost always of a business character, and when the minds of men were strongly excited their hands were acenstomed to wield heavier weapons than goose quills.' A pageant on the other hand, was essentially a peaceful exhilition. It was arrangerl lofwehand to the smallest detail,-it could be observed minutely and chronicled with accuracy.

In this case we have a complete muster roll of the lords and gentlemen of rank who were in London at the time of Edward the Fonth's death. The principal actors in the events which followed wore all absent,-Glocester, Buckingham, Rivers, and the young king limself; but there was a large attendance both of the old and new nobility. The blond relations of Edward's queen-the marquis of Dorset, Sir Richard and Sir Edward Woodrille, met in peace over the grave of Edward with Hastings, Stanley, and the Earl of Lincoln. In less than fou weeks the marquis and the Woodvilies were declared encmies of the Government, and ships were fitted ont to take Sir Erlwand at sea. ${ }^{2}$

\footnotetext{
1 Thus simon Stalworthe in one of his shont leteres to Sir William Stonor (Excerptal Historica, p. 26) mentions the general distrust that prevailed after the cxecution of Hastings, and says that a linge body of new from the North was expected in London, adds that he" is " so sick" (apparently fiom race
}

agitation) "he ean hardly lold a "pen." Under the pressure of danger nien now write letters of considerable length, as was hown by the correspondence during the Crinean wir.

"Nichols' Grants of Raward Y. p]. 2., :3. 
Another contemporary accomt of this linneral is to be foumd in the MS. jommals of Roger Machado, also in the Herald's Colloge (Arundel MS. 51.) It is written in French, is imperfect at the beginning, and not so minute in its detirils, but so far as it goes, agrees pretty closely with that which we have printed. The conchusion of the ceremony, which the latter omitis to relate, is worthy of notice.

"Alter the said noble king was thus placed in the ground the mreat oflicers of his noble house, to wit, the great steward, the chamberlinin, the treasurer of lis noble household, the controller, threw all their staves into the grave of the king in token of being men without a master, and ont of their offices. And in like manner all the heralds threw their coats of arms, which belonged to the king, into the saicl grave; and immediately there were remlered to the said heralds other coats of arms of the kings of England, which they put on. And after the said coats of arms were given them they all cried "If rey est rif! Le roy est vif"! " Le roy cost rif!" Praying to God ; and saying Pater noster, and Are Maria, for the defunct."

Of the three short months of violence and terror Circumwhich compose the reign of Edward the Fifth, our $\begin{aligned} & \text { stances } \\ & \text { connceted }\end{aligned}$ letters and paper's give us no further intelligence. with the All such materials connected with that period have of Richard been alpeady printed either in Drake's Ehoracum, Davis' III. York Records, the Priston Letters, or Mr. Nichols' Grants of Edward V. Mr. Nichols' Historical Introduction eontains some importint remarks in correction of Lingard and Sharon Turner, which show how difficult it is to avoid lash assmuptions in daling with this obscure portion of om history. It is my desire in these pages to wroid as far as possible, making statenents, the truth of which is open to controversy, but one important tiact relating to the accession of Richard III. appeas to ne to have been misund astood even by Mr. Nichols. It is known that writs were sent ont on the 13th of May for a Parliament to meet on the 25th of June. On the 2lst of June, however, a wit of supersedeces wats received in the City of York to prevent its assembling; and Mr. Nichols considers that the Parlia- 
ment did not actually meet, a fact which he says is further declared in the act of settlement of the first year of Richard III. Now the words of that Act do indeed declare that there was no true and legal parliament, but they appear no less distinctly to show that there was the semblance of such a thing. In plain ordinary language the parliament really did meet, but the meeting was an informal one, and what was done was of doubtful validity until confirmed by a parliament regularly assembled. Parliament did meet, and the petition to Richard to assume the Crown was presented by a deputation of the lords and commons of England, accompanied by another from the City of London, on the very day ${ }^{1}$ that had been originally appointed for its meeting: The previous issuing of the supersedeas to some of the boroughs may, perhaps, account for the informality. That act may, as likely as not, have been the work of Richard's enemies; the portion of the council which met at the Tower, while Richard and his friends held meetings at Crosby's Place.

\footnotetext{
1 Sir Thomas MIore's History of Richard III. (which, there is reason to believe, is a translation of a work of Morton), though it speaks slightingly of the whole affair, fixes the date exactly. Dr. Shaw's celebrated semon at Paul's Cross was on Sunday the $22 d$ June. Buekingham's speecl at the Guildhall, aecording to More, was on the Tuesday following (i.e., the 24th.) "Then he tells us, "on " the morrow after (the 25th) the

" mayor witl all the aldermen and

" chief commoners of the eity in

"their best manner apparelled,

" assembling themselves together,

" resorted unto Baynard's Castle

"where the Protector" lay. To

" which place repaired also the
}

“ duke of Buckingham with divers " noblemen with him besides many " knights and other gentlemen," \&c. 'This 25th of June, as we have said, was the very day originally appointed for parliament to meet. "The next day," we then read, "the Protector with a great " train went to Westminster Hall," \&e. It is true that Riehard himself, in his instruetions to Lord Mountjoy hereafter mentioned, speaks as if the petition was not presented to him till the 26 th, the same day that he took his seat on the throne in Vestminster Hall, and commeneed to reign as king. But here, I have little doubt that More is more accurate. 
This much at least is certain that a speech was prepared for the opening of that Parliament by the Lord Chancellor, which has been printed by Mr. Nichols. The Chancellor expected that the young king was to meet his Parliament in person, and according to custom he grounded his oration upon a text of Scripture. The words occurred in the service of the Nativity of St. John the Baptist, which was the day before the speech was to be delivered; Audite, insulde, et attendite, populi de longe; Dominus ab utero vocavit me ${ }^{1}$ (Isaiah xlix. 1.) The isles, he said, were the lords Spiritual and Temporal. the people from afar were the Commons. God had called the king to rule over them in his tender age. The simile was dwelt upon after the fashion of the times, and apparently with a pointed personal allusion. Islands, although surrounded with water, were themselves firm ground; there was more surety and firmness in them "than in the sea or any great Rivers." The unstable water which surrounded them was the lower people, as St. John said in the Apocalypse (xvii. 15), "The waters which thon sawest are peoples " and nations." There were many important things in which the king required the advice of Parliament to assist his inexperience. His father in his latter days had felt much anxiety on account of the bad faith frequently exhibited by his allies. But it was of chief importance that the authority of the Protector should be confirmed until the ling attained his majority; " among all the causes of the assembling of the Par"liament in this time of the year, this is the greatest " and most necessary first to be affirmed." "

1 "I have taken a trimembered text, such as I found in the divine service of yesterday's feast, the which to my purpose implieth the present estate of our nobles, our commons and of our glorious prince and Fing. Edward V. here present." Niclols' Grants of Iidward V. p. xxxix.

Ih. !. xlix. 
This speech, most probably, was not delivered. When Parliament met it agreed to strengthen Richard's authority, not by confirming him as Protector, but by placing lim upon the throne.

Let us here say what can be said, not to palliate the conduct of Richard III., but to make it intelligible, as far as our knowledge and judgment will permit. In the broad view of liistory which necessarily presents itself to most minds, the murder of his nephews must appear virtually to have been a part of the act of usurpation. In point of time it followed very close, and the natural inference seems to be that it was deliberately planned to give security to a throne so wrongfully acquired. It is not necessary, however, to entertain quite so dark a view. Detestable as the act must be under any aspect, we had rather not regard it as having been cogitated and considered for several weeks before. If it was, it certainly was the reverse of politic, for there can hardly be a doubt that whatever disafiection was previously felt to Richard's cause, gained strength from the moral indignation which that act aroused. However we may be accustomed to regard the celebrated scene in the Guildhall, he was certainly at first supported by more than a few hired retainers of Buckingham; and we may lie tolerably certain that the mere change of sovereigns was not at that time so repugnant to the feolings of Englishmen, as it atterwards appeared when the sernel was divulged. Whether Richard's plea was true that his brother's children wore by law illegitimate, is a question which need not be here discussed; but there had been enough of evil in the minority to reconcile wost men to its termination. The statc of anarchy harl been simply intolerable; London had been kept in a continual ferment with plots and counterplots; and it is certain the spirit of faction was not wholly on Richard's side. 
Two days after his accession Richard sent an impon-Richard's tant message to Calais by Lord Mountjoy. The gall- message to rison there had, on receiving the news of Edwarl the son of Fourth's death, taken an oath of fealty to his son, Calais. declaring that they would lieep the town, castle, and marches for king Edward the Fifth, and not suffer any one to enter with an armed force except the king himself or lord Hastings his lientenant. Shortly afterwards, perhaps after the execution of Hastings, which took place on the 13th of June, lord Dynham wrote from Calais to the duke of Glocester as Protector, desiring an answer to certain questions and petitions from the inhabitants, of which the first related to this oath. In answer Mountjoy, who was soon afterwards appointed lieutenant of Guines, was instrueted to say that as the oath had been taken in ignorance of "the very sure " and true title which our sovereign lord that now is " hath and had the same time to the erown of Eng" land," every true Englishman was bound to disregard it and tender his fealty to the real king, "whose "sure and true title," say the instructions, "is evi" dently showed in a bill of petition which the lords "spiritual and temporal and the commons of this land "solemnly porrected unto the king's highness at Lon"don, the 26th day of June. Whereupon the kingss " said highness, notably assisted by well near all the "lords, spiritual and temporal, of this realm went the "same day unto his palace of Westminster, and there in "sueh royal [estate] honounably appareller, within the "great hall there, took possession and declared his mind " that the same day he would begin to reign upon his " people; and from thence rode solemnly to the cathedral " church of London, and was received there with pro" cessiom, with great eongratulation and acclamation of "all the people in every place and by the way that "the king was in that day." The estinate which a king like Richard the 'Third ehooses to give of his an:n populauity is of course open to suspicion, but the above 
extract manifestly contains some fincts which could not have been misstated.

His rela- We see most of Richard, however, in his relations tions with with foreign powers. A friendly message was received
foreign power's :from Spain, desiring alliance with England against France, and the ambassador gave a singular explanation of the causes which had led queen Isabella before to favour France against England. Edward the Fourth had committed a most unkingly act in making a real love match, and Isabella "was turned in her heart from " England for his refusing of her and taking to his " wife, a widow of England ; for the which cause, also, "was mortal war betwixt him and the earl of War"wick, the which took ever her part to the time of" " his death." Edward IV., however, was now dead; Lewis XI. had broken four principal articles of his treaty with her, and would not allow her to marry her son to the heiress of Navarre. She was, therefore, anxious to renew a good understanding with England. Her ambassador was received by Richard with great magnificence at Warwick. According to Rous, who lived in the neighbourhood, and probably was present on the occrsion, he also brought a proposal for the marriage of Richard's only son with one of the daughters of Ferdinand and Isabella. T'o this we know not what reply was made. To the other overture, Richard retuned a cordial answer, and proposed to renew a league marle with Henry IV. of Castile. But he seems to have had no wish to provoke hostilities with France, and marle no reply to that part of her proposal.

Britanny was at this time offering an asylum to his most dangerous enemies. In July Richard sent thither Dr. Hutton to propose a diet for putting an end to private acts of hostility which had taken place between the subjects of Fngland and the dnchy. The death of Edward IV. had been supposed to put an end to existing treaties, and the commcree between the two countries had suffered in consequence. While anxious 
that things should be put on an amicable footing it is evident that Richard had little confidence in the duke. He proposed that the diet should be in England and nowhere else; and he instructed Hutton to "feel and " understand the mind and disposition of the duke "anempst Sir Edward Woodville and his retinue, "practising by all means to him possible to ensearch " and know if there be intended any enterprise out " of land upon any part of this realm." At the same time he expressed his willingness to satisfy all just claims of the duke's subjects, and promised that an agreement made by the late king for compensation to some Breton merchants should be carried out whenever Edward's will was administered.

In August, just two months after Richard's accession, the duke despatched George de Mainbicr to England in answer to this overture, promising to send ambassador's about the feast of All Saints, after the meeting of the estates of the duchy, to treat on the subject of Hutton's charge. The duke complained much of the depredations of the English, and was anxious to show that for his part he had risked the enmity of France out of friendship to Richard. Henry, earl of Richmond, was then an exile in the duke's dominions. Though afterwards King of England, his claim by mere lineal descent was never of the strongest, and but for the great crime of Richard III. it would not have been even plausible. But, such as they were, even his pretensions might have disquieter the late minority, as they did with better reason the reign of Richard himself. Since the death of Edward IV. Lewis XI. had made repeated applications to the duke to deliver him into his hands, and finding that his demands were not listened to threatezed war. Of course this gave the duke a strong claim to the support of England. Richard was entreated to consider "the great "power of men of war, artillery, and finances which the "said king of France has, and the nearness of the said 
"kingdom to the duchy of Britanny, the two lands " joining together without having between them brork " or river which might hinder the said King of france "firom entering the said duchy of Britanny with all " his power:" The duke asked for 4,000 English archers to be maintained six months at the expense of England, and followed by others if necessary, for whom he would pay himself. Richard sent aid, but not immerliately, nor to the full extent of his demands. On the 26th of June next year, he commissioned lord Grey of Powis to go to Britanny with 1,000 archers, which was probably all the force lhe conld with prudence sparc.

He might, indeed, have found two very fair excuses for refusing the desired assistance altogether. Lewis XI, of whom the duke stood in awe, was actually deal at the date of Mainbier's instructions; and, what still nore completely altered the case, the earl of Richmond in less than two months sailed for Britamy to invade England, aided by money from the duke. Such were the obligations of Richard III. to Britanny.

France. As for France, the few shont letters that had passed been Richard and Lewis XI. in the brief intorval between the accossion of the one and the deatl of the other scarcely enable us to judge what might have been the relations between the two comntries had Lewis lived a little longer. When he died he left his son Charles VIII. a minor under the care of his sister, Madanne de Beanjeu. France was in one respect happier than England had been after the death of Edward IV., for Charles was in his 1 th he year and might soon he reclared out of his minority, while the prospect of a long minority in England, attended with constant intrigues and conspiracies for power, had in all probability done much to favour the usurpation of Richard III. But even in France the manifest lineal right did not silence the pretensions of rival claimants to the throne. Two princes of the 
blond Royal, the duke of Mrleans, afterwards Lewis XII., and the duke of Bombon, came formand to dispute the crown. It was objected to Charles that he was not only a boy, but that his complexion was that of a physically weak boy. As for his sister, the law did not snffer a woman to reign, and it seemed mmeasonable that she should bear the rule.'

The question was referred to the Estates General, which met at Tours in Jannary. The session was opened by the chancellor, Guillamme de Rochefort, in a speed in which he pointedly referred to the parrallet case of England, and urgeal them to take warning hy what had happened there only a few months previously. France, he remakel, with a strange forgetfulness of his country's history, had never been motaithenl to her king, but England had openly sanctionerl usurpation. "See," he said, "what has taken place in that "country since the death of King Edward. Consider. " his children, alrealy tall aud brave, butchered with " impunity, and the erown transferred to the assassin "by the favor of the penple." " The estates came to the deternination that Charles, having attained the age of 14, should be considered out of his minority ; that the lady of Beanjen, however, should still have the are of his person, and that all acts of state shonlit be administered by a comucil of 12 persons. It was a clumsy compromise and proved a firlure. The Conncil of twelve became mere ciphers, and the laty of Beaujen usmped all anthority. The consequence was that the country wass soon involred in civil wal.

'Mezeraร.

" Regariez, je vous prie, les " evenenents qui apres la mort du " roi Elowirl, sont amives dans " ce pays. Contemplez ses enfins.

" dejar grands et braves, mas-

"sereres impnnement, ot is con-

" ronne trausporte at l'assiassin par"

" la divenr des penples."--.. fon des Etats Generaux de France tenus "Tours cn 1483-4, p. 39. It is important to remalk that thi; was said in January 148\%. 'Tlat waslrpation of lichard was in the pineceting Junc, and the nurker of his nephews is holieved to have ment in Alloust. 
We have no correspondence between Richard III. and France after the death of Lewis XI. We only know that his rival Henry, on the failure of his first expedition to England, which was intended to act in concert with Buckingham, returned to Britanny, and when he was about to be delivered up by Britamn, found a refuge in France under the protection of Madame de Beaujeu. Here he matured his plans in safety. Even Calais was not in complete subjection to Richard III. The inmprisoned earl of Oxford prevailed upon James Blount, captain of Hammes, to let him have his liberty, and both repaired to Richmond in France. The castle of Hammes itself held for a time against king Richard. ${ }^{1}$

Contrast A comparison of the reigns of Richard III. and between Henry VII. camnot fail to show us how much the of Richard destinies of a nation may be influenced for good or III. and HenrvVII. evil by the personal character of its sovereign. Their position upon the throne, their relations to their subjects, and to foreign powers, were not materially different. They might both be considered as usurpers; both had to meet rebellions in their own dominions; both had rivals abroad supported by foreign princes. But Richard was the last of a family of soldiers; Henry the beginner of a dynasty of statesmen. The morality of statesmenship in that day was not high, but it was better than the cruelty of brute force and violence, and it secured for itself that supremacy which force and violence had been unable to attain. There was a recklessness in the personal character of the princes of the House of York that might have sufficed to ruin their cause, apart from their internal clivisions, injustice, and ferocity. The Tudor throne had to be

1 A short MS. Chronicle in " was the $\mathrm{xr}$. daie of Decembur, Trinity College, Dublin (E. 1. 26), “ $\Lambda^{\circ}$. Domini $\mathbf{M}^{1}$. iiijc. lxxxiiij." mentions that "the sege of Ham- IIall mentions the circumstance, " mys by king Richard the iijde. but does not give the date. 
supported by the most cautious diplomacy, and by a strict regard for law. For law, generally speaking, as the instrument of justice, but in some cases, undoubtedly, as a means of oppression. The very fact that it was so perverted is a proof of Henry's greatness. That a king, whose title was one of the most ambiguous ever seen in England, who was frequently troubled with rebellion, and placerl on the throne by a successful rebellion himself, should have succeeded in making the authority of law so strong as not only to enable him to put down his enemies, but to become in his hands an engine of extortion, is evidence of Henry's ability as a stateman quite as great as the respect cntertained for him by foreign sovereigns.

Henry's foreign policy was always in farvour of peace. Peaceful No one knew better than he the expedieney of non- walicy of interference in the affairs of other kingdoms, and the advantage of husbanding the resources of a wasted country. Thongh the designs of France against Brittany aroused a strong feeling in England both in favour of an old ally and against an ancient enemy, all the national eagerness for war could not impel him to prosecute it in earnest. He did indeed raise benevolences, cross the sea, and make a short campaign, but Mis French he returned without striking a blow. Having secured campaign. payment from France for the expenses of the expedition, and an annual sum which might be looked upon as tribute, he withdrew his forces and left Brittany to its fate. The old pretensions of our kings to France had never been given up; another king would have attempted to show that the English were still masters there; but Henry knew that it was impracticable, and cared more for policy than glory.

His conduct towards Scotland was a still more re- Iris mole markable instance, not only in itself but in its conse- of dealing quences. In France he preserved a friend, while forced land. to put on the guise of emmity; in Scotland he conciliated an enemy and laid the foundation of an ultimate 
union. He was not less aware than his predecessors of the necessity of having some control over the Northern kingdom, but he adopted a different method to secure it. Instead of raising up a spirit of opposition by the old assertion of feudal sovereignty, he at first made friends within the kingdom itselt to keep the king in check. He bound the Earl of Angus by indenture, under certain circumstances, to make war on James the Founth-that powerful Farl of Angus who had acquired the surname of Bell-the-Cat, by taking the lead among the Scotch nobles in opposition to James III.' He engaged at the same time the attainted lord Bothwell and Sir 'Thomas Todd to seize the person of the King of Scots and his brother and carry them to England. Lord Bothwell was a nseful instrument; though he did not effect that object, he was of great service some years later, when James undertook an invasion in favour of Perkin Warbeck. By him Henry secured the assistance of James's own brother, the Duke of Ross, and of other S'cottish nobles, to throw every obstacle in the way of the expedition. By him he was informed minutely of all the preparations that had been made, - of the Scotch king's peemiary necensities, - of the number of gruns in Edinburgh Castle, - of the place where the Scottish forces were to muster, and the fact that they had but four or five days' provisions, - of the facility with which their retreat might be cut off, and of the excellent opportunity that existed for burning all the navy and seaport towns of Scotland. But Hemy was kinder to Scotland than some of her own sons.

Fox's negotiations.
A few months after the invasion, while Warbeck was yet in Scotland, occirred the most formidable of all the rebellions that tronbled Henry's reign. By some

1 According to Douglas' Perage | covenant with Henry VII. One of Scotland, (I. 43t), he was made year before it he had a licence from high Chancellor of Scotland in Henry to come to Hugland on pil1493, which was two years after his grimage. Scotch Roll, 5 Henry VII. 
mismanagement, the Cornish malcontents were allowed to make their way unopposed to within view of London. They were defeated at Blackheath on the 22nd of June, 1497. Warned by the danger which had thus been averted, Henry, a fortnight afterwards, drew up instructions for Fox to treat for peace with James. The document is an interesting specimen of his wary policy. Terms had already been offered by the Earl of Angus and Lord Hume on the part of Scotland. Henry could not afford to throw away the chance thus offered, but disguised his own anxieties. He selected Fox, probably his ablest minister, to negotiate, and provided him with two separate sets of instructions. The first declared that the offers of Angus and Hume were unsatisfactory, and that peace could not possibly be made without further concessions. Every effort was to be used to induce James to consent to one of two alternatives. In the first place, what Henry would have preferred to everything else, Fox was to insist on the delivery of Perkin Warbeck, on whose account the late invasion of England harl been undertaken; "the which deliverance," the king added, "we " desire not for any estimation that we take of him, " but because our said cousin received him within his " land, and favourably hath entreated him and divers " others of our rebels during the peace concluded be" twixt us both; and over that, having him in his " company, entered in puissance within our land, the "which was the cause and ground of the breach of " the said peace. And less, therefore, may we not do " with our honor than to have the deliverance of him, "though the deliverance or having of him is of no " price nor value." Anticipating opposition here, however, Henry offered, as an alternative, to make peace on the following conditions: first, that James should send an embassy to England; second, that he should come himself to a personal interview there with Henry; third, that he should be bound under ecclesiastical cen- 
sures to the observance of the treaty; and, fourth, that he should make compensation for injuries done in the war, giving hostages for the fulfilment of these conditions. Beyond this, it was to appear that Fox had no further commission; and he had it in his discretion to show his instructions to the Scotch commissioners to give them that impression. The fact was, however, that he was empowered to go much further, and if peace could not be made with the conditions desired by Henry, he was directed by the other set of instructions to accept the offers of Angus and Hume without modification.

Warbeck actually left Scotland the day after the date of Fox's instructions, ${ }^{1}$ so that the question of delivering him up could no longer be entertained. A truce was shortly afterwards concluded, which a few years later was superseded by a permanent peace; and in 1503 James was married to the Princess Margaret. Exactly a hundred years later their descendant James the Sixth of Scotland mounted the English throne. When another hundred years had passed, and four years more, not only the crowns of England and Scotland, but the kingdoms themselves were united.

Ireland. Ireland, too, under Henry VII., almost belongs to the Department of Foreign Affairs. It is, indeed, under English rule, for the governing race acknowledge their allegiance; but it cannot, from the nature of things, be very much under English control. What was remarked by the late Lord Macaulay of India was necessarily true at that time of a country much nearer home. Ireland could only be governed in Ireland in spite of all the efforts made to govern it in England. English laws, English dress, English customs, might be imposed by authority; Kildare might be displaced by Poynings as Lord Deputy, and every act of the Irish legislature might be dictated by the English 
council; but the practical business of government could only be carried on upon the spot. The breadth of St. George's Channel lay between the deputy and his responsibility.

Ireland had all along been more favourable to the House of York than to the Lancastrian line. The Duke of York, father of Edward the Fourth, had large possessions there, and, when sent thither to put down a rebellion in the reign of Henry the Sixth, used his personal influence with such good effect, that he and his family were ever afterwards held in high respect. Even under Edward the Fourth, however, the authority of the crown had once been most outrageously set at nought. The Earl of Kildare had summoned a parliament in defiance of an explicit prohibition from the king, and that parliament had passed acts and levied a subsidy. His son, the eighth earl, succeeded him as Lord Deputy in the later years of Edward IV., and was continued in it by Richard III. A Kildare was not to be removed by a king newly seated on an uneasy throne; but from the very first Henry saw the importance of obtaining some feeble security for his faithfulness. John Estrete was sent to Ireland, almost at the very commencement of this reign, to tell him in answer to a request he had put in to have the deputyship confirmed to him for a term of nine or ten years, that the king was desirous to consult him personally upon the affairs of the country. The king was aware what good service he had rendered to Edward the Fourth, especially after he had been with him in England, and considering his long experience, thought no man more competent to advise him. He

\footnotetext{
1 That his instructions, printed at page 91 , were not given him by Richard III. as supposed in the Catalogue of the Cottonian MSS., is I think sufficiently shown by their
}

general nature, which is much more in accordance with the politic character of Henry than that of Richard. 
therefore desired, not for the first time, that Kildare should repair to his presence before a certain day, promising on his so doing, not only to confirm him in the lieutenancy: but to make him a girant in tail of the manor of Leixlip and the keeping of Wicklow castle. Besides these conditions, the earl had been so bold as to demand written assurances under the seals of the king and some of the nobles for his security while in England. This was declared to be inconsistent with the king's honour, and Kildare was informed that he must content himself with an ordinary protection under the sign manual. The story, whether true or not, of his burning Cashel cathedral, and 1,leading, when called to answer before the council, that he had only done it because the archbishop was inside, gives us a notion of ntter irresponsibility, which is borne out by the most authentic documents. On another occasion when Hemry summoned him to England, he took no notice of the letter for ten months, and at last sent an excuse backed by the lords of the Irish parliament, stating that his presence was so essential to the peace of the country that he could not be spared. ${ }^{1}$

Spain. Of all Henry's foreign alliances the most important was with Spain. He appears from the first to have looked upon it as a country destined to be great, and he was not mistaken. Spain had already somewhat recovered from severe internal struggles, such as had lately desolated England; and the consolidation of power at which Henry aimed had been in part effected by Ferdinand and Isabella. Out of the four Christian kingdoms in the Peninsula, the two most powerful were united by their marriage, and there appeared some hope at length of driving ont the Moors. Scarce

' See Appendix A. p. 377. A $\mid$ mentioned (28 July) being a clerisuspicion that might arise as to the date of the lords' letter (4 June), or of the king's letter therein cal error, is completely removed by Kildare's letter which follows. 
had Henry been three years upon the throne when he began to negotiate for the marriage of his son Arthur with Catherine of Arragon. Though planned when they were both infants, unlike the generality of such projects it took effect when they came of age. It took effect because England and Spain had both grown stronger in the interval. Granada had surrendered to the victorions arms of Ferdinand, and the last embers of discord had been crushed out in England, not without cruelty and injustice, in the execution of the son of Clarence. ${ }^{1}$

For more than a century after the alliance or the emmity of Spain was the leading feature in the foreign politics of England.

The Spanish correspondence in this volume belong's chiefly to the period just before Catherine's arrival in England. It is full of the expression of Henry's desire for the marriage, and his impatience to see it accomplished. That period was the turning point in his reign, when he got out of troubled waters into comparative rest and tranquillity. He was now too strong to be disquieted by impostors employed to work out the designs of others. He was strong with foreign power's, and not less so in the good will of his subjects. The shows and "goodly disguisings" which welcomed Cathe.

${ }^{1}$ Hall says in relation to this, -

" The fame after his death sprung

" that Ferdinand king of Spain

" would never make full conelu-

" sion of the matrimony to be had

" between prince Arthur and the

"Iady Catherine his daughter, nor

" send her into England, as long

" as this earl lived; for he im-

" agined that as long as any earl

" of Warwick lived, that England

" should never be cleansed $\mathrm{Ol}^{\prime}$

" purged of civil war and privy

" sedition." Lord Bacon also mentions a tradition that a long time aftel'wards when Catherine of $\mathrm{Al}^{-}$ragon was first informed of Henry VIII.'s intention to procure a divoree from her, she used some words to the effeet "that she had " not offended; but it was a judg" ment of God, for that her" for" " mer marriage was made in blood, " meaning that of the earl of " Warwick." The importance attached by Ferdinand to the exeeution of Clarence is confirmed by the first paragraph of De Puebla's letter printed at page 113 . 
rine to England reflected truly the happiness of a contented people.

The satisfaction which this great alliance gave the king himself may be judged from the anxiety with which he had so long looked forward to it. Its accomplishment was in every way a joy and trimmph. Parental pride and political ambition were equally gratified; and a pleasing dream might be indulged of a future line of kings descended from a prince named Arthur, peacefully inheriting the claims both of York

Death of Prince Arthur. and Lancaster. Alas! that dream was soon to be dispelled. In proportion as the hope was great, was the disappointment bitter; nor are we without warrant in asserting that Henry's feelings were better than those of a mere politician. An unknown but contemporary writer has left us this touching record of the manner in which he and his queen received the heavy blow.

"In the year of our Lord God 1502, the second day of April, in the castle of Ludlow, decensed Prince Arthur, first begotten son of Our Sovereign Lord King Henry the Seventh, and in the 17 th year of his reign. Immediately after his death Sir Richard Poole, his chamberlain, with other of his colmeil, wrote and sent letters to the king and comneil at Greenwich, where his grace and the queen then was, and certified him of the prince's departure. 'The which council disereetly sent for' the king's ghostly father, a friar Observant, to whom they showed these most sorrowful and heavy tidings, and desired him in his best manner to show it to the king. He in the morning of the Tuesday following, somewhat before the time acenstomed, knocked at the king's ehamber-door; and when the king understood it was his confessor', he commanded to let him in. The confessor then commanded all those present to avoid, and after due salutation begau to say, Si bona de manu Dei suscipimus, mala urtem quare non sustineamus? and so showed his grace, that his dearest son was departed to God. When his grace understood that sorrowful heary tidings, he sent for the queen, saying that he and his queen would take the painful sorrows together. And after that she was come and saw the king her lord, and that natural and painful sorrow, as I have heard say, she with full great and constant comfortable words besonght his grace, that he would, first after God, re. 
member the weal of his own noble person, the comfort of his realm and of her. She then said that my lady, his mother, had never no more children but him only, and that God, by his grace, had ever preserved him, and brought him where that he was. Over that, how that God had left him yet a fair prinee, two fair princesses; and that God is where he was, and we aro both young enough; and that the prudence and wisdom of his grace spliung over all Christendom, so that it shonld please him to take this accordingly theremto. Then the king thanked her of her good comfort. After that she was departed and come to her own chamber, natural and motherly remembrance of that great loss smote her so sorrowfully to the heart that those that were abont her were fain to send for the king to comfort her. Then his grace of true, gentle, and faithful love, in good haste came and relieved her, and showed her how wise comeil she had given him before; and he for his part would thank God for his son, and would she do in likewise." 1

At this time, though there were no more distu1bances from impostors, attempts in favour of the House of York were not altogether at an end. The story of the earl of Suffolk has hitherto been very imperfectly told, and cannot be fully read without the aid of papers which are here for the first time published We will therefore relate it, as it appears in these documents and in other sources, as briefly as possible.

When Richard III. lost his only son in March, 1484, The Sufhe declared his nephew, the earl of Lincoln, son of folk family. John, duke of Suffolk, his suceessor in the kingdom. He at the same time arranged a mariage for Anne De la Pole, a danghter of the same house, with the duke of Rothesay, heir apparent of the Seottish throne But these projects for the elevation of the family vanished on Richard's death, and the disappointment was not unfelt by the younger members. Suffolk himself, not being of the blood royal, did not provoke the jealousy of Henry VII, but was a loyal subject all his days. He was appointed to bear the new king's sceptre at the coronation, and treated with every mark of confi-

${ }^{1}$ Leland's Collectanea, 'ง. 373-4. 
dence. Even his sons for a time retained their allegiance, and when in the spring of 1486 , lord Lovel took up arms against Henry, the earl of Lincoln repaired to the king at York. Next year, however, Lincoln revolted, and it became at onee apparent that he had not altogether abandoned his prospects in regard to the succession. He was present at "a great council" summoned by Henry at Sheen in the beginning of the year to meet an embassy which had arrived from France. Immediately after, he secretly left the country, and joined lord Lovel and the other adherents of the House of York in Flander's. Simnel was then in Ireland, enacting the character of the earl of Warwick, and laying claim to the crown as the son of Clarence. Lineoln had seen the earl of Warwick at Sheen just before his departure, but he did not seruple to declare Simnel to be the real earl pursuing his just right. He joined the mock king in Ireland, accompanied him into England, and perished at the battle of Stoke, fighting in the canse of one whom he knew very well to be an impostor. An act of attainder, of course, passed against him, so that his lands could not de. scend to his younger brothers; and his father died in 1491, of grief, it is said, for the ruin of his family.

Edmund His brother Edmund, however, did not allow his de la Pole. hopes to be dashed by adverse fortume, an impoverished patrimony or a family disgrace. $\mathrm{He}$ is described as a man of violent temper, rash, and headstrong. His letters certainly give us the impression of a rude and careless writer: Their spelling is anomalous and unintelligible far beyond the ordinary even of illiterate men in those days, and the landwriting is sprawling and irrescular to mateh. It is true that the earliest notice found of him, when he was a student at Oxford, speaks of his "penetrating, eloquent, and brilliant genius ;"1

\footnotetext{
${ }^{1}$ Napier's Historical Notes of the Parishes of Swyncombc and Ewelme, p. 162.
} 
but it must be understood that this was in a letter addressed by the university to his uncle king Edward the Fourth. On his father's death he succeeded to the dukedom of Suffolk; but the family estate being reduced by his brother's attainder, he made a compromise with the king to content himself with the dignity of an earl on the restoration of it portion of the confiscated lands. $\mathrm{He}$ continued in favour for some years. In $149 \mathrm{t}$ he took a leading part in the tournament at the creation of prince Henry as duke of York, and gained one of the prizes for the second day's achievements. Next year he received the king under his own roof at Ewelme. Soon after, he was made a knight of the garter, and on St. George's day, in 1499, he was present at a chapter of that order. ' It must have been very shortly after this that he first manifested disaffection.

All that has hitherto been known of the story of His revolt his revolt is derived from Polydore Virgil and his as related translator Hall. Thongh in some respects inaccurate, we cannot relate the leading facts of it better than in the words of the latter.

"A few months before the marriage of Prince Arthur, Edmund Pole, earl of Suffolk, son to John duke of Suffolk and lady Elizabeth, sister to king Edward the Fourth, being stout and bold of courage, and of wit rash and heady, was indicted of homicide and murder, for slaying of a mean person in his rage and fury. And atthough the king pardoned him whom he might justly have eondemned for that offence, yet, because he was brought to the King's Bench bar and arraigned (which fact he reputed to be a great maim and blemish to his honor), took it seriously, and shortly ifter for his displeasure fled to Flanders, without any licence or safe conduct given him of the king, to the lady Margaret, his aunt on the mother's side. Nevertheless, whether he was stirred by his privy friends or moved by the king, or whether he, trusting on his unviolated truth, feared no danger nor penalty; he returned again, and excused himself so to the king that he

${ }^{1}$ Napier's Swyncombe and Ewelme, p. 168. 
was thought to be guiltless and inculpable of any crime that could be objected to him, and therefore he was permitted to go frankly at his liberty and pleasure.

"But when this marriage of prince Arthur was kept at London with great pomp and solemnity, and that all the nobility were set on pleasure and solace, and that the king himself was principally given to joy and rejoicing, this Edmund, either for that he had been at great and excessive charges at the same triumpl and solemmity, and by reason thereof sore charged with debt,-either solicited, allured, and provoked by that old venomons serpent the duchess of Burgoyn, ever being the sower of sedition and hegimner of rebellion against the king of England, - or else stimulate and pricked with enry, which could not patiently with open eyes see and benold king Henry, being of the adverse line to his lineage, so long to reign in wealth and fclicity,-in conclusion, with his brother Richard, fled again into Flanders. This sad chance, I think, happened among the great joys and solaces of king Henry, lest that be might not by overmuch forget himself; which displeasure at another time before to have chanced it is manifest and well known to you.

"When the king understood certainly that this earl was de. parted and returned again, he was not a little vexed and unquieted, mistrusting that some new tumultnous business should be begmn again, and chiefly therefore blamed himself of foolish folly that he had given him his pardon for his offence lately committed ; although it was manifest enough that he did it for this purpose, that he might dissemble and wink at the matter so long milil such time he lad some sure token and perfect knowledge of his conjuration, the which he perceived now to be surely attempted and begun. As soon as Edmund De la Pole Earl of Suffolk was fled again into Flanders, Sir Rolort Curzon, whom the king had promoted to the honour of knighthood and made captain of Hammes castle, a valiant and circumspect man, dissimulating himself to be one of that conspirncy, went into Flanders, doubtless to espy what was done there by the Lady Margaret against King Henry. 'This opinion was settled in every man's head at the fir'st broaching of the matter, and so yet continueth, grounding npon this principle that he, neither rexed nor molested with any point of displeasure or injury by his prince or any other, fled to the king's enemies; and after all things were known, opened, pacified, and suppressed, he willingly returned, and was received into high favom with the king his master and sovereign lord. Howbeit the king, like a wily fox, knowing the faithful intent of this Sir Robert, and intending to put him ont of all jealonsy and suspicion with the Lady Margaret and Edmund De la Pole, caused the said earl and 
the said Sir Robert Curzon and five persons more to be aecursed at Paul's Cross, the first Sunday of November, as enemies and rebels to him and his realm. But, howsoever it chanced, whether it were for the easing of his heart or from some privy policy, the king after the marriage of his son Prince Arthur was so vigilant, so circumspect, and so intentive, that he espied and tried out such as he knew partly to be the inventor's of mischief against him, and partly to bear no goodwill or sincere affection towards his person, that he conld readily name and rehearse their names and surnames; whereof a great part were within a few dluys apprehended and taken. And among them Lord William Courtney, son to Edward Earl of Devonshire (a man of great nobility, estimation, and virtue, which married Lady Catherine, daughter to King Edward), Lord William, brother to Edmund Earl of Suffolk, Sir James 'Tyrell, Sir Joln Wyndham. Both these Williams before rehearsed, were rather taken of suspicion and jealousy because they were near of blood to the conjurators, than for any proved offence or crime. . . . . . . . And Sir James Tyrell and John Wyndham, because they were traitors and so attainted, the 6th day of May they were on Tower Hill beheaded. But when the Earl of Suffolk heard that some of his friends were put to execution and some other committed to perpetual prison and captivity, he was in a great agony and fear of himself; and so, being clearly desperate to have any fortunate snccess in his pretensed enterprise, wandered about all Germany and France for aid and succour, proving if he could find any aid or succour at their hands. But when he perceived no steadfast ground to eatch anchor upon (to the intent that in conclusion he might understand that a shameful death due to a man for his offences and crimes caunot by man's help or man's reason be either eschewed or diverted from him) he sul)mitted hinself under the obeisance and defence of Philip, Archduke of Austria and Burgoyn and Earl of Flanders. But Richard, his lmother, being an expert and politic man, so craftily conveyed and wisely ordered himself in this stormy tempest, that he was not entrapped either with net or snare."

This account is in the main corroborated by the Correcpapers relating to Suffolk here published, and may be made in presumed to be correct wherever we have no better Hall's acinformation. The chronology, however, is a little count. erroneous. The indictment of homicide appears to have been, not a few months, but three years before Arthmr's marriage; for it was found by Mr. Napier among the 
records of the Queen's Bench in Michaelmas term 14 Henry VII. (1498). Lingard also surmised from the act of attainder that the date of his first flight must have been as early as the 1st of July, 1 1499 , from which day the forfeiture was to take effect retrospectively, and this conjecture is confirmed by article xvii., which shows that when Sir Richard Guildford and Richard Hatton were despatched on a mission to the archduke in September of that year they received instructions to use every effort to persuade Suffolk to return. He appears to have been, not at the court of Margaret of Burgundy, but at Calais, or perhaps more strictly speaking at Guisnes, with Sir James Tyrell, who was executed three years afterwards as one of his adherents. At this time Henry conceived 110 mischief was done past mending. Suffolk had not openly renounced his allegiance, and if he could be induced voluntarily to return, the matter wonld attract no further observation. If not, he was to be formally summoned on his allegiance by the authorities at Calais. He did return voluntarily. He was received again into favour, and treated so entirely as one on whom no suspicion rested, that in the next year, 1500, he followed the king over to Calais. ${ }^{1}$

In the year after, he was again a fugitive. This second flight occurred at the date to which the first is attributed, that is to say, shortly before Arthur's marriage. It certainly was not caused by the expenses he had incurred at that celebration, for he was then in Germany. Our papers now afford much more full information than Hall and Polydore; and it appears that in this case the Macchiavellian character of Henry's policy has been somewhat over-estimated. Curzon was not sent after Suffolk, but went before him. So early as the 29th of August, 1499, he obtained licence

${ }^{1}$ Chronicle of Calais, p. 3. 
from the king to quit his post as captain of Hammes castle to fight in the cause of the church against the infidels. ${ }^{1}$ In this service he succeeded in gaining the high esteem of Maximilian, who created him a baron of the empire. ${ }^{2}$

Talking of the affairs of England with the emperor, Curzon was encouraged to speak of the "murders and tyrannies" of Henry, and the design of Edmund De la Pole to recover what he called his right. Maximilian at once declared his sympathy with De la Pole. He told Curzon that if so prominent a nember of the House of York would come and trust himself to his protection, he would assist him to obtain the crown of England; and declared that he would not desert him, though the enterprise should cost him as much as a year's value of all his dominions. It was on being informed of this that Suffolk left England a second time, in the month of August 1501.3 He at once repaired to the Tyrol, where the emperor then was, rehearsed certain injuries that he alleged Henry had done to him, and said that it had been the king's intention to murder him and his brother. Maximilian welcomed the fugitive as his kinsman, and showed him every attention, but at first declined to assist him on the ground of the existing amity between England

\footnotetext{
1 Rymer, xii. 729 .

2Gough's Camden, ii. 306. It is also said that he was made a baron of England by Henry VIII., but perhaps the truth is only that he was licensed to bear his foreign title. He is not noticed by any of the Peerage historians.

3 "In this year in the month of

" August departed secretly out of " the land the Earl of Siffolk, and " so sailed into France, accom"panied him with Sir Robert - Curzon, knight, before season in
}

" like manner departed. For the " which the king charged all off" cers, as searchers and other, to " make due search, every man in " his country to see that none " other in like manner departed "his land without his licence." MS. Cott., Vitellius A. xvi., f. 183. 'The statement that the earl sailed to France probably means no more than that he went beyond sea: otherwise it was written in igno. rance. 
and his son the Archduke. When, however, Suffolk was going to have retired and sought his fortune elsewhere, the emperor pressed him to remain till he had more fully deliberated how he could assist him. He, accordingly, did remain at Imst the space of six weeks, and was then offered the aid of from 3,000 to 5,000 soldiers for one, two, or three months. A formal agreement was then drawn up between him and the imperial treasurer; and leaving his steward Killingworth at the court, he went to Aix-la-Chapelle with letters of recommendation from the emperor to help him to obtain that assistance which Aix was best able to afford.

Suffolk's His expectations were doomed to be wholly disdisappoint- appointed. From a mutilated and very illegible MS. we can just make out that the emperor's promises were from time to time evaded by different excuses. In the spring of 1502 , the plan was that Suffolk should embark from Denmark.' When this failed, the emperor proposed to make terms between him and Henry VII.; then threw out a hint that he might obtain assistance from France; and then found out and was forced to acknowledge that Henry would listen to no proposition in his favour. ${ }^{2}$ Still he went on advising the earl to have patience, and that he would yet assist him; and still, when the time came, he was unable to redeem his promise. Suffolk was most bitterly disappointed; he felt that he had been betrayed. In private letters to Killingworth he complained of the emperor's dissimulation, and bid him tell his Majesty plainly that he had left his country on the promise of imperial aid, and by so doing had forfeited as much property as would have supported an invading army of 10,000 men. Meanwhile his friends in England were being apprehended and exe. 
cuted, and he himself was not secure against being delivered by treachery into Henry's hands. ${ }^{1}$

The arrest of Sir James Tyrell was well calculated Arrest of to alarm him. Sir James had been induced to leave Trrell Guisnes castle where he was besieged by the whole ar'my of Calais, on the promise of the Lord Privy Seal that he should go and come in security, and when he came on board ship, Sir Thomas Lovel bid him send a token to his son whom he had left in charge there, to deliver up the castle; threatening, if he did not comply, to throw him overboard. The token was sent, the castle surrendered, and both Tyrell and his son were thrown into the Tower." The father alone suffered the extreme penalty of the law. ${ }^{3}$

On the 20th of June the same year, a treaty was made at Antwerp between Henry VII. and Maximilian by which the emperor was bound not to receive within his dominions any English rebels, or allow others to give them the slightest assistance, even if they should be of the rank of dukes," as De la Pole pretended still to be. This treaty was confirmed by Henry on the 14th of August. It was what Henry had determined to obtain from the moment he

\footnotetext{
1 Pages 179, 180.

- Page 181 .

3 In the reign of Henry VIII., in spiritu ductus, the remembrance of this innocent hath caused me that in my bed this night I could not reference to another case of a boy being implicated in the treason of his father, Sir Brian Tuke wrote to Wolsey to intercede in these words:

" Like it your grace, I am neither

" moved of affection, meed or other

" partial cause, as I take God to re-

" cord, for I never knew nor" saw

"the parties, nor have to do with

" any their friends, alliance, or ac-

" quaintance; but whether it be of

"fatherly compassion, for I have

" children of mine own, and one

" much of that age, vel nescio quo

"forbear to water my plants, having " in fresh remembrance what I knew " in King Henry the Seventh's days was considered and alledged

"tonching the difference between

"the King's laws and an instinct " and law that is in nature; when "Sir James 'Tyrell and Sir John "Wyndham were put to death, and " their sons upon that consideration " pardoned." State Papers, iv. 487,8. " "Etiamsi ducali aut alia dig" nitate quacumque prafulgeant." Rymer, xiii. 23.
} 
heard that De la Pole had gone to the emperor. A month after his flight ${ }^{1}$ Sir. Charles Somerset and William Warham received power to treat with Maximilian; but it was not without months of delay and considerable haggling about the terms, that the treaty was thus concluded. Maximilian had so far pledged himself, in words at least, to De la Pole, that he could not immediately consent to order him out of his dominions, and he alleged that rebels could not be banished from the free towns of Germany without the consent of the electors. At last, however, the terms were agreed to, and Maximilian ratified the treaty at Augsburg, on the 28th of July. On the same 28th of July (the coineidence was not accidental) he signed an acquittance for 10,000l. received from Henry for prosecuting the war against the Turks.

TheTurks. Only in the preceding year the pope himself had sought Hemry's aid against the 'Turks in vain. Such aid lid not appear uncalled for: the Turks were the dread of Christendom, and were no imaginary danger. If any thing could have made the nations of Europe combine for a common object it was the fear of them. For a century they had been steadily extending their conquests, and more particularly since the fall of Constantinople. They were by this time masters of about the same territory as at present, with the addition of Greece. In the course of the next 30 years they captured Rhodes and nearly dismembered Hungary. Their fleets scoured the Mediterranean. It was not certain that they might not ravage Italy, and even make the pope fly from Rome. From time to time attempts were made to combine against them the arms of Christian nations but without result. Christian princes were seldom at pence among themselves, and when they were, they did not trust each other. The pope at this time was

On the 28th Sept. 1501. Rymer, xiii. 18. 
the notorious Alexander VI., and however willing he might be to collect money for a crusade it was pretty certain he would not devote it to such an object. When he applied to Henry VII. for this purpose Henry mocked him with an answer worthy of Roman cliplomacy itself, except that it was more honest in the transparency of its real meaning. He would be very sorry, he said, if the Turk came into Italy or disturbed the peace of Christendom; but for his own part, thank God! he was at peace with all Christian princes. It was very landable in the pope to propose to go in person against the infidels with the help of France and Spain; Henry was sorry he was too far off to give assistance. It was quite right that Germans, Hungarians, Bohemians, and Poles should do their best, as they knew the mode of warfare of the Thurs; but Henry's council were of opinion that England could do little good. The voyage between this country and Italy generally took the Venetian galleys seven months, and preparations could not be made for months to come. ${ }^{1}$ Such were the excuses offered to the pope. It cannot be supposed that Henry had much greater confidence in Maximilian; but the 10,000l. he gave him were doubtless well laid out. It was very well known that the emperor was always in want of money, and that money was omnipotent with him. The 10,000l. was but the price of the treaty which was to deprive De la Pole of the power of doing harm.

Henry had now reigned about seventeen years, and it Ferdiwas not for the interest of himself and his subjects only $\begin{gathered}\text { nand's am- } \\ \text { bassador in }\end{gathered}$ that he should remain in undisturbed possession of the Germany throne. The alliance by which he had so greatly promises to strengthened himself made it also a matter of interest to mumd De Ferdinand and Isabella, that nothing should be allowed ${ }^{\text {la Pole. }}$ 
to interrupt the natural course of the succession. They accordingly wrote to their anbassador in Germany, Don Juan Manuel, to urge the emperor to expel De la Pole from his dominions, telling him that they considered it a thing that directly concerned themselves. Don Juan obeyed his instructions, and afterwards wrote to Spain, that he had made the matter safe. De la Pole was to be delivered to the ambassador by a certain day, and Ferdinand made arrangements for consigning him to the custody of his general Gonsalo Fernandes at Naples, until it was known what Henry wished to be done with him. 'The scheme, however, did not take effect, De la Pole made his escape from Germany, and Ferdinand was greatly displeased with his ambassador."

France also was willing to serve Henry in this matter. Lewis XII. made a spontaneous offer to procure, by a bribe to certain friends in Germany, the delivery of De la Pole into Henry's hands. Matthew Baker was instructed to reply that the king did not hold De la Pole of any consequence, but would wish to have him "pour l'ounnemr quil en peult advenir," and accordingly would he glad if his good brother would get him and as many of his followers as possible taken and handed over to him. For this he would not grudge 10,000 or 12,000 crowns of gold. It appear's that at this time, June 1502, De la Pole, despairing of assistance from Maximilian, was going to seek it from the Count Palatine.2

De la Pole About Easter, in the year 1504, the exile obtained Gneldres. permission from the Duke of Gueldres to enter his territory. His object, as he afterwards states in a letter to his brother, was to visit George duke of Saxony, at that time governor of Friesland, from whom he intended to ask aid to pay his debts. He was so

\footnotetext{
1 Memorials of Henry VIr., pp. " Lettres de Rois, Sc. de France 268 and 412. 
hard beset by creditors, that he had been obliged to leave his brother Richard at Aix as a hostage. But instead of attaining this object he was made prisoner by the duke of Gueldres; and before getting finally released from his power, his debts, we may presume, were considerably angmented. Among his papers is a draft agreement in the handwriting of Killingworth (Art. xxxvin.), by which the duke consents to set him at liberty on payment of 2,000 florins for the expenses he had incurred in Gueldres. It is evident this proposition was made, not by the duke but to him, and represents the terms that De la Pole was willing to submit to.

Little as this looks like over-firendly treatment, at first he appears to have been too well received, and James IV. of Scotland, whose own contingent interest in the English succession was endangered, thought it necessary, notwithstanding his old and cordial alliance with Gueldres, to write his mind to the duke in the following fashion :-

"First of all, you cursorily allude to what our servant Patrick Letter of Halyburton formerly demanded of you tonching Edmund De la James IV. Pole, late earl of Suffolk, and you refer to copies of letters on to the duke this subject. This brevity is a grecible, that a tedious repetition of Guelmay be avoided. You need not have exensed the humbleness of the secretary, for the time requircel that a wary and reserved messenger should be sent . . . . . Secondly, yon relate your vigilance about the affair entrusted to you, for which we return you our best thanks. But you imply that the opportunity for accomplishing the thing well is over, this Edmund having gone over some time ago to the king of the Romans. We leave this for the present. Thirdly, about Easter, in the year 1504, yon write that there came to you a servant of De la Pole, desiring that his lord might be permitted to reside in your dominions; which in your fourth article you plainly acknowledge that you readily granted, so that at this moment he freely inhabits your country.

Herein, beloved kinsman, I may with the more freedom accuse you of violating your engagements; for you formerly promised 
Letter of James IV. to the duke of Gueldres.

us in your letters that you would absolutely deny him your dominions, make proclamation every where against him, and severely punish any contravention of it. You allege as your reason for doing so, that having taken comsel, you expected it wonld be of great nse to you with our father the king of England, to admit bim within your bounds, so that a condition of peace might be procured by your mediation, for which he promised you full power and anthority. What our opinion is understand in a few words. It is useless excusing yom'self to men of experience with a feigned pretext of mediation; you make but a lame defence of your innocence. Nothing conld justify you in departing from your promise for the sake of a perfidions man withont consulting me to whom yon had bound yourself, especially when De la Pole's inconstaney was already more than sufficiently known to you; to whom formerly, though a fugitive suppliant rebel, when he retrined to England the king most mercifnliy forgave all his revolt. Therefore $I$ tell yon this as a thing most sure and certain. 'The king's prudence deigns not now either to reeall De la Pole from his error, or to listen to any composition; that rebels by the infiction of the due punishment of treason may lay aside contumacy and impicty. He considers, besides, that it is neither compatille with kingly honour, nor is any prince acenstomed to make peace with a subject. A king is mercifnl to a subject when he is worthy of pardon. So that either yon have been inconsiderate, or, what I fain would rather believe, his coming to you was without permission, nor was any assurance given him that it should be with impunity, but by accident he has eseaped your vigilance; and on this I congratulate you, and give you thanks.

You add, fifthly, that by the agency of De la Pole, in Gelderland, an an'med band of about 6,000 foot has often met in your country mider leaders, but for what olject was manown. You say that it was suspected they would turn their arms against England, and that you gave orders to the anthorities at all your ports to prevent this, and that no fleet shonld be allowed to sail, warning De la Pole, at the same time that he should not fraudulently nse the impumity extended to him in your dominions against the law of nations, nor attempt anything hostile against England, which would offend the bond of our relationship; and that satisfied with this, he desisted. In so far as you were serviccable in this matter, consin, I owe you much; but you would have done better to have passed over the eircminstance in silence, and not allowed a vain hope to carry you through tortnons 
ways. It is quite absurd in you to pretend, nor does it appear probable to us, that a needy man whom you supply with food keeps a thousand arned men in his pay. One of two things, I think you are attempting, either that the king of Eugland through vain foar shall conciliate De la Pole, or that he shall expect to see him restored by your arms. It is nonsense talking of fear in a king hitherto unconquered, whose friendship the greatest princes eagerly cmbrace, and who by his bravery has repeatedly overcome, with great slaughter, strong bands of enemies; and as to restoring De la Pole in England, if you or the greatest prince of all Europe entertained such a notion, and if De la Pole had conspired to bring in a rebel, the enterprise might lead to greater difficulties, and be remembered for ages. Beware. This Edmund will dcceive you by too much promising of friends; he, who lately, after actually returning, and being fully restored to his friends by the king, fled from his country and supporter's in poverty and dearth of friends. I wish, therefore, you had refrained from empty threats, and talking of his boasted power.

In comection with this you say, in the sixth place, that from the needy poverty of De la Pole, you have sustained no small charges ever since he came to you, and that you will not he whle to bear them longer, for the heavy expenses of war. Pray excnse me, illustrious consin, if I deal not gently with you now. Yon treat kindly a rebel of England, an exile from the greater part of Christendom, to the disgust of your friends, and to the complication even of your own aftairs, at a time when you ought to be coneiliating princes rather than exasperating them. Is this what has come of our supplications? Is our bond of consangninity at an end? Have your promises come to this? Overtrustful that I was! I represented you to nuy most illustrious father the king of England, as a well meaning and friendly prince: you openly declare yourself his encmy, and the sole refuge of his rebels. And for these egregions merits, forsooth, you demand, in the seventh place, that we should come to your snccour against the great and powerful kings of the Romaus and Castile, who for our sake ordered this Edmund, whom you cherish, away from their persons and their kingdoms. See, then, how you are your own enemy, how incompatible are the things you demand with what you do, and how justly they are refused to yon; unless we were to be guilty of eumity against friends, ingratitude to those who descrve well of us, and perfidy towards allies. Which things, in as much as they are unworthy of kings, in so mnch are they adverse to your demands being complied with, and if they be true, alienate us 
from you entirely. Nor do we like to irritate against you the mind of our most excellent father with your uscless figments, lest from your vain letters his wisdom think little of you, or from being a troublesome person should think you the more so, beenuse you do not stand to your promises; beeause you thoughtlessly, and on frirolous grounds evade fulfilment of your pledges; becanse yon hoast the pretended power of De la Pole; who, if you permitted it, would by this time have wandered over the world in disguise, or have fallen long ago into the power of the king.

Do not think that we have written to you too harshly; it eoncerns the surest interest of our most illustrious father, our most serene brother, our most gentle wife. . . . . Whom if you love me, you will not regard otherwise . . . But the unhappy De la Pole is an obstacle to our desires; so long as he is secure, you will never be conscious of our wealth, or of that of friends. Your hateful guest denies you arms, men, and money. Therefore, duke and kinsman, as soon as you can, get rid of this mhappy wretch, and strive yet to reconeile yourself to our most benerolent father, by the same way by which you have offended him, you may study to conciliate him. Send away that perfidious man who has made ner attempts in your dominions without your orders, sinee he neither satisfies you nor his ereditors, nor is bound by the law of nations; and if you abide homourably by your promise, we will strive to replace our mutual good will, and to moderate the riolence offered to you."'I

De la Pole is delivered of the duke of Gueldres. Suffolk was confined in the

It was not an enviable lot, however, to be in the hands lip, king of town of Wageningen. He attempted to escape towards
Castile.

Thiel, but had not proceeded a mile before he was recaptured and brought back. He had still some hope of regaining his liberty through the medium of Philip, king of Castile, between whom and the duke of Gueldres arrangements were then making for a peace, but he had great misgivings. "The duke of Gueldres" "servants said plainly he would not come to the king"

\footnotetext{
${ }^{1}$ Epistola Regum Scotorum, rol.i. | to faror the Burgundians in their pp. 1 I, sq. In Jannary 1507, when war with Gueldres, James threatened Je la Pole was safe in the Tower, England with war if he should and when Henry VII. was inclined attack the duchy. Ib. p. 40.
} 
"as long as the king of Romans is there, with great "words." De la Pole, therefore, wrote urgently to Killingworth to see Philip at Brussels, and intreat him to get him " out of that man's hand." "And say "these words," he adds, "If I were in the furthest " end of the world I would be at his commandment " to fulfil his pleasure and commandment as any ser"vant of his house." On the 28th of July 1.505, his wishes were partly accomplished. The peace was made, and the duke of Gueldres delivered him up along with the city of Hattem into the hands of the king of Castile. But only a few days later, his servant, the bastard of Oyskerk, writes to Killingworth that Philip had delivered him again into the hands of the duke to occupy his old quarters at Wageningen. This, however, appear's to have been but an interim arrangement. De la Pole's chaplain and other servants could have access to speak with him, and he himself desired them not to be dissatisfied on his account.

About this time, probably, was written the paper which forms our No. xxxvi. It is a corrected draft in the handwriting of Killingworth, of a letter intended to be addressed to his master. It conveys excuses from some person unnamed, mentioned only as "your "friend," for not having communicated with De la Pole earlier, as he had hoped to send him news from England. This friend I take to have been ove Paul Zachtlevent, who is mentioned by his Christian name in the latter part of the letter, a merchant of Amsterdam, born in Pomerania, who had given him pecuniary assistance. He sends De la Pole four ells of satin by a servant of his own rather than by De la Pole's chaplain, Sir Walter, who might have been stopped. "And " he bacle me write to you," says Killingworth, "that

\footnotetext{
1 Edmund be la Pole to Don L'eter, | " Page $25:$ Ellis' Letters, Third Series, i. 131.
} 
"touching you he heareth nothing but good." Nevertheless, as the writer was going to have hinted, he was not altogether satisfied about De la Pole's prospects; but on second thoughts the expression of suspicion was struck out of the letter. One thing, however, there was no concealing: it was all Killingworth could do to get him to furnish a gown for De la Pole and a gown and bounet for Sir George Nevill. Concerning some further advances he had been asked to make for "De la Pole's servants, and for payment of a debt to "the host in Zwolle," he hesitated to give an answer. We next come to a singular passage. Whether" "Mr. Paul," who is now mentioned by name, be the firiend above alluded to is not absolutely certain ; but there can be no doubt he is the Paul Zachtlevent A creditor mentioned in another letter. This Paul, it appears,

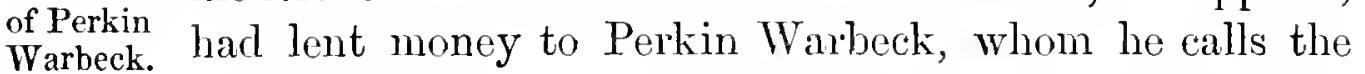
duke of York; and in order to obtain repayment, he was reduced to two very unpromising alternatives. The first was to send in his claim to Henry VII., threatening, if the king did not discharge it, to give his utmost support to De la Pole; the second was, to obtain a certificate signed by De la Pole, that Perkin Warbeck was the true duke of York, on which he believed that the king of Denmark and the duke of Pomerania would grant him letters of marque against the English merchants.

The stipulation for De la Pole's ransom already mentioned is dated 2tth of September 1505. He retired again into Philip's territory, and the next notice is a letter written by himself from Namur on the 17th of November. ${ }^{1}$ It was but a change of keepers, for here too, he was in prison, the rigor of his confinement only mitigated by promises from Philip, to which, in 
his despair, he attached an unreal value. ${ }^{1}$ Philip was then preparing to embark for his new kingdom of Castile, and De la Pole seems to have been anxious before he left to obtain some pecuniary relief for himself and his brother. He endeavoured to make firiends with some of Philip's council. His old creditors at Aix were advised to wait mpon the King of Castile. They returned empty-handed and again dunned his brother for their money. They threatened to proclaim Edmund to the world as a perjured promise-breaker, and gave significant hints to Richard that if he could not satisfy their claims they would sell him to King Henry. For the possession of his person, alive or dead, Henry was ready to pay them all that they demanded; and Richard feared to be seen in the streets Danger of of Aix, lest he should be seized and delivered up to Richard soine emissary of England. His brother sent Oyskerk at $\Lambda$ ix. and Killingworth to Philip to obtain a remerly; but several weeks passed away, and Richard was still in the same precarious situation. On the 4th of January following he wrote to his brother:-

"I have received your letter by Sir Thomas, the morrow after New Year's Day, by the which I have no comfort. And here I lie in great pain and poverty for your grace, and no mamner of eomfort I have of your grace or none other; nor none is coming, as far as I can see. Wherefore I pray God to send me out of this world. Sir, as for the matter that I sent you word of, ye sent me word ye conld not do nothing therein becanse ye were in the King of Castile's hands; and the same answer I have made, and as soon as I have any word of it, I shall inform your grace thereof. Sir, I have put away all my folks, and the bringer hereof can show you what danger I am in. Sir, by my truth, ye deal very hardly with me, I being your brother, in many things. I know not what the meaning is, as God knoweth."'

'Page 276. 2 Ellis' Letters, Third Series, i. 129,130 . 
These are sad and painful words enough, but Edmund's fate was still more unhappy. The time was now at hand when the protection he had received from Philip was to be withdrawn, and himself delivered to his mortal enemy. Philip set sail in the beginning of January, and was driven by stress of weather to land in England. Henry took advantage of the accident to show him a little kingly hospitality, invest him with the garter, and obtain from him some concessions, of which one was the delivery of Edmund Belmurird De la Pole. Unconscious of what awaited him, the De la Pole prisoner at Namur meanwhile proposed making overhargain for tures to Henry for a reconciliation. Nisfortune had parton. not taught him humility. His commission to Killingworth and Griffith to treat on this subject, is worded in the style of a sovereign prince, and the object of it is stated to be to appease "the troubles that are in the "realm of England by reason that it standeth betwixt " the King of England and me as it doth." The terms on which he would condescend to receive the king's pardon were ineonceivably extravagant. The earldom of Suffolk to which the king had limited him in the days of his loyalty was not enough for him now; he demanded the dukedom. The dukedom itself was not enough for him without the restoration of certain lands which Edward IV. had compelled his father to release to the college of Windsor. As it was possible Philip might wish to keep him in captivity, Henry himself was to use efforts for his liberation, and to respect the rights of his widow and daughter: if he should die in prison. William De la Pole and his other adherents in England were to be set free. On these conditions he would consent to be the king's true subject.

He in de- While De la Pole was thns, within the walls of a livered prison at Namur, ofiering conditions of reconciliation up to 
driven to land at Weymouth, was on this way to visit Henry at Windsor. The tempest which had cast him on the shores of England was one which the Londoners must have long remembered. The brazen eagle on the spire of St. Paul's cathedral was blown down, and in its fall battered to the ground the sign of the Black Eagle tavern in Cheapsicle. As the Emperor bore an eagle in his arms the omen was believed to point at him. It was considered to be accomplished in the ill fortune of his son who was thus assailed by tempest in going to his own kingdom, and who did not live long after he had arrived there. A close resemblance was not sought for between the portent and the event; but Edmund De la Pole was not unlike the meaner eagle brought lown by the misfortune of the other. Being in England, Philip yielded to the personal influence of Henry, concessions which he would not have made elsewhere. He signed the commercial treaty long held in detestation by the Flemings as the intercursus malus, and shortly after consented to the extradition of De la Pole. A contemporary narrative of Philip's reception in England says that he offered this last withont solicitation; ${ }^{1}$ but it is much more likely, as stated by Hall and Polydore, that he consented only when he found no excuses would be accepted, and on a promise given by Henry that De la Pole's life should be spared." That promise was not violated during the life of Philip or

\footnotetext{
1 Memolials of Menry VII., p.302. " contenant entre autre cho, " "

"Adrian de Croy writes to Maxi- " eion et pardon de tout ee qu'il puet milian 23rd Mareh 1505-6:- " "avoir mespris et offené́ cuvers

“Dautrepart, Sire, ledit Seigneur " ledit Seignenr roy d'Angleterre,

"roy votre filz s'est tellement "lequel a aussi promis et donné

" trouvé pressé du roy d'Angleterre "son scelle de bien traictier icellni

"qu'il lui a convenu mectre en ses "seigneul de suffolk toute sa

" mains monseigneur de Suffole, "vie." Chmel's Urkunden zur

" moyennant son appoinctement, Geschichte Maximilians I., p. 229.
} 
during that of Henry himself; but an ugly tradition is preserved by lord Herbert of Cherbury, that Henry, before he left the world, recommended his son to do that which he had promised not to do himself. However this may be, the truth is that in the year 1513, when England was at war with France, and Richard De la Pole took service under the French king against his country, Edmund was sent to the block, apparently without having committed any new offence of his own.

Killingworth's letters to Maximilian in his behalf.
Thus the adventures of Edmund De la Pole came to an end: in March he was delivered up and lodged in the Tower. We hear no more of him in these papers except that his faithful Killingworth still continued to do for him what yet remained in his power, still loping, from the promises of the emperor, that some arrangement might be made with Henry for his liberation. To this end he writes to Maximilian in very miserable Latin :- "As to my fidelity to the said lord " duke, I remit myself to your sacred Majesty, because I " have proved it well to the knowledge of your sa" cred Majesty for six whole years, and now I am in the " seventh year; and under correction of your Majesty, " that is sufficient trial for a man; and I have served " my said lord duke for 20 years, which is not it " small period. And for the service of my said lord " duke I have left my wife, friends, and goods, which, " though it be an unnatural thing, grieves me little, " but the evil fortune of my said lord duke grieves " me very much."

Richard De la Pole was more fortumate, because more politie, than his brother. We cannot trace his history minutely, but it appears that the year after Edmund's being delivered up, he took refuge in Hungary. On the 18th April, 1507, he writes from Buda to Erard

1 Page 312. 
De la Marck, bishop of Liege, to thank him for some measures he was taking in behalf of his brother.' A few years later we find hin, as alleady mentioned, in the service of France. He was looked upon as one of the most distinguished of the French captains, and fell, with the flower of their army, at the battle of Pavia, where Francis I. was taken prisoner, in 1525.

The papers from which most of the above information is derived are a portion of the correspondence of Suffolk and his steward Killingworth, which appears to have found its way into the hands of Henry the Seventl. Some of them perhaps may have been seized when Suffolk limself was sent prisoner to England in 1506 ; but I am more inclined to think that the whole correspondence was seized at a later period. They are almost all letters addressed to Killingworth or eopies in his hand; and the later letter's of Killingworth to the emperor are drafts in his hand also.

One subject now mainly oceupies the short remainder The Low of the reign. The relations, commercial and politieal, Countries between England and the Low Conntries, have at this death of time a peculiar interest. The death of Philip in $1.5066^{\text {Philip. }}$

left those provinces defenceless against France, and threw the govermment of Castile again into the hands of Ferdinand. Philip's eldest son, afterwards Charles V., was then only six years old, and it was necessary for the States to appoint a regent; his widow Joamna was queen of Castile in her own right, but, owing to her unhappy mental debility, unfitted to reign. During the life of Philip, Franee and Arragon had combined to disturb his government in both parts of his dominions; on his death Castile became an easy prey to Ferdinand, and the Low Countries, which were perpetually suffering from French interference, expected renewerl aggressions. Charles of Gueldres and Robert De la 
Marck made inroads and ravaged them with the connivance of Lewis XII. Henry VII. was looked to for his support, both by Philip and Maximilian; but though he sent Francis Marsin to dissuade Lewis from comtenancing Gueldres, ${ }^{1}$ he had recommended to Philip that the disputes shonld be arranged by the arbitration of himself and Lewis. ${ }^{2}$ In his view the true policy was to conciliate France, and he had good cause to interest himself in the government of the Low Countries. A marriage was at that time arranged between him and Margaret of Savoy, Philip's sister, who on her brother's deati was appointed regent of the Netherlands. Her father, Maximilian, thought highly of the match and recommended it to her by several arguments. She herself made objections, but it does not appear that the project was ever abandoned on the part of England; for only half a year before Henry's death no less a person than Thomas Wolsey was sent over to the Netherlands to promote it.

Wolsey's There is a marvellous story told by Cavendish of negotia- Wolsey's being employed by Henry VII. on a mission
tions. to the emperor, which he accomplished with such expedition as to return to the court at Richmond on the third night after his despatch. How far this may be an exaggeration, we cannot say; but Bernard André notes in his Amnals of Henry VII., that on the 8th August 1508, a messenger returned from Calais with remarkable celerity. ${ }^{3}$ There are, among the Cottonian MSS., a number of papers in Wolsey's own hand, relating to a mission of his on the matter above referred to. Unfortunately they are so burnt about the margins that, between the difficulty of the handwriting and the mutilation, it is impossible to extract any meaning from a mere perusal of the MSS. themselves. A record, how-

1 Lettres de Louis XII., t. i. 78 .

${ }^{3}$ Memorials of HenryVII., p.127.

2 Page 298. 
ever, of negotiations by Wolsey at this early period, appered to me too interesting to be given up without some effort to make it intelligible. I transcribed it line for line, leaving blanks where the original was mutilated or presented doubtful readings. By comparison of one paper with another I found much that was lost was capable of being supplied. At last I was able to ascertain that the whole budget belonged to the months of October and November 1508, and had reference to the conferences then held preparatory to the treaty of Cambray. ${ }^{1}$

In the beginning of that year" was sent over to England in embassy from Margaret of Savoy, George de Theimseke, provost of Cassel, whom Sir Thomas Kore a few years later met at Bruges, and mentions in his Utopia as a min of great eloquence, leaning, and experience in affiirs. His letters to Margaret printed in this volume show that he was urgent to procure the armed interposition of England against France and Gueldres; but he could not prevail. He found Henry and his comcil were determined not to go to war; he told Margaret they must depend upon themselves alone, and suggested that he eould probably do her better service at home than attempting to make friends of the friends of fortune. In point of fact, Henry wished them to make peace with France, and thought this course would be politic for themselves. He told the provost that France was far too strong to be successfully resisted, and that if he could advise the emperor he would show him at thing which would be

\footnotetext{
1 Lord Bacon, who mentions this mission of Wolsey, probably saw these papers, for many of the facts in his history of IIenry VII. are derived from the MSS. in his friend, Sir Robert Cotton's library. It is to be regretted he did not give them more attention, as they were then

ummutilated. In a marginal note of that age they are erroneously dated 1501 .

"He arrived in London on the 3rd of February 1508.-Bern. André, Memorials of Henry VII., p. 108.
} 
much more to his advantage. He could tell him how, as gnardian of his grandson Charles, he might obtain the entire administration of Castile, where Ferdinand's authority was regarded as a usurpation; but he declined to tell the means to any but the emperor himself. Those means, however, appeared a little later, when Edmund Wingfield, the English Ambassador, advised Margaret to endeavour, during the conferences at Cambray, to loosen the bond between Lewis XII. and the king of Arragon which, so long as it existed, preserved the latter in the government of Castile. If this policy had taken effect and Henry had lived a little longer, there can be no doubt it would have given him a footing in Spain; for, as Bacon truly says, "as for Maximilian, upon twenty respects, he could " not have been the man."

It was at this time Wolsey was sent over to the Low Countries. His instructions were to communicate with a person who is always mentioned in the despatches by the name of A., concerning whom we discover that he was an ecclesiastic, had considerable influence with the emperor, and held benefices in England. These facts enable us to identify him pretty safely with the bishop of Gurk, who was one of the emperor's council, and to whom Henry had granted the arehdeaconry of Surrey. Gurk was going to take part in the conferences of Cambray, where many things were to be determined affecting not only France and the empire, but the whole of Europe. Henry hoped, through his means, to obtain the government of the Low Countries, and promised, in the event of his success, to give him the principal control there. To cement the political alliance Henry proposed to give his daughter Mary to the young archduke Charles, and to marry her aunt the regent himself. If Gurk coukl bring these two marriages to take effect, the king would give him new benefices in England to the value of 1,000 
nobles a year. The papers relating to these negotiations will be found in Appendix B. (No. VI.)

This was not the first mission in which Wolsey had been engaged by Henry VII. Though the fact appears to be unknown, he was sent to James IV. of Scotland in the spring of the same year in which he was sent to Gurk. The object was to keep James true to his alliance with England, for Scotland at that time showed a considerable disposition to be troublesome. Contrary to the treaties, ambassador's passed and repassed through England, without demanding Henry's safe conduct, to Gueldres and other countries which England had no reason to regard with favour. The Earl of Arran and his brother, Sir Patrick Hamilton, had thus passed through to France. On their return, Henry ordered them to be detained in London, under such very lenient custody that they were banqueted by the lord mayor and one of the sheriffs. Sir Patrick Hamilton himself wrote to Margaret that the earl had been well treated, but he reported the contrary to James, and James would listen to no explanations. A clespatch written by Wolsey, from Scotland, upon this subject, has already been printed by Pinkerton,' but is erroneously attributed by him to Dr. West, the historian, not being aware that the MS. from which he printed was in Wolsey's handwriting.

I have found other evidence of this mission of Wolsey's in a panegyric afterwards written upon the cardinal when he was in the height of his greatness. A MS. poem ${ }^{2}$ which describes his rise in the style of a prophecy contains these lines:-

“ Illum purpuream princeps cum accerset ad aulam Septimus Henricus, sæcli laus prima futuri, Praficietque sui rebus majoribus orbis;

Hist. of Scotland, ii. 445 。 1 2 Royal MS. 12 A. Ixii., Brit. Mus. 
Usque adeo ut quondam transmiserit inclyta ad agri

Regna Caledonii legatum, foedera sanctæe

Confirmaturum pacis, quo rex Iäcobus

Tempore fulva manu gestabit sceptra potenti.'

In commenting upon the historical materials for this reign it may seem an omission to pass over in silence the extortions of Empson and Dudley, and the misguided statesmanship whose paramount object was to make the crown rich and powerful. About this well known blot in Henry's reign our letters and papers are silent, but the evidences of it may be found among the records of the Exchequer. The abuse is also, with other's of which we have seen some specimens, very pointedly alluded to by More in his Utopia: ${ }^{1}$

"But what (said he) if I shonld sort with another kind of minister's, whose chief contrivances and consultations were, by what art treasure might be heaped up? Where one proposes . . . . . Another proposes a pretence of war that so money may be raised in order to the carrying it on, and that a peace might be concluded as soon as that was done; and this was to be made up with such appearanees of religion as might work on the people, and make them impute it to the piety of their prinee, and to his tenderness of the lives of his subjeets. A third offers some old musty laws that have been antiquated by a long disuse, and which, as they had been forgotten by all the subjects, so they had been also broken by them; and that the levying of the penalties of those laws, as it would bring in a vast treasure, so there wonld be a very good pretence for it, since it wonld look like the executing of law and the doing of justice."

1 The value of this notable work, in connection with Tudor history, has never been sufficiently recognized. The character there given of Cardinal Morton (the only portrait we possess of Henry's great minister), and the discussions on the prineipal evils of the time and the means to mend them, not to men- tion the illustration afforded by the very plan and subject of the work, of the influence of a newly discovered world upon men's thoughts and imagination, render the Utopia really one of the most important listorieal monuments of this clark period. 
It is time now to leave these letters and papers to tell their own tale. Those in the present volume are necessarily an imperfect collection; but they will be found to eontain most important documents in the British Museum and other public repositories in this country, which had not before been edited. Others of no less interest will be given in a second volume. The collection of materials so dispersed, has been a work of difficulty, and the search for them has not always been satisfactory. In some cases paper's, known once to have existed, are not now to be found. ${ }^{1}$ Sometimes two portions of the same MS. were found apart from each other-even in different volumes. Imperfect, however, as this attempt may be, the editor cannot but hope that his labours will have done something to redeem from neglect and confusion original sources of information touching an important period of English history.

I must not omit to state that I am indebted to Sir Charles Young, Garter King of Arms, for calling my attention to the description of Edward the Fourth's funeral, which forms the first article in this volume.

I In a catalogue of documents in the State Paper Office. compiled in the 17th century (Addit. MS. 11, 595 , Brit. Mus.) are notices of some letters not known to be now extant. Among others the following:-

"A letter of Mr. Svile (sic, for Stile), the king's Ambassador with the king of Arragon touching the king's marriage with the lady Katherine, his brother's widow, Amo 1505." (N.B. This deserip- tion is evidently from an endorsement of IIenry VIII.'s tine.)

"A letter of Perkin Warbeck, in the name of Richard, one of the sons of the Inke of Clarence, directed to the Earl of Desmond in Ireland, to come into sicotland to his assist. ance" (also mentioned by Ware).

“A letter firom Mr. Molesworth, the king's agent at Rome, to king IIenry VI." 



\title{
CHRONOLOGICAL TABLE OF CONTENTS,
}

\author{
WITH NOTICES OF SOME ORIGINAL LETTERS PRINTED IN \\ OTHER PUBLICATIONS.
}

A.D. 1483.

Page

April I. Funeral of Edward IV.

3

28 June. II. Instructions to lord Mountjoy and others to make answer in the name of Richard III. to a letter addressed to him as lord Protector by lord Dynham. The oath of allegiance to Edward $V$. must not be considered binding, the lords having found Richard III. true heir to the crown, \&e.

July. III. Proelamation before the coronation of Richard III. . . . . . . . 16

IV. Negotiation for the restitution of French prizes. Instructions to Thomas Grafton and others to treat with the Sieur des Querdes.

$\mathrm{V}$. Overture to Britamny for mntual redress. Instruetions to Dr. Thomas Hutton. Diet proposed

VI. Relations with Spain. Instructions to Bernard De la Forssa .

21 July. VII. Lewis XI. to Richard III. Acknowledging letters by Blane Sanglier . . . .

30 July. VIII. Philip of Austria to Richard III. Complaining of acts of piracy and murder done by the English

8 Aug. IX. Message of Queen Isabella of Castile by G. de Sasiola her ambassador, delivered to Richard III. at Warwick. She desires peace with England, and is ready to give aid against Lewis XI., \&e. .

18 Ang. X. Richard III. to Lewis XI. Touching the observance of the truce. Complaints of English merchants trading with Bordeaux . . .

20 Aug. XI. Same to same. Desires to procurc certain wines of Burgundy for his household . . 
A.D. 1.183.

26 Aug. XII. From the duke of Britanny. Instruetions to George de Mainbier, to show the king of England, that the duke will send an ambassador about All Saints' day, after the meeting of the Estates of Britamny ; that depredations are committed at sea on his subjects by the English; that Lewis XI. threatens him with war if he do not give up to him the earl of Richmond; and that the duke requires the aid of a body of English archers

[Aug.] Ellis' Letter's, Second Ser. I. 156.-Lord Dynham to the lord Chancellor. Death of Lewis XI. Campaign of the arehduke Maximilian in the Netherlands, - surrender of Utrecht. The king should have a flect betreen Dover and Calais, \&c. [MS. Harl. 433, f. 233 b.]

XIII. Government of Ireland. Instructions to William Lacy sent to Ireland. Edward the king's son to be lieutenant of Ireland, and Kildare his deputy . . . .

XIV. Custody of Gnisnes Castle. Instructions to lord Dynham and others. Sir Ralph Hastings to deliver to them the town and castle of Guisnes. Mountjoy to have the keeping of it . .

XV. Answer to the message of Isabella of Castile. Instruetions to Bernard De la Forssa. England proposes a renewal of the leagne made between Edward IV. and Hemry IV. of Castile . .

16 Aug. XVI. James III. to Richard III. Proposing to send an embassy to treat of peace .

16 Sept. XVII. Richard III. to James III. Offering a safe conduct for his ambassadors

Rymer, XII. 200. Richard III. to Isabella of Spain. Sends Berm. de la Forssa to her upon the business for which she sent Sa. siola. [MIS. Harl. 433, f. 246 b.]

9 Sept. Rymer, XII. 201. Same to Peter de Mendoza. cardinal of Toledo, on the same subject,and a similar letter to the bishop of Paleneia. [MS. Harl. 433, f. 246.]

10 Sept. Rymer, XII. 201. Same to Count Haro (whose name Rymer has omitted to print), on the same subject. - And a similar letter to the Count Leryn. [il.] 
A.D. 1483.

12 Sept. Rymer, XII. 202. Same to Ferdinand of

Spain. On the same subject. [MS. Harl. 433 , f. 245 b.]

12 Sept. Rymer, XII. 202. Same to Isabella. On the same subject. [ib.]

6 Nov. Ellis, Third Ser. I. 109. James III. to Richard III. In answer to XVII. Sends the names of the lords whom he wishes to send in embassy ; and proposes an abstinence of war till the 15th of March. [MLS. 433, f. 248 b.]

12 Oct. Ellis, Second Ser. I. 159. Richard III. to the bishop of Lincoln. Requiring him to send or bring the Great Seal. [Rec. Off.]

2 Dec. Ellis, Thirel Ser. I. 111. Richard III. to James III. Sends the safe condnct. The abstinence must be deferred until the coming of the embassy. [Harl, 433, f. 248 b.]

22 Nov. XVIII. The duke of Britanny's warrant to A.D. 148t. advance money to the carl of Richmond .

18 Jan. Rymer, X1I. 210. Letter of the Emperor Frederick III. in favour of Nicholas de Poplair. [MS. Harl. 433, f. 255.]

10 Feb. I6. 211. Richard III. to John Maximilian Sforza duke of Milan, in favonr of Guliclmus and Nicholaus de Ariotis, who wish to return to Milan, their brother Germanus being dead. [I6. f. 249.]

Ib. 212. Same to Ludorico Maria Sforza duke of Bari. On the same subject. [Ib. 250.]

29 Feb. Ib. 214. Same to the Pope. Sends Thomas [Langton] bishop of St. David's to inform him touching his clevation to the throne. Recommends John Sherwood to be bishop of Durham. [Il. $250 \mathrm{~b}$.]

2 Mar. Ib. 216. Richard III. to the Pope. Requesting him to make Sherwood a Cardinal. [Il. f. 254.]

2 Mar. Il. 217. Same to the Cardinals. On the same matter. [Ib. f. 254 b.]

9 Mar. Ib. 220. Same to the Pope. Credentials for Langton, bishop of St. David's, the archdeacon of Richmond (Sherwood) and John Dunmow, Canon of Windsor. [Il. f. 252 b.] 
A.D. 1484 .

10 Mar. Rymer, XII. 220. Same to Cardinal St. George. Thanks for his letter's of congratulation on his accession, \&c. [Il. f. 251.]

10 Mar. I6. 22I. Same to Cardinal St. Mark. Thanks for the favour he bears to Sherwood as expressed in his letters of the 20th Jan. [ [Ib.]

10 Mar. Halliwell's Letters, I. I53. Circnlar of Rich[1484?] ard III. to the bishops for the suppression of immorality. [Ib. f. 28I.]

11 Mar. Rymer, XII. 221. Richard III. to Charles VIII. Credence for the bishop of St. David's. [I6. f. 251 b.]

31 Mar. Ml. 244. Same to the Pope. The bishop of Durham has to protect the realm against the Scots. In one castle 100 soldiers must be kept even in peace. The king begs there. fore that he may be released from payment of a portion of the first finits. [Ib. f. $252 \mathrm{~b}$.]

31 Mar'. Ib. 225. Same to the Cardinal. To the samo effect. [ח. f. 253.]

13 April. XIX. Instructions to Northumberland herald to arrange an alsstinence of war between England and Scotland

July. XX. Regulations for the Conncil of the North, nnder the carl of Lineoln as president, for preserving impartiality, \&e. The council to sit at York at least once a quarter, and take cognisance of all offenees against the peace .

21 July. XXI. James III. to Richard III. Naming his ambassadors, who are to be at Nottingham on the 7th Sept.

7 Aug. XXII. Richard III. to James III. Sending a safe conduct for the embassy . . .

9-14 Sept. XXIII. Reception of the Scotch Ambassadors at Nottingham

Sept. XXIV. Message to the carl of Desmond. Instructions to the bishop of Enachden to tell him how his father's services to the king's father, Richard duke of York, are appreciated, \&c.

XXV. Message to the earl of Kildare and other lords. Instrinctions to the bishop of Enachden to tell Kildare how O'Neil and O'Donnell shall be dealt with tonching the carldom of Ulster. Desmond to wear English elothing, \&c. 
A.D. 1484 .

Oct. XXVI. Instructions to Sir Marmaduke Constable, steward of the honour of Tutbury. Measures against retaining, giving liveries, extortion of bailiffs, subletting the king's lands, \&e. . XXVII. "A remembrance made" for the more speedy collection of the revenue and better administration of Crown lands

5 Dec. Halliwell's Letters, I. 151 (Translation). Richard III. to Leonard :de Prato. Permitting him to come to England for the visitation of the Order of St. John. [Harl. 438, f. 272 b.]

Dec. XXVIII. Preparations for defence. Instructions to commissioners appointed in every county to muster and review men for the king's service.

7 Dee. [Not printed. See 23 June 1485.] Proclamation against the earl of Richmond's adherents. [Harl. 493, f. 273 b.]

8 Dee. XXIX. Richard III. to the dean and ehapter of Salisbury. Recommending them to elect Langton bishop of St. David's as their bishop

1485. Halsted's Richard III., vol. ii. p. 560. In-

22. June. struetions to commissioners of array in every shire. [Harl. 433, f. 220.]

22 June. Ib. p. 562 . Letters to sheriffs to reside at their shire towns. [Ib. f. 220 b.]

23 June. Tb. p. 563 ; and Fenn's Letters, II. 318. Renewal of the proclamation of 7 Dec. preceding. [Imperfeet in MS. Harl. 433. f. 220 b.]

\section{HENRY VII.}

$1480^{\circ}$ ? I. Instructions to John Estrete, sent to the earl of Kildare to require his presence in England, the ling desiring to have his advice upon the government of Ireland . . . .

1486. App. B. No. I. Heads of an oration to be made

(circa) by the English ambassador at Rome to the pope and cardinals

1487? ILallizell's Letters, I. 171. Henry VII. to

13 May. the earl of Ormond on the landing of the rebels in Ireland. [Titus, B. xi. f. 24.] 
A.D. 1487.

5 July. II. Henry VII. to the Pope. Relates how one who had spoken slightingly of papal interdiets, emboldened by a false rumour of the king's defeat by the rebels, was visited by a divine judgment. Requests that the Irish bishops who faroured simnel may be exeommunicated.

24 Oet. Ryland's IIistory of Waterford, 26. Henry VII. to the city of Waterford. Letters of marque against the earl of Kildare and inhabitants of Dublin. [Lamb. MS. 632, f. 250].

App. A. No. IV. Lettel of the archbishop of Armagh

1.188. Stute Papers, vi. 9. Charles VIII. to Henry

:29 Aug. VII. Concerning the French victory at St. Aubin, and the death of Jord Scales, who, Charles is aware, left England without Henry's eonsent. [Rec. Off.]

149-93. App. A. No. I. The Lords of Ireland to Hemry VII. Urging that the earl of Kildare, who has been summoned to England, be allowed to remain in Ireland for the safety of the comntry .

App. A. No. II. Gerald earl of Kildare to Henry VII. On the subject of the preceding App. A. No. III. Desmond and others to Hemry VII. On the same subject
State Iupers, vi. 10. Anne duchess of Bri1490. Stute Pupers, vi. 10. Anme duchess of Bri-
2 May. tamy to the great master [lord Willoughby de Broke] and esquire of England. Concerning the insolent contempt of her anthority shown by Marshal de Riens. [Rec. Off.]

"3l July. M. p. 18. Same to same. [Rec. Off.]

1.5 Aug. III. Henry VII. to the Spanish eaptains in Britanny. Excuses their delaying to join the English forces

1491. IV. Henry VII. to the bishop of Durham. The

5 Feb. franchise of St. Cuthbert shall be respected in the matter of Sir Roluert Chamberlain's arrest

16 Nov. App. A. No. V. Agreement of Hemy VII. with the eart of Angus

1492. Dutt's Volumen Rerum Germenietrum, 502.

8 Feb. Henry VII. to the electors of Germany. Urging them tr take up arms against Chirles VIII. of France, who has redneed Britamy and earried off the duchess, though affianced to the king of the Romans. 
A.D. 1492.

8 Feb. Il. Henry VII. to the Pope. Expressing indignation against France on the grounds above mentioned. The French are trying to besiege Calais.

1493. Areleceol. XXVII., 199. Perkin Warbeck to 25 Aug. Isabella of Spain [MS. Egerton 616].

1493-5. App. B. No. II. Blyth's oration at Cambridge

1494. Ellis, First Ser., I. 19. Hemry VII. to Sir

$20 \mathrm{July}$. Gilbert Talbot. Desiring him to have four seore men at arms ready to resist any invasion in favour of Perkin Warbeck.

App. A. No. VI. Creation of Henry duke of York 386 Arehceologia, XXVII., 200. Instructions to Riehmond ling of arms, sent to Charles VIII. in answer to a message about Maximilian's support of Perkin Warbeck in Flanders, and Cliarles' intended expedition against Naples. [MS. Cott. Calig. D. vr. 18.]

1496. Archceol. XXVII. 205. Depositions of Ber14 March. nard de Vignolles tonching a plot of Sir John Kendal, prior of St. John's, and others. [MS. Cott. Calig. D. vi. 30.]

2 July. V. Petrus Carmelianus to Ferdinand and Isabella of Spain. Thinks it very desirable that the allianee so long treated for should be concluded Ellis, First Ser., 1. 22. Lord Bothwell to Henry VII. Tonching Perkin's reception by James IV. [Vespasian C. XVI. 164.]

8 sept. Il. p. 25. Same to same. On the same subject. [Vespas. C. xvi. 162.]

18 Oct. Archceol. XXVII. 182. Perkin Warbeck to Bernard De la Forsa. [Egerton, 616.]

1497. VT. The cardinal of Perugia to Henry VII. Re-

June. commending John de Giglis for promotion to the see of Worcester . . . . . 102

5 Jnly. VII. Fox's instruetions to treat with Scotland; to demand the delivery of Perkin Warbeek, \&c. . 104

5 Ang. Ilalliwell's Letters. I. 174. Henry VII. to the eity of Waterford, commending their loyalty in informing him of Warbeck's landing at Cork. \&c. [Lamb. MS. 682, f. 251.] 
A.D. 1497.

12 Sept. Ellis, First Ser. 1. 32. Henry VII. to Sir

Gilbert Talbot. Perkin has landed in Cornwall. Orders Sir Gilbert to be at Wood. stock without delay "with six score tall "men on horseback."

17 Sept. VIII. Sir Henry Wentworth to Sir William Calverley. News of Warbeck's landing in Cornwall

18 Sept. Ellis, First Ser. r. 36. The carl of Devonshire to Henry VII. Account of the siege of Excter by Warbeck.

20 Sept. Ellis, First Ser. I. 34. Henry VII. to the bishop of Bath and Wells. The siege of Exeter.

17 Oet. Halliwell's Letter's, I. 175. Henry VII. to the city of Waterford. Of Warbeck's attempt on Exeter, \&c. [Lamb. MS. 632, f. 251 b.]

23 Oct. Areheol. XXVIT. 209. Hemry VII. to De Pnebla. [Egerton 616.]

3 Dec. Wood's Royul and Itlust. Iadies, I. 114. Eliz. queen of Henry VII. to Isabella of Spain.

1498. App. B. No. III. Norroy's mission to James IV.

1499. App. B. No. IV. Despatches of Warham and Hatton relative to the commerce with the Netherlands . . . . . . .

15 June. IX. The cardinal of Sienua to Henry VII. On the promotion of Thomas Jane to the bishopric of Norwich. Rhodes threatened by the Turk, \&c.

15 June. X. Henry VII. to Ferdinand and Isabella. Thanking them for comprising England in their treaty with France

1 Ang. XI. Elizabeth queen of Henry VII. to Ferdinand II. of Spain. Recommending Henry Still, who desires to serve him against the Infidels

Sept. XVII. Private instrnetions to Sir Richard Guildford and Richard Hatton, to urge Erdmund De la Pole to return to England

[Date?] App. B. No. V. Instructions to Richmond king of arms scnt to Maximilian and Philip.

1500. XII. De Pnebla to Ferdinand and Isabella. The

11 Jan. tranquillity of England established; the Scotel marriage; the expected arrival of Catherine, \&c. 
20 June. XIII. Henry VII. to Ferdinand and Isabella. Is glad they have determined to send Catherine at the end of the summer . . . 119

24. Jnly. XIV. Same to same. Catherine's coming delayed till next summer. . . . . . 121

18 Dec. XV. Same to same. Requesting that Ayala be allowed to remain in England till Catherine come . . . . . .

1501. XVI. Henry VII. to Catherine of Arragon, wel-

[Oct.] coming her to England . . . .

1501-3. XVIIT. A statement coneerning Edmund De la Pole. Showing how he was indneed to leave England on the promise of Maximilian's assistance to obtain the Crown, \&c. . . . .

1501. XIX. Instruetions to Somerset and Warham sent to Maximilian to renew the league, promise assistance against the Turks, and see the English rebels banished. Proposed marriage of Henry duke of York and the arehduke's daughter. XX. Somerset and Warham to Henry VII. Negotiations with the imperial commissioners on the above subjects. Intercession made for Edmund De la Pole.

App. A. No. VII. Arrangements for the reception of Catherine of Arragon .

1502. Ellis, First Ser., I. 48. Henry VII. to the Pope. In answer to a brief desiring assistanee against the Turks. [Cleop. E. III, 150.]

12 May. XXI. Letters of Edmund De la Pole to Sir George Nevill, Killingworth, Bontemps, and Maximilian

Juno. Lettres de Rois, ed. by Champollion-Figeae, II., 511. (Collection de Doenments Inédits sur' l'Histoire de France.)--Matthew Baker to Henry VII. Proposed marriage of Henry prince of Wales to the sister of the count of Angouleme. Offer of Lewis XII. to procure the scizmre of De la Pole in Germany and his delivery to Henry VII. [MS. Cott. Calig. D. 1. 42.$]$

1503. XXII. Negotiations of Brandon and West with Maximilian at Antwerp. Ratification of the treaty. Interviews relative to Maximilian's receiving the Garter, his support of De la Pole and other English rebels, \&e. . 
A.D. 1503.

XXIII. Instructions to Wiltshire to keep the king informed of the movements of the rebels, to go through Germany with Norroy and see the league proclaimed, \&c. . . . . .

App. A. No. VIII. Norroy's instruction relative to Maximilian's receiving the Garter . . 417

XXIV. Depositions touching Edmund De la Pole . 220 225

$3 \mathrm{July}$. XXV. Warrant of Maximilian for a payment in behalf of Edmund De la Pole . . .

1503? XXVI. Flamank's information against Sir Hugh Conway, treasurer of Calais. Dangerous conversations about the succession . . .

1504. XXVIT. Ferdinand II. to Hemry VII. He sends 24 Nov. to De Puebla the bull of dispensation for the marriage of Henry and Catherine . .

1505. App. A. No. IX. Anon. to Killingworth (received

Jan. 5 Jan.) . . . . .

17 Mar. XXVIII. Silvester de Giglis bishop of Worcester to Henry VII. The Pope desires him to go to England with the dispensation for the marriage, a copy of which had been sent to Spain for the consolation of Queen Isabella on her deathbed.

XXX.-XXXIT. Edmund De la Pole to Thomas Killingworth and others . . . . $\quad 253-5-6$

Ellis, Thind Ser., I., 123-5, 130-140. The same (ten letters.)

XXXIIT. Richard De la Pole to his brother Ed. mund

6 July. XXXTV. Passport for Thomas Killingworth from the Schont of Amsterdam

28 July. XXXV. Edmund De la Pole to Paul Zachtlevent and other's. On his being delivered np by Gueldres into the hands of the king of Castile

1505? XXXVI. Killingworth to Edmme De la Pole. Concerning De la Pole's outfit, and debts of Perkin Warbeck to Paul Zachtlevent . .

1505. XXXVII. Griffon Bastard of Oyskerk to [Killing. 4. Aug. worth ?]. Their master is delivered into the hands of the dnke of Gneldres; but does not wish his servants to complain of it

24 Sept. XXXVIII. Stipulation for the ransom of Edmund De la Pole from the duke of Gueldres . . 269 
A.D. 1505 .

23 Oct. XXIX. Cardinal Hadrian de Corneto to Henry

VII. Had niged the Pope to punish the forgery of the bull of the bishop of St. David's, bnt understanding the king's wishes has interceded for the offender's. Extracts from letter's received by him from Polydore Vergil and John Hans on the subject.

17 Nov. XXXIX. Edmund The la Pole to the Bastard of Oyskerk

24: Nor. XT. Richard De la Pole to his brother Edmund. Impationce of Edmund's creditor's. Henry VII. has offered bribes to get Richard into his power.

27 Nov. XLI. Edmund De la Pole to Oyskerk and Killingworth . . .

1505? XLI. Sir George Nevill to Killingworth. Is

31 Dec. anxions to join Killingworth or have him.in his company at $\mathrm{Aix}$. . .

1506. Ellis, Third Ser. I. 129. Richard De la Pole

4. Jan. to his brother Edmmerd. Is in despair, secing that his lorother camnot relieve him.

24. Jan. XLIII. Fdmund De la Pole's commission to Killingworth and Griffith to treat for an adjustment of the differences between him and Henry VII.

28 Jan. XLVI. Edmund De la Pole's instructions to the above-named, to demand of Henry VIT. restitution of the dukedom of Suffolk and other conditions. . . .

9 April. XLV. Hemry prince of Wales to Philip king of Castile. In behalf of the princess Catherine's chamberlain, now going to Spain . .

27 May. XLVI. The knights of Rhodes to Henry VII. Nominating him Protector of their Order • 287

31 Ang. XLVII. Lewis XII. to Henry VII. Proposing that France and England should arljitrate between Castile and Gneldres. . .

16 Sept. XLVIII. Hemry VII. to Philip king of Castile. 289 As Inewis XIK. has offered to mediate between Philip and Charles of Gnelelres, adrises him to submit to the arbitration of England and France

14 Sept. XLIV. Maximilian to Henry VII. Letris XII. in violation of his oath has given his danghter in marriage to Francis duke of Valois. Maximilian therefore desires to arrange a marriage between Charles and Henry's daughter. 
A.D. 1506.

19 Sept. L. Maximilian to Henry VII. Acknowledging lettcrs from Henry of the 13 Ang. . .

20 Sept. LI. Maximilian to Henry VII. Has not been able to persuade his danghter to a match with Henry VII.; bnt will visit her to urge it .

15 Nov. LIT. Passport of the bishop of Liege to Thomas Killingworth • . • . .

1507. LIII. Richard De la Pole to the bishop of Liege. 14. April. Requesting preferment for Nich. de Haghe . 309 18 April. Ellis, Thive Ser. I. 141. Same to same. Thanking him for kindness shown in behalf of his brother. [Ree. Off.]

1507? LIV.-LVIII. Memorials of Killingworth to the Emperor tonching Edmund De la Pole 310-323

1507? LIX. Summary of the answer made to the English Ambassadors, on the part of Maximilian, tonching Henry VII.'s proposed marriage with Margaret of Savoy

May. LX. Henry VII. to Margaret of Savoy. Commer-
cial intercourse with the Low Countries, which had been interrupted by excessive tolls, to be renewed

LXI. Henry VII. to Lord Berghes, On the same subject

3 Sept. LXII. Henry VII. to Almaçan. Is about to send ambassadors to Ferdinand for a more intimate alliance.

29 Sept. LXIII. Henry VII. to Ferdinand II. Concerning an important communication made to him by De Puebla.

[Dec.] Henry VII. to the mayor and aldermen of London. Announcing the treaty for the marriage of Mary with the primce of Castile. [Titus, B. I. 5.]

1508. LXIV. James IV. to Henry VII. Requesting a

March. safe conduct for the bishop of Murray . .

[1508?] Chronicle of Calais, p. 52. Henry VII. to Sir

24 May. John Wiltshire. On the king's proposed marriage with Margaret of Savoy. [Vesp. C. vi. 309.]

1508. LXV. The Provost of Cassel to Margaret of Savoy. 14. June. Can get no promise of assistance from England against Gueldres . 
A.D. 1508.

$20 \mathrm{June}$. LXVI. Same to same. Reporting all interview with Hemry VII. on the subject of Gieldres and the Government of Castile

$29 \mathrm{July}$. LXVII. Same to same. Fear's a combination of England and France . . . . . 365

23 Aug. LXVIII. Henry VII. to the bishop of Gurk . 367 Oct.,Nov. App. B. No. VI. Wolsey's Negotiations in Flanders

7 Dec. LXIX. The Flemish ambassadors to Margaret of Savoy . . . . . 368

NOTE.

DE PUEBLA'S CIPHER, pp. 114, 115.

By the kindness of Mr. Bergenroth at Sinancas I am cnabled to present the reader with a key to the words in cipher in De Prebla's despatch of the 11 Jan. 1500.

Page.

114. declxxv., an error for decclxxy., nuestris alteras,-your highnesses.

115. mecxviijo., le fiju del Rey de los Romunos,-(Margaret) daughter of the King of the Romans.

, decccxxj., el Rey de Escocia,-the King of Scotland.

., moxxxix., Milan.

,, dec ${ }^{\circ} 1 \mathrm{xxx}^{\circ} \mathrm{j}$,, el Rey de Francia,-the King of France. 



\section{CORRIGENDA.}

Page 9, 1. 1t, alter ${ }^{5}$ to $i$ in referenee to foot note.

$72,1.4$, dele "said" repeated.

92, 1. 15, for "this" read "hiss."

95, 1. 9, dele comma after " potifiealesve."

$118,1.11$ of text and 1. 12 of translation, for "Pantales" reud

"Pantaleon."

$124,1.15$, for "sul" read " sus."

136 , marginal note, for " 5001 " iecel " 5000. ."

229 , last line of text, dele hyphen.

230, 1. 6, for "Reuntu" read "Renntu."

$327,1.2$ from bottom of text and of translation, for "Baenst" read

"Baeust." 



\title{
LETTERS AND PAPERS
}

\author{
ILLUSTRATIYE OF THE
}

REIGNS OF RICIIARD III. AND IIENRY VII. 



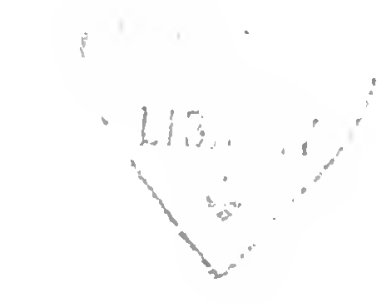

\section{LETTERS, ETC.}

I.

Funeral of Edward the Fourth.

[MIS. T. 7. f. 7. College of Arms.]

Here foloith the Ordenaunces which shalbe done in the observaunce at the deth and buryall of a annoynted king.

WHen that a king ammoynted ys deceassed, after his A.D. 1483. body spurged, it most be washed and clensed by a bishop $\Lambda$ pril. for his holy annoyntment. Then the body most be bamed, if it may be goton, and wraped in lawne or reynes, then hosen shertes and a pair of shone of redde lether, and do over hym his surcote of clothe, his cappe of estat over his hede, and then laie hym on a faire burde covered with clothe of gold, his one hand upon his bely, and a septur in the other hand, and on his face a kerchief, and so shewid to his nobles by the space of ij. days and more if the weder will it suffre. And when he may not goodly lenger endure, take hym away, and bowell hym and then eftsones bame hym, wrappe hym in raynes well trameled in cordis of silke, then in tartryne trameled, and then in velvet, and then in clothe of gold well trameled; then lede hym and coffre hym, and in his lede with hym a plait of his still, name and date of our, se. And if ye care hym, make a ymage like hym, clothed in a sureote with mantill of estat, the laices goodly lyeng on his bely, his septur in his hand, and his crown on his hede, and so carry him in a chair opon, 
A.D. 1483. with lightes, baner's, accompanyed with lordys and $\Lambda_{\text {pril. }}$ estates as the comnsaill can best devyse, havyng the liorse of that chair traped with dyvers trapers, or els with blacke trapers with seoehons richely beten, and his officers of armes abowt hym in his cottes of armes. And then a lord or a knyght with a courser traped of his armes upon hym, his salet or basnet on his hede crowned, a shilde and a spere tyll he come to his place of his entring. And at the masse the same to be offered by noble prinees.

But when that noble king, Edward the iij., was reeeased at Westminster in his palais, which was the $\mathrm{x}^{1}$ day of Aprell, the xxiij yere of his reigne, first the eorps was laide upon a burde, all naked saving he was covered from the navyll to the kneys, and so laie $x$, or xij ours that all the lordys bothe spirituall and temporall, then heing in London or nere ther abowt, and the majer of Lourlon with his brether sawe hym so lying. And then he was sered, and so brought into the cliapell on the molne after, wher were songon thre solempne masses; the first of Our Lady, the ijde of the Trenitie, the thrid of requiem (the which was songon by the bishop of Chechestre). And at after none ther were songon diriges and commendacions. And after that he had the holl savter said by his chapell; and at nyght well wached with nobles and other hiss servauntes, whose names appere in the wache roll, from the first nyght unto the tyme his $\left[\right.$ body $\left.^{2}\right]$ was buryed. And at the masse of reyuiem the lord Drere, the quenes chammberlain, offred for the quene; and the lordys temporall offrerl daily at the same masse, but the lordys spirituall offred not to the bishop but to the ligh anter, and other the kinses servantes offred also. This order was licpt in the palais

\footnotetext{
1 Fisward died on the 9th. The writer appears to have madic an frror of one day thronghont in his compatation of the days of the month.

$=0 \mathrm{~m}$. in MS
} 
viij dais, saving after the first lay ther was but one $\Lambda .1$. 1486. solempne masse wich alwais was songon by a bishop. April.

And on the Wednesday the xvij ${ }^{1}$ day of the moneth aforesaid, the corps was conveyed into the abbey, borne by divers knyghtes and esquiers at were for his bodye; that is to saie, Sir Edward Standley, Sir John Savage, Sir Thomas Worthley, Sir Thomas Mullineux, Wellys," John Cheyny, maister of the kinges horse, Water Hongerford, Guy of Wolston, John Sabacotes, 'Thomas Tyrell, John Riseley, Thomas Dacre, John Noreys, Boys de Brytaill, Christofer Colyns, having upon the corps a riche and a large clothe of gold with a crosse of wilite clothe of gold above, above that a riche camape of clothe imperiall fiynged with gold and blewe silk, borne by Sir Thomas Seintleger, Sir William AParre, comptroller, Sir John Assheley, and Sir William Stoner, knightes; and at every corner abancr, the first of the Trenite, the which was borne by Sir Henry Ferris, the seconde of Our Lady, borne by Sir Jamys Radcliff, the thrid of Saint George, borne by Sir George Browne, the iiij of Saint Edward borne by Sir Gilbert Debynham. And the lord Haward ${ }^{3}$ bare the kinges baner next before the corps amonges the officers of armes, wher was ordened a worthy herse, like as it apperteneth, having before hym a great procession, and the archibishop of Yorke, ${ }^{4}$ chancelor of England, the bishop of London, ${ }^{5}$ the bishop of Chestre, ${ }^{6}$ the bishop of Bathe, ${ }^{7}$ the bishop of Chechestre ${ }^{8}$ the bishop of Norwiche, ${ }^{3}$ the bishop of Durham, ${ }^{10}$ the bishop of Lyncolne, ${ }^{11}$ the

116 th. The 17 th was a Thursday.

- Christian name omitted.

3 Jolm IIoward, afterwards created duke of Norfolk by Richard III. on his accession.

'Thomas Scott or Rotherham.

5 Thomas Kemp.

"That is to say, of Coventry and Lichfield, Chester not being at that time a see. His name was John IIalse or IIales.

'Robert Stillington.

${ }^{s}$ Edward Story.

9 James Goldwell.

${ }^{10}$ Willian Dudley.

"John Russell, afterwards chancellor. 
A.1. 1483. bishop of Ely, the bishop of Rochestre, the abbot of April. Awendon, the abbot of Barmsey. Thise lordys foloed the corps and abowt the corps, being then ther the erle of Lincolne, ${ }^{3}$ the marques Dorset, ${ }^{4}$ the erle of Hintyndon, ${ }^{5}$ the vicecounte Barkley, ${ }^{6}$ the lord Standeley; stward, \&c., the lord Hastinges and the kinges chamberlain, the lord Dacre the queenes chammberlain, the lord Dudley, the lord of Burgenye, the lord Audeley, the lord Ferrys, ${ }^{8}$ the lord Lysley, ${ }^{9}$ the lord Morley, Sir Richard Wodvile, Sir Edward Wodvile, the lord Cobham, the lord Wellys, Sir John Bourser, Sir Thomas Bourser and Sir Thomas Bowser, of Barneys; which lordys were [in $]^{10}$ the herse that service, and on the morne also the service at Westmestre, was done by the archbishop of Yorke. And at the masse the abbot of Barmsey was dekon. Ancin that herse abowt the corps and the clothe of gold above said there was a personage like to the symilitude of the king in habet royall crowned with the crown oon his hede, holding in the one hand a septur, and in the other hand a ball of silver and gilt with a crosse pate. And after that the lordys that were within the herse and bishops had offied, the maier of London ${ }^{11}$ offred, next after hym the chief juges and other juges, and knyghtes of the kinges howse with the barons of the eschequier and aldermen of London, as the nyght weyned too. And when the masse was done, and all other solempnitie

\footnotetext{
'Tohn Morton, afterwards Cardinal Morton.

2 Edmund Auciley.

${ }^{3}$ John Dela Pole, son of Tohn duke of Suffolk by Elizabeth sister of Edward IV.

1 Thomas Grey, stepson of Elward IV.

${ }^{5}$ William ILerbert, created by Edward IV.

"William de Berkeley, created
}

by Ldwaxd IV.; afterwards cleated earl of Nottingham by Richard III.

'Thomas Stanley, created by Henry VII. earl of Derby.

$s$ Walter Devereux, lord Ferrers of Chartley.

"Edward Grey, second son of Edward lord Grey of Groby. He was created a viscount by Richard III., on his accession.

$10 \mathrm{Om}$. in Mis.

11 Edmund Shaw, goldsmith. 
and the lordys were redy for to ryde, ther was ordened A.n. 1483. a royall chair covered with hlacke velvet, having above April. that a blacke clothe of gold, with a white crosse of gold, under that a blacke magestie, clothe of sarsenet drawen with vj coursers traped with blacke velvet, with certein scochons beton upon sarcenet with fyne upon the fore horse, and the thil horse sat $\mathrm{ij}$ chariot men, and on the iiij other horse sat iiij hor'semen. On either sycle of the forsaid draught went dyvers knyghtes and esquiers for the body and other, summe leyng ther handes to the draught and somme leding the horse in tymo thei passed the townes. And the lord Haward, the kinges banerer, rode next befor the forhorse, bering the kinges baner upon a courser traper with blacke velvet with dyvers seochons of the kinges armes, with his noming hode upon his herle.

When the corps, with the personage as above, with procession of bishoppes in pontificulibus and the iiij order of freris, was conveyd to the chair, and in orter as above, to Charing, wher the bishoppes sensed the chair, and the lordys toke ther horses and so proceded to Syon that nyght, wher at the chirche dore the bishoppes sensed the corps, and the corps and the personage was borne as before into the quere, and ther the bishop of Durham dyd the service; and on the moru in like order as above he was conveyed to the chair, and from thens to Wyndesor, wher, at Eton, the lishop of Lincolne and the bishop of Ely, with the colege, met and sensed the corps; and so proceded to the eastell by the way at the brigge, and met the procession of Wyndesor at the eastell gate. Tharchibishop of Yorke and the bishop of Wynchestre sensed the corps, being ther with the bishop of Norwiche, the bishop of Duresme, the bishop of Rochestre, with the chanons of the colege and the kinges ehapell, and so proceded to the new chirche,

\footnotetext{
${ }^{1}$ Sic in MS.
} 
A.D. 1483. wher in the quere was ordened a mervehs well $\Lambda_{\text {pril. }}$ wrought herse, and furthwith dirige, and in the evening thei of the colage said the holl sawter. And ther was a great wache that nyght by great lordys, linyghtes, esquier's for the body, gentilmen usshers and other whose names ensue, dc. First, within the hor'se, the lord of Bungeyne, the lord Audeley, the lord Morley, the lord Lysley, the lord Haward, the lord Wellis, the lord Lawar, the lord FitzHugh, the lord Cobham, Sir John of Aiundell, Sir 'Thomas Bourser of Barneyse, knyghtes; withont the herse, Sir Thomas Seintleger, Sir Gilbert Debehim, Sir Herry Ferris, Sir Joln Savage, Sir Edward Standeley, Sir Thomas Wortley, Sir 'Thomas Mullineux, Sir William Parker, Sir William Stoner; essuiers for the body, John Cheyne, maister of the horse, Willian Barkley, William Odill, Robert Poyntz, Jolm Riseley, Lois de Biytails, Antonc Malyverer, John Sabacotes; gentilmen usshers, Willian Colynghorne, Edwad Hargill, Bassett," Nicholas Cromer; William Mydilton, Christofer Colyns, William Clifiord; officers of armes, Garter ${ }^{3}$ and Norrey ${ }^{4}$ kinges of armes, Glocestre, Ruigecrosse, Gynys, Harington puryvauntes; esquiers of howsehold, Thomas Mortymer, Dymmok," Redmell Delmmere, Edmond Gurgis; yemen usshers, William Riler, Roger Chelsall, George Cheyne, James Pemberton, with dyvers and many yemen of the crowne and of the chamber and howsehold which held torchies.

And on the moro after the commendacions began the masse of Our Lady songon ly the bishop of Duresme; at which masse Sir Thomas Bomser ofired the masse peny because their was no greatcr estat present, and after hym all other as were in the herse. After that masse was done began the masse of the Trenitie songon

1 Sic in MS.

"Christian name omitted.

John Wrythe.

' John Moore. 
by the bishop of Lincolne; at which masse therl of A.I. 1483. Huntyndon offred the masse peny, and after hym $\Lambda$ pril. other lordys and nobles as above. At the begyning of the masse of requiem, which was songon by the archbishop of Yorke, the officer's of armes went to the vestry, wher thei receyved a riche embrothered cote of almes, which Garter king of armes hold with a great reverence as he cowd with that at the hed of the herse tyll the oftring tyme. At which tyme, atter therl of Lyncohe had offred the masse penny, presented it to the marques Dorset and to therl of Huntyngdon, they offred it, and the said Garter receyved it again of the archbishop, and held it still at the high auter ende tyll the masse was done. Likewise in forme Clarencienx ${ }^{5}$ and Norrey ${ }^{2}$ kinges of armes received the shilde, and at offering tyme presented it to the lord Nialtravers and to the vicecounte Barkley. But ther was a question whether the somne and heier of an erle should go above a vicounte. And Marche and Yreland king of armes received a riche sword which had byn send from the Pope, and in likeforme behaved themself and presented to Sir John and Sir Thomas Bonrser the kinges amntes somnes. Also Chestre ${ }^{3}$ and Leicestre ${ }^{4}$ herauldys receyred a basnet of a riche crown of gold, and presenied it to the lord Hastinges. And Glocestre ${ }^{5}$ and Buckingham ${ }^{6}$ herauldes, with Ruigecrosse, Roseblache, Calais, Guynes, Barwike, and Harington, pursyvauntes, went [with] the knyghtes and esquiers for the body to the chirche dore for to receyve of Sir Joln Cheyny, maister of the horse, the man of ames, which was Sir. William APare, armed at all peees saving he was bareheded, laving an axe in his hand, the pomell doneward, and

\footnotetext{
1 Thomas Holme, afterwards Sir is mentioned by this name in Rich 'Thomas Holme.

2 John Moore.

${ }^{3}$ Thomas Whiting.

4 Probably Roger Machado, who ard III.'s time.

${ }^{5}$ Ric. Champney?

${ }^{6}$ Unknown.

${ }^{7} \mathrm{Om}$, in MS.
} 
A.D. 1483. thus companyed to the quere dore, wher he dyd alight. $\Lambda$ pril. And the decon toke the horse which was traped with a riche traper of the kinges armes, wher the lord Audeley and the lord Ferrys receyved the man of armes, and with the forsaid company of knyghtes and esquier's, herauldys and pursyvauntes, accompanyed him to his ofiring: which done, every lord in mornyng habet offied for hymself, and after that dyverse other noble knyglites officers, Sc. Incontynent that done, the lordes offred certein clothes of gold to the corps, everyche after lis degre or estat, that ys to saye, therl of Lincolne iiij by cause he was the kinges nevewe and some and heir of the dulie of Suffolk, the marques of Dorset iiij, the erle of Huntyngilon iij, the lord Maltravers $i j$, by that he was sonne and heier to the erle of Arundelle, the vicounte Barkley $\mathrm{jj}$; and every baron and other knyghtes morners by cause of nyghnes of blokle. I cannot order how they offred, by cause the prese of the people was soo great bytwene thom and me, but the lowest in estat or degre to the corps begane first. The names of the barons and knyghtes aforesaid; the lord Standeley, the lord Hastinges, the lord Audeley, the lord Burgeyne, the lord Dudley, the lord Ferris, the lord Fitz Hewe, the lord Delawar, the lord Morley, the lord Lysley, the lord Cobham, the lord Haward, the lord Wellys, the lord Nountjoye, Sir John of Arundell, Sir $\operatorname{Tom}^{1} * * *$

'IIrie the aceont is alrupty discontinued. 
II.

[1]arl. 4:3: f. 238.$]$

COPLES OF INSTRUCCIONS FURST AFTER TIE BEGTNAYNA of the Reigne of King Richard the Thrid, etc.

Trues be the articles of instruccions geven to the A.D. 1483. lord Nontjoie, mister Jobne Cooke, archi- 2s June. dekyn of Lincolne, and Sir Thomas Thwaytes, knightes, answering to the lettre of the lort Dynham, late direct unto the kinges grace als then Protector of England, which lettre resteth in iiij principalle poyntes.

ThE first article remembred the othe which they of The oath of Calais perteynyng to any of the thre juristiceions ther allegiance incontynent upon knawwlage of the deth of king Ed-V. ward the iiijth, whome God assoille, commen unto them, made holy togedyr upon a booke to be true unto king Edward the $\mathrm{v}^{\text {th }}$, his son, as their liege lord, and to kepe the towne, eastelle, and marchies of Calais iruly to him, and to suffre no man with power. to entre into the same, except the kinges persone or the lord Hastinges, then being the kinges lieutenant, and not without due payment to be made to the sonldiors and other oficers of alle that to theim shalle founde due for the sure kejing of the said towne and marches.

As to that article. It shalle move beside that how be it suche othe of ligeance was made sone upon the dethe of the said king Elward the iijutin to his sone, not onely at Calais but also in diver'se places in Eugland by many gree astates and personages, being than ignorant of the verraye sure and true title which oure soverayn lord that now is, king Richard the iijto, hath and had the same tyme to the coroune of England; That othe not withstinding now every good true not to be Englissheman is bounde upon knowlage had of the binding, 
A.D. 1483. said verraly true title to depart from the first othe so 2s June. jgnosantly gyven to hin to whom it apperteyner not, and theruyon to make his outhe of newe and owe his service and fidelite to him that good lawe, reason, and the concorde assent of the lordes and comons of the roy:umne have ordeigned to reigne upon the people, which is oure said soverayn lord king Richard the iijte, brother to the said king Erlward the iijth, late decessed, whome God pardone; whose sure and true title is the lords evidently shewed and declared in a bill of peticion

having

found

Richard

1II. the true heir to the throne. which the lordes spirituelx and temporelx and the commons of this land solemplye porrected unto the kinges highnes at London, the xxvjti day of Juyn. Whereupon the kinges said highnes, notably assisted by welle nere alle the lordes spirituelle and temporelle of this royaume, went the same day unto his palais of Westminster, and ther in suche roialle honorable appareilled within the gret halle ther, toke possession and declared his mynde that the same day he wold begyn to reigne upon his people; and from thens rode solemply to the cathedralle cherche of London, and was resseyved ther with procession with grete congratulacion and acelamacion of alle the people in every place and by the weye that the king was in that day. The copy of the whiche bille the king will to be sent unto Calais, and ther to be redd and understanded, togeder with thise presentes. Desiring right effectuously alle maner persones of the said thre jurisdiccions what astate, degre, or condicion that they be of, and also them of Guysnes and Hammes, to make their feithes and othes to him as to thair soverayn lorde, like as the lordes spirituelx and temporels, and many other noble men in gret nombre being in Englind, frely and of goode herte have done for their partes. And that the said towne of Calais, alle castelles and forteresses being within the said marches they wille sanfly kepe unto the behoove of oure said soverayn lord king Richard the 
iijde, and them not to deliver to any persone but by A.D. 148s. his eommaundement onely.

The seeond article comprised in the lettre of the said Iow lord Dynham concerned a peticion made by him in the grantecs names of him selif and other which do thair daly holders are servises at Cialais, that they might not be hurted loy affected hy any act to be made in the parliament which they of the thought then shold have holde, or in any other wise, uppon any grauntes of offices, fermes, landes, fees, or privileges to them made, as wele within Fngland as within the said towne and marches, but that they might enyoie alle suche possessions and grauntes as they had at the tyme of the clecesse of the saicl king Edward the iiijth, and that wayes may be founde that good assired payment may be had and contynued for the ordinarie nombre of the souldiors of the said towne and marches as it hath bene hiderto.

To that it may be said that the king wolle make to be into be serched in his recordes and elleswhere the tronth quiredinto. may be best knawen, what direccions have be taken in like case of change by the linges that have [been $]^{1}$ before, latting the same lord Dynham and alle they of his company to wit, that his grace wolle considre the gode and feithfulle scrvices that they have clone ther, and see that every persone be allowed and rewarded according to his merites, in as good maner and forme as any suche like persones have be seeyn to by any of the kinges noble anncestres in yores past, his prerogatif and dignite roialle alweys saved.

The iijde article remembreth the crewe of souldiors Pay of the which be now bothe at Calais, Guysnes, and Hammes, garrisons. and how they have hiderto be paied monethly; and how dangerous it were for the suerte of the towne, if the saicl crewe shuld either faille in their nomber or in the maner of their said payment, sce. 
A.D. 1483. Therto the king wolle it be said, that his highnes 28 . Tune. considereth wele the weight of that article, and that therto he trusteth ther shalbe no lak in him as touching thentreting togeder of the said crewe, and the monethly payment of their wages. For his grace maketh daily provision therfore, like as within short tyme they shalbe therof largely acertayned. And than his entent is that none of the said souldiors, either of the crewe or of the ordenarye shalbe discharged or put out of wages without true contentacion and payment of the same.

Compensa- As for the iiijth and last articlue, wherin the said tion for lord Dynham besecheth the kinges grace to liave con-
lands lands
flooded by sideracion to the gret losses that diverse persones ther order of lave susteyned by latting in of the salt water, and IV: for the therby drownyng of much land to them belonging, defence of lyeng nigh the towne of Calais, which drownyng Calais. was made by the commanndement of the ling that dede is for the suerte of the said towne, and desiring therfore, that the said persones may have somme resonable recompense for their said hurtes, either there or ellestwhere.

The king thinketh that desire resonable, and is content that the said Lord Dynham sue for alle and everiche of the said persones so hurted, shewyng the certaynte of every mannys hurt in that behalve, wherin his highmes wolle provide suche convenient recompense as of reason they shalbe content with.

oficers to Memorandum, that the kinges highnes is pleased

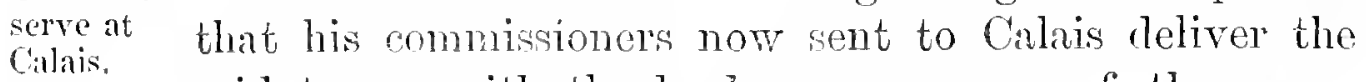
said towne, with the hool gouvernannce of the same, to the hord Dynham, as to the kinges depute there, he so to concynue during the linges pleasure.

Ttem, that Sir Humfrey Talbot, marsshalle, John Foskewe, maister porter, Adryan Whitell, comntroller,

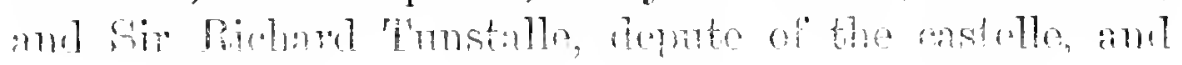


Sir John Dunn, depute of the toure of Risbank, con-A.D. 1483. tynue in their offices during the kinges pleasure. 28 June.

Item, that they put Sir Thomas Thwaytes in thoffice of tresorership of Calais, and discharge William Slyfeld of the same of pice

Item, that William Roosse, vitailler of Calais, contynue in his office.

Item, that Sir John Blunte, knighte, lord Mountjoie, be put in possession of lientenantcy of Guysnes, anrl Sir Rauff Hastinges discharged of the same.

Item, that Jamys Blunt contynue lieutenant of the castelle of Hames.

Item, that the said commissioners take a vewe of the nombre of the crewe, and also to take a verre of the artillerie and habilimentes of werre of Calaise, Guysnes, and Hammes, and to bring writing therof to the king.

Item, to appoynte with Sir Rauff Hastinges, on the kinges behalve; that he shalle peasibly have, occupie, and enyoie alle such offices, landes, possessions, and other goodes meveable, as he hath in those parties there; and also to treate and appoynte with him for alle suche stuff and habiliments of werre as he hathe ordeyned for the defence of the castelle of Guysnes.

\section{By the King.}

Trusty, etc. And wolle and desire you that yc yeve full feith and credence to our trusty servantes Robert Bradboury, Robert Allerton, Hugh Bago, and Thrustayn Hatefelde, in suche thinges and newes as we have commaunded thaym to sherve unto you on oure behalve; which by you herd we pray you to disclose to sinche of oure subgrettes as be uncler your rule in our castelle ther, as by your wisclome shalbe thought most according. And of their disposicions, which we trust verraily wolbe with oure pleasure, we desire you furthwith in alle hast possible to accertayn oure righte trusty and wolbolured the lord Mombioie, Sir Thomas 
A.D. 1483. Thwaytes, and mister John Cooke, oure commissioners 28 June.

at Dover; whome we have carged there to abide your answere, and that had, to addresse them orer mo you, fully instructed of our ferther mynde and pleasure in every thing concernyng the same. Faille ye not the premisses, as ye woll do us specialle pleasure. Yoven under oure signet at our cite of London, the xxriij ${ }^{\text {ti day }}$ of Juyn.

To Sir Rauff Hastinges, knight,

lieutenant of our eastelle of Guysnes.

III.

[MS. Harl., 433, f., 239 b.]

Copie ol Prociamacions made afore tile Coro-

July. NACION RICARDI IIICi.

For preser- Richarn, lyy the grace of God, king of England and vation of peace. of France and lord of Ireland, straitly chargeth and commandeth, undre peyn of deth, that noo manere of personne, of what estate, degre or condicion soever he bee, for old or new quarel, rancor, or malice, make any chalenge or affray, nor roble or dispoille any personne, nor breke any saintunies, wherthurgh his peax shalbee broken, or any sedicion or distourbance of his said peax shall happenne, within this his citie of London or any place therunto adjoynyng. And in cas peradventure that any mysrewled or mysadvised personne attempte to do the contrary, our said souverain lord chargeth that noon othre personne for familiarite, affeccion, or othre cause, yeve help or assistence to the personne soo offending, bot that every personne, being present at the place and tyme of suche offense doon, put hym in his ntermost devoir that the persome soo offending bee bronghte and clelivered to the maire of the said eitie of London for lis framelise, or to the stieward of the kinges houshold within the precincte of the yerde, as the caas shal reguire, hy thaym 
snerly to bee kept unto the tyme the kinges highnesse, $\Lambda \mathrm{D} .1483$. certified of the manere of thoffense, shewe unto thaym July. his mynde and pleasure what forthre shalbee doon in that behalve.

And also our said soverain lord, considring how it $A$ liens to is unto hym and this his land both honourable and amicably proffitable that straungers and aliens, being at this tyme within the said citie and places therunto adjoynyng, upon the trust of amitie, confederacions, or treuxes, bee peasibly and laufully entreated, chargeth therfor and commanndeth under peyn of deth that noo manere persone make any quarel or unlawfully doo any bodily harme or hurt to any of the said estranngers or aliens, nor roblue or dispoille any of thaym in thair goodes or eatailles in any wise.

And over this, our said souverain loid straitly Lodgings chargeth and commaundeth, that no manere of nian, to be alupon peyn of emprisomment at lis pleasure, take any the king's manere of loging within the citie of London or sub. harbingers urbes of the same, or other places nygh adjoynyng, bot by thappointement and assignation of suche herhigeour or herbigeours as by the kinges highnesse shalbee appointed.

And to thentent that peax and transquillite amonges No man to his people may bee rathre kept ard had, and thoccasion be abroad of breche of the same duely remoeved, our said son-night.

verain lord straitly chargeth and commaundeth that every man bee in his loging by $x$. of the elok in the nyght, and that noo personne othre than such that his lighnesse lath licenced or shal licence within the franchise of the said citie or in places therunto nygh aljoynyng, bere any manere of wepon such as has been underwriten; that is to say, glayves, billes, long debeofes, long or short swerdes and buklers, under. peyn of forfaitur and losyng of the same and emprisomment of hym or thaym that soo offendeth, to cndure at the kinges pleasure. 
A.D. 1483 . IV.

July.

Negotiation for the restitution of French prizes.

[MS. Harl. 433. f. 240.]

Instruccions geven to Thomas Grafton, merchaunt of the staple, and to William Laverok, sent by the king to Boloigne to have communicacion with the lord Cordes or his deputees or deputee for disaresting and restitucion of two shippes perteynyng to the lord Cordes within the haven of Sandewiche, and other in the West Contre pertenyng to other Frenshemen, if they be asked of the partie, and of many other shippes and goodes pertenyng to divers Englisshemen arrested in the parties of Fraunce on the other partie.

Finst, the shall see and understande what power any suche deputees or deputee of the said lord Cordes will shewe; and therupon, if any suche be had sufficient forto trete and appoynt in this mater, they shalle, by rertue of the kinges comission to them delivered entre communicacion therupon, which may be suche as foloweth. That is to say, that how be it upon a spoille of an Englisship afore Boloigne doon Restitution by Frenshemen to the gret hurt and prejudice of cerof two Freneh ships arrested intended by Edward IV. tain Englisshe merehauntes, the said two shippes were put under arrest at Sondewich at the sute and instaunce of the same merchauntes (for the which the restitucion of the same shippes was delayed at the tyme that the servantes of the said lord Cordes demaunded it in England of the King that is decessed, whome God pardone): vit so it was that the same King afore his dethe was in full purpos and mynde to have entended the said restitucion demannded, so that his subgettes, their shippes and goodes for that cause arrested in Fraunce might be also delivered and 
restored, and therfore willed that my lord Dynham A.D. 1483. shuld assaie some practik therin and fele the mynde July. of the said lord Cordes, like as the king is enformed that he hath done, and brought it to this poynt, that it pleased the said lord Cordes to write unto him his lettres of the date of the xxvijti day of May at Hesdin. By the which it appereth that upon the sending of eny persones of this partie to Boloigne ayenst any certain day to be appoincted to speke of the meanes of the said restitucion to be made, the said lord Cordes therof before advertised woll send his commissioners thider ayenst the same day to procede summarily in the same mater, like as in the said Commislettres, wherof ther is a copie redy to be shewed, powered to more plainly it is expressed. And forasmoche as the treat with said lord Cordes asketh in his said lettres not onely those of the restitucion of his shippes but also satisfaccion of his Querdes. damages and interesse, \&c., they shall fele to what summe the said damages and interesses woll amounte, and insist for the moderacion thereof asmoche as they can. And when they have brought it as lawe as they may, shewing and allegging the gret damages and interesse whiche Englisshemen have borne and sustened by prinse and arrestes committed by the Frensshe partie ayenst them, shall assent that the said ij shippes with asmoche appareill as was in theim at the tyme of the arrest (and, where any therof is lost, other as goor to be purveied therfore), shalbe restored by a certayn day to be appoincted, suche as within the which the said shippes may be wele rigged; provided and assented by the said lord Cordes or his deputees, how and by what day the persones, shippes and goodes of the realme of England taken and arrested in the realme of Fraunce shalbe delivered. In practesing wherof they shall, by as good discrecion as they can, insiste to have good suertee for the same deliveraunce, and within how nany dayes after the restitncion the 
A.D. 1483. said ij shippes pertenyng to the said lord Cordes, the July. said generall restitucion for Frensshe partie shalbe made. And therupon, if it be asked, the said ij shippes of France arrested in the west contre shalbe promised and assured to be delivered. And as for other prises and takinges uppon the see of either partie, of England and of Frannce, they shall speke that ther may be a diete appoincted betwene bothe kinges for reformacion of alle attemptates, to be entended at more leyser, that the truex that yet endureth may be wele observed herafter. In alle which matiers, they shalle do pass, write and sealle, with the said lord Cordes or his deputees under suche forme and maner as they can best fynde them agreable unto according to thentent before specified. And if nede be, they shalle apoincte an other diete for thexecucion of the premisses or any part therof, certefying from tyme to tyme with alle diligence the linges counsaill of suche defficultes and novelties as they shall happe to finde in any of the premisses.

I.etter of the Sieur Des Querdes.

Monsieur de Draman, je me recommande a vous. Jay recen voz lettres ou mescriprez la response dunes lettres que pieça vous ay escript par Calais, aftin dappaiser les questions et arrests par moy faiz sur les subgetz du roy Dangleterre. Et ensuivant ce que je vous ay escript, quant nos navires, dommages, et interestz mo seront rendouz je serray prest de faire lever la main

\section{Transhation.}

Mr Lord Drandu, I commend myself te you. I have received your letters in which yon write to me, in answer to a letter which I long ago wrote to you ly Calais [pursuivant] in order to set at rest the disputes and arrests mate by me upon the subjects of the king of England. And, in aceordance with what I wrote to you, when our ships, losses, and injuries are restored to me, I shall be ready to remove my hand from 
de tous les arrestz que a ceste cause jay fait faire; et veul $\Lambda .1$ ). 1483 . bien commetere ancun a Boullongne pour avoir adviz et July. communicacion avecques ceulx que y vouldrez envoyer, aftin cle regarder les moyens comment ceste restitucion de mesdicts navires se devra faire, et aussi la main levee desdicts arrestz. Ft quant vous vouldrez aller sommerement en ceste matiere, vous ne trouverez de ma part point de delaye en ce qui serra appointe parles deputez de vostre part et de la menne. Et pourrez prendre jour pour faire trouver vos gens audict Boulone, et le faire savoir a mon lieutenant audict lieu pour men advertier, et les mens se y trouveront. Esperant que ceste chose puisse prendre briefve fyne. Et a tant, Monsieur de Dynham, je prye nostre Seigneur quil vous ait en Sa saincte garde. Escript a Hesdin le xxvije jour le May.

$$
\text { (Ainsi signe) Le bien vostre, }
$$

PHE. DE C.

A Mons. de Dynham, Lieutenant de Calays.

all the arrests that I have caused to be made on this accomt; and I will commission some one at Boulogne to have alvice and communication with those whom you propose to send thither, in order to consider the means how this restitution of my said ships is to be made, and also the release of the said arrests. And if you would proceed promptly in this matter, you shall not find any delay on my part in that which shall be arranged by the deputies of your side and my own. You may choose a day for your people to he at Boulogne aforesid, and intimate it to my lientenant at the said place, that he may let me know, and my people shall be there. IIoping that this affair may speedily be lrought to a conchusion. And so, my lord Dynham, I pray our Lord to have you in His holy keeping. Written at Hesdin, the 27 th day of May.

Wholly yours,

'To Lord Dynham, (Higned) PH[HWP]E DE C [ORDES.]

Lientemant of Cinlitis. 
A.D. 1483. July.
V.

Overture to Britanyy for mutual Redress.

Instruccions geven to doctor Thomas Huton upon the lettre of credence which he shall deliver to the duc of Britaine on the behalve of the kinges highnes.

Finst, after recomendacions and reverences according, he shall shewe unto the said duc or to his counsaill the good wille and purpos that the king and the nobles of this lande have and bere unto the duc and his subgettes, according to suche convencions as have be made betwene the king our late soverayn lord decessed and the said duc.

Item, that how he it upon the hasty departyng of the said king out of this worlde diverse folkes of simple disposicion, peraventure supposing that the peas had be expired by the deth of the said king, felle to prinses and takinges upon the see, the oo partie ayenst the oder, to the gret trouble and hinderannce of thentercours and fete of merchandises exereised by the subDiet pro- gettes of both the sides. Yet it is thought that by posed. meane of a diete to be sette betwene bothe princes a full reformacion of alle attemptates may wele be had; wherunto the king and the counsaille of England wilbe wele disposed, so that the dne wille for his part be of the same disposicion. And as touch. ing certain persones of Britan which have macle long sute in England, and yet be not recompensed according to suche direccions as the king decensel toke with then in his lyff, he naty say that their recompense inust growe of the goodes and tresoure 
belonging to the said king decessed, whereof as yet A.D. 1483. no man hath takyn alminystracion. And assone as July. administracion shalbe committed to suche persones as wolle take the charge upon them, the dukes said subgettes shalbe paied and contented with the first creditoures.

Item, in commmicacion to be ferther had upon the premisses, and namely tonching the sairl diete, he shall move, speke and accorte upon a certain tyme and place, when and where the commissaries and compleynamtes of bothe parties may assemble, so that i sufficiaunt and resonable warnyng therupon be had afore, provided that the place be in England and no where elles.

Item, he shall fele and understand the mynde and disposicion of the duc anempst Sir Edward Worlevile and his reteignue, practizing by all neanes to lim possible to enserche and knowe if ther he entended eny enterprise ont of land upon any part of this realme, certifieng with all diligence all the newes ant disposicion ther from tyme to tyme.

\section{$V I$ 。}

\section{Relations with Spain.}

[MS. Iarl. 433, f. 241.]

Instruccons geven by the king to Barnard de la Forssa to be shewed and opened to the kinges cousyns, the king and quene of Castelle.

Finst, after the presentacion of the kinges lettres to his said comsyns with recomendacions in suche case accustumed, lie shall shere and rementre the said king of the tendre love, trust, and efleccion that the king 
A.D. 1483. oure brother now decessed (whome God pardon) had July. and bare towardes his said cousyns, latting them wit that his highnes is and evere entendeth to be of like disposicion towardes them in alle thinges that he may conveniently doo to their honnor and pleasure. And in likewise by alle meanes convenient the said Barnard shalle shewe that the king trusteth that his said cousyns wolbe of like benevolence and disposicion towardes him.

Diet And where in the yere last passed the kinges said agreed to brother sent his ambassiate to his said consyns for diverse IV., and mater's then not fully concluded, and amonges other Ferdinand for thentreteignyng of the peas, ligne, and amyte passed bella. and concluded betwixt lis highnes and Henry late king of Castelle, against which many attemptates have be and daily be committed; whereof, if due reformacion were not had, the said peax, ligue, and amite cowd nut long contynue: it was therfore appoynted and concluded with his said cousyns to have had a diette in Spayn at Midsomer then next following, or afor, to the which the kinges said brother was fully agreed.

But for asmoche as it pleased Almighti God to call him out of this miserable worlde unto his mercy afore the tyme appoynted for the said diette; after whose lecesse no gret maters might conveniently be appointed afore the king corouacion and ordering of his realme:

The sail Barnard shall, for that and other causes suche as shalle best serve after his discrecion, excuse the tarying of comyssioners that shuld have come to that diette, and, by the auctorite and power to the said A new day Barnard comitted by the kinges comission, agree and to be appoynte ${ }^{1}$ with the kinges saill cousyns or their commissioners to a new day of meting for reformacion of the said attemptates, suche as shall pleas the kinges cousyns aforesaid.

1 appoynted, MS. 
And that the said Barnard after thappoyntmentes of A.D. 1483. a day of meeting soo agreed, in alle goodly hast acertain the king and his counsell of the same, to thentent that commissioners may be sent thider sufticiently instructe and auctorized for due reformacion of the siaid attemptates to be had and made of their partie.

\section{VII}

\section{Lewis XI. To Richard III.}

[MS. IIarl. 433, f. 236 b.]

Monsieur mon cousin,-Jay ven les lettres que mavez escriptez par vostre herault Blane Sanglier, et vous mercye des nouvelles que mavais fait savoir. Et se je vous puis fair quelque service je le feray de tresbon cueur, car je vueil been avoir vostre amytie. E a Dieu, monsieur mon cousin. Escript aux Montilz lez Tours, le $\mathrm{xxi}^{\text {me }}$ jour de Juillet.

\section{LoYs.}

Villechar'tre.

\section{Trixshation.}

Mr lord and consin:-- I have seen the letters that you have written to me by your herahl Blane Sanglier, and thank you for the news of which you have apprised me. And if I ean do you any service I will do it with very good will, for I desire to have your friendship. And farewell, my lord and consin. Written at Montilz lez Tours, the 21 st day of July. LEwis.

Villechartre. 
A.D. 1483 . $30 \mathrm{July}$.

\section{VIII.}

\section{Philip of Austria to Richard III.}

[MS. IIarl., 433 f. 236 b.]

Demanding redress for acts of piracy and murder.

Treshault et trespuissant prince, treshonnoure sicur et cousin, je me recommande a vous, tant comme je puis. Et vous plaise savoir, treshanlt et trespuissant prince, treshonnoure sieur et cousin, que pluseurs plaintes et doleances mont este faictes par mes subges de cestui mon pays et conte de Flandres dez prinses qui journellement se font sur mer par lez subges de vostre royanme, en quoy pluseurs de mesdits subgets, tant de mez villes de Neuport, Ostende, Dunkerke et antres ont este tresgrandement et excessivement interessez et adommagies, en tant que par ceulx de vostre dit royaume, qui se tiennent atout pluseurs navires sur mer, ilz ont este prins et destroussez; et leurs biens, marchandises, et navires vendus et butinez en icellui vostre royaume comme biens dennemis. Et que plus

\section{'Iraxsmation.}

Most high and mighty prince, most honored lord and consin, I commend me to you as much as I may. And please it you to know, most high and mighty prince, most honored lord and consin, that many complaints and grievances lave been marle to me lyy my suljects of this my country and eartdom of Flanders of the seizures daily made at seth lay the suljecets of your kingdom, wherein several of my sind suljects, als well of my towns of Nenport, Ostemk. Dunkirk, an ofhers, hare been rety greatly and excessively wronged and injured, in as much ats they have been taken and plundered by those of your realn, who kece always

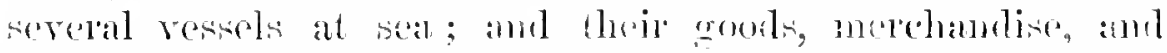

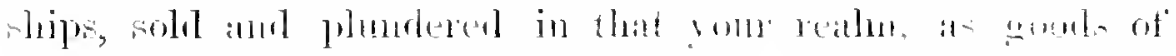
enemies. Ant, what is more serental of my sait subjects 
est, les pluseurs de mesdits subges ont este gettez A.D. 1483. outre bort et inhumainement mis a mort. Lesquelz exploiz, qui sont exploiz de guerre et dennemis, ont desja este contynuez par trois moys et plus, en venant parce directement contre lentrecours dela marchandise qui est entre vostre royaume et les subges ${ }^{1}$ dicellui dunepart, et mez pays, seignemries, et subges dautre. Duquel entrecours ceulx de vostredit royaume ont joy et joyssent soubz moy et sont en tous leurs negoces et affaires traicties en toute raison et justice. Neantmoins mesdits subges ainsi arlommagies et interessez, quelque poursuite quilz ont faicte devers vous, nont ${ }^{2}$ peu avoir ne obtenir restitucion diceulx leurs damages et biens ainsi a eulx prins. Et, que plus est, iceulx adommagies et autres mes subges qui frequentent la mer en la pescherie dez harencs et autrement warchandament mont raporte que lez navires de gutere de vostredit royaume estans en mer se

have been thrown orerboard and cruelly put to deatl. Which acts, being aets of war and of enemies, have already been continued for three monthis and more, in direct contravention of the treaty of merehandise which exists between your realm and subjects on the one side, and my countries, lordships, and subjects on the other; of which treaty, those of your said reahn enjoy the benefit under me and are treated in all their affairs according to reason and justice. Nevertheless, my suljects this wronged and injured, whoterer suit they have male towads you, have not been able to olitain restitution of those their danages and goods thes taken. Ant, moreover, those thus injured and others my sul. jeets who frequent the sea in the herring fishery and other. mercantile traflic, have reported to me that the ressed of war of your sail realu, being on the real, vamt that they

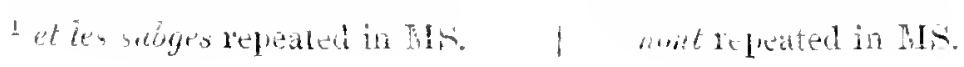


A.D. 1483. vantent de continuer de plus en plus sur eulx lesdits $30 \mathrm{July}$. exploiz de guerre, et en tout cas lez traictier comme ennemis; en me requerant sur letout lez pourveoir au bien et a la seurte deulx et tellement quilz puissent paisiblement frequenter et hanter la mer. Et pource, treshault et trespuissant prince, treshonuoure sieur et cousin, comme de ma part jay entretenu et fait entretenir ledit entrecours dela marchandise envers ceulx de vostredit royaume et que entre vous et moy na aucune canse ne occasion de guerre, mais tonte amitie et bonne intelligence de mon coste, rescrips pardever's vous par ladvis deceulx de mon sang et dez autres de mon grant conseil ordonnez lez moy. Et vous prie et requiers tant acertes et effectueusement comme faire puis, que en entretenant ledit entrecours dela marchandise qui sera le commun bien de vostredit royaume et de mesdits pays, vous vueillies faire cesser et deporter lez gens de guerre de cellui vostre royaume estans sur mer de plus faire ancuns exploiz de guerre sur mez sulyges de mondit pays de Flandres, ains

will continue more and more against them the said deeds of war, and in all cases treat them as enemies; reguiring me, all things considered, to provide for their good and safety so that they may peaceably frequent the sea. Wherefore, most high and mighty prince, most honored lord and consin, ats on my part I have kept, and cansed to be kept, the said treaty of merchandise towards those of your sad kingdom, and as between you and me there is no callec or occasion of war, but all amity and good understanding on my side, I wite to you by the advice of those of my kin and the others of my great comncil appointed to be alout me, and pray amb repuest you as truly and affectionately as I ean, that in keephing the said treaty of merchandise, which will be for the eommon weal

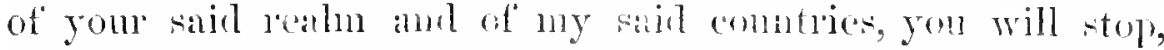
and camse to be lemoved the men of wall of yome satil

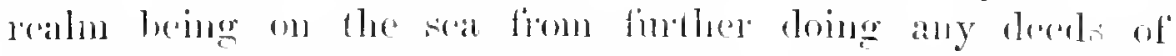

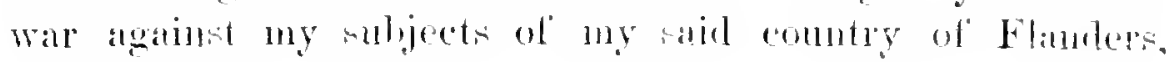


lez souffrir et parmectre paisiblement hanter et A.D. 148 . frequenter la mer en leurs negoces et marchandises et 30 July. aussi en vostredit royaume sans lez prendre ne leur faire aucun desplaisir en corps ne en biens, tontainsi que jay fait, et que vouldriez que je feisse doresenavant a voz subges hantans et frequentans mondit pays de Flandres; et avecque ce faire rendre et restituer a iceulx mez subges adommagies leurs biens, navires, et marchandises qui leur ont este prins et destroussez sur mer par cenlx de vostredit royaume, comme raison est, et que selon le dit entrecours faire se doit, et tellement que de raison ilz aient cause de eulx tenir contens. Et pourtant que ceste matierc est fort a cueur a mesdits subges jenvoye devers vous Replemonde portem de cestes, mon officier darmes, pour vous soliciter et me reporter vostre response; vous priant et requerant, comme dessus, vouloir faire ce que dit est. En quoy faisant me ferez chose tresagreable. Et sil y a chose que pour vous faire puisse,

and allow them peaceably to frequent the sea in their husiness and merchandise, and likewise in your said realm, without taking them or doing them any injury in body or goods, even as I lave done, and as you would wish that I should do lenceformard to your subjects frequenting my sald conntry of Flanders; and, moreover, cause to be restored to those my suljects aporieved their goods, ships, and merchandise which have been taken and plundered from them on the sea by those of your said realm, as reason is and according to the treaty should be done, and so as of reason they have canse to be satisfied. And lecause this matter much concerns my said sulpjects I send towats you Replemonde, bearer of these, my officer of arms, to solicit you and hing me hack your answer ; praying and requesting you, as above, that you will do what is aforesaid, wherein you will do me a singular pleasure. And if there be anything which I can do for 
A.D. 1483. en le me signifiant je lacompliray de bon cueur, 30 July. aydant nostre Seigneur, qui vous, treshault et trespuissant prince, treshonnoure sieur et cousin, vous ait en Sa garde.

Escript en ma ville de Gand, le penultime jour de Juillet, lan iiij ${ }^{\mathrm{x}_{\mathrm{x}}}$ et troys.

Vostre cousin,

Philippe Dostrice, duc de Bourgogne, de Brabant, de Lembourg, et de Luxembourg, conte de Flandres, de Haynnau, de Hollande, de Zellande, et de Namur.

DE BEER.

A treshault et trespuissant prince, treshonnoure sieur et cousin, le roy Dangleterre.

you, on your signifying it to me, I will perform it with good will, with the help of ow Lord, whom I pray, most high and mighty prince, \&e., to have yon in His kecping. Written in my town of Ghent, the penult day of July, the year' ' 33.

Yonr cousin,

Pincte of Austria, duke of Burgmily, Brabant, Lembourg and Luxembom's, connt of Flimders, Hainanlt, Holland, Zealand, and Namm.

To the most high and nighty prince,

DE BERR. most honores lord and cousin, the king of England. 
IX.

A.D. 1483.

8 Aug.

Message of Queen Isabella of Castile.

[MS. Harl. 433, f. 235.]

Es quæ ego, Graufidius de Sasiola, indignus atque humilis orator serenissima atque potentissine domince reginæ Ispaniarum, supremæe dominæe meæ, virtute credentiarum serenitatis sure dixi, affirmavi, et promisi illustrissimo atque potentissimo principi Anglia, etc., regi, coram dominis de consilio suo, in die, mense, et anno infrascriptis, in villa de Warrewic, sunt qua sequintur.

In primis enim dixi quod intentio, voluntas, et pro- Desires positum deliberatum dicte serenissimæ dominæ reginæ, England, supremie domina mere, est habere bonam et firmam pacem cum dicto illustrissimo rege Anglixe, et cum subditis terris et dominiis suis et integraliter cum toto regno. suo.

Et subsequenter, est de mente et intentione dictie supreme dominie mea reginæe denuo facere, inire, et firmare cum dicto domino rege bonas et firmas ligas, confoederationes, êt alligantias, ut sint initi, alligati, et confarderati firma liga confoederationeque optima adinvicem se couhunanda tanquam boni et fideles cognati et confoederati.

Et subsequenter, virtute dictarum credentiarum ex $\underset{\text { ready to }}{\text { and is }}$ parte dicta serenissimæ dominæ reginæ, supremæ domina give asmere, dixi et promisi, quod si dictus dominus rex Angliee sistance velit movere guerram contra regem Lodowicum Francize Lewis XI. ad recuperandas terras, dominia, et possessiones suas quie sunt de pertinentibus coronse Angliae, quod dictar domina regina dabit dicto domino regi, gentibus et capitaneis suis, omnes portus suos maritimos liberos et 
A.D. 1483. securos, et victualia et arma necessaria in bono foro 8 August. et pretio, et per mare naves suas armatas pro justis stipendiis.

Item, per terram, si opus fucrit, milites et equestres, viros fortes optimeque munitos, et pedestres, ejusdem generis viros, in copia numeroque competentibus ad justa stipendia dieti domini regis. Qure omnia dicit dicta domina regina tam pro se quam pro illustrissimo atque potentissimo principe domino suo Ispaniarum rege. Quæ omnia dicta, acta, et promissa fuerunt per me dictum oratorem octava dic mensis Augusti, anno Domini m.eccelxxxiij".

Cause of Besides thise instrucciones geven in writing by this her aliena- orator he shewed to the kinges grace, by mouth, that EdwardIV. the quene of Castelle was turned in hur hart fro England in tyme past for the unkyndeness the which she toke against the king last decessed, whom God pardon, for his refusing of her and taking to his wiff a wedowe of England; for the which cause also was mortalle werre betwixt him and the erle of Warrewyk, the which toke ever liur part to the tyme of his deth. And therfore she moved for thise canse against hur natur, the which was ever to love and farror England, as he said; she toke the Frenche kinges pant, and made liges and confideracions with him.

Now the king is dede that shewed hur this mkyndenesse; and, as he said, the Frenche king lath broken four prineipall artieles appointed, concluded, and sealed betwixt him and the king of Castelle and lum. Wherfore, she now retournyng to hir maturall kinde and disposicion, desireth suche thinges to be anpointed and concluded betwixt thise two reyalmes, England and Spayne, as ye may understande by thise instruccions of hur saic oratour.

An nother cause which moved her to depart fro the ling Loys, was that she had a graunt of the 
quene of Naver ${ }^{1}$ to have hur doughter and heip ${ }^{2}$ for $\Lambda$. D. 1483. the prince of Castell, ${ }^{3}$ hur son, if the consent of king Loys might therin have ben had. And forsomoche, as he by no maner meane wold be therunto agreable she taketh a gret displeasure with him, and desireth by alle meanes to hur possible to make thise alliaunces and confederacions with the kinges good grace, as be shewed in thise instruccions.

She hath in hur possession, as hur said oratour saith, the towne of Pampillion, and a $\mathrm{m}^{1}$. speres therin; and the nobles and citees of Naver have answerd plainly unto hur, that if the quene of Naver wold be disposed, as she is not, to mary hur said doughter at the wille and pleasure of king Loys, they will deliver unto hur alle the strang townes and castelles of the said kingdom of Naver. She lieth with a gret part of the nobles of Spayne, a litille from Victoria, not two dayes jorney from Naver.

The nombre of speres and horsmen the which the king shalle have of Spayne shalbe at his pleasure, x.ml. speres if he will, or moo, and $\mathrm{xxx} \cdot \mathrm{m}^{\mathrm{l}}$. fotemen. 'Thus the said oratour saith by mouth, and offreth him selff also to write the same like as he liathe done as afore.

1 Madeleine, widow of Gaston de Foix, prince de Viane, and from 1479 to 1483 , regent in behalf of hel son Franeis Phœbus, who died in the beginning of the latter year.
"Catherine, sister of Francis mentioned in the preceding note, and by his death queen of Navarre in 1483 .

${ }^{3}$ John, prince of Castile, ob. 1497. 
A.D. 1483 . 18 August.
$\mathrm{X}$.

\section{RICHARD III. To Lewis XI.}

[MS. Harl. 433. f. 237.]

Desiring to Morsieur, mon cousin, jay veu lez lettres que mavez protection envoiees par Boukingham leherault, par lesquelles will be jentens que voulez bien avoir mon amitie, dont je Inglish suis bien content, en bonne forme et maniere; car merchants je nentens point rompre telles treves comme cydevant estoient conclutes entre feu de tresnoble memoire le roy mon frere trespasse et vous, pour le terme dicelles. Toutesfois lez marchans de cestui mon royaume Dangleterre, voyans lez grandes occasions a eulx donnees par vos subges en prenant les navires et mar.chandises et autrement, doubtent grandement de eulx aventurer claller a Bourdeaulx et ailleurs en vostre obeissance, jusques ace quilz puissent estre asscurez depar vous depovoir seurement et sauvement exercer le fait de leursdits marchandises en tous lez lieux de

Translation.

Mr lord, my cousin, I have seen the lettel's you have sent me by Buckingham herald, whereby I understand that you wish to have my amity, of which I am very glad, in good form and manner ; for I do not mean to break such truces as have hitherto been concluded between the late king of most noble memory, my brother decensed, and you, for the term of the same. Nevertheless, the merchants of this my kingdom of England, seeing the great oceasions given them by your subjects by taking vessels and merchandise and otherwise, doubt greatly to adventure themselves to go to Bordeanx and elsewhere in your obeisance, until they may be assured on your part that they may surely and safely exereise the feat of their said merchandise in all the places of your said obeisance, 
vostredit obeissance, accordant audroit desdites treves. A.D. 1483. Sur quoy, affin que mesdits subges et marchans ne 18 August. soient deceubz soubz umbre dicelle, je vous prie que par mon serviteur ce porteur, lun des chevaucheurs de mon escuierie, me vueillies faire savoir par escript vostre plaine entencion, ensemble se chose desirez que pour vous puisse, pour lacomplir de bon cueur. Et adien soiez, monsieur mon cousin.

Escript en mon chasteau de Lexcestre, le xviije jour daoust.

according to the right of the said truces. Upon which matter, in order that my said suljects and merchants be not deceived under the shadow of the same, I pray you that by my servant, this betrer, one of the grooms of ny stable, you will let me know by writing your full intention, and at the same time if you desire anything that $I$ ean do for you, that I may do it with good will. And farewell, my lord my cousin.

Written in my castle of Leicester, the 18th day of August.

$\mathrm{XI}$.

Richard III. to LEWIS XI.

[MIS. ITarl. 433. f. 237 b.]

Monsieur mon cousin, je me recommande a vous Desires a tant comme je puis. Jay rescript a mon serviteur wines of Blanc Sanglier, apresent estant pardevers vous, affin de Burgundy. faire provision daucuns vins du creu de Bourgoingne

\section{Transtation.}

Mr lord my cousin, $I$ commend me to you as much as I can. I have written to my servant Blane Sanglier, now being with you, to make provision of certain wines of the growth of Bur- 
A.D. 1483. et de la Haulte France pour moy et la royne ma 20 August. compaigne. Si vous prie pource, monsieur mon cousin, que vueillies donner commandement a voz officiers et subges quilz le seuffrent faire la provision desdits vins et franchement conduire ou faire conduire et passer en cestui mon royaume Dangleterre sans aucun destourbier ou contredit, et vous me ferez en ce ung bien singulier plaisir. Et sil est aucune chose que je puisse faire pour vous, en le me faisant savoir je lacompliray tresvoulentiers, a laide de Dieu, qui, monsieur mon cousin, vous ait en Sa saincte garde.

Escript en mon chasteau de Notingham le $x^{\mathrm{e}}$. jour daoust.

gundy and la Haute France, for myself and the queen my consort. I therefore pray yon, my lord my cousin, that yon will give order to your officers and suljects to suffer him to procure the said wines, and freely conduct them and pass into this my realm of England, without any disturbance or contritdiction, and you will do me in this a very singular pleasure. And if there be anything which I can do for you, on your informing me I will accomplish it very willingly with the aid of God, who, my lord my cousin, have you in His holy kceping.

Written in my castle of Nottingham, the 20th day of August. 
XII.

A.D. 1483. 26 August.

\section{From the Duke of Britanny.}

[Harl. 433. f. 247. b.]

Instructions pour Georges de Mainbier presentement envoie par le duc devers le roy Dangleterre dece quil a a dire audit roy.

Premier, apres la presentacion des lettres et recommendacions en la maniere acoustumee, dira audit roy que le due le remercie tresaffectueusement du bon voelloir et affection quil demonstre avoir a lui, dont il a este acertene, tant par messire Thomas Huton, chaplain et ambassadeur dudit roy que par maistre Francois Dupon, secretaire du duc, nageres retourne devers lui: en le priant de continuer et perseverer. Et certifiera audit roy que le due na point moins a lui damour et daffection; en quoy il entent de bien en mieulx perseverer.

\section{Translation.}

Instructions for George de Mainbier now sent by the duke [of Britanny] towards the king of Englind, of what he shall say to the said king.

Finst, after presentation of the letter's and recommendations in the usual manner, he shall say to the said king thit the duke thanks him most affectionately for the good will and affection which he exhibits towards him, of which he has been assured, both by Mr. Thomas Hutton, chaplain and ambassador of the said king, and by master Francis Dupon, the duke's secretary, lately returned towards him ; begging him to continue and persevere. And he slinll assure the said king that the duke has not less love and affection for him; in which ho intends to persevere from good to better. 
A.D. 1483. Item, dira audit roy que le duc le prie lavoir pour 26 August. excuse de quoy presentement il na envoie devers lui de sez serviteurs pour besoigner et conclure ou fait de la charge baillee audit Huton son ambassadeur, et dont le dit Huton a fait declaracion au due, sur laquelle le duc lui a fait response telle que ledit roy pourra savoir par sondit ambassadeur. Car le duc, The Es- ainsi quil a deconstume chacun an, a fait assigner tates of lez estas de son pays a tenir vers la fin de Septembre to meet in prouchain, pour lefait desquelz lvi est necessairement September. requis avoir sez serviteurs avecque lui; mais incontinent aprez lesdits estas finiz, qui dureront lespace de dix ou douze jours, le duc envoiera de sez serviteurs devers lui environ la Toussains, on plustost sil lui est possible, lesquelz auront puissance de besoignier sur la charge dudit Huton. Et ainsi desire leduc lefaire pour la grant amour et affection quil a audit roy et a son royaume.

Also he shall say to the said king that the duke begs him to hold him exeused that he has not at present sent to him any of his servants to treat and conclude of the charge given to the said Hutton his ambassador, and of which the said Hutton has made declaration to the duke, whereupon the duke made him answer such as the said king may know by his said ambassador. For the duke, as he has been accustomed to do every year, has appointed the estates of his country to be held towards the end of September next, for the doing of which it is rery necessary to have his servants with him; but imnediately after the said estates are ended, which will last the space of ten or twelve days, the duke will send some of his servants to lim, about the feast of All Saints, or sooner if it be possible to him, who shall have power to treat upon the charge of the said Hutton. And so the duke desires to do for the great love and affection he bears to the said king and his kingdom. 
Semblablement, dira audit roy comme leduc a este A.D.1483 adverti que grant nombre de navires dudit royaume 26 August. Dangleterre se mettent en guerre sur mer, et quilz se sont vantez de prendre et pillier les subgets du duc. Pource dira audit roy que le duc le prie quil face filire deffense a sesdits subgets et antres sur grosses paines de nen riens prendre ne pillier sur lez subgets dnduc, et $y$ donner telle provision que telles prinses et roberies cessent pour le temps advenir. Car le duc de sa part veult et entent ainsi le faire.

Pareillement dira audit roy que le roy Loys de Lewis Xi. France depuis le deces de feu prince de bonne urges him memoire le roy Edward clernier decede, a par plusieurs up the earl foiz envoie devers le duc le prier et requerir de lui of Richbaillier le sieur de Richemont son cousin. Et a ledit roy Loys fait farre auduc de grans offres; mais le duc ne lui en a donne nul actraict, doubtant que ledit roy Loys en voulsist porter ennuy et dommage

Likewise he shall say to the said king how the duke has been advertised that a great number of vessels of the said kingdom of England put themselves in warlike array upon the sea, and lave threatened to take and plunder the subjeets of the duke. Wherefore he shall say to the said king that the duke requests him to prohibit his said subjects and other's under heavy penaltics from taking or plundering anything from the subjects of the duke, and to make provision that such seizures and robberies cease for the time to come. For the duke on lis part wishes and means so to do.

In the like mamer he shall say to the said king, that king Lewis of France, since the decease of the late prince of good memory king Edward last deceased, hits several times sent to the duke to pray and request him to deliver to him the lord of Richmond his cousin. And the satid king Lewis has made the duke great offer's; bat the duke hits given him no inducement, faning that the said $\operatorname{king}$ Lewis would therely create ammogince and 
A.D. 1483. a aucuns dez amis et bien vueillans duduc. Aloc26 August. casion de quoy ledit roy Loys domne grandes menaces auduc de lui faire la guerre, et en sont lez apparaissances grandes.

Maismes remonstrera audit roy lagrant puissance de gens de guerre, artillerie et finances que a le dit roy de France, et la proximite dudit royaume au duche de Bretagne, qui sont joignans ensemble terre a terre, sans y avoir entre deux ruisseau ne riviere qui empesehe ne puisse empescher ledit roy de France de faire entree avecque toute sa puissance oudit duche de Bretagne. Et combien que le duc ait bonne et grande puissance de gens de guerre et artillerie, toutesfois il Toprent ne lui seroit possible porter longuement le faix de la which, guerre contre une telle puissance que celle dudit roy must aid Loys sans laide et secours dudit roy Dangleterre ct Britanny desez autres parens et amis. Parquoy par necessite against France. pourroit le duc estre constrainct a baillier audit roy Loys ledit sieur de Richemont, et faire autres choses

injury to some of the firiends and well-willers of the duke. In consequence of which the said king Lewis give: grent menaces to the duke of making war upon lim, and the appearances of it are great.

Also he shall represent to the said king the great power of men of war, artillery, and finances, which the said king of France has, and the nearness of the said kinglom to the duchy of Britanuy, the two lands joining together without having between them brook or river whicl: might hinder the said king of France from entering the said duchy of Britanny with all his power. And although the said duke should lave good and alumdant strength of men of war and artillery, nerertheless he would not be alle long to support the war against such a power as that of the said king Lewis withont the aid and snceour of the said king of England and of his other consins and friends. Whereby of necessity the duke might he compelled to deliver to the said king Lewis the said lord of Richmond, and to do other things to which he would be very 
qui lui seroit a grant deplaisir pour le dommaige A.D. 1483. quil congnoist que ledit roy Loys en porteroit et ${ }^{26} \mathrm{\Lambda}$ ugust. pourroit porter ausdits roy et royaume Dangleterre.

Pourquoy dira andit roy comme le duc le prie que en entretenant lez amitiez et traicties parcydevant faiz entre ledit feu roy Edward et le duc, il lui plaise secourir le duc alencontre dudit roy Loys, sil encommence la guerre au duc, et lui envoier pour partie de son secours le nombre de iiij.m. archiers Dangleterre, garnis de bons capitaines et dun bon chief, souldoiez pour six moys aux despens dudit roy Dangletcre, et iceulx envoier dedens ung moys aprez lia requeste que le duc en fera, ainsi que ledit feu roy Edward avoit promis de faire; et dece baillier son seelle et lenvoier au duc; et aussi envoier auduc, sil le requeroit, oultre ledit nombre de iiij.ml. archers, deux ou trois autres mil archers dedens ung autre moys prouchain, garnis de bons capitaines, a la soulde et despens du duc. Et en ce faisant le duc attendrar

loth for the injury which he knows the said king Lewis wonld or might inflict upon the said king and kingdom of England.

Wherefore he shall say to the said king how the duke requests him that in maintaining the anities and treaties herctofore made between the said late king Edward and the duke, he will be pleased to succour the duke against the said king Lewis if he commence war against the duke, and send him for part of his succours the number of 4,000 English arclicr's, furnished with good eaptains and a good chief, and paid for six months at the expense of the said king of England, and to send the same within one month after the duke shall make request for them, as the said late ling Edward har promised to do ; and to give his seal for this and send it to the duke; and also to send to the dnke, if he should require it, besides the said number of 4,000 archers, two or three other thousand archers within another month, funished with good captains, at the pay and expense of the duke. And so doing the duke 
A.D. 1483. laventure de la guerre, telle quil plaira a Dieu lui 26 August. envoier, plustost que baillier en la main dudit roy Loys ledit sieur de Richemont, ne faire chose prejudiciable ausdits roy ne royaume Dangleterre.

Et si ledit roy Dangleterre accorde ledit secour's, ledit Georges lui dira que le duc le prie quil lui plaise lui en envoier son seelle et certification par escript par ledit Georges, affin que le duc sen puisse tenir sceur et en asseurer ses subgets, qui sera cause de mouvoir lesdits subgets du duc davoir tousjours de plus en plus ferme amour audit roy et royaume Dangleterre; en lui certifiant que ce faisant il gaignera le duc et le duche pour lui a jamais et les obligera a vouloir et pourchacer a leur pouvoir son bien, sceurte et prosperite en toutes lez facons a eulx possibles.

Ou tout desquelles choses ledit Georges besoingnera en toute diligence sans faire sejour devers ledit roy

will await the fortune of war, such as it shall please God to send him, rather than deliver into the hand of the said king Lewis the said lord of Richmond, or do anything prejudicial to the said ling or lingdom of England.

And if the said king of England grant the said suecours, the said George shall say to him that the duke begs lie will be pleased to send his seal and certification of it by the said George in order that the duke may hold himself sure of it, and assure his subjects; which will be a cause to move the said subjects of the duke, to have always more and more firm love to the said ling and kingdom of England. Certifying him that by so doing he will gain the duke and duchy to himself for ever and oblige then to desire and procure, according to their power, his weal, surety and prosperity hy every means to them possible.

In all which things the said Geologe shall accpuit himself with all diligence without making longer stay with 
fors trois on quatre jours auplus; et incontinent sen $\Lambda . D .1483$. retournera pour advertir le duc du tout.

Fait et expedie a Nantes le $\mathrm{xxvj}^{\mathrm{e}}$. jour dAoust, lan mil iiijc. iiijax. et trois.

\section{Gueguen.}

the said king, than three or four days at the most; and shall immediately return to apprise the duke of everything.

Done and expedited at Nantes, the 26th day of Angust, the year 1493 .

Gueguen.

\section{XIII.}

Governient of IreLand.

[MS. Harl. 433. f. 242.]

InstRUCCIONS yeven by the king our soverayu lord to his trusty welbeloved maister William Lacy, sent from his highnes unto his said lande of Irland.

The said maister William Lacy shal take with him certain the linges lettres missives under his signet, directe aswell to the counsaille ther in generall as to the particuler persones of the same, and by vertue of thaim he shal shewe and open by wey of credence suche thinges as followen, deviding the maters according to the personages that he slial speke unto.

Item, the said master William shall shewe that the king after the stablisshing of this lis realme of England, principally afore othere thinges entendeth for the weele of this lande of Irland to set and advise suche good rule and politique guyding there as any of his noble progemitor's have done or entended in tymes past to reduce it. 
A.D. 1483. Item, he shal shewe that the king hathe ordeyned $\Lambda$ ugust. for the weele of his lande of Irland the righte highe

Edward prince of Wales to be lieutenant of Ireland, and Kildare his deputy. and mighti prince Edward his first begoten son to be lieutenaunt of his said lande of Irland fro the xix day of July last past during the termes of thre yere next folowing, \&c.

Item, he shal shewe that therle of Kildare is "ordeyned and made deputie lientenaunt to Edward his said first begoten some during a yere following, to begynne at the last day of August next commyng, and so lenger to contynue at the kinges pleasure, receyvyng for wages and fees rately as it shal be requisite for the same. And the canse is why that the king woll alwey be at his libertee, to thentent the relief of that lande by his immediat auctorite, whensoevor he may have furst leiser therunto.

Item, that in consideracion of the good fame and noble disposicion that Thomas Fitzgerard erle of Kildare is reported to be of, and namely for that he hath endevoired him self by his noble corage wele and feithfully to occupie as lieutenant to Richard late duc of York, the king hath ordeyned the said Thoms Fitzgerard to be deputie of the said mighti prince Edward now lieutenant during the kinges said pleasure.

Item, because the disposition of the said erle of Kildare aught furst to be understande afore any shewe or openyng to be made to other of the counsaille ther, considering that the gret part of al the direccions to be takyn in this behalve, resteth upon his alssent in taking upon the said deputacion, therfore the saicl maister William Laey shal practise to have speche with him afore any othere.

Item, in delivering the kinges particuler lettres direet to the said erle, and in shewing to him his eredence apart, he shal say that the king our soverayn lord hathe the said erle for his gret merits in special favor and tendreness, trusting right moche upon his saddenes 
and trouthe. And for that he hath abled him to be A.D. 1483 . deputie to the said mighti prince his first begoten $\Lambda$ ugust. son, as it shal appere by a commission made to him as deputie.

Item, the said maister William shal delivere the said erle upon his agrement to take the charge upon him, as well the commission which the king hath marle to my lord prince, as that my said lord prince hathe made to him, whiche bothe commissiones the said maister William shal have with him.

Item, upon thacceptacion of the said commissions and office the said maister William shall insist that the said erle come or sende in all possible hast to the king in England to endent with his grace as it shall mowe be best accorded betwene thaim, havyng respecte as well to the ease of this tymes as to othere presidentes passed afore.

Item, the said maister William shall have with lim a lettre undre the kinges prive seall concernyng the mynte of Irlande, the whiche lettre is directe unto the lordes of the counsaille there, and he shal ensiste that in al possible hast the content of that lettre be put in execucion.

Item, the said maister William shal shewe that the king wolle that every of the kinges officers shal aswell in his courtes, the chief justices of bothe benches and barons of theschequer as other officers ther, to enyoie theyr offices during the kinges pleasure.

Item, to appoynt officers besides the maister of the mynte, with the advise of the kinges counsaill, as shal finde sufficient suerte for the said office, that is to say, wardeyn and comptroller, \&c. of the said mynt.

Item, the said maister William shall have with him a copy of the last indentur, and therupon commune with the said erle by protestacion that nothing shalbe takyn for concluded in that matier without the kinges especiall advise and assent, soo and in 
$\Lambda . D .1483$. suche wise that the mater of the said endenture may

$\Lambda$ ugust. be wele ripe afore. And as for any certain terme to be assigned therin, the king woll that it be for one yere, to begynne the first day of Octobre next to comme, aud so furthre at the kinges pleasure, the charges and emolymentes to be borne and perceyved rately for suche a tyme above the said yere according to the said indenture.

Item, he shal say to the kinges counsaill there that the kinge woll his sealis of Irland to be renewed, chaunging the graving of the said seales.

Item, to understand the kinges redynes of his lande of Irland.

Item, to shew the kinges counsaille that the king woll the statute of premenire be put in execucion against alle thaim that make labour to have benyfices by provision.

\section{$\mathrm{XIV}$. \\ Custody of Guisaes castle.}

[MS. Harl, 433. f. 243.]

INstRUCcIons yeven by the kinges highnes to his fulle trusty counsellors, the lord Dynham, lieutenant of the towne and marches of Caieys; maister John Cooke, archedeacon of Lincoln; Sir Richard Tunstalle, Sir John Scott, and Sir 'Thomas Thwaytes, knightes, upon certain articles of peticion made by Sir Rauff Hastinges, knight, late lientenant of the towne and castell of Guysnes.

FIRst, where the said Sir Rauff Hastinges in the first article of his peticions desireth to have the kinges lettres of pardon; and in the secunde article to have the kinges lettres of confirmacion of alle suche landes and offices as he had of the kinges graunt, late decessed; 
the kinges said commissioners shall have with them $\Lambda . D .1483$. his lettres of pardon, and also his lettres of confirmacion August. of alle suche landes and oflices as the said Sir Raufi had of the graunt of king Edward, late decessed, at the tyme of the dethe of the same king; which lettres of pardon and confirmacion the king woll his said commissioners delyver to the said Sir Rauff, he first delyveryng to them to the kinges behoove the kinges towne and castell [of] ${ }^{1}$ Guysnes. The which towne and Lord castell so by them receyved the king woll they delyver Mountioy the same to Sir. John Blonte, lord Mountjoy, he to have keeping of the rewle and keping of the same during the kinges Guisnes pleasure.

Item, where he desireth in the iijte article to have full contentacion of his wages, and of the wages of his felosship, \&c., and for all suche reparacions and fortificacions as he hath done upon the said place; the king woll his said commissioners, upon serche by them made what resteth to him and his said felos. ship due and unpaied, appoynt with him for his and his said fellosshippes contentacion and payment. And in like wise they shall appoynt with him for reparacions and fortificacions by him made necessarie and behovefull to the kinges place there, so that the said Sir Rauff yet hiderton hath not be contented ${ }^{2}$ nor allowed for the same.

Item, as touching the iiijth article, where he desireth that he may peasibly have and enyoie the wardshippes of the heires of the lord Grey of Wilton, and John Dyne of Northampton, \&c., the king woll his said commissioners shall say that the king is right wele content that he have and enjoye all suche barganes as he hath made with his subgettes according to his lawes.

Item, where he desireth to have respite till Michelmisse come xij. moneth of the delyveraunce of the said

Om. in MS.

${ }^{2}$ The final $d$ of this word is struck through, but by a later hand. 
A.J.1483. place, there to the kinges said commissioners shal August. saye that the king is no thing content with that desire, as his grace hath shewed his mynde in tymes past fully and fynally determyned in that behalve. But his grace is wele content that his said commissioners finde suche weyes and meanes as the said Sir Rauff shalle move frely without enpechement or trouble remove out of the said place suche goodes and stuff as he liath within the said towne and castell, or other places there. And over that, that the said Sir Rauff be agreed with for alle suche vitailles and stuff as he liath porveyd for the same place, sc.

\section{XV.}

Answer to the Message of Isabelia of Castile.

[MS. IIarl. 433 , f. 244 b.]

Instruccions yeven by the king to Barnard do la Forssa, whome his highnes at this tyme sendeth to his derrest cousyns the ling and the quene of Spaigne.

Finst, after the presenting of the kinges lettres to theim of credence, with suche recommendacions and good wordes as shalbe thought most convenient and acceptable to theim, he shall shewe his credence in maner and forme folowing:-

That the king our soverayn lord hath recived a lettre of credence from his derrest cousine the quene of Spaigne by hir orator the bachiler de Sasiola, and by the same hath clerly understande the gret luff and singuler benevolence that hir highnes beres towardes his grace, and therfore thankes her in his hertiest maner, latting her wit that his highnes is of noo lesse good will towardes hir housband and hir, but woll in all convenient wises be as glad to do 
that, that may be to the honour and wele of theim A.D. 1483 . and their realmes as any prince lyvyng.

$\Lambda$ irgust.

And forsomoche as by vertue of credence committed to hir said orator, and by him shewed to the king by mouth and also writing, his grace hath understande his said cousins to be utterly disposed to have with him good and ferme peace, lieges, alliaunces, and confideracions, to thentent that they shuld be joigned, alyed, and confederate in perfite liege and confideracion as good and feithfulle cousins and cofiderates:

The said Barnard shall in that behalve say that the king therfore thankes his said cousins in his hertiest maner, and is therof as desirus as tiney be, and wolle to the perfeccion therof intende by alle weyes and meanes convenient and resonable. And how that incontinent upon the said credence so opened the king, seing that the said orator whiche had no England specialle commission in writing, nor instruccions so proposes a large as shuld be requisite to the making of so grete the league a ligue, made to be serched up the ligue that was last made taken betwene the late king Edward, his brother, and Edward king Henry of Castille, late brother of the said quene, IV. and whome God pardone. Wherby it was thought unto of Castile. him and his counsaille that the beginnyng of the best intelligence betwene both parties shuld be grounded upon the articles of the said ligue, considering that by long and ripe advise and deliberacion the articles of the said ligue were practized and concluded.

And over this the said Barnard shalle shewe that the king our soverayn lord, not willing any long tracte of tyme or other impediment of so goodly and behovefull entent shuld be on his partie, and specially when he is so instanced by the said orator to sende thider in all goodly hast for full expedicion of the same, his highnes hath at this tyme sent thider the said Bernard to common of the best and spediest wayes. 
A.D. 1483. In which communicacion the said Barnard shalle by August. alle meanes of policie dryve theim to conforme ${ }^{1}$ the olde ligue withont making of a newe; to the whiche if they can be founde by his wisdome agreable, than he shall mow desire to have suche forme of commission made by the kinges cousyns ther to suche as shalle please them to deliver to him their part of the ligue sealed as he hath to deliver the kynges parte also sealed, keping him close alwey from knowleging that that he hath any suche commission or ligue sealed unto suche tyme as he utterly understande their myndes of suche commission and delivere to be made by theim.

And in case they wolle in no wise agree to make any suche confirmacion of the ligue now made, but utterly insiste to make a new, either like or more large with some new articles, then he shall labor by his wisdome the wayes that suche orators may be sent with him into England, as may have of the kinges cousins their fulle auctorite and power to common, appoincte and conclucle, as by theim the said mater may take good affecte ${ }^{2}$ and conclusion.

Morover the king is content that whethir the ligue shalbe desired to be alle new made, or any addicions to be had to the olde, the said Barnard speke frely with theim of suche new articles as they desire, and that he common and debate upon theim in suche wise as by his discrecion shalbe thought best for the king and his land, advoiding as moche as he can any gret and certaine charges that the king might be put unto; provided alwey that by any thing so to be spoken, commoned, or treated the king be not bounden above the olde articles, but be at his hole libertie in alle suche new maters unto the commyng

${ }^{1}$ Sic in MS. $\quad{ }^{2}$ and conclude,-effecte] repeated in MS. 
of thenbassate of Castille into England, and till they A.D. 1483. and the kinges commissaries have throughly passed in August. all poyntes.

Item, where the said Bernard hathe an other commission to treate and appointe upon attemptates aswele with the governors of the provinces as with the counsaille of the king and quene, and to appoincte a diete for the same; the king wolle that he doo and procede in thoos maters according to the said commission, and to suche instruccions as he had delivered unto him therupon afore.

\section{XVI.}

\section{JANES III. TO RICHARD III.}

[MS. Harl, 433, f. 246 b.]

\section{By the King of ScotTes.}

RIGHT excellent, hie and mighti prince and right Proposing trusty and welbeloved cousing;,--We commende us unto eight you in the most hertlie wise. And how beit that oft abstinence tyme afore certain rupcioun, breke and distrublaunce ${ }_{\text {with a view }}^{\text {of }}$ has bene betwixt the realmes of Ingland and Scotland to a perbe the werkyngis and menys of evil disposed persones, panen, incontrarie our mynde and entencion, as God knowes; Neverthelesse we remayne in the said propose afore like as we wraite to the right noble prince your brother, quham God assoilze, to observe and kepe luff, pece, concorde and amyte with alle Cristyne princes, and above others with our nichebouris and realmes next approchand to the bordures of our realme of Scotland, for the good of peax, and till enchew the effusioun of Cristyn blode. Now at this tyme has sende to you our lovit serviture Dingvale persewand with thir oure lettres, that we may be certifit of your noble mynde 
A.D. 1483. twiching the good of peas in tyme commyng to be $16 \Lambda$ ugust. observed and kept betwixt your realme of Ingland and oures of Scotland. And gif it bei sene expedient and proffitable unto you that ane abstinence of werre war taken be sey and lande for the space of aught monethis for the fyne and entent that the gret commissioners of both the reahmes might mete at convenient and custumable place on ne bordures for the or, to send propose above expremit. Or gif it were thought more an em-
bassy. bassy. lordes of our realme in our legacion come within your realme of England, and till appointe, aggre, and concorde upon the goode of peax (they havyng conduyt of your highnes for thaim, their famuliaris and servituris to the noumyr of lxxx of persones or within, quahis names our said serviture shall shewe you gevin to him in writ), the abstynence of werre enduring in the meane tyme. Praying your serenite that ye will certifie us of your good mynde and disposicion in alle hast in the premisses by your writing with our said serviture or any other of youres, $\Lambda$ s we trust in your right excellent cousinage, the quylk God kepe. Written under our signet at Edingburgh, the xvj day of August.

To, sc., the King of Ingland. 


\section{XVII.}

\section{Richard III. TO JAMES III.}

[MS. Harl. 433, f. 247.]

\section{By the King of England.}

RIGIIT high and mighti prince, right trusty and A.D. 1483. welbeloved consin, we commaunde us unto you. And offering a where as by your lettres brought unto us by your safe-conpursevaunt Dyngvale, as amongst other largely shewed will send that for oecasion in tyme past thenterupcion, breehe, ambassaand disturbaunce of peas betwixt both realmes, lath dors. growen thrugh the meanes of evyll disposed persones contrarie to your mynde and entencioun, and that ye remayne in good purpoos to thobservaunce of love, peas, and concorde of the same royalmes to be had, and for that entent have sent, at this tyme, unto us your said pursuyvant to understande our goode mynde in that behalve, meovyng us for that cause that certaine your legates mought eome unto us enstrueted with your mynde in that partie; cousyn, we acertaine you our mynde and disposicion is and ever shalbe confirmable to the will and pleasur of God our aller Creatour in all resommable and convenient peax, without fenyng, that shuld be desired of us by any nacion. And if that your desire and pleasure be to sende hider suche personnages to treate for thaceomplisshing therof, we, havyng knowlage fro you of their names, shall yeve unto theim oure sure saufeonduyt for ane resonable nombre and scason. And God kepe you, right high and mighti prince, our right trusty and welbeloved cousyn. Yeven the $\mathrm{xv}^{\mathrm{j}^{\mathrm{th}}}$ day of September.

To, se., the King of Seottes. 


\section{XVIII.}

\section{The Duke of Britanny's Warrant to advance MONEY TO THE EARL OF RICHMOND.}

[From the orig., MS. Cott. Julius, B. vi. 95, on parchment.]

A.D. 1483. Francoys, par la grace de Dieu, duc de Bretaigne, 22 Nov. conte de Montfort, de Richemont, dEstampes, et de Vertus, a noz bien amez et feaulx conseillers, les gens de noz comptes, salut. Nous vous mandons et commandons expressement que allouez et passez, en clere mise et descharge, anostre bien ame et feal Gilles Thomas, tresorier de nostre espergne, a ses comptes, quant mestier en aura, la somme de dix mil escuz dor; quil a baillee des deniers de nostredite espergne, de nostre expres commandement et ordonnance, par maniere de prest, a nostre treschier et tresame cousin le sire de Richemont, sans aucune difficulte y faire, raportant seulement ces presentes avecques relacion de nostredit cousin de les avoir receuz, comme dit est, car tel est nostre plaisir; nonobstant quelzconques

\section{Translation.}

Francis, by the graee of God, duke of Britamny, earl of Moutfort, of Riclmond, of Estampes, and of Vertus, to om well-beloved and faitliful counsellors, the anditors of onr aecounts, greeting. We command you expressly that you allow and pass in full payment and discharge, to our well-beloved and faithful Giles Thomas, treasurer of our exchequer, in his accounts, if he shall require it, the sum of ten thousand crowns of gold, which he has delivered of the monies of our said exchequer, hy our express eommandment and order, in the way of loan, to our most dear and well-beloved eonsin the lord of Richmond, without making any diffieulty therein, bringing back only these presents with our said consin's acknowledgment of having reeeived them, as is 
mandemens, ordonnances, deffenses, restrinctions, ou A.D. 1483. autres choses a ce contraires. Donne en nostre ville ${ }^{22 \text { Nov. }}$ de Nantes, le xxijme jour de Novembre, lan mil ccce. quatrevings et troys.

\section{(L.S.) Francoys.}

Par le duc de son commandement,

Gueguen.

said, for such is our pleasnre: notwithstanding whatsoever commands, orders, prohibitions, restrictions, or other things to the contrary. Given in our town of Nantes, the 22nd day of November, in the year 1483.

Francis.

By the dulke's command,

Gueguen.

\section{XIX.}

[MIS. Harl. 433, f. 238.]

Instruccions geven to Northumbreland herauld by A.D. 1484 . the kinges grace at Notingham, the xiijth $13 \Lambda_{\text {prill. }}$ day of Aprill, to be by him executed.

Funst, the king wol that the said Northumbreland make his tarying and abode at Berwik from the tyme of his commyng thider unto the xv. day of May next commyng, to thentent that the Scottisshe ambassiadours within that day may certefie him of suche thinges as they have promysed the kynges grace to doo before that day.

Item, the king wol that if the said Northumbreland To arrange by the said enbassators be certefyed there that theire an abstiprince is agreed and concluded to have an abstynence war beof werre, bothe by see and land, to endure to Criste- tween masse or Alhalowentyde at the lest, than the said and ScotNorthumbreland to common and cause a certein day land. 
A.D. 1484. to be appointed, that aswele the same abstynence may $13 \Lambda$ pril. within and upon the borduris of Scotland as upon the bordures of England, Berwike, and Domnebarre be proclaymed, and, the said abstynence concluded to see be proclaymed in alle places afore expressed and elleswhere on the bordures of England accustumed the same day.

Item, the king wol that if there be desired a saufconduyt for the said ambassiatours or any moo joyned with theim to come into this royaume for the good of peas to be laboured to his grace, than the same Northumbreland to delyver to suche as from the Scottes king cometh the sanfconduyt to him delyvered in that behalf.

Item, that in the said abstynence that hit be ordeyned that no grownde on the West bordures called Batabeile Grounde be othrewise occupyed than hit is at this day by any partie, \&c.

\section{XX.}

\section{Regulations gor the COUnCha of the: North.}

[MS. IIarl. 433. f. 26: b.]

A.1). 148t, July.

Imparti- Furst, the king wolle that none lord ne other persone ality to be appoynted to be of his counselle, for favor, affeccion,
observed. hate, malice, or mede, do ne speke in the comnselle

'John De la Pole, earl of Lincoln, the king's nephew. 
otherwise then the kinges lawes and good conscience $\Lambda . D .1484$. shalle require, but be indifferent and no wise parcell, July. as ferr as his wit and reason woll geve him, in all maner maters that shalbe mynestred afore theym.

Item, that if there be any mater in the said counselle moved which toucheth any lord or other persone of the said counselle, than the same lord or persone in no wise to syt or remayn in the said counselle during the tyme of thexamynacion and ordering of the said mater enlesse he be called, and that he obeie and be ordured therin by the remenant of the said connsell.

Item, that no maner mater of gret weght or substaunce be ordered or determyned within the said counselle enlesse that two of thise, that is to say * $*$ * * * $\quad * \quad *$ * $\mathrm{I}$

with our said nepveu be at the same, and they to be commissioners of our peax thoroughout these parties.

Item, that the said counselle be, hooly if it may The Counbe, onys in the quarter of the yere at the leste, at cil to sit at York, to here, examyne and ordre alle billes of com-least once pleyntes and other there before theym to be shewed, in a quarter and oftyner if the case require.

Item, that the said counselle have auctorite and power to ordre and direct alle riottes, forcible entres, ristresse takinges, variaunees, debates and other mysbehavors ayenst our lawes and peas committed and done in the said parties. And if any suche be that they in no wise can thoroughly ordre, than to referre it unto us, and therof certific us in alle goodly hast therafter.

Item, the said counselle in no wise determyn mater of land without thassent of the parties.

Item, that our said counselle for great riottes done and committed in the gret lordships or otherwise by 
A.D. 1484, any persone, committe the said persone to warde to July. oon of our castelles nere where the said riott is committed. For we wolle that alle our castelles be our gaole; and if noo suche castelle be nere, than the next common gaole.

Item, we wolle that our said counselle incontynent after that they have knowlage of any assembles or gaderinges made contrarie oure lawes and peas, provide to resiste, withstande, and ponysshe the same in the begynnyng according to their demerites, without ferther deferring or putting it in respecte.

Item, that alle lettres and writinges by our said counselle to be made for the due executing of the premisses be made in our name, and the same to be endoced with the hande of our nepveu of Lincolne undre nethe by thise wordes Per Consilium Regis.

Item, that oon suffisaunt persone be appoynted to make out the said lettres and writinges and the same put in regestre from tyme to tyme, and in the same our said nepveu and suche with hin of our said counselle then being present, setto their handes and a seale to be provicled fre for the sealing of the said lettres and writinges.

Item, we wolle and streitly charge alle and singuler our officers, true liegemen and subgiettes in thise North Parties to be at alle tymes obeieng to the commaundementes of our said counselle in our name and duely to execute the same as they and every of theym wolle eschue our gret displeasture and indignacion.

Memorandum, that the kinges grace afore his departing do name the lordes and other that shalbe of his eounselle in these parties to assiste and attende in that behalve upon his nepven of Lincolne.

Item, memorandum that the ling name certen lierned men to be attending here, so that oon alweys 
at the lest be present, and at the meting at York to A.D. 1484. be alle there.

Item, that the king graunt a commission to my lord of Lincolne and other of the counselle according to theffect of the premisses.

\section{XXI.}

\section{JAMES III. TO RICHARD III. ${ }^{1}$}

[MS. Harl. 433. f. 263 b.]

RIGHT excellent, hie, and michti Prince, and right A.D. 1484. traist and welbelovit cousing, we commende us unto 21 July. you in the maist hertly wise. Signifying unto your cousinage that we are nowe advertisit by the relacion of our traist and welbelovit cousing and counsaillor Robert lord Lile, our lovit squier Duncane of Dundas, and also by the feithfulle repoort of your familier squier Edward Gower shewen to certain lordes of our counsaille and by thaim to us, that your consinage is wele appliit and inclynit to the gud of trewes [and] ${ }^{2}$ abstinence of werre betuix you and us, our realmes and lieges, and also that luf, amytie, and specialle alliauncez of mariage was avisit, appointit, and concludit betwix your blode and oures; whereunto we ar in likewise inclinit. And according to your empleasire and to shew in that parte onre gud mynde to the commone gude of treux and abstinence of were, We Naming have fynijt and ordand our traist and welbelovit cou- lis amb. singes and counsalor's Coline erle of Ergile, lord Cambell Lorne our chaunceler, a reverend farder in Gorl William bisshop of Abberdene, Robert lord Lile, Lan-

"Headed in the original MS. "The king of Scottes lettre sent to the "king."

"Om, in MIS. 
A.D. 1484. rence lord Oliphant, Johnne of Drummond of Stob21 July. halle and maister Archibald of Quhitelawe, archidene of Lothiane our secretare, with fulle powair and commission to comme within your royaume unto you to your towne of Notingham the vij day of Septembre next to comme, to avise, common, and conclude upon trewes and abstinence of weir to be observit and kepeit betuix your lieges and oures. And also upon luf, friendship, aliaunces, and mariage to be had betuix your maist noble blude and oures, like as we were present in propre persone to the ferme observacion and stabiliment of the said trews. And like as ye have geven in charge to your squier forsaid that abstinence of weir be had betuix the realmes be see and land, and commaundit your wardeins, lientenantes, admiralles, and capitaines of weir, that none hosting, riding, truble, nor noo manere of weir be made by any Englisshemen agains us, our realme or lieges, and that reformacion salbe made of alle attemptates that shal happen to be doon or commyttit be see or by land unto the agayncumming of our ambaxiators of England, and viij dayes efter their cummyng within our royaume, we have in likewise commaundit oure wardains, lieutenantes, admiralles, and capitaignes of werro that nane hosting, riding, truble, nor no manere of weir, be maid by any our lieges agains your royaume or lieges, ant that reformacion salbe made of alle attemptatess that sall happen to he done or committit by sce or by land, unto the agraine cummyng of our ambaxiators of England, and viij dayes after thair cummyng within our royanme according to your worship and oures. And to the eise of your lieges and oures that shalle happen in the meane tyme to susteyne dampnage or scathe in their persones or groodes; and that your anufconduyt in the meantyme may be sent to the persones aboue expremit to the nombre of a $c$. of hors or within, to come to your toune above expremit. Richt 
excellent hie and michty prince and traist cousing, the A.D. 1484. Blessit Trinitic have you in keping. Writen undre 21 July. our signet at Edingburghe, the xxj day of July,

\section{JAMES.}

\section{XXII.}

\section{Richard III. to JaMES III. ${ }^{1}$}

[MS. IIarl, 433. f. 264.]

RIGIIT high and mighty prince, right trusty and $\Lambda . D .1484$. welbeloved consin, we commaunde us unto you in the 5 ing. moost herty wise. And where it hath pleased your safeeoncousinage to addresse unto us nowe of late your ho- duet forthe norable lettres by our trusty servant and squier Edward bassadors. Gower, signifing by the same lowe that upon the retornyng of your trusty and welbeloved cousin and comsaillor Robert lord Lile from us into your royaume agayne, and by his relacion and others ye lave ben advertised of our mynde as tonching the good of peas and abstinence of werre betwene bothe royaumes. Whereunto we shewed us wele applied and inclyned in suche manere as we largely commoned with the same lord Lile and yave in charge to our said serrant topen unto your said highnesse or to suche lordes of your counsaille as it wold please you to depute and assigne to here the same. And that thereupon your said cousinage likewise inclyned, and according to our pleasire hathe lymited and ordeigned certaine grete lordes and othre of your counsaille with ful powair and commission to comme into our towne of Notingham the vij day of Septembre next to comme, to advyse, common, and conclude upon treux and absty-

\footnotetext{
'In the MS. this letter immedi- | headed "The kinges lettres of anately follows the preeeding, and is "swere unto the same."
} 
A.D. 1484. nence of werre to be observed and kept betwix your

7 Aug. lieges and oures; and also upon love and frendship aliaunces and mariages to be had in your blode and oures, like as in your said lettres it is conteigned more at large. Right highe and mighty prince, righte trusty and welbeloved cousin, we late your cousinage wite that this your loving and toward disposicion is to us right agreable, trusting that by the mean of this your ambassade instructed in al the forsaid maters as plenerly as the caas shal require, and to doo therein as largely in al pointes as ye were present in propre persone, according to that that is expressed in your said lettres, suche good weyes shalbe taken betwix bothe royaumes whereby effusion of Christen blood may be eschewed, love and tendrenesse growe daily and encreace, aswele betwix you and us as the inhabitauntes of bothe royaumes, whiche we take God in witnesse we as hertly have entended with good condicions, and soo shal hereafter, as any prince lyving cann or may. And to thentent no thing faille necessary or behoveful to the spedy execucion of the premisses, nor of your partie ne of oures, we have passed our lettres patentes of saufconduyt undre our gret seale for the sure commyng, abiding, and retornyng of your said ambassade, and the same lettres sent by this berer according to your desire and pleasure. Right high and mighty prince, right trusty and welbeloved cosyn, the blessed Trinite have you in his keping. Yeven undre our signet at our palois of Westminster, the vijth day of August.

Ricardus Rex. 


\section{XXIII.}

\section{Reception of the Scotch Ambassadors.}

[This article is derived from two leaves which, although A.D. 1484. contained in the Cottonian Volnme Caligula B.v., originally Sept. belonged to a MS. now in Vespasian C.xvi. At the end of folio 79 of the latter volnme is an ineomplete sentence, which will be found continned at f. 147 of Calig. B.v. The portion in Vespasian C.xvi. is the speech of Arehibald Whitelaw, which it is scarcely necessary to print, as Bucke has given some extracts (Kennet's Complete Hist., T. 572), that pretty toleribly indieate its general character. The only faet of interest that it contains is a statement that the speaker had been sent ambassador by James II., abont 25 year's before, to the king's father (Richark Duke of York), in Ireland, and conehded a treaty with him]. ham.

ix ${ }^{\text {no }}$ die Septembris apud castrum de Notyng-

It ys advysed certeyn lordys that ys to wyte the byshopp of Syut Asse, therle of Notyngham, lord * * * $*^{2}$ Maister Thomas Utton, doctor of canon, and other knyghtes whele yncompanied to mete with the lordys and other commyng out of Scotland yn ambassad un to the kynges hyghnes, and they to convey the seyd ambassadors un to ther logyng yn the towne of Notyngham, etc.

\section{$\mathrm{xj}^{\mathrm{mo}}$ die Septembris.}

Thus day at aftyr none thembassadors cam yn to Nothyngham acompanid with suche lordys and other as ys a fore sayd, etc.

'Richard Redman.

1 "A line and a half blank in MS.

D $8+$ 
A.D 1484 .

Sept.

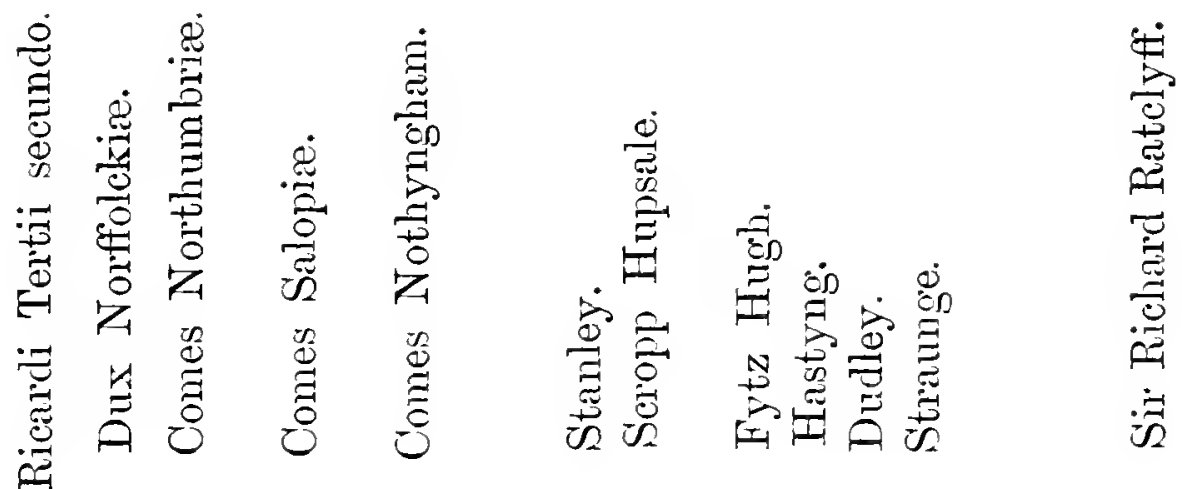

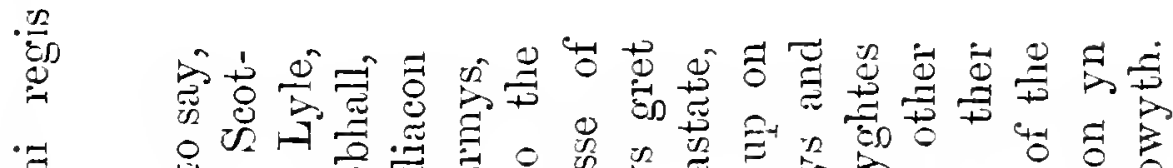

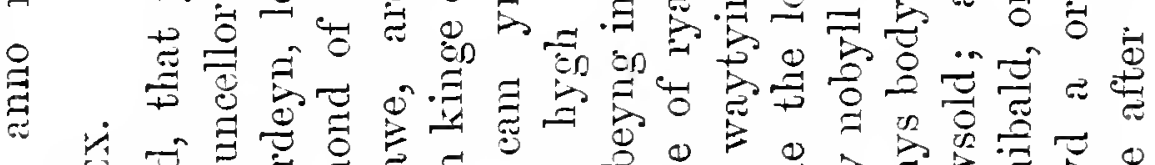

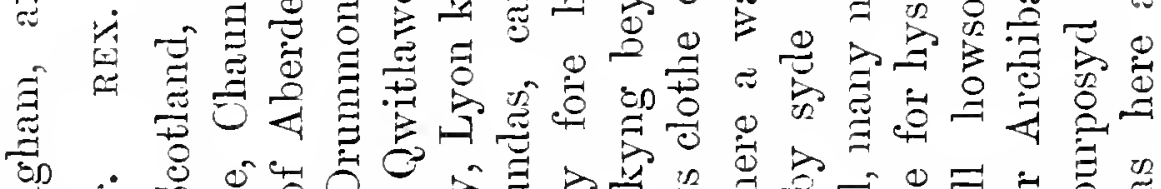

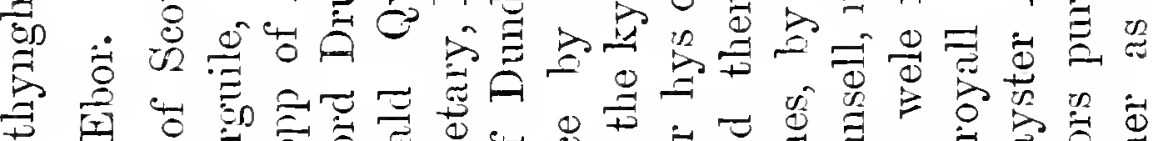

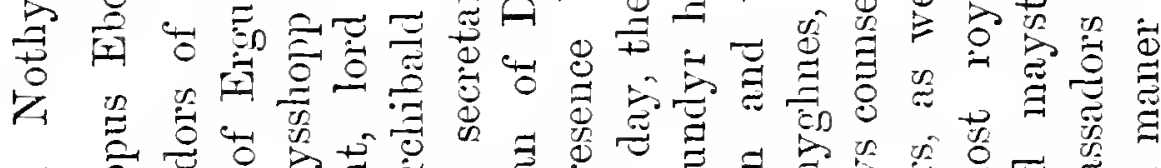

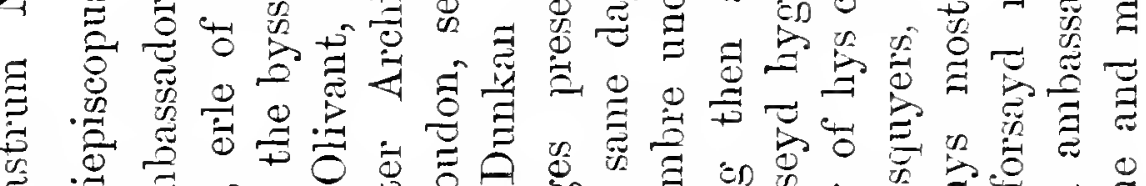

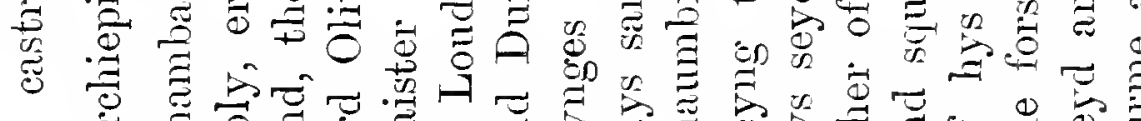

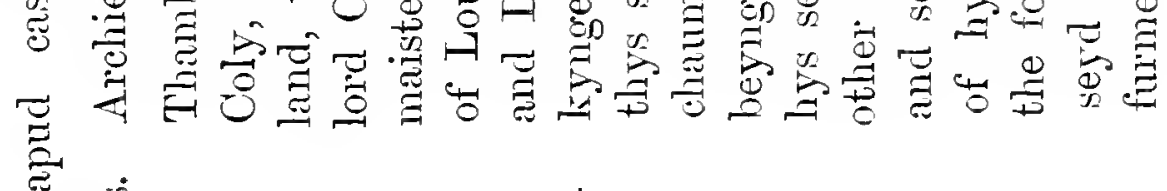

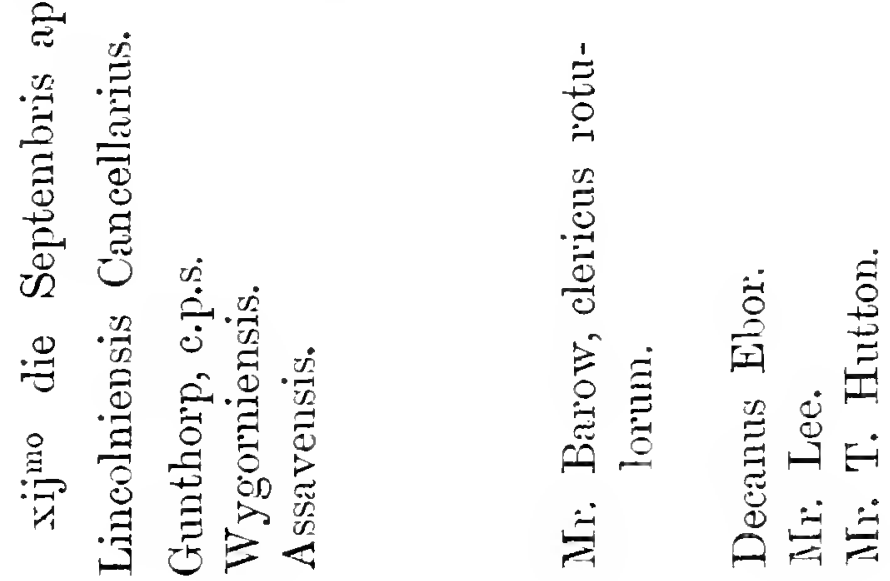




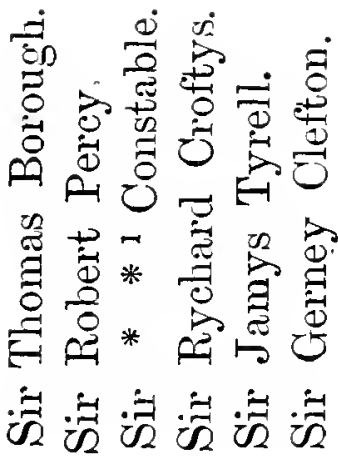

A.D. 1484 . Sept.

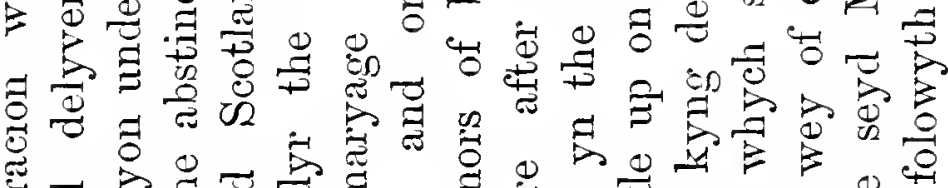

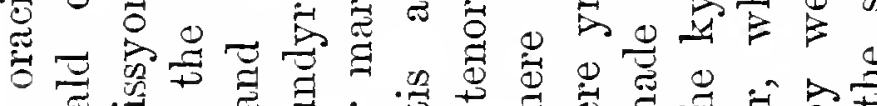

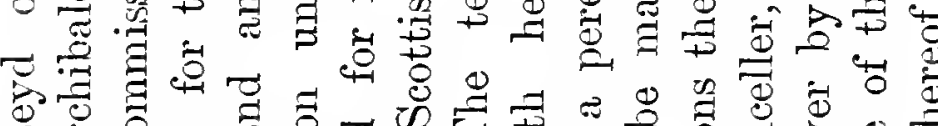

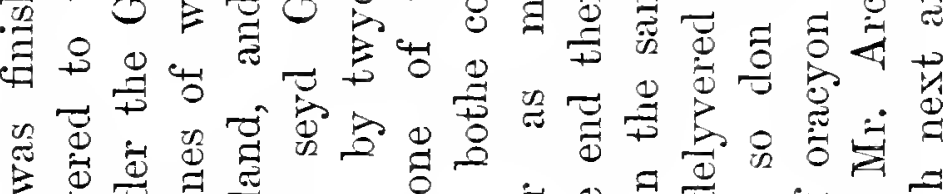

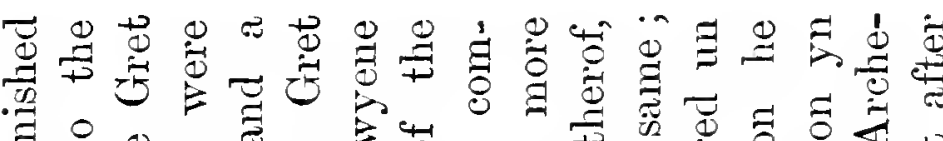

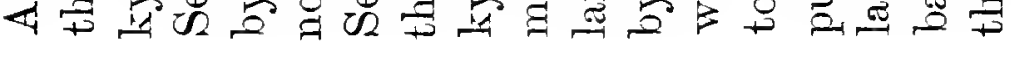


A.D. 1484. xiijomo. die Septembris apud castrum Nothyngham. Sept.

Thyes be the names of the lordys whome the kynges hyghnes hath ordeyned and mad to be hys commissarys ther to appoynt, accord, and conclude with the forseyd orators of Scotland, that ys to sey, the erle of Arguile, the bysshopp of Aberdyen, and other, etc., for the peace to be made of bothe reamys. The tenor of her commissyon here after mor at large $y t$ schall appere by indentors yu thend of the sime.

John, bysshopp of Lincoln, chameeller.

Richard, bysshopp of Seint Assaph.

John, duc of Norflolk.

Henry, erle of Northumbyrland.

Mr. John Gunithrop, c. p.s.

Sir Thomas Stanley lord Stanley.

Sir [George Stanley]1 lord Straunge.

Sir [John Grey $]^{1}$ lord Powes.

Sir Herry lord Fyghugh.

Sir Humfrey lord Dacres.

Sir 'Thomas Barow, mayster of the Rolles.

Sir Thomas Bryan, cheffe juge of the Comyn Place.

Sir Rychard Rutelyfir.

William Catesby.

Rychard Salkeld.

Item, the namys of the lordys that schall commyn for the maryage:-

Thomas, archybysshop of York.

John, bysshop of Lyncoln, canc' of England.

John, due of Norffolk:-

John, erle of Nothyngham.

John, bysshopp of Worcester.

Joln Sutton lord Duclley.

[Thomas]' lord Scroop Upsale.

1 Blank in MS 
Sir Wylliam Husey, knyghte, cheffe justices of $\mathrm{y}^{\mathrm{e}}$ A.D. 1484. kynges benge.

Sept.

Sir Rychard Ratclyff.

William Catesby.

The tenor of ther commissyon more at large yt schall appere here after by indentors.

Hæe indentura facta inter nos Thomam, Dei gratia Eboracensem archyepiscopum Anglia primatem et Apostolicæ Sedis legatum, Johannem Lincolniensem cancellarium Anglie, et Johannem Wigorniensem, episcopos; Johannem dncem Norffolckire comitem marescalli, marescallum et admirallum Angliae, dominum de Moubray de Segrave et Howard, Willielmum comitem Nothynghamie dominum Barkeley, Johannem Sutton dominum Dudley, Johannem dominum Scroop de Massam, milites; Willielmum Husey capitalem justiciarium domini regis ad placita coram ipso rege tenenda, militem, Ricardum Radelyff ordinis garterii, militem, ${ }^{1}$ et Willielmum Catesby armigerum pro corpore excellentissimi ${ }^{2}$. . . .

\section{XXIV.}

Message to the Earl of Desurond.

[MS. Harl. 433. f. 265 b.]

Instruccions geven by the kinges grace to his counsellor the bisshop of Enachden, ${ }^{3}$ to be shewed in his behalf to his cousyn therle of Dessemond, and other nobles and gentiles of his land of Irland.

Funst, where the said bisshop hath enfourmed his services said grace of the good toward disposicion and herty done by

\footnotetext{
1 inclitem, MS.

${ }^{2}$ Here the MIS. breaks off abruptly.

${ }^{3}$ His name was Thomas Baret. No. 133, Calendar of Patent Rolls, printed in Report ix. of the Deputy Keeper of the Public Records, See Patent 24 Feb., 2 Ric. III., p. 2, App. ii, p. 120.
} 
A.D. 1484. desire that the said erle hathe for to doo him pleasur Sept. and service to his power, as feithfully and humbly as
ather to the king's any other of the kinges subgiettes; the said bisshop father, shalle on the kinges behalve thanke him, shewing that duke of aswele for the noblesse of bloode, as remembryng the York. manyfold notable service and kyndnesse by therles fadre unto the famous prince the duc of York the kinges fader at diverse seasons of grete necessite in thoos parties to his gret jeopardies and charges doon, causeth the kinges grace to accepte and reteigne him in the tendre favor of the same, trusting of his contynuaunce.

The earl Also, he shalle shewe that albe it the fadre of the shall be said erle, the king than being of yong age, was exsecute torciously slayne and murdred by colour of the lawes those who within Irland by certain persones than havyng the procured his fath's governamce and rule there, ayenst alle manhode, reason, death. and good conscience; yet, notwithstanding that the semblable channce was and hapned sithen within this royaume of Eingland, as wele of his brother the duc of Clarence as other his nigh kynnesmen and gret frendes, the linges grace alweys contynueth and hathe inward compassion of the dethe of his said fadre, and is content that his said cousyn now erle by alle ordinate meanes and due course of the lawes, when it shalle lust him at any tyme herafter to sue or attempt for the punysshement therof.

Oath of Also, the kinges grace wolle that the said bisshop allegiance have anctorite forto take in the kinges name of the hy him. said erle his othe of ligeaunce as other lordes have doon here within this his royaume after the fourme here ensuyng:- " I, A. erle of Dessemond, become true and feithfulle liegeman unto my soverayn lord Richard the iijde, by the grace of God, king of England, and of Fraunce, and lord of Irland, and to his heires linges of England, and to him and theim my feith and trouth shalle bere during my lif naturalle, and with him and in his cause and quarelle at alle tymes, shalle take his 
partie and be redy to leve and dye ayenst alle erthly A.D. 1484. creatures, and utterly endevor me to the resistence and Sept. suppressing of his ennemyes, rebelles and traitors if [I] ${ }^{2}$ shalle any knowe to the uttermost of my power, and nothing concele that in any wise may be hurting to his noble and roialle persone. Soo helpe me God and thise Holy Evangelyes."

Also, the said bisshop shalle shewe unto the said The king erle the kinges gret pleasur touching his dealing or vide a entring into any mariage with any blood without marriage thadvise and knowlage of his grace, considred that the same with alle celerite entendeth forto ordeigne and provide in that behalve for his said cousyn in suche wise and of suche noble blode as shalle redounde to his weele and honnor, and of alle his frendes and kynnesmen, trusting that the said erle wolle remembre the same and utterly applie him therunto.

Also, the said bisshop upon perfite understanding He is to that the said erle shalbe of hoole entencion, and promise give up the to his powair to perfourme the premisses, and over that utterly to dispose for many consideracions eoncernyng the kinges highe pleasur and entent, for to renounce the wering and usage of the Irisshe arraye, and from thensfurthe to geve and applie him self to use the maner of thapparelle for his persone after the Englisshe guyse; and after the fasshon that the kinges grace sendeth unto him by the said bisshop, aswele of gownes, doublettes, hosen and honettes, and soo folowingly in tyme eommyng as the cars or channge of the said fasshion shalle require, that thim the said bisshop shalle deliver unto his said cousyn in most convenient place and honnorable presence the kinges lyvree, that is to wite, a coler of gold of his devise, and other apparelle forsid for his persone. 
A.D. 1484. Also, above alle other thinges he shalle shewe the Sept. said erle that the kinges grace in noo wise wolle oure booly modre the Churche to be wronged, deroged, or prejudiced weither in liberties, fraunchies, grauntes, custumes, or any other spirituell emolumentes belonging to the same, but that his said cousyn shalle mayntene, assiste, and support it in every behalve, as justice and righte requiereth; and over that to see that no maner robberys, spoliacions, oppressions or extorcions be suffred to be committed amongst any of the kinges subgiettes of thoos parties, of what astate, degree, or condicion soever they be, and in caas any happen to be, to see theim so offending utterly to be punyssed according with the kinges lawes. And that the said erle shalle by alle weys and meanes of pollycie see and provide that by the passage of the commune highe wayes there the kinges subgiettes may be assured to goo and passe without robbing and unlawfulle letting; so that the said erle, according to the kinges gret trust, and also to his graciouse demeanyng here in this royme of England may appere and be named a veray justicer, aswele for his propre honnor and wele as for the comon wele of those parties, \&c. 


\section{$\mathrm{XXV}$. \\ Message to the Earl of Kildare, \&c.}

[MS. Harl, 433, f. 266 b.]

Credence given by the kinges grace to his coun- A.D. 1484 . saillor the bisshop of Enachden to be shewed on 22 Sept. the kinges behalve to Therle of Kildare.

Furst, he shalle shew unto the said erle that the How specitlle and singuler canse of his message at this O'Neilland tyme is to endevor him to accomplisshe the kinges shall be gret desire forto enduce by alle meanes possible suche dealt with persones as deteigne and kepe from his grace his the earldom right and enheritaunce of his erldom of Wolstre, and of Ulster. that it may be ordeyned and brought to the kinges handes and possession, as it hathe been in late dayes of his progenitors. Wherin the king said grace thinketh and perfitely understandeth that no man can do more than his said cousyn, seeng and considred that the gret Onealle that hath maried the said erles sustre hathe and occupiath most part therof; whome the kinges grace for the cause of that mariage and the love of his said consyn, wolle be the rather applied to accept into his favor, as his brother late king of England before had his fader, and gave unto him his lyvree.

Moreovere, if Odomnaylle, by the meanes that the kinges grace hath committed, and shewed unto the said bisshop, wolle come in, and either to be his liegeman or true peax man, that his said consyn of Kildare shalbe content so to receive and entre ${ }^{1}$ lim, as the said bisshop shalle advise him more at large 
A.D. 1484. by mouthe, or at the leest that his said cousyn, set22 Sept. ting apart almaner parcialite, affeccion, or favor, shalle take partie, fortefie and support thoos of them havyng of the said said lyvelode, by whoos meanes, strenghte, and commyng in the said erldome may sonnest be had and reduced to the kinges handes and possession. ${ }^{1}$

Also, over this, he shalle shewe to the said erle that the kinges wille and pleasur is that he for his part, the Plonkettes, or any other lord or noble man of that land, bordurer or other, shalle in alle wise conforme and applie him to alle suche good weyes, meanes, and advertesementes touching the goode effecte, and wele of the premisses as by the said bisshop shalbe devised in any wise.

Passport for the bishop.

Richard, \&c. To alle maires, shireffes, bailliefes, constables, and alle maner otheir our officers, liegemen, and subgiettes, aswele within this our royaume as oure land of Irland, whom unto thise presentes shalbe shewed, greting. Forsomoche as we sende at this tyme into our said land the reverende fadre in God, oure fulle welbeloved counsellor the bisshop of Enachden into those parties for certain gret maters concernyng our pleasur, and the prosperous wele of our said land; we, therfore, desire and nathelesse commaunde you that in his passage and repassage by you ye goodly and curtesly, accept and entreate lim and his servantes in every behalve, and with the more tendre benivolence at oure instaunce, as ye desire to please us. Yeven, \&c. at Westminster, the xxijti day of September, $A^{0} i j^{\text {do }}$.

\footnotetext{
${ }^{1}$ In the blank space at the end of $\mid$ occur in the same hand as the this paragraph the words " $A^{\circ} 2^{\circ} " \mid$ text.
} 
Parcelles of the clothing to be delivered by the said bisshop to the said erle.

A.D. 1484 . September.

Furst, a long gowne of eloth of gold lyned with sattan or damaske.

Item, a long gowne of velvet lyned with sattayn or damask.

Item, two dublettes, oon of velvet and an other of cremysen saten.

Item, thre shertes and kyrcheffes for thre stomakers.

Item, thre pair of hosen; oon of scarlet, an other violet, and the third blake.

Item, thre bonettes, two hattes, and two tippetes of velvet.

Item, the said bisshop hath a lettre direct to Piers Curtesse, keper of the gret warderop for the deliver of the said stuff.

Item, a nother lettre direct to Mr. William Dawbeney, clerk of the kinges juelles, to deliver unto the said bisshop for the said erle of Dissemond, a coler of gold of $x^{t i}$ oz, $x_{x x^{t i}}$ li.

\section{To therl of Desmond.}

RIGHT trusty and right welbiloved cousin, we grete Desiring you hertily wele. Lating you wite that nat oonly him to wear the zelous desir and herty affeccion that ye bere elothing. unto us according to the duetie of your ligeance, rapported on your behalve by the reverend fader in God, our ful trusti counseillor the bisshop of Enachden, bringer of these, bot also the reteignyng in our mynde of the manifold benivolent services and kindenesse by our cousin your fader in sundrie wise to the famous prince of noble memorie our fader, whom God rest, in

'Desmond, not Kildare, this schedule manifestly referri: $g$ to the letter which follows. 
A.D. 1484. seasons of great necessite, and after that to our broSeptember. ther, late king, doon and shewed, causen us to have and accepte you into our singler favor and grace. And forasmoch as it hathe pleased God to sende now the rule of this your reame, to have you the more tenderly recommended in the same as our said counseillor hath more plainly to shewe unto you aswele therin as our entent and pleasure for to have you to use the manere of our English habite and clothing; for the which cause we sende you by hym a coller of gold of our liveree and divise with othre apparaill for your persoune of Thenglish fassion, which we wol ye shal receyve of hym in our name as we have advised; trusting that at somme convenient season herafter we shal have you to comme over unto us hider, and bee more expert, both in the maner and condicions of us and othre honorable and goodly behavynges of our subgrettes here, as by instruccions we have informed hym therin more at large. And as touching your demeanyng in mariage, that for special causes greatly resteth in our mynde and pleasure, we have in likewise shewed unto hym the same by our said instruccions, to whom in declaring therof, and of everi othre thing concernyng the premisses, we desire you to yeve unto hym ful feith and credence, and with al effect applie and endevoir you to thexecucion and performyng of the same, as our great trust is in you. Yeven, dc. the xxix. day of Septembre.

\section{To Therle of Fildare.}

The earl of RrgHt trusti, \&c. Certifieng you that as touching Tincoln appointed lientenant of Treland. the lientenantship of our land of Irland, we have ordeigned and appointed our entierly biloved nepren Therl of Lincolne to that office; and have arvised and willed him that ye shalbe his deputie in the same, wherunto he is agreable, as your servant besides this 
can accertaigne you more at large; in the which we A.D. 1484. pray you to doo and continue as ye have doon for September. the good and wele of our said land. And over this where as we sende at this tyme unto thoes parties the reverend fader in God our ful trusti counseillor the bisshop of Enachden, bringer of these, for certain materes greatly concernyng our pleasure, which by our commandement he hath to shewe unto you, we desire you therin to yeve unto hym ful feith and credence, and with al diligence to the performyng of the same, what great pleasure in soo doing ye shal ministre unto us oure said counsaillor shal in like wise on ou belalve cnforme you. Yeven, \&c. the xxij. day of Septembre.

\section{To the Lord Barrey of Monyster.}

Rrant trusti, \&c. And where as we bee informed Touching by the reverend fader in Grod, our ful trusti counseil- lands withlor the bisshop of Enachden, how that in dayes here- him in tofore in parte aswele thorough your awne negligence Wales. for lak of due sute and labor, as otherwise, ye lave ben injured and wronged of certain lyvelode and landes, that ye clayme of enheritaunce, lieing in Wales; we assure you that if ye by your self, or any other persone for you, shalle lust to make diligence for your recovere therof, after the processe and due ordure of our lawes we shalle shew you therin any thing that may apperteyne, asferforth as your said right, and our lawes shalle require in any wise. And over that for the true hert and feith that by our said counsellor we understande ye bere unto us according to the dutie of your liegeaunce be minto you and alle your kynnesmen verray good and graciouse soverayn lord in any other canse or mater, as we lave commannded him to shewe unto you in ou behalve; to whome lierin ye wille geve playne credence, as our trust is in you. Yoren, Scc. the xxi day of Septembre. 


\section{A.D. 1484. To John Poner and Piers Power, and aither of September. them.}

Acknow. Righte trusty and welbeloved we grete you wele. their servi-Latting you wite that we have understande by the ces against credable reaporte of reverende fadre in God the bisshop the king's of Enachden of youre fast and good demeanyng, and and urging specially in repressing and subduying of our emnemyes

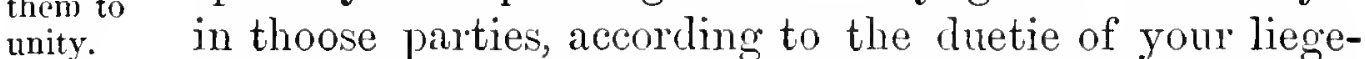
aunce. For the which and your perfite contynuaunce in the same we shalbe verrey good and graciouse soverayn lord unto you and alle your kynnesmen. Desiring you both and aither of you to see that ye and they deale of oon accorde and mite, adroiding alle variaunces and stryves amonges you, as ye and they desire to please us. And our said counsellor hath in our name to shew unto you more at large concernyng the same, to whome therin ye will greve pleyne credence, as our trust is in you. Yeven, \&c. the xxijti day of Septembre.

$$
\text { To \&e. }{ }^{1}
$$

Thanking Right trusty and welbeloved, we grete you wele. him for his And have understanden to oure fulle good pleasur by the king the reaport of the reverende fader in God, oure fulle and his futher. trusty counsellor, the bisshop of Enachden, this berer, that ye be descended of the auncien blood and lynage of our auncestres of Wolster, and also the good feithfulle hert and obeissaunce that ye bere unto us according to the duetie of your liegenunce. Reteynyng also in mynde the noble service that ye and your kynnesmen in dayes past have doon unto the famouse prince of noble memorie, our fader (whom Jesu rest), and other our progenitors. For the which we can you specialle thankes, lesiring you in oul herty wise fermely to contynue the same towardes us, and that 
ye of that blood amongest you applie and dispose you A.D. 1484 . to be of oon demeanyng and unite for the wele of September. your self and of the contre there, exhorting other lordes and gentilles, as ferforth as ye may to doo the same, as our trust is in you. Latting you wite that we more at large have enstructed our said counsellor with our ferther mynde and pleasur in our name to shew unto you; wherein ye will geve unto him plaine credence, and in alle wise conforme you to thutter accomplisshing therof. For the whiche soo doyng we assure you to bee good and graciouse soverayn lord unto you and alle your kynnesmen in any your causes herafter. Yoven under our signet at Westminster, the xxj. day of Septembre.

Item, two other lettres of the same reteignew.

\section{To Sir Alexander Pluntiett.}

Trustr and welbeloved we grete you wele. And late Commendyou wite we have understande by the credable reaport ${ }_{\text {fidelity }}^{\text {in }}$ of the reverend, icc., the bisshop of Enachden of your fast warring and good demeanyng, and specially in repressing and Irish the subduyng of our ennemyes in those parties, according to the duetie of your liegeaunce, for the whiche and your perfite contynuaunce in the same we shalbe verray good and graciouse soverayn lord unto you and alle your kynnesmen, as our said counsellor hath in our name to shewe unto you more at large concernyng the same; to whome therin ye will geve pleyne credence, as our trust is in you. Yoven, \&c., the $\mathrm{xx}^{\mathrm{ti}}$ day of September.

A like lettre to Sir Rowland Eustace, tresourer of Irland.

A like lettre to Sir Olivere Plonkett.

A like lettre to the Baron of Delevyn,

A like lettre to the Viscount of Gormeston. 
A.D. 1484 .

To the Lord Barry et Monystre.

September.

Righr trusty and welbeloved, we grete you wele, 'To the same effect. Latting you wite we be enformed by the reverende fader, \&re, the bisshop of Enachden, that ye be enhabited in thextreme parties upon our ennemyes of the wilde Iresshe, and according to your liegeaunce daily kepe werre with them in the defense of your self and other our subgiettes there to your gret troubles, hurtes and charges. For the which we can you gret thankes, desiring you so perfilty to contynue, whiche we shalle not unremembre, but for the same be unto you and alle your kynnesmen good and graeiouse soverayn lord in alle your causes herafter, as our said counsellor hath by our commaundement to shew unto you more at large; to whome therin ye will geve fulle feith and credence. Yoven, sc. the xxij day of September.

A like lettre to the lord Staundon of Connaghte. A like lettre to the lord Nangle of Connaghte.

A like lettre to the lord Excestre of Connaghte.

A like lettre to the lord Roche.

A like lettre to the lord Byrmyngeham of Connaghte.

A like lettre to the lord Barryet of Comnaght. And a nother lettre not directed. 
[MS. Harl. 433, f. 270.]

Instruccions yeven by the king unto Sir Marmaduc Constable, knighte, steward of thonnor of Tutbury.

Furst, that the said sir Marmaduc shalle take the Against othe of alle thinhabitiuntes within the said honnor retaining that they shalbe true and feithfulle liegemen unto the king, and not to be reteigned to any lord or other, but immediatly to the linges grace.

Also, the said sir Marmaduc shalle see that no lyveres and giving ne conysaunce be geven within the said honnor con liveries, trarie to the lawe and to the statutes therof made.

Also, where heretofore diverse extorcions and oppres- extortion sions have ben doon by the countie baillieffes, upon of bailiffs, trust that they shuld contynue and not to be remowed from their offices, the king wolle that fromhensfurth the said sir Marmaduc put able and wele disposed persones in the said bailliefwykes, suche as been sufficient to answere the king of his duetie; and they to be chaunged from yere to yere, and that a proclamacion to be made at every gret court that if any persone wolle come and compleyn of any of the said baillieffes that they shalbe herd, and due reformacion and punysshement be had according to the kinges lawes and their demerites.

Also where as there be certen fermeholdes laten to subletting diverse persones which occupie but litille, or summe the king's part therof to their owne propre use and make leesses of the residue over unto other suche as be not the kinges tenantes, the king willing his tenantes to be preferred to suche fermholdes and to be fermours immediatly to his grace, wolle that the said sir Marmaduc discharge alle fermors of alle such parcelles soo 
A.D. 1484. sette over by lesses unto other and to late the same October. fermes amonges the kinges tenantes to suche as be able to do the king service and to answere him of his ferme. and waste Also the king wolle that the said sir Marmaduc of the wele and diligently survie alle his wooddes within the
king's woods. said honnor, and to see that noo waast be made in theim, ne that no brusing be made in them in the wynter season but suche as shalbe necessarie, and to the leest hurt to the kinges woodd.

Also the said sir Marmaduc to see that there be noo wood fallen within the said honnor for paleyng but such as is moost mete and convenient for the same, and the coppies of the said pailling wood with the brewsing that is metely for thexpenses of the kinges houshold or his reparacions be kept therfore, the residue to be praysed and sold to the kinges most advauntages.

Also the kinge wolle that noo lyverey trees be geven within his parkes and woodes but oonly under his speciall warrant or suche as liave it by specialle graunt of olde tymes past.

Means to secure efficient officers.
Also, where as the king hath enlarged the fees of his parkers, to thentent they shuld be attending daily on their offices when they awaite not on his grace, and in their absence make sufficient deputies suche as wilbe of good demenaunce to the kinges wod and game, the king wolle that if any suche depute be founden not suffisaunt ne of good demeanaunce then the said sir Marmadue to discharge him and to certifie the kinges grace, that a suffisaunt deputie may be put in his rowme; and also that no parker have of duetie in any of the kinges parkes over $\mathrm{ij}$ kyen and two horsses.

Also the king wolle that tharbage of alle his parkes be latten or approwed to the kinges monst advantages, savyng suffisaunt pasture for the dere, and the kynges fermes not dymynysshed; forseen alway that the 
parkers of the same be neither fermors nor approwers $\Lambda . D .1484$. of the said herbage.

October.

Also that the lieutenant, the boweberer and receivors of wardes be suche persones as be of good demeanaunce ayenst the kinges wood and game and sworne to the same; aud that they and every of theym wele and duely oversee the game and woddes in the parkes and waardes of the said honnor according to their offices as they have bene accustomed afore tyme.

Also the said sir Marmaduc to put into thoffice of bailliefwykes that be accomptauntes, good and suffisaunt persones and suche as be able to doo the king service and to content the king of suche as they shalbe charged withalle upon their accomptes.

\section{XXVII.}

[MS. Harl. 433, f. 271.]

A Remembraunce made, aswele for hasty levy of the Kynges revenues growing of alle his possessions and hereditamentes, as for the profitable astate and governaunce of the same possessions.

Furst, that alle the kinges officers of his court of eschequier use and execute hasty processe ayenst almaner persones accomptable, and other being the kinges dettors, as the caas shalle require; and also to here and determyne accomptes of the same, and thissues, proffuytes, and revenues commyng therof to be levied and paied into the kinges receipt without delaye.

Also that no persone accomptable, ne other persone being in dette to the king, have any respet, stalment, or favor in the said court, whercby the kinges dueties may be delayed over the space of iiij monethes next after the tyme that any suche persone owith to yelde his accompt, or owith to pay his debt, whatsoever it 
A.D. 1484. be. For it hath bene said that many diverse officers accomptable have bene respected of their accomptes from yere to yere, and also of their paymentes by space of many yeres, to the kinges gret hurt, in tymes passed.

Also that no officers havyng office in the said court of theschequier have or occupie any office in the receipt.

Also it is thoughte that the auditors of the said eschequier shuld yerely make a boke of alle the revenues, issues, and proffuytes growing of alle shireffes, eschetors, collectors of custumes and subsides, tresourer of Calais and Guysnes collectors of clismes, baillieffes of cities, burghes, and portes, and of alle other maner officers accomptable of the said eschequier, with the reprises and deduccions therof, and the same boke to declare afore suche persones as the kinges good grace shalle like to assigne to here and to see it; whereupon his grace may yerely se the prouffites of the said court.

Also that the tresourer of England for the tyme being yerely shuld make a declaracion of alle suche money as is received or assigned within his office, be it in the receipt or be it otherwise, for that yere afore the said yeres.

Also that the said court of eschequicr be clerely dismyssed and discharged with any medling with any forayn lyvelode in taking of accomptes, as Wales, duchies of Cornewaille, York, Norffolk, Erldoms of Chestre, Marche, Warrewick, Sarum, and of alle othre landes being in the linges handes be reason of forfaictor; whiche is thought most behovefulle and profitable to be assigned to othre foreyn anditours for diverse canses ensueing, etc.; that is to sey:-

First, for more hasty levic of money. Also for more ease and lesse coste of the officers of suche lyvelode Also for cause that the lordshippes may be yerely sur- 
veied by the stiwardes, auditors, and receivours in the A.D. 1484 . tyme of accomptes of officer's of the same for reparacions, wodesales, and for othre direccions to be had amonge the tenantes, with many mo causes necessarye, etc.

And where that many lordshippes, manours, londes, and tenementes perteynyng to the crowne bene committed to diverse persones for fermes in certeyn, by the whiche the kinges woddes and his courtes, with othre casuelties, bene wasted and lost to his gret hurt, and gret allouances had for raparacions of his castelles and manors, and they not forthy repaired, as it is said ; and also the said lordshippes ofte tyme set within the value; it is thoughte that a foreyn auditor shuld be assigned for alle lordshippes, manors, landes, and tenementes belonging to the crowne, and a receivor for the same yerely to ride, surveie, receyve, and remembre in every behalf that myghte be most for the kinges profite, and therof yerely to make report of the astate and condicion of the same; by the which the kinges grace shuld knowe alle the lordshippes that perteyneth to his crowne, whiche as nowe be unknowyn, as it is said, etc.

Also, it is thoughte that suche certayn auditors as ben of gode, true, and sadde disposicion and discrecion, shuld be assigned to here and determyne thaccomptes of alle the kinges foreyn livelode as is above discharged fro theschequier, and to have so many auditours and no mo but as may conveniently and diligently determyn the said livelode betwixt Michelmas and Candelmes, with sadde and discrete examinacion of alle defaultes and liurtes of alle officers accomptable severaly in their offices executing, wherein thawditors of theschequier can never have so evydent knowlege for reformacion of the same.

Also, that the receivours of gode and true disposicion and also of havour of richesse be assigned to the said 
A.D. 1484. lyvelode; and they to se for reparacions of castelies, manors, milnes, parkes and othre, and in the cirquyte of their receipt they to sethe wele of every lordshippe.

Also, it is thoughte that alle auditours afore said, aswele of theschequier as of foreyn livelode, shuld yerely make declaracion of alle suche livelod as they have in charge, afore suche persones as the kinges grace wol therto assigne at London, alway betwixt Candelmes and Palmesonday, so that his grace may be asserteyned ycrely of the hole revenues of alle his livelode, and what therof is paid and what is owing, and is whos defaute. Also, where that lordes, knightes, and esquiers, many of them not lettered, bene made stewardes of the kinges livelod in diverse countres, thay taking gret fynes and rewardes of the kinges tenantes to ther propre use, to the linges hurt and poveresshinge of his said tenantes, and also wanting cunnyng and discrecion to ordre and directe the said lyvelode lawfully, with many moo inconvenientes Therfor it is thoughte that lerned men in the lawe where most profitable to be stiwardes of the said livelod for many causes concernyng the kinges profite and the wele of his tenantes.

Also, it is thoughte that alle londes being in the kinges handes by reason of wardeshipp of lordes sonez or othre noble men shuld not be let to ferme hold for a certeyn, but that the same landes shuld remayne in the kinges handes during the nonnage and that auditours of the same londes shuld yerely determyne thaccomptes therof and to make declaracion as is above said, for the more profite to the king, \&c.

Also, for temporalties of bisshopriches, abbayes, and priories in likewise, \&c.

Also, it is thoughte that alle the forsaid anditours every yere at the fest of Michelmes next after the declaracion made of alle foreyn lyvelod by for the said persones by the king so assigned, shuld delivere or doo to be delivered the bookes of accomptes of the 
same into the kinges eschequier afore the barons ther A.D. 1484. after the first yere of the premisses, ther to remayne of recorde, so that the bookes of accomptes of the later yere be alway in the handes of the said auditours for their presidence, the duchie of Lancastre, the lordshippes of Glamorgan and Bergevenny alwey except, sc.

\section{XXVIII.}

\section{Preparations for Defence.}

[MS. Harl. 433, f. 274.]

Instruccions geven by the lkinges grace to the December. commissioners appointed in every shire of this his royaume.

Furst, that they on the kinges behalf thanke the people for theire true and lovying disposicions shewed to his highnesse the last yere for the suertie and defense of his moost royal persone and of this his royaume ayeinst his rebelles and traytors exhorting theim soo to contynue.

Item, that the said commissioners incontynent after the receipt of theire commissions diligently enquere of alle baillieffes, constables, and other officers of townes, towneships, villages and hundredes within the procincte of theire commission, the nombre of persones suffisauntly horsed, harneysed, and arrayed as by every of theim severelly were graunted to doo the kinges grace service before the olde commissioners whansoever his highnesse shuld commaunde theim, for certaine dayes in theire said gramtes expressed, for the resisting and subduyng of his enemyes, rebelles, and traytours; and of the same persones and theire array to take a good vieu and see that they be hable men 
A.D. 1484. and wele horsed and herneysed, and noo rascal, and December. to endevoire theim to encrease the nombre by theire wisedoms and policies if they can.

Item, that they also diligently enquere of al suche money for the wages of the said persones as in every place hath ben gadred and leveyed, and to whoos handes and keping the same was delyvered, and wheder it soo resteth or not; and thereupon to ordre and see that the same money be alwayes redy in the constable or baillieffes handes or othre by theire discrecions, to be delyvered to the said persones without any manere delay when they shalbe commannded to doo the king service; and in likewise to ordre and see in every place where no suche money have be gadered and leveyed, that it forthwith be leveyed and delyvred to the handes of the constable, baillieffes, or othre; there to remayn and surely to be kept for the wages of the personages soo by theim graunted to doo his grace service.

Item, in caas that any parte of the same money heretofore leveyed be by any persone taken out of the keping of any of the said constables, baillieffes, or othre ayeinst theire willes or othrewise, that than the said commissioners not oonly see the same restored to the said constables, but also the soo taker to be commytted to warde and punysshed after theire discrecions.

Item, that the said commissioners at the vieu of the said persones, yeve theim strait commaundementes to attende upon suche capitaynes as the kinges grace shal appoint theim to attende mpon, and on noon othre, as they wol adroyde the kinges highe displeasire at theire utterest perilles.

Item, that the said commissioners on the kinges behalf yeve straitly in commanndement to all knightes, squiers, gentilmen, and othre, being hable men of theire bodyes, to doo the kinges grace service to prepare 
and arredy theimself in theire persons soo to doo when A.D. 1484. they shalbe thereunto warned and commaunded withDecember. out any excuse, as they wil advoyde the kinges highe displeasire at theire perilles.

Item, that the said commissioners in al goodly hast certefie by writing to the kinges grace theire ordering of the premisses in every behalf, with the names of the persones soo by theim seen and vieued.

Item, to shewe to alle lordes, noblemen, captaynes, and othre that the kinges noble pleasire and commaundement is, that they truely and honorably, almanere quarelles, grugges, rancors, and unkyndenesse layed aparte, attende and execute the kinges commanndement, and everyche be loving and assisting to othre in the kinges quarelles and cause, shewing theim plainly that whosoever attempt or presume the contrary, the kinges grace wol soo punysshe theim that al alle othre shal take example by theim, \&c.

\section{XXIX.}

[MS. Harl. 433. f. 273.]

\section{Ricardus Rex. ${ }^{\mathrm{I}}$}

By the king.

'T'Rusty and welbeloved, we grete you wele. And forasmoche as by calling from this uncertaine and transitory lif of your late bisshop, ye stande destitute and desolate of a pastoralle hede and spirituelle governor; for the whiche, by auctoritie of oure licence royal, ye must hastely procede to theliting of a newe pastor and bisshop: We, havyng tendre regarde aswele unto the laudable merites, highe vertues, and profounde

1 Added in another hand of the period "littera bona." 
A.D. 1484. cunnyng, that the righte reverend fader in God, our

8 Dee. righte trusty and righte welbeloved counsaillor, the bisshop of St. David, ${ }^{1}$ is notarily knowen to be of, as unto othre his notable desertes, contynued trouthe, and feithful services to us in sundry wises doon to our singler pleasire, desire and hertly pray you that in your said eleccion ye wol have him to the said preemynence and pastoralle dignitie before alle othre especially recommended and preferred. Wherein we doubte not ye shal not oonly provyde righte sadly for the wele of the said cure, and for the honnor of our cathedralle churche there to the pleasire of God, but also cause us to departe with you the more largely the favor of our good grace in suche thinges as may be for the universal wele of you and of our said churche in tyme to come. Yeven undre our signet at oure palois of Westminster the viijth day of Decembre.

To our trusty and welbeloved the dean and chapitre of oure cathedral churche of Sarum.

1 Thomas Langton. 
H E N R V I I. 



\section{HENRY VII.}

I.

[MS. Cott., Titus B. xI. f. 23.]

Instruccions yeven by the kinges grace unto hi A.D.1 $\$ 86$ ? counseillour and servant John Estrete to be shewed to Therl of Kildare, etc.

FURST, as touching the article of the peticions of The king, the said erl for to have his office of deputie lieutenant desiring $_{\text {Kilde's }}$ of that land for the terme of $i x$. or $x$. years, the said advice John Estrete shall say that to thentent the kinges upoverngrace may the better counseill, conclude and devise ment of for the bringing of his land of Irland into pleyn obeissaunce and suche estate, welth and prouffitte as it hath be in tyme passed, he desireth in that partie to here thadvise of the said erl, considering that for the long rule that he hath borne there, ther can no man therin better counsaill his grace than he.

Item, his grace hath ben wele advertised that the said erl in his said office served king Edward the iiijth nobely, trewely, and hardely, and moche better after the tyme he had been with him in this bis royalme.

Item, his grace trusteth that upon mutuall sight and communicacion had betwixt his grace and his said cousin, his grace shall the rather be enclined to take his said cousin into his nigh favor and grace, and his said cousin on his partie shall moche the better be couraged, moved and sturred trewely and fastely to serve his grace, and therupon in his owne 
A.D.1486? persone conclude, not oonly for himself, but also for his ehildern, bredern, kynne and alies according to the secrete credence whiche the said John Estrete on the behalve of the said [erl shewe]d u[nto the kin]ges grace. For whiche causes and the perfite performacion of the same the king willeth and desireth his said cousin . . . . . her . . . sses and excuses aparte,

requires his presence in England before the and be with him personelly in this his royalme before the furst day of August next commyng, whersoev[er] his grace shall than be. And for the suretie of his persone and of alle suche as shall comme in his company for the tyme of his or their commyng, abiding; and retornyng, the king marveilleth that he can desire any promises, seales, or writinges of any of his lordes more than of this grace oonly, eonsidering not oonly that suche a suretie can not stand with the kinges honour, but also that neither the said erl ne any other hath seen that his grace hath broken promyse or assurance by him made unto any persone. Wherfor his grace sendeth by the said John Estrete unto the said erl his lettres of proteccion and tuicion undre his signet and signemanuell, whiche he wol as duely kepe and see kept as if they were passed undre the seales of alle the lordes of his land.

Item, the said John Estrete shall say that upon the said erles commyng and being with the king by the said day, the king shall as benignely, tendrely and largely take him into the favor of his grace as ever did King Edward the iiijth, and in so ample wise departe with him as shalbe to thencrese of his honor, pronffite and preferring, and at the same tyme enlarge his graunte of his said office of deputie lientenant of that his land for ix. or $x$. yeres according to his desire.

[Item,] to the seeond article of the said erles peticions eoncernyng thassignacion of $\mathrm{m}$ ! li. for his wages in the said office, the said Fohn Elstrete shall say that the 
kinges pleasir is that the said erl, at his forsaid A.D.1486? commyng unto his grace, bring with him in writing the certainte of the kinges revenues of that his land of Irland, with the rharges going oute of the sime, whiche seen shall mowe appere what remayneth clierly unto his grace, and if the same wol answere the said $\mathrm{m}^{1}$. li. the king is content at his commyng unto his grace to make him a graunte therof for his wages. And in caas the said revenues comme not clerely to somoche, his grace wol than at the commyng of the said erl soo covenant and indent with him for the certainte of his wages and contentacion of the same as of reason he shal have cause to hold him content and pleased.

Item, where the said erl desireth to have of the kinges graunte to lim and his heires masles the manoir of Lexlep and the keping of the castell of Wekenlowe, the said John shall say that upon the said erles commyng unto his grace, the king is content and wol make him a suflicient graunte therof according to his desir.

Item, finally, the said John shall shewe unto the said erl that there is noo thing doon by the said erl in tyme. . . d ne sur . . . . r reporte of him made unto the king ne favour, affeccion or ennemyte of any persone of [w] hat condicion so ever he be, that shall torne his grace from the said erl, but that upon his commyng unto his presence he shalbe as good and gracious lord unto him as is above rehersed, and more largely if the said erl can it reasonably desire. In witnesse wherof, his grace hath with his signemanuell signed thies instruccions and caused his signet to be put unto the same.

(Endorsed.) Instruccions unto John Estrete into Irland. 
II.

\section{Henry VII. to the Pope.}

[From the Vatican Transcripts in the Brit. Musenm, MS. Addit. 15,385. f. 315. Headed "Ex Autogr. libro Memorabilium Pii U.," pag. 101. $t^{\circ}$ Arm M., caps. III.]

Sanctissimo clementissimoque Domino nostro Pape.

A.D. 1487. Beatissime pater, post humillimam commendationem

5 July. et devotissima pedum oscula beatorum. Cum divina clementia certissima nobis et manifestissima signa nuper dederit, quibus solvendi potestatem at,que ligandi tam vestrae Sanctitati ejus vices gerenti quam præedecessoribus successoribusve suis traditam, ratam omnino, stabilem, perpetuam atque irrevocabilem esse perpetuoque fore ostendit, non possumus certe quin vestram Sanctitatem ad sui et sacrosanctre istius Sedis Apostolica consolationem non mediocremque latitiam certiorem reddamus, et tanti nostri gaudii participem faciamus. Rem When the itaque nti se habet ordine perscribemus. Cum in hostes king went rebellesque nostros paulo antea exercitum duxissemus, rebels ru- atque his admodum propinqui essemus faeti, ut sæpe mors were ex fraudulenta hominum natura fieri solet, adversa et his army prorsus erronea et conficta de nobis et nostro exercitu had been fama Londonias et apud Westmonasterium fuerat perrouted. lata, sicuti et in plures alias regni partes licenter evagaverat. Ferebatur enim tam nos in fugam versos quam universum nostrum exercitum dissipatum. Ea igitm re audita, nonnulli ex his qui ob sua patrata vel in nos vel in alios scelera, privilegiis Westmonasterii et immunitatibus gaudere [speraverant], ' arbitrantes sibi ea tempestate omnia esse permissa, potissimum quod, nefario quovis scelere perpetrato, liberam ad ipsum eundem privilegiatum locum se habere semper putent 
redeundi facultatem, sicuti aliis nostris literis ad ves- A.D. 1487. tram Sanctitatem pro reformandis hujusmodi enormitatibus latius scripsimus, arma sumentes ut eorum domos quos nobiscum esse cognoscerent ad bella ${ }^{1}$ profectos spoliarent et in scelus quodque prorumperent, continuo in unum sunt congregati. Ex horum numero quidam Johannes Swit, homo magis temerarius quam audax, sociis omnibus silentibus, "Lt quid," inquit, "ad censuras ecclesiasticas, pontificalesve, potestates? "Videtisne hujusmodi interdicta nullius omnino esse " momenti, posteaquam ante oculos habetis eos ipsos " qui ea pro se impetrarunt esse profligatos, et in capita " eorum omne anathema esse conversum?" Hæc ubi pronuntiavit, illico in terram mortuus cecidit, ejusque Appalling facies et corpus totum ipsa caligine nigrius confestim fate of a apparuit; paulo vero postea cadaver ipsum tantum ex papal inse foetorem emisit ut ad id accedere nemo prorsus posset. ${ }^{\text {terdicts. }}$ Hrec res sic gesta est, Beatissime Pater, nec nisi ita certo esse sciremus ad vestram Sanctitatem scripsissemus. Agimus profecto gratias Omnipotenti Deo quas possumus uberiores, qui pro sua ineffabili misericordia tantum in regno nostro de fide Christiana miraculum ostenderit. Agimus quoque et vestræ Sanetitati amplissimas, quoniam ad jacenda pacis in hoc regno nostro fundamenta suos nobis favores gratiose sit impartita. Sed de hac re hactenus.

Cum nonnulli ex prælatis Hiberniæe, archiepiscopus Requests scilicet Dublinensis, ${ }^{2}$ archiepiscopus Armachanensis ${ }^{3}$ et ${ }_{\text {Irish bish- }}^{\text {that }}$ episcopi Medensis ${ }^{4}$ et Darensis, ${ }^{5}$ tam in nostri dominii opsw ho quam censurarum ecclesiasticarum contemptum, rebel- famber libus hostibusque nostris opem et juvamen impenderint, simnel ac spurium quemdam puerum ${ }^{6}$ quem victoria potiti in may be excommunicated.

\footnotetext{
1 bellos, MS.

2 Walter Fitz Simons.

${ }^{3}$ Octavian de Palatio. See $\mathrm{Ap}$ pendix $A$.

4 John Pain.

${ }^{5}$ Donald O'Fallon, bp. of Derry.

6 Lambert Simnel.
} 
A.D. 1487. manibus nostris habemus, ad rebellium ipsorum et hos5 July. tium nostrorum confingentium puerum ipsum ducis quondam Clarentia filium esse, in regem Angliæe coronarunt, ad grave nostrum et totius regni nostri pre. judicium, vestram Sanctitatem bumillime imploramus ut præfatos prælatos in censuras incursos ecclesiasticas postulare velit, atque in eos de jure procedere. Faciet equidem hac vice vestra Sanctitas justissimi inprimis prontissimique pontificis officium, et a lege Dei deviantes in rectam viam et semitas salutis reducet, rem preterea supra quam dici possit efficiet et nobis gratismam; aliis denique ne hujusmodi imposterum facinora aggrediantur certissima relinquet documenta. Id ut agat vestra Sanctitas etiam atque etiam ex animo rogamus. Ex regia nostra juxta Castellum Kenelworth die quinto Julii, 1487.

Ejusdem Sanctitatis vestræ,

Devotissimus atque obsequentissimus filius,

Dei gratia Rex Angliæe et Francie ac

Dominus Hibernire,

\section{HENRICUS. ${ }^{1}$}

Litere suprascriptæ restitutie fuerunt D. Secretario.

${ }^{1}$ Hulricus in the transcript. 
III.

Henry VII. to the Spanish Captains in Britanny.

[MS. Egerton 616, f. 2.]

Henricus Dei gratia Rex Anglix et Francia ac A.D. 1490. clominus Hibernia, magnificis atque eximiis dominis $15 \mathrm{Aug}$. F. R., oratori, et comiti de Salinas, ac Petro Carillo, screnissimorum principum regis ac regine Castella, Iregionis, Aragonii ac Sicilice, etc. capitaneo, et ducibus cxercitus, salutem et prospera votorum incrementa. Accepimus literas vestras decimo septimo die Julii scriptas quibus vestram credenciam in magnificos oratores serenissimorum principum vestrorum hic existentes factam intelleximus. Ipsos igitur dominos oratores audivimus. Hi namque pro parte vestria nobis Holds them exposucrunt cum sit quod vestri supremi in mandatis excused for vobis dedissent ut cum primum Britanniam intrassetis, join the cum armatis nostris quos illic" habemus velletis vos $\begin{gathered}\text { English } \\ \text { forces in }\end{gathered}$ coujungere, et vos tamen, ob certas quasdam cansas Britamy. corundem pincipum vestrorum jussis in hunc usque diem non paruissetis, prafatos vestros supremos id factum molesto animo ferre, atque etiam vos timere ne et nos quoque ex eadem re gravem aliquam cepissemus displicentiam; causasque vestras cur non fueritis cum nostris juncti iiden oratores nobis ostendermnt. Equidem, magnifici viri, licet inter nos et serenissimos vestros principes conventum esset ut cum armatis nostris istic existentibus quam primum vos adjungeretis, tanta tamen est nostra erga serenissimos vestros silpremos aflectio et praecipua amoris mutui vicissitudo ut rem ipsam modeste feramus, nec persuadeamus aliquam idcirco esse nobis illatam injuriam. Diximus itaque prefatis dominis oratoribus ut ad serenissimos vestros principes scriberent et pro vestra excusatione ostenderent nos nullam exinde cepisse displicentiam. Putamus cos illico scripturos et desiderio vestro esse satis- 
A.D. 1490. facturos, quod si opus fuerit ut nos quoque ad suas

15 Aug. sublimitates pro eadem causa scribamus id faciemus perlibenter. Interea tamen vestras nobilitates rogamus ut pro illa cordiali atque intima amicitia et conjunctione quam cum supremis vestris habemus, ita vos gerere velitis ut tam vestrorum principum obedientissimi quam et nostri amantissimi facile possitis ab omnibus judicari. Erit autem id nobis vehementissime gratum. Ex regia nostra de Eltam, die xv Augusti m.ccc.lxxxxo.

\section{Henricus Rex. ${ }^{1}$}

Adelressed: Magnificis atque eximiis dominis Francisco de Rojas, oratori, ac comiti de Salinas, capitaneo generali, et Petro Carillo, serenissimorum regis et regine Hyspanice deputatis in Britannia missis, amicis nostris carissimis.

Endorsed. Littera Regis Anglix;-also, Del Rey de Inglaterra al conde de Salinas y a Rojas, ete.; -in a third place, Littera Reris Anglix ad comitem de Salinas, ete.

\section{IV.}

\section{Henry ViI. to the Bishop of Durifam."}

[MS. Cott., Titus F. iii. f. 91.]

\section{By THE KIncr.}

H. R.

A.D. 1491. RigirT reverend farder in God, right trusty and right 5 Feb. welbeloved, we grete you wel. And have seyn youre The king writing of the date of the xxvj. day of Jannary, will respeet the wherby and other wayes we understande wel that Sir

\footnotetext{
${ }^{1}$ Below the signature is written f though undoubtedly contemporary, in a modern hand "Del Rey Hen- is not Henry's. The letter is there" rieo de Inglaterra del sn mano;" fore only a eopy, though folded and but the signature is in the same addressed like an original. hand as the letter itself, which, a John Sherwood.
} 
Robert Chambrelayne and diverse personnes with hym A.D. 1491. in company be taken at Hertilpole, within the precinct 5 Feb. of the fraunchise of Saint Cuthebert belonging to you of St.Cuthand to youre chirche of Duresme. Wherin ye beseche bert in the us humbly that we wol not doo breke, nor interupte sir Robert the said franchises. We late you wite that for thonnor Chamberof God and of that glorioux Confessor Saint Cuthebert, arrest. we be and shalbe as good and favorable souverain lord unto you and to thoes franchises and libertees as any oure noble progenitors lathe been in tyne passed, and shal moche rather assist and defende theym then in any wise suifre theym to be interupted or defeicted. Desiring and hertily praying you that oure trusty and welbeloved servaunt Sir Edward Pykering; knight for omre body, may bring the said Sir Robert and thoes other oure rebelles and traitours to our presence. And if youre shirief of the bisshopriche have the conveyance according to your said fraunchise, both of our said servant and of our rebelles and traitors asfer as the bondes streicheth of youre said libertiees, for the better sinfgard of the same, we shalbe therwith content and plaised. And astouching the goodes taken with our said rebelles, we be content also ye have theym, if that your said fraunchises so require: how be it the lord Clifford maketl clayme unto theym by raison of certain his libertees that he pretendeth to have in the lordship of Hert and Hertilpole forsaid. And inasmoche as for divers grete eonsiderations it behoveth us to understande what writinges and othre goodes our said rebelles had with theym, we eftsomes praye you that by billes endented betwene you and your officers on the oon part and our said knight on the other, we may be certefyed purticulierly and by parcelles of all [su]che writinges and goodes as shalbe founde in their caskettes, males, tronkkes, or in othre their cariages. $\Lambda$ ssuring you that our mynde ys not therby nor othrewise to breke or interupt your said fraunchises, but rathre 
A.D. 1491. to .....' and defende theym as above. Yeven under 5 Feb. our signet at our paloys of Westminster, the ${ }^{\text {th }}$ day of Februarij.

Addiessed: To the Right Reverend Fa[der in God, our] right welbeloved the bi[shop of Duresme].

\author{
V. \\ Petres Camielianes to Ferdinand and Isabelad \\ of SPAin.
}

[Holograph, MIS. Egerton 616. f. 4.]

A.P. 1496. Serexissum atque invietissimi principes et domini, 2.July. domini nei observandissimi. Post humillimam ac derotissimam commendationem. Quantopere sim ego, fucrimque semper, ac perpetuo sim futurus vestris majestatibus affectus, nulla certe lingua, nullove sermone aut epistola referre possem. Quoniam vero dominus doctor de Puebla, vestrarum majestatum orator insignis, lunjus mei animi et sincerre mentis plane conscius est, non me extendam ulterins ad servitutis mese quam gero erga vestras serenitates sinceritatem ostendendam, quandoquidem ab ipso domino oratore, viro curiosissimo, et omnium quos unquam norim ant viderim diligentissimo, non dubitem easdem vestras majestates certiores antehac sepe esse factas. Satis sit me esse ac semper fore vestris celsitudinibus tanta fide et devotione obstrictum, ut addi prorsus possit nihil, nee aliud quicquam gratius mili obtingere posse quam, post illud quod serenissimo domino meo regi debeo

${ }^{1}$ Lost by the mutilation of the MS. 
servitium, de vestris majestatibus benemereri valeam. $\Lambda$.D. 1496 . Habeo gratias sempiternas vestris sublimitatibus pro 2 July. literis suis gratiosissimis superioribus amnis ad me datis, atque illas humiliter obsecro ut mihi ignoscere relint quod nihil ante hunc diem ad easclem scripserim; hocque meum tam diuturnum silentium in meliorem partem accipiant, nec mea negligentix aut oblivioni quovismodo, sed temporum qualitati hanc tantam meam taciturnitatem ascribant. Caterum, serenissimi principes et domini, domini mei observandissimi, licet Thinks it Satis intelligam vestras serenitates summa prudentia et very desirconsilio in suis agendis nti, et ea omnia prospicere quae the alliance sibi commodiora atque honorificentiora esse possint; so long $_{\text {tred for }}$ quoniam, tamen, locorum distantia interdum efficit ut should varii varie referant, et veritas rerum quandoque ta- be conceatur et oceultetur, ego pro illa devotione et ficleli mente quam gero erga vestras majestates non postponam remonstrare illis quod sentio quodque certo scio, hoc unum, scilicet, quod foedus istud affinitatis tamdin tractatum maxime mihi conducere videtur ut ad effectum deducatur; neque certe me movet amor aut servitus ulla quam exhibeo huic meo serenissimo regi, sed ipsius mei principis virtus inclyta, divinum ingenium et potestas amplissima ad hrec demonstranda nue invitant et impellunt. Quam foecundos autem et uberes fructus hujusmodi vinculum sit paritur'um videor ego satis, veluti e sublimi cuadam specula, intueri. Consulere autem in tanta re homo ipse imbecilis neque debeo neque possum. Tantum liceat mibi commemorasse quid sentiam; quod si in hoc quoque imprudens aut nimis audax visus fuero, ignoscant, quæso, vestrre majestates desiderio meo atque amori quem gero erga illas, cujus sane tanta est vis et magnitudo, ut fortisse modum excesserit. Superest ut vestrie serenitates felicissime valeant ad vota; et si qua in re studium aut officium meum sibi gratum esse possit, non secus opera 
A.D. 1496. nea utantur quam humillimo et fidelissimo quoque 2 July. suo servulo. Ex Londonia die ij. Julii $M^{\circ}$. cccelxxxxvjo

Vestrarum carundem majestatum,

Hunillima creatura,

Petrus Calimeinanus Brixiensis,

Serenissimi domini regis Anglixe, etc. secretarius

Latinus, etc.

Addressed : Serenissimis atque invictissimis principilus et dominis, dominis Ferdinando et Hellisabeth, Dei gratia regi ac regina Castelle, Legionis, Aragonum, Sicilire, Granatre, etc., Dominis meis semper olservandis.

Eudorsed: Secretarii regis Anglia, ii. Julii anno 96.

\section{VI.}

'The Chrdinal of Perugia to Henry VII.

[Orig., MS. Cott., Cleop. E. iii. f. 145.]

A.1. 1497. Strenissime Rex atque inclyte domine, post comJune. mendationes. Scripsi paucis ante diebus ad majestatem Recom- vestram regiam quae nunc non repetan quia puto eas that the literas una cum iis venturas quibus venerabilem virum of Worces- dominum Jo. de Giglis vestrne majestatis oratorem ter be con- iterum ei commendandum uberius duxi. Nam post-
ferred on John de quam priores erant clause intellexi episcopum WigorniGiglis. ensem vita functum, ejusque ccclesiam regimine pastorali destitutam. Motus itaque benevolentia qua dictum dominum Johannem complector, ob singulares ejus rirtntes et propter sincerau firlem quam cognosco illum gerere majestati vestra, non inconveniens putavi illum

1 John Lopez, a Sisaniard, afterwards abl. of Capua. 
commendare ut majestas vestra virum hune suum A.D. 1497. fidissimum et integerrimum servitorem ad dictam ecclesliam promoveri faceret: in quo rem quidem dignam se vestra majestas geret, virum de se benemeritum honestando, et Sanctissimo Domino nostro totique huic curiæe gratissimum, ut ex literis Sanctissimi Domini nostri intelliget; mihi vero mirum in modum acceptum, qui cuperem præfatum dominum Johannem pro meritis honestatum videre. Quod si forte majestas vestra aliquam difficultatem faceret, quia timeret ne, si in curia talis ecclesia vacare ex persona ipsius contingeret, alicui provideretur absque voluntate serenitatis vestra, non est profecto quod timeat in hoc; paucis enim ante annis ${ }^{1}$ memini ecclesiam Dunelmensem in curia vacasse, tamen expectata est voluntas majestatis vestre eirciter annum, et ei provisum pro quo majestas vestra supplicavit. Multo magis Sanctissimus Dominus noster expectaret in hoe vestre Serenitatis voluntatem qum Sunctitatis sure intuitu et commendatione prefato domino Johami provideretur. Itaque majestas vestra de hoc satis quieto animo esse potest, quoniam si id eveniret, amici vestri qui norunt morem jam antiquitus observatum non paterentur super eo aliquid innovari. Commendo ergo iterum ex animo ipsum dominum Johannem majestati vestr:e, quam Deus felicem conservet. Rome die . . Junii mececlxxxxvij.

Ejusdem Regiæ Majestatis

Hunilis Servitor

Jo. Caris Perusinus.

Sacræ Regire Majestati Anglorum.

\footnotetext{
In 1494, when Sherwood bp. of $\mid$ were granted to Richard Fox, nn Domham diud at Rome. IIis death happencel on the lith of January, and the temporalities of the see

the Sth December following.

" Blank in orig.
} 
A.D. 1497 . VII.

5 July.

Fox's Instrudetions to treat with SCotland.

[MS. in Record Office.]

By THE KING.

Instruccions geven by us to the right reverend father in God the Bisshop of Duresme, keper of [our] pryveseall, for thappesyng of suche questions and debates as resteth bytwixt us and our cosyn the kyng of Scottes.

First, wher dyvers offres wer made by therle of Aunguyssh and the lorde Home in a treatie late had at Jenyn Hangh, it is thought unto us and our counsaill that thos offies in no wise suffiseth to the conservacion of our honour, nor yet for anny convenyent recompence for suche damages as hath ben doon unto us and our subjectes by our seid cousyn. Todemand And therfore ye shal demaunde and requyre on our the de- behalve of our seid cousyn to make delyvere unto us Perkin Warbeck ; of Perkyn Werbek; the which delyveraunce of hym we desire not for anny estimacion that we take of hym, but by cause our seid consyn rescived lyym within his londe and favorably hath entreacted liym and dyvers others of our rebelles duryng the peace concluded by twix us both, and over that, havyng hym in his companyshe, entred in puyssanmee within our lande; the whiche was the canse and grounde of the breache of the seicl peace. And lesse therfore may we not doo with our honour then to have the delyveraunce of hym, thought the delyveraunce or havyng of hym is of no price nor value. Howe so be it, for the good will and effeccion that we bere unto our seid cousyn we shalbe contented to take such a peace and intelligence with hym as shlialbe thonght reisunable to onts and his comyssionars, so that lie do make de- 
lyvcraunce unto of us the seid Perkyn, and also do send A.D. 1497. unto us a solemne ambassate, as was spoken of in 5 July. the said treacte had at Jenyn Haugh. And wher as it was spoken in the same treacte that our seid consyn shuld send unto us suche persons in ambassate, and at suche tymes and places as we wold assigne and lymytte; we shalbe contented that he send unto as in ambassate, incontynently and without delay, at suche place within this our realme wher we shalbe attc tyme of their commyng, the reverend father in God the bisshop of Murray, therle of Aunguissh, and the lorde Home his chambrelayn, with suche other as it shal pleace our seid cousyn to sende.

Item, if our seid cousyn wil not be agreable to the or, if this delyveraunce of the seid Perkyn unto us, as is be- he refused, forc reliersed, the which as we thynke, sith he is not the parson that he surmysed to be when he opteyned his salveconduct of our seid consyn (as it is wel knowen thurgh all thes parties of the worlde) he myght with his honour and without his damage wel doo, and so sattisfie our mynde for our honour on that behalf; yet we, havyng consideracion to the lovyng mynde of our seid consyn in the tyme of the rebellion of dyvers of our subjectes, as it is shewer unto us, atte reverence of Alnyghty God, and in evytyng theffusion of Christen blode, havyng in our remembraunce the nyghmes of blode by twix us and our seid cousyn, be content to take an other way for the peace by twix us, thowgh non other coude be to us so acceptable nor so wele satisfie our mynde and honour. That is to say, that it may like first, an our seid consyn furst to sende his solemne ambassate be sent by unto us, as is before rehersed; and also the same our James to cousyn to come in person unto our town of Newe and, seCastell, and further within this om realme; wher we eondly, a inay mete, commen and conclate with hym for thob- interview 
A.D. 1497. servyng of the saide peace, and of further intelligence 5 July. to be taken by twix us and hym, be it by way of between aliaunce $o[r]$ other wise; and also for the due ordryng
the two Kings in and refourmyng of suche debates and attemptates as England. shalmow . . . . growe in tyme comyng by twixt our both [subjec]tes, the which ean not so brevely and assure[dly be] ordred and concluded by ours and his c.[ommissione]rs as sholde mowe be by our selffes beyng [present in] persons. And over that, glad wold we [be to com]me so ferre to see our seid consyn, [trustyng by the] meane therof that more fast love [and affeecion] thould growe [by twix us, and over that suche] conclusion shulde be taken as shuld be to the pleasour of God, the honour and wele of us both, [our] realmes ard suljectes. Accordyng it is to noblesse and also kyndenese that anny too princes so nyghe [of] blode and so nygh inhabited to guyder as our seid cousyn and we be, shuld have liy mutuall communicacion a more quayntaunce and a faster benyvo. lence than is yet by twixt us and our seid cousyn. And for the sure comyng, abydyng and retournyng of the same our cousyn at his pleasour and libertic, ye shal offre on our behalfe suche surety and pleages as shalbe though unto hym, his counseill and to you resonable and behoveful; the which we shal in every thyng do and observe.

If peace be Item, over this it is thought [to us] and our counmade, the sail that if we shuld take a peace with our seid cousyn, Seots to be that he shuldlue lounde to thobservyng of the same bound un- and also to thaceomplisshyng and perfourmyng of astical cen-suche articles as wer communed and treated at Jenyn sures, Haughl, not only by his letter and great seall amel solemne othe, but also uppon payn of the consuris of the Holy Cherche and in an obligation of Nisi, to thentent that uppon a light enformacion or sugrgestion like breche as hath ben of late tyme hat shuld not 
ensule. And we shalbe contented for our parte to be A.D. 1497. bounde under our lettre and greate seall, and, rather 5 July. then to faile, to be sworn uppon the Holy Evangelistes for the due observyng on our behalf of the seid peace.'

Hit is not to be mervailed of this our desire though ther be thought therin any inequalite; for the breche of the peace last concluded bytwixt us grewe not, nor yet was doon by us. And also our seid cousyn shuld by force of the seid articles treated at Jenyn Hangh sende mito us his ambassate and revoke the seid salveconduct, and forprice any aide to be gevyn to the seid Perkyn and his adherentes, accordyng to the said communication and treatie, the which resteth only by our seid cousyn to be perfourmed.

Item, moreover it is thought to us and our cons and to sail that we may not with our honour take peace make comwith our seid cousyn, as is before rehersed, without for injuries that he do make such a convenyent recompence as done in the slialbe thought to the commissioners of us bothe, unto our subjectes for the damages that thei had by the throwyng doon of their castelles and fortilaces atte tyme of his furst beyng within this our lande, havyng then with hym the seid Perkyn and others our rebelles as is before rehersed.

Item, over and besides al thes premysses it is be-IIostages hoveful and necessaly that in case we shal take peace required. with our seid cousyn under such modificacions and

1 and, rather then to fuile... " "case our seid consyn wiì not peace $]$. The second copy of in- "bynde hym self under the censuris structinns mentioned below, reads as "of the Chereh, and in the seid fullew: :- "and also in le sworn "obligacion of Nisi, yet rather then " "Ipon the Holy Frangelistes for "to faile, shal we be contented to

" the due observyng on our behalf " take for surety his solemne othe

"of the scid peace, yf yecan non "uppon the Holy Evangeistes with

"otherwise enduce hym. And in "his lettre and greate seall." 
A.D. 1497. lymytacions as beth before written, that then uppon 5 July. the conclusion of the same our seid cousyn shuld fourthwith ley plegges unto us, they to abide aboute us, or in any other place within our obbeisance as shalbe thought good to the comyssioners of bothe parties, men of good estate and condicion, as, two erles or their sonnes and heires, or two barones or their sonnes and heires, thei so to remayne til the seid ambassate come unto us and other thynges concernyng the seid Perkyn Werbek be perfourmed and accomplisshed, as is be fore rehersed. And howe so be it that it is thought unto dyvers diserete and wise men of our consail that consideryng the greate preparacions that we have made, as wel by lande as water, and conveyng of our artillery and vitall, and other preparacions that we have made for the exploite of thes warres in Scottlond to our inestimable charges and costes, we shuld not mowe with our honour so lightly for the perfourmyng and accomplisshyng of the seid premysses, the which ben of smal importance, condescend to a peace with our seid cousyn; yet we atte reverence of our Lorde, and in evytyng of theftusion of Christen blode, and in trust of an assured frendilyhod to be had by twix us bothe, and in especiall consideryng the natural inclynacion, affeceion, and good wil that he, as ye have written, berith and specially bare unto us in the tyme of the forsaid rebellion, be contented, thes premysses by ours and his comyssionars thoroughly assured to be observed and perfourmed as is above rehersed, to take a peace with hym, and theruppon ye to revoke our armee nowe beyng uppon the see. And we shal in like wise restreign our armye by londe and all other hostylite.

Nowe have we shewed unto you our [hole] mynde and pleasure in thes maters. And if the [re] shal growe amny occasion unto... . to wri[te. . ] lones 
unto us theruppon ye shal mowe se.

- A.D. 1497 .

us beyng at . . . .

Subjoined to the above is another copy of instructions, the same in tenor with the preceding, omitting the last paragraph, and with the following additional articles:-

And finally, ye shal, by al wise meanes to you possible, enderoir your self to have the said Perkyn to be delyvered unto us, and also the said solemne ambassate to be sent unto us as is before rehersed; the which to opteyne and have sluuld be for the conservacion of our honour most our desire and pleasom. And in case that our seid consyn wol not be agreable to the delyrere of Perkyn with the sendyng of the seid anbissate, then yo shal persuade and insiste by al wise mounys to you possible that he do sende the same his soleme ambassate unto us, and also to come in his own person to the Newe Castell or further; and orer that to be bounde in an obligacion of Nisi, or atte lest uppon his othe, and to make satisfaccion on to our subjectes by hym endamaged: and by sides that to ley suche plegres as is before more at large rehersed. And in case ye can not enduce hym to delyver Perkyn and to send the seid ambassate, the which is the furst part ank way of these your instruccions, then shal ye resortc to the second parte and way, that is to say, our seid cousyn furst to send mito us his ambassate: secondly, to comme unto this our land in person; thridly, to be bound in the obligacion of Nisi, or atte lest by his solemne othe; fourthely, to do make a convenyent recompense for such castelles and piles as have ben throwen doown by him: and fivethly, to lay plegges for the perfourmyng of his promysses as is before 1nore largely rehersed. And if our seid consyn wol not be agreable to anny of thes two waies so before specitied, then may ye shewe unto theym thes our other artieles of instruccions, to thentent thei may wel see th[at ye] have nom auctorite to doo any thyng ferther in this mater then is comprised [in] thos articles. Howe so be it, if it be thought by your discrecion behovefull, ye [may], rather then to fill to a bieche, canse thejm to

"Mutilated. The concluding, "sembly of our army. Yeven at words restored as follows. in a "our manor of Sheen the ris day of moderu hand, on a piece of paper "July, in the xii, year of our pasted on :-". . . . make as- "reign." 
A.D. 1497. send to their prince for ferther understondyng of his mynde 5 July. in this be[ha]lf: and thereuppon to advertise us without delay to howe many of thes articles thei wilbe agreable.

Onr fynal and resolved mynde is that ye obteyne al thes articles comprised in the second parte, over and besides thos articles that wer treated at Jenyn Hangh, and if ye can not obteyne all theym, then to obteyne as many of theym as shalbe to you [p]ossible. And if so be that our seid consyn wol not be to any of theym agreable, yet syth that the tyme of this yere is so far passed, and our subjectes sore weried, and also thissn of bataill is ful nncerteyn, we shalbe contented, for dyvers reasons movyng us and our consaill, rather then to breke in to warre, to accepte such offres as wer unade unto you at Jenyn Haugh, with such plegges, othes, and suretes as ye shal mowe opteyne for thobservyng of the same. Hit is thought unto us and our consaill full necessary that consideryng the shortnes of the time that we have appoynted for the settyng fourth of our vaungarde and our armee by land, that such thynges as shal ensue by you of this treatie of peace by twixt us and our seid cousyn must be son, and withont delay, assured secretly in writyng by twixt our comyssioners and his, and entrechannge your sealys upon the same: and thernppon plegges to be layde by our seid cousyn, as is before rehersed. The which so doon, the commyng of his solemne ambassate and other thynges may be thertippon and after perfourmed to onr honour and pleasour, as it is before specified. Howe so be it, we wold not that ye hasted thexecucion of this mater so fast for ons or twyes metyng with our seid consyus comyssioners, but that ye handle so the matier as may growe most to our honom and avauntage, so that therby ther growe non extreme breche by twixt us, you, and theym. And we trust undoubtedly that ye wol endevoyer your silf for thobtcyning and acchyvyng of alle thes premysses or of the greate parte of theym to the best of your power, havyng therin and in all other thynges as ye shal thynke good, syngular respecte so to ordre thaym as it may be most to our honour and satisfaccion of reason to our subjectes. And in your so doyng ye shal do unto us light singular pleasure and servyce.

Nowe have we shewed unto you in thes our articles of instruccions plenarly our nynde in every thynge concernyng the mater comprised in theym. And for the more assured way that ye shal mowe take on this behalf, our pleasour is that if our seid cousyn of Scotlond wil agree to perfourme and fully accomplisshe anny of the seid two wai[es] before rehersed, then fe to conclude and passe with theym. And theruppon 
to entrechange your seales without any ferther delay. And A.D. 1497. if our seid consyn wil not agree entirely to neither of thes 5 July. two wayes, that then ye entretain theym, and conclude not finally with theym til ye have advertised and acerteyned us to which and howe many of the seid articles he wolbe confourmable. Wheruppon we shal encontynent sende unto you our mynde and pleasonr.

Our mynde and pleasour is that ye kepe nuto your selff secretly this boke of instruccions, and that ye shal . . . well as ye shal thinke good, shewe minto the comyssioners of our seid cousyn that other boke of instruccions, and also [the] letter wherin thei wer encl[o]sed; signyfieng nuto heym that yo have no ferther anctorite then is comprised in thos instruccions so $t[0]$ theym by you shewed. And over that, for thavoydyng and eschewyng of wer bytwix us and onr seid cousyn, we wol that ye inserte in suche convencion as shalbe bytwix you and his seid comyssioner's made, an article accordyug to the tenour comprised in a paper herin enclosed orelse by your wisdome of like or more force, as shalbe thought unto you behoveful, for the puttyng aparte and escheweng of all nianer of . . . . . . seid consyn by meane of any attemptatte to be don . . . . . . by any of ours or his subjectes.

This is the copie of the paper before specified the which was enclosed in the forsaide articles.

Item, conventum, concordatum, et conclusum est, quod si aliquid fuerit atte[m]ptatum contra tenorem sen effectum istorum foederum sell conventionm per gardianum sive gardianos Marehiarum utrinsque sen alterins prefatorum principum, ant per aliquem sive aliquos ipsornm subditorum, quod nihilominus dicta treuga et pax mancant in suis robore et effectu inviolate. Et quod pars damnificata per hujusmodi attemptata cum litteris sui principis ipsius damna specificantibus, pro congruo remedio in ea parte obtinendo veniat ad principem damnificantis. Sic quod per eum superinde valeat obtinere justitix complementum. Et si contingat quod princeps damnificatus deneget sic petenti justitiam ant eam ei debite nou ministret, princeps tamen ipsius damnificati, postquam intellexerit per legitimas probationes justitiam sic fuisse denegatam, non propterea dictam treugam et pacem violatam habeat sen teneat, sed quod licite possit parti damnificatre reprisalias, marquas et contramarquas ad valorem hujusmodi damni illati concedere, dicta treuga atque pace non eo minus in suis robore et effectu permanentibus. 
VIII.

A.i. 1497. Sir Henry Wentworth to Sir Wilimam Calyerley. [Orig., Addit. MSS. 18,738. f. 6.]

RIGHT worshipfull cosin, I recommend me unto you. And where it fortuned in my retourne home frome Westchestre to meit my lord Darby, nyy lord Strange and other at Whalley Abbey, by whome I had the sight of suche lettres as were directed unto them frome the kinges grace, apperceyving by the same that Perkin Warbeke is londid in the west parties in Cornevell. Wherfor I wolle pray you and allso in the kinges name advertise you to be in aredynes in your owne persone with i ache company als you make to serve his highnes upor an our warnyng whan his grace shall calle upon you; for the which I doubte not but his highnes shall geve you thankes according, as our Lord knoith who preserve you. Wretin in the Kinges Castell of Knaresburght the xvij. dey of Septembre.

\section{Your and ${ }^{1}$ Cosyn, Sir \\ Hary Wentworth.}

Addressed: To his worshipfull cosin Sir William Calverley, knight, in liaste.

A.D. 1499. 15 June.

IX.

The Cardinal of Sienna ${ }^{2}$ to Henry VII.

[Holograph, MS. Cott. Cleop. E. iii. f. 111.]

Serenissme rex, domine clementissime, plurimam commendationem. Hodie cun cogeretur sacer senatus,

1 Sic.

? Francis Piccolomini, afterwards Pope Pins III. The same MS. volume contains another holograph letter of his, dated 10 June 1497 , to the same effect as the letter of the Cardinal of Perugia at p. 102. 
prasidenti summo pontifici et reverendissimis dominis A.D. 1499. cardinalibus assistentibus, majestatis vestræe literæ quibus 15 June. acclesiam Noruici inprasentiarum vacantem reveren- $\Lambda$ new Jum patrem dominum Thomam ${ }^{1}$ commendabat, lectre fue- Norwich. runt: quæ quidem literre, cum indignum, retate scilicet matura, doctrinaque et experientia conspicuum commendarent, non solum s. . placuerunt, sed magnam quoque religionis et prudentire laudem recepit vestra majestas, quippe qui nisi dignas et bene meritas personas, omnique commendatione adornatas, ad tantas istic ecclesias promoveri curet. Quæe majestatis vestræ mens utinam cateris quoque principibus familiarior inesset. Expedita fuit ad vota magno pontificis et sacri collegii assensu promotio ipsa prefati Thome ad ecclesiam Noruicensem, sicuti ex literis reverendi domini Wigorniensis ${ }^{2}$ oratoris sui lat[ius] confido intellecturam vestram ma "statem. Caterum ut ex is quæ hic dicuntur aliquid pro officio me[o] vestrie majestati consignificem, etiamsi ipsa plurima ac prope omnia intelligat, hrec non tacebo. Rumore nuper vulgatum est classe illa quam Bhores dudum validam paravit et numerosam, Tur[corum] threatened regem Rhodum insulam aggredi statuisse. Utinam by the mendax sit fama, et vires tan[ti] hostis adversus nos et religionem nostram irrita sint penitus et vanæ. Hrec cura val[de] solicitat pontificis et sacri collegii mentem. Multa proinde cogitantur, et promoventur q[uæ] adjumento futura sint et saluti illius insulre et sanctre fidei nostræ. Milites tamen Rh[o]dienses et magnus indidem magister expeditionem hujusmodi maritimam pridem agnoscentes [ne]quaquam dormierunt. Munierunt enim se loco, et omni necessario usu armorum, commeatu, [mi]lite, et animo inprimis religioso ac forti, sperantes divini numinis præsidio non solum tue[ri] se egregie adversus feroces hostes, sed victoriam quoque de his Christiano nomini relat . adeo parati sunt,

\footnotetext{
'Thomas Jane, LL.D. | $\quad$ 'Silvester de Giglis.
} 
A.D. 1499. adeo confidentes. Romanorum deinde regem aiunt 15 June. cun parte excrcit[us] sui in Vallem Telinam quie Mediolanensi orre contermina est, descendisse, eo consilio ut in ses[e] Suicenses pluribus viis aggressus citius an officium et fidem reducat; pressos vero acriter S[uicenses] a rege jam pacem petere: ad quam consequendam Mediolanensis ducis favorem ntuntur. Quæ impresentiarum habui vestræ majestati significanda. Commendo me serenissimæ majestati vestræ, quæ diu felix valeat. Romæ, die xv Junii M. I. D.

Excellentissime vestre majestatis

Humillimus servitor,

F. Cardinalis Senensis.

Addressed : Serenissimæe Regire Majestati Anglorum.

X.

Hendiy VII. to Ferdinaxd axd Isabelia.

[MS. Egerton 616. No. 8.]

Serenissmess ac potentissimis principibus, dominis Ferdinando et Hellizabeth, Dei gratia Regi atque Reginæ Castellæe, Legionis, Aragonum, Sicilize, Granatæe, etc., consanguineis et germanis nostris carissimis, HexRICUs eadem gratia Rex Anglize et Francire ac dominus Hybernix, salutem, et prospera successuum incrementa. Thanks Intelleximus ex clarissimo oratore vestro domino them for doctore de Puebla circa conclusionem vestrarum mahim in jestatum cum serenissimo Francorum rege factan, artitheir treaty culum quendam ${ }^{1}$ in nostrum favorem per vestras maFrance. jestates initum; quod sane, si ita r'cs sese habuerit, non potuit nisi ab optimo animo vestrarum majestatum erga nos proficisci, et ingentes gratiis de nobis benemercri,

\footnotetext{
1 Corr. from illum.
} 
quanquam nostra communis necessitudo, et vinculun A.D. 1499 . quibus invicem astringimur, id genus officii de se postulare videatur. Creterum ad notitiam nostram pervenit vestras majestates de negotiis nostris et Scoticis sinistre informatas esse, et longe aliter quidem quam veritas labeat. Hinc est quod nos, licet singularis vestra sapientia sit nobis perspecta, persuadeamusque nobis vestras serenitates quæ intelligenda sunt omnia intelligere, presertim hæe nostra et Scotica, quæ omnibus ferme patent et sunt cognita, liabuimus cum preefitto domino oratore vestro longam de his rebus collocutionem, qui et ipse ex sese satis hæc ommia intelligit; quem non dubitamus veram vestris majestatibus facturum relationem; que felices semper valeant ad vota. Ex castello nostro de Shena, die xv. Junii $\mathrm{m}^{0}$.cccc.lxxxxviiij”.

\section{HenRiCus R.}

Addressed: Serenissinis ac potentissimis principibus, dominis Ferdinando et Hellizabeth, Dei gratia Regi atque Reginæ Castellie, Legionis, Aragonum, Sicilixe, Granatie, etc., consanguineis et germanis nostris carissimis.

Endorsed: A sus als. Del Rey de Inglaterra, xv, de Junio de xcix.

15 June.

\section{XI.}

\section{Elizabeth Queen of Henry VII. to Ferdinand II.}

[MS. Egerton 616. No. 9.]

Serenissmo ac potentissimo principi, domino Fer- A.D. 1499. DINANDo Dei gratia regi Castellæe, Legionis, Aragonum, 1 Ang. Sicilie, Granate, etc., consanguineo ac germano nostro mending carissimo, HellizaberH eadem gratia Regina Angliae et Henrystill, Francia ac domina Hybernix, salutem et prosperitatis to serve incrementum. Commendavit serenissimus dominus meus Ferdinand 
A.D. 1499. et maritus vestræe majestati suis literis latorem præesen-

1 Aug. tium Henricum Still, suum fidum ac bonum ser[vitorem, against the qui] maxime cupit vestræe serenitati contra infideles ser-
Infidels. vitium suum impendere $p . . .{ }^{1}$ regnum pacatum et tranquillum videt. Is Henricus apprime est nobis notus, et quamvis corpore parvus, inter tamen strenuos et fortes milites bonum nomen tenet, quo fit ut eum nostris favoribus prosequamur, potissimum quod fidus ac diligens semper sit habitus, et adversus Christianæ fidei hostes dimicare intendat. Quare, licet serenissimi nostri consortis commendationem per sese satis esse ducamus,

- voluimus tamen et nos quoque nostram superaddere. Rogamus itaque vestram majestatem $\epsilon x$ corde ut hominem ipsum nostro etiam intuitu commendatum suscipiat et militiæ suæ ascribat ac favoribus suis prosequatur. In quo vestra majestas nos plurimum sibi devinciet. Non dubitamus equidem ipsum Henricum ita sese habiturum ut et vestrre majestati et nobis gratus et acceptus servitor sit futurus. Reliquum est ut vestra majestas felix sit et longreva; cui communem filiam tam suam quam nostram illustrissimam dominam Katerinam, cujus saluten et incolumitatem semper cupimus, ex corde commendamus. Ex oppido Hamptonæ, die primo Augusti Mocccelxxxxviiijo.

Elysabeth R.

Addressed: Serenissimo ac potentissimo principi domino Ferdinando Dei gratia Regi Castellae, Legionis, Aragonum, Sicilixe, Granatx, etc., consanguineo et germano nostro carissimo.

Endorsed: Al Rey n. S. Dela Reyna de Inglaterra $\mathrm{p}^{\circ}$ de $\Lambda$ gosto de xcriiij.

Paper decayed. 
XII.

\section{De Puebla to Ferdinand and Isarelala.}

[MS. Egerton, 616, No. 16.]

Mur altos y muy poderosos Principes, Rey y Reyna, A.D. 1500. Señores.

$11 \mathrm{Jan}$.

The tran-

Despues de por mi besados los reales pies y manos quillity of de vuestras altezas, les fago saber que, en dicha de is now vuestras altezas y de la señora princesa de Gales, esta thoroughly ya tal este reyno como de quinientos años aca nunca established. se vido, segund los que mas saben to dizen y parece por las coronicas; porque sienpre al avia abrojos $y$ espinas de calidad que tenianlos Yngleses causa de no estar asosiego in obediencia a su rey, por aver diversos herederos del reyno, y de tal calidad que la cosa se podia disputar de amas partes. Agora a plazido a Dios que todo se aya purgado y alinpiado justa y devidamente, de manera que una gota de sangre real dudosa no queda a este reyno, sino la verdadera del rey y de la reyna

\section{Transhation.}

Most high and powerful princes, the king and the queen.

After kissing the royal feet and the hands of your highnesses, I canse you to know that by the good fortune of your highnesses and of the lady princess of Wales, this kingdom is at present so situated as has not been seen for the last five hundred years till now, as those say who know best, and as appears by the chronicles; becanse there were always brambles and thorns of snch a kind that the English had occasion not to remain peacefully in obedience to their king, there being: divers heirs of the kingdom and of such a quality that the matter conk be disputed between the two sides. Now it has pleased God that all should be thoronghly and duly purged and cleansed, so that not a doubtful drop of royal blood remains in this kingdom, except the true blood of the king and queen, 
A.D. 1500. y para el sello de todo la del señor principe Artur; y 11 Jan. porque desto y de la justicia que se fizo de Perquin y del fijo del duque de Clarencia muy largo por diversas vias to he escripto a vuestras altezas, non les quiero con larga escriptura dar inportunidad.

The Scotch El rey de Scocia, sobre su casamiento con la fija in a fair del señor rey, parece me que alo que yo tenia por way to be mas dudoso, que era aver de esperar quatro o cinco settled. años de no se casar, a la clara escrivio que era muy contento; no queda diferencia otra sino a la cantidad de la dote, porque dize el rey de Scocia que seria razon que le diesen tanto como declxxv. le davan. Este rey dize que le quiere dar dos tanto que el rey Duardo tenia concertado con su padre de le dar, la qual contia no allega a la meytad de lo que el rey de Scocia pide. $\mathrm{Y}$ porrue me prece que este casamiento viene bien al rey y conozco que ruestras altezas siempre lo desearon, aprieto quanto puedo, para que la cosa se concluya. Bien creo que el rey de Scocia,

and above all, that of the lord prince Arthur. And since of this fact and of the execution which was done on Perkin and on the son of the duke of Clarence, I hare written to your highnesses by various ways, I do not wish to trouble you with lengthy writing.

The king of Scotland, it appears, in what I held most doubtful, touching his marriage with the daughter of the king, which was the having to wait and not marry for four or five years, wrote plainly that he was quite satisfied. There is no other point at issue remaining, exeept as to the amount of the dowry; for the king of Scotland says it would be reasonable that they should give him as much as 775 gave him. This king says that he wishes to give him twice as much as king Edward had agreed with his fither to give; which amount does not come up to the half of what the king of Scotland demands. And because it appears to me that this marriage suits the king well, and I know that your highesses have always desired it, I mige it as much as I can, in order that the matter may come to a conclusion. I well believe that the king of Scot- 
segund la gana que muestra, vendria ala razon, y no A.D. 1500. menos este señor rey, y por dineros pocas vezes se $11 \mathrm{Jan}$. suele desconcertar semejante negocio. Esto me a muy largo comunicado el rey. Crean vuestras altezas que si la venida de mccxviijo,, no altera la voluntad de dccccxij., la cosa es fecha; a especial si vuestras altezas ahincadamente escriviesen al rey de Inglaterra y rey de Escocia.

En grande cuydado continuo estoy fasta ver aca un A despatch criado mio que a vuestras altezas muchos dias ha abie in cipher con todo el despacho que me abiaron mandar, en el qual the King alguma duda tenia sy la cifia tocante al rey de Francia sy venia errada, y parece me que segund lo que don Juan Manuel por su ynstrucion mostro y me dio escripto de su mano y firmarlo de su nonbre que non fue errada salvo que a quello se fizo y concluyo aca como vuestras altezas me lo abiaron mandar, y caso que despues de aquello algunas cosas ayan sucedido al mundo asi lo de mdxxxix como lomas que cadadia procura decolxxxoj., ui por aquello vuestras altezas devrian diferir de me

land according to the disposition he shows would come to reason, and not less so this ling; and seldom is a like negotiation apt to be disturbed by money. This the king has at great length communicated to me. Your highnesses may believe that if the arrival of 1218 do not alter the will of 921 , the thing is done; more especially if yom highnesses were to write migently to the king of England and the king of Scotland.

I am in great and constant anxiety until I shall see here one of my servants, whom I many days ago sent to your highnesses with all the dispatch with which you commanded me to send, in which I had some doubt if the cipher relating to the king of France was right. And it appear's to me, according to what Don Juan Manuel by his instructions showed and gave me, written by his hand and signed with his name, that there was no mistake, but that that was done and conchuderl here, as your highnesses had commanded me; and in the erent of some things having since happened in the world, as well in reference to 1539 as to the most which 781 every day solicits; 
A.D. 1500. abiar a quel despacho. Pues deben considerar que 11 Jan. aquel venido y la venida de la señora princesa a qui ciusaran nuevos mundos mucho conforines a la voluntad de vuestras altezas. Esto non lo digo a beneficio de natura sino por que yo y los mas cercanos a este rey esto mesmo dizen, e por las continuas platicas del rey lo mismo se conoce. Asi que a vuestras altezas suplico sin dilacion me manden abiar todo despacho segund que por un memorial que aquel mio llevo avian visto, y a que otro abio, qui a mi parecer la dilacion a semejante negocio non conviene a servicio de vuestras altezas. The arrival Ytem, ya avran memoria vuestras altezas delo que of Cathe- por letras claras, syn yntervenir alguna cifra, me escriArragon vieron cerca de la venicla de la señora princesa de Gales expected. diziendo que avia de ser, Dios queriendo, a qui en conpliendo el principe catorze años. Despues de lo qual vino a qui don Juan Manuel, y lo que dixo al rey cerca desto y mostro por ynstruciones de vuestras

let not your highnesses on that aceount postpone sending me that dispatch. Besider, you ought to consider that his coming and the coming of the latly princess to this country will caune a new state of things very agreealle to the will of your highnesses. This I do not say as being naturally so disposed, but because $I$ and those nearest this ling say the same thing, and the same is known by the continual sayings of the king. So I entreat your highnesses to send me on without delay every dispatch, as by a memorial which that man of mine carried, you will have seen; and here $I$ send another, because it appears to me that delay in such a transaction does not condnee to the interests of your highnesses.

Also, your highnesses will remenber what you wrote to me by clear letters withont any cipher in reference to the coming of the lady princess of Wales, saying that she was to be here, Grod willing, when the prince completed his fourteen years. After whieh hither came Don Juan Manuel, and what he said to the king in reference to this and showed by instructions from your lighnesses was that your higlmesses had 
altezas fue que vuestras altezas certificavam avia de A.D. 1500. venir el verano que viene, plaziendo a Dios, y dixo 11 Jan. mas que sino lo estorvara la afermedad de vuestra alteza la reyna nuestra señora, que los dias pasados avia tenido que sin esperar esta dilacion de los catorze años del principe fuera ya aci venida la señora princesa, porque este verano, mediante nuestro Señor, vendria a mejor sazon, porque el señor principe avra conplido los xiiij. años; lo qual asi mismo don Juan Manuel me lo dixo y certifico a mi e me lo dio firmado de su nonbre. Per todo to qual crean vuestras altezas que se adereçan tantos cosas aca para esta venida que non son de creer lo que allo se gasta y continuon, se entiende; y pues asy es suplico a vuestras altezas manden escrevir donde, plaziendo a Dios, a de abarcar la señora princesa, y en que mes, y todo lo mas que a este articulo les parecieren ser su servicio.

Otrosy, ya avran visto vuestras altezas lo que este rey por dobladas letras a escripto, por do avran considerado

certified she was to arrive, God willing, in the coming spring; and he said, moreover, if the illness of your highness the queen, our sorereign lady, which you had in past days, did not change the plam, that without waiting for this delay of the fonrteen years of the prince the lady princess wonld already have arrived here, because this spring with the help of ou Lord, she would come at a better season, because the prince will have completed his fourteen years; whieh also Don Juin Mannel told me and assured me of and gave it me signed by his name. By all whieh your highnesses may he assured that so many things are got ready here for this arival that it is not to be believed what is spent and will continue to be ;that may be imagined. And since it is so, I cntreat your highnesses to write where, God willing, the lady mineess is to land, and in what mouth, and everything else whieh may seem to you to be for your service in this matter.

Also, your highnesses will alleady have secultho which this king has written hy duplicate lettern, ly which you will have 
A.D. 1500. que yo no quise acebtar el obispado ni easamiento, por 1l Jan. que me parecio que si tal cosa acebtara cometia especie de prodicion y de mal servidor; y segund a la veresidad en que yo estoy (do gracias a Dios) que tal determinacion fize que tres años a que de un dinero non soy proveydo, de que estoy en mucha afrenta. A causa de un cleposito que de mi fue fiado y en guarda puesto, y de otras deudas que me aquexan, umilemente a vuestras altezas suplico y sus reales pies y manos beso, me manden proveer de lo que mes devido por via de aquel que proveyo a don Pedro de Ayala o por via de Pantales y misen ' Centurio, lo qual recibire en muy señalada merced; y 10 menos $^{2}$ manden responder alo de este mi casamiento, segund que les pareciere mas ser su servicio, que por Dios verdadero, de aquello sere yo mas alegre y contento que de otra cosa alguna.

No tengo de presente que mas escrevir, fasta ver re-

considered that I did not wish to aeept the bishopric or the marriage, beeause it seems to me that if I were to accept any such thing I should commit a kind of treason and act like a bad scryant; and according to the truthfulness in which I stand, I give thanks to God that I have so resolved, when for three years now I have not been provided with one fraction of money; on account of which I am in great disgrace. By reason of a deposit made by me and placed in pawn, and of other debts which oppress me, I humbly entreat your highnesses and kise your royal hands and feet, that you cause me to be provided with what is due to me, by means of him who provided to Don Pedro de Ayala or J'y way of Pantales and Misen Centurio, which $I$ shall take as a very great merey; and also cause an answer to be sent as regards this my mariage, according to what shall seem most to be for your service, of which before God truly I hall he more happy and contented than of any other things.

I have nothing at present mone to write, until I shall see

$1 m j n$, MS.

2 no mens] Reading doubtful, the MS. being woln. 
spuesta de tarrtas como he escripto, o fasta ver aquel A.I). 1500. mio que tauto a que alla esta; sino que nuestro Señor II Jan. las vidas y reales estados de vuestras alterals aureciere y prospere con muy mas reynos y señorios y conplimiento de sus deseos en todo. Amen.

De Londre, el xi. de enero de ind. años.

Umill siervo de vuestras altezas que sus reales pies y manos beso,

\section{DotTor de Pulebla.}

Addresserl:- $\mathrm{A}$ los muy altos y muy poderosos principes, Rey y Reyna Señores, el Rey y la Reyna unestros Señores.

Entorsed : $\Lambda$ sus al. Del dotor de la Puebla, xj. de enero de D.

the answer of so many things that $I$ have written about, or until I shall see here that man of mine who has so long been there; unless it be that our Lord may increase the lives and royal estates of your highnesses and bless you with many more kingdoms and dominions, and the accomplishment of your desires in all things.

From London the 11 th day of January 1500.

The humble servant of yom highnesses who kisses your royal hands and feet,

Tire Doctor de Puerla.

To the most high and powerful princes,

the king and queen onr sovereigns.

\section{XIII.}

Henry VIl. to Ferdinand and Isabella.

[MS. Egerton, 616, No. 13.]

Subnassmas atgue potentissimis principibus dominis A.1). 1500. Ferdinando et Elisabetra Dei gratia Regi et Repina 20 June. Castellæe, Legionis, Aragonice, Sicilize, Granatie, etc., con- 
A.D. 1500. sanguineis et germanis nostris carissimis, Henrıcus ea20 June. dem gratia Rex Anglice et Francie ac dominus Hibernice, salutem et prospera votorum incrementa. Literas vestrais clarissimus orator dominus doctor de Puebla nobis tradidit, ex quibus intelleximus gratum fuisse serenitatibus vestris illud matrimonium inter illustrissimos dominos filios utriusque nostros per verba de presenti contractum, necnon conclusionem muture amicitia et confederationis factre ac initre inter vestras serenitates et nos. Intelleximus preterea ex relatu ejusdem vestri oratoIs gladthey ris majestates vestras decrevisse in fine hujus restatis have deter- illustrissimam dominam Katerinam filiam vestram ac
mined to send Ca- nostram Wallie principem hue transmittere, ipsumque therine to deliberatum animum vestrum in ea re ex his literis quas the end of ad eundem oratorem dedistis apertius novimus; quie the sum- omnia nobis extitere admodum grata; nee ab re, cum
mer. ex tam fausto felicique matrimonio, ${ }^{1}$ tamque fido pacis et amicitire inter nos firmato foedere, utrique nostrum, regnis et subditis nostris maximum obventurum bonum non ambigimus. Accepimus insuper ab eodem oratore vestro quasdam serenitatum vestrarum literas paeis et amicitice inter majestates vestras et nos initre et concluse confirmatorias, quas quidem vestræe sublimitates pro ejusdem pacis et amicitice fortiori stabilimento in formam instrumenti publici redigi manuque et sigillo suis ac aliis firmissimis vinculis roborari fecerunt. Nos quoque pro parte nostra ut eisdem serenitatibus restris vicissitudinem rependeremus, similes nostras confirmationis literas in presentia reverendissimi domini Cardinalis Cantuariensis ${ }^{2}$ caterorumque nobilium et magnatum in eisdem nostris literis descriptorum pari firmitate roboratas, eidem oratori vestro dedimus, necnon predictam amicitiam proclamari mandavimus. Nil aliud fam restat quam ut illustrissima princeps

'matrime, Mis.

1 - Cardinal Morton. 
domina Katerina filia vestra et nostra hujus anspicatie A.D. 1500. foederis et amicitie inter nos perpetuum futurum 20 June. pignus ad prestitutum tempos huc transmittatur. Reliquum est ut vestree sublimitates felicissime faustissimeque semper valeant ad vota. Ex civitate nostra Cantuarix, vicesimo die mensis Junii, anno Domini Meccec.

\title{
HeNRICUS R.
}

Addressed: Serenissimis atque potentissimis principibus dominis Ferdinando et Elisabeth Dei gratia Regi ac Reginæ Castellae, Legionis, Aragonice, Sicilia, Granatie, etc., consanguineis et germanis nostris carissimis.

\author{
XIV. \\ Henry VII. to Ferdinand and Isabella. \\ [MS. Egerton 616, No. 14.]
}

Strenissimis ac potentissimis principibus, dominis A.D) 1500 . Ferdinando et Helisisabeth Dei gratia Regi et Reginie 24 July. Castellæ, Legionis, Aragonum, Siciliee, Granate, ete., consanguineis et germanis nostris carissimis, Henricus eadem gratia Rex Anglice et Francia ac dominus Hybernie, salutem et prospera votorum incrementa. Legimus literas vestrarum majestatum credentiales ex Civilia ultimo Aprilis ad nos datas, quas egregius vir dominus Guttiere Gomez de Fonsalida, commendator de Haro, vester orator, nuper nol.is reddidit; cujus eredentiam et diligenter et ad longum annotavimus. Ex eo namque primum andivimus, quod vehementer seire

1 'The original of this letter is mutilated; some of the lost words are supplied within brackets. 
A.1. 1500 . cupiebamus, de bona, scilicet, valetudine, deque felici 2. July. et prospero statu vestrarum majestatum, simul et de rebellibus Saracenis domitis ac plena victoria ct triumpho ex illis reportato; quibus sane ommibus vestris successibus gavisi sumus supra quam dici possit, atque, ut par est, eisdem ex intimo corde gratulamur, quandoquidem vestras omnes secundas res accessionesque et incrementa nobiscum communes reputamus. Deinde exposuit nobis idem orator negotium concernens traductionem illustrissima domina Chaterina communis Although vestræe ac nostræe filixe, quam quidem juxta conventa Hected ex- conclusa, et hinc inde inter nos reges determinata, circa Catherine finem mensis Septembris proxime instantis indubitanter in England expectabamus; nec fuit aliquid alind quod a nobis of Septem-majore cum desiderio atque ardentiore animi affectu ob ber, singularem quam gerimus in illas affectionem, necnon et desiderium ingens ipsins domina videndre hoc tempore expectaretur. Accepimus itaque ex ipso oratore vestrarum majestatum in declaratione sure credentiæ nomnulla quibus fieret ut non absque magno incommodo praefata illustrissima domina Catherina infra tempus limitatum traduci ad nos posset; quibus tamen non obstantibus idem orator nomine ac vice vestrarum majestatum obtulit ipsam [dominam . . . . . ]o vellemus juxta finem mensis Octobris proxime esse transferendam, demonstravitque idcirco prater nostram omnem spem et expectationem . . . . . . rem gratissimam efficeremus si vellemus esse contenti quod ipsius illustrissima domina Chateriuse ad nos et ad hoc nostrum regnum traducti[o . . . . ]ram astatem sit prorogata. Nos vero, licet hujusmodi traductionem summo cum desiderio propediem expectaremus, atque ad [ipsam dominam hon]orifice, ut decet recipiendam non mediocris üuparatio esset ubique facta, item et summam illam pecuniarum nobis in dotem prom[issan . . . . . . . ]e ipsius matrimonii nobis solvendam enm ijsa traductione simul in fine dicti mensis Sept[embris expectar]- 
emus (nam [dilato tempore tr] aduetionis sequitur ut ipsa A.D. 1500. quoque pecuniarum solutio differatur) : nihilo tamen mi24 July. nus ob. . . . quam labemus u . . . vestris . . . . majestatibus in quibuscunque valeamus rebus, item et singularem ac paternum nostrum amorem quo ipsam illustrissimam dominam Chaterinam . . . . . pote quod celebrato inter se et illustrissimum principem Áthurum nostrum primogenitum per verba de prasenti matrimonio non aliam eam reputamus quam propriam nostram filiam, nec minore etiam dilectione ipsam prosequamur quam vestrie ipsæe majestates. Nolentes nos ut periculis aliquibus maritimis imminentibus et formidolosis quoquo pacto exponeretur, postpositis omnibus nostris desideriis et eomplacentiis ae commodis et emolumentis ad nos ratione prime traduetionis speetantibus et pertinentibus, movemur et innitamur ut vestrarum majestatum votis molem geramus. Quocirca ad vestram gratificationem sumus contenti ut præfata illustrissimie domine Chaterina ad nos traductio usque ad festum he is willSincti Johannis Baptista ${ }^{1}$ proxime futurum sit proro- grant a degata; dummodo, tamen, et eum hac conditione et non lay tillnext aliter, quod vestræe majestates in ea forma quam ad illas in scriptis manu nostri secretarii subscriptis eum his mittimus de verbo ad verbum per suas literus suo plumbeo sigillo sigillatas et propriis manibus subscriptas, suis denique corporalibus juramentis prastitis munitis, se nobis obligent, et obligationem ipsam sie roboratam citra festum Natalis Domini proxime futurum, ad nos mitti tradi et deliberari realiter faciant; quoniam si hæc obligatio omitteretur visum est nostris consiliariis quod omnia et singula qua super dieta traductione fuerant prius inter nos eapitulati, conclusa et determinata, prorsus essent extincta et invalida, ipsacue traduetio utrinque esset ineerta et indeterminata, nosque ideo ob ipsam ineertitudinem, ea providere et disponere 
A.D. 1500. quae ad hujusnodi receptionem pertinent, nequaquiun 24 July. possemus. Promittimus autem et per presentes nos obligamus ubi dictan vestram obligationem nobis realiter tradi et deliberari feceritis nos omnia et singulir super dicto contractu matrimoniali antehac inter nos concordata et conclusa, nondum executa, quatenus nos tangunt, firmiter observaturos esse et adimpleturos. Superest ut vestræ majestates felices valeant ad voti. Ex palatio nostro Grenwici die xxiiij Julii $\mathrm{M}^{0}$. ccccc $^{\circ}$.

Henricus R.

Addressed: Serenissimis ac potentissimis principibus dominis Ferdinando et Hellisabeth Dei gratia Regi et Regina Castellæe, Legionis, Aragonum, Sicilie, Granate, etc., consanguineis et germanis nostris carissimis.

Endorsch: A sul al. Del Rey de Ingleterra xxiii[j] de Julio de $\mathbf{D}$.

\section{XV. \\ Hentr VII. to Ferdinand and Isabella.}

[MS. Egerton 616. No. 15.]

A.D. 1500. Serentssimis ac potentissimis principions, dominis Ferdinando et Hellizhbeth, Dei gratia Regi et Regince Castelle, Legionis, Aragonum, Siciliae, Granatie, ete., consanguineis et germanis nostris carissimis, Henricus eadem gratia Rex Angliae et Francia ac dominus HiberRequesting nix, salutem et prospera votormm incrementa. Cum rethat Ayala verendus pater dominus prothonotarius de Ayalia nuper
may be command- nobis ostenderit vestras majestates sibi istuc redeundi ed to re- potestatem fecisse, putavimus certe quod cum panco England tempore lic penes nos moram traxerit et adventus till the ar- illustrissime domine Chaterinie tantopere instet [cuorl]
rival of the Princess non tam cito esset revoeandus. Quocirea cum is dominns Catherint. 
prothonotarius et nobis et universe nostre curiæ A.D. 1500 plurimum gratus et acceptus sit, nee unquam desistat 18 Dec. ea meditari et curare quie ad nostram et [vestra]rum majestatum dignitatem et honorem pertineant, videtur nobis plurimum conducere ut hic penes nos maneat donee et quousque ipsa [illustrissi]ma domina ad nos venerit, et etiam tanto diutius postea quanto magis vestris majestatibus expediens fuerit visum. Erit nempe (ut . . opinio) et nolus et ipsi illustrissimse dominse non parvum solamen et recreatio, tum o[b] singulare ejus ingenium modestiamque et probitatem, tum etiam ob illius affabilitatem atque hilarem naturam, quibus et nuptias decorare et juveniles principum animos mulcere, alacresque ct jucundos retinere possit. Rogamus itaque vestras majestates quatenus eidem domino prothonotario suis literis injungere velint ne a nolis quoquo modo se absentet, quinimmo ipsius illustrissime domine adventum immoretur, nobisque et illi cum applicuerit, presertim in nuptiarum solenniis obseruatur, donec aliud a vestris majestatibus manlatum acceperit. In quo sane vehementer nobis gratificabuntur vestre majestates, qua diutissime ac felicissime valeant ad vota. Ex oppido nostro Abindoniae, die xviijo. Decembris mo.ecece.

\section{HENRICUS R.}

Addressed: Serenissimis ac potentissimis principibus, dominis Ferdinando et Hellisabeth, Dei gratia Regi et Regine Castelle, Legionis, Aragonum, Sicilire, Granatie, etc. consanguineis et germanis [nostris] carissimis.

Endorsed : $\boldsymbol{\Lambda}$ sus al. Del Rey de Ynglaterra xviiio de Dez ${ }^{\mathrm{e}}$ de D. 


\section{XVI.}

\section{Henry ViI. to Catherine of Alragon.}

[From a corrected draft in the King's own hand. MS. Galba L.II., f. 149.]

\section{A.D. 1501. MADAME, \\ [Oct.]} roy[aume] nous est tant a . . . . ot si tresagreable que bomnement [ne] sçaurions dire ne exprymer le grant plaisir, joye, [et] consolacion que nous en arons, et especialement de voir vostre noble presence, ${ }^{1}$ ce que avous sourenteffoiz desire et sou[haite,] tant pour les grans graces et vertuz que entendons quil a ple[u a Dieu] de sa grace $a^{2}$ attribuer a votre persomne que aussi $\mathrm{p}$ [our la] mutuelle amytye, confederacion et bonne allian[ce qui est] entre noz bons cousins lez roy et royne dEspaig[ne vos p]arens et nous, la quelle a ceste

\section{Transtation.}

MADAI,

[Your late arrival] here in our realm is to us so.. - . . . and so very agrealsle, that we camot well say or express the great pleasure, joy, [and] consolation which we have from it, and especially [in the hope] of secing your noble presence, which we have often desired, both for the great graces and virtues which we hear it has pleased [God] to give to your person, as also for the mutual anity, confederation, and good alliance between on grood cousins the ling and queen of Spain [your] parents

1 persome, corrected.

2 The words in italies underlined cancelled. 
foiz sera par vo[us . . . . e]t grandement aug- A.D. 1501. mentee qu'aussi pour . . . . . tiere affeccion [Oct.] que leur' portons. ${ }^{1}$

[Ma]dame, semblablement ce nous a este t[resagreabl]e que vous avez evade et passe lez grans [danger's et per]ilz de la mer, et que estez arryve ${ }^{2}$. . . . . . . po]rt de salut, vous et vostre belle compaign[ie . . . . . nous, et regracions Dieu de tout . .

[Et] au surplus, Madame, nous vous offr[ons . . . . . et] donnons touz les commodites et a . . . . . . . . . s en y a en nostre royaume pour en o . . . . . rement a votre bon plaisir et vol . . . . gnier.

[Mardame,] vous [. . . . . . . . vous] plaise no[us tenir] et repputer doresena[vant c]ome votre bon et a[ffectionne] pere, aussi familierement que feriez lez roy

and us, which at this time will be by you . . . . and greatly angmented.

Madam, it las likewise been [very satifactory] to us that, you have eseaped and passed the great [dangers and perils] of the sea, and have arrived [here in a] port of safety, you and your fair company . . . . us, and we give thanks to God for all . . . . . . ]

And for the rest, madan, we offer . . . . . and give yon all the advantages and . . . . . . in our realu, to . . . of it . . . at your good will and pleasure

[Madiam, I [beseech yon that] it may please you to regard us henceforward as your good and [loving] father, as familiarly as you would do the king and queen your

\footnotetext{
See note 2 in pleceding page. | ${ }^{2}$ " $b o \ldots$ scored ont.
} 
A.D. 1501. et royne [vos] parens, car de nostre part nous sommez [Oct.] resoluz et del[iberez] de vous traitter recuillir et favoriser comme notre $p$ [ropre et] naturelle fille, et en aucune maniere plus [ou moins cherem]ent que nulz de noz propres et naturelz enfans . . . .

[Ma]dame, il ne mest bonnement possible de vous - . . en venue, ne de vous recepvoir si bien et favo[rablement que mon] cuer et couraige le desir et que voz vertuz et $[$. . . le merite $]$ nt; mais aumoins, madame, vous plaise [scavoir nostre bon v]ouloir et couraige et de prandre en pa . . . . .

parents, for on our part we are determined to treat, receive, and farour you like our own danghter, and in no wise more [or less dearly] than any of our own children.

Madam, it is liardly possible for me to [meet] you on your arrival, or to receive you so well and finourably [as my] heart and mind desire, and as your virtues and . - . merit; but at least, madam, it may please you [to redit my good] will and to take in . . . . . . . 


\title{
XVII.
}

Private Instrucinons tolching Fomund De ta

\author{
Pole. 1
}

[MS. C'ott. Galba Ir. f. i0.5.]

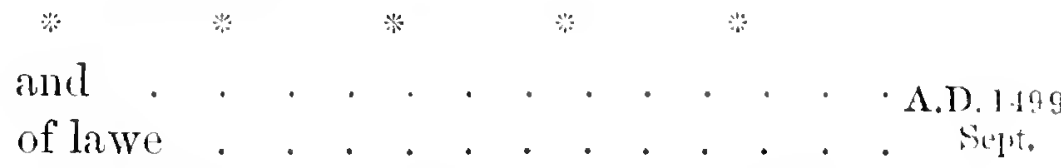

Furst he shal saye that aftre the said Sir Richard Gilford and maistre Rich:ud Hatton have receyved and seen the Kinges instructions, and theruppon and the contentes of the same communed and wel debated with the said erle of Suffolk, the kinges mynd is that at suche tyme as the caas shal require, and when it shalbe seen moost convenient to them ${ }^{2}$ the saicle instructions Guildford he shewed and redde at length word by word to the and IIatton said erle, suffring also hymself to rede it if hym liste, the instrueand to take it with hym to his lodging and see it at rens they his laiser. And thus they shall doo as of themself and the earl for the favour they specially bere unto hym, and as of Suffolk, they soo did withont the kinges knowlege.

And in caas the said exle be content to retorne and and to urge comme unto the king undre the oon or the othre of him torethe said condicions or articles conteyned in the said king; othre instructions, the king wol yet nevertheles that considering the divers great chirges that his grace hath committed unto the sivid comptrollow. ${ }^{3}$ and doctor to be shewed to his comsin tharcheduc over and above the matiers touching the said arle, and specially forsomoche as the said comptrollom knoweth well that

' From a corrected draft, muel nutilated. The writing is upon three leaves of paper, of which the second has one side blank, all but a mutilated endorsement, showing that the document must have been originally folded with this leaf ontside. Nevertleless the order of the folios appears borne out hy internal evidence. The date in the margin is inferred from an entry in Henry VII.'s privy purse expenses. Sce Excerpta Ilistorica, 123.

"them] corr. from "the said Sir "Richard." Similar corrections nceur thronghont.

SSir Richard Guildford was controller of the louseholl. 
A.D. 1499. hy Toyson Dorre that was here with the king, his grace Sept. wrote to his said cousin that he wolde furthwitl sende to hym oon ambassad, and that also the same Toyson Dorre knewe bifore his departing that the said comptroliour shnlde be oon of the said ambassad, the said [*f, 105 b. comptrollour*

th Tyrell

And if it - yng to his grace to come to $t$. . . . difficultie soo to doo, onles he maye have the said comptrollom in his company; the king wol that the said comptrollour endevoire if possible, hym for the canses bifore rehersed to contente the said Jritl sir erle to take Sir James Tyrell in his company to the Tyrell. king, and that he hymself maye contynewe furth his journey to tharcheduc; seing as above that the king hathe committed to hym and to maistre Hatton many divers great matiers to be shewed to tharcheduc over and above the matier touching the said erle, and that the king hath written by Toyson Dorre to tharcheduc that he wolde briefly sende unto hym his ambassad. And that also the same Toyson Dorre knewe bifore lis departing that the said comptrollour shulde be oon of the said ambassad. And over this the comptrollours name is in the kinges lettres of credence directed to tharcheduc, as well as the name of the said maister Hatton. It standeth also with the kinges great honour, hoth within his reame and withont, that the said erle comme to his grace rathre without the said comptrollour than with him. By thies reasons and suche rithre as the said eomptrollour shall canne best devise, he shal enduce the saicl erle to be contented to take in his company to the king the said Sir James and suffire hym departe to the archeduc.

If he will not eome, reept in Guilaford's company, the latter

And if the said erle wol in noowise comme unto the king onlesse he have in his company the said comptrollow, mothe than the matier shulcle bneke therfor the ling is content that lie leve his jorney to tharcheduc 
粠

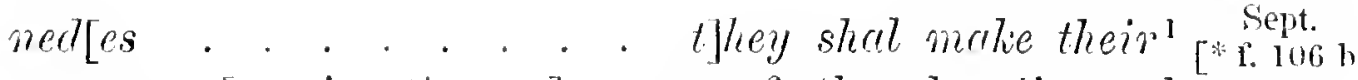
tions must. A.D. 1499. sommonan[ce in the pr]esence of the deputie and shall give counseill of [Calais and of the] maire of the town, the uphis maire or lieutenant of the staple, and suche othre of the to the most honourable persones of that town as they shal archduke. think good.

They shal also bifore the said erle, and in the presence of the said deputie, comseill, mayres and othre, not oonly summarily declare theffect of their othre instructions relivered to theym lyy the said William Pawne, but also to cause Lathbury, clerk of the cownsell, ${ }^{2}$ openly and distinctly to rede theym, and that no man he suffred to departe til this be perfitely doon. And that, the said boke oons redde, they cause the sain Lathbury to putte in writing in the ende of the same instructions undre the kings signe manuell in what day, what yere, in what place, and in whoes presences (namyng every of thaym by thair names), the sairl sommonance was made and boke redde. And that every of the said depntie, counseill, maires or lieutenant, in testimony of the same subscribe with theis owne hand their names. And that the said Lathbury doo the same wise.

Item. ${ }^{3}$

And if the said Sir Richard perceive that the same elle wol nedes depart and kepe furth his jouney without the kinges licence, he shat then, "byfor he sommen hym, take hym apart, and as it were of hymselve and

"The worls in italies seored ont in orig.

"Corrected from "watche."

${ }^{3}$ Another item of the instructions appears to have heen supplied in the left-hand margin opposite this place, but is now entirely lost by the burning of the elge of the MS., unless the firament noticed at page
132, note', be the latter part of it.

tafter the said sommonance made to therl of Suffolk. Suruck out.

she shal then .... k [nowtedige] interlined in Fox's hand, and in the margin, instead of the works "the "said Sil" Piichard shail then," which are struek ont. 
A.D. 1499. for the favor he bereth hym, and as it we[r] without Sept. the kyngs $k$ [nowledge], shewe to hyn that the king wol furthwith advertise every prince standing with him in amytie, aliannce, and confederacion, that is to saye, the Frenshe king, the kinges of spayne, Portugal,

[*10\% and Scotland, ${ }^{*}$ *his glace. . . . . . . . . . . - eter soo to doo to thar [cherhe]. . . . . . s there redy immediatly . . . [t]he king to make the same advert

He shal atso advise the said erle to considre for his owne weal and suretie that this doon he maye make hym wel assured that noon of the said kinges nor princes, nor any othre leing in the kynges amitie and confederacion, woll nor maye receyve, favour, socour, or entreteigne, nor suffie hym in any maner of wise to abide or remayne in any place or places of any of their obeissances, but to his uttre clere destruction take and sende hym to the king, for they be bound to the king soo to doo undre their writinges subseriluer with their hander, sealed with their seales, and confermed with their othes.

The said Sir Richard shall advise lyym sadly to remembre this matier, and therwith rekynne in his mynd what place or prince he hath to goo to for any socour or entreteynement aftre he be thus exchuded from France, Spayn, Portugal, Scotland, and tharchedukes lands.

Item, ${ }^{2}$

1 This is the last word of the text on p. $106 \mathrm{~b}$.; but the following words in Ruthall's hand, probably the latter part of the item inserted in the margin, (see note ${ }^{3}$ on preceding page), are risible below :-

". . . . . the depute the cownsell and the sayd mayrs or leftenant “. . . . . s to thentent thay may undyrstand tine kyngs gracyous “. . . . sayd erle. And thus to be doon and declaryd as thow; ". . . . fyr and mocion of the sayd depute and cownsell. And ". . . . mawadment or knowlege."

A caret is inserted before the next article, referring to a marginal note now almost entirely lost by the mutilation of the Mt: 
He nuste also remembre that if he be in the com- A.D. 1499. pany of any frince or any othre persone and make Sept. warre against any of the kinges firendes, alies, and confederates, that is to saye the Frenshe king, the kinges of Spayne, Portugal, Naples, or Scotland, or thareheduc, the duc of Millain, the Venicians or any of the eities of Italy, he shal therby attempte the breche of the kinges peax, his amytie, and conferleracion, that he hath with th[e] said kinges, princes, and townes; and in his so doin $[\mathrm{g}]$ he shal expressely doo treason against the king" .

to therle that lie . . . . . . r entreteigned in France, Spayne, P[ortugal, Sont]land, nor tharehedukes landes, an is als[0] co[n]teyned in the salne instructions [and that

and fa. . . . $]^{1}$ If he than perceyve that the erle (the said sommonance and advertisementes notwithstanding) wol alweys kepe furth his jommey, he shal, at of hymself, and as it were for the singlier fivour that he bereth to hym, and without any knowlege of the king, salye that albeit the said sommonance for his descrtes hath been made to liym, the king is yet nevertheles at his libertic uppon his good albering in his absence to repute lyym and take hym and deale with hym as it shal please his grace.

He shal therfor arvise hym that during his absence he and his companye behave theym and demeane theym in every place in woord and dede as the kinges true and faithful subgiettes noo thing doing ne saying that myghte sownte to the kinges displesir or dishonour. And he and they soo doing maye fortume at the sute of his fiendes, to callse the king in tyme commyng to have pitie, gratce, and mercy upon hym, pardonne hym his said disobeissance, and suffre him to retonrne and

\footnotetext{
1 This very mutilated clanse within brackets is added in the margin in fox's hand.
} 
A1).1499. enjoye that he liad when lie departed; the whiche sept. othrewise than by his good lemeanur and trewe behavyng towardes the king in lis absence, he maye never loke to recovere ne comme to agayn.

Endorsed (f. 106). . . . . . . . Maistre Ric.

Archeduc.

\section{XVIII.}

\section{A Statement concerning Ediend De la Pole.}

[MS. in Recurd Office.]

A.1. 1501. Furst when my lord Corson ${ }^{1}$ in his going to Thurkey declared to the king ${ }^{2}$ the murdres and tyrannyes of miliansay- H., with the propos of ny lord of Suff. ayeinst king ing he $H$. to recover his right, de., the kinges majestie would assist any onc of the louse of lork io risaniswerde to my lord Corson, that if his majestie mighte have oon of king Edwardis blode in his handis, gain the and bee revenger upon $\mathrm{H} ., \mathrm{or}$ elles he wold spende crown, asmuehe money as his hole landes were in value fur an lole yere.

the eari of U Uron this the said duke of Sufi. was by the lord Sunfolk left Corson acerteyned, and soo departed ont of the reame of England. And at the said ducis commyng to Seyntjonc, ${ }^{3}$ he sent to the kinges majestie his lakkey with his lettres dectaring to the king the cause of his connmyng, and to knowe his plaisure for his commyng to lis presence.

but, Un Upon this the said duc camme to the kingres crming to presence at Ympst, declaring playnely to his grace peror, the murdres doon by H., and that H. also entended

\footnotetext{
' Sir Robert Curzon, whom Maximilian created a baron of the $\mathrm{Lm}$. pire. See Gongli's Camden's Britamia, 11., 306.

"Maximilian, king of the Romans, commonly called Emperor.

"ar Seyntrone? Probably st. Joham in the 'Tyrol.
} 
to have murdred him and his brodre, with the wronges A.D. 1501. H. had doon to him. Wherupou the said lue besought the kinges majestie, insomuche as he was cm1rower, of his ayde, according to justice to lielpe the said duc to his right.

The kinges majestie welcommed the said duc, taking him as his kynnesman, and desired him to goo to his logging And sent to him to his logging his commaillurs doctor Newdek, chaunceller of Austriche, and the quenes chaunceller: Whiche on the kinges behalve shewed to the said duc, that by mean of the pais bytwix $\mathrm{H}$. and my lord archdue, and insomuche also that by the la[kkey] of my lord archduc the kinges majestic had sent to him his seal for tract of pais bytwix his grace and $H$., his grace mighte not aydu the was at first silid duc. Neverthalas, the kinges majestic by his denied said counsaillors offered to the said duc his saulconduit to abyde within the empier and al other countreys belonging to the kinges patromony and inheritance.

The said duc with the kinges saufconduit and this aunswer, having the kinges lettres of licence to depart, was contented to have soughte his flendes in other parties, and w[ould] have departed incontinently. And when the duc had thus aunswered, the [ducis] said counselloners reapported it to the kingis majestie.

And upon that camme the next day again to the said duc the is...... with theim and . . . . monsieur le tresorer Bontemps, lesiring the said lue [to have] pacience for viij daies, bycause of the businesse his grace then had to doo with [the] cardinal of Roan ${ }^{1}$ and other ambassadoures of Frannce. And that if it wold pleaso the sayd due soo to doo, the kinges majestie woll studie and divise som waies for the said due that shuld loo him good.

\footnotetext{
1 (reorge Amboise.
} 
A.1). 1501. The said cluc at the kinges instance taried at then per- Ympst by vj welies, and then amme thicker to the warded to said due the forsaid momsire Tresorer with a lettre from Inst six wecks; the kinges majestie, to whom the kinges grace desired that the said duc shubl yere fiul faith and credence.

\section{The Credence.}

and finally That the kinges majestie woll helpe the said due promised he his of cousin to his right, insonuche as the tresorer on 500 sol $^{-}$the kinges behalf offied to the sald duc iij. iij. on diers. $v . m$. men of warle at his plaisire to serve the said duc for j., ij., or iij. m[onths]

[*1. 2. **they shuld receive any wages of the said duc, and that the said nombre of men shuld bee redy with diligence. Insomuche as Walter Yugar, on of the huissher's of chambre, was then sent to my lord Henry, erl of Ardek, to make redy the said men. The whiche erl had promised the king like nombre of men of warre at the linges plaisir for iij monethes wheresomever it shuld please the king to sencle theym. And if the said erl performed not this matier, the kinges grace wold fyncie other remedic for the said nombre of men, and also for shipping, \&c. The said iij. moncthes ender, the said lue being in his right: in England, at his libertie either to contente the waiges thus due, ste, or elles, an other tyme when the kinges majestie shuld have nede, the said duc to aycle lis grace with like nombre of men at his changes. And besides this the said duc was meved by Mr. 'Tresorer in [the] kinges nime to hee agreable to certain other thinges, whiche the said due by his - . . instruetions signed and sealed, performed in every thing as the kinges majestie desired.

The said due inmbly gare thankes, \&c., for the linges oftre of ayde and helpe, and concluded with monsire Tresorer to have iiij. $\mathrm{m}$. fotencen, and $\mathrm{vj}^{c}$. 
horsenten. And soo the sirid duc by thappintement of the king came to Aeon, having his lettres of recommendacion to the connsail of the same towne.

The said duc leving with the king his steward with Chapelle thinstructions aforesaid, according to the tresorers de-cmperor's sire, to sollicite the said ducis causes, and to conclude A.1). $1.501-2$. in the premisses.

At Brounck ${ }^{-1}$ the stewerd camme to the kinges presence, and there declired to the king the said credence, [an]d shewed to the king thinstructions aforsaid. With the whiche the king was we[ll c]ontented, and with the said duc, that he upon Bontemps credence had fultilled the kinges desire, commanding the stewerd to kepe the said instructions, til the commyngs of the forsaid Walter Yngar from therl of Ardek.

And then camme the said lord Herry, erl of Ardek, The emto the king him silf; but the kinges promesso stode peror's provoyer, and toke noon effect. fulfilled.

Upon this the steward was sent by the ling to the said duc with lettres; to whom the king desired the duc to geve full faith and eredence to suche thinges [as the] steward [shewed] to the said due on the kinges behalf.

\section{The Credence.}

[Forasm]uch as the king was then determined to h[av]e goon to . . . . he for that tyme cuulde not performe his [prom]esse made by the . . . . king desired the said duc to bee of good combitort and to . . . . tyme. And that withoute faille the king wold helpe him oon wa[ye] or other; and if oon waye wold not take another shuld. Insomuche as the king saied, "I see wel this must bee myn owne dede, and I shal pro[vide] for $\mathrm{xxx} . \mathrm{m}^{1}$. $\mathrm{g}^{\prime}$. to bringe this matier to passe." And to thentente the sa[id] due shuld alwaies be 
1.1) 1502. sure for shipping the king appointed maistre Basti[an] oon of his chapellains to goo to the king of Demare to appointe with him to bee the said ducis frend, and that in 1100 wise the said king shluld take latis with king $H$. And his lettres and instructions to the king of Demmarc, maistre Nichola[s] Zigler lard in commaundemente to make theym.

The steward being in Ulmes received lettres from the said due whiche caused hin . . . . again to the king, the sayd maistre Bastiam being ther not goon, and sollicited for

[* 1. :3. " of Demmarc in this weighty matier, and then the king appointed a bisshop in [his] stede.

And when the king had openned his mynd to the bisshop, for his preparacion he desired lut viij. daies respect to mak him realy to goo into his countre and to retorne, and in this maner not despached was this bisshop ax daies. And then the king brak to the steward that lie must nedes occupie the bisshop to bee a commissioner to goo with the cardynal for to gadre toguid[er the] pardomne money.

Then the king appointed a gentilman Ufford to goo to the king of . . . . Mr. Kigler had made in his lettres and instructions lor . . . And the king was soo grood lond to the said duc . . ma . . upon his suretie and the said dukes meved therl of Ardek . . to the waid duc xx.ml. guld. to have therfor again xl.m1. . . And that the said crles son shuld have groon with the said dne [into] England. And the kinges majestie caused the tresorer and the steward to commone in this matier with therl of Ardek. Whom by his worde [he] founde soo towardly, that the said xx.m1. guld. shuld have been redy [by] Saint Georges Day then next following, and soo this said duc to have [gone] into Denmarc aud taken shipping. 
Menorandun. - The date of my lordis lettre to the A.D. 150. steward that Robert Wellesborne had to king Herry was the xij day of . . . . . And the . . bytwix the kinges majestic . . . Was taken by the commissioner's the xx day of Juyn . . . . .

And in the same space the sending into Den- 20 June. mare, and the xx. m.g. was disappointed. And then The ear is the king at Auxborowe showed to the steward thal[t] arpointed he wold helpe my lord for all that. And saied there is of promised warre [between] Geldre and Cleve, whiche shuld breke up shortely, and the king . . . . . . . . wold spede to the due of Cleve for my lordes helpe at [the comping up of the men of warre; and that waye the lking sil . . and . . wise therot.

[The] lkinges majestie after being in Ulnes, where the steward . . . . clue . . . the king that if he wold not... . . . that it might please . . . . . . . his ma[jestie] could not cthrewise . . to recompence to . . . had by raison of his abiding at the kinges instance. And having the kinges licence and linour was contented to departe and trendes.

Then incontinently by the kinges commandement the treasorer declared [to the] steward the kinges mind lor a peace bytwix the said duc and whiche the steward hath in writing to shewe according as the . . penned it.

\section{iij. myle fiom Ulmes.}

The kinge after, at Yetting castel, openned himself his mind to the steward . . . . . said pais, and desired the steward to have goon and declared the same to his mai[ster] and to have retorned to the king with thaunswer wh . . to do asmuch as the king determined to

\footnotetext{
' Probably at line lost.
} 
A.D. 1502. *with the steward to the said duc, that they ij. tognider [" p. 4. shmld openne the kinges mynd to the said duc for the said pais and bifore the king depached the lakkey to the said duc, certifierig the same duc that within iiij. daies then next after his majestic wold lave despached the steward.

Then wane my lord Corson to Auxburg to the king to knowe the kinges mynd concerning his piromesse adorsaid. The king aunswerd that though he had many thinges to do, yet his grace wold soo doo for the sajd duc, that he shuld bee contented.

The countie Nasso and Bontemps after by the kinges commaundement delivered [to] my lord Corson and to the stewerd in the presence of thambassidor of Spaigne the kinges instructions for tract of pais bytwix my lord and $\mathrm{H}$.

The king him self saied to my lord Corson and to the steward, that al though his grace meved the said duc to this pais, if it pleased the said due soo to doo at his instaunce, yet for al that the king wold doo for Maxi. the sail duc secretly asmuche as he cowle. Gicving

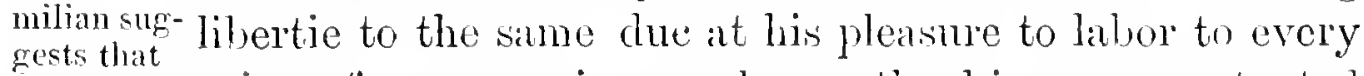
he should apply to prince for succor, insomuche as the king was contented France. that my lord shuld labour to the king of France, sayeng" thise wordes, that, "though his subgrettes and myn camnot aggree, yet he and I wolbe frendes shortely. And the king of F. is a man that hath good and wol araunce money shortely; thinkyng that an othre day my cousin volbe my grood fiende and ove me [none] the werse wille."

The king said also, that oon of the sjeciallest causes that he desired the said due to . . Was for the stre conveying home of my locd archeduc onte of Spayne into his countrey. Desiring to have the dues silid aunswer by writing. And if the said duc wold conforme him therunto at the kinges desire, his majestie wold pertorme his sayenges, and also thinstructions atorsaid.

Then aunswered my 1. C. and saied to the king, 
"If my lord wo[ld consent] to this pais, howe shal he A.D. 1502. lyve in the mean tyme?" The king [said] to my l[ord] Corson] "Lette me have but my cousin, your maister" . . . . and my morler, his aunte." Wo shal soo prov[ide . . . . . . . . . . . . . . . . shalhave homnorable entreteignement."

. . . accorling to the kinges desire and at the ki[nges

. . . . . lim to this pais, and sent the stewerd to the king with an amowere . . . . . upon the kinges said instructions. Wherewith the king . . . wel. . . and promised to the stewerd to have delivered to him furthwith a $\mathrm{m}^{\mathrm{l}}$. $\mathrm{g}$. for thentreteignement of the said duc, and appointed v. ml. $g$ for his dislogge, as R. Ruffyn and Marinyer knowe.

And firtlue the king knewe somuche that $H$. was contented that my lord and my lady his wife shnule bee in the kinges cont, and that al suche persommes as were with the said duc that had landes or goodes in England shuld enjoie them and have alis recompence of the revenues of the same. And for the conchnsion of almaner thinges the king wold then have sent into England diverse homorable personaiges in ambassade.

*vj Leeges bysydes Auxburgh.

After this at the towne of Werde the king lirake to the steward that he founde king $H$. variable and that he sigheth ${ }^{2}$ wel that king $H$. mynd was utterly to destroye the said due and howe that king $H$. had meved the king to doo thinges whiche shuld bee to the said dukes destruction, wherunto the kinges majestie wold never assent. And therfor the king saied if king IFer'y contynmed in that mynd, his majestie mights with his honom breke al thinges that wore begrinue.

\footnotetext{
1 XIargaret of Burgundy, | " sight, MSS.
} 
A.D.1503? bytwix him and king $H$., and helpe the said duc, witho[ut] king $\mathrm{H}$. wold kepe his promesse.

Upon this the king had knoweleege of the comyeng of king $H$. amba[ssadors] in lis commyng to Brabant ward, and then the ling shewed to the steward that his grace, the said duc, and king $\mathrm{H}$. ambassadonrs shuld mete al toguider to commyn and conclude in almaner causes. Insomuche as the king wrote accordingly to t[he] said due and sent his lettres to Casius for to delivere to the said due $\mathrm{m}^{\mathrm{l}}$. gultel.

The king after in Istelgorffe ${ }^{1}$ and Weesyll commaunded the steward to goo to Acon to the said duc, there to alide for viij. daies, willing the steward to delivere ag[ain] to his grace the assignement upon Casius for the said $m^{1}$ guld. And by thende of the said viij. daies, the saied he woll sende to the said due the sair $\mathrm{m}^{1}$ guld. for his entreteignment, and also a saufconduit for the steward that he mighte comme into Braband to sollicite the causes of the said luc; whiche the king performed not. And the king herde the said ducis . . . . no man thereto amnswere for him, whiche was honnorably nec .

The s[aid] duc, seing that the king thins dilaied him, sent lis pursyrant [ . . . . witli] lettres [to thle king to Andewerpe, beseching his grace for to have knowen his plaisire and [if] the king wold not performe his said promesse, the said due besonghte the king to gere licence to leparte upon such thinges as were conteyned in [the] said ducis lettres.

[The] king then sent to the said duc diverse his lettres desiring lim [to have a li]tyll pacience, for within r. or [vj.] daies after he wold sende to the said d[uc certaine] of his comnsail to rleclare to the seid duc the linges . . . . . . . . . . . . . as his gince had opemed and declared at large [to the] stew[ard]. 
the moneth of Marche the A.D. 1503. king sen . . . . . . . . . grace had sont his ambassador into England. From [whom] the king had noon answere. But his grace. . . . . . . . . . . to sende to the said duc suche aun. swere as he shuld bee pleased.

*. . . . . le Roy des Romaynes et de A.D. 1501 Ungherie, dre.

Treschier et tresame cousin,-_Nous avons recen voz Letters lettres, ensemble celles que nostre ame ot feal chevalier trom MaxiR. Corson nous ay escript. Par lesquellez suffolk, avons entenclu les eurses pour lesquelles estes parti du reame Dangliterre. Et desirez de savoir ou vous nous pourrez venir et parler anous. Surquoi, treschier et tresame cousin, vous advertisons que avons entencion de demourier encoires par aueunes jours pardeca. [Vous] nous y pourrez trouver. Ce scet nostre Seigneur auquel nous prions quil soit garde de vons. Escript [en] nostre ville Dysbrouch le ix. jour de Septembre, lan $x v^{\mathrm{c}}$ et ung.

\section{Per' Regem.}

\section{Marinter.}

\section{Transtation.}

The King of the Romans and of Hungary, \&c.

Most dear and well-beloved consin, - Te have received your letters, together with those which our beloved and faithful linight Sir Robert Curson has written to us, wherely we have understood the canses for which you have left the realm of England. And you desire to know where you can see us and speak with us. Wherefore, most dear and wollheloved consin, we apprise you that it is our intention to remain yet some days here, where you may find nis, as knoweth our Lord, whom we pray to be your protector. Written in onr town of Inmsbruck, the 91 h day of September. 1 sol. 
A.D. 1501. Maximilianus divina fivente clementia Romanorum rex 22 Sept.

\section{semper Augustus.}

Lctters Illustris sincere dilecte, - Andivimus te in Zierl apfrom Mraxi- plicuisse. Cum autem hic propter venationis causam suffolk. simmus te hortamur ut clas de sero huc ad rillagium Delfs te transferas. Facies in eo nobis rem pergratam. Datum in Delfs die Mereurii ${ }^{1}$ post festum Matthei Apostoli, anno Domini millesimo quingentesimo primo, regui nostri xvi".

Ad mandatum domini regis proprimm.

2.) Seppt.

Maximilianus ${ }^{2}$ ut supra, de.

Tllustris sincere dilecte,-Seripsimus hodie ad te ut cras ad villagim Telphs proficiscereris. Cum autem lroe propter incommoditatem hospritiorum importunum sit, risum est nobis commodius in Pettnan proximo illic loco, quo te masens nostre tabellarius alducet exspectare. Quocirca te hortamur ut sine moria te illuc conferas, nbi quan primmm de voluntate nostra te restioren rerlemus. Datum in Telplis mona cal. Oetobris;" anno ut [supra].

Ad mandatum romini regis proprium.

MARINIER.

Le Roy de Romaynes, \&e.

30 oct. Treschien et tresame cousin,-Combien que essions delibere et estoit nostre desire de voz faire savoir de nโoz] nouvellez, toutesvoyes, olstant les grans et urgent affirires que noms sont snrvenuez depuis nostre reparte-

\section{Trinslation.}

The King of the Romants, \&e.

Most dear and well-helored consin,-Althomgh we hart determined, and it was om desire to inform you of our news; norerthelers, owing to the great and urgent affairs

'22 Sept.
"The original of this letter' ex-
ists in the l'?ecord office. 23 Selpt., although the dite olght to be the sance as that of the lact letter. 
ment de Ympst nous ne lavons peu bommement faire; A.D. 1501. mais bien brief nous envoyrons dever vous aucun de 30 oct. nous servitures, et par ycelluy vous signifirons de noz from Maxinouyelles. Atant, treschier et tresame cousin, nostre milian to $_{\text {Sufoll. }}$ Seigneur soit garde rle vous. Escript en nostre ville d. Bosseen lo penultime jon doctobre, lan xve et ung.

Per regem.

MARINIER.

Le Poy dez Romains et de Hungery.

Treschier et tresame consin,-Nous enroyes' presentement par dever vous nostre ame et feal conseilleur Jehan Bontenips, seigneur de Salans, pour vous dire et declarier acung choises de nostre parte. Sy rous requirons le vouloir croire pour ceste foys de ce quil vous dire depar nous. Atant, treschier et tresame. cousin mostre Seignen soit garde de rous. Escript at Bosseener le vi. jom de Novembre, lan xve et ung.

Per regem.

Ad mandatum domini regis proprium.

which have come upon us since on departure from Imst, wo have not been well able to do so; hit very shortly we will send to you some one of our servants, and by him we will signify to you our news. Thus, mont dear and well-heloved ronsin, our Lord be your protector. Written in onr town of Butzen, the Both diry of Ortoiner, 1,501.

The King of the Romans and of IInngary.

Most dear and well-beloved consin, - We senul to you at. present our beloved and fatheul comsellor Jean Bontemps. lord of Salans, to saly and declare to you certinin things on onr part. Accordingly we request you to give him credence for this occasion tonching what le will say to you on on whalf. Thus, most dear and well-beloved consin, our Lord be your protector. Written al Botzen, tha 6 th day al Novenuber, 1501.

\footnotetext{
Sie in MS.
} 
A.D. 1502. Memorandum. The lettre in Laten of credence was brenned by my lord that was dated in Jamary, when I was commyng to iny lord and retoumed bak from Ulmes, was brenned, \&c.

$20 \mathrm{July}$.

$$
\text { Le Roy de Romaynes, \&c. }{ }^{1}
$$

TrR[ESCIIER et ame cous]in, nons avons recen roz lettres par' . . 'Lagnay portenr de cestes, et entendn ce que nous avez fait dire et declarer par vostre maistre dostell estant dever nous. Surquoy vous advertisons que dedens quatre jours apres le date de cestez renvoyerons dever vous vostre dict maistre dostell, et avee luy ung de noz servitures, par lequel vous ferons faire responce du contynue de vosdites lettres. Atant, treschier et ame cousin, notre Seigneur soit garde de vous. Donne $a^{3}$ Yetting, le xx. jour de Jullet, lan xic deus.

Per regem.

MLtinier.

\section{Trayelation.}

The king of the Romans, \&se.

Most dear and woll belornd cousin, we liave received yom letters by - . . Lignay hearer of these, and madestood what you have cansed to he said and declared to no by your steward being with us. Whereupon we inform you that within fonl days after the date of these we will sond back to you your sait steward, and with hin one of onr servant, by whom we shall cance answer to be mate to tou on the contents of your said letters. Tins, most dear and hedored consin, our Lord be yom protector. Given at Iretting, the 20 th day of J11ly, 1502 .

${ }^{1}$ The original of this letter is in the Cottonian Collection, 215 . Calla B. rv. f. $132 \mathrm{~b}$, (117 b. of the oll foliation), pasted on the back of a letter of later date, with which it has no commexion. The address, is legible through the other letter. " $\Lambda$ "nostre treschier et ame consin, la " tue de suffock."

"The MS. heve is illegille, and the original letier is mutilated in the very smite pluce.

sen, MS., hut a in orig. 
Illustris ${ }^{1}$ consanguinee carissime. Cum nuperrime a A.D. 1502. nobis petieris ut anctoritate nostar tibi indulgere dig- $24 \mathrm{Feb}$. naremur quod ubique per totum imperium tibi insidiantes from Maxiet in te adversa machinantes punire possis; visum fuit Suffolk, id aliquantulum civitatibus imperialibus posse præjudi. care. Cumque generale habeas mandatum, ut ubique hujusmodi tros insidiatores edoceas quod tune unaqureque civitas ad tui instantiam in eos jus administret. Quapropter tibi scribendum duximus ut in eo contentus esse relis, ne gravion nobis exoriantur inconmoda. Iatum in oppido nostro Innspruge, die xxiiij Februarij, anno Domini M.DIr., regnorum nostrorum Romani decimo sexto, Hungarie [vero duo]decimo.

Per regem.

Ar mandatum domini regis neoprium,

. . . . . . . of Juyl or therin camme Sir Robert Corson. And where a servant of the kinges . and openned the kingis mynd to my lord for a tracte of accorle bytwixt . . . . . . . . . . of his commyng it was known. For Sir Robert wold take upon $h$.

structions -. . to my lorde : and I yode to Frankford for the $\mathrm{m}^{1}$. . d. - . . namid with his lettres of aunswer tonching the said.

Maximilianus divina farente clementia Romanorum rex semper Auguatus.

[Illustr]is sincere dilecte, nunciamus dilectioni tuæ oratores serenissimi principis, domini Henrici regis Anglorum Sufi (?) . . . . . . . eos brevi apud nos futuros. Quod cum factum fucrit tractabimus cmm

\footnotetext{
The original of this hetter is in mond have been supplied which are the Record oftice, and from it some thening in this MS.
} 
A.D. 1502. eisdem [de] negotiis dilectionis the propter que magis21 Dee. trum curie ture ad nos misisti. Preterea significamus . . . speramus brevi proficisci versus dilectionern tuam, ubi et simul conreniemus tractaturi latins do omnilus. Quor to latere minime volumus. Datum in oppirlo Dornstat die xxja Decombris anno xveij". Per regem.

Ad manratum domini regis proprim, Coltater Doctor.

Memorandum. At this tyme the king wrote [a] lettre in my lordis farour to the bisshop of Lege and to other princes, and the bysshops lettres were delivered to him afore king $H$. ambassarlours.

Item, memorandum touching thambassadours; and therfor the king was not contented and wold not comme hy my lord, nor lette me goo with hym into Brabant, but commaunded me to retorne from Cieynes in Cleveland to Acon to my lorr, and then Don Peter rode in Braband from Andewirp.

Memoraudum. So that the king sent a lettre to my lord steward 'f. that he shuld cone forte ny lord, sce, which. . . . to my lord and lord . .

*l'rescriner et tresame consin. Nous arons receu roz A.D. 1.503.
9 Fel. lettres escript en nostre ville Dhays le jour et feste de $\left[{ }^{*}\right.$ p. $i$. Nostre Dame derrain passe. Lesquelles nous avons venez lien et longne. Surquoy vous advertissons que deans iiij jours nons envoyerons ancm de noz servitmes dever rous pour vons advertier de filire response tant sur le continue en rosdictes lettres, que sirr co

\section{Traxiation.}

Most dear and well helowed conin. We lave received your letters written in on town of $A$ ix the day and feast of Onr Lady last past, which we have regarded well and long. Whereupon we apprise yon that within four diass we will send to you some of our servants to make answer to gou. loth upon the

John de Horne. 
que avies donne charge a vostre maistre dostell, quest A.D. 1503. retourne dever vous. Atant, treschier et tresane cousin, Letters. nostre Seigneur soit garde de vous. Escript en uostre from Maxiville de Anver's le ix jour de Fevrier lau $x v^{c}$ et deux. Suffolk.

Per regen.

Ad mandatum domini regis proprium.

MARINIER.

Theschite' of ame cousin, nous avons pecou voz 19 March.

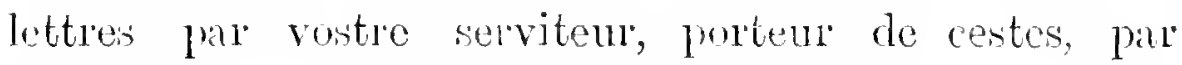
lesquelles avons entendu vostre necessitie. Lit nous requerez: vous aider aims que vos dictes lettres le contiennent plusanlong. Surpuoy vous advertissons que bien toste anoyerons dever vous et rous advertirous des causes que nous ont fait tant tarder et esperons que cu serez" bien content. Atant, treschier et ame cousin, notre Seigneur soit garde de vous. Donne cu nostre ville Danvers le xix. jour de Mar's lan $x v^{\circ}$. et deux.

$$
\text { I'er regeru. }
$$

MLRINIER.

contents of gour sad letters and upon that which you gave [in] charge to your steward who is retumed towards your. Thus, most dear anel well beloved comsin, onr Lord he your. protector. Written in our town of Antwerp, the 9th day of Febrllay, 1502.

Most dear and beloved consin, we have received your letter's by you servint, bearer of these, whereby we have moderstood your necensity ; and you ask this to aid you, als your said letter's contain more at length. Wherenpon we intimate to you that we shall forthwith send towath you and inform you of the canses which have mate us so long delay; and we hope that you will he satisfied therewith. Thus, most dear, \&e. Given in onl town of Antwerp, the 19th day of March 1502.

\footnotetext{
1 The original of this letter cxists in the liecord Office.

${ }^{3}$ scrons in transcript.
} 
A.D. 1501? Le roy des Romanin, nostre seignemp; a litit declarer a messire Robert Corson, en lit presence . . . . - . . Despaigne, les pointz et les articlos cy apres declariez. A celle fin que ledict messirc Robe[rt] . . . . . . . au duc de Suffoll..

Et primers, luy a fait declarier que, actendu que ledict due de Suffolk est yssu de lin con . . . . . . . et dudict roy Despaigne, que si mabjestie le vouldroit conseiller et dressier et ses aftiares et . . . a la restituicion de ses biens, rentez et revenues quil ay en reame Dangleterre jar condicions lionestes, et ainsy en temps deu et possible.

Daultrepart, considere litfinitie que ledict roy Despaigne et monsieur larchidac ont avec le roy Dangliterre, et les grans affaires que leu's majesties ont a present, semble a roy nostredict seigneur que par amiabletie (?) et par condicions et meanes propries ledict duc de Suffolk doit ace proceder et faire som

\section{ThaKoLATHa}

'Tue king of the Rimans, our' lord, hat cillised to be declined to Sir Robert Curson, in the presence [of the mbatsador's of the king] of Spain, the points and articles hereatter declared, to this end that the said sir Rotrert [may ingriing them] to the duke of Suffoil.

And first, lie had catised to lee electarcil to him that, considering that the said dule of sufulk is spring of the [lin of the king of Englandj and of the said ling of spain, that his majesty wonk atrige and direct him in his aftilis . . . to the restitution of lis goods, rents, and revenues which he has in the realm of England ly honorable conditions, and also in the scason when practicalte.

On the other hand, considering the allince which the said king of Spain and the archeduke have at present with the king of England, and the great adtin' that their majesties have at present, it appears to the king our sain lord that the said duke of suffolis ought by amicable wayt and hy proper conditions and moans to proceed thereto, and matse his treaty thereof, 
tracter len, prenant layde et su[ccons] de roy nostre A.D.1501? dict seigneur et dudici roy Despaigne; lesquelz pour les causes dessusdictes et saunce aucune doubte - . afinire sondict tractie ason utilitie. Doultre semble au roy nostredict seigneur et audict ambassadeur que lon doit practiquier et solliciter dever le roy dAngliter'e puy vueille mettre hos's dexil ledict duc, nesme pource quil luy farce . . . . et mettre a son framc arhitic sa femme et ses enfans en semble ses nous . . . . . joye de ses rentes et revenues et quil puist tirier ses dictes rentes el revennes hor's du

ainssi 1.. gaml devoroit pur la plusgran[rle] suretie et

aux gaiges et servico dudiet roy Despajgn[o . . . - . de . . . z. Et tousjour's . . . du jais du roy des Romaines. Car en se faisant il s.. - . . a an . . . . . de sa par[t . - . . J agreablo an Dien et a lui honorablo et ainsi choise aggreable a . . . . . dont il pleut a]voir aucunes remmemarion dems. Et par eo moyen pource estre . . . . . en lon . . .

Endorsed: "The matiers as my lord was handelled with the king of Romaynes."

taking the aid and snecont of the king on said lord and of the said king of Spanin, who for the canses aforesaid, and without any doubt [will assibt him] to make his said treaty to his advantage. Berides, it appears to the king onr said lord, and to the said ambissador, that direct and indirect application shonld be made to the king of Englind, that he wonld recall the said duke from banishment, eren becuse he would make him . . . and place at his free disposal his wife and children along with his . . . . . enjoy his rents and revenues, and that he might drat his said revenues from the

[The rest mintelligible.] 


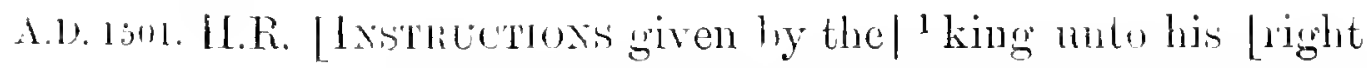
trinsty serrants, Sir Ch] arrles somerset, knight, his vice[chamberlain] and to Maistre William Warliam, maistre of the rolles in the kinges chancellary, for to be shewed to the king of Romalyns.

ECnst, aftre prescutacion of their lettres and cluc recoumendacions they sh[all] saye that the king onre souverain lord hath wel undrestande asw[ell] by the lettres of tharcheduc as also by Mons de Sempye am |the] prorost of Arres his ambassadours then being in England [with our] ${ }^{2}$ said souverain lord that the same areheduc by thordenance of [the king] of Romains had sent oon Maistre Jargues Gowdrant [president of] Burgoigneye to have shewed to our said souverain lord in thle presence] of the said ambassadours certain credence to hym committe[d by the] said arclieduc.

And forasnoche as by the visitacion of God the said Maistre [Jaques] Gowdrant, to the great bevyness and displeasure of om sa[irl souverain] lord, saving the will of God, disseced bifore he co[uld cone to] his presence, the silid ambassadours of tharched[ue, having] the same instruccions that were committed to the said [Maistre

\footnotetext{
1 The original MS. of this doenment is so much injured by the fire that many words near the margins are burned away. The true order of the folios has also been disturbed and the greater part of the document

dislocated fiom its true position. "Modern coing alno burned.

The modern foliation of the MS. is here given in the margin. In the beginning the bracketed words are supplied from an imperfect modern copy in the same volume made before the fire.
} 


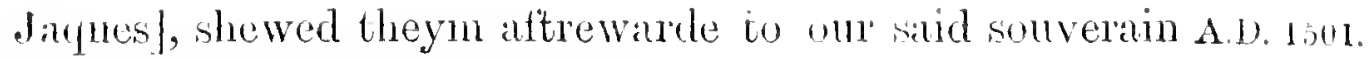
lord in [manner following:

That is [to] say, [that the said ki]ng of Romayus considering [like] a veray Cathollic prijnce peace and amitie bitwix Cristen princes to be the principal maintenor, defendor and releve [of] the faith of the Churcho of Criste, desireth of all his h[eart] love, confederacion, and fraternite of all princes cristened, and anonges othre singlierly with oure said souverain lord, ha|vingl' in his remembrance the great fraternite and aliannce [that] hath been bitwix theym in tyme passed, and know[ing] also thentier affection amitie and kyndencs that is [betwixt] onre said sonverain lorel and tho said archeduc his son. [Wherefore] he is contenterl to have and take aliance, confederacion [anitie] and fraternitee with ome said sumverain lord.

The king on souverain lord, seing that the said considera[cion], desirc, and contentacion of the said king of Romayus procede[the] not oonly of his great noblesse, wistom, catholique mynde and golly disposicion for the tuicion and defens of the Churche of Criste, but also of a remembrance of thancie[nt] *fraternite, love, and ["f. 53. [atfleccion that in ti]me passed hath be bitwix theym, in his most herty [wise] thanketh the same king of Romayns, assuring him that for the honor of God thexalta[cion] of his Churche and the confusion of the enuemyes of our fai[th] he is for his partie of like desir. to have peax with all princes, and specially with hym, remembring that ther hath be not [only] bitwix theym in tyme passed great love, amitie, and ali[ance], but also bitwixt the hool impire and the noble proglenitors] and antecessours of oure said souverain lord. And over th[is with] moche the bettre will for thentice love and fadrely [affeccion] that he bereth to the said archeduc, whom he tendr[eth no les] than he doeth 
A.D. lsol. in manter his propre son the prince of [Wales], and also for the consanguynytee and nyghnes of bl[ood that is] bitwixt the said ling of Romains and our said sonver[ain lord]. Acertaynyng hym that it shal not faile uppon [the party of] our said souverain lord, but that

[H. 5:3 b. suche love any [tee, alliance] *and confe[deracion shalbe had] and taken bitwix theym as m[ay] be to the hon[Or of God] the confort and pleasure of theym, [their] firendes and allyes, and the weal ind restfulnesse of the[ir] realmes and subgiettes. And where the said uredence shewed by his ordenance to our said souverain lord purpor[teth] that there shalbe noo default in Naximi- the said ling of Romans, but that the said amitie lian desired and confederacion be redintegrate aftre the maner and the league, fourme that the lord Bever's h[ad] in tyme passed according to the over- 1 averture of to the same king of Ro[mans] upon the ture of lord behalve of our said souverain lord. The whiche overBevers, and receive ture made by the said lord Bevers the same king of from Eng. Pomayns aflermeth to be suche as foloweth, that is to land 50,000 say, that for the renovalling of the said amitic our an expedi- said sonverain lord was contente to arance to the said the 'Tums; king of Romayns 1. ml. escuz of goold to furnysshe therwith his entreprises ayenst the Turques.

[*f. 5 t. $*$ It is also sayed in the s[aid credence that] to was willing thentent the same aliaunce and amytee frate[mal] mayc Garter as be the moor ferme and stable bitwixt the said kinges, formerly, if the said king of Poma[ns] is contented aftre the said the prince amitie and aliaunce be passed and renovelled as afore of Wales wear is saicle to bere the garter as he hath d[one] in tyme the Toison passed, and that tharchedue shal doo the sa[me]; d'Or; provided that oure said sonverain lord take and bere thordre [of] Thoyson Dorree and cause lis son the prince of Wa[les to do] the same.

and hoped Moreover the said king of Romayns by the saide Henry cred[ence desiretl] that our said souverain lord will

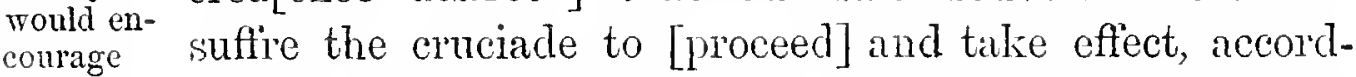
the Cru- ing to thoffie that our said somverain [lord hath] also sade. 
made to the satid king of Romayns to thentent [he A.D.1501. may] be the bettre socoured and holpen in his entreprise [against] the 'Turques.

As to this. The said ambassadour's shal saye [that lieply. our'] souverain lord considereth well [that whensoever] *and as often [as any amba]ssadours have passed bitwixt [*f'. if b. [him] and tharched[uke t]her hath be alwayes ineidently sp[eech] and communicacion had bitwixt oul said sonverain lond and the sa[me] ambassadour's for the redintegracion of the said peax, lo[ve], amitee, and confederacion, thoccasion of which [speech] was that where ther was entier love, amytee, kin[deness], and affection bitwixt oure said sonverain lord and tha[rche. duke] it was thought evill fitting that ther shulke be any [strange]nesse or unkindenesse bitwixt onre said souverain lord a[nd the] silid ling of Ronnains fadre to the said archeduc. But [as touching] any overture for the renovelling of the said amytee m[ade by] the lord Bevers the veray trouth is that our salid somverain Lord Belord never gave hym commission in that behalve, neithre vers had no by mowthe nor yet by writing, nor never was the [re] commission bitwix our onic sonver.in lore bitwix our said sonverain lord and the said lord Ject frand. Bevers dem[and], oflee, and speche of the said somme of money or of any oth[er], nor of any entreprise ayenst the Thuques ur communicacion of *cruciade, [*f. 55. wherof maye [he very dear a]nd evident apperaunce, forsomoehe as at the tyme th[at th]e said lord Bevers was in England with oure said souverain lord ther was noo warre, nor yet speche nor likelihode of warre ayenst the said 'Turques. An[d] if the king' shulde undie that inaner of forme have graunted any money to any prince it shulde have be thought and spoken [that] he had granted it for a peax, the whiche he never did, nor hi[s] progenitour's kinges of England nerer ${ }^{1}$ so

'The remainder of the noterin after this are supplied from mero copy is lost. The bracketed sords conjectupe. 
A.D. 1501. didde to any prince, [for it] coude not so sitande with their homour nor the contentacion of th

Neverthelesse good anitie, alliance, and confederacion oo[ns being] had and taken bitwix theym with snche affection folow[erl, that] otlure princes nuyght clerely knove that ther were good [love and] kindenes Henry is bitwixt theym, oure said sumverain lord coude be willing
give aid [content] to shewe somoche kindenes on his partie to against the the said k[ing of] Romayns as to ayde and succour Turks, him by some good a[nd honest] meanes for the fur. nishing of his entreprises ayen[st the 'Turques,] and rathre to hym than to any othre prince, and sp[ecially for so] good an entent. And in like wise the [*f. 5.5 b. said a[rchduke and] *oure said so[verain lord could be] righte glad and wel conten[t that the] said ordres of the [Ga]rter and Thoyson Dorree be taken an[d bornc] upon bothe parties according to thoverture of the said arch[chlke] made by thordenance of the said king of Romanns. And for [the] same oure sald souverain lord right hertly thanketh him. And at suche tyan as the said ambassadours shalhave f[ull] communicacion mion the said maticrs, and specially upon thami[ty and] tharticles that shallse couched in the sane, they shal [then] forsee that they in noo wise rectinbut not to tegre nor renewe with [the saill] king of Romayns the renew the treatie that was last bitwix our s[aid sovereign] lord which was and hym, forsomoche as it was and is a confeder[ation] against and corenant bitwixt theym twayn for warr junctly France. ma[king] ayenst the Frenshe king, with whom the king lath nowe pre[ace] and anytee for terme of his life; and soo he undrestande[th] that the said king of Romayns and the king of Spayne hat[h], and in like wise tharchedue and all othre princes.

And for their furthre instruccion and informacion for [*f. 101. the speciallties] *of the said amitie they s[hall endeavour] theym to the best of their powayrs to get it passed $w$. . . . es delivered to theym in writing signed 
with the kinges hand, saving that if they can not have A.D. 1501. [it] forevermore as it is conteyned in oon of tharticles of They shall the said writing signed with the kinges hand, they shal to obtain a take it for the lyves of bothe princes and of eithre of permanent theym lenger living a[nd] for oon yere aftre, with a an anticle confirmacion of the successour of the [prince] that shal of rebels. first decence as it is purveyed in the treatie of . . 'Jhey shal also endevoir theym to have the said amyltie made] with tharticle of rebelles like as it is ordcyned and mor[e at large] expressed in the furst article conrernyng the said r[ebelles, and] the said articles signed with the kinges hand. And [if they can] not obteyne the said article of rebelles aftre the said [manner and] forme, they shal endevoir theym to have the sairl ar[ticle . . .] aftre the secunde maner and forme as it is expressed [in the] said artieles signed with the linges hand.

The said ambassadours shal also surely forsee tha[t in one of] the said ij. articles of rebelles thore lo a special In [rovision that the] *kinges rebelles . . . . . thoes [? f. $101 \mathrm{~b}$. parties aftre and . . . to the furst mir . . - hing the said rebelles that nowe be . . . . moore plainly it is expressed amonges the said articles sig[ned] with the kinges hand. And if it can not br. soo had, they shicl than take it aftre the second forme tonching the sa. . . nowe rebelles, as it is also expressed amonges the said alrticles] signed with the kinges hand.

They slaal also see the banysshement of the said They shall nowe r[ebelles] solempuely doon and proclanned bifore see thr their departin[g from] the king of Romayns. And that banisher thofficer of arm[es whol attendeth npon theym le pre- before they sent to the same. And also cause the said officer of armes behind theym to undrestande [and] see that the said rebelles assuredly departe ont of the count [ry] of thr said king of Romayns, and that he departe not [but] 
A.D. 1501. he maye bringe the king the verray certaintee of the sam[e]. And if noon of the said articles concernyng the rebelles can [be] obteigned ne noon of the formes

[. . 102, bifore rehersed, the sa[me] ambassadours shal, rathre than they shulde departe without [the] *amytie, passe the said a[mytie with an] article that noo ayde, succor, favo[r], nor relief, neithre in men, money, vitailles, shippes, nor in noon othr[e] maner wise, publice vel occulte, be geven to the said rebelles. Albeit they shal saye that oure said somverain lord hath amyte with the Frenshe king, the kinges of Spayne, Portugale, and Scotland, and with tharcherlue with the said articles of reb[elles], and that in tyme passed ther was with a like article for rebe[lles], an amytee concluded bitwix the emperour Sigismund [and the] hool empyre, and the king of England, king Henry t[he Fifth], like as they have therof writing redy to be shewed.

Also, if the said amitie can not be had by noo de. voir [with] the confirmacion of the See Apostolique, the said amb[ssadors] shal, rathre then the matier shulde breke for that cans, [leave] without the said confirmacion; and yet to move the said [king of] Romayns to agre to the same confirmacion, they shal [say] that thanytees bitwixt our said sonverain lord and t... . . and the king of Scottes and othre princes be con[firmed by the] said See Apo[*f. 102 b. sitolique, and fastly they shal stike . . . . . . *articles of [the said] confirmacion Apostolique as far as the $[y]$ maye conveniently and honestly doo.

They shal also endevoir theym to passe the said amitie with a[n] article that eithre of the princes be hounden to swere, and to see the king of Romayns swere it in his per[sone] or they departe, and that the king swere it in the [presence] of his servatio that shal comme for his money. Neverthele[s] if they can not obterme the said anytic with the saibl. . they 
shal, rathre than faile, passe thamytee without t[he A,D. 1501. same]. They shal also take with theym oon of the original bu[lles] contras tumiultucintes, and if they maye finde oportunitee. . mete season, or convenient occasion they shal declare the . . . therof. And also shewe the self bull, if they see that th[ey] maye conveniently soo doo, to the said king of Romayns, and as many othre estates, nolles, and othre, specially prelates of th[e] Churche, as aftre their cliscrecion they shal thinke good. And specially if thamitie conclude with tharlicle of re[belles. . ] the onn or the othre of [*f. 10\%, thes. . . es, and elles not.

And in eass the king of Romayns saye that he hath The king been and is content to have and take the said amitie wance the with oure said sonvera[in] lord, soo that he wil money avamee hym the said somme of money, they shal when the answere hym that the said amytee had and conchu[ded] conchured. betwixt theym, the ling wolbe content to shewe hym such [e] kindenes as is alovesaid.

And if the said king of Romayns be not contente wilh t[he said] answer, they shal then saye that our said sonverain lor[d perceiveth] wel by thinstruction geven to the said Mrr. Jaques that the] said king of Romayns desireth of the king our said souv[erain lord] twoo thinges. The furst is, that the king wolde for his . . . succour towardes his expedicion ayenst the Thrkes avam[ce to lim] the sair money, wherby it appereth that he entend[eth to make the] said jommey and royage against the Turkes. Wherin [they shall,] with as good wordes as they can use, geve hym as grr[eat praise] and lawde as they can.

His second desir is that our said sourerain lord wil s[uffer the] *rnciate to [have] course within his [*? 10? $\mathrm{r}$ reame. But wherf[ore] he maketh that desir, they sha? salye he lathe not shewe[d nor] oure said sonvernin lord hathe not yet undrestande. Nevert[heles] they shal singe that astouching tho said cruciate. the [pone] 
A.D. 1.on. hath written to the king for it with right great inNotwith. stannce . . . . that our said souverain lord suftre standing
the popes thexecucion thernf with [in his] reame. But for many request,
Irenry causes he hath not yet anse[nted] to the popis clesir

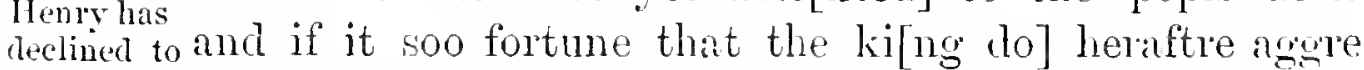
allow the therto, as they stande in great dou[bt that] he wil doo, Crusade they thinke that he wol employe [the money in] that becollected expedicion hymself, and not to suffie themplo[yment] lant; therof by the pope nor nown othre, like as all othrle princes] doo, for that that is levied by the meanes of the said cru[ciate] within their reames. Albeit they shal saye that the [king], seing the catholique mynd and noble entent of the said king of Romayns ayenst the Turkes, shal perauventure [for] his sake be content aswel to suffie thexecucion of the cruciate within his reame, as also that a good part of the] money that ["f. 104. shalbe reyse[d in the] reame by mean of the said cruciate and othrewise be employed ayenst the l'urkes loy the but might, saici king of Romayns. And though the said crucia[te] perllaws, it for can not conveniently be put in execucion bifore Lent allow it for of $n\left[\mathrm{or}^{\prime}\right.$ the money rommyng therof can not be levieal Maximi- within oon yere folowing, wo that the money that
lian. shal growe eithre upo[n] the cruciat, or a disme, sulssidie or othrewise, within this re[almel for thexpedicion ayenst the Tinkes, shal not anounte to [a] somme moche above the said x.m! li.; yet, a good a fmity being f furst had bitwixt the king and the king of Romain[s, the saili] ling shalle contented to doo hym soo great a plea[sure. . . .] accorting to his desir to araune hym the said [ $\mathrm{xm}^{1}$. li.] of the money that shal growe within his reame of the saidl cruciate, and otherwise, for aicle and succor against [the sair Turks]. Provided always that the pope, at the sute and refrnest of $\mid$ the king of Romayns write and sende his breve [to the king,] praying and desining hym by the same that he [will allow that the said king of Romains lave of the [money that] shathe leviert 
within his reame for thexpedicion [against the] *Turkes. A.D. 1501. the s[aid sum of $x, m^{1}$. li.] And if the said king of Roma[ins] ["f. $10+\mathrm{b}$. make donbt or difficultie in the popes agreement to t[he] premisses, or that they fele that he wol be lothe to atte[mpt] the pope in that behalve; They shal then saye th[at to] doo hym the pleasure that the king maye honourabl[y do] in ayding hym towardes his said entreprise ayens[t the] 'T'urkes, he shall peradventure (a gool amitie furst [had] betwixt theym) bc contente to avaunce hym upon the [money] that shalise levied within his reame for ayde aye[nst the] Turkes the somme of xx.m. angel nobles. And o . . . . . at his adventure thagrement or disagrement bi[twixt] the pope and hym for that matier: Albe it the sa[irt] cruciate can not be executed bifore Lente, nor the [said] money growing ther of be levied within oon yere aftr. $[\mathrm{e}$, nor that the money that shal growe eithre upon the cruciate, disme, subsidie, or othrewise within his reame for expedicion ayenst the Turkes shal not amounte to any somme moche above the said $x . m^{1}$ li.

*And over this they shal sily. . . . . t be not [*f. 96, for his sake the king woll not suffre the said moncy in noo wise to passe his reame nor to be employed neithre by the pope nor by noon othre, but oonly by hymself or his deputees. And if the said ling of Romayns saye that he wol sende to the pope to undrestande lis will and pleasure in that behalve, they shal than endevoir theym to conclude and passe thamyte, and by vertue of their commission bynde the king to the pay[ment] of $x . m^{1}$. li. if the pope sende hym the said breve and in.. . of the said breve to bind the ling in xx.ml. angel nobl[es . . . . loringing thamitic with theym, and leving thobligacion . . . take their leve and comme away, and bringe with theym . . . . a servant of his as he wol depute for the receipt of [the saidi] money, furnysshed 
A.D. 1501. with suche auctoritees and writinges [as be] specially expressed heraftre.

The said ambassadours shal wisely and discrete[ly endeavour] theymselfes to conclude upon the said x.m. li. in such form] and noon othrewise that the king [*f. 96 1). of Romains . . . . *breve ad . . . . and that the same breve be s[ent] and delivered [to] the king fro the pope aftre the four [me] before reherced, er and bifore the king paye any part [of] the said x.m. li. And also, that thamitie be furst . concluded betwixt the king and hym aftre the form . . . delivered to theym in writing, signed with the kinges [hand], with tharticle of the rebelles aftre the furst maner, or a $\mathrm{t}$ the] leest aftre the second maner, with a provision that [all the] kinges rebelles now being in thoes parties be immedi[ately] banisshed sub poence capitali aftre oon of the ij. four[mes] bifore rehersed. Anrl in caas they can not ag[re] upon the sair x.m. li. with the said condicions concernyng the [said] breve ${ }^{1}$ they [shall] then condescende and agree to xx.m1. angel nolles without the breve, ${ }^{2} \mathrm{pr}[\mathrm{ovided}] \mathrm{that}$ thamitie be also concluded with an article for rebel[les] aftre oon of the said $\mathrm{ij}$. ways and with the same provision [for] the said now rebelles that that is bifore reherced, that is to s[ay] aitre the oon or the othe waye conteyned in the said artic[le] of rebelles.

And, if the said king of Romains be not content [*f. 97. with *neithre of the said w[ays, desiring] theym furthre for the avauncement of the said money, they shal aske howe the king shalbe repayed in cas he wolde lene hym the said mone[y], and what sureties he shalhave for the repayment therof; and if the matier comme to sureties namyng, they shall name Esstrelinges, or if they faile, some towne of Flandres,

\footnotetext{
'Concernyny the [said] brie]. of Wolsey.

Interlined, apparently in the himd 'Interlined also in Wolsey'shand.
} 
or if it faille tharcheduc, or in default of hym to A.D. 1:01. $\mathrm{na}[\mathrm{me}]$ hymself to be bounden undre his great seal signed $w[i t h]$ his hand. And if he be content to make any of th[ese] sureties they shall then desire to see and undrest[and the] specialtees of the amitie that shal passe bitwix[t them] And if he wolbe content to passe thamitee with th[article] of the rebelles aftre the furst forme therof, and with [the] confirmacion of the pope, and also the banisshem[ent of] the rebelles that nowe be in thoes parties im[mediately] and furthwith, aftre the furst or second way to. . said rebelles that nowe be, or with tharticle . . . aftre the said furst forme and with the banis[shement]* of the s[aid rekels] being in thoes [*f.97 b. parties . . and immediately after oon of the said $i j$. formes . . . withont the said confirmacion they shal offre by w[ay of] loone xx.m? angel nobles, and not excede that so[mme]. And in cars he wol not accorde hym to the said . . . . with tharticle of the rebelles aftre the said furst f[orme] and that he wol passe it with tharticle concernyng [the] rebelles according to the second forme comprised $i[n$ the] said articles signed with our said sonverain lordes han[d . . ] the said confirmacion of the pope, and the banissh[ement] of the said nowe rebelles aftre the furst or secon[d] forme, or with the same article and the said banish[ement] and withont the said confirmacion, they shal offr $[\mathrm{e}$. . . ] hym by way of loone xv.ml. angel nobles, or if it ca[n] noon othrewise be, xx.ml. angel nobles.

And in caas he wol not accorde hym to neithre of th[e] said wayes concernyng the said rebelles, that is

- "Neithre aftre the furs[t nor after the] seconde; ["f. 98 . And that he wol agree to the thrid way [com]prised amonges the said articles signed with the kinges hand, that is to saye that he shal geve the sair rebelles noo ayde, succor nor favor: They shal accordc 
A.D. 1501. theym thereto, and soo passe the said anitic. But they shat noo thing offie, nor geve, nor promyse for this thrid way.

And if he saye that he desireth not the said somme of mo[uey] by way of loone, but by way of a gramt to succour hy[m in] his entreprise ayenst the 'Turkes, aftre somme hon[est] reasons and diflicultees made in that pritie t[hey sha]l] fynally conrlescende to promyse; furst, the said xv[m.' angel] nobles, havyng thamite furst passed. Or if the[y will] not soo agree, than the said xx.ml. angel nobles, h[avyng] the said anitie furst passed, with the said article o[ [" rebelles] aftre the furst or seconde forme, with the banisshe[ment of ] rebelles that nowe be in thoes parties inmed[iately and] furthwith aftre oon of their wayes and fou[rmes, [*f. 98 b. and] *othrew[ise they shall] make noo gramnt of any [of the said sommes of money.

And for the performance herof they shil, according [to] the kinges commission, that they have for that p[urpose] with theyme, bynde the king for the payment of $t$ [he said] somme of money, to be made to any his trusty ser[vantes] to the king for the receipt of the said money . . bringing with hym and delivering to the king the con[firmation] undre the king of Romayns great seal and signe[d with his] hand, of the treatie that shalbe conchuded bitwi[xt the said] commissioners, and bringing also sufficient auctori[ty in] writing in like wise undre the said king of Romai[ns] Great seal and signed with his hand to receive the s[aid] money, and also a sufficient quytannce semblably [undre] lis great seal and signed with his hand testefying t[he] payment and receipt of the said money.

And this thus doon and performed upon the behalv[e [*f.99. of] *the said king of Ro[mayns, our sai]d souverain lorel shal, furthwith and withont furthr[e de]lay, canse the said somme of money to be payer to the said servant, be it that he wol have it in the linges 
reame, or by way of eschaunge in any othre convenient A.1. 1501. place beyond the see within the archedukes obeissannce where there is any banke. And also at the same tyme deliver to the said servant his confir[macion] of the said treatie undre his great seal signed wi[th] his hand.

And if the king of Romains denye and refuse to The em-

the kinges said rebelles nowe being in thoes peror ought par[ties], allegging for his excuse that he hath geven that he has the [ym his] saveconduit, the said ambassadours shal given the saye th[at it] standeth not neithre with honnor of conduct, the princes nor $g$. . . convenience (amytce being but revoke bitwixt theym) th[e one of $]$ theym to susteigne the rebelles of the othre; nor [that no] lore nor amytie can soo contynewe bitwixt t[heym, for] evil is he worthye to be ealleal my frend that [sustaineth] my mortall ennemye. And therfor if lie wo[ld make] *the king [give him] his money he muste of a[l] $[* f .93 \mathrm{~b}$. reason take suche wayes as the said rebelles be $\mathrm{r}$ [oided] his landes and contreys, the whiche they shal $\therefore$ [ay] in their opinion he can noo better do than ly - . of the revocacion of the said saveconduitt, cxec[pt that] he hymself or his counseill by theil. great wis[domes] will devise any othre way. And if he theru[pon] devise any way that maye be sufticient and ra. . . for thavoiding of the sairl rebelles they shal follow] and aceepte it. And elles for the revocacion of [the] said saufeonduit they shal reasone with hym aft[re the] forme folowing.

Furst, they shal saye that not oonly his predecessour[s] emperoms in tyme passerl, but also all the hool e[mpire] have had perpetuall amytees with our said somverain lor[des] progeniton's kinges of England with semblable provisi[ons] for rebelles, wherof they liave antentique witing redy to be shewed, and scing that the king of Ro[mains] may vomably saye that the same anytee in als [muchl ${ }^{*}$ as it is perpetuall [*fo 100. [. . . . . . a aurl soo at this day standeth in 
A.1. 1501. his ful strength [and] effect, and that in consideracion therof the graunt of the said saveconduitt, insomoche as it is expressly contrary to the said amitee, is voide and onghte not to be availlable to the said rebelles. The said king of Romains maye with all lawe and reason, and of his homnor shulde, and is bounden upon a reasonabl[e] warnyng geven to the said rebelles to departe his landes a[nd] eountreys, openly deelare the said saveconduitt to have [been] graunted directly ayenst the said amytee, and an[null] and revoke it.

Secondly, they shal saye that the said rebelles [for their] said rebellion against the lking be accursed aswe[ll by pope] Innocent that last was, as also by pope Alexan[der that] nowe is. By reason of whiche excommunicacion that [the said] rebelles nowe stande in they shulde have noo recei . . . bidling nor conversacion in the said king of Romayn[es landes] and contreys, nor with, nor amonges his subgiettes, [and] that if the sairl ambassadours made no sute in. . . . yet, linowlege had of the said exeommunieacion, the [*1no b. [sair king] of *Roma[yns should not o]nly voide theym in h[is own] persone [but also] canse his subgettes to doo the sa[me.] And seing that the said rebelles: stande thus aceurs[ed] by the popes bulles, the ling of Romayns maye b[e] content that furst the said bulle be openly shewed [to] hym and his counseill and aftreward if he w[old] solempnely publisshe it as it shal please hym . . . fynably the said saveconduit aftre the premisses $d$. . . maye and shulde for the same consideracion lau[fully] and honorably be revoked.

By these reasons and suche othre as of their wi[sdoms] they shal finde and derise they shal instante[ly and] stedefastly insiste for the revocacion of the said [safe] conduitt, or at the least that it be voided and an[nulled] by oon mean or by othre.

And if they shal perceyve that the said saveconduit 
shal undoubtedly exspire within iij. of vj moncthes, or A.D. 1501. that the king of Romains will in noo wise revoke [it], they shal than offre hym the said sommes of mone[y] aftre the formes and with the condicions bifore reherse[d]. *[An]d that it be paye[d, one half when] [*f. 56. soever the said servant furnisshed with the auctoritee[s and $w$ ]riting ss bifore said shal comme for it; and the othre half wh $\mathrm{n}$ the said saveconduitt shalbe expired, and they voided. Provided that the said king of Romayns bynde him by the said treatie of thamitee to banisshe theym than, and in the mean tyme yeve theym noo aide succor nor favor etc., as bifore is rehercerl.

Also, the said ambassadours aftre the said amytee be ha[d and] passed, shal sollicite the king of $\mathrm{Ro-}$ mains to write by $\mathrm{t}$. . . to tharcheduc to receive the Garter when the king sh[al send] it to hym, and they to promyse upon the kinges bels[alf] that the prince shal accepte the Thoyson Dorree wh[en tho saidl] archeduc shal sende it to hym.

*Item as touching what. . . ]le hath in ch[irge [*?.5r. [to say] to tharch[educ] of mariage bitwixt my lord marriage of $\mathrm{Y}$ [ork] the kinges second son and the said archo- of IIenry dukes fu[rst] begoten doughtre, ${ }^{1}$ if this speche take culke of any eff[ecte] and that tharcheduc answer that he wol the arelo $\mathrm{g}$. . . . entende therto or make any othre duke's answer of . . . . of the specle of the matior, the said ambas[sadors] if thamitce conclude with the king of Romay[ns] shal shewe hym suche spede as they ha[d with] tharcheduke touching the said mariage.

H. R.

1 Eleanor, afterwards marrice to Emmannel king of Portugal. 


\section{XX. \\ SOMERSET AND WARHAI TO HENRY VII.}

[MS. Cott., Galba B Ir. 90.]

A.D. 1501. Pleas it your grace to [understond] that, accordyng to suche enstruccions [as your] grace sent unto us by your last lettres, we have enterid communicacion with the [kyng of] liomanys commissioners and shewid to them that their commission was [not] sufficient, and that if we shuld conclude therapon bothe thei and w[e shuld] labor in vayne. Wherme thei answerid that for asmoche as [there were] communicacions had betwene them and us in tymes past, we. . . . defanlte in the said commission, thei thought that we fownd . . . defiulte to none other entent but only to deferre the $t$ [ime, which] we answerid them on our faith and honeste we enten[ded not to do.] 'That notwithstondyng thei seid they wold not be content . . . other commission for thei knewe right well as . . . . shuld send ageyn to the kyng of Romanys he wold ta . . . . defrande and delayc of tyme; and rather then t[arry] for any other commission then thei have, thei wold . . . . ageyne and entermedill no ferther in the matic [r . . . adreitise the said kyng of Romanys. Notwithstnu[ding . . . . contentid with the clause Omnes et singulos ta . . . . defectus, ete. to lie put in the clanse of confirmacion w[hereof we wrote] unto your grace by our last lettres.

After thys the same commissioners shewid unto us [that they would make] noo delay with us anc paryed us to doo the same . . . . amytie that was betwixt you greace and the archicluke their maister, th[ei] entendid to dele rowndly and playniy 
with us, and promysid us on the[ir] othes soo that A.D.1501. we wold do in like wise with them to shewe us the resolute mynde of the said kyng, promysing thei wold not stike apon any article that thei thought we of reason ought not to be contentid with. Wherapon we seid we were contentid so to doo, if they wold first disclose their my[nds, $]$ wherunto thei were agreable. And furwith thei declarid as here folowith.

Thei seid on their othes that the resolute mynde of the kyng of Romanys was that he was contentid to bynd hym self, his heires and succes[sors,] and also all Muximihis subgiettes, and all suche londes as belongid $m[\mathrm{to}]$ lian will hym by reason of any enheritaunce, in suche mancr and self and the fourme as was conteigned in articles, as we delivered linds of his to the said comm[issi]oners to be sent to the kyng of ance, but Romanys. And the said kyng knew[e] right well bind the that the kyng of Fraunce ne Slayne, ne yet none cmpire. other prince otherwise wold be bownde then bynding hym self, [hi]s heires, successors, subgiettes, and alle his enheritable londes; but [as] towching the londes of the empire, whiche he hathe by eleccion [and] not ly enheritaunce, withoute the expressie consent of alle the [elize]rs he may in no wise bynde, which elizers lie kinewe well [wold] never be agreable to bynde the empire to the matier [contei]ned in the seid articles; allueit he was contentid to be [bound] unto your gralce in a boke to be made aparte, that he wold not favor: aide, [assist ne suc]cour any that be your rebelles $n$ [ot] being within the empire, nor suche as shall be at any tyme within his lond nor withoute, with any money, shippes, mon, armes or victaile, as more playnly is expressid in a [boke of] articles whiche is sent to your grace by this berer, but he [wold not] les agreable to the opyn bannysshement of any your r[chelles] that be in the londes of the empire nowe, nor of [others] that shall fortune to be your rebelles there at [any time] herafter. 
A.D. 1501. ii. Ferthermore thei shewid unto us that as to[uching the matter] of confirmacion to be opteigned with censures . . . . of the See Apostolique, the kyng of Romanys w[ould not] therunto agree; for he seith it was never seyn . . . . . submitted his owne persone to be suspendid or . . . . . pope, and withoute the consent if the elizer[s he could not] bynde the londes of the empire to any $m[$. . And if] he shuld so do, he shuld not only provolie th . . . . . . . . hym, but also alle the hole empire, but . . - . to make any othe to observe alle s[uch . . . . I be concluded betwene your grace . . . . . . ${ }^{1}$ seying, on their feithes to be the hole and resolute mynde of th . . . . . . And praied us t[o put ap] ]arte alle resonynges considering that by the resonyng of us their myndes myght not be removid from the determynate mynde of the said kyng of Romanys, and praied us in like wise to disclose the determynate mynde of your gra[ce] in this behalfe.

Thei seid also that the kyng of Romanys toke thonkfully [the] offerture of the advauncement of $x^{\text {ti }}$ thowsand angels towardes the warres anempste the Turkes, albeit seyng $t[h e]$ ferneis of the joumey anempste the same Turkes and the nombre of people that he muste IIe will not lave with hym in his hos[t, he] trustith rerily that your conclute grace, heing oon of the myghtyest princes [o]f alle the the league Cristyn faithe, and considering the nyghmes of blodde IIenry al- that is betwene your grace and hym, he doubtid not vance $.0,000$ but your grace woll advaunce unto hym the somme of crowns l. thousand crownes of gold, whiche somme he of longe fur the wainst the tyme hathe desired of your gra[ce]. And the same Turks. somme so advaunced, the said commissioners seid [th]ei were contentid to conclude anyte as is aforesaid, and clles [no]t in no wise.

${ }^{1}$ Iere occurs this marginal note " $\mathrm{B}$. $\mathrm{ij}^{\text {tus }}$ articulus et ultimus hujus responsi." 
[To] this we answerid, considering that the articles A.D. 1501. whiche [were] delivered to the said commissioners to be sent unto the kyng [of R] omanys were very resonable, and that we thought verily [that] the said kyng of Romanys wold have made no stikyng [therein b]ut passid the same articles in suche maner and fourme [as t]hei were sent unto hym, and that we had so adver[tised] your grace, and accordy[ng thereun] to your grace had sent us your re[solute] mynde; but for asmoche as nowe we understode by their $r$ [eport] that the said kyng wold not passe the said articles in s[uche form] as thei were to hym sent, but that he wold bynde hy[mself] and his londes of his inheritaunce, the whiche londes [are in] ferre contrees to the whiche your subgiettes seldom or [never have] eny resorte, and so that bond shuld be of litill eff'[ect. And] where he wold be bownde a parte, for his ow[ne..... . ] and wold not bynde the londes of the empire . . . . as for his owne persone, consirlering the nyghne[s. . . ] also that he is of your order of the garter, $h[\mathrm{e}$. . . ] nor with his honor m[ay in] his owne persone attempte to doo your grace or any of your . . . displeasure. And - . not be bownde for alle the suhgiettis of tho emp[ire . . . .] color the said kynges subgiettis of the empire . . . and socoure your rebelles, as well within the land[es . . . . Jas withoutc. Wherfore we sawe no good . . . . unto your grace by reason of any of the sa[irl . . . .]

iii. $\mathrm{We}^{1}$ shewid ferther unto the said commissio[ners that if] the kyng of Romanys had be contentid to . . - . in like maner as we delivered them to the $\mathrm{s}$. . . . be sent unto the said [k]yng, [th]en suche at good anytie had and concluded, your grace coulde have

'Marginal note, " B. iijus articulus et ultimus istius responsi." 
A.D. 1501. bene contentid that we shuld, on the behalve of your grace, made offerture of a right goode somme of money to be advaunced to the said kyng for warrys to be made ayenst the infidels; but, for asmoche as he varied from the said articles, we had none expresse instruceions of your myn[de] howe we shuld demeane our selves in this behalve and praie[d] them to have pacience till we had writyn unto your grace to knowe y[our] ferther pleasure in this belialve.

[iv.] And where as the said kyng wold in no wise be contentid with the confirmacion of the See Apostolique under the cens[ures] of the churche, we said for asmoche There is no as in tymes past bet[wixt] your grace and the said

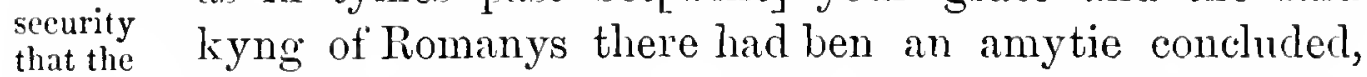
emperor sealid and subscribed with the hand of the said kyng, will obscrve the and that notwithstandyng he observyd not the same; treaty, un- $[\mathrm{w}] \mathrm{e}$ therfore thought that there coude noo sure amyte less he is - contynue [bet]wene your grace and the said kyng der ecele- withoute the confirmacion [of the said See Apostolique. censures. And we said also, that we [saw] no prejudice thiti shuld comme unto the persone of the [said] kyng in submittyng liym selfe to the censures of said [See] Apostolique, for by Goddlis lawe and mannys lawe he was [bound]e to submitte hym selve to the same Sce

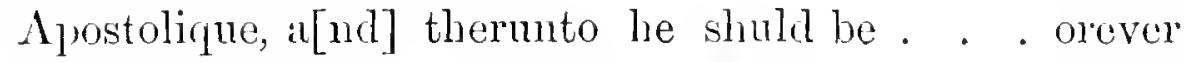
he were declarid empero[r.] Wherfore it is to be thought that the said linng is not myndid to the contynuanuce of any amytie, for [if he] were he wold be argreathe to the opteignyng of the [said] confirmacion. But whan he had opteigned of . . . that he woll have, lse wold aslitill care for th . . . of this amytic as he lat he for other in tymes past . . . concludicl and sealid. Furthermore we shewid to the saidl commissioners that thei were contentid at our last communica[tion with] then to passe the said anticle of continuacion [as we] advertised your grace, wherfore we mervaile that [they] varie from the same. 
Whermto the said commissioners answerid th[at if A.D. 1501. the kyngl of Romanys wold bynde his londes of enhe- Reply of ritau[nce in suche] fourme as his sonne the archeduke the impewas bon . . . . you in any amytie conchuded with missioners. your Grace, sey[ng . . . . . ] said kynge myght ride in his owne londes belong . . . . . . enlieritamnee from the towne of Brusels in Bra[bant], $u[n t o$ the] whiche divers of your merchauntes dayly resort . . . . . But the londes of the empire he mygh $[t$ [not bind, for] if he shuld it shuld be to lis dishonor . . . . . profite. Wherfore he wold not so do $f$. . . otherwise promise than he myght . . . . . . . And as touching the confirmacion of . . . . . thei seid in no wise [the kyng mbyght passe it. But thei were right well assured that the said kyng woll aswell kepe suche thinges as shuld be concluded, as though it were confermyd by the said $\mathrm{Se}[\mathrm{e}]$ Apostolique. For if suche a confirmacion shnld be opteigned, thei thinke there shuld litill cffecte folowe of it, in case your grac $[\mathrm{e}]$ or elles the said kyng observed it not; for there is no man lyr[ing] that ever hath knowyn eny execucion made anempste any $s[. .5$. ] apon the bretche of any amytic by the vertue of the said cla[use] of confirmitcion. Wherfore thei thought that the othe of th[c] satil liyng shuld cause hym bettir to observe the amytic then shuld the article of confirmacion; for every prince wold think [it] more dishonor to be perjured than he wold for suche a cause strive with the Pope. Thei seid also that thei varied not on [the] article of confirmacion, albeit thei had a communicacion with u[s on] the same confirmacion, yet therapon thei nothing concluded, a[nd] also seying that the said kyng their master, having such resona[ble] groundes as be afore rehersid, was in no wise contentid with the said article of confirmacion. Wherfore thei muste nerles also chaunge their myndes accordyng to the mynde of the sitil kyng. 
A.D. 1501. Seying, furthermore, forasmoche as we seid that we had [n]one instruccions from your grace to make offerture of the [ad]vauncing of any somme of money but desired delay to know [your] pleasure in this behalve, thei knewe right well that we [inte]ndiid noo thing but to dreve the tyme with them. For [that] we desired a delay for a newe commission to be [obtei]gned of the said lyng, whiche thei denyed. Wherfore thei [seid] we songht a nother occasion of delay in desiring to write [unto] your grace to have newe enstruccions; seying also thei [were] right sory that thei had lost so moche communicacion in idell [worde]s.

To this we answerid . . . . . . . we entendid $n$ no delaies for $t$ [hey] inyght right well perceyve that your grace myght in no wise underston[d] what answere the said kyng at this tyme wold send to hys commissioners. And your grace conde not geve us sure and l . . . instruccions to suche thinges as your grace of a certayntie knewe n[ot of]. After which answere thei were contentid that articles shn[ld he] conceyvid acerrilyng to this communicacion, and we withoute d[elay should] advertise your grace and knowe your fynall pleasure in all thinges]. And we protestyng that in no wise by an[y thing that] shuld he conteigned in any of the said articles, we ent[ended in] eny wise to bynde your grace, but only to advertise your

v. Fynally too bokes of articles were by the said comm[issioners] conceyvyd. In the oon boke $\mathrm{e}^{1}$ [the said] kyng is contentid to bynd hym self, his subgiettis [and his] londes to the whieh he is inheritor. And in the [other he] byndith hym selve as tonchyng the em-

"boke.] The words "which by us was deli[reled unto the] commis"sioners to be sent to the said kyng of Roma[nys]" here follow, but are struck out. 
pire in [such] fourme as more playnly it doith appere A.1. 1501. in the seid bo[ke and in the] bokes of articles we send your grace at this ty[me by] Berwyke. We endevourid our selfe $t$. . . . . boke consernyng the empire an article of . . . . . rebelles that be nowe there, and of all other which may theder resorte, but we coulde $m$. . . . . .

. . nothir accordyng to suche articles. . lord the archiduke, nothir aceord[yng] to the article that was concluded with the emperor Sigismond; for thei sey if the said kyng shuld forthwith ban- The redcels nishe your rebelles owte of Acon, yet that bannisshe- cammithe ment notwithstond[yng] thei myght there abide, and irm framalso in other fraunchesied p[laces]. We desired to phlaces. have an article for the bannishement of [your] rebelles owte of alle suche places of the empire as were. . - f fraunchesied; and thei seid withoute the consent of th[e] Elizers the said kyng myght not make that graunt, an[d] that we myglit well pereeyve by the article of rebelles comprised in the amyte concludid with the said Sigesmond, which was not only sealid by the same Sigismond but also confermyd by the said Elizers.

Yf your grace can be contentid to aceepte the articles 'The emwhich at this tyme we send to your grace in like peror will fourme as thei be conceyvid and none otherwise, yet tent with we knowe by their othes and demoynures that thei in less than noo wise wolbe contentid with any lesse somme then crowns for the somme of l. thousand crownes to be advaunced to the expedithexpedicion of his warres ayenst the Turques. And the Turks. as touching the place of the paiement of suche money as your grace woll advaunce in this behalve we can nother cause [them] to resecyve it in London, Cales nor Graveling; but with . . . . ht moche payne we have caused them to be contented to [res]ceyve it in suche usuell money as hath course within your [re]alme, 
A.D, 1501. rating every crowne accorlyng to his verie value ${ }^{\text {I }}$ fand the] same to be paied at Seynt Omers.

vj. The said commissi[oners also de]sired us to write to your grace that in case your grace woll advaunce to the said kyng thle] somme of l. thousand crownes, that it myght please your g[race] to send unto us a copic of suche acquitaunce with the whic[h your] grace wold be contentid at the tyme of the entrechaungy [ng] of bothe your sealis, and the delivere of the said somme, for . . . shuld conceyve the acquitannce, at the iyme of the re[ceipt] of the said money your commissioners peradventure shu[ld] think the same acquitamce sufficient. And soo ther . . . . have matier of delay, of the whiche thei wold b

vij. And as touching the cruciat and dyvers othe[r - . . your grace may perceyve the said kynges mynde in . . . in Frenche herin enclosid and to us deliverid [by the] said commissioners.

The impe- [v]iij. The said commissioners desired us to mov[e your rial eom- grace] to graunt your rebell the late erle of Suftolke intercede . . . . bothe for his body and goodes, the whiche for Ed- ${ }_{\text {mela }}$ if he . . . . kyng of Romanys seeing that be Pule. lathe amyte. . , and also that by liys moynes ye be soo gra . . . . . hym shall have a resomable occasion to cause [him to] advoide alle the lonkles of the empire . . . . of hys obeisamee.

ix." Fnrthermore the said commissioners moved [us that your gracej shuld take noo displeasure though the sai[d king of] Romanys dyd sett in his howses and hy [. . . . such] armes as belongith to the cluchie . . . As herunto we answerid that your grace . . . . . that he wa[s. . . . . ] of blodde to your grace, and also was a prince of right great

\footnotetext{
1 cocorlyng. . valup] corr. from | 2 Numbered viij. in the margin of \begin{tabular}{l|l} 
to the value of iijgs. sterling. & the MS.
\end{tabular}
} 
wisdone, wherfore he of hi[s] wisdome wold none other-A.D. 1501. wise bere the same armes then as he of right ought to doo, and in soo doyng your grace coulde not of reason be displeasid with the setting or bering of the same ar'mes.

In our moste humble wise we beseche your grace that in the premisses we may knowe your finalle and resolute pleasure, whiche accordyng to our ducties we shall folowe in every behalve.

\section{XXI.}

\section{LetTers of Ediund DE la Pole.}

[From copies in the Record Office.]

Cousin Nevyll, I recommand me to yowe. And it A.D.1502? is soo that by this day I truste assuredly that eche thing is at a good point for my departing from hens, and To Sir the stewerd ${ }^{1}$ is commen hycler with the necessars ${ }^{2}$ bifore, ${ }_{\text {Nevill. }}$ and I tarye for noothing but oonly upon the commyng of the Bastard. ${ }^{3}$ Wherefor, cousin Nevill, this is my mynd; that maister Wylliam shall goo and speke to the lordes of the thre towns, Zwolle, Campen, and Daventre, after this maner:--That where as I have About neundrestande by Mr. William, that there was a man of gotiatiag Daventre at the tyme of my departing from Hattam, towns of which camme by the command of the lorkls of Daventre, Kampen, to have spoken with me, offering me certain offres, as and Mr. William knoweth more at large, I will, furst that Mr. William enquere for the same man and if he be there, and reherse to hym his said message, and lette Mr. William shewe him that he is commen to speke with the lordes of the towne for the same matier. And $y f$ the same man bee not there, lette hym speke in this matter to the lords of the towne, and shewe

\begin{tabular}{l|l}
1 'Thomas Killingworth. & very badly written.
\end{tabular}

" This word is doubtful, being 1 'The Bastard D'Oysekerke. 
A.D.1502? to them that I have undrestande of the messaige of the said man, wherupon I sende Mr. William to theym to thentent to knowe more of their mynds touching the same. And yi by any dryfte there comme noon effect theretipon, lette hym doo noo more but handle hym sylf soo that he in any wise, if it bee possyble gette me sure gley of the lordes of Daventre. And thene, gley obteyned, if he can soo dryve, lette the lords of Daventre sencle with hym oon to the lords of the other townes, soe it bee by their drife and not by myn. And lette this matier bee handelled as secretly as ye can, and kepe it secretly to you tweyne, as my trust is in you.

ToThomas Thoma, accepi litteras vestras datas $x^{a}$ die Maij, ex

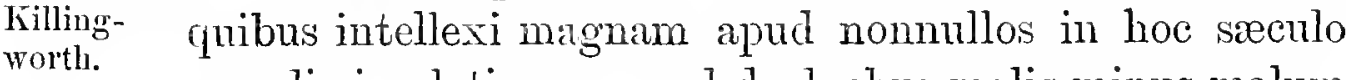
esse dissimulationem; sed de duobus malis minus malum mihi esse eligendum vestris litteris consulitis. Et ideo omnir mea negotia apud R. M. Ro. ${ }^{1}$ agenda v. d. ${ }^{2}$ committo. Nam video vos omnem diligentiam possibilem meis rebus indies exhibuisse. Video id non oportere facere quod cateri omnes faciunt, hoc est dissimulatione uti; quod ego pro mea parte faciam, quamquam libenter id facere non cupiam. Ego plane percipio Ro. regem mecum omnia dissimulatione quadam tractare; quare vos volo eadem apud illum dissimulaIIe must tione uti. Video enim regem ceterosque suos conari use dissi- me longa mora hic fatigare ut mea bona inutiliter towards consumam, ut sic paupertate gravatus compellar ad Maximilian, as Maximilian does towards pacem cum H. Angliae ineundam; quod si ego facere recusarem me vitse periculo exponerent, quo quidem periculo per media quorundam quos dictus $H$. pecuniis his master, corrupit omni hora diei maneo. Quare, si dominum regem meas causas indies differre, prout hucusque distulit, inteillexerit mentem meam sure majestati in forma sequenti exponatam.

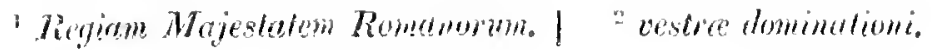


"Sacratissime rex, per M. Bontemps dominum A.D. 1502. meum in spe magna posuistis quod si idem dominus 12 May. meus certis desideriis ex parte vestre majestatis per dic-. tum Bontemps ei exponendtum acquiesceret, quæ quidem desideria ad vestram majestatem per me misit, ei auxilium tam in pecuniis quam hominibus vestra majestas concederet. Et nunquam ab aliquo principe praterquam a vestra majestate auxilium petiit; et vj menses continuis suis expensis in Acon mansit, quo tempore a terra domini archiducis vestri filii in maximum stuum præjudicium, ${ }^{1}$ nec umquam tam inhumaniter actum and show est cum aliquo nobili quomodo cum eo actun est. how injuSemper tanquam vester consanguineus expectavit rele- De la Pole vamen a vestra majestate, et quamquam alii nonnulli is his long nobiles ei auxilio esse obtulerunt, tamen eorum con- at $\Lambda$ ix; silium recusavit, solam suam spen in vestra majestate ponens. Et ex parte domini mei audeo affirmare quod omnia quæ vestræ majestati promittet re ipsa perficiet. Et quia est vobis conjunctus sanguine, solum ad vestram majestatem pro impetrando auxilio venit. Et antequam a regno Angliæe exiret dominus Corson pro parte vestræ majestatis eum certiorem fecit, qnod sibi in singulis auxilium daretis; quod ille antequam regnum Angliæ [reliquit] ${ }^{2}$ amicis suis patefecit, et sub spe habendi auxilii a vestra majestate amici sui consulerunt ei ut ad vestram majestatem veniret; et cum ad vestram majestatem accessisset, Bontemps ex parte vestrie majestatis ei auxilium promisit, et sic amicis suis in Anglia de promisso vestr:e majestatis verbum misit. Et quamquam ego palam loquor vestrie najestati rogo parcatis mihi. Et quantum nocet domino meo sua continua mora in Acon vestra majestas facile juclicabit, nam ipsis bonis qua in Flandria et in Anglia amisit et quæ pro se et suis in Acon exposuit, exercitum x.M. virorum potuit in Angliam traducere; preter-

\footnotetext{
$' \Lambda$ verb is evidently wanting here, $\quad{ }^{\prime} \mathrm{Om}$. in MS,
} 
A.D. 1502. quam quidam suns amicissimus, ${ }^{1}$ qui manerium de 12 May. Bray juxta Windesoram R. B.2 militi vendidit, et qui custodiam castri de Porchestre habuit, captus est, et apud Wintoniensem decapitatus; qui cun omnibus bonis qua in illo castro erant, ad eum veniendo erat; et apud me est unus selvitorum suorum Petrus Harter. In Vigilia Ramispalmarum "decapitatus est."

Domina de Ispania reconvaluit. Rogo omnino ut and that if servitorem meum ad me mittatis. Et cum habebitis the king's communicationem cun sacra majestate de nois rebus, Henry dicatis "quod si secundus Henrici filius esset mortuus, were to die nullum esset dubium de titulo domini mei. Et ideo would be si dominus meus maneret ex ista parte maris usque no donbt of ad mortem dicti Henrici, qui diu vivere non potest,
DelaPole's ad title. junior filius suus domino meo in nullo nomine poterit. ${ }^{4}$ Et si dominus meus tantam pecuniarum sum. mam in bursa haberet quantam habuit cum primum in has partes applicuit. non diu maneret extra regnum Anglire." Et si dictus iex de pace ex parte mea cum Henrico ficienda volis aliquod dixerit, patienter eum andietis, et dicatis quod libenter velitis talem esse pacen, sed non audetis "a allorui mihi in illa causa, et sic vos plus audietis de eorum mentibus. Sed hoe promitto robis in mea fide quod nunquam audivi verbum quod Henricus daret mihi meas terras ant pensiones, quod si rex aut alii milhi alloquantur, volo eos andire. Hoc promitto vobis, $H$. et ego nunquam simul erimus simul ${ }^{6}$ in Anglia sine meo vel sno dimno; quare velim ne me timeas quicquid de me audieritis, quia sum omni tempore idem homo. Ste. de B. recessit. H. emit eum $c$. libris, quarum $\mathrm{xx}$. recepit in manibus. Rogo vos ut prudenter videtur' ut paretur mihi locus prope mare propter diversas

\footnotetext{
"This was doubtless the "Charles "Ryppon, late of Porchester," mentioned in the act of attainder, 19 Henry VII. See Rolls of Parl. vi. 545.

- Probably Sir Reginald Bray.

3 'The eve of Palm Sunday in 1502 was the 19 th of Mirch.

${ }^{1}$ Sie.

sudietis, MS.

${ }^{6}$ sie.
} 
causas; quantum ad illan materiam de qua E. locu- A.D. 150:2. tus est ad vos, ut vos alloqueremini regem, rogo 12 May. quod vos nihil facietis in ea re. Misi ad vos ijas litteras cum earum copiis; unam majestati Romanorum, aliam Bontemps. Et infra vj. dies sequentes mittam vobis residuum mentis mere.

Et Ja. Ty. ${ }^{1}$ pulcris verbis dominus privati sigilli Treatwent et Dan $^{2}$ promittentium ut secure iret et rediret, et of Sir datis fidejussoribus, eductus est a castro de Guisnes 'Tyrell. in quo castro reliquit post se suum filium, et cum primo in mari navem ascenderet, accessit ad eum 'T. $\mathrm{Lo}^{3}$ et præcepit ei ut mitteret signum filio sno quod castrum traderet in manibus dicti Lovel et aliorum; quod si non faceret, doceret eum natare in mari. Et totus exercitus de Calais obsidebat dictum castrum. Lit cum dictus Jaco. hoc intelligeret, misit secretum signum filio suo; quod cum filius vidisset reddidit castrum, et tune dictus Ja. et illius filius positi sunt in Turrim. Et dictum Ji. sui fidejussores salvarunt ; ${ }^{4}$ sed filius ejus est in periculo. Datum in Acon xija dic Maii.

Monsieur le Tresorer, de bon cueur je me recom- To the mende a vous, et vous remercie de ous les plaisirs Treasurer et peynes lesquelz avez pris tous jours en mees affaires; lesquelz alayde de Dieu je desirvirey ung foys tellement denver vous, que roz serray contente de moy. Et cy jay eut de quoy je rous donne aceste

\section{Trinslation.}

Mr. Treascrer, I recomment myself cordially to you, and thank you for the pleasure and pains you have always taken in my affairs; which, by the help of God, I shall one day in such manner merit towards you, that you will be satistied with me. And if I had wherewith, I would give

1 Sir James Tyrell.

2 sic.

"Thomas Lovell.

'salucrant, Mis. Sir Jannes
'Ty'rell, however, was actually executed six days before the date of this letter, 
A.D. 1502. heure; mais jay espoir in bricf temps davoir in telle 12 May. facion qua je porray contente vous et tous mees aultres bonnes amyes. Au surplus, monsieur le Tresorer, je vos prie pour parle au la bonne grace du roy touchant mon caas, le plus favourablement que vous poves comme ma fiance este en vous. Car sur la Hoped ere credence que vous avez monstre a moy a Ymps, depar this to have commandement du roy je pensoy a leheure destre way to bien pres Dangleterre pour recouvre mon droit. Et make good oultre je vous face savoir pour certain que le filz du his claims. Roy H. lequel avoit espouse la fille du roy Despaigne quil est mort; lequel morit sur le nuyt de pascques flouries. Aultre choise pour le jresent, cy non que Dieu vous doint bonne vie et longue. Escript au Hayes le xij. jour de May.
A Monsire le Tresourer Maistre
Jehan Bontemps, Seigneur
de Salans.

Le tout vostre,

you at this very hour ; lut I have lopes that in short time I shall he so situated as to satinfy you and all my other good friends. Moreover, Mr. Treasmer, I heseech you to speak (1) the king's good grace toncling iny case, as farorably as you rin, as my trust is in yon. Because going upon the letter. of aredence, which you showed nie at Imst, by order of the lino, I thought at this hour to have been rery near England for the purpose of recorering my right. And besides, I cause you to know for certain, that the son of the king, who Had married the daughter of the king of Spain, is dead; he died on the night of Palm Sunday. No other thing for the present; except that God give you a good and long life. Written at $\Lambda$ ix, the 12 th day of May.

Altogether yours,

E. $S$.

To the Treasurer, Mr. efolm Bontemps, lord of Salans.

\footnotetext{
'This is a mistake. Pahn Sunday in 1502 was the 20th of March. Prince Arthur died on the 2nd April.
} 
Please vostre noble grace savoir que jay receu vos- A.D. 1502. tre ${ }^{1}$ lettres de mon maistre dotell que se tient dever vous, sur le xj. jour de May, escript en vostre ville To Maxide Myndelhem le iij. jour dudict moys, par lesquellez je sciet bien que vous estes mon ${ }^{2}$ et gracionx seigneur dever moy; pour quoy, siem, tant humblement commo je puis, je remercye vostre grace, et je mettre tont mon cas en vostre main. Et que vostre grace vueille rementener le loyal cneur et fiance que jay dever vous; ear vous estez le prince que jay serche an monde pour avoir ayde et succours et an nul aultre vueille serche. Pour quoy je vous supplie quil rous plaise de vostre grace moy aider; et pur ma part la promesse qque jay fait avous par escript, donne en vostre main depar mon. maistre dostel, je moy oblige lealment tenir durant ma vie de toute na puissance. Et que plaise au vostre grace de pense de ma longue demoure perdeca et vien-

\section{TransLation.}

MaY it please your noble grace to know that I received your letter's from ny steward who is with you, on the 11th day of May, written in your town of Myndellem, the 3rd diny of the said month; by which I well know that you are a gracions master to me, and for which, sire, as hunbly as I can, I thank your grace, and will place my whole case into your hands. And may your grace remember the loyal heart and the confidence which I have for you ; because you are the prince whom above all in the world I seek to have for an aid and help, and from no one else do I seek it. On accomt of which I besech you that it may plesse you of your goodness to help me; and for my part, the promise which I have made to you in writing, given into your hand by my stewark, I do loyally bind myself to keep during my life with all my power. And please it your grace to think of my long residence in this place, and seeing the danger in which ne good friends

\footnotetext{
${ }^{1}$ Sic in MS., vire $\quad$ " sic.
} 
A.D. 1502. ant lc daungier en quoye mees bonnes amies sont et 12 May, encoures seront tous les jours pluis et pluis en attenciant ma vemue. Et ainsy jay donne cognoissance a vostre grace pour vrai que le filz du roy H., Arthur, que avoit espouse lir fille du roy Despaigne est morte li iuyt de pasques flouries. ${ }^{2}$ Et ainsy plaise vostre grace savoir touchant le credence que monsieur le 'resourer maistre J. Bo. moy remonstre depar vous au Ympst, je pense aceste heure destre bien apres Dangliterie, par quoy je pense faire a vostre grace service, devande que leste fuit passe, lequel estoit nul home au monde que desire pluis de vous faire quelque bon service que moy, et cy faire tous jours durant ma vie. Ainsy plaise vostre grace savoir que je suys bien adverty pour vray, que roy $H$. pourchaisse en tous quartiers et au tous gens que puis rechate pour oor et argent pour moy destroyer ; et pourtant, sieur, le pluis longuement que je demoure hor's Dangliterre le phuis forte serra roy $\mathrm{H}$. et depure ${ }^{2}$ pour

are, and will yet he every day more and more whilst awaiting my arrival. Also I inform your grace, that in truth the son of king Henry, Arthur, who had married the kanghter of the king of Spain, died the night of Pam Sumby. And so may it please rour grace to know touching the credence which the treasurer; Mr. J. Bontemps, showed me on your part at Imst, I expected at this time to have been very near England, by which I hoped to render your grace a service ledore the summer were orer, as there is no man in the world who desires more to render you rome good service than myself; and to do so always during my life. Also may it please your grace to know that I have been truly very well informed that $H$. king practises in all quarters and with all kinds of people, whom he can corrupt with gold and silver to destroy me; and for all that, sire, the longer I reside out of England the stronger will bo king II. and 
moy; pour quoy je vous prie treshumblement que vostre A.D. 1502. grace ne soit male contente que je escripe avous tant 12 nay. playnement, car il moy touche forts en daunger et necessite ainsy rescripre. Et cy je puis venir moy meismes denver vostre grace, je auserra remontre tous choises a vostre grace pluis et plain de ceste matier et des aultres de lesquelles vostre grace serroit bien contente. Toutesfoys jay rescripe denver mon maistre dostell pluis et playn de ma entencion, et quil vous plaise de vostre grace luy donner credence. Aultre chois, sieur, je ne vous rescripe pour le present, cy non que Dieu vous donne laccomplissement de tous vous haultz et nobles desires. Escript en vostre ville Dhaics le xij. jour de May.

Le tout vostre humble cousin et servitenr,

ED. SUFFOLK.

$\Lambda$ tres hault, tres puissant, et

tres excellent prince,

le roy des Romaynes.

the worse it will be for me; wherefore, I very humbly beseech you, that your grace may not be dissutisfied that I write to you so plainly, because it concerns me much to write thus in danger and neecsity. And if I ean come myself towards your grace, I will take the liberty to show your grace everything mole fully of this matter and of others; of which your grace will he satisfied. Nevertheless, I have written again more fully to my steward of my intention, and may it please you of your grace to give hin credence. Other things, sire, I do not for the present write to you, except that God may give you the fulfilment of all your high and noble desires. Written in your town of Aix, the 12 th day of May.

Yom devoted humble cousin and scrvant,

Ev. SufFoli.

'To the very high, very powerful, and

very excellent prince, the

king of the Romans. 
A.D. 1503. Maximilian van Godz gnaden Romysche konyng.

InstRUCTION was unnser $g$ [etrewer liber Jheronimus] Lay, unnser Jegermaister [in Gheldren bey] Burgermaister und Rat der st[at Aach und sunst] von unsern Wegen handel[l und ausrichten soll].

Aufrungclichen sol er sich zu Inen inn die s[tat Aach fueren] oder sonerr Im solichs nit gelegen sein w[olt, etlich vom Rat] zu Ime gen Mastricht erfordern, und Inen [erstlichen sagen] unnser gnad und alles gut; und darnach an[zaigen, nach dem] der herzog von Suffockl ain zeit lanng bey [Inen In der] Stat Aach gelegen und $\mathrm{clar}^{2}$ Innen ain Summa [gelts schuldich] sey, Nu mugen sy wissen, das wir und [kunyug Hainnrich] von Engellandt von der Rotten Rosen in k[urz versthiner ${ }^{8}$ ]

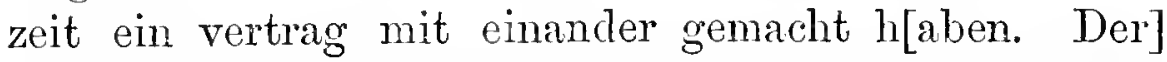
under annderm innhaltet das wir denselhen [herzogen

Translation.

Maximilian by the Grace of God, King of the Romans.

Irstruction as to what our faithful and belored Jerome Lay, master of the hunt at Gueldres, shall treat and conclude with the burgomaster and council of the town of Aix, and of other matters in our affair.s.

In the first instance, he is to call upon them in the town of $\mathrm{Aix}$, or, in case that should not be convenient to him, to summon some of the members of the comncil into his presence at Maestricht, and tell them, first, of our grace, \&c.; and afterwards inform them, since the duke of Suffolk has staid for some time with them in the town of $\mathrm{Aix}$, and ats he owes them a sum of money, they may know now that we and king Ienry of England, of the Red Rose, have some short time ago made a contract with one another, which,

1 'The spelling of this doeument, like that of the preeeding letters in the same MS., is very corrupt, and full of gross misreadings, such as Herhog for Heraog, gesapt for yestryt, ic. It has been eorrected aecording to the original, which is in the
Cottonian collection, MIS. Vitellius 13.xvin. f.174, execpt in the words between brackets, which, in that MS., are burnt away.

"Sie, for da cr.

${ }^{3}$ sic, for verstrichener, origr. burnt. 
von] Suffockh in nichte weitter wider den beru[rten A.D. 1503. kunyng] Hainrichen von Engellandt nit furdern sa[llen.]

Und nachdem der gemelt Herzog zu Suffock da[rauf aus unser] Stat Ach verrucken wyl, und unns angezaigt [hat das Er] mit Schulden hinder euch verhest, umnd Ime [nit muglich] sey Euch zu bezalen; wie wol wie Ime [nu dar Innen] hilf zu thun nit schuldig weren, angesehe[n $\mathrm{n}^{1}$ das wie dem] selben herzogen von Suffolk in solicher seiner [sachen zu helffen] nie zugesagt haben, noch anch Ime sunst w[eder mit] sipschaft oder ver. stenntniss nit verwannt gew[esen, auch noch] nit sein, dan allain das wir Ine in seine[n ellend] mit gnedigen Augen angresehen haben, der Ho[finung das] Ime das so er unns angezaigt hat, ergan[gen und wider] faren solt sein ;-

So haben wir dannocht Euch zu gut a[uch in Anseh-

amongst other things, contains that we are not in any way furthermore to encourage the same duke of Suffolk against the above-mentioned king of England.

And since the aforesaid duke of Suffolk wishes thereupon to quit our town of $\Lambda \mathrm{ix}$, and has notified to us that he leaves debts behind him with you, and it is not possible to him to pay you, we (though we are not obliged to sive him any help in that matter, considering that wo never promised to assist the same duke of Suffolk in such his affairs, nor have ever been comnected with him, either through relationship or mutnal understanding, nor are so to this present moment, except that we have looked upon him in his misery with mereiful eyes, in the hope that what he had notified to us would have taken place), have, novertleless, for your sakes and also in consider- 
A.D. 1503. unng] das E. voin unns furcermgs brief ge[hebt hat, bewillight ein hilfi, neuchli]chen ${ }^{1}$ nit Drew Tausent gullin Reinisch [zu thun]. Und darrauf mit Cunraten Neuman [unnsern] Burger zu Autrorfi sovil grelianndlt, das $\mathrm{cr}^{\circ}$ [Inen] an sollicher Trer schuld yctzo inverzogenlichen Tausent gulden Reinisch bezalen wercle. Darzu so Śchichhen Wir Inen hirmit ain Verweisung und Descharge aut den Remntmaister in Brabant, lauttend, der werde Inen von der steur so mus durch unnser Nider-Burgundisshen Lannde auf, zu knnst umnsers Suns und Fmsten Ertzhertzogen Philipsen zu Ostcreich, \&c, bewillight und zugesagt ist, so bald solich Steu gefillen wurdet, zway Tausent gulden Reinish auch antwurten und geben.

Und so der gemelt unser Jegermaister in Gheldren, Jheronimus Lay, dise Werloung muntich an die von der Stat Ach gethan und geworben hat, soll er Inen

ation of his having hald letters of recommentation from us, consented to give some assistance, namely with three thousand Rhenish florins; and in consequence lave so far arranged with our citizen at Antorfl, Connal Nemman, that he shall pay them on this their deht. now withont any delay, 1000 Rhenish florins. Noreorer, we at present hereby forward to them an assigmment and dischare upon the channberlain in Brabant, which is to the effect that he shall atso deliver over and give to them 2000 Rhenish florins, fiom the taxes which are promised and allowed to us through our Nether Burgundian lands, in favor of our son and prince the archduke Philip of Austria, \&e, as soon as such taxes fiall due.

And as sone as this onr said master of the limnt at Gueldres, Terome Lay, shall have done and performed this lunsiness orally with those of the town of $A i x$, le shall

\footnotetext{
${ }^{1}$ Sic, for nähmichen.
} 
darauf und daneben solich Werbung, nach laut der A.D. 1503. artickhl diser instruction nacht der leng in geschrift uberint wurten und dar Innen nichts auslassen. ${ }^{1}$

thereupon, in addition to this affair, according to the tenor of the articles, deliver to them this instruction at length in writing, and not omit any thing therein.

\section{XXII.}

Negotiations of the Englisil Ambassadors? with MAXinilian.?

[MIS. Cott., Galba IB. 11. f. 110.]

. . . . . . that on Tuesday [which was the] A.I). 1503 last day [of January the king o]f Romaynes then lyeng . . . two myles . . . [th]e monastery . of Saynt . sent unto us the . . . . . Lang fore . . of August and . . m . . . maistre to thentent to advertise . . . . . . . same daye at nyght the sail king wold be . . . And . . at thabbaye of Saint Nighel . . . Wednesday then next ensueng he wold . • . . us co[me] unto his presence and give us benygn audience.

'The original contains an additional paragraph relating to a different subject, and is dated at the end, but the date is mutilated. So far as visible, it is " 18 th day of the " month of [. . . . fifteen hun-

"dred] and three, 18th year of " Maximilian's reign."

"Their names were Sir 'Thomas
Brandon and Nicholas West (afterwards bishop of Ely). Rymer xiı. 35.

${ }^{3}$ This document is unfortunately so mutilated by the fire that the order of the pages depends only on internal evidence. The modern foliation of the MS. is given in the margin. 

A.D. 1503. S[aying] that the king wold not have com so som
31 Jan. . . . had . . . . for oure sonar expedicion. Sayeng fu[rther]. . . . . the said king was right sorye that we ha. . . . to com unto hym. According to the same advertisement the sa[id king of] Romaynes come downe by water and arrive [at Antwerp] the said Tuesdaye at evenyng. And . . . . . .

I Feb. [W] the Purification of oure Lady . . . . . the bisshop of Laufenburgh, doctor H[aydon, one of] his counseil and the marshall of his . . . . . the whiche come and shewe[d us that] the kinges pleasire was that we shold com[me] . . . at aftemoon towardes us long tyme . . . . a ambassadors . . send unt $[0]$. . . . . he wold . . . . . . . . . . . ve had . . . . . that th . . . . . . called hym . . . . . . . prin . . . . . loked to have . . . . yng as standing. An[d] . . . . . the same $\left[{ }^{*}\right.$ f. 110 b. opinion . . . . . . $2 *$ ma . . . . . g to the churche and beyng there.. . . d please . . majeste to assign and comma . . . . places according . . youre oratours or els . . . pleas hym to resp. . . . . oure comyng unto hys majeste till the tyme and place where we shold have andience.

Question of Of . tymes the said bisshop, doctor, and marshall

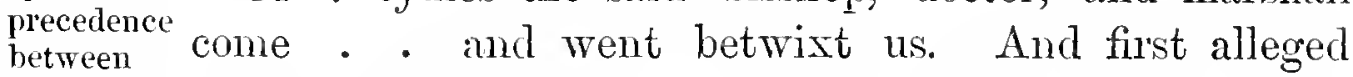
Spain and divers canses un[to] us for the whiche the SpaynEngland. eshe oratour shold have preemyne[nce] before youre oratours, seyeng that they so had in the courte of Rome, but we proved the contrary; and that the kin[g] of Spayn had doon meny grete and notable acts in subduen[g o]f Granarla and other wise. And som 
said apart that the [said kin]g wold have the said A.D. 1503. orator of Spayne wele entret[ed until] his son tharcheduke were saufly com home . . . . t notwithstanding any motion we had allwaies a . . . . . e duetie singuler respecte unto your honour. And . . . . eire reasones wold not agre to com toguyder in p . . . [t]he said Spaynyard giving preemynence of place . . . . . therfor finally it was shewed unto us yn good w . . . . . king for theviting of thinges whiche mowg $[\mathrm{ht}]$. . . . . parte to the derogation of your honour whiche $h[\mathrm{e}$ hath in like c]onsideration as his owne. He had devised . . . . . ld be brought into the quere of the churche [of Seint Mi]ghels where he wold hier evensong before h . . . . . . thuder, and directly before the place apoyn . . . . . ing to abide his commyng. And . . . . . . d the delivery of youre lettres unto hym . . . . ng his sa . . . . . for hym in chur[ch upon the ri]ght side of . . . next towardes the hi . . . . . . brought incontynently and sett in the st. . . . . o quere directly . . . nst the king. And th . . . . to sitt on the . . . . of the king *same side . . . . . was appoyncted.

The whi . . . . . [to] us was thought most honorable . . . . . And therf . . went unto the chu[rch] . . . d according to the same devising every thing ens[u]engly on that behalve w . . doon. And in deliveryng of youre saide letters we . . wordes of youre recommendations unto the king. And $\mathrm{h}[\mathrm{e}]$ said that it was evensongtyme and therfor he wol[d] hier evensong and after that give us audience.

In commyng into the quere all thambassators . . bey . . come before the king except the Spanyard, whiche $f$. . . . on the lefft hande.

The place appoyncted for the king was han[gerl 
A.D. 1503. with] clothe of gold in the length of iiij stalles l leb. of . . . . open without any travars. And next the . . . . of blakke velvett, where the Spanyard . . . . Saxon, the marques of Brandeburgh . . . . . bisshop of Laufenburgh were sett.

Maximi- Evensong nygh ended, the ling comaund[ed the said] lian gives bisshop, the doctor, and the marshall to [come into]
audience to the ambas- lis chambre, and he wold sone after comme t[o them] sadors. Whermpon we went unto his chambre ling come sone after. The whiche sta[nding benenth] his clothe of estate red your saide lettres; an[d when he hadl] herd oure proposicion before hym made th . . . the said provost Lang after the king had. . . . . of his counseil in communication gave auns . . . name that his majeste full acceptaluly . . . . . . every thyng as well in your saide lettres . . . . . us preposed. And . . . thamyte be[twixt him] and your grace concluded and confermed [it was unto] lyym right joyous and syngnlerly accep[table] . . .

observe and fulfill every . . . . . . comprehended. And dothe take and repu[te]. . . . . during his lif your grace as his dier brother . . . Whiche thinges shold at all tymes herafter appere by dede as largely as they beth nowe spoken and promysed hy worde. And as to any thing that we had to comyn aparte with his majeste, he wold assign an other daye for the siame.

Thes things in effecte spoken, the king taking us aparte, asked right hertily of your prosperous estate and of the tranqui[lite] of your reames. The whiche when he by oure relation h[ad] undrestande he gretly rejoyced therof. And furthermor[e s]hewed unto us that he was right sorye that we had labo . . . . long tyme before he gave us audience. Howesobeit h[e said] that his busynes was suche in every 
place that he cow . . . . . no convenient layser A.D. 1503. to hier us till his comnyng hu . . . . . herfor 1 Eeb. he wold give us nowe the better audience and sh. . . . cion. And becruse it was then within ny . - . . was abcut vij of the clokke, therfor he wold app . . . . . er tyme to comen with us and then to send fo[r] . . . . so deliverd us for that tyme.

. . . were present at the said proposing the duke of Sax[ony, the m]arques of Brandenburgh, thoratours of Spayne . . . . the said bisshop of Laufenburgh, the said b . . . d Cambremaistre, Sir Cornelius de Bargges, th . . . . . of An warpe, Sir Joys Prant, and meny other [ . . . . c]hambre full.

* On Thurs[day which was the day of the fea]ste of the $\Gamma^{*} f .112$. Purification o[f Our Lady about . .] of the clok before $2 \mathrm{~F}<\mathrm{b}$. noon the said bisshop, [doctor, and] marshall come to fett us unto the churche o[f Sainte Ma]rye, whiche is the principal churche of the said towne, sayeng that the king [wold] be there at high masse and there offerre his cand[le] and all thambassadors in like wise to doo. Howe sobei[t we] supposyng that in goyng to thofferyng the Spanyard [should] be preferred, for the same cause we desired to be had ex[cused] of oure thuder commyng. Wherupon the king efts[ones] sent unto us the said bisshop and others, sheweng [that] he wold commen with us after masse in the said. and that nother we nor the Spanyard shold off . . . our stalles in thoffering tyme. And so w . . . . candeles by thaym prepaired, beyng holden be . . masse tyme bremnyng with skochions of . . . . thaym. And the Spanyardes in like wise and . . sators with tharmes of theire princes th. . . . after the masse ended werre taken by the $d$. . with oure offeringes.

The king when mas was fynesshed and 
A.D. 1503. downe from oure stalles towards hy . . . unto

2 Feb. us, seyeng that about ij of the clo . . . . he wold have secrete comynycation $\mathrm{w}$. . . of us whiche and howe meny of his . . . . have present at that communication. Th . . : . unto his pleasire. And so we depart . . . . quere by his commaundement there 1 . .

[*f. $112 \mathrm{~b}$.

* At tw . . . . . . . . [t]he king sent tor us by the bisshop, doct[or, and marshal abo]ve said. And yn the same place where. . . . . we recited every thing acording to oure instr[ucti]ons for the first day, of oure communication. Wherupon the said lord provost Lang, after communication had by the king aparte with hym and other's of his counseil, shewed openly that the king was contented to observe thorughly everything comprised yn the said amyte for his parte and toke it right acceptably that your grace bare so good mynde towards hym, promyttyng that he wold yn like wise do towards you $[w]$ hile he lived.

[An]d as to the othe, his majeste was pleased to give it [in the] churche on Sonday then next commyng. [And] for the maner and circumstance of the givyng of it [he would] send certain of his counseil unto us the next day, [the which]e shold be Filday, or upon Satreday, to comyne . . . de with us upon the same. Being pres[ent at this] communication the said lordes, provost Lang, the . . . . the said bisshop of Laufenburgh, Sir Joys P[rant, the doctor $H$ ] aydon, and the said marshall, and at thend [of our communica]tion come yu Sir Cornelius de Bargges .

- . aunswere given with oure congratulation . . - dly disposicion in that behalve in the best $w$.

- . The said king toke us aparte and said .

- had long tyme been in communication and now.

- . con[c]luded, whereof he was right glad.

. . . . shold be wole observed and good off . . . . e therof. 
. . . [s]aid that he was mouche bounden unto A.D. 1503. your [grace for tharc]heduke his son, to whom in $2 \mathrm{Feb}$. all his neds ye [had been a p]atron and fadre and succurred hym me[ny] *tymes wh[en]. . . . not [*f.113. succour nor helpe hy[m].

Wherupon we s[aid that your] grace before ye had seen the said archeduke b[are goo]d mynde towardes hym, as appered by your grete actes doon for hym; but aft [er] ye had seen hym and comyned with him as ye $d[i d]$ ye had mouche better, and as good mynde towards $\mathrm{h}[\mathrm{ym}]$ as ye cowd have to your naturall son.

For the whiche he entierly thanked you.

On Satreday while the king rode on . . . . 4 Feb.

- come unto us the said lordes provost and . . .

- whiche beth chief of counseil and may . . .

. . . theire maistre of any men as we can per-

. . . . . man saythe and also doctour Haydon wh . . . . . . bothe lawes and knight.

They shewed unto us that for the . . . othe Form in the king was resolved into th . . . . . forme which the followenge. First whe . . . . . beyng with proposed him he appoyncted so . . . . for the tyme of to take the givyng of the said . . . . . . . differre it till Mondaye next commyng . . . . . been accustumed at all tymes to make . . . . . werkendaye and never upon an holy d[aye]

* custume he . . . . . . hen to give it yu [*f. 113 1. the grete churche o1 . . . . f Saint Mighell aforsaid. And undre this ma[ner.]

When the masse b. . . . . hym were almost at sacryng, then we to com unto hym and require bym to suere acco[r]ding to the contentes of tharticle, we redyng to hym the same contentes. And therupon he layeng his right hande upon the Holy Evangelistes and at thelevation of the sacrament openly lokyng upon the same wold saye, Juramus.

Ayenst the whiche daye, the tyme of the masse and 
A.D. 1503.t[he] forme, we persuaded. First ayenst the daye, 4 Feb. bec[ause t]hacte was solempne and to be loon to the Ofjections laude of Allnygr[hty God] and to the strengthe bassadors. and encreace of Christen feyth, it sho[ld be done] on a solempne daye. And also every other prince giv . . the accustumed the same. And therfor we . . . . his majeste beyng above all other princes wold doo s . . . te nor with lesse but rather with more solempn . . . . . se persever in his first aunsuere to give it on Sonda[ye]. [And as to] the said tyme of the masse, we said it was mome . . . . . the reding of the forme of thothe by ns with th . . . . g of thothe by hym cowd not folowe according . . . . le of thamyte. And also that the sacryng tyme. . . tyme convenient therfor, but suche a tyme as . . - Id applye thaym self to devotion and to no such

[And as to] the forme and miner we seid that thothe was . . and of mere motion assented and promysed . . . . n. And therfor the griving of it shold procede . . . . re fincte of the giver. And over that we were . . . . . to putt any othe unto hym but assigned . . . ym to give thothe and

[*f. 114. to be present at the gi[ving] * of it accordin[g] . .. . behalve.

Furthermore as $[$. . . . sa]ide churche of Saint Mighel we thonght it [a con] venient place for the giving of the said othe because it is a solempne churche of a grete indowed monastery. Howe be it we asked yn what place of the churehe and howe the king shold stande at the giving of the said othe.

They said yn his travers to be made nygh to the high auter. Wherunto we persuaded that it was not [well] according so solempn an acte to be cloon so prively b[ut] openly. And so we disired to have it doo[ne] upon a festefull daye, in the saide churche 
before the high auter, before Agnus Dei t.

. then torning about with the sacrament. A. .

A.D. 1503

4 Feb.

king to rede thothe hym self according to th[e form] to thaim delivered. And the same to subscribe [with his own] hande. And to require the notaries that th . . . to make an instrument upon the same. [And that] doon to have tharticles of thamyte to be red . . . . . to be blowen, Te Deum to be song with [ringing of] belles and making of fyres thorngh the

With meny reasones and persuasions we jus . . . . of the premisses to thaccomplisshing of . . - . on every parte insuchewise as they t . . . . considering the same as they wold she $[\mathrm{w}]$. . . . . condescend to cvery poyncte of oure des . . . . . the notaries which they saiu he w . . . doon, for he thought that the testifieng . . . . whiche shold be present shold suffise . . . . accordyng.

*. . . . . . . . . [Tu]esday the vijth day 7 Feb. of February [we were with th] aim ayen in ${ }^{1}$ communi- $\left[{ }^{*} f .114 \mathrm{~b}\right.$. ation. In the whiche $\mathrm{d} . .$. . . . with thaym two sondry times. First in . . onyng at oure lodgyng, where they shewed that the king upon oure motions and persuasions was agreable to make this othe at the said churche of Saint Jligheles on Sonday then nexi ensueng, because we desired it to be doon in a solempn daye and openly without his travers, and that the notary shold inacte the same.

Howe so be it he woll have the masse first doon Discussion and then to go to the high auter, and an hoste to be as to the taken out of the pix over the ligh anter, and before . . . same to give his othe to be redd by hym self. Albe . . re more brief forme then we shewed. $[\mathrm{Nev}]$ erthelesse we insisted as we dud first specialy . . he congruence of the tyme after the Pater- 
A.D. 1503. noster [ . . - m]asse. So after thothe made then $r$ Feb. the preste tha . . . the masse shold folowengly syng $\operatorname{Pax} D[$ omini] . .

nd tyme of oure communication with thaim the sa . . . . . . at the lodgyng of the marques of Branden[burgh . . . . . . ]s to a grete sowpar and to a goodly bankett [where he shewed u]nto us that the king wold not be agreabl[e . . - Jtyme before Agnus, but after the masse. reste that shall syng the masse to con$\operatorname{secra}[t . . .+$.$] And thothe to be given$ before the hoste th . . . . . ayne. Albeit [*f. 115. we persisted as we dud . . . * before all . . . . . . ng of that thing whiche myght . . . . or suspicion or doubt layeng unto thaym th . - rd and suspicious myndes of the people.

9 Fei. On Thursdaye the ix. day of February, the . . unto us in the mornyng to prepaire us ayenst . . on hawking with hym. And in likewise dud . . . and Wednesdaye next before, but the wedre [was not] convenient. And at noone there come. . . . . of Thorne and Vertenberg and brought [us unto. . . ] the monastery gate where the kinges lodg[ing: was, we] abiding his commyng. And sone after he c. . . . horsebakke with meny noble men about . . . toke us on his lefft hande and bothe on . . . . . homwardes comyned with us all the $w[$ ay . . . . . . . . passe thorugh the

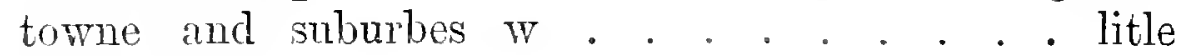
waye.

He asked what newes we had, and we s[aid that we had] none. Then said he that he wold shewe [us some,] seyeng that he had certain knowlege [how that [*f. 11 , b. the] * Frenshemen [had sufiered] a grete fall and discomfite by th[. . ., an]d that on the Frenshe partie were slayne. . . de of Besynyan an Italian and other grete capitanes with x.ml. men. And over that 
the lord Daubeney with iijo. speres furnesshed and A.D. 150\%. thre thousand fotemen was also discomfited.

The whiche newes the king reherced with grete rejoycing of the fall of the Frenshe parte.

As we founde tyme convenient so we made instance unto hym for oure expedicion. And he said that on the next daye his comnseil shold conclude with us upon thothe to be made on Sondaye next commyng.

[T]he next day, whiche was Friday, the comnseil 10 Feb. com . . . . us, of whom we obteyned thothe to be doon and. . . . at suche tyme and with suche solennyteis and [other circum] stances as wele contenter The Enus. Nrothing restin[ $g^{\circ}$ to be con]cluded but only council the forme of thothe, the which [in no] wise we cowd think there obteyne to be according to the forme [by us r] of your counseil, for it was aunsuerd u[nto us Non] words in decet tantum principem mastare jurcumentum. . sticorum, but that fewar wordes shold suffise. . - nce. And that therfor the king hymself . . . med thothe out of tharticle in suche a forme [as they had] shewed unto us herafter foloweng the sil . . .

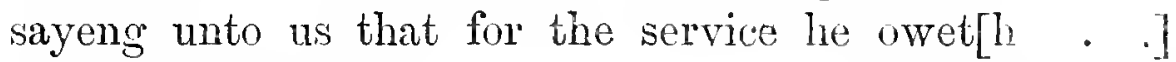

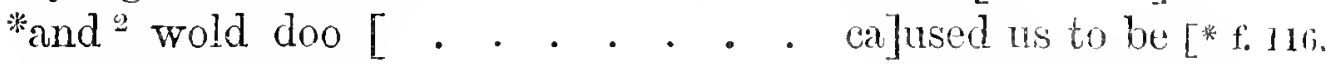
contented with that forme... . or styking at the matier we mowght be fur[ther from our]e purpose. The whiche forme here foloweth.

"Ego Maximilianus promitto in verbo regio per Sancta De[i] Evangelia corporaliter tacta ac pei" sacrosanctum Corpus Domini nostri Jesu Christi corporaliter visum, quod bona fide, et sine fravrle a[ut] dolo aut simistra interpretatione quacunque, bene, fideliter ac inviolabiliter omnia et singula capitula tractatus

\footnotetext{
${ }^{\prime}$ Robert Stuart Sieur D'Aubigny. I in addition to a short space at the

${ }^{2}$ and $]$ Perhaps a line is lost before bottom of the preceding page. this word at the beginning of f. 116 ,
} 
A.D. 1503. inter me e[t] serenissimm principem dominum Hen10 Feb. ricum regem Anglie fratrem [meum] charissimum nuper facti, ac omnia in eodem contenta tenebo, obser[vabo] et adimplebo, ac a meis teneri, adimpleri et observ[ari faciam] ac mandabo, nec aliquid contra aliquam partem ali[cujus] articuli tractatus pradicti, publice vel occulte fier[i vel] attemptar'i permittam, sed expresse [et in] effectu contradicam et impediam."

And notwithstanding the counseil of the s[aid commissioners] we after that have so endevoired us as we ob[tained such] additions unto the above written othe, as apperi[the in a boke] given by the king, howe beit it was ix. [of the clokke] on the same Sonday in the whiche thothe w[as given or] we cowd it so obteyne.

The circumstances and solemnyteis of givin[s the same] othe herafter appereth.

12 Feb. On Sonday the xij day of February in $t$. . . the monastery of Suint Mighel in Anwar . . . x. of the clokke before noone, we beyn[g . . . . $]$ before the place prepaired for the king w. . . . stalles on the right hande towardes the . . . .

* $[\mathrm{f} .116 \mathrm{~b}$. * the whiche $[$. . . . . el]oth of gold iiij. stalles long and th. . . . . with cloth of gold of like length all op $[$. . . . t]ravers, and from thens towardes the quere [and] certaine stalles and the deskes llanged and covered with blakke veivett and other blakke silkes; and in likewise the other side of the quere ayenst the same. The ling come into the said quere in a gowne of clothe of gold; and we humblyng oure self unto hym, he gave us very good chier and countenaunce, seying, "Nowe shall we performe all thinges."

Then he ascended into his said place. And in the stalles next unto his clothe stode the marques of Brandenburg[he,] the dukes of Mechelburghe and of Theek.

And he commaumded us to be in the stalles directly befor [e hy]m, being next unto us in the same side 
the deane [of the] churche of Colone, whiche is one A.D. 1503. of the dukes of Bo . . . . . . orator from the archebisshop of Colone. ${ }^{1}$ Thora . . iee and the bisshop of Luke. ${ }^{2}$ And the row [me betw]ixt the quere and the highe auter was full of no[ble men and] gentilmen.

[And the] bisshop of Beryten in pontificalitus song the h[yghe mass]e, which was full solempnly doon, which the b... . ell organs, trumpettes and other instrumen[ts].

[When] the Pater Noster was songen of the high masse [and the bi]sshop had given the benedictions, then the $[$. . . k]ing from his said place called us unto hym . . . . us on his lefft hande went unto the highe $[.$. . . . be]fore the high auter, the said marques, d[uke, an]d bisshoppes foloweng.

[The sai]d bisshop whiche sang the masse torned The cere. from [the au]ter and stode before the king very nygh mony of and . . . tly unto hym, having the patene of the ch[alice]* in his lefft h[and]. . . . . of the Hoste broken yn his right h[and]. . . . patene. And the deane of the chap[ell . . . h]eld open the masscboke, upon thewhiehe the king leyd his right hande. And in his lefft hande he had a parchement wherin thothe w[as] writen; wliche he, loking first upon the saeramen[t], dud rede, word by word, we kneling at his lefit side w[ithout] any voide space betuixt hym and us. And the said marq[ues, dukes, and other estates standing nygh on every side.

The whiche othe when the ling had distinctly red [and] subscribed it with his owne hande, and delivered it u[nto the] notarie Thomas Laurence, requyryng hym at [our] instaunt petition to make an instrument upon t . . . and the noble men standing about to be

\footnotetext{
1 IIerman, son of Lewis I., land- | "i. e. of Liege, Jean de Horn, grave of IIesse.
} 
A.D. 1503. witnes[ses, as] we made like requisition. And in12 Feb. contyne[ntly after] the said bissho' as he stode before the $\operatorname{kin}[\mathrm{g}]$. . . . . . . . towardes the quere with the saide parte of th . . . . . . . his hande, openly before and in the sight of . . . . blissyng with it, sang Et pax Domini sit se[mpiterna]. And then torned unto the auter.

This doon the king repaired into his said also the said lordes orators and we to oure fo After that the said bisshop of Luke broug[ht . . . .] unto the king. And when the king had ta . . . and the said bisshop had delivered the pat[ene unto the] deane of the chapell, then the king com[manded the] same cleane to bryng the Pax unto us . . . . - he and to none other.

When the masse was endend ${ }^{1}$ the said. . . . . standyng about the myddes of the quere . . . . the highe auter, full eloquently declared

$[* f .117 \mathrm{~b}$. * voice and $\mathrm{g}$. . . . . . . . ande of God and strengthe of Christen feyth [ . . . bet]uixt the said ling and youre grace concl[uded and c]onfermed and at that day by the said king his maister sworn. The wliche he by his said maistirs commaundement there declared to the dukes, erles, lordes, and to all people, to thentent to give congratulation therof; sheweng that because it shold not be doubtfull to any man what that peace and amyte was, the same worde by worde as it was concluded, shold be forthewith redd open[ly], prayeng every man to give good hiryng therunto.

And therupon incontynently one of the secietaries standing by the same doctor having the same boke of thamyte whiche was by your commissionars sealed with [a]udible voice red it word by word.

[A]nd that doon the trumpettes were blowen in the rode $[$. . An]d after that the said bisshop 
standing still at the hy[ghe au]ter in pontificalibus A.D. 1503. beganne Te Deum, the cha . . ting the same with $12 \mathrm{Feb}$. solempne song and organes [ . . . T] $]$ hewhiche ended the said bisshop sang this versic . . . . e fiat pax in virtute tua, etc., and red the collect [Deu $]$ s a quo, etc. And also the belles were rongen [in all t]he churches of the towne.

[When] this solempnyte was thus doon, the king commy[ng down] from his said place, toke one of us on his right [hand and the] other on his left hande. And so goyng thor[ugh the qui]ere and churche seyd unto us, "Nowe blissed be Go[d, we hav]e made an end of this matier." And we shew[ed our sel]f right joyous therof, with as good wordes as . . . . And when he entred into the cloistre w . . . e weye to his lodging on the right hande, a . . . . . the lefft hande, he wold not suffre us furt[her . . . ${ }^{*}$ further $[*$ f. 118 . to go . . . . . . ng that we offered unto hym and . . . . . we myght give attendance upon hym.

At nyght there were fyres made rownde about all the markett place and other principal places thorugh the towne, with brennyng cressentes out at the wyndowes the most parte of the nyght and grete sembleis and tryumphes made in meny places.

After the said Sonday the xij. day of Februar[y it was] Wednesdaye then next ensueng, the xv. da[y of is Feb. the] same moneth er we cowde upon oure daily . . unto the kinges presence. On the whiche d[ay about] Interview iij. of the clok at after noone in the same . . as to the place where he allwaies gave us audience $\mathrm{v}$. . . ' receiving - of estate, beyng present the bisshop of Via . the Garter. . . . provost Lang and Cambremaister, and doct[or Haydon] we proposed the matier for the receiving of [thorder of] the Gartier. In the whiche matier $\mathrm{s}$. . . . . . . was had before betwixt his counseil and [us... .] on theire partie by 
A.I. 1503 Occasion of $\mathrm{s}$. . . . . . . commission wherin $15 \mathrm{Feb}$. is specified bothe th. . . . and of the Gartier.

Provost Wherupon, after the king had comyned [with hang says his] counseil, the said provost Lang aunsuerd [that reeeived it the lingl had received the said ordre yeres passe[d. before; . . . . ] Gartier, mantell, and statutes, and swor[n [*f.118 b. . . . . . . ] *And therf[ore . . . . . . . - i]f nowe eftsones he shold receive [. . . . . - . t]hothe ayenne, he shold do thing contrary

to which Wherempon we shewed that because his proctor come the ambis- not to be enstalled for hym, and to present his helthat he had met, \&c. by the tyme lymyted by the said statutes, not been therfore aswel the receiving of the said ordre as the within the givyng of thothe were voide and of none effecte, likeneessary wise as if they had never be doon. Wherfor, inas-
ime. ime. mouche as it is an article comprised in thamyte that after the conclusion and confermation of the same amyte, he shold accepte the said ordre upon hym, we instanced hym eftsones that he wold so doo.

Wherunto the said movost, after the king had comyned with hym and others aparte, aunsucred that his majes[te wo]ld send unto us the next day some of his counseil to [she]we unto ns his further unyude nijon the same.

[Then] at the same tyme we shewed of the proclamations [and] bammeshementes made by your commaundement yn pl[aces und]re your obeisannce, according to thamyte, [as] appered by a copie of the same proclamations wh[ich we] said we had to shewe; Beseching his majeste [to com] maunde semblable proclamations and banneshemen[ts to be] made in cities and townes undre his obeisaunce; [with t] ine whiche, after brief communication with his said . . . al, the said provost Lang aunsuerd that his ma[jeste was co]ntented to do make proclamations and banneshe[ments in iijij. of the principal cities of thempire, and 
[. . . o]f the succession. But in whiche cities, an[d A.D. 1503. undre] what forme those proclamations shold be made [we sho]ld knowe by his said counseil the next day; [we in] stancyng that the towne of Acon myght be [oon of] thaym. And the king lawgheng at th[at] *desire saide . . . . . . . . have it there then yu [*f. 119. all thother. . . . . . . ye nor nay to oure said desire.

And immediately thermpon the said provost Lang Maximiasked of us whether we had any auctorite or noo to to obtain a comyne [of] any matier concernyng Edmund de la Poel, pardon for whom h[e] called the duke of Suffolk; for the king De la Pole. entend[ed] to purchesse his pardone and grace of your highnes, or [to] helpe that some composition myght be had for hym; wherin he wold comyne with us if we had any s[uche] auctorite.

To the whiche we aunsuerd that we had no suc [h auctorite], but reherced the menyfold offenses and lightn[esses of the] said Edmund, with thabomination he is $h$. . . . . humble petition of your counseil, the resolu.... . . grace upon the same with every other thin $[g . . . .$.$] according to oure saide$ instructions in the... . . . we cowd to putt hym out of allmaner of $t$. . . . . suche thing to be obteyned. And so req[uired him] to make no suche petition, for the thing w[as such as cowd] not stande with your honor to graunte, bu[t . . . . . . . ] incontynently to banneshe hym accordin[g. . . . . . . . ] by hym confermed and sworn.

Wherupon the king, having communication . . . . . . . said counseil, there was a grete lawghyn $[g]$ . . . . . . . at the first worde that the king spak. . . . . . . what it was we knowe not. And . . . . . . . . comynycation the said lord Lang, sta[nding . . . . . . . king as he all-

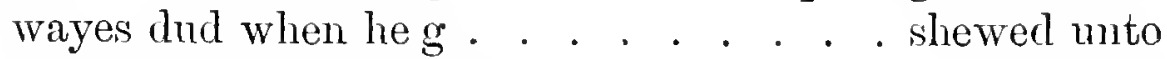
ns, that though his ma[. . . . . . . . . to comyne 
A.D. 1503. for some composition to be ha[d for the said] * Ed-

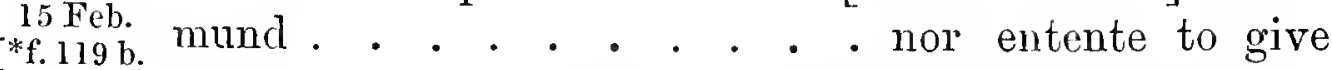
unto hym suc[cor, aid, nor comfort he]nsforthe, but to observe every poynt of th[amity . . . .]gin, and all others like as he is.

And then incontinently the king toke us aparte, saieng that he wold have broken with us in meny matiers touching the Frenshe king, yn the presence of thorator of Spayne, because it touched the king of Spayne; but the said orator is so full of ire because of this contention and variaunce betuixt us and hym, that he wull yn no wise be present toguydre with us. And therfor he wold commytte those matiers unto his ambassators to shewe the same unto your grace yn the presence of thorator of Spayne that ys with your [h]ighnes yn England.

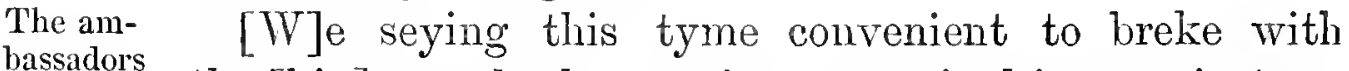
charge him the [kin]g yn thother matiers comprised in oure instrucwith giving tio[ns, she]wed unto hym at large of the reporte made
assistance to English unto [your] grace of the aid, comforte, and relief by rebels. hym giv[en unto] your rebelles beyng in Acon according to oure [said]e instructions; addyng therunto that we [had] spoken with Robynet Ruffyn, whiche confesse[d to b]eryng of money and writing from the said [king] to the comforte of the said rebelles, and th[at we h]ad seen his lettre late sent imto the bisshop [of Liege ${ }^{1}$ ] for like entente; all contrary to thamyte concl[uded and con]fermed.

[Th] whiche said thinges reherced of oure instr[uctions, with yo]ure saide additions he confessed to have $b[$ een done $b] y$ his commaundement, and of his knowleg[e, sayin]g that he thought he mowght with his . . . . so doo notwithstanding the saide amyte [so conclu]ded and also confermed, as long as

[*f. 120. there . . . . . . * any thing . . . . . . . . . as there dud all 
The whiche othe. . . . . . . n he may not $\Lambda . D .1503$. nother wull from hensforthe $g[$ eve u]nto your said rebelles, any aide, comforte, or relief in any wise, but fulfill and kepe e[very]thing according to the said amyte.

To the whiche aumsuere where as we replied, all . . his confirmation, subscription, and sealyng of the [said] amyte, the whiche dothe bynde hym to observe the s[ame], though the said othe were never given nor requy[red] to be given. He said as he dud before, s[aying] further that he knewe not whether that amyte [would] stande or noo, because it was shewed unto h[ym that $]$ your grace was not in mynde to kepe thamyte. . . . And over that unto the tyme he had spoken . . . . . . and herd us as he hath doon, it was suppos[ed]. . . . wold have desired some other thinges of hym . . . . . concluded in the saide amyte, or els contra . . . . . . amyte to the breche therof. And therfor. . . . . . . he thought not hymself before the caus . . . . . . comyng knowen, and thothe given to be . . . . . anyte.

None other aunsuere nor excuse he gave [save that he] promysed never herafter to give any maner [aid, succour,] or relief to the said nor other rebelles [and likewise] to observe every poynte of the saide amyte.

Item, we shewed unto the said ling of [the treaty] and alliannce that nowe beth betrixt [your grace and] the king of Scottes. And of the m[arriage which shall be] solennysed this next somer, according to [the same]. The whiche thinges the said king sei and smylyng seid, "It is meny yeres $p$ ". * of England . . . . . . . The whiche thing, he ["f. $120 \mathrm{~b}$. said, is as gr[ . . . . . . ki]ng of Hungary to wedd a lady out of Fra[nce.]" Howe be it he said that he undrestode she was an Englishe woman, called the lord Kendales doughter, whose landes he supposed to lye in England. 
A.D. 1503. And we aunsuerd that she was none Englishe woman, 3. Feb. nor yet that her fadre had any landes within England, but that, as we supposed, his auntecetry come out of England at the tyme of the subdueng of Fraunce.

Item, we asked of hym whether there were peace betuixt hym and the said king of Hungary or noo.

The Em- He said yee, but not very good peace, for there was a peror's litle grouge betuixt thaim. Howebeit, he said, that with Hun- [th]e king of Hungary dud nothing to hym, nor he to

Fary and
France.

. . we desired to knowe what peace was betuixt hym [and] the Frenshe king. He aunsuerd undre this form[e, follo]weng, "We have peace, but I shall shewe you ho[w tli]e last somer the Frenshe king laye at Millain, and . . . . . at Trent, within iij. daies jorney to Millain. [And I ha]d assembled myne hoste $\mathrm{ij}$. tymes to have fough[t with] hym, having meny Souchyvers in my said host. [And i]n like wise the Frenshe king had goten meny of [them] into his parte. The Souchyvars whiche [were] appoyncted to liepe my vanguarde avaunced tha[ym for] wardes without my knowlege, not stoppyng . . . . . . . come to Millain, supposing that I had folow [ed. And the Fren]she king supposing in like wise that I had . . . . . . . departed from Millain to Pavia, where he. . . . . . grete ryver betuixt hym and me that it w[old not 1)] possible for me to come to annoye hym. "[The $\mathrm{Fr}_{\mathrm{r}}$ ]enshemen remaynyng in Millain with th[e]

[*f. 121. * Lumbardes, if . . . . . . . . . ars, and discomfited thaim. $\mathrm{T}$. . . . . . . $\mathrm{n}$ I undrestode I was myscontented w[ith them that] they had approched so nygh to Millain, without my [com]mandement, and they in like wise were not contented that I folowed not to theil su[ccour, as] they supposed I wold have doon. And in the mean [time] the Frenshe king sent his ambassators unto me to tre[at for] peace, whiche was at that tyme concluded betwixt u[s, 
writen only in a papir. And before it was conferm[ed] $\Lambda$.D. 1503. the Frenshe king had begome warre ayenst the king; is Fel. [of] Spayne in Napules. Wherfor, when the Frenshe $\mathrm{k}$ [ing] come eftsones unto me with a confirmation of th[e same] undre his sign and seale, I wold not receive, nor . . . . but said that I wold have an universil peace, or els . . . . . Howsobeit I trust that my son tharcheduke [eoming] homvardes shall take som good conclusion . . . . . . The which so doon we shall have good pea[ce]. . . . . shall have warre."

Item, we desired to knowe what he entend[ed IIis intenagainst] Millain. He said, "Nothing;" for the Frensh . ganring - . . and agreid to hold it of hym as his vasall Milan.

. . . . . Seyeng further "that thentrates and rem. . . . . Teth vi lundred thousand ducates yerly . . . . king hath appoyneted iiij hunched thous[and . . . . ] and defence of the countrey and $\mathrm{jj}^{\circ}$ thousand . . . . . . he take the to his owne profite, whiche. . . . . And thus the Fronshe king, what by . . . . . Napules and his owne countreys recei . . . . . somonche money yerly that he know . . . . . therwith but to oppresse his own ne. . . . . daily dothe and wull doo. Wher[fore . . . . . . king of England and I wull have oure . . . . ${ }^{1}$ and reig . . . . for us [*f.121\%. to take hede u[nto . . . . . . w]hiche matier I prilye you to commende . . . th the matier of Turkes, ayenst whom I en[tend]e to make warre after my warre be doon ayenst the Geldres. And at this next somer to kepe a dicte for the saide matier of the Turkes; to the whiche I wull praye the king of England to send his orators, like wise as every other prince shall doo."

\footnotetext{
1 Besiles a word or two at the that a whole line is lost at the be-

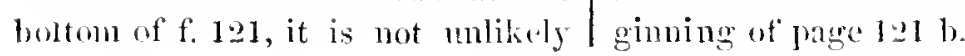


A.D. 1503. After we had given Jaude to his noble purpose ayenst 15 Feb. the said Turkes, he sail that the Grete Thiko feared not the pope, the Frenshe king, nor the ling of Spayne, nor yet any other prince, but only hym; and therfor the Turke hath often tymes sent unto hym for peace, the whiche he hath [a]llwaies denyed to take with hym. And the said Turke [se]yng that he cannot obteyne to have peace with hym [the]rfor he hath defierl the king of Romaynes and acer[tained him] that lo woll destroye his comntreys. And thus . . . . . . that he must nedes make warre ayonsis the Turke.

[Wh] Jerpon we shewed unto hym the sime tyme, and [like]wise at otler tymes to other lordes at divers communicati[ons, accor]ding to our instuctions howe we herd $y[$ our highness diver]s tymes in comynyng of that holy viage wissh [that] ye wer in his companigh in the said riage, [and t]hat so mondoulstedly ye wold be if ye were as ny[gh unto] hym as the ling of Hungary.

[To th] whiche he said with herty maner, "I thanke h[is grace of his] good mynde, for I had lever have his perso[n in my comp]anigh then any other thing."

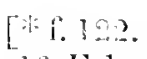
$16 \mathrm{Fel}$.

The Emperor stil! declines to receive the Garter second time.
* On Thurs[day after, which was the xvj. day of Februa [ry] there come u[nto us the bishop of ] Laufenlumgh, the prov[ost] Lang and Cambr[emaister and locttor Haydon. And the provost recited the substannee of [the] sairic petitions made mito th [em] for the Garticr, proclimations and banneshements, giving [moto] us like amnsuere upon the matier of the Gnitier as was [rloon] the day hefore in the presence of the king; sayeng thrat the] king was determyned in his mynde not to accepte of ne[w the] said ordre, nor to give thothe, but to stand to that ho had . . . amb hy his proctor, whom he wold send with his orators per . . the resirne.

Whermon we alleged thaticie of thamyte byndyn[g him tol the contrary, and persuader mo thaim ly 
meny r[easons in] the best wise we cowde, and so A.D. 1503. playnely as th[at they were] somwhat meoved and 16 Feb. myscontented with us [therein but] fynally they were pacified and convinced by . . . . . so as they were contented and thought it . . . . . . eftsonos to meove the king to accepte this ord[re . . . . . I we reherced that he dud not were the Ga[rtier as he was] bounde to doo by thothe that he marle when h[e accepted] thorrlre. They aunswerd that they doubt[ed not hat he] wold were it, and the Cambremaistre had . . . . . . har the Gartier there, for he harl it carried al . . . Then we shewed unto thaim of a George w[lich the knightw] of that ordre shold were, and also a colar . . . . . . . we shewed unto thaim according to oure in[structions . . . . And they said that the king had undrest[oorl. . . . . . George, the whiche he wold be contented to [were . . . . that every thing performed according to thor . . .

And as to the proclamations and bamneshe[ments they gave] unto us the names of the cities of themp[ire where they should] be made, that is on saye, Colone, Osbroke, ${ }^{1}$. . . . Norimberg and Iubek.

*And as to th[e proclamations and ba]neshementes to [*f. $122 \mathrm{~b}$. be made in Acon [they said that the kin]g was deter- IIe wishes myned to differre the procl[amations and] bineshementes to defer there till the commyng of $h[$ is am] hassators unto your menis. grace, and in the meane tyme to monyshe Edmund de la Pool to prepaire hymself to departe ont of all lordeshippes mdre hym and thempire, and also give wannyng unto his creditors of his said monition, to thentent they shold see for theire contentation of suche summes as he owed unto thaim. And if after the commumication of the kinges said ambassators with your grace no compo-

1 Augsburg. 
A.D. 1503. sicion cowd be had for the said Edmund, then he $16 \mathrm{Fe}$. incontynently therupon to do make the said proclimations and banneshementes yn $\Lambda$ con. [W]herunto we replieng said that suche delaye was contra[ry to t] hamyte, and over that the cause of suche delaye, [the h]ope to obteyne suche composicion of your grace for the [said] Edmund, whiche is also ayenst thamyte, is but vay $[n$. . . . ]es, rehereyng at liuge accorting to oure instruc[cions, lik]ewise as we dud before to the king, sayeng b[oth to the] king and to thaim that it was aparte of oure cr[edence to shejwe the same. And so we persuaded those prodam[ations and b]ammeshementes to be made in Acon incontynently. [They] amsmerd that the king denyed not to do it, a[lbeit in consi]deration aswele of his owne honor as of the h[onor a]nd wele of yom grace he was determyned to diff[erre it as is] abovesaid; sheweng furthermore howe [at the fi]rst commyng of the said Edmund mo the king [he had promi]sed unto hym favor and succor for the lady Mar[garet's sake and] at her instaunce, amte unto the said Edmund . . . . e unto hym his salveconduct. And alsow . . . . . for hym to be had in suche

[*1.123. favor, trust, and c[redit] *as he hath. . . . . . - [t]he singuler trust of $h$. . . comforte and su . . . . . his promys. And therfore if nowe he shold sodenly . . c and bamneshe hym, tho[rongh] the whiche percaas his creditors, whiche have trusted hy[m . . ] upon the said kinges writing wold destroye hym, it [shold] redomide to his grete dishonor, and tiramy shold [he] ascribed unto liym for the same.

In consideration wherof, and also for the restfulnes an[d] profite of your grace in evityng of the daunger and trou[ble] that might ensue, as have doon in like cuas hertofore . . . . if this matier were thus at large and rawly lefft [he] wold be glat to putt his handes to bave suche a co[neord] as mowght ap. 
peace all partios if it covel be had, [wherely] ho A.ls. lsos. wull leve his handes of hym in suche hon[or as] $16 \mathrm{Fcb}$. is according for a grete prince to departe fr[um one] that hath putt trust in hym.

Seyeng furthermore upon oure replieng . . . . considerations that it sholdbe a solen bann[eshnucit, that] sithens thamyte was no rather perfeite till. . - . were given by bothe princes, as it was not ylet done.]

We amsuerd that thanyte was full perfite. . . - . therof, though there were never othe giver to then. . . . . . . and banneshements sholdbe therupon inco[ntinently mate] as appereth by an article of the sinne . . . . . desired the saide proclatmations and banu[eshonents to be] made in Acon without delay accordi[ng. . . . ] and not to deferre it one mynute ö́ . . . . . discomodite $01^{*}$ dammage that was feare[d migh come to your] grace or to your reame by this light man. . . . For no suche thing can ensue sithens h[e is liche in] no regarde but had in despecte and ab[horrence of all] people with [*f. 12: b. . . . . . mes and menyfold offenses and trato. . . . . . specialy after the singuler grace, fardone, and bo . . . nsmes he founde in your highnes.

Upon the whiche and meny other aunsuers and replications they were contenterl to meove the sail ling according to oure desires, and to acertain us the next lay of his mynde $i[n]$ the same and in the matier of the Cartier; and also to bring the forme of the prodamation and bamneshenent to be made incontynently in the saide cities, for the king wold not folowe the forme brought with us.

[On] Satreday then next cusueng, the xviij clay of [Fehru]ary come unto ns the said provost Langr, the [18 Feb. Cimbre[mister and] doctor Haydon. They shewed :mto us that acco[rding to thei]re promysses they hand 
A.D. 150\%. shewed muto the king suc [h reason]es and persuasions is Feb. as we lad mache for the takyng [of the o]rdre of the Gartier, and for the banneshementes [to be inconty]nently made in Acon and otler places. Howebe[it they sa]ide that the king was thorughly determyned [to send] his ambassator's unto your graree to comyne with y[ou on thie]s matiers, and also a proctor sufficiently auctor[ised to be inst]alled for hym, and before their commyng un[to you he w]old no thing doo further in that matier. [ $\Delta$ nd further, t]ouching the wering of the Gartier they sa[id that the] ling supposed the Gartier to have be there b. . . . - . . . And then we aaid we wold provide for [*f.124. on . . . * They suid it . . . . . . king wold differce every thing in that [matier till the com]yng of his said ambassat|or] and proctor unto your grace. They bronght aycine the is . . . . partron of the colar, seying that the king wold be [content] to were a colar aceording to the same upon Saint G[eorges] dayc.

And as to the forme of the proclanations the shewed [us a] mynute therof, the whiche with certain additions th[at] we desired to be nade therinto, and they condescended [to] the same, we thought to be rood and according to thar[nyte, and trusted the sime to be putt in execution. A[nd they] pronysed to make up the same forme perfeictly accord[ing as] it wais then agreid amongst us and to send it . . . . And ovex that we eftsones so convinced tha[im tonching the] matiers of the Gartiel and banneshements [which should be] made in Acon that they salid they wold a[dvise. . . ] the king to do according to oure desires th[crein].

2o Feb. The Monday then next ensueng they c[ame again unto] us after the king was riden on huntyng [and told us that] the king persisted allwaies in like mynde 
[tumhing the] bamneshements in Acom ats is above A.D. $150 \%$. rehe[reed, and would not] for any reasunyng chanuge 20 Feb. his said m[ynde].

And as tonching the forme of the proc lanations they said] that they had male it according to o[u* desire . . . I and delivered it unto the king, whiche: - . . I And at his retornyug hone ayeme which would be]next daye they wold send it unto us.

- by all oule P. . . meanes to have it and that it ow . . . inco]ntynently in Acon. Wherupon they a[nswered] that, the wordes of thanyte of

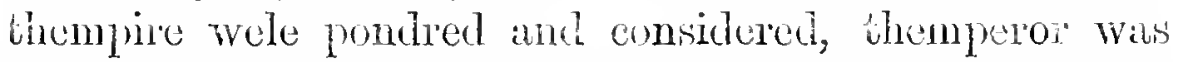
not bounde to make any bimeshements nox yet proclamations within thempire.

From the whiche theire opinions we by our perstatsions zemeoved thaim; and so they remayned.

On Tuesday, late in the evenyng, the king cone 21,22 fir. home, and on Wednesdaye then next ensueng, the rxij day [of] February, they sent ninto us by doctor Petre, secretary . . . . tyn, the forme of a proclanation, acerteyryng us that i]t was conceived by the inynde of the king.

[The w]hiche forme and none other he wold to bo publis[hed; and whe]n we had seen it, it pleased nothing, for it w[as but o]uly a notifieng undre fewe wordes howe that [peace] is conchuded betuixt your grace and hym, nothing . . . . yng what is the tenor or effecte of that anyte [nor of] any article therof nor yet sownyng to any marnner ban] eshements, as appereth by a copie therof wite[n by the sajid secretary. And therfor we wold not - . $t$, but made contynuel sute to bave it mad[e in the florme male by yom grace, whiche was atecording . . . And we sest owerly unto the conscil for.... 
A.D. 1503. ['They an]suerd that the king hath been alcens22 Feb. tum[ed.. . . Jnes in semblable cases to make his proclama[tions in tha]t geneanll forme, the whiche he

[*f. 125. wold not ch[aunge. * . . . . . ${ }^{1}$ exp . . . • • • • • . . . hym confermed . • sworil wh. . . . . . . y besought hym . . . . And as to his ambass[ador a]nd proctor we ofierred om. . . and in like wise at all tymes before desired to go in. . . . with thaym.

Wherunto the said provost Lang, after the king hat comyned] with hym and his comseil, seid that for suche re[asons and] considerations as were shewed unto us diver's tym[es before] by his comseil we shold be contented with suche au[nsueres] as the same comseil had given unto us and tak [e this for $]$ a fynal aunsuere.

The En- Albe it we male replications therunto in su[ch wise peror in - that] the king, leving his counseil and all the 1[ordes
sists on delay till took us] aprarte and praied us to recommaninde hym his ambas-
sadorshave [unto your] lighhnes as to his lovyng and dier spoken broth[er and promise] unto you that he wull perwith forme and fulfill [the amity in] every poynt. Howsobeit lie differ[led the] tyme till his ambassators had spoken with [yom grace]. And we salil that it was contrary to tha[myte to make] any suche delaye, and that therfor y[om highness] wold not belive us that we had doon o[ur dutyl yn pursute of the same. Wherfor we be . . . . to have that aunsuere to be putt undre w[riting which] he gramed and commamuled the said . . . . . . . doon, and so he chud. Albe it the...... . shold not have in writing all his my . . . . . . . . reserve those maticrs with others to . . . . . . his said ambassator's.

Wherupon we shewed unto hym th[at]

1 Most probably a line has been lost before this fragmentary word at the top of page 124 . 
lis proctor must be a knight, as none . . . . A.1) 150:\%. appoincted to be his ambassator's.

*And he said [ . . . . . . . . s]heweng [*f. 12.5 b. [us] that his said a[mbassator . . . . ] with hym and sholdhe depecched . . . hens. And the knight whiche shold be his proctor was at Saint Omer's in their waye. Then we desired that his commission myght extende not only to thenstalling and presenting of the helmett and other thinges, but also to do every other thing in that ordre as he shold to if he were there in persone. Whernuto he amsuerd, "Donbt ye not it shalle wele inough, for he shall have prover to doo every thing that shalbe agreid betuxt the kimg and nyne ambassator.[s]."

[Fu] rthermore, upon his promys made unto ns for his [proclama]tions to be made intombinently in $\Lambda$ eon [we be]songht hym for that thing to be doon aceording [to the] same.

Wheru|nto he saide it shold he doon incontynently [How] heit he marvailed that we were so importun[ate in tha]t behalve, sithens the said Elmund is upon. - . ging. We besought hym to knowe whiclr[e] - . . . he knewe not, but to seke his fortunc.

[And] where as we at oure last communication withe th . . . desired theim to meove the king to have th. . . present when we shold be with his majes[te] . . . . t as wele to perceive what the matier shold . . . . the Frenshe king as is above reherced. As . . . . . . our commamement touching the demeany[ng of the sili] Spanyard for your said rebell.

The king shewed that he had doon accordilug

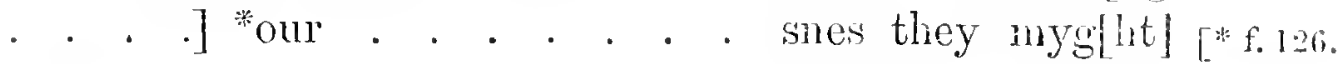
not give unt . . . . . . to take aunsuere. . . the king hymself.

Wherupon we made su[te to] come unto the kinges pre[sence;] and so we dud on the Thursday then next a: licb. 
A.D. 1503. ensuchg . . . . On the whiche ditye when the 2:3 leb. Jing had dyned. . . . was commyng unto a place ahout the myddes of th . . . to se newe dothes of Alasse, he sent noble men [unto] us to come unto hylu. And so we duci. Ancl taking . . . . on his leffe hande riding thorugh the towne ant [o his] lorlgyug, fell in communication of the chuke of Gellue, seyeng that he was the inkyndest man in the [world,] for he had norisshed hym and brought hym up of a boy in] his hous and aftervardes sufircel hym to occu[py the said] dukedom of Geldre, not withstiunding th . . . . . . . of the same nade by his fadre.

Upon the whiche his sayeng we inconty[nently asked] hym to considre the like and grettar thin[ges of your rebell at Acon, whom your grace besides [binging] up of hym, had, after his rebellion and [miny other] offenses, giren ayenne into hym his hud . . . . with meny other gracious firvors ame be[neits.]

1'o the whiche the said king amsuerd". . . . of tionthe, and therfor I wull not comsusel his garce] to thlie hym into his reume ayeme." A nod this will] lue saye moto the silid rebell if ever it [fortune him] to spele with hym, for he said he thonght him] Juí a lyght persone.

And with that we lighted downe of with the king come into the chambre - seasons he gave us andience. And t - livosost standing nexi unto the kiping and nneny noble inen standiag abon[t us and given . . . our comnyng unto lym benygn andie[nce and tonchi]ng thamyte hath fulifled every

1 Possibly some entide lines lost here, besides the dotted space. 
thing h[ide]rto. And so desired us to shewe and A.D. 1503. reporte unto your highnes. Howebeit he thought there 23 Feb. was difference betuixt his majestie and us in cortinin thyiges, the whiche he supposed we wold shewe uito your grace. And he had commytted unto his ambassators to comyne and conclude with youre highnes upon the same, whom lie wold spede in all goodly liaste, praieng us take oure jornay before thaim unto Calis, to thentent that at theire commyng thuler they myght have spedy [p]assage to come without delaye unto the presence of your [highl]nes, to whom he desired us to mikle entire recommen[Gation] is as to his dier and lovyng brother.

[Wher]upon we, marvailing of this solen depecthing . . al amonsuerc seyng divers natiers as undeterrnlyner . . . Jerd that for tho favorable areepting and benign[e receivin]g of us we hunilly thanked his majeste, . . . . s to thexpedicion of the matiers of thamyte foir the whi]che we were sent unto hym, we said that as [touchin] malie reporte howe he had [taken i]t, but as to thexpolicion of the matiers of . . . . proclamalions and bamneshements we besoughtht lim. . ]e to jarldone us, for we cowd make no relatio[n of our expedicion on that behalve; reheruyng . . . . that andience to thamnsuers given unto us by . . . the whiche we expresiy there shewel to $D[\mathrm{e}$ contrary c]o thanyte; and ther'ou whatsoever aunsu[cr. . .] his counsoil, we doubt not that his maj[ciste being so ex]cellent a prince, wold give us aunsuer . . . . 


\section{XXIII.}

[MS. Cott., Galba B 11. 59, burnt in the margin.]

A.b. 15a: Memoire [a Wilshere ${ }^{1}$ dentendre de Messire Chark conme il se devra conduyre pardela es attairus du Roy nostre Seignem.

Wilshire Prmmenenent remonstrema andict Messire Charles is to inform comme la mageste du roy la ordonne en son albsence the motions de se tenir et resider pardelit ponr une espace de temps, of the re- ation de temps a aultre luy filire savoir de telles nonbels. velles quil pourra entendre et savoir du fait et gonvernement de ses rebeiles, et ou ilz deliberent daller; et yuilz entondent de faire.

Et que pour plusficillement en estre adverty, que ledict Messine Char[les] luy line avoir conghoissanco

\section{Thasention.}

Menorandum [to Wilthire] to learn from Miessire Charles how he is to comluct himself there in the attinirs of the ling ond master.

Finst, he shall show to the said Messire Charles how the kinges majesty has appointed him in his alsence to remain amb reside there for a spate of time, to intorm him from time to time of such news as he can lentrin and know of the aretions and conduct of his relich, and where they purpose to go, and what they intend to do.

And to be the more readily informed thereot', let the satid Messire Charles put hin in communication with such spies as

\footnotetext{
${ }^{1}$ Probably Sir John Wriltshire, Calais in 150:3. French roll, who was appointed Controllen of 1 IIInry VII. m. (2).
} 
avecques tolles espyes quil a en main. [Et] ledict A.D. 150\%. Wilshere en pourra praticquer daultres aftin den estre acerte[int] a la verite de tous costez, pour veritablement en advertir la Majeste d[ [u Roy].

Item, ledict Wilshere solicitera tellement envers ledict Messire Cliarl[es quil] le accointe et face avoir congnoissance avecques les entrep[renncurs] et aultres quil a praticquez dempuis sa demeure et residence p [ardeli - . I Et se mectra ledict Wilshere en son effectuel devoir, tant avec[ques lesdicts] entreprenneurs que aultres quil pourra pratiquer, que . . . . . cutreprinse puisse sortir a bon effect et conclusion sy po[ssiile est] dele faire en quelque maniere que ce soit, a celle fin que [sil vient] ancun bien an ladicte ontrepinse que le roy en puisse part[ticulierement etre] alverty, a intencion de les remmerer selon quilz lo deserv[ent. Et] pour laceomplissement dicelle ledict Wilshere mectra tou[sjours lesdicts] entrepremens's an bon espoil et confort,

En les alvertissans que silz peuent parvenir alexe-

he has in his employ. And the said Wilshere may use others, in order to ascertain the truth from all sides, and to inform the king's majesty of it truly.

Also, the said Wilshere shall so solicit the said Messire Charles that he shall make him known to and canse him to have intelligence with the enterprisers and others whom he has engaged since his residence in those parts. And the said Wilshere shall use his utmost efforts, hoth with the said cnterprisers and others whom he can engage, that [the said] enterprise may lead to good effect and conchision, it [it be posisille] to do it in any manner, to the end that. . . . . . any good in the said enterprise that the king may [be particularly] informed thereof, in order to remunerate them as they deserve. And for the accomplishment of the same, the said Wilshire shall always put the said enterprisers in good hope and comfort,

Informing them that if they ean achieve the excention of 
A.D. 1503. cucio[n deladicte] entreprinse quo le roy le recongnoistra tellement enver[s eulx que] par raison ilz auront cause deuls tenir pour bicn cont[ent. Et a ce] que leur a este offert parcidevant par ledict Messire C[harles pour] parvenir a ladicte cxccucion delentreprinse que le roy ser[a prest a] parfourmer et accomplir ausdicts offres precedentes [sans filire] ancune difficulte, ja soit ce rue les endentures so . . . .

Whenever Item, quant ledict [Wilshere] aura congnoissance que the league largent que le r[oy doit] payer an roy des Romains with Maxi- soit prye en la cite de Londres et les lect[res] patentes Wiltshire deliviez de lentreeschange delamytie conclute et accorshall go [dec] entre le roy et le dict roy des Romains, solicitera throngh Germiny with Norroy, ind see it prorlaimed; envers les commissai[res] dicelluy roy qui pource auront charge de incontinent orlonne[rr $1 \mathrm{~m}]$ officier clarmes dudict roy des Romains pour et en la compaig[nie] de Norrey a aller es Allemaignes affin de faire publier par.

the said enterprise the king will acknowledge it to them in such wise that in reason they shall have canse to hold themselvos well satisfied. [Anit as to] what was formerly offered them by the said Messire Charkes for the accomplishnent of the waid enterplise, the king will be rearly to fulfil the said lormer offers [without making] any difficulty, eren if tho indentures be . . . . . .

Also, when the sain [Wilshere] shall have intelligener that the money which the king is to pay to the king of the Romens: is paid in the city of Lomlon, and the letters patent delivered of the amity concluded and granted between the king and the said king of the Romans, he shall solicit the commissioners of the aid ling, who shall have charge to that effect immediatcly to appoint an officer of ans of the said ling of the Romans to go in the company of Norroy" into Gemnany in arder to

1, st sic in MS. ?hristopher Carhill. Sie $\Lambda_{p-}$
pondix $\Lambda$. 
les gr[andes] villes, citez, et aultres villes et places de $\Lambda . D .150 \%$ lempire et des lieux d[u] patrymoyne dudict roy des Pomains ladicte amytie.

Semblablement la bagnyssement des rebelles du roy with the nostredict sire hors d[e tous] les lienx et jlaces cie son- banishdict patrymoyne et succession; et que [ladicte] procla-reble. macion soit faicte aux prouchaines bonnes villes du [pays] on se tiendront lesdicts rebelles du roy, tont ainsi on la four[me et] maniere quil est contenu en la proclamacion qui a este dev[isee on] irancois et en latin par le consuil dir roy laquelle est b[aillec] aulict Wilshere pour la deliver audict Norrey quant le c[as le] requerria. Ft fera ledict Wilshere icelle translater en all[emain] affin de la monstrer aux commissaires dudict roy des Rom[ains. Et] que lecict Norrey soit tousjours present a veoir faire liudicte proclamation.]

Item, lerict Wilshere baillera par escript andict Norrey les no[ms et] stimoms dos rebelles du roy

proclam the sait amity throngh the towns, citics, nut other towns and places of the empire and of the lands of the patrimony of the said ling of the Romans.

Likewive the banishment of the rebels of the king our said lord ont of [ail] places of his said patrimony ind succession; and that the said proclamation be mate at the neightoming good towns [of the country] where the ling's said reberis slitl be, exactly according to the form and manner that it is rontained in the proclamation wlich has been devised in French and in Latin by the ling's council, which has heen given to the said Wilshere to deliver to the said Nortoy when the case shall require it. And the said Wilshere shall canse it to be transinted into German, in order to show it to the commissioners of the king of the Romans. And let the saill Norroy he always present to see the said proclamation male:

$\Lambda$ ko, the said Wilshere shall give in writing to the said Forroy the names and smranes of the king's ieticls that they 
A D. 1503. pour les faire bagnyr, nomm[ant] chacun par soy, come il appartient, par lesdictes bommes villes [et citez] des Allemaignes, assavoir du patrymoyne et succession dudict roy [des] Romains.

IIe is to Item, se ledict Wilshere entend que Messire George get Sir ireorge Neville bamished fiom Miaestricht, Neville nest [pas] encoires bagny hor de Mastryc, quil lo face faire; et sy ap[res] ledict bagnyssement il reside et se tient cn ladicte ville ou aultr[e] dela sulogection èt obeissance delarcheduc on delevesque dul[ . . . ] quil pourchasse $a$ en faire fitire lexecution, et de tous les anit[res re]belles quil entendra estre es lienx dont ilz miont este bagn[ys.]

and to pro- Iten, trouvera moien an mientx [quil pou]rra de

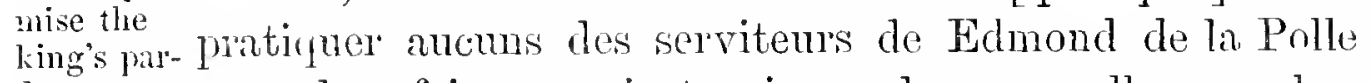
don tony pour luy faire savoir tousjours des nouvelles, en luy Eervants of promectant delapart du roy son pardon par ainsi que il De la Pole, feclairerat ceulx quil congnoist et entend estre de laflinite who will give durlict Edmond, et ce a sal venue et arryvee devers le mation. roy nustrentict sire.

Item, sil ya ancuns aultres des gens et serviteurs

may he hanished, naming each one separately in the form through the said good towns and cities of Cermany, 10 wit, of the patrimony and suceession of the said king of the Romans.

Also, it the satid Wilshere hem that sir George Neville is not yet banished fiom Maestricht, that he cause it to be lone: and if after the said hanishment he reside in the said town, or any oftere under the rule of the archerluke or of the hishop of" - Hhat he procure his execution and that of all the other rebls whom he shall lean to be in the plices from which they shall have been banished.

Ako, he shall find means, to the best of his power, to engage some of the servants of Edmund de la Pole always to give him intelligenee, promising him [them], on the king's part, his pardon, on contition that he will declane those whom he knows and understands to be of the affin ity of the said Edmmel, and this on his coming to the king our silid lord.

$\Lambda$ loo, if there are any other of the rentlemen and servants 
dudict Edmond De la Polle qui desirent a avoir leur A.D. 1503. pardon et abolucion, ${ }^{1}$ le roy est conten de leur pardonner leurs vies moiennant quilz feront dechira[cion] de tout ce quilz sciyvent et congnoissent.

Le bou plaisir du roy est que ledict Wilshere revisite souvent s[es] instructions, affin quil ne puisse riens mectre en oubly [dans le] contenu en icelles, sans les monstrer a personne quel[conque] fors seulement a Messire Charles.

H. R.

of the said Edmmul De la Pole who desire to have their pardon and absolution, the king is content to pardon them their lives, provided they make declaration of all that they know.

The good pleasme of the king is that the said Wilshere revise fiequently his instruetions, in order that he may not forget anything in their contents, withont showing them to any person whatever, except ouly to hessire Charles.

II. R.

\section{XXIY}

Deposttions touching Ediund De la Polle.

[MIS. in Reeord Office.]

BYFor my departing out of England, shewing my A.D. 1503. mynd to W[. Huse] in what wise I shnld departe, I asked hym his advise. $A[n d$ his] conseil was that I shuld not refuse the jorney, and that I . . . incontinent commyng by youd the see applye me to the

1 Sic in MS. 
A.D. 1503. true and feithful service of Ed. De la Pole. And I said to doo hym true service shuld be my mynd; howAstrologers beit, I wold not incontinent appr . . . therunto to to be con-
sulted as to the chances shuld be his liklye fortune. And if so be that ye of Dela la her say that be with him in his service and comcess. paignye, trust than verely tha . the judgement of astronomyers hee shal come to his desires.

Item, W. Huse said he wold to no service, if he might know that . . . fortumate, and that he wold shortlye com. And I said the nttremes. . . knowleg that I cowdo gete he shuld have hit shortly after. And .. delivied he me his tokens.

Item, he shewde me in the Towre that he was acerteyned how that E[dmund] within r. or rj. nyghts Suspicions of his departing bankketid prively in a place in Loncreated by his deparrime. don with lord marques, ${ }^{1}$ lord Essex, lord William of Devonshire, and Jeffed them ther and departid, and with hym Sir Thomas Grene. And tha[t] this was commyn to the kinges knowleg, he bad me shew hym. And so [I] ded; and his answer was, "it happed soo often tymes that we wer in such compaignye to geder, but to say they knew of my departing that I p... you they den not, and Sir Tho. Grene wis in no such compaignyon."

Item, Ed. de la Poul shewde me that he said to ny lork marcues and lo[rd Winliam] when he was apointed to ther nuwitting to departe, "Sirs, I have geven to either of you an horse. I wil advise you wake them by . . . and send to my stable." And who har them I woot not.

Item, I showd to Ed. that I unilerstoule by the said Huse that to litil afor lis departing he shuld have mynyd in Warwik Lane witherl of Devonshir, and 
that therle cam unto his uttre jayct to receif hym A.D. 1503. with gret reverence, for " the which it is thought in many mens myndes that your jornee was not unknown to hym, but lie was therunto agreable, and also that ye shuld apoint you to land in his countree, or nygh to him. Hee ansuerd no mor but this, "I see weill ther ys many praty castinges of eyes made to eny cowntenanse that was shewde me; but no force . . . . let them judge by utward cowntenanse what they wil."

Item, forasmoch as I cowde gete noo counseil of the astronomyers, bicanse they had not his nativite like as I. promysed, I kept me from his compaignye, and by rapports of such newes as I hard, gate the most favor I. cowde of hym and his: and thes newes, specialy such as wer eny thing thinkful and secrete, John Chambrelen shewde me them to the entent I shuld send them to hym.

Item, he bad me shew hym that Hourts was a bouglat to do hym a gretter displaisir than was the deliverance of the prisonner, and how Hourts servant and John Brit had ben in England with the kinges grace.

Item, hee gave Gelikin warning in Lent last passed that Will'm Cowper was a bought to get away the shipp maister, and at that tyme Ed. wold not byleve hit. Afterwards fro tyme to tyme, as the said Corper cam to sollicite the same purpose, he shewde hit sum tym to Gelikyn, and sum tyme to me; so that Ed., wenyng that all thies advertysements had comen fro me, gave me grete thanks.

Item, he shewde Gelikin that Wilshire ${ }^{2}$ had fro the king pardones for Edward $\Lambda$ wnsham and Derick. And Gellin desired me that I wolr write hit to Acon, by-

\footnotetext{
for] This word struck out with
the pen.
} 
A.D.1503? canse his messager lay seck of thapes. And Ed. wrot a gain to Gilkin and me, and had us speke no mor of Fiward nor Derick, for he knew all that matier.

Item, Erl. sent to me that I wold privey hym a crosbow of Bruxells or of Andewarp, making to the weight of iiij.li. And by canse I hat noo money I shewde this to John Chambrelen, and he spake to Richard Symonds beldell of the English nation to aspye hym a gode how for asmoch as he cowde skill of a how. And so he ded, and John Chambrelen paied therfor xij.s. flemmysh; and I sent hit to hym and shewde hym a welwiller of his had paied therfor which at that tyme wold be nameles.

Item, at the retornyng of my messager which of Sir Ro. Cursun byhalf shewde me that in breve tyme they wold depart fro thens, I, to the entent I myght linow wheder they wold departe, went to Acon, and ther likewise as I shewde to the kinges grace Ed. shewdo me. And at that tyme cowde I gete noo knowleg of his ajed, ner of the eomntre ther he loked for his ayed, ner of than shipping ner of his conforte at his landing, but hee desired me lator to the astronomyer to know what day wer most expedient and surest for hym to make a privey jorney, and bringing that day I shuld know mor of his jorney. And at that tyme I adrised hym as thus; "For eny povertie or nedynes make noon. hasty passage without ye be assured to passe strongely or ellys to fynde them byfor you in England that ye be assured of shall ayed and strength you suficiently a gaynst all that shal make resistence; and cast not a way your self for hastynes and withont favor of astats. Trust not the comyns, for in them without theyr hedys never was ner shalbe stedfastnes." And he said, "Goo a bought that, I desire you, and herafter ye shal know that shal content you."

Item, he bad me at my commyng to Nalyns speke with Gilkyn . . . . of hym he said, "I shuld 
know tidings fro the countres he him . . . . . A.D. 1503. ben yn." And I ded speke with hym, and he shewd me . . . that seith the tyme of the lege he had ben with king of [Romans] and that the king gave hym answers to such as he cam froo th . . . . nether for lege nor seal they shuld mystrust hym, for his cos[in] of Suffulel ayed shuld not be dymynyshed, ner lis jorney by on howr for that bond.

Item, Ed. shewd me that it was rapported to hym how th . . . knyglits of the North shuld be prisonner's in the Towre. He desir[ed me] to make all the diligens I cowde to senul hym ther numes an! . . . .; yet I sent hym no word therof, for asmoch as I have ben a . . . . and Baruligh ever sitî All Halowmasse.

\section{XXY. \\ Whiliant of BLAmmilan.}

[MSs. in Record (Hifice.]

Wri, Maximilian, von Gotes genaden Romischer A.D. 1503 Kuning, zuallentzeiten merer des Reichs, zu Hungern, 3.July. Dilmacien, Croacien, Eertzheztog zu Osterreich, Herizog For a payzu Burgundi, zu Brabant, und Phaltzgrave, \&ce, Ein-made in bieten umserm getrenwen lieben Hartan Aichorn behalfof uninserm Camermaister zu Innsprugg unse: ginad, und De la Pole. alles gut. Als unnser und des Reichs lieber getreuver-

Tidxshaton.

We, Maximilian, liy the grace of Gor king of the Romans, jerpetual angmenter of the kingdom, of Homgany, Dahnatia, and Croatial, archduke of Austivia, duke of Burgundy, of Brabant, and l'alswave, ace. semel to our faithful and beloved Martin Aichorn, our chamberlain at 


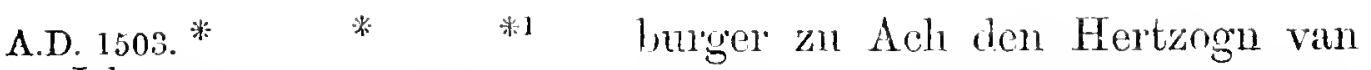
3 July. Suffocq, dasebst zu Ach vol umsern wegen ab gesprochen hat, nemlich umb zwaytausend gulden Reinisch; Demnach Emphelhen wir dir mit crnnst daz dw dem bemelten * * * * solich zwaytatusend gulden Reinich von unnsern Remntu, und gulten deines Lmpfangs, von Weichenechtn schierest kunftig uber ain Jaer, gegen seiner quittung ausrichtest und bezallest. So zollen dir dieselben zway tausendt gulden auf dits unnser geschefft, und die berurt quittung in deiner Rayttung gelegt und ab gezogen werdn; und tu duest daran unnser Ernstlicher mannung segen. Zu Fuessen am drittu tag des monats Julij, anno Domini funffzechnhundert und in drittin, unnserer Reiche des Romschen im achzechendn, und des Hungrischn in vierzechnden Jaren.

Funprets, oni grace, \&c. Whereas our and the kingdom's beloved and fathrul * * ${ }^{2}$, burgess of Aix, has asted the duke of Sufrolk there at Aix for 2,000 Rhenish florins on our aceount; therefore we camestly request you that you setile and pay such 2,000 Rhenish florins within a yeali from Christmats, next ensung, for his acquittance. And the sune 2,000 fiorins for this our buriness; and the aforesaid acyuttance shall he placed to your discharge and taken ofi. And theren you thall give us singulat satisfaction.

At Fuescong, on the 3 d dity of the month of July, 1503 , the bist year of our reigin of the Romans, and the thth of IIungary. 


\section{XXVI.}

FlAMANK'S INFORMATION.

[MS. in Record Office.]

To the Kynges Most Noble Grace.

Abour the last day of Septembre last past, beyng in a secrett counter within your deputie ${ }^{1}$ is place at Calis, he, Sir Hughe Conway, your treserer ther, and Sir Sampson Norton, master porter of that your sayd toune, cald to them my brotre William Nanfan and me. Then said my master. you" depute to us, "Sirs, we must comyn here now of many great matres touchyng the kyngis gance and the surtie of this hys tome of Calis. Therfore by canse ye be next unto me, I nust somtyne put you in tryst more then other. Ye shall hype bere thces luatrys that we intend to comyn of; but first ye shall be boythe sworen upon a boke that ye shall never utter nothyng that is now here spoken, withont it be to the kyngis grace yf nede shall require, or els to mon lyvyng creature." Then after many matris spoken by my master your depute and resonned to the sime by your treserer and porter, wiche matres and wherof they were I ame and shalbe [ready] ${ }^{2}$ to shew to your hygnes at suche tyme or tymes that best shall plese your grace that I so do.

Then seid Sir Hughe Conwaye, "Master depute, yf Sir Hugli ye knew as moche as I do, ye wolde saye that ye hade conway asgrett cause to take kepe to your sylfo as ony lyvyng the deputy creature; and therto ye be asmuche bownden to thank against God for that ye have askaped hetheito as ye have, for conspiI know thoos persons that have be sett to murdre you, and by whoos cause and inenys they so lyde." Mi master askyd byu what they were he wold then shew hym, but seid that he wold shew hym more of that mater at a nodre tyme ivhen we shall have more

1 Sir Richard Nanfan.

Em. in MS. 
A.D.1503? layser. So for what he said now ame I and master porter asfyr into the daunce as ye be, for I promyse you of my fitythe that all thoos that be and were proffered hydre into ther lomes by my Lord Chamberlayn ${ }^{1}$ shall never love non of us, and specially thoos that were his houssold servauntis tofore. The cause whij they soo do I camnot tell, but for that we folow the kyngis plesure and so wildo. Therfor good yt is that we sce to our owne surtie, aswell as fore the surtie of this the kyngis tomne, that yt may be sure to hym and his, wat world so ever shall hapen to fill here after, to have in remembrans that the gretter and more partic of thoos that be in the kyngis retenu here be of my lordis prefferment. Also loke hoo stronge he is in the kyngis conte of his houshold servamntis for the more partic of his garde be of thoos that were my Lord Chamberlayn servauntis tofore. and hard liyt is to know mennys myndis yf God should send a sorten change, as he hayth here tofore.

Then said my master, your depute, that "I darst reseve the sacrament that my lord is as true to the kyngis grace as ony man lyvyng;" and in lyke wyse seid master porter.

Item, my master your depute, said, "My lord Chanberlayn was very shlake in oone jorny, wherwith 1 knowell that the kingis grace was discontent; for and he had done his parte welle, the Cornyshe men hade never made the kynge feld at Blake hethe, but had all ben distroyed longe before ther comyng thedre, that I knowell the kyngis gace hate lever larle be done then. $\mathrm{xx}^{\mathrm{m} 1 \mathrm{l}}$. li for his honour.

Item, after many wordes spoken, Sir Hughe Conwey seid, "Mastres, I hanot spoken theys wordis for no untrothe that I do thynk be now in my lond Cham-

\footnotetext{
1 Giles lord Daubeney, formerly $\mid$ of repeated in MS.
} deputy of Calais. 
berlayn, for I dar say now as ye do that he lovyth A.D.1503? the kynge aswell as any man cando lyryng; but yt haith be sene in tymys past that chaynge of worldis hayth cansed chaynge of myncl."

Item, the same Sir Hughe said, that "we be heres now togedres the kyngis true servamtis to lyve and dy, and also to spend all that we have in the world to (lo his grace servis. Therfore watt so ever we spekt or comyn for his surtie, and for the surtie of this his toune, canbe no tresone; so good yt is that we loke and spcke of thyngis to come as well as thoos present. I do speke this for a eause that is good that we loke The king's sadly to, for the kyngis grace is but a weke mam and health syklow, not lykly to be no longe lyvis man. Yt ys not men in longe sithens his hyoues was syke and lay then in his lingland maner of Wangsted. Hyt hapned the same tyme me rifferently to be emonges many grett personages, the whiche fele as to who in communicacion of the kyngis grace and of the world cued hin. that shouldbe after hym yf hys grace hapned to clepart." Then he said that some of them spake of my lorde of Buckyngham, sayng that he was a noble man and woldbe a ryall ruler. Other ther were that spake, he said, in lykwyse of your troytor Edmond De la Pole, but none of them, he said, that spake of my lord prynce. Then said master porter to hym, "Have ye never broken to the kyngis grace of this mater?" Then said Sir Hughe Conway to hym agayn, "I pray you souffer me to tell forthe my talle, for I amnot yet athe ynd. Ye have in mynde wat that I have shewed you touchyng this matris. Of my fayth, in lyke wyse sythens my comyng I have shewed the same to Sir Nycholiss Voux, lieutenant of Gysnes, and to Sir Antony Broune, lientenant of the castell here, and they answeryd me both this, that they lad to good holdes to resorte unto, the wiche thay seirl sholdbe sure to make their paxce, ho so ever the workle tourne." Then my master youre depute, and master porter, 
A.D.1503? boyth said to hym that he conld no lase doo but shew thes matres unto youre hyghnes. He said that, " Hyt ware good that the kyngis grace knew thees sayyngis, but asyet I have not shewed hym no part theroff, nother never I wildo." Then said master porter to liym angrely, and sware by Godis precious soule he be the mose to blane to liepe suche matris from his hygnes; and in lyke wyse said my master your depute, and all we beyyng there.

But it is Iten, after many wordis spoken touchyng the to disclose sime, Sir Hughe Conwaly said, "Yf ye knew kynge such Harry oure master as I doo, ye woldbe ware how that matters. ye lirake to hym in ony suche matres, for he wold take $y^{t}$ to be said but of envy, yll wille and malis. Then should anion have blame and no thanke for his trouth and good mynd; and that have I welle proved here to fore in lyke causes, for that tyme that the when Con-lord Lovell lay in Colchester a trysty frend of myn way gave came to me and shewed me in councell the day and tion of lord tyme of hys departyng, and of alle hys purpos. I was trigues, the sworen to hym that I should never utter thys to man ling was lyvyng to hys hurte; butt yet forthwith after wardis, with hine for rensing and whewed hym all as is abowe, and forthrith he said informant. that Miaster Bray shewed the same unto the kyngis." Wheruppon I was brought byfore hys hygnes and I aftimed to be true as my seid frend hade shewed; and the kynge said that hyt could not be so, and resoned with me alwayes to the contrary of my said sayynger. At last he asked what he was that told me thms tale of hys departyng. I prayed hys hygnes to pardon me, for I said that I was sworen to hym that I should never atter hym, to he drawen with wyld horsses; wherewith the kynge was angry and displesed 
with me for my good wille. I shall no more tempt hym A.D.1503? wile I lyve in sucho eauses." Then said master porter, "I thynk that ye drast never speke thees wordes to the kyngis grace as ye have rehersed them now here," and he sware many grett othes that he dyde.

Item, my master youre deputie said that "I knowell It was iong that the kyngis hyghnes is harde of eredens in suche before he matres; and that knowe ye," he said, "master porter, sir James aswell as I, for how longe was yt er hys grace and tyrell's hys councell wold belyve ony thyng of untrothe to be in Sir Jame ${ }^{1}$ Tyrell; and some said I dyd seke to do hym hurte for malis.

"Item, a nodre tyme I dyd wryt unto his hygness sir Robert that oone hade shewed me that Sir Rober' Clyfford Clifford should say liere in this tome to a lady that Perken clared PerWarbeke was kynge Edwardes sone. Never wordes kin Warwent coldre to my hart then they dyd. Hys hygnes the son of sent me sharpe wrytyng agay that he wold have the Bdward prouffe of this matier: I hade no witines then but my sylfe; but as hyt hapned afterwardes I caused hym by goon crafte to confesse the same he had said to me be fore hym that was marshell here at that tyme, and els I hade lykly to be putt to a grett plonge for iny trothe. At the last al thought that hit was not to shewe this to youre grace withont better proffe; yet master porter said yt was grett pitty that the linge dyd not tryst hys true knyghtes better; and to geve them credens in suche thynges as they should shew for hys surtie, for giett hurt may come by that mene."

Item, after this the treserer said, "Master depute and master porter, what daunger be we in now, remembryng all thynges welle, for we have no suche holdes to resort unto as thees other men lave, consydryng also oure many enymies that we have in this tome and 
A.D.1503? els where tinat wilbe glade to distroy and nurdre us all yf other should come to the kyngis grace then wele. A book of And for trothe I knowell that he cumot longe conprophecy tynu for hyt is wryten of hym that he shall no longer. that Ifenry laygne then dyd kynge Edward, wiche," he said, "was VII. will but xxijte yere and lytle more." Then said my master. nonger" than youre depute, "I by sherve lys liart that so dyde Edward wryte, and also I pray God send all them that thynk IV. dict. the same tobe true a shorte shamfull rlethe." The treserer said agayn, "We maly not be angry in this matris when we shall comyn for the surtie of oure sylfes aswell as of this the kyngis tome, for I thynk not veryly thus to be all true that I have said, but I knowell that every manys mortall and must dij, and that that I have siaid I shall shew you my boke that shall declare you the same playnly to be as I have said and spoken." Master porter said, "Then I pray you, master tresere, brene that boke, and a vayngens take the first wryter."

Item, then said my master youre depute to mastel Convaye, "I pray you leve thys profyciyng of the kynge, for ye spelie of thynges that I never kepe never hire nor see, and that my prayer is that I never leve day nother oure longer then the kyngis grace and hys ehylile shall have and inyoye the realme of Inglond." And likevise spake master porter and we all beyng there.

There is Item, then said master Conway, "All this that I danger to have spoken is to thentent to have all thynges to be Calias as made sure for the kynge and hys chyldre, and specially fong as this hys tome of Calis; and that cane never be done is in the without good and wyse commucacion had of the same castle. byfore; for I tell you for surtie that that shall never be aslonge as the lady Luse shalbe in the castell, that we cane sure the kynge of thys hys toune, for the castell is the kay of this tome; he that is therin beyng of a contray mynd may lett mon inow in 
oone nyght to distrij us alle wyle we shalbe in ome A.D.1503? beddes sleepyng. I know, masters," he said, "wat longeth to suche matres better then ye do; therfore I pray you seuffer me for to speke. Lett not us If the king: thynk the contrarij but and the kyngis were ons were to die departyd, she beyng in the castell here and Fdmond help her De la Pole hire cosen at hys lyberte, hont that mumb It she wolde helpe liym in liys causes with all hire la l'ole. poure and to lett hym come into this toune by the postren of the castell to the distruceion of us alle. Remenbre welle how uy that Kent is hydre, wat a lyans thay be of there." He spake of Sir Edward Poynynges, Sir Rychard Gylforth, Sir Thomas Bonchir. Wat he sail of ther demener, master porter, yf youre grace eximmen hym can' shew youre liygnes better then I can do. Also he said, "Remenlore all the company of this the kynges retenu here, wat ille mynte. they here minto us that wilbe all redy then to follow hyre mynd as they doo now, and to don us the most myschyfie thay cando:" and named Rychard Wodhouse and John Clynton speris. Item, Raynold of the Chambre, a constable of the retenn, with other. "Thees men," he said, "never lovyd the kyngis grace, nor never wollo, with many mo of the same mynd within this tome. Now I lave shewed all the wyrst. This be a sherwile company sett in yll mynde. Dont ye not but this will falle in dert. lut good prorysion be made for the remedy in tyme."

Item, then sairl my master your depute, "Yf suche thyng shall happen, as I pray God that I never leve to se, the kyngis grace to departe byfore me, hut and $y$ t please Gorl that he shall so do, to be for the surte and use of my lorde prynce and for all my mastris childre to have this toune alle tymes at ther owne wille and rule; and rather then yt shouluh otherwyse I hade lever sonffer dethe. And we do wysly, I doutnot but hy good comnsell we shatbe athe 
A.D.150:? by good polici to clistrii alle the captayns and ryngledres that be of yll and contraigj nnyde; that done, the other wilbe good to rule. So I tryst that we shall alwayes licpe the tome and marches to the kyngis use and hys." More of this touchyng this last artycle was spoken, wiche is not now perfetly in my remenbrans; but well I remenbre that everyman named oone to ryde the wrold of, yf suche daunger should come to pase, as I tryst never to se by Godis grace, whon ever preserve youre hygnes.

Item, by the fayth that I bere unto my Savyour Cryst Jhesu and to youre hygnes, this byfore rehersed was the sayyng of every of them as nyghe as I kan call now to my remenbrans.

Recapitula- Thees folwyng be the wordys that Sir Hughe Contion of the charge. way dyd speke in the hyryng of Sir Rychard Nanfan, knyght, youre depute of Calis, Sir Sampson Norton, your porter there, Welyam Namfan and John Flamank.

First, he seid that the kynge is but a weke man and syklow, and not jykly longe to contynue; therfore good yt is that we see for oure owne surties aswell asfor the surtie of this hys toune of Calis.

Item, he said that my lorde chamberlayn was a stronge and mighti man of men in the kyngis courte aswell as within this the kyngis toune of Calis and els were, and said, "Put yt that he be true as ony mam lyvyng to the kyngis grace now, yet chaynge of worldes haith caused change of men myndes, and that haith be sene many tymes.

Item, he said that the firthermust that he could ever se or rede of the kyngis grace was that he should raygne but as longe as kynge Edward dycie, whiche he said was but xxijti yere or lytle more.

Item, he said that when my master youre clepute, and master porter wolde have hym, he wolde biyge 
hys boke of profici to Welyam Nanfan, and he should A.D.1503? rede $y t$, wiche should playnly declare the same.

Item, he seid that the kyngis grace lay seke aboute a iiij. yeres past in hys maner of Wangsted ; "At wiche tyme," he seid, "fortuned me to be in the company of many dyvers and grett personages, the wiche as at that tyme hapned to commune of the kynge oure master, and wat world shouldbe yf hys grace deperted, and hoo should have the rule in Inglond then. Some, he said, spoke of my lorde of Buckyngham, that said that he woldbe a ryall ruler, and so gave hym grett prees; and other of them in lykwyse spake of the traytour Edmond De la Pole, hut non of them, he said, spake of my lorde prynce."

Item, he said that he hade shewed all this mater to Sir Nycholas Voux, lieutenant of Gysnes, and to Sir Antony Browne, lieutenant of the castell in Calis, and said that ther answere to hym was saying that they had too good sure holdes to resort unto, the wiche should make ther peaxce hoo ever the worlde tourne.

Item, he said that the lady Luce was a proude hij myndyd woman, and lovyth not the kyngis grace, and that Edmond De la Pole was hyr kynnysman, to whom, he said, she wildo all the plesme and helpe she cando in the wrold, and that yf any thyng should come to youre grace other then wele he doutednot but she wolde lett hym by the postren of the castell to the distruccion of us all.

The cause and ground whij and to what intent he spake all thees wordes by me here wryten my master, youre depute, and Sir Sampson Norton, whoo herd all the same, and soo dyde Weliam Nanfan in lykwyse,

\footnotetext{
It appears from the Privy Purse expenses of Henry VII. (Excerpta Historica, 123) that the king was at

Wanstead in December 1400, which was probably the time refered to.
} 
A D.1503? that cane shew and dechare alle unto youre hygnes moche better then I cando. Butt by the faythe that I owe and bere unto my Savyoure Cryst Jhesu, and to your most noble srace, I herde hym speke all thees worles in ther presens, with nore then my poure mynr cane serve me to declare unto [your] hygnes.

Item, I have herd master porter and Welyam Nanfan saij dyvers tymes, that they have herd Sir Hughe Conway say that ther shouldbe never more popys in lome after hym that is now, nother kynges in Inglond after youre grace.

Item, upon a tyme I brought a letter to Sir Hughe Conway, that Sir Nycholas Voux had sent to my master. After that he harl rede the same letter to thrend, he toke me by the arme and said to me, "Brodre Flimank, thij master and master porter benot aswye as I wold that they were; for now may Je ser that other men cane have knowlyche dayly of every thyng or grett mater that is done in Tnglond and we cane have no knowlych of nothyng but by them. This is not goor, nother no sure waye for us. T have often tymes spoken to them to have a sure and a wyse man to lij a boute the court styll at oure coste and charges; he may all tymes send us how the world goyth. I pray you tell them that I wille bere halfe $y f$ that hyt should cost me $x^{\text {li }}$ a yere, rather then to leve this to be done, for God knoweth how sodenly a change may fall;" with many more wordes touchyng giett peryll that my fall $\mathrm{y}^{\mathrm{f}}$ this be not don.

Youre most lanly sugett \& selvamt, John Flamaits. 


\section{XXVII.}

\section{Ferdinand II. to Henry VII.}

[Orig. in Record Offlee.]

Serenissmo principi Henrico, Dei gratia Angliæe A.D. 1504. regi, fratri nostro dilectissimo, Ferdinandus eadem 24 Nor. gratia Rex Castellæe, Legionis, Aragonum, et utriusque Sicilie, Granatie, etc., salutem et prosperorum successum incrementa. Accepimus litteras vestras quas Ferdinandus Dux orator noster ad nos attulit, qui ea omnia fideliter nobis retulit que secum ace cum doctore De la Puebla, oratore nostro, super materias spectantes an augmentum affinitatis et amicitia nostre et ad reliqui negotia contulistis. Mirum itaque in modum in primis delectati sumus cum certiores facti sumus de salute et prosperitate vestra. Propter nimium enim amorem quem erga vos gerimus non minus vitam et prosperitatem vestram quam propriam nostram exoptamus. Oblectati preterea sumus de salute principum, communium filiorum nostrorum; nam quamvis de illorum ac vestra incolumitate et secundis rebus sæpe per litteras istic factas certiores reddamur, cum id ipsum per personas qua oculata fide omnia nobis particulariter enarrant, uti nune Fernandus Dux fecit, ingenti afficimur gaudio. Quamolrem obnixe vos roganns ut semper de salute et incolumitate vestra nos certiores reddere velitis. Quantum vero ad dictas materias que ad augmentum affinitatis et amicitice nostro attinent, consideratis ingenti inter nos amore aretissimo affinitatis et amicitise nostre vinculo, cognita praterea magna virtute vestra, laetabimur mirum in modum, cum affinitas et amicitia nostra modis omnibus quibus poterunt augeantur, atque id quamcitius fieri poterit ut fiat et concludatur curandum est. Et quoniam ad ea que circa hoc per eundem Ferdinan- 
A.D. 1504. dum Ducem oratorem nostrum nobis referre fecistis, 24 Nor præfato doctori De la Puebla, oratorj. nostro copiose respondimus, obnixe vos rogamus ut illi plenam et Ferdinand indubiam fidem exhibeatis. Creterum eidem doctori De Puebla De la Puebla oratori nostro dispensationis bullam mitthe bull of timus, quam sanetissimus papa noster concessit ad dispensa- matrimonium celebrandum dietorum principum commarriage munium filiorum nostrorum, eidemque super ea re of Henry scribimus quxe ipse vobis referet, cui iterum ut fidem rine. adhibere velitis oramus. Demum, priusquam Ferdinandus Dux hue appulisset, redditre nobis fuerunt litterre vestree quas Anglico harmm latori ad nos deferendas dederatis. In quibus mentio fit litterarum quas a nobis petitis circa vestrorum subditorum oneranda navigia in regnis et dominiis nostris. Primum igitur ut vobis morem geramuis, tum ob ingentem amorem et indissolubile affinitatis et anicitixe vinculum quxe inter nos sunt, tum quia rolumus quod subditi restri ita in regnis ${ }^{1}$ et dominiis nostris tractentur aesi nostri essent subuliti, tum etiam quia pro certo habemus quod absque ullo discrimine nostri subditi tamquam vestri in reguo et dominiis vestris tractabuntur, litteras nostras super id ut petitis in pelle et Latina lingua seriptas et nostris manibus signatas, sigilloque nostro plumbeo munitas robis mittinus, quarum vigore subditi vestri navigia sua et subditorum nostror'um libere onerare poterunt in ommibus regnis et dominiis nostris; quas quidem litteras per ommes portus regnorum et dominiorum nostrorum publicari jussimus, ut ommibus note sint et per ommes serventur. Serenissime rex, frater noster diloctissime, Omnipotens Deus regiam personam et statum restrum diutissime et felieissime custorliat arl roti. Datum in oppido 
Metina Del Campo, vicesima quarta die mensis No-A.D. 150 . vembris, anno millesimo quingentesimo quarto.

\section{Yo EL REY,}

Almaçan Secretalius.

Achlressed: Serenissimo prineipi Hemrico, Dei gratia Anglia Regi, fratri nostro dilectissimo.

Fndorsed in the land of Sir Thomas Wriothesley, "Ferdinandus king of Castelle to the kinges Ma te." This endorsement was roubtless made alsout the time of Henry VIIL.'s divorce from Catherine of Arragon.

\section{XXVIII,}

The Bistrop of Worcester to Henry VII.

[Orig, in Record Office.]

SACRA Regia Majestas, post humillimam commen- A.D. 1505. dationem, Sc. Jam arbitror intellexisse potuit ma- 17 Mareh. jestas vestra per breve apostolicum, et per instructiones The Pope al. Johannem Paulum fratrem meum una crm ultimis to go to litteris missis, placuisse summo pontifici ut ad majes- with the tatem vestram venirem, et bullas originales dispcnsa. dispensationis matrimonialis afferrem, legitimasque causas dila- tion forriage tionis earundem, et animi dolorem ac molestiam quam a copy of Sanctitas sua contraxit ex transmissione ab Hispaniis been sent in Angliam copire dictarum bullarum, quam ad ulti- to spain mam consolationem serenissima ac Catholicissime consolation dominæ Helisabeth Hispaniarum regine morientis ora- of Queen tori istic suo concessisset sub fide et sacramento lier deatl silentii ac taciturnitatis, coram majestati vestræ ex- bed. ponerem, cum nonnullis aliis privatis negotiis, quae mihi in mandatis datura erat; et insuper sacrum cusem, quo potissimum majestatem vestram ex omnibus principibus Christianis hoc anno insignire voluit eidem presentarem. Sane si quid unquam votis optare, ref 
A.D. 1505. non immerito forsitan expectare potui ex hoc ponti17 March. ficatu Sanctissimi Domini nostri, cui me Altissimus affinitatis vinculo astringere dignatus est, satisfactum est amplissime desiderio et expectationi mere, assequutus sum cumulate, et supra votum quod continue expectavi ex eo tempore ex quo aliquid esse incepi sola gratia et benignitate majestatis vestræ. Tandem concessum est creaturæ vestræ ad auctorem factoremquo suum redire; et eum coram intueri revisere et venerari, cui non solum fortunas et facultates debeo, sed quod vivo, quod spiro, quod omnino aliquid sum eidem acceptum refero. Quam profectionem meam ad majestatem vestram, quoniam pre creteris omnibus mihi gratissimam habeo, brevi accelerabo, et intra paucos dies ex Urbe me experliam. Non dubito quin adventum meum clementia vestra pro sua erga me benignitate et humanitate laetanter suscipere dignetur, et humilem creaturam suam eo vultu aspicere quo me ab humo tollere dignata est, et tot immortalibus beneficiis, honoribus ac dignitatibus honestare. Quibus cum nulla gratia mere pares esse possint, silebo potius quam infinita ejus erga me merita inepte recensendo minora faciam; sed me ipsum peisonanque meam cidem coram reverenter tradam; sum est quicquid ago, quicquid cogito, quicquid cupio. Rogo non verba, que debitum meum exprimere non possunt, sed corpus, spiritum et animum qui totus ex illa pendet, benigne accipiat, et ita de ne sentiat, meipsum milhi ipsi tum demum placere posse, si cum ad illam vencro inveniam aliyuid a me factum quod majestati vestrae placere intelligam. Quan opto ut Altissimus diutissime conservet felicem, et cui interim me quam humillime commendo.

Novitatum nihil in presenti est quod auribus majestatis vestra dignum putem, proterquam quod superioribus dicbus Sanctissimus Dominus noster in regrotatiunculam levem incidit, quam, acceptis quibus- 
dam pilulis, statim rejecit, atque in pristinam salutem A.D. 1505. continuo Sanctitas sur restituta est. In rebus autem ${ }^{17}$ March. que Sanctre Romanxe Ecclesire statum concernunt Sanctitas sua die noctuque vigilantia quadam inira repetitura creditur quicquid occupatum superioribus annis fuerat, et nunc cum Venetis egit ut magna tcrrarum pars quas sibi ab ecclesia verterant, eidem Sancte Romanie Ecclesice restituatur. Reliquum est ut me iterum clementissime majestati vestre quam humillime commendem. Rome dic xvij. Martii I.D.V.

\section{Excellentissime Rijostatis Vestrie \\ Factular et humillimus subditus, \\ Sill. Episcorus Wigorniensis.}

Post scriptar venit in mentem meam dignum esse ut majestatem vestram certiorem facerem de legatis sive oratoribus regis Polonire, qui superioribus diebus de consuetudine in Urbem suscepti, primam eorum audientiam a Beatissimo Patre nostro in publico auditorio die x. Martii superioris habuerunt, atque ipsi Sanctissimo Domino nostro obtulerunt varia munera, ct quae summam duorum millium ducatorum caperent.

Addressed, Sacre Regie Majestati.

Endorsed in a 16 th century hand, apparently Brian Tulse's, "the xvijth of March 1515." 


\section{XXIX. \\ Gardinal Hadran de Comneto ío Henri VII. \\ [IIolograph in lecord oftice.]}

A.D. 1505 .

23 Oct. Sacha Regia Majestas, humillimas commendationes Had urged Quoniam his mensibus R. dominus episcopus Wintonithe Pope to ensis ${ }^{1}$ scripsit Sanctissimo Domino nostro et mihi de illa punish the falsitate comperta istic in bullo episcopi Menevensis," the bull of rogans quod sua Sanctitas pro justitia et honore suo the bishop et Sedis Apostolicae provideret ut illi falsarii punirentur
of St. David's; et non transirent sine debita aninadversione, et hoc ipsum episcopus Lincolniensis ${ }^{3}$ etiam sure Sanctitati et mili per proprios cursores eorum sumptibus scripsit; et how fecerunt tanquam boni episcopi et pro fervore justitice et jro jurmento quo astringuntur papae et Ecclesice. Jigo etian ab illis et eadem ratione prastiti juramenti, et quia Polidorus seripserat mili per plures suas, prarum copiam mitto nujestati vestre, quod tenbaverat mentem vestram et eratis contentus, et ita rolebatis quod justitia fieret; et quia etian Sanctissimus Dominus noster, his omnibus lectis et visis, sic voluit et mandavit; propterea scripsi majestati vestre et diligentian adhibui ut onmis hre falsitas in lucem prodiret, et veritas claresceret, non credens neque credere debens quod restre majestati in aliquo quod placuit displicuisset. He hee est mera ef pura veritas. Quare vestra majestais dignetur neque ipsis dominis episcopis neque mihi, servitoribus vestris fidelibus, aliquid imputare. but, as he Poster cinm intellexi per literas meorm vestram now inderstands. majestatem mutasse propositun, et ubi jrins iogabat

1 Richard Fos. of St. David's on the 1: April

2 Robert Sherborne, afterwards 1505.

bp. of Chichester, was made bp. ${ }^{9}$ William Snith. 
ut fieret justitia, nunc . . . ${ }^{1}$ nia feci et firciam A.D. 1505 . pro viribus, et quantum in me erit, ut vestra majestas the king cognoscat nou stare per me quo minus sibi satisfiat. wishes Et jom fui cum pontifice et usque ad reprehensionem cifully oravi ut illis parceret, nec de catero yuoad potero desis- dealt with, tam nt, si possibile sit, pontificis hactenus immutabile ceded for propositum flectatur. Et in hoc et in ommibus conabor them. obsequi voluntati et mandatis vestre majestatis, cui me humillime commendo. Ronre, xxj Octobris, 1505.

\author{
Vestrie Majcstatis \\ Servitor humilis, \\ Hadrianus Camdinalis S. Chrysogoni.
}

Nova nulla hic sunt, nisi de matrimonio Hispanie, et multi multa loquuntur de vestra majestate, sed quid sit verum adhne nos latet. Veneti continuant occupare illis duas Ecclesice civitates, tamen sunt valde territi de pace ista que dicitur inter hos dnos reges, et etian acceperunt magnam jactmam in aromatibus qua passim veniant de illis insulis per Portugallenses repertis. Florentini quiescunt sine civitate Piscrum. P[a]pa, intellecta compositione hujus pacis ruie dicitur facta inter istos duos reges, dixit mihi of multis aliis cardi. malibus dum essemus in civitate Conneti, in qua egro natus sum, "Isti duo reges diviserunt sibi vestimenta mea, sed illis significari fecimus aliqua super" his. Videbimus qua sequentur." Poster dixit nihi soli post conam quod offerebant Ecclesia sum amnum censum, et quod habebat literas a Gallia quod vestra majestas dabat illustrissimo principi suo nato illam puellam Dinguleme. in uxorem. Dixi non posse me hoe credere cum jam essent contracta sponsalia per verbir

\footnotetext{
'Paper gone.

Margarot, daughter of Charles duke of Angoulume, sister of

Fiancis 1. See State Papers of IJenry VIU., vol. viii. p. 663.
} 
A.I. 1505. de presenti cum filia Hispanire, media dispensatione $2: 3$ Oct. sure Sanctitatis, et quod hoc . . . . . . . ${ }^{1}$ regi Hispanise. Respondit quod scribitur sibi quod in hoc consentit inse rex Hispanice. Nunc vestia majestas habet quæ nova audivi a sua metuendissima Sanctitate. Die xxij Octobris, Rome.

Vestrae Majestatis humilis Servitor, Hadrianus Caris. S. Chrisogoni.

\section{Ex literis Polidori ad Curdinulem $S^{\text {ii }}$. Chrysogoni datis xxv. Junii 1505.}

Tentavi primum voluntatem regis ut casu quo Sanctissimus Dominus noster provideri vellet, sicut certe opus est, recte sciret quod regia majestas pro justitia favebit. Die xxij. prasentis . . . . . ' tem sum et rem ab ovo narrare copi, que benigne mihi respondit, lixitque quod parata semper erit favere Sedi Apostolicie ejusque honorem fovere, et ut nunc Sanctitas sua possit crimen persequi dominus Wintoniensis scripsit Sanctitati sure rem omnem.

\section{E. Tileris ejustem, iij. Septembris}

Comes Nuntius cum literis et brevibus Sanctissimi Domini nostri datis $x$. Augusti venit hue, quibus lectis statim ivi ad regem ot suas reddidi ejus majestati, cui naravi quo studio et juris rigore, ut decet, Sanctissimus Dominus noster persequitur hos falsarios, eamque oravi ut in presenti idem faceret, quandoquidem majestas sua jam habet negotium in manu sua, sicut illa his diebus prope Gilfort mili dixit, se desiderare, videlicet, ut pontifex sibi scriberet. Tunc majestas sua multum sane commendavit Sanctissimi Domini nostri justitiam et severitatem in istis

\footnotetext{
${ }^{1}$ Paper gone.
} 
rebus, nam aliter omne decus curiae Romane periret; A.1. 1505. et dixit se lecturum literas et breve pontificis, mox 2:3 Oel. mihi responsurum. Posthec sua majestas rocavit me, dicens, "Policlore, ego vidi breve Sanctissimi Domini [nostri et] ${ }^{1}$ literas cardinalis, et cognovi desiderium pontificis, videlicet ut isti falsarii puniantur sicut merentur; quod dignum et justum est quod pro rei magnitudine egomet unacum comsilio meo volo hoc negotinm bene examinare, et dum ero Londoni ommia adimplebo, et guod provisum est satis quod isti qui sunt suspecti non fugient. Et ita scribatis cardinali ut nomine meo referat pontifici." Et quia, ut videmus singulis diebus, magna ris est pecunice nbique gentium, cavendum at quod Sinctissimus Dominus noster non flectatm literis alicujus hominis guominus hi falsarii puniantur, cum prasertin tota patria haec rem hanc cognoscat, ut de illa sencx, foemina, puerque loquantur, et certe non possem rerbis explicare quibus laudibus domini hujus regni et alii ommes efferant Sanctitatem Domini nostri ejusque [justitiam] ${ }^{2}$ arlmirentur, utpote qux ita prater spem istorum cmialium cuaverit tueri honorem Sedis Apostolice, de qua nonnulli sunt qui adeo male sentiunt, qui ommino credebant quod minima pecunia isti omnes impune evaderent.

\section{Ex literis ejusclem, xx. Septembris.}

Mater regia, mulier sanctissina, jromisit se locuturam cum serenissimo rege ut nullo pacto favent falsariis, sicut ipsamet scribit in suis literis ad clovainationem vestram. 
A.D. 1505 . 2:3 Oet.

Ex literis ejusclen, arj. Septembris.

Regia majestas perstat in sententiam in isto negotio falsariorum, et dicit yood non vult impedire justitiam sed ipsamet dabit operam ut examinentur et debita animadversione pmiantur.

Ex literis Johannis Hans alterius ministri mei in Anglia, arij. Septembris.

Majestas regia replicavit siepius quod nou obliviscerer scribere ad dominationem vestram quod volebat omnino fieri justitian. "Absit," inquit, "quod velim eam mpedire; sed," incquit, "ad Sanctissimum Dominum nostrum scripsi in commendatione Wigorniensis sic . . . p pietate motus, tamen volo expectare responsum a sua Sanctitate prinscuam alind scribam."

Ex literis ejusctem, arv. Septembris.

Die xxij. hujus allocutus sum regiam majestatem, que milhi dixit quod isti episcopi dederant cantionem de comparendo esse representaudo omnes quatuor sue majestati ad summ beneplacitum sub pœua iiijor milium librarum; item, quod scripserat ad archiepiscopum Cantuariensem et Londonicnsem ut exequentur commissionem Sanctissimi Domini nostri, et suam celsitudinem esse dispositissimam omnia agere secundum crood moxine Sinctissimus Dominus noster suis literis jusserit, adeo quod omnis res consistit in responso quod dilbit sua Sanctitas.

Ere literis ejoclen, ultimu Septembris.

Majestas regia iterum atque iterum dixit mihi quod isti non sunt ita culpabiles ant criminosi ut dicitur;

- Paper' gone. 
"quod si ego," inquit sua majestas, "scirem ipsos esse A.D. 1505. reos talis delicti sibi impositi, ego sum is qui primo 23 Oet. animadverterem in eos." Hoc certe siepius mihi dixit, et quod non videbat neque audiebat aliquid fieri in Urbe; in quo corte etiam concordat dominus Wintoniensis qui dixit quod nihil factum est in Urbe de illis incarceratis. "Et quare," inquit, "non fecerunt processum et miserunt huc?"

Sacra regia nuajestas, omnia ex literis originalibus legi sapius Sanctissimo Domino nostro qui dici non posset quantum laudaverit vestran majestatem quie sit ita bene dispositil erga justitian et pro honore Sanctitatis suce et hujus Sanctie Sedis, dixitque et jurejurando aftimavit se non prosse aut velle aliquo pacto parcere illis falsulis, etiamsi essent sui nepotes; quod etiam scribit per sum breve vestra majestati, et addidit quod non potest sibi muquim persuadere quod vestra majestas, quae supradicta omnia dixit et aftirmavit, velit favele potius falsarius in tali ac tanto [facinore yoam] Sedi Apostolice in justitia, et quod cst et erit semper hujus frmi et immutabilis propositi, et sic mandavit etian mihi ut scriberem. vestra majestati ; et mittit processum authenticum contra cos hic formatum, qui non potuit ob absentiam ipsorum falsariorum plenius formari, scribitgue illis archiejiscopo Cantuariensi et Londonensi ac Norwicensi episcopis, expectatque cum snmmo desiderio et firma opinione quod vestra majestas satisfaciat justitice juxêa tot promissa vestrce majestatis que supradictis literarum clausulis continentur, neque vult audire quenquam pro illis loquentem, et sape increpiut diversos qui eos ${ }^{2}$ misericordia aut amicitic moti eos ${ }^{2}$ comnendabant, Et his diebus dum Conneti esset s[ua Sancti]tes et quidam Bartholoin:us Dorsini, Lucensis, affinis episcopi Wigorniensis, lituras episcopi et majestatis vestre Sanctitati 
A.D. 1505. sure reddere veliet, pontifex ei dixit ut si amplius 23 Oct. ante conspectum sum accederet enm talibus literis projici eum faceret de fenestris, noluitque literas episcopi accipere; solum illas legit quie restra majestas ei mittebat. Postea, die Meremii, eum accepissem a Johanne Hans literas de ultina Sepitembris per proprium eursorem mira celeritate allatas, ivi ad Ostiam ubi erat sua Sanctitas, narravique qualiter vestra majestas etiam tertias literas commendatitias seribere pro eis decreverat ad suam Sanctitatem, sua Sanctitas severo vultu et tubato fronte adnodun hae audivit, disitque carlun, viclelicet, yuod non posset sibi persuadere guod vestrir majestas sit aliud factura puam totiens et ultro dixerit, et quod novit integritatem et constantiam vestre majestatis, jussitgue illi breve ut supra clixi suribi et processum et alia nitti per proprium ac eelerimum cursorem, quem voluit omnia deferre et brevia ad vestram majestatem manibus propriis consiguare, aliquidque . . . . . ministris murmurando suspieari visa est. Credat majestas vestra quod in similibus sua Sanctitas est rigorosa et ut dixi immutabilis, nee est homo vivens qui possit suam Sanctitatem ita deliberatim aliter Hectere. Volui omnia vere et seriose seribere vestrice majestati, quæe pro sua sajientia et justitia omnia recte disponet, eui me humillime eommendo. Romie xxiij. Octobris, 1505.

$$
\begin{aligned}
& \text { Vestre Regie Majestatis } \\
& \text { Hunilis Survitor } \\
& \text { HAdruxus Caris. STr. CHrYsogone. }
\end{aligned}
$$

Sacrat Regia IIajestati Anglie. 


\section{Ednund De la Pole to Thomas Killingmorth.}

[Addit. MS. 18,738, Brit. Mus., f. 8. Holograph.]

Tomas Kellengwort, I prae yov goe yn to Bremryrissceles to the king, and speke yov with my lord Wele, and with ys broder, and recomand me to them, de serreng them to be my govd frendes as my spesale treust ys yn them. And that yt veld ples them to remenber me to the $\mathrm{K}$. And that $\mathrm{yt}$ vold ples the K. that ys gras vold be so god lord to me that I met he hovt of thest manse hand, for as I her that ale the land saeys planle he vele nat com to the $K$. And ef $y t$ lie so the $K$. mae se a lekleode wedder the dewke vele com at hem or nat; stresting my lord my cosons, bovthe my lord Vele and my iord Fennes ys hroder the vele" have me yn rembererans, as the hovt ${ }^{3}$ promes me. I ame her by the kinges comand ment, and ys ats grad to do the K. pleser and sarves as onne mane. And sae thest vordes them "Ef I vare $y$ the fardes yent of the vord, I veld be at ys comand ment to forelfele ys plessor. and comand ment as hone sarrant of ys ys hovs." Marke vele thest and do yt vesle, and planle, with govd and lovle as you kane.

Also go to yenker Flovrens, and sae I recommand me to hem; and sae to hem that I send yov spesale to hem for my heelepe be chescheng ${ }^{5}$ hem to speke to the K. for me, as ys vrytrn be fore; bovt yov mae nat let my lord Vele chake ${ }^{6}$ that yov come

1 Philip, king of Castile.

" " they will."

3 "they both."

f "wisely."

5 " heseeching."
${ }^{6}$ chate cheke, i.e. know. The word occurs frequently in suffolk's jetters, but nowhere else so fir as the Editor is aware. 
A.D. 1505. to yenker Flovrens, for hon of them lovef nat a nodder. Yov mae sae I ame her, and that the dewke of Gelder send me no vord vat I sale do, nor heelpes me nat with notheng, as Petter aale chove yov, bovt vane yov com therechove the Baster ale your masches ${ }^{1}$ and fale nat the of.

Vat letters vat that the Baster sent you to Anssterdane vryt me yt yn Ingles.

Also I prae the Baster to send the menes I mao have som remede to have mone, ${ }^{2}$ for ther vele none of my frendes vele heclpe me with a pene, as yov ma chowe hem as yov have haneser fro Pole ${ }^{3}$ welyes ${ }^{4}$ I be her with the dervke of Geller. Also, ef you se the $K$. of the Romes mak me recommand dase amurs ${ }^{5}$ to hem, and as yov yov ${ }^{6}$ cheke $^{7}$ hove the mater stovd be teven the $K$. of Romes and mo, chev yt. And sae "the favt vas nat yn my lord, for my lord provfferd of yovr gras veld en terten my lord for to monnet ${ }^{8}$ with xij hores, my lord vas vel contend to bcerl yovr fluser, and rane my lord vas gone I loor be liend xx lays to cheke" your plesser," with ferder as yov thenk hest.

EDMUND SUFFolk.

\footnotetext{
"show the Bastate all your | "my recommendations." "mescage." "sic.

" "money"

"Qu. Paul, i.e. Paul Zachtlerent? " " "fon'two months,"

1 "whilst,"
} 


\section{XXXI.}

Eduund de la Pote to [

丁.

[MS. holograph in Record Office.]

急

*

*

*

wyt a letter to my lord Fennis and alletter to yes broder of recommand daseom as lovwele as yov kane.

To my lord Chevers cosene yn my harteles wes ${ }^{1}$ I kane I reeommand me to, deserreng yov to be my govd frend. And, coson, yt has plessed the k. gras ${ }^{2}$ that I hame yn yovre hand to bed ${ }^{3}$ ys gras plesser, wehes I have ben and voled be glad to hes gras plesser and sarves ef yt be yn my poovre. I deser yov, cosen, to beches the $k$. to be my govd lord as I have gevef ys gras kas and vold do wele I lenf." Cosen, I prae yor that yt vold ples yov to gevf credens to thest berre.

Prae . . vele as yov kane for mony for . . . . for nonodder manner chov my lord Chevers yt ples the $\mathrm{k}$. to send me ger, ${ }^{6}$ bovt $\mathrm{I}$ have nodder doblet nor crest nor hoos, and I vas fane to be fover ${ }^{7}$ for my goun for la . . d. And ef yov have mone send me a bonenit of reed and with aggelevttes as that I vilre vane yov vare her bovt lett yt be govd.

Speke to my lord Vele and to my lovrd Fenes, I sitrest the $k$. vele lett me have some vatte to spend; and chove them that I vas fane to be fovre" for my gomes that the k. sent me and dobbeletes, as I have sade be fore.

\footnotetext{
1 "heartiest wise,"

" "the king's grace," Philip king of Castile.

3 " bicle."

"cause, and rould do while I

"live."

5 "this bearer",

" "my gear."

"as I have given his grace " "to buy fur."
} 


\section{Edinum de la Pole to Thomas Kildingworth.}

[MS. holograph in Record Office.]

TOMAS KELENGYORT, I have, reseved yovr letter, and also my schertes, and to cheerges, and a bonete, I thanke Clakes' Bakker. I marrele yov sond me nat my naggeletes," and my haste "and bedes. I toked yov mone for yt, and thenke yov met vele send me that that I thake yov mone for ; bovt I se vele ef I thake yor no mone yov rold make bovt letaile cheeufe for me. Ther restes in yorr handes more thane xij. geldranes of the mone that Petter thoke yov to be my ger, ${ }^{4}$ and also the mone vas as gevd mone as coode be. Yov have done viesle to send Parrelebene to my consene Nevele to port me to more coostes. Yt vas nat my commandment that yor chorld do so. Me thenke yov do nat riesle nor honestele. I have notheng bort bovt ${ }^{5}$ yov have $y t$, and yor purt me to ale the coste, nat so meches as gakre (?) bort I vas fane to geerf heme mone for ys retrovre, and yeet yov sent nat me my ger, that I thoke yor mone to be ${ }^{6} y$ t. And ale that I marvele nat so mes ${ }^{7}$ as of yov, and of John Grevforn, that you send nat me vord with yn viij daes. A vas yovr a pontement with me. I vis yn that kas that I vest nat ${ }^{8}$ vat vas best to do ; for I had vent" yov and John boovt ${ }^{10}$ hatd heen trovbovld; and ef yt hat ben so, parraventer

1 Clukes. This word doubuful. There was a Nicholas or Claus Baker in the succeeding reign, who is mentioned in connexion with Richard De la Pole.

$\because$ "mine aiglets."

3 " hat."
1 "buy my gear."

${ }^{5}$ sic, apparently a word repeated.

¿ "buy."

r "much."

" "in that case that I wist not."

s " weened," i.e. thought.

10 " both." 
I vold a found some remedie for my cheelvf, bovt be A.D.1505? yovr bout folles ther met a theng a happenid veches ve ale met a repentte. Loke vat dae yov a pont me to have vord frome yov. Fale nat the dae. Ve sal her: the K. ys nove cerstond . . . Also the capetene has vord that the $K$. of Romes has send for me my naggetels iiij. pore, a nodder rede bonet. Thest ys to lettele a gret dele, my beddes my chekves for ale thest yov have mone, for the reng I her no vord of yor.

Let me have vord for yov with ale hast, as yov have vord form the marchand, and also as yov her vord of the $K$. Cheis vele with the herres for mone for me as veille as yov kane; yov mile sae I ame vele, and of I hade mone. Ef you se the Bastard Oskereke, sae I vort to you that I marled I hard no vord of hem. He chekes ${ }^{1}$ bettst hove I stand her; and of he be the mane I thenke he be, me thenke he nnct best spreke that I met have some honestle en tert:nement with mone. And tele hem, thove he has for me, I have nat fore geet lem. And I strest hones for ale thest to make heme grovd cher with govd maner, and pavt hem to the speches for $y t$; bovt be you nat bee vane he spekes. ${ }^{2}$ Also chove hem of my xx geldrens for the months of $\mathrm{xx}$ stevers for the geldrens, and yet I most bed tele the monthe be hovt ${ }^{3}$ or I kame have my gret and honorerabovle entertanement.

Yov hade $\mathrm{x}$ geldrens for my chertes, and the cherggs veches I hade, and a geldrans for my caskeet; ver be comes ale the todder mone? Provf vele for my reng.

Ediund Suffolis.

1 See page 258, note 6 .

" "but be you not ly wheu he speaks."

3 "bide till the month be out." 
Richard De la Pote to ims prother Edmend.

[Lddit. MS. 18,738. Brit. Mus., f. 12. Iolograph.]

Str, I ombully recomaund me on to your grace, Sir, I beseche your grace gyf credens to Stase towchyng soche mater as ys brokyn to me of, and of the sayd mater that I may shortly have answare how ye wyll stonde in thys cawse.

Sir, I beseche your grace semd me som what to helpe we with all.

$$
\begin{aligned}
& \text { Be your lovyng broder, } \\
& \text { Rintind Siffolk. }
\end{aligned}
$$

A.D. 1505.

6. July.

\section{XXXTY}

\section{Passport for THOMAS Kethagmorti.}

[From the Original in the Record Office.]

Lreve gheminde. Alzo Thomaes Killingwort, Engels man, mijn goede vriend, my to kennen ghegeven heeft hoe dat hij zeker saken te doene cule rolgen heeft in den landen hior ontrent, ende besnmder op ende over

\section{Thasithon.}

Dear and well-belorel-Wheres Thomas Killingworth, Englishman, my good frimd. has given me to understand that he las ertain things to do and exeente in the lands hereabouts, and espocially upon and leyend the Zuyder Zee. we 
der Zuyder Zee, Begeeven daer omme an u lied ende A.D. 1505. an elcken van u besondre, dat ghij den selven Thomaes 6 July. veylick wilt laten passeeren, gaen, ende keeren, doende zijne vornaemde affairen ende saken, Behonden dat de selve syne zaken in geender manieren hindedic ${ }^{1}$ scadelic noch lettelic wesen en sullen der K. M., zijnen landen, noch onder saten voors. In Kennessen mijns handteckens hier onder ghestelt, den zesten in Julio, anno $\mathrm{xv}^{\mathrm{c}}$. vive.

Uwe goedwillende, Schout van Amstordamme, overste ende superintendent der Wapeninge, opter Znyderzer, geordonncert bij der K. M.

Jo. BANNICKER. ${ }^{2}$

notify therefore to you and every one of you that you will let the same Thomas freely pass, go and come, doing his aforesaid husiness; provided that the same his business in no manner interfere with the interests of his royal majesty, nor his countries. In witness whereof I have subscribed my signature liereto, the 1st July 150J.

Your well-willer, the "sehont" of Amsterdam, chice and superintendent of the "Wapeninge," appointal ly the King's Majesty.

Jo. BANXICKER.?

\footnotetext{
Sic MS.

2 Signature doubtful. Initial letpressed by a k, with an abbreviation mirk. $\tilde{k}$. ter $B$ or V. 'The last syllable ex.
} 

oTHERS.

[From copies in Riceord Office.]

Desiring Frdeusstre mi amice, ego me vobis affectuosissime hispre- recommendo, maximas vobis agendo gratias propter Jattem. vestras bencvolentias et amicitias mihi et meis semper gratissime approbatas; que omnia, Deo farente, ita adeo considerabo quod spero in paucis diebus ad mag num vestrum honorem elit. Et qua in causa modo extitero non est vobis ignotum credo. Propteren, si vobis placuerit hue in civitatem de Hattem mili renire, ego ad hoc ros justantissime desidero et quxso pro cortis causis meam utilitatem concernentibus, cujus rei ficluciam in vobis pro creteris omnibus ad vestri alventum propalabo. Lt rogo quod credentiam super hoc velitis adhibere domino Waltero nei capellano, hujus liter:o latori. Valeatis in bono. Raptim in civitate de Hattam xxriij die Julii anno xr. C. v.

Et ros exoro, mi amice, ut ibi in vestris partibus intimos mei singulos amicos ex meis rerbis salutetis. Itermm vale, hominum constantissime.

'lo my frend Pauhus Zachtlerent in Amsterdammiis.

To the Salutes plurimas. Vestro maxima benevolentic et "schout" amicitive amice mi prastantissine, quas non solum in dam. nos, verum etiam in nostris gratissime habuistis, nonnullas dominationi vestra gratias nos semper referce cogunt. Qua nt in re perseverare amicabiliter velitis, dominationen vestram instantissime qureso causa ob quan pracipue vobis modo literas dederim; hac est, credo quod dominationi vestre non latet, quod Dei provichentia et meturndissinni regis Catholici subrentione et tuitione, nos ex castro, et si verius dicam, ex carcere deliberari, et in civitate modo de Hattam per 
paucos dies moram trahere, ubi id quod nostri com-A.D. 1505. modo fieri ${ }^{1}$ possit nobis providere necesse est. Quan- 28 July. obrem nostro amico fidelissimo Paulo Zachtlevent jamjam literis nostris significavimus ut nostri desiderio sibi placuerit sie nos cum omni diligentia visitare. Nam et vestri et sui et aliorum nostrorum amicorum auxilium admodum nobis implorandum est. Dominationem vestram proinde affectrosissime exoramus quatenus ad hoc vestri consilium sibi adhibere dignemini. Et hoc unum pro firmo sciatis, si Superi id faveant at res an vota prosperius succedant, nos semper and vestri optata et desideria paratissimi fore, et hac pro vobis: in brevi facere confidimus, quod imperpetum et vestri et posteriobus ${ }^{2}$ vestris in maximum erit honorem. Valeatis.

Sculkteto in Amsterdammis.

Plurimas salutes et dilectionis affectum. Honorabiles To the buret aplrobatissimi domini, viri consultissimi. Vestres andComeil omnes humanitates et amplissime amicitice quas nobis, of $\Lambda$ ix et post nostri a civitate vestra decessum carissimo nostro fratri habuistis, nonnullas dominationibus vestris gratias nos semper referre cogunt. Qure omnia, Deo favente, si vixerimus, erga vestri dominationes considerare plenarie speramus. Et quamquam sinistra fama din retulit nos hic an placitum proprium et voluntatem exstitisse, prudentias vestras non latet existimo, et vos et creditores diversimode alias per nos certificari contrarium. Et si plures fortassis ad id credentiam minime adhibnere, verumtanen jamjam omnibus cujusque generis rei veritas experta est. Superis Had placed quoque attestamur quod singularis causa hujus nostri himself in periculi et incarcerationis et ita nos posuisse in manus or the duke (ucis Geldrice sub sui salvo conducto, nullo certe alio of Gueldres affectu fuit nisi ut libere sui patrian preterire potuis- deavour to 
A.D. 1505. semus, et quosdam nostri amicos pro debitis creditorum 28 July. solvendis approbasse. Difficultate hujus adversitatis satisfy his non obstante, nunc Dei provisione civitas de Hattem and is now et nos cum castro in manibus regire majestatis Castellæe delivered sumus deliberati. Et si res adeo prospere successit ut hands of speramus, et maximas vestri benevolentias et gratisthe king of simas vestri amicitias, ut decet, ac etiam creditorum
Castile. debita quam citius nobis possibile erit totis nisibus promereri conabimur. Et super hoc nobis profecto gratissimum semper acciderit quicquid pro dominationibus vestris nos licite reddere possimus. Et ut mentibus creditorum de his satisfacere velitis, prudentias vestras instantissime quasumus. Valete, hominum constantissimi. Raptim de civitate de [Hattem.] ${ }^{1}$

Vestri Amator perseverandissimus.

Venerabilibus dominis, burgi magistris et consiliariis civitatis Aquisgrani, viris prudentissimis, suis amicis constantissimis.

To his Charissime et mi dilectissime frater. Figo me tota mother. mentis affectione vobis recommendo, fraternitatem vestram certificando civitatem, me et castrum de Hattem in manus regice Castellie majestatis jam fore redditos. Et non est vobis ignotum, charissime mi frater, credo, quod super salvum conductum ducis Geldriae me sui patriam prateriisse proposui versus ducem Saxonia et comitem de Guidon pro quibusdam promissis inter nos factis, et pracipue pro debitis creditorum obtinendis; pro qua singulari causa in his periculis diu steterim; et quamvis pluribus increditum fuit, tamen rei veritas omnibus modo nota est. Et quam cito Deo placuerit me illam potestatem habere (quod in brevi confido), IIopes soon ego et ros ad libertatem reducam et creditorum debitis to sethim at satisfaciam. Ad quam quidem rem totis viribus, ut 
convenit, me penitus applicabo. Interim fraternitaten A.1. 1505. vestram exoro quatenus hoe in omnibus faciatis quod 28 July. est in mei et vestri honorem semper fore possit. creditors. Valeat fraternitas vestra in prosperitate. Ex civitate de Hatten.

\section{XXXVI.}

[Killingwortit (?) TO EDNund DE la POLE].

[MS. in hecord Office.]

Sir, and if your frend liere had not heen, I had sent A.D.1505? to you or this tyme. He tarient soo ling or he sent to you to thentent he woll have certified you of som newes onte of England; but as yet le hath herde noon. And he bad me write to you, that touching you he hereth noo thing but goon; and also he bad me write to you of tharlesting of the shippes in the kinges: landis; whiche men salyc secretly shuld bee for you. And, sir, upon the caas he sigh you in him sylf, he sendeth you iiij elles of the best saten he can bye here, and lynyng therunto, and clothe for ij paire hosen and lynyng. And with this gere he sendeth i servant of his own for fere it mighte bee taken from Sir Water ${ }^{*}$ [and also, as me scemeth, to thentent his servant maye see howe ye stande; for I perceived by the sculken ${ }^{4}$ he mistrusteth your cala. ${ }^{5}$

For your gown he axked me howe many elles velvel wold serve you. I told hym xiiij. Enghishe yerdis; and then he saicl, "What lynyng theremto?" I answerde "Sarcenet" by cause of the lest coste to helpe it forward. And he saide to me, "Wel, I shal sec what I can doo therin." Soo, sir, if it please you to wlite to him in Duche, and thank him, and geve but oon worde therein

\footnotetext{
1 Probably Paul Zachtevent ${ }^{3}$ De la Polc's chaplain montioned mentioned in the preceding doch - at page 260 . ment. tile. 
A.D.1505? towching your gown, I doubte not ye shal have hyt. And as to the helpe of my lord Nevyll ${ }^{1}$ and your servauntis, and for the looste in Zwolle, I meved him therin after your mynd, and thus muche I perceive that [seing the povertie ye bee in $]^{2}$ that my lord Nevyll, I think he wol helpe of a gown and a bonet, but further he speketh not, neither for the payment of the hoost nor yet for the helpe of your servamitis. And also he sayeth ye spake not to hym of noo suche thinges. And, sir, and ye had therin spoken playnely to hym, it hat been otherwise. For he is a kynde and a frendely man, and oon worde of your own mowthe had been worth an c. of an other mannys. LAnd, sir, for your servantes some remedie must bee founden. Ther shulbe elles werke ynough to doo]. And, sir, . . . ${ }^{3}$ ele you to write ${ }^{4}$ the cause of my lord Nevill and your servamtis and the . . ment of the hoost in your said lettre. I trust some good shal comme therof whiche shalbe for your honour, for oon remedy or other must bee founden, or elles ther shalle . . . the . . . and your servauntis, and . . . to know your plaisire therin also . . . shewed.

Nowe, sir, this day on Lady d . . Mr. Paul shewed ne $^{5}$ certain specialites and writinges under the signe and seal of the duc of Yorke $^{6}$ concernyng money as was due to hym by my lord of Yorke ; and, sir; under this maner he brak to me. He wolde fayne helpe you and bee also hable to doo you good service at the point, and this is his manyng. Howe bee it, therin noo thing wol he doo, but after your own mynd and plaisure. If it pleaserl you to bee content, he wold send by a bode of this towne to king Herry the copyes of suche writingis and dueties as the duc of Tork oweth hym under notaries signes, desining hym

\footnotetext{
'Doubtless Sir George Nevill. | 'joyne, corr.

2 These passages struck out with st brake to me, corr. the pen.

${ }^{3}$ Faded.

${ }^{6}$ Perkin Warbeck.
} 
where as he laath lent his goodes unto the due of A.D.1505? York [which was the right king of England, and that $]^{1}$ seing that loe is dede without payeng, that it wolde please king $\mathrm{H}$. to paye to hym tive same noney; and if king H. wol not soo dho, as he is sure he wol not, then he wold shewe king II. plinynely that he wol leane to you and ayde you with his body anl goodes to lis power. This is oon waye whereby he wold perceive king H. answer. Item, sir, another waye is this. Paulus was borme in the Estland in the due of Pombernes lindes joynyng upon the king of Denmarke landes, whider dailly resorte merchantes of England, where the princes of the landes ar his frendes; and therfor, if it pleased your grace, this is lis desire for that purpose. Ye knowe wel thabusion king $H$. hath minle against the due of Yorke that he was a counterfeyt. He desireth therfor to have your certificat that lit is untrue, and your anctorite, and if it please you to sette your signe manuel ${ }^{2}$ to this parchement that this bringer shall, ${ }^{3}$ and upon that the same writing salbe made here, if it bee your pliaisure. ${ }^{4}$ And theruppon he trusteth by the helpe of the king of Denmark and the dnc of Pomberness to have recoverey shortely ${ }^{5}$ of this good upon some Englisshe merchauntis, and that in short tyme [if your cause goo not wel] and helpe yoo therwith; and to thentent your grace shal perceve it is his owne desire he hath subseribed it with his owne hand, and also he sendeth your grace therwith the secret tolsen bytwix your grace and hym; which secret token he beseecheth your grace to sende hym again by this bringer.

Endersed:- Van der Visser Rosen.

\footnotetext{
1 Struck out with the pen.

" and seal struek out. Sic.

"elles if you" grace wol cause it to

"bee made there, at your plaisure

" he referreth it."

"iff-plaisure] corr. from "or ${ }^{5}$ Interlined.
} 
A.D. 1505. 4 Aug.

\section{XXXVII.}

\section{Tie Bastalid of Orskerk to [Killingworth ?]}

[MS. in Record Uifice.]

'Their master is in the hands of the duke of
Gueldres; mayn de duc de Gheldres par le commandement du roy; et sus este avecques, et monseigneur mon maistre ma comande que me laissiez savoir se maistre Pouwel est venu, que au cas quil soit venu que il vucllie venir, et vous aveeque ly, jusques a Waghenynghe, car la paix est, et quil peult bien venir seurement pour parler a monsicur nostre maistre. Se au cas est quil fait defeculte pour venir en la ditte ville de Waghenynghe envoye missier Wanter oa aultre quelcunq. Monseigneur nostre maistre lem envoyra ung saufconduyt de par le due but does de Gelres pour venir on quelque eure quil vouldront not wish et scurement. Et monseigneur le maistre, monsicur,

\section{ThaSLATION.}

Moxsenatert le maistre, I recommend myself to you, letting you know that my lord our master is hronght into the town of Wagenymghe into the hands of the duke of Gueldres, hy command of the king. And I have been with him, and my lord my master has commanded that you let me know if master Patul (?) is come, that in case he be come he would go, and you with him, to Wagenyolse, for it is peace, and he my come in security to speak with my lord om master. If les make any difliculty to come into the said town of Wageningle send Sir Walter or any other. My lord our mastel will send them a safe conduct from the duke of Gueldres to come in anfety at whaterer hour they please. And my lord 
vous commande que vous tenez bonne maniere et que A.D. 1505 . vous ne parlez point trop, et tous ses gens et servi- 4 Aug. teurs; et leurs dites aynsy, car monsiegneur nostre to complain maistre le veult et est hien content de estre la puil est, et je men voye pour cersier tout son cas enver le roy. Et vous savez bien comment les seigneurs ont parle a ly, et il vent tout sur ung pourpos; et tenez pourtant bonne contenance, ear tout est pour bien par la grace de Dien, la quello vous garde en bonne et longue vie. Escript a Arnhnem, le iijo jour de August lan xv.c. et cinc.

Le tout vostre amy,

Griffon B. DE OYSTERK.

Monseigneur nostre maistre se eommande bien annyablement a monseigneur Nevell et at tons aultres ses hons serviteurs, et leur prie guil soint bien content, car leur maistre est bien content.

the master, monsieui, commands you to keep a good manimer, anch not to speak too much, and all his people and servants; and you shall tell them so, for my lord on master wishes it, and is quite satisfied to the where he is ; I am going to somul al! his ease with the king. You know well how the lords have spoken to him, it is all with one purpose ; keep, nevertheless, a good conntenance, for everything is for good by the grace of Ged, which I pray to preserve you in good and long life. Written at Arnlien the the of Augubl, 1505.

Your chtire firiend, Grafon bistime de Oyshinis.

My lord ont maste commends himself in nost loving wise to my lorel Nevill and all his other good servantis, and prays them to be satisfied, for theru master is satisfied. 
A.D. 1505. Monseigneur le maistre, sachiez que Sir Water a este ycy mais est retourne sims parler a moy on quelque aultre serviteur de nostre maistre, par quoy je ne say que response il a apporte, et pour tant jour ceste foiz rien plus vous ne saly escripre. Et sachiez que je fuisse desja reparti envers le roy on liait de nostro maistre, se ne fuisse que je attens pour savoir la response que Sir Water a apporte, et ay pourtant envoye ung messagier apres ly pour savoir la response de ly. Lt me laissiez anssy savoir response de vous, et se ledit marchant est avecque vous le confortes et ly dites hardiment quil ne sochie de riens, et je escry aussy une lettres a ly, et envoyez noy lir causse de monseigneur.

A numsejgneur le maistre serviteur des monscigneur de Sullolk.

Monseigncur le Maistre, understand that Sir Walter lais been here, hit las returned withont speaking to me, or any other servant of onr master; wherefore I know not what answer he las brought, and accordingly at present I linow nothing more to wite to you. And know that I would already lave departed torards the ling on the business of our master, were it not that I am waiting to know the answer that sir Walter has brought, and have accordingly sent a messenger after him to know the answer from him. And let me also liave an answer firom you ; and if the said merchant is with you, comfor't him and tell him boldly he need not le anxious aloout anything. I am writing a letter to him also ; and send me my lord's canse.

To my lord le maîte [d'hîtel ?] rervant of ny lord of Sulfolk. 


\section{XXXVIII.}

A.D. 1505.

\section{Stipulation for the Ranson of Ediund De ia Pole.}

[IIS. in Record Office, corrected drilft.]

Presens seriptum testatur quod ego dominus Carolus dux Geldria, ${ }^{1}$ etc., tractavi, concordavi, et promisi Griffoni Bastardo Doysekerke, famulo domini Edmundi ducis Suffolchire de Anglia," quod pradictus domims dux Suffolchio solvat ant solvi faciat prafato domino Carrolo de Gleldres ml. ml. millia ${ }^{3}$ [florenorum] ${ }^{4}$ pro expensis ejusdem ducis Suffolchire et famulormm suorum in terra Geldrensi sub forma sequenti $;{ }^{5}$ videlicet, quingentos aureos infra octo dies datum prosentium immediate sequentes. Et infra tres septimamas dictos oeto dies inmediate sequentes alios quingentos aureos. Et infia duos menses predictas tres septimumes immediate sequentes, mille florenas, in plenam solutionem prodictorum 111. n1'. anreormm. Et predictus dux Geldria ${ }^{6}$ est contentus et per presentes tenetur seipsum esse contentum de predictis $1 \mathrm{~m}^{\mathrm{l}}$. $\mathrm{ml}$. mille aureis, sic quod Anthonins de la Vaale, mercator Ispanice, commoranss in oppido Andewarpensi, vult eidem domino Carolo pro eisrlem peeuniis esse respondens sub forna nt predictmm est. ${ }^{7}$ Et immediate cum prodicti primi prenominati quingenti anrei sunt ${ }^{8}$ soluti predicto domino

'dux Gelliria, etc.] Corr. from de Ciheldies.

2 de Anglia] Corr. from consanguineo meo carissimo.

"Sic, pro duo millia.

4 Om. in MS.

${ }^{5}$ prealirtus dominus dux Suffolchice - sequenti.] All this is an interlineation sulstituted for the following words which formerly stood in the text:-pro duobus millibus flurenis
24 Sept. 
A.D. 1505. Carolo duci Geldriæ, et promissio habita super obligatione 24 Sept. prædicti Anthonii de la Vale pro solutione de residuo pradictorum duorum mille florenorum eidem domino Carolo sub forma preedicta, ${ }^{1}$ idem dominus Carolus dux Geldriæ firmiter promisit et promittit per præsentes quod immediate super hoc faciat predictum dominum Edmundum ducem Suffolchiro habondum suam plenam libertatem, eundum de manibus et terris suis ad placitum et voluntatem ejusdem domini Edmundi sine ulteriori dilatione. In cujus rei testimonium hoc presens scriptum ego predictus dominus Carolus de Gheldres manu propria subscripsi, ${ }^{2}$ vicesima iiijta die Septembris, anno Domini millesimo quingentesimo quinto.

A.D. 1505 . 17 Nuv.

\section{XXXIX.}

Ednund De la Pole to the Bastard D’Orsekinke. [MS. in Record Office. Copy.]

BAstart, je me recommende a vous. Jay receu vostre ${ }^{3}$ lettres par Hans, et je suys bien joyous de vostre retoume, car jay forte doubte du departement

\section{Transiation.}

Bastard, I recommend mysolf to you. I hare receired your letter by Hans, and I am very glad of your return, fir I hal great fears of the departure of the ling before

'sub forma pradictu] Corr. from a st sigillum meum apponi man"1' prediclum est. 
du roy devand vostre venue, vieant le caas en lecuel A.D. 150\%. je suys; car, comme vous savez bien, cy le roy fuys departe que je ne savoye de nul luy entendre le plaisir du roy. Surquoy jay envoye le maistre dostel denver vous, an la entencien que vous et luy ensemble faisent tout le diligence que vous poves denver le roy et son counsail pour moy et pour mees causes, en telle manier que vous dire. Et touchant les lettres que monsieur de Shevers ay envoye ycy au le receivour pour lentreteynement de mees servitures, le receivour ay responde an Donpeter que il ay parle an monsieur de Sheviers depuis que le lettre este fait, et que mul choise fuyt escript dedens le lettre touchant moy et moes servitures. Et touchand mon frere et roy Henry, jay espoir que jay bottre le matier in telle suretie quo mon frere doyt faire comme je vouldray quil faiste en tous choises, et que il [ne] laisseray point defaire pour nul damgier ne povertie du monde. Et pour lo conduit de ceste chois jay ayde an mon frere avecy mon argent.

your arrival, secing the ease in which I am; for, as you know well, if the king were gone I should not be alble to learn from anybody the pleasure of the king. Whepefore I have sent the steward to you to the intent that you and he together nse all the diligence yon ean with the king and his council for met and ny causes in such manner as I will tell you. And tonching the letters which my lord Chieveres has sent hither to the receiver for the entertaimment of ny servants, the recoiver has answered to Don Peter that he has spoken with my Lord Chievres since the lotter was writen, and that nothing was written in the letter tonching me and my selvants. And touching my hrother and king Incmey I hope that I lave put the matter in such security that my brother shall do as $I$ wonld have him in everything, and that he will not neglect to to so for any dimger or poredy in the worlt. And for the management of this thing 
A.D. 1505. Et ainsy1 il fault que jay luy ayde plus bien brief $1 \%$ Nov. comme jay luy promise par mon escript que ch . . . je fi. ... an monde. ${ }^{2}$ Et Dieu vous garde. Escript a Namur les xvij. jour de Novembre.

Ausy, cy il est possible, Bastard, trouveres vous le manie pour argeant pour moy ayder pour mon frere et envoyes moy incontinent. Et parles vous meisme an $\mathrm{Ha}[\mathrm{ns}]^{3}$ Wittershaw pour argeant.

Au mon servitur le Bastart

Le Oyselinke.

I lave helped my hother with my money. And also it is nexessary that I help him very shortly as I have promised him ly my writing that . . . . . . And God preserve you. Written at Nimur the 17th day of Novembre.

Likervise, if it be possible, Bastand, find you the means for money lor me to help me for my lnother and send [it] mo forthwith. Aud speals yourede to Ma[ns] Witlershaw for money.

'To my servant the

Bastard of Oysekiste.

\footnotetext{
'ainsy]. Probahly for aussi.

"aultre amye comme mon maistre

2 il fimelt . . . monde ]. Interlined over the following words, which have been struck out :- “ jay luy "ayde avecd c. flolens par ung

" dostell vous dire."

${ }^{3}$ Paper worn. The final dash of the $s$ fitintly visible.
} 


\section{Richard De la Pole to ilis brotimer Edaund.}

[From a copy in the Record Ofice.]

\section{Sine,}

JE me recommande humblement a votre grace. Vous plaise assavoir que les bourgoys dAix sont retomne di roy de Cistelle. Quel response il ont eu je no scay, mais dedens iij jours apres leur ievenue vint a moy Mirtyn hoste du Pot, et diverse aultres, en lil rue Impatience recontrant, en demandant de moy leur arcent. To of be la leur donne la milleur response que je scens pour les ditors. contenter. Au derrein il me dirent "Votre frere est lo pluis false homme que uncques fuyt de sa promesse, ot nous voullons faire a luy comme il doit estre serrye. Nous luy voullons metrre sus en ceste ville et tons aultres villes partinent a lempire, que tout le monie sarra quil este ung false homme parjure; et nous vouilons avoir notre argent de vous. Et sy vous ne voullons ${ }^{1}$ trouver remede pour nous, nous avons ${ }^{1}$ trou-

\section{Thenglatox.}

Sine,

I necommen myself hmully to youl grace. Please it you to know that the burgesses of Aix have returned from the king of Castile. What answer they have had from him I know not, but within four days after their return came to me Martin host of the Pot, and divers otliers, meeting me in the street, and demanding their money of me. I gave them the best answer I could to ratisfy then. At last they said to me, "Your brother is the falsest man that ever was of his promise, and we will do to him as he ought to be served. We will acruse him in this tow and alt the other town belonging to the empire, that all the world niay know that he is a filise perjured man; and we will have our money from you. Am] 
A.D. 1505. vere le remedie pour nous meismes, et pour tant en 21 Nov. toute haste faictes nous votre response."

Sire, tant que je pris persevoir il ont quelque comforte pour ce faire que de mettre votre grace a telle deshomnor et moy ainsy au deshonnor et graunt danger de mon corps; car je suys advise de deux persones Henry VIr quy sont mees bones amyes, que le roy $\mathrm{H}$. ay desire has offered des bourgois dAix quil moy deliverent trois lieuwes get Rich- hors de la ville dAix, et il les pairay. Et ainsy ung ard De la Pole into his power. suis tue sur la rue, le roy Herry leur pairey leur argent. Je pense bien verytablement que se soit fait a nin que je soye mieulx contente de faire le plaisir au roy H., lequel este de vous abandonner et de feire comme il me commandre de faire: lequel serroit a votre deshonneur et de moyen tout le temps de notre vie. Neantmeyns, sire, se vous voullons faire envers moy comme jay deservie et comme ung frere doit faire a son frere, lequel este ycy en ostage pour vous, et que je puis veoir que vous faictes le mieulx pour moy pledger

if you will not find a remedy for un, we will find one for ourselves; and therefore make your answer to us in all haste."

Sire, as fur as I can pereeive they have some encouragenent to do this, putting your grace to such dishonor, and me also to "lishonor and great personal danger ; for I am apprised by two persons who are my good frieuds, that ling H. has desired the burgesses of Aix to deliver me three leagnes out of the town of $\Lambda$ ix, and he will pay them. And so I am advised no longer to go into the street, for if $I$ am killed in the street, king Henry will pay then their money. I think in very truth, it was done to the end that I might be the more willing to do king Henry's pleasure, which is to abandon you and do as he shall command me; which wonld be to your dishonor and mine all our lives long. Nevertheless, sire, if you will do towards me as I have deserved, and as a brother ought to do to his brother who is here in hostage for you, and I see that you do the best to 
dhors accordant a votre promesse, vous moy trou- M.D. 1505. vereys votre loyal frere viengne que en venir porray. 24 Nor.

Sire, que vous desire semblement, sy pour caas este que lees bourgoys vous mettent sus en ceste ville ou je suis, a votre grant deshomnor et le moyen, comme il diste quil veulte faire, faictes votre mieulx pour vous declairer ung homme loyall, comme ung bon et loyall homme doit faire, comme vous moy voulles trouvere votre bon et loyal frere, comme vous avez faict, et tous jour's ferez en ce faisant. Vous plaise de dommer credence au Ewstas, porteur de cestez. Sire, jay ony nouvelles de Derik. Jiry esperance quil nons apporteray sauns accune fanlte bonnes nouvellez. Rien pluis, cy non que Dieu vous domne bonne et longue vie. Escript a Aix le xxiiij jour de Novembre lan $\mathrm{xv}^{\mathrm{c}}$ cince,

$$
\text { par votre loyall fiere, }
$$

RichaRd SUfFoLK.

A monsien mon frere.

ransom me according to your promise, you wili find me your loyal brother, come what may.

Sire, I request you likewise, if the case he that the burgesse's accuse you in this town where I am, to your great dishonor and mine, as they say they intend to do, do your best to declare yourself an honorable man, as a gool and honorable man ought to do, as you would find me your good and true brother, as you have done and always will do, in so doing. Please it you to give eredence to Eustace, bearer of these. Sire, I have heard news of Derik. I have hope that he will bring us good news without fail. No mole, except that God give you good and long life. Written at Aix, the 24th day of November 1505 ,

by your loyal brother,

To my lord my brother.

Richarid Suffolk. 
A.D. 1505. 27 Nov.

Ediund De la pole to Oyskerk and Kinhingworth.

[From a copy in the Record Office, subjoined to the preceding.]

I Have sent you a lettre by this berer which I praye you shewe to my lords Ville and Feynes, that they maye shewe it to the king; for what it is T cannot saye, but sythens the burgoys of Acon were with the K. they bee more herder both of there dedes, and also of their wordes. Howe it comes or by whom I cannot saye, but me thinketh if the kinges conseill had been my frendes it lad not been after this manier. Wherfor I ean see noon other remedic but my bro. ${ }^{1}$ and I both must loke wel upon this matier and wol doo. I have great mervaille I here noo words from you howe my matier goes, and that I know not the kinges plaisir in Notwith. noo thing. I have been in his hands thise iiij. monethes standing and mor, and you ij. were the messengiers that broughte Plilip's promises, he ean get in him. He was my good lord, and wolde doo for me no relief,

and lis brother is in great damger. me worde from the king that I shuld putte noo doubte many things, but I cannot perseyve it. I lye here to my paine and shame, and also spende what I canne gette of my frendes, and i have noo thing but feire wordes; wherby I an as a man undoon by your message, and also my broder like to be delivered to $\mathrm{K}$. H., ${ }^{1}$ or elles to be dryven by force to forsake me, or elles to be slayne in the towne of Acon by the borgoys $;^{l}$ and alle by thie reason of my being here in prison, where I maye not goo to my frends to fynde the remedie, neyther for my broder ner for my sylf. Wherior me thinketh, and if the king were advetized of me and my broder lowe we stande, and al by reson that I am here at the K.'s command, I

' $\Lambda$ mark ocems in the margin of the MS. opposite these passages. 
f'ut noo doubte his graee wol have som regard what A.D. 1505. deunger my broder is in. For my sylf I desire not 27 Nov. soo great hatast, but after that manier as I sent the K. word by Roderik de la Lain, by the bastard, and by the stewerd, wherof I praye you to take good regard. And shewe my lord Ville and my lord Feyneys, as they bee noble men, to remember their promes whiche they made me for the king.

Written the xxvij. dling of November.

E. SuFrolk. ${ }^{1}$

XLII.

A.1).1.30.5?

:31 ber.

Shi Geolge Nevild to Killingworti

[MS. Molograph in Riceord Ofince.]

MALster Steward, I hertyly recommend me unto you, thankyng you for your tokyns ye sent to me by Bir Thomas Grenhyll; I wold I ladde to do yow so grete plesur, but I have nat. Mr. Steward, I pray send Is anxims ne word whedyr ye contynew in that partyes or nat. Ko joilling Iff ye do, I wold be glad to kepe you company; yff worth, on nat, and $y$ ff ye come to this parties I shall make you ho have in lii as sure as ony burghgar of the towne. And what ye company thynke best me to do I shalle gladly folow your mynde. ${ }^{\text {at }}$ Aix. I am very loth to tarry hier with owte compeny. Commend me to Sir Water. And I priny you to remembre

The original of this letter exists in the Fecord Ofice in Edmmel I) la l'ole's own hand writing, and h:ts been printed by lillis (I'hird
Series, i. 138 ), in its own extmordinary spelling. It is athersent to the Bastard Van Oyskuke and Thonats Killingworth. 
A.D.1505? me as I wold remembre you, yff I were yn your case. 31 Dee. And ytt lye yn my poure, I shall nat forgete your kyndnesse, by Goddes grace, who evyr preserve yow. Wryten at Haye, the last day of Decembre.

By your frend,

Sir G. Nevylu.

To hys ryght welbelovyd and especiall good frend,

Thomas Kyllyngworth.

A.D. 1506 .

\section{XLIII.}

$24 \mathrm{Jan}$.

Edmund De la Pole's Commission to Treat with HENRY VII.

[Orig. in the Record Office.]

The dis- Be hit knowen to alle princes, nobles, and true pute be- Cristen men, by this present writing, that we, Edmund twing and duke of Suffolk, of England, on the xxvj day of Dehimself, being a eause of troubles in land, by reason that it standeth by twixt the king of
England. England. England and me as hyt doeth.

Wherupon my servant, Thomas Kyllyngworth, my stewerd, axked me wheder my mynd and entent was as I spake it. I answerde "Ye on my faith;" and soo I, the said duc, shewed to liym more largely my said entent and mynd concernyng the same playnely as it is.

The said Thomas therupon hath retorned to me the xxij day of this instant moneth of Janury, shewinge and acerteyning me that he hath openned and disclosed my said entent and mynd to the kinges servant, John Chamberlayn, and that the same John is goon to the 
kyng to thentent to yeve the king undrestanding and A.D. 1506. knowleage of the same. Wherwith I am contented and 24 Jan. pleased. Wherupon I have nowe eftsones of newe Suffolk comyned in this matier, and shewed my full entent authorises and playne mynd to the said Thomas Kyllyngworth, worth and and also to my servant John Gryffyth. And for the Griffith to trust I have in the trowthes to me of the said Thomas adjustment. and $J_{\text {ohn, }}$ I have openned at large to theym my hert in this behalve. And by vertue and anctoritie herof I have yeven to the said Thomas and Johm, and by thise presentez yeve to them jointely full power and anctoritic to have comynycacion with suche person or persones, honnest, God dreding, as shalbe by the said king of England sufficiently auctorized, ordenned, and assigned. And whatsomever they shal on my behalve promise by their worde or writing tonching the premisses, I, the said Edmund duc of Suffolk, promise and bynde me by this my present writing upon myn honnor and faith to God of a true Cristen prince that I shal and wolle faithfully and truely kepe and observe the same in eche point and article, like as I have further auctorized theym in that behalve. In witnesse wherof $I$, the sayd duke, have sette my signemanuell and seall to thise presents, and also undrewritten the same with myn own hand, the xxiiij day of January, the yere of our Lord God a thowsand fyve hundreth and sex.

$I^{1}$ seste my hand to thest yn tent that ale mamner of mene sale chake ${ }^{2}$ that I vele pariorvme thest be forc viytvn, and also vat that the prommes on my be havalf.

Edmund SufFolK.

\footnotetext{
'This paragraph added in Suffolk's
wit hand.
} 
A.1). Liviti. פg Ja1.

XLIV.

Ediendid De al Pule's Instructons to treat with HENRY VII.

[Orig. in Record Office.]

Instructrons yeven by the right excellent prince my lord Edmund duc of Suffolk, the son and heire of my lord John sometyme due of Sufiolk, to his trusty and welbeloved servantes Thomas Kyllyngworth his stewerd and to Joln Griffith, howe and undre what maner the said ducis full mynd, entent, and plaisir ar, that the said Thomas and John shal demeane and handell theym selfes on the said ducis behalve with the kinges highnesse for the pacifieng and fynal determinacion of suche gruges, variances, and causes as ar depending at this tyme, and long saison have doon, bytwixt the kinges said highnesse and the said duc their maistre.

Ednund Suffolk.

To offer FURST, and principally the said ducis mynd is that De la
1'ole's sub- the said Thomas and John on his behalve shal humbly mission beseche the kinges highnes to bee his good and gracious and clesire the King's souverim lord, and that it maye please his grace to parton. withdrawe from the said tue his high displaisir, and to poute alerely onte of his hert suche erugge and malice an liss grace hath had ayeinst the sairl due. And that it also maye like the kinges highnesse to necepte and admitte the said lord Edmund to his cstate ans my lords his grantfinder and finler were acepted and taken in tyme passed: and the said duc is and shalbe realy to receive the kinges pardon and wolbecomme his true sobget and liegeman, and semblably after the ling our sourerain lordes decesse contynue to my lord prince the kinges son and to his heires, withonte eiring or dedynyng from the same, whyles he lyveth.

Edmund Suffolk. 
Secondaryly, the said Thomas and John shal on the A.D. 1506. said ducis behalf lumbly beseche and require the kinges 28 .Jan. grace that it may please his lighnesse, as honour and restitntion noblesse and right require, to restore to the said duc of the and to his lieires alle the homnours, castelles, maners, of Suffolk, lordships and heriditamentes apperteynyng to the said duchie of Suffolk, holly and entierly as the same were lefte to the possession of the said nowe dukes facler, with suche offices as my lordes his grantfader and fider have liad of the yefte of the kinges or princes aforetyme or by inheritance. And over this, that they shal beseche the kinges grace that it maye please his highnes, as right and conscience requiren, to restore to the said duc alle suche sommes of money as his grace or any persones by his auctoritie and commanndement have received, aswele toaching thanmuties of creacions yeven by kinges lon thestat of the said inchie, as of the rovenues of thinheritances aforsaid, from the tyme of the deth of the said duc Tohn to this day; and also to bee restored to such goodes and stuf of howsehold as the same duc had at his departing fro England.

Fonund Sumfolk.

Thirdly, as to the town of Leighton Buzard, which of the king Edward enforced the said ducis fader to relesse to town of the colleage of Windesor, the said rue besecheth humbly Buzzard the kinges highnesse to bee good lord to him therin, and other and that he maye be restored therunto, and that al things thein doon by ny lorkes fader maye bee disannulled by the lawe and by the parliament, the said due restoring to the said colleage suche money as can bee duely proved that my lord his fader received for the same of king Edward, or of the said colleage. S'enblably for the towne and castell of Orford with thapportonances, whiche the lord Willoughby hath; the mance of Filberdes which Sir Richand Gylutond hath; the maner of Hanwel whiche the Coferer hath; and al 
A.D. 1506. othre lands alienned by the said duc, or by his fader to 28 Jan. Sir Water Herbert, or any othre. And also as to the maners of Bulcamp, Hynham, Sirlesterne, and Newton, whiche were relessed to Sir Tirry Robsert son at the labour of Sir William Carewe, that the said duc maye bee also restored to eche of the same, restoring again the money of theim received.

\section{EDMund SUfFolK.}

To ask IIenry's assistance to recover his liberty.

Fourthly, if it shulde soo happenne that the king of Castelle, or the gouvernors of his landes in his absence, after the tyme that the kinges grace and the said duc bee accorded, wil not bee aggreable ner suffre that the said duc shal departe oute of their hands, but kepe him by force, the said duc then beseecheth the king to helpe him to his libertie under the maner as his grace shal seme best. And wher no creatur is sure of his lif it mighte peradventure in the mean tyme happe the said duc to dye, as God forbydde; neverthalas whatsoever maye fortune in this behalf the said dnc wol bee and contynue the kinges truc subject to thend of his lif. Beseching therfor lnmbly the kinges lighnes that incontinent upon the said aggrement hit maye please his grace to suffre my lady the said ducs wif tordre and make officers in his lands as he shuld doo him sylf and to receive the revenues of the same during the tyme he shalbe kept as prisoner by the king of Castelle or any othre.

\section{EDinum Suffolk.}

That if he Fyftely, if it soo shal fortune, as Almighty God die in pri- forbydde, that the said duc decesse withoute issue out male male of his body lieufully begotten and commyng in issue, his the mean tyme and saison of his keping prisoner as
widow may we allowed afore is saied or afterward. That then ymmediatly her join- after the said dukes decesse hit maye please the kinges tire and highesse to permitte and suffre my lady the said ducis 
wiff to have, holde, and enjoye, paicibly and frely her A.D. 1506. jointour in the saicl lands for the terme of he lytr 28 Jan. jointour in the saic lands for the terne of her lyit, his dangl according to the lawe of the land and her right. And ter to inthat also at the humble request, desir, and supplica- herit. tion of the said duc, hit maye like the kinges said highnesse to bee agreable and to accorde, and that at this present comynycacion and tract hit maye bee accorded and finally concluded, that my lady Elizabeth, the doughter of the said duc, shalbe reputed, accepted, and takenne as the doughter and heire of the said luc, and that the same lady Elizabeth and the heires of her body lieufully begotten and commyng for evermor maye holde, possede, and enjoye the hole enheritannces of the said duchie of Suffolk, as above is saied.

\section{Edimen Suffolk.}

Sextly, that it maye plese the kinges grace, aswele for that the the part of his grace and my lord prince as for the part points and suretie of the said duc and his heires, upon such ou may be pointz and causes as shalbe accorded and concluded drawn writing herupon bytwix the king and the said duc, or bytwix under the the king and the said Thomas and John, in the said seals of ducis name, wheder the said pointz and causes bee herin and prinec, expressed or not, of whatsoever weight and substance and conthey bee, that the same maye bee engrossed under the parliament. writing or seales of the king and my lord prince, and also enacted and confermed by anctoritie of parliament under suche maner as shalbe to the king thoughte moost expedient. And also such writinges and bondes as shalbe divised by the king, and made for the part of the said dne by the said Thomas and John in his name and under his seal. For whiche entent the said duc hath to theym delivered his scal and certain blanks signed with his hand, or ells that shallo made by the said Thomas and John, for the part of the said due in their owne names, as it shal please the ling, the said due promiseth and obligeth hym sylf truely to observe and performe the same in eche behalf at the 
A.D. 1506. kinges plaisir in his own person, yf God sende hyme his 23 Jan. lif and libertie, or larger as it shalbe devised by the kings grace.

EDMund SufFolK.

That Wil- Sevently, that it maye please the kinges highnesse at liam Ine la the humble request of the said duc that, incontinent upois others be this aggrement, his grace wil putte to libertie my lord set at li. William of Suffolk, and al suche gentylmen and othre
lerty. jersones, whatsoever personaiges they bee, whiche ar in prison for the said ducis sake or canse, or at the kinges commandement under suretie; and that he and they maye bee restored frely to their goods and ${ }^{1}$ lands, or their sureties to bee dischargeth, as the ears requireth. And that al suche gentilmen or othe persones, whatsoever they bee, that been dede, and have loste their landes for the canse of the said duc that their heires maye bee restored to their mheritances. And over this, that it maye like the kinges aid highnesse to have respect unto Sir George Nevyll, and that the same Sir George maye have and cujoye such lindes as he hath light muto in his own title, or in my lady his wifes touching hei jointon and dower in therl Ryver's lands.

Giterd SUFFon.

Wightely, the said luc faithfuily byndeth him by thise proventez, and promiseth on his faith of a true Gristen prince, or alles nttucly to bee reputed the contrary, that never whiles he lyretl he shal breke nor doo contrary to the said promesses and aggrements, ner defimlte in hym shalbe founden: reving by thise presentz full power and anctontie to the said Thomas and John to eonclude thorongly with the kinges grace, or with his depnties, in this behalf having the kinges power, like wise an the said duc shulde doo if he wer" luesent him syli, the suretio for the said lucis person 
except, and for his snbmission and the maner of his A.D. 1506 commyng to the kinges presence, which the said duc 28 Jan. reserveth, to commone therin hym silf, as he shal see eause to require, with suche nobles and men of honnour of the kinges counsail as shalbe in this partic deputed, and as therin he hath somewhat opened his mynd to his said servantes. And to thentent that thissame maye bee groundely and playnely knowen to all kinges, princes, and nobles, aswele in England, ass elleswher that it is the full mynd, dede, and commandement of me the said duc, I have caused the said Thomas Kyllyngworth, to write thise articles, to every of the which I have sette my haml for record. At the castel of Namure, the xxviijty lay of January, the yere of our Lord God, a thousand $v^{c}$ and sex.

\section{(L.s.) HDMUND SUFFOLK.}

\section{XLV.}

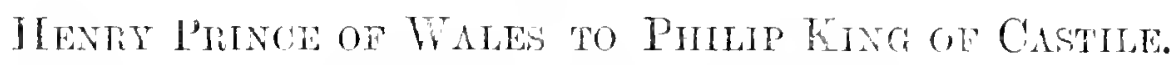

[Addit. MS. 21,404. Brit. Mus.]

Tresinume, tresexcellent, et trespuissant prince, jo In hehalf me recommande a vous le plus afiectueusement of de of the hon cuem que faire pris. Pource que le chambellan catinerines de ma treschere at tresamee compaigne lin princesse chamberma femme sen va presentenent pardevers vous pour going to aucunes matieres ruil dit avoir afiaire pardela, ma spain. supplie et requis vous voulloir escripre en sa faveur.

\section{(Tianslation.)}

Most high, most excellent, and mighty pince. I commend mysolf to you in the most anfectionite and hearty mamer that I can. Whereas the chamberluin of my nost rear and well-beloved consort the prineess my wife is geing at present to you for certiun matter's which he says he has to transact in that quarter, he has requested me to write to you in his favor. I pray you very heartily, most high, 

A.D. 1.506. Je vous prye trescordiallement, treshault, tresexcellent,
$9 \Lambda_{\text {pril. }}$ et trespuissant prince, que le vueillez en sesdites affaires avoir pour recommande, et me vouloir de temps en aultre advertir et faire savoir cle vostre bonne sante et prosperite, laquelle je desire singulierement et de tout mon cueur estre de longue continuacion et bonne duree comme je vouldroye la myenne propre. Et de ma part, quant je pourray recouvrer messagier propice je suis bien delibere de vous faire le semblable.

En me signiffiant, au surplus, sil y a quelque chose pardeca enquoy vous pourroye faire honneur et plaisir et je mectre payne de vous y complaire de tout mon cueur, par le bon aide de Nostre Seigneur, anquel je prye vous donner, treshault, tresexceilent, et trespuissint prince, bome vie et longue. Escript au manoir de Grenewiche, le ix jour davril.

\section{Vostre humble cosyn,}

Henry Prynce de Galles.

A treshauult, tresexcellent, et trespuissant Prince, le Roy de Castille, de Leon, et de Grenade, etc.

most excellent, and mighty prince, that you will hold him recommended in his said affair's, and that you will apprisce me from time to time and let me know of your good health and prosperity, which I particularly ame with all my heart desire to be of long continuance as I would my own. And iol my part, whenever I can find a titting messenger I am letermined to do the like to you.

Moreover, on your intinating to me if there be anything here in which I can to you honor and pleasure, I will take pains to satisfy you in it with all my heart, by the good aict of Our Lord, whom I pray to give you, most ligh, most excellent and miglity pince, good life and long. Writen at the manor of Greenwich, the 9 th day of April.

Tour liumble consin, Henix Prince of Wales.

To the most high, most execllent, and mighty Prince, the king of Castile, Leon, and Grunala, \&c. 


\section{XLVI.}

\section{The Knigitss of Rhodes to Henry VII.'}

[Orig., Cott. Charter VI. 10.]

SErenissmo ac illustrissimo principi, potentissimoque domino, domino Henrico Dei gratia Anglia, Francie, stc., regï. Nos frater Emericus Damboise Dei gratia Sacre domus hospitalis Sancti Johannis Jherosolymi magister humilis, pauperunerue Jesu Christi custos; Et nos conventus Rhodi domus ejusclem, tamquam humiles servitores et clientuli, salutem in Domino prosperosque ad vota successus ac nostram humillimam commendationem premittimus. Noster ordo et nos hic in oriente continuam residentiam facicntes ac bellum gerentes pro defensione Christiani nominis proventus nostros in partibus occiduis hine inde sparsos habemus, quos cum difficultate recolligimus et huc conduci facimus. Preterea, quia proventus ipsi sunt tenues, et ad ipsos multi sinistris viis anhelant, consuevimus protectores habere qui nos et res nostras Christiano nomini dedicatos contra Turcos defendant ut professionem nostram ad honorem Christian:e fidei complere valeamus absque Christianomm impedimento. Quare supplicamus humiliter vestræ sacræe regice majestati, verie catholice et honoris Christiani zelantissima, non dedignetur has nostras literas hilari vultu et lieto animo suscipere qui de vestrie sacrie regia majestatis benignitate, clementia, ac mansuetudine confisi, de nostro deliberato consilio ac certa scientia serie presentium omni meliori via, modo, et forma quibus melius, decentius et magis convenienter facere possumus et debemus, vestram sacram regiam

'A copy of this letier was found | parchment roll larger than the orlately among the Chancery records dinary rolls of Chancery, and conformerly in the Rolls Chapel, on a taining this single entry. 
A.D. 1506. majestatem facimus, creamus, constituimus et solemniter 27 May. ordinamus nostrum nostrecque religionis et militice per Nominating him universum Christianm orbem et in suis inclytissimis Protector regnis protectorem, fautorem, patromm et defensorem, of their obnixe et affectuose ipsam rogantes ut ordinem ipsum
Order. ejusque milites et negotia in sua benevolentia recipere et tenere velit tamquam suos deditissimos servitores, et ipsos defendere et protegere contra cuoscumque molestatores, et per suas literas Sauctissimo Domino nostro, ac sicro reverendissimorum dominorun cardinalium collegio, creterisque ecclesiasticis prelatis et dominis commendatos facere ad hoc, ut nos et dictum ordinem in nostris privilegiis et immunitatibus sine molestia conservare dignentur; ut magis quiete bello contra infideles inservire valeamus, et sub suo prasidio, prout nostra firma spes est, molestiis extraordinariis careamus; pro quo quicquid facultatis in nobis est eidens offerimus, et ipsam participem facinus de meritis et omnibus bonis operibus, qua hee religio et ejus milites tam in oriente quam per universum orbem complent. Sperantes quod hrec nostra parva oblatio vestre sacres regia majestati erit grata non minus quan denarius al anicula in gazofilatio positus. Dens vestram sacram regiam majestatem felicen conservet. In cujns rei testimonium bulla nostra communis plumbea presentibus est appensa. Datum in nostro conventu Rhodi dic vigesima septima mensis Maii anno millesimo quingentesimo sexto.

$$
\begin{array}{cc} 
& \text { Bintri. Policianus, } \\
\text { Rotulatir in Cancellaria. } & \text { Vicecancellarius. }
\end{array}
$$

In the hant of Policianus. 


\section{XLVII.}

\section{LEwIS XIT. TO HeNRY VII. ${ }^{1}$}

[MS. Addit. 21,382. Brit. Mus ]

Treshaule et trespuissant Prince, nostre trescher et $\Lambda . D .1506$. tresame frere et cousin, a vous tresaffectueusement et do 31 Ang. bon cueur nous recommandons. Et vueillez savoir que nous avons recen les lettres que nouz avez escriptes, tant par messire Francois Marezen chevallier, vostre fimillier serviteur, que par Mace de Villebresme nostre varlet de chambre. Et par enlx avons amplement et bien au long entendu toutes les choses que de vostre part ilz nous ont dictes et declairees, et mesmement le lesir, vouloir et affection que vouz avez a lentretenement et continuacion de la bonne amytie, confederacion, at fraternelle intelligence qui est entre nous; de quoy

\section{Thanslation.}

Most ligh and mighty prince, our most dear and wellloloved brother and consin, we commend ourselves to yon affectionately and sincerely. And please it you to know that we have received the letter's you hare written to us, hoth by Sir Francis Marsin, knight, your familiar servant, and by Mace de Villebresme, om valet de chambre. And by then we have finlly and at length nuderstood everything that they have said and dechred to us on your part, and likewise the desire, wish, and affection that yon have for the maintenance and contimuing of the good anity, confederation, and brotherly understanding which is between us: for which we thank you

\footnotetext{
'Tiom a copy in the hand of Ifenry VII.'s Fieneh secretary

sent with the letter immediately tollowing.
} Meautis, doubtless that which was 
A.D. 1506. tant et si cordiallement que faire povons nous vous 31 Ang. mercions. Et vous advertissons que de ce navons jamais eu et navolis aucun doubte, et nous en sommes tousjours tenuz et tenons aussi certains que de nostre propre fait, et jusques icy effectuellement en toutes choses avons bien congneu vostredit bon vouloir. Aussi de nostrepart soiez sceur, treshault et trespuissant prince, nostre tresclier et tresame frere et consin, que vous nous trouverez a jamais en telle et semblable voulente sans variacion quelconque; car nous avous desire et desirons lentretenement de vostredite amytic et alliance pardessus toute aultre, et ieelle inviolablement garder; vous priant tant et de si bon cueur que faire povons croyre fermement que rous nous trouverez a jamais vostre bon, loyal, et entier frere.

Et pource que nous arons entendu, tant parce que nous a dit vostredit serviteur, comme aussi par les lettres que avez envoyees par ledit Villebresme, le desir et affection que arez a ce que le different qui est entre nostre trescher et tresame fiere et cousin le roy de Castille et nostre cousin le duc de Gheldres se

as much and as heartily as we ean, and assure you that of this we have not and never lave had any doubt, hut we lave felt as assured of it as of our own act, and up to this time have effectually known your gool will in everything. Be sme that on our part, also, most high and mighty prince, \&e., you will find us always in the like will, without any variation; for we have desired and do desire the maintenance of your said amity and alliance above erery other, and to keep it inviolably; praying you as carnestly as we can to believe fimly that you will find us always your good, trie, and devoted brother.

And beenue we have undertood, both by what your sad servant has told us, and also by the letters that you have sent by the said Villebresme, the desire and concern you have that the difference which exist hetween om very dear and well-beloved brother and tonsin the king of Castile and our consin the duke of 
puisse appaiser par voye et moyen amyable, en delais- A.D. 1506. sant les voyes de fait et hostillitez, pour les causes et 31 Aug. consideracions que vostredit serviteu nous a dictes, lesquelles trouvons tresbonnes et raisonnables, et en ensuyvant icelles sommes deliberez de ace nous employer de nostrepart. Et pour ace mieuls et plus tost parvenir avons envoye a toute exireme dilligence et en poste, ung de noz varletz de chambre pardevers nostre cousin de Gheldres, pour surce luy declairer nostre vouloir es intencion qui est semblable et conforme au vostre, assavoir de prendre quelque bon moyen et expedient pour parvenir a paix en ceste matiere. Et entre aultres nous semble que si nostredit frere et cousin le roy de Castille, et nostredit cousin de Lewis Ghellres vouloient entierement soubz mectre tous les ${ }_{\text {France and }}^{\text {that }}$ differends qui sont entre eulx sur vous et nous England (ce que croyons que nostredit cousin de Gheldres fera), should arseroit le bien et prouffit deulx. Car nous sommes tween sceurs que vous et nous lem garderions a chacm ce Castile and

Gueldres should be settled by amicable means, aets of hostility being abandoned, for the canses and considerations that yom said servant has mentioned to us, which we find very good and reasomable, we are determined to exert ourselves according to the same for our part. And in order the better and more speedily to effect this, we have despatched with extreme diligence and in post one of our valets de chambre to our cousin of Gueldres, to declare to him on this matter our will and intention, which is ximilar and conformable to your's, that is to siy, to take some sood moan and expedient to uttain peace in this business. And among other's, it appears to us that if our said brother and consin the king of Castile amd our said consin of Gueldres wonld wholly submit the diferences between them to you and us (which we think om said cousin of Gmeldres will do) it would he for their good and advantage. For we are sure that you and we would kecp to ande of them that which belonged 
A.D. 1506. qui lew appartiendroit par raison. Et parce moyen $31 \mathrm{Aug}$. cesseroient les voyes de fait de hostillite. Et soubz Ifehas, cest espoir arons incontinent contremande et fait artherefcre, rester la plus grosse bande, que envoyeons a nostrewanded dit cousin de Gheldres, laquelle estoit sur lextremite thathe was des marches et frontiere de nostre royaulme. Et se sending to plustost eussions este advertiz de vostre desir surce, the latter. neussions laisse partir cenlx qui desja estoient passez. Esperant aussi que de vostre part ne laisserez point partir les vostres jusques ace que aurez certaines nouvelles dece que nostredit varlet de chambre aura besoingne devers nostredit cousin de Gheldres, ceque esperons avoir dedens dix ou douze jours au plus tard; pendant lequel temps avons este daviz que vostredit serviteur deust icy demourer, lequel despescherons incontinent que aurons responce de ce que dit est. Et avecque luy envoyerons quelqum de noz privez serviteurs pour de ce et aultres choses vous advertir plusamplement de nostrepart. Priant Dien a

to them in reason. And by this means acts of hostility would cesse. And in this hope we have comntermanded and stopped the largest band, that we vere sending to onr said consin of Gueldres, which was on the extreme frontier of our linghom. And if we had been apprised sooncr of your desire on this point, we would not have allowed those to leave who lint alrealy gone. Hoping also that on your part you will not. allow yours to leave till you shall have certain news of what our said valet de chambre shall have negotiated with our saicl consin of Gueldres, which we hope to have within ten or twelve days at the latest; during which time we have been of opinion that your sajd servint shond remain here, whom we shall despateh whenever we shall have an answer to what wo have mentioned. And along with him we shall send some one of eme privy servants to inform you the more amply on on part of this and other matters. Praying Cod, meimwinile. 
tint, treshault et irespuissant Prince, nostre trescher et A.D. 1506. tresame frere et cousin, quil vous vueille tenir en sa $31 \mathrm{Aug}$. saincte et digne garde. Escript a Bloys, le derrenier jour dicoust.

Linsi signe, Vostre bon ct loyal fiere,

LoYs.

Et du Sceretuire, RobErTET.

Et cue dessus de la lettre.-A tres-

hault et trespuissant prince,

nostre trescher et tresame frere

et cousin, Le Roy Dangleterre.

most high and mighty prince, our most dear and well-beloved brother and consin, to have you in his holy and worthy keepiug. Written at Blois, the last day of August.

signed, Your good and faithful brother,

LEwis.

and by the S'ecretriy Rowerter.

Superscribed: To the most high and mighty

Prince, onr most dear and well-beloved

brother and cousin The King of England. 


\section{XLVIII. \\ Henry ViI. to Philip King of Castile.}

[MS. Addit. 21,404. Art. 6. Brit. Mus.]

A.D. 1506. Treshaút et trespuissant prince, nostre trescher et 16 Sept. tresanne frere, cousin, et bon filz, a vous nous recommandons tant affectuensement et de bon cueur que faire povons. Depuis les derrenieres lectres que nous vous avons escriptes de nostre chasteau de Windesore, nostre trescher et tresame frere le roy Loys de France, apres le retour vers luy de son varlet de chambre, Mace de Villebresme et arivee de nostre serviteur Messire Francois Narezen, et entendu la declairacion de la charge que luy avyous baillee par instruction pour la lui exposer, delaquelle vous avous envoye le rouble; il a, puis quatre jour's encza, envoye vers nous mig des chevancheurs de son escuierie qui nous a As Lewis presente unes lectres de sa part, par lesquelles il fait, XII. has recit dela reception de celles que lui avyons escriptes
offered to mediate par les dessusnommez et demonstre quil a bon vouloir, between

\section{Thanshtion.}

Most high and mighty prince, on most dear and wcll-heloved brother. cousin, and good son, wo commend ourvelves to you as affectionately and cordially as we can. Since the last letters we wrote to you from on castle of Windsor, our nost dear and well-beloved hother, king Lewis of France, after the return towarels him of his valet de chambre, Mace de Villebresme, and mival of our errant, Sir Francis Marsin. and having understood the declantion of the change which wo had delivered to him ly instruction to show to him. of which we have sent you a coly. has within the last four days sent to us one of the grooms of his stalle, who hat presented to us a letter on his helall, wherein he makes mention of the receipt of those which we had written to him by the albove named, and declares thit he has good will, desire, and affec- 
desir, et affection que a nostre requeste et persuasion, le A.D. I506. different qui est cutre vous et messire Charles de Gneld- 16 Sept. res puisse estre appaise par voie et moien amyable, en Charles of delaissant toutes voies de fait et de hostillitez, pour les Gueldres, canses et consirleracions que nostredit serviteur lui a dictes et declairees par nostre ordonnance ct commandement; et que a cest intencion il a envoye devers ledict messing Charles ung sien varlet de chambre, cn le exhortant de prendre quelque bon moien et expedient pour parvenip a paix, et a ansi fait retirer incontinent la plus grosse bende quil envoyoit devers ledit le Gueldres; et que sil enst este plustost adverty de nostie resir; il neust pas laisse passer cenls qui desja ront passez; esperant que nous ne laisserons point partir cenlx quentendons envoyer dever's vostre lientenant general, aumoins jusques ace que amons certaines nonvelles du besongne de sondit varlet re thambre, quil espoire estre dedens dix ou douze jours ensuyvans li date de ses lectres, comme de toutes les choses dessusdites et claultres lesdites lectres le portent plus a plain, le

tion that at our refuest and persuasion the diffrence which is between you and messire Charles of Gueldres nay he composed in an amicahle manner, leaving all acts of hostility, for the causes and considerations which our said servant has shown and reciared to him ly om order and command ; and that with this intention he has sent towards the said messine. Charles, a valet de chambre of him, exhorting him to take some good means and expedient to arrive at peace, and has also inmediately withdrawn the largest hand that he was sending towards the said De Gueldres; and that if he hatd been soonel apprised of our desire he would not have allowed those whe have alrealy gone to pass; hoping that we will not allow to depart those that we intend to send towarels your lientenantgeneral, at least till we have certain news of the negotiation of his said valet de chamber, which he hopes to the within ten or twelve lays following the date of his letters, as with

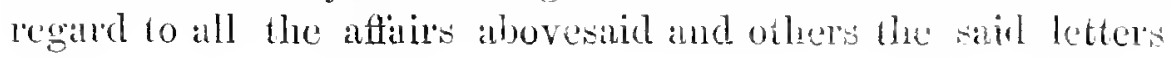


A.D. 1506. double desquelles vours envoyons cy dedens encloz aftin 16 Sept. que puissez le tout ententre.

Et pour responce sur le contenu en sadite lectre nous le mercions du bon vouloir et affection quil demonstre avoir a nostre desir a la pacifficacion des dits differends. Et que entant quil a contremande la dite grosse bende qui estoit sur la frontiere preste a passer; aussi sur lesperance et bonne confidence que nous avons en luy quil fera retirer ses aultres gens de gucre quil a envoiez oudit pais de Gueldres, et de non y envoyer. nulz aulties cy en apres, et quil face aussi cesser ledit messire Charles de toutes voiez de fait et de hostillitez, et de ne permectre ou souffrir estre fait aucune invasion ou exploict de guerresur voz pais et stibgetz aussi bien dedens ledit pais de Gueldres que ailleurs en vostre Henry has obeissance:-en ce cas avons este et suysmes contens delayed the de differer et retarder lenvoy de nostre secom's que succours he about avous promis bailler et cuvoier, (lesquelz sont tous prestz to send, alpartir) aumoins jusques ace que soions a la verite acer-

contain more at length, the copy of which we send you herein cuclosed, in order that you nuay understand the whole.

And for answer to the contents of his said letter's, we thank him for the goodwill and affection which he profesices to have to the appeasenent of the said differences. And that inasmuch as he has conntermmded the said great hand which was upon the frontier ready to pass; also in the hope and grood confidence that we have in lim that he will withdraw his other men of war that he has sent into the said comutry of Gucldes, and not send thither any others thenceforward, and that he will by all means lestrin the said messire Chartes from acts of hostility and not permit or suffer any invasion or warlike exploit to be done upon your comtries and subjects, either in the said country of Gueldres or elsewhere in your dominions:-in this case we have been and are content to defer and put off the sending of on snceon's which we promised to give and send (which are quite ready to leave), at least till we be 
tenncz par nostredit serviteur Francois Marezen de A.1) 1506. la responce que aura faicte ledit messire Charles a 16 sept. sondict varlet de chambre.

En le advertissant, oultre, que si aloccasion du retardement et envoy de nostredit secours ce que faisons de present a sadite responce, il y eust quelque invasion on exploict de guerre faicte sur vosdits pais et subgetz que len mectroit le deffiult et blasme sur nous. Dont, se aussi advenoit, entant que nous avons retarde lenvoy de nostredit secours, la chose redonderoit a nostre deshonncur et reprouche, dequoy auryons tresgrant regret ot desplaisir. Et pourtint quil $y$ vueille bien penser? at pourveoir, en telle facon et maniere que nostre honneur puisse estro garde en cest endroit.

Et dabondant nous lui signiftions, que nons serons bien joyeulx et contens de avec luy nous emploier en tout ae que pour'ons ala pacifticacion desclits differens; mais nous semple que pour mieulx parvenir ala-

truly ascertained liy our said servant Francis Marsin of the answer which the said messire Charles shall lave made to his said valet de chamber.

Intorming him, moreover, that if, in conserpuence of the delay of the envoy and of onr said succoms which we make al present to his sald answer, there should be any invasion or cxploit of war done mon your said comtries and subjects, the defant and liame would be laid upon us ; to whose dishonome and reproach, if it so happened, the thing wonkl redomel inasmuch as we have delayed the sending of on' said succoms; whereat we should have rery great regred and dissatinfaction. And therefore that he would think well and provide in such fishion ad manner that our honor may be preservert in this belate

And moreover we signified to him that we shall be very whin to cooperate with him in all that we can to the appeasement of the said differences; but it appears to us that, in order the better to arrive at the said peace and union, it is 
1.D. 1506. dite paix et union, estre expedient et tresneccessaire, 16 Sept. que les choses dunepart et daultre soient remises en lestat enquoy elles estoient au jour de vostre departeand advises ment et allee en Espaigne; et des aultres choses qui Philip to resteront en difficulte, se vous et ledit messire Charles the arbitra- les voullez mectre en la judicature de nous et de luy, lion of En- nous en deciderons et les vuyderons ala raison, selon France. droit et bonne equite, sans faire tord ne a vous ac a luy. En le advertissant pour la conchusion de nustredite lectre de responce, que des choses dessuselite: en advertirions vostredit lieutenant-general et conscil quavez laissez pardela, en les conseillant et exhortant que de leur couste il ny soit tronve aucun defiunt, ct que de leur part toutes voies de fait et de hostillitez puissent cesser, et deulx conclescendre a tout bon ef iaisonnable appoinctement; ce que leur avons cscript et conseille faire, ammoins pendant vostre absence, pour evicter les dangier's et tresgrans inconveniens 'pui en pourroient ensuyvir; et pour non vous mectre,

rxpertint and very necessaly that thing he restored on each side to the condition in which they were on the day of your departure and going into spain ; and ans to the other things which shall remain in difliculty, if you and the wain messire Charles will put them in the arbitration of $11 \mathrm{~s}$ and finin, we will decide thereon and elespatch them reasonably, areorting to right and good equity, withont doing injury cithere to you or him. Notifying to him, for the conchusion

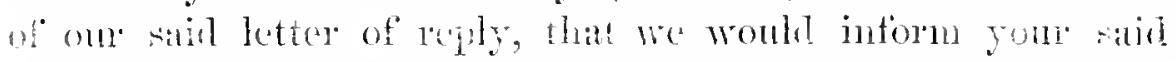
lientenant general and enuleil whom you have left there of the things ahove said, adrining and exhorting them that on their side there be found no detinlt, that all acts of hostility may cease on their prut, and that they should ngree to any good and reasonable appointment: which we have written to them and contrelled them to de, at heast during goul alsenee, to aroid the dingers and very great inconreniences which might ensule, and not to put you, your 
voz pais et subgetz en charge, si la necessite grande-A.D. 1506. ment ne le requiert. Et avons adveriy oultre vostre16 Sept. dit lieutenant-general et conseil que oucas que ledit nressire Charles ne se veult renger a la raison, et se ondescendre a tout bon et raisonnable appoinctement yue nous leur envoyerons nostredit secons, qui est desjic tout prest apartir, comme dit est, quant besoing serar, pour le desir et afiection que nous avons de vous complaire et firire plaisir en voz affaires. Fit ausisi tost que nous aurons entendu lia responce que aura eu ledict varlet de chambre dicellui messire Charles, et scen en ce lintencior, vouloir, et disposicion de nostredit bon frere le roy Loys en arvertirons en toute uxtreme dilligence vosdicts lientenant et conseil. Et avons cest espoir que ledit roy Francois fera of tiendra ce quil nous a escript, et quil se deportera de bailler ancun aide, faveur, et assistence audit messire Charles, entant quil congnoit, que [jam]ais nons voullons mesler de vostredit affaire de crueldres en vostreclite

contries and subjects to expense, if necessity do not greatly require it. And we have further informed your said liententut general and council that, in case the said messire Charles will not yichl to reason and condescend to any good and reasonable appointment, we will send to them our said succonrs, which are now quite leady to depart, as alrealy mentioned, whenerer necessury, for the desire and affection we lave to sitisfy you and do you pleasure in your afairs. And as soon as wo hall have heard the answer which the said valed de chambre shall have had from the same messire Charles, and known herein the intention, will, and pleasure of om good brother king Lewis we will inform your said lientenunt and conncil thereof in all extreme diligence. And we hase hope that the sild French king will do and keep that which he has promised 11s, and that he will forbear to give any ali, favol, and assistance to the with messire Charles, inismuch as he knows that we would never interfere in your said business of Guektres in your

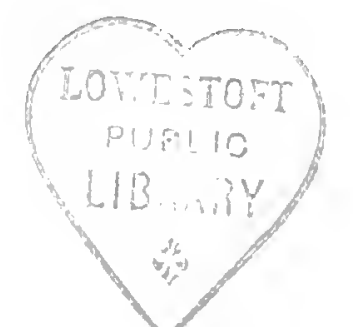




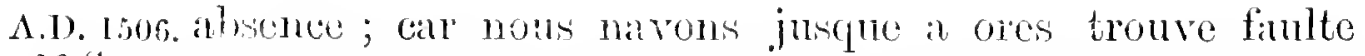
16 sent. an promesse quil nous a firicte. De toutes lesquelles choses vous avons bien voulu adrertir, comme a nostre frere, cousin et bon filz, lhomnenr, bien, et prosperite ducuel nous desirons singulierement estre de bonne et longue contynuacion et perseverance antant que de prince qui vive. Ainsi que scait nostre Scigneur qui, treshault et trespuissant prince, nostre trescher et tresime frere, consin et bon filz, vouz vueille entretenir. en sia tressaincte garde. Escript en nostre manoir de Guylford, le xrje jour te Septembre lan xve. et six.

$$
\text { Tostre fiere, cousin, et bon pere, }
$$

Hexry R.

MEaUTIS.

Addressed: A treshault et trespuissant prince, vostre trescher et tresane fiere, consin, et bon filz, le roy de Castille, dec.

siblel ahence: for we have not to this time fomsd him wanting in any promise that he has makle to $11 \mathrm{~s}$. Of all which things we have desired to grive you intelligence, ats to onl brother, consin, and groed son, whore honor, weal, and prosperity we especially wish to be of good and long continuance, ats much an of" iny prince living, as knoweth Our Lord who, nost high and mighty prince, se, preserve you in his most holy kecping. Writen in our manor of Gnildford, the 16th day of Sientemble 1506 .

Tonr hother, cousin, and reod fiether,

Hextix R.

'To the most high and mighty prince, onr most dear and well heloved brother, rousin and good son, the king of Cistile, \&c. 


\section{XLIX.}

\section{Maximilian to Hentiy VIJ.}

[From copy on a parchment roll in the Record Office, found among the Chancery Records formerly at the Rolls Chapel.]

Serenissimo principi domino Henrico Regi Anglize, Ec., fratri et consanguineo nostro charissimo.

Maxmmlanus, divina favente clementia, Romanornm A.D. 1506. Rex semper Augustus, ac Hungariae, Dalmatiae, Croatiae, $1+$ Sept. ctc., Rex, Archidux Austrise, Dux Burgundiae, Brabantice, etc., Comes Palatinus, etc., serenissimo principi, domino Hexrico Regi Anglia, etc., fratri et consanguineo nostro charissino, salutem, et fraterni amoris continumm incrementum. Serenissime princeps, frater et consinguinee charissime, significavimus nuper serenitati vestra pacem et concondiam inter nos et sublitos ac incolas regni IImgariae eum satistactione nostra initam atque conclusam. Et cum pro singulari vestra in nos benevolentia ac mutuo fiatermo amore non mimus existimemus serenitatem vestram ex sinistris nostris successibus accipere moerorem, quam ex prosperis et felicilus lectitiam et oldectationem; jdeinco volumus eirlem tanquam amantissino et confirlentissimo fratri nostro significare, quamvis Francortum rex alias filiam suam unicam Claudiam illustrissimo Carolo, archiduci Austriac, etc., nepoti nostro chanissimo matrimonio locare promiscrit, et nedum nobis super hoc literas et sigilla sua in validissima forma dederit, sed etiam strictissimo juramento super corpus Domini nostri Jesu Christi et ejus sacram crucem et sancta Quatuor Evangelia manibus suis corporaliter tacta, bona fide et in verloo regio, etian sub censuris apostolicis quibus se Lewis XII, in casu contraventionis subjecit, necuon sub obligatione in violation st lypotheca omminm bonornm suornm prosentim of his oath, futurorum ac poena perjurii quam possit tali casn in- his danglcurcere, illud inviolabiliter olservare solemnites se ol- teriage to ligaverit; nihilominus, his omnibus nom attentis, pre- lake of fatan filiam smam, relicto natrimonio prodicto, amn ralnis. 
A.D. 1506. voluntate et consilio regni sui contra fidem et jusju14 Sept. randum priestitum de novo duei de Valloys, delphino, et successori regini Franciae desponsavit; idque per oratores suos nobis palam et publice significavit, non alia excusatione usus, nisi quod prius existimavit matrimonium cum filio nostro Carolo fore utile et proficuum regno Francise; nunc vero edoctus sit. illud cedere in maxinum prejudicium et damnum regni sui; conaticue sunt prafati oratores in conspectu nostro et plurimorum principum et procerum imperii et curas nostrac fucato et phalerato sermone tam apertum et impudens facinus honestare et ostendere tanquam pro commolo et utilitate sua. Nihil sit quod eis non licent, neque fides servanda sit nisi quantum expedit eis; quod eum timeamus nihil boni portendere neque ullum bonum finem sortiri josse, et merito omnibus Christianis regibus et principibus, quibus cum Gallis tractandum occurret, exemplo esse debeat ut aperte cognuscant, quotiens eis libuerit, quod pro eorum arbitrio et libidine, quoscumque tractatus violare non verebuntur, asserentes non esse ex utilitate et commodo ipsorum. Ideirco voluimus hoc serenitati vestre per litteras nostras significare ut de iniquis et malignis Gallorum machinationibus certior esse possit, et si forte tanquam vulpes frandes suas etiam apud serenitatem vestram colorare conarentur, quamvis non dubitemus insam de veritate jamdudum edoctam esse; tamen illa iterato intelligat et millam eis fidem adhibeat. Et cum necessinium sit pro securitate nostra ct statum nostrorum contrahere novam affinitatem per desponsationem dicti nepotis nostri Caroli, emperemus supra omnia illam cum serenitate vestra fieri, ut quanto major inter nos indies amicitia ct enjunctio orietm tanto formidolosiores reddamux omnibus inimicis et adversariis nostris; possimusque ${ }^{2}$ nedum corum conatus reprimere sed etiam aliquando ita eos coerer'e et compescere, ne inposterum contra nos pro libidine ipsorum

1 fterwards Francis $I$. 
moliri audeant. Et quum per nonmullos bonos viros A.D. 1506. et amatores communis beneficii nostri fuerinus admo14 Sept. niti, postquam illud matrimonimm Caroli cum Francia nullum sortietur effectum ut cum filia vestra conchideremus, habuimus in hoc bonam complacentian et Maximidesideramus quod concludatur cum conditionibus, quem- lian is admodun super hoe latins scripsimus filio nostro desirous serenissimo et Catholico regi Castellie, adlortantes ut that a marde illo cum serenitate vestra tractari, et concludere arranged faciat; et habemus pro certo quod illud non recusabit. Chetween Scimus enim, tum ob naturalem animi sui afiectionem, and tum beneficia et paternas demonstrationes ei post nu- lenry's fragum in mari passum a serenitate vestra exhibitas, cum nom mims cordialiter et ferventer serenitatem vestram colere et amare, quam nos, sum proprium et naturalen parentem; neque nos aliud desideramus nisi guod nos aubo et communis filius noster simus una persona in voluntate et domus nostre sint ma ${ }^{2}$ in perpetuun, cum totil sinceritate, firme et immutabiles ad utramque fortunam contra quoseminque, in quo ex latere nostro 100 deficiemus, sed ita in omnibus nos adhibuimus ut quos cognoverimus de vobis male meritos non minus existimabimus quam si nos ipsos offendissent, et communem semper nolis omnem fortunam vobiscum esse reputabinus. Significamus preterea serenitati vestre nos diligenter fecisse inquisitionem de oratoribus Gallicis qui ad Hungariam per Venetias profecti fuerunt, et habemus compertum eos ad regem Hungarice pervenisse et cum magno luctu fuisse per eos ploratum propter obitum regina." Non tamen potuimus percipere quod frater ducis de Suffolch apud illos fuerit, quamquam, mortua regina, nullum ulterius periculum sit guod Hungari nune propter nimian enum barbariem, nec modernus rex aliquid pro eo faciet. Nos tamen continuo inquirenus et conabimur intelligere ubi sit,

'Philip.

unna, Mss.
${ }^{3}$ Anne, queen of Iatislans VI. of IIungary. 
A.D. 150c. et de omnibus serenitatem vestram certiorem reddemns; 14 sept. ruod serenitatem vestram latere minime voluimus, ita enim reipsa experietur; quam diu incolumem in felici regimine perseverare cupinus. Datum in oppido nostro Celeya, die Luma decina quarta mensis Septembris anno Domini r. quingentesimo sexto, regnorum nostrorum, Romani vicesimo primo, Hungarice vero recimo septimo.

$$
\operatorname{MAxI}{ }^{\mathrm{C}}
$$

Votre bon frere. ${ }^{1}$

Arl mandatum domini regis proprimm.

I.

\section{Maxmilian to Hentiv VII.}

[From the same roll as the preeding.]

19 Sept. Maxmmuaves, divina favente clementia Romanorum Rex semper Augustus ac Hungaria, Dalmatice, Croatice, etc. Rex, Archidux Austrise, Dux Burgundie, Brabantice, etc., Comes Palatinus, etc., Serenissimo principi domino Hexrico Regi Anglize, etc., fratri et consanguineo nostro carissimo, salutem et fraterni amoris continum Acknow- incrementum. Serenissime princeps, frater et consanledging
letters from recepimus vestras litteras datas ex manerio suo Grenwici $\Lambda$ ug. die xiij. Augusti plenas fraterni amoris et benevolentia ; que nobis gratissimic ot supra nodum expectate fuelimt. Et quia arl easdem per unum oratorem nostrum ad serenitatem vestram pro hoc et aliis negotiis summa importantice responsuri sumus, ideo imprasentiarun noluimus aliud secenitati restra significare nisi quod

M Maxius. eotre bon fiere] The handwriting of these words in this and the two following letters ap- pears to be an imitation of Maximilian's signature. 
in omnibus aque respondebimus ommi fraterna mutua A.D. 1506. benevolentia, ut serenitas vestra aperte cognoscat nos 19 Sept. nihil magis appetere, nihil magis a Deo exoptare nisi quod prastetur nobis occasio ostendendi serenitati vestrae quam sincere illius voluntati commodis et dignitatibus adesse et morem gerere cupiamus. Quam Deus Omnipotens diu felicem et incolumem in suo regimine conservare dignetur. Datum in oppido nostro Petovia die Sabbati xix. Septembris, anno Domini millesimo quingentesimo sexto, regnorum nostrorum Romani vicesimo primo, Hungarize vero decimo septimo.

Votre bone frere,

$$
\text { Maxi }{ }^{\mathrm{US}} \text {.' }
$$

Ad mandatum domini regis proprium.

LI.

Maximilian to Henri VII.

[From the same roll as the preceding.]

Maximlianus, Divina favente clementia Romanorum 24 Sept. Rex semper Augustus, ac Hungarice, Dalmatia, Croatia, etc. Rex, Archidux Austrix, Dux Burgundia, Brabantire, etc., Comes Palatinus, etc. serenissimo principi, domino Henrico, Regi Angliae, etc., fratri et consanguineo nostro carissimo, salutem et fraterni amoris continuum incrementum. Serenissime princeps, frater et The Emconsanguinee carissime, quamquam frequenter per lit- peror has teras manu nostra propria scriptas et oratores nostros been able et filii nostri missos apud illustrissimam Margaretam, to persuade et fili nostri missos apud illustrissimam Margaretam, his daugharchiducissam Austriae, ducissam Burgundiae, Braban- ter to a tire, etc., viduam relictam Sabaudiæ, institerimus et nihil match with pratermiserimus ut eam induceremus ad prastandum consensum suum in matrimonium inter vestram serenitatem et ipsam per nos conclusum, tamen nuper habuimus responsum a præfatis oratoribus nostris quo intelleximus eam adhuc perseverare in opinione non contrahendi matrimonium sed continuo rem differre, certumque

' See note in preceding page. 
A.1\%, 1506 habemus id opera et studio atyoe artibus Gallorum fieri,

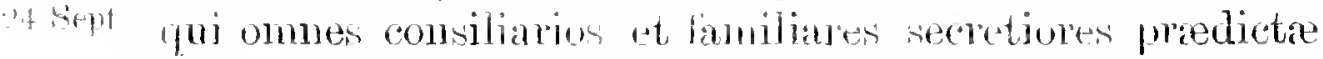
filixe nostra subormame ef mumeribus cormperment eam in hac opinione teneant of per hoc serenitatem vestram nobis minus derinctam reddant. Quocirca volumus hoc serenitati vestrce significare, hortantes onmi quo possumus studio ne hajusmodi sinistris enulorum nostrorum axtibus et conatibns cedere et assentivi velit. Nos enim pollicemur adhuc serenitati restrat nom desistere donec a filia nostra hujusmodi cousensmm obtineamus; but be will et pro hac re, sive ante adventum nostrum ad Urbem

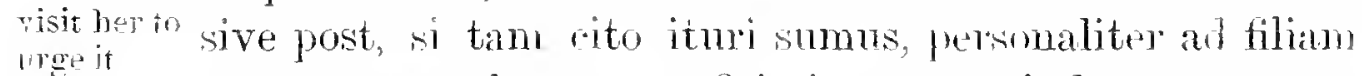
nostram pro hac re proficisci et eam inducere ut onnino voluntati nostrie moren gerat ot consensm sum mebeat, quemadnolum boc brevi latius jer oratores nostros vestrae serenitati significabiums. Quam diu felicem et incolumem in sho regimine perseverare cupimus. Datum in oppido nostro. Gret., lic Joris vicesima quarta Septembris, ano Domini millerimo quingentesino sexto, regnorum nostrorum, Romani vicesimo primo, Hungarixe vero decimo septimo.

Yotre hone frer, MAXI ${ }^{\text {Us }}$ :

Ad mandatum domini regis proprium.

\section{LiII.}

A.D. 15ng. Passport of the Bishop of LifaE Th Thomas 1. Noy

\section{KILLIRGHORTH.}

[MS. Cott. Vespasian E. III. No. 172.]

Erarde De la Mark, par la grace de Dieu Evescup de Liege, Duc de Buillon, conte de Loz, etc. Savoir

TRM⿻上丨Th.

Exaro De la Mark, by the gace of Goul hingoj of Liege.

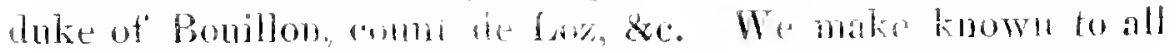


faisons a tous que nous avons donne, et donnons par A. I 15ut ces presentes, bon et leal suretie et saufonduit luran du jourduy, date de cestes, jusques a quinze mois entiers prochamment venans, et apres non vaillable, iu Thomas Kyllyngwortl, maistre dostell de Monseignem. Edmund duc de Suffolk, de Engliterre, pour venir en nostre citie de Liege et aultres bones villes part tout nous pais en generael, et y estre, demourer, et sejourner, se mestier est, acompaniez de quatre servitures au dessoubz, portan[s] dagnes, espees, javellines, ou aultres bastons non deffenduz, pour la suretie de leurs persomnes et deffenses de leurs corps; Et en iceulx nous pais et lieux dessudits aler, venir, hanter, frequenter, demourer, et sejourner, se mestier est, pour aucuns leurs negocies, besongnes, et atiaires durant ledit temps. Mandons pour ce, et commandons a tous nous justiciers et officiers, gardez de pontz, passages, bonnes villes et destroiez, et autres nous hommes, subgets et servitures, prions et requerous tous quil appartiendra que audit Thomas Kyllyngworth, se gens et servitures, en sejour-

men that we have given, and give by these presents good and finithinl surety and safe conduct enduring from to day, the date of these, to 15 whole months next coming, and not available alterwards, to 'Thomas Killingworth, stevard of my lord Edmund of Suffolk, of England, to come into our city of Liege and other good towas thronglont our countries in general, and to be, remain, and sojomm there, if need be, accompanied by four servants or under, carrying dagerses, swords, javelins, and other weapons not forbidden, for the security of thein persons and defence of their bodies; and in the same our conntries and places aforesaid to go, come, hamb frequent, stay and sojom'u, it need be, for any their affairs and busmess doring the said time. Wo therefore molei and command all on justices and officers, wardens of hridges, passages, good towns and liberties, and other on men, subjects and servants; we pray and request, all to whom it shall appertain that io the said Thomas Killingworth, his men 
A.D. 1506. nant, venant, retournant, passant on repassant, a cheral 15 Nov. ou a pie ou sur aultre monture, portans dagues, espees, javellines, ou autres bastons non deffendus, pour la suretie de leurs corps et personnes, ainsy que dit est, durant le temps et espasse de quinze mois entiers ilz ne meffacent, mael dient, mettent ou donnent, ne facent mettre on donner, par eulx ne par autres aucun destourbier ou empeschement, en corps ne en biens, et quelque facon et maniere que ce soit, mais les laissent paisiblement aler, venir, sejourner, demourer et retournier en nostredite citie, villes et autres lieux de nous dit pais se mestier est. Pourveu toutesfoys que durant ledit temps ledit Thomas Kyllyngworth, se gens et servitures, ou acm deux, ne feront, diront, ne pourchaisseront aucume choise en nostre prejudice, ne noz gens, pais, subgets et servitures, en corps ne en biens, en quelque facon ou maniere que ce soit. Donne en nostredit chateau de Hnye le quinze jour de mois de Novembre, lan mil cincqceus et six.

ErARD.

and servant, in sojourning, coming, returning, passing ol repassing, on horseback or on foot or otherwise mounted, carrying daggers, swords, javelins, or other weapons not, forbidden, for the security of their bodies or persons, as above, during the time and space of 15 whole months, they do not eause or give, by themselves or ly other's, any disturbance or impediment, in hody or goods, in any manner or mode whatsoever; but permit them peaceally to go, come, sojourn, remain and return to our said city, towns and other places of our said countries, if need be. Provided always that during the said time, the said Thomas Killingworth, his men and servants, or any of thenr, shall not do, say, or procure anything to our prejudice nor to that of our men, countries, subjects and servants, in body or in goods, in any mode or manner whatsoever. Given in our "said" castle of Huye the 15th day of the montl of November in the year 1506.

Erard. 


\section{Richard De la Pole to the Bishop of Liege.}

[Addit. MLS. 19,398, Brit. Mus.]

Reverendissime prosul, illustrissimeque princeps, requesting post debitam commendationem, rogamus atque excel-preferment lentissimam vestram dignitatem supplicamus quatenus las de vestra illustrissima dominatio tantum ob amorem nos- Iraghe. tri agere velit, ac placeat providere quendam dominum Nicholaum de Haghe, Aquensem, harum latorem, de quadam prabenda aut in ecclesia Sancti Dionisii, Sancti Pauli, aut Sancti Johannis in civitate vestra Leodiensi. Si id illustrissima dominatio vestra nostri ob amorem fecerit, in futuro Deo dante recompensabimus, atque itidem aut majus, si opportunitas occurlerit, facturi sumus. Valeat vestra reverendissima atque illustrissima dominatio atque optata nobilissimi cordis vestrae Optimus Deus adimpleat. Datum Buda xiij". die Aprilis, ammo Domini, 1507.

Per vestrum consanguineum,

RychaRd SUFFoLK.

Addressed : Reverendissino in Christo patri, illustrissimoque principi, domino Erardo Episcopo Leodiensi, Duci Bullon' ac comiti Lossen', domino neo colendissimo. 


\section{LIV.}

[MS. in Record office.]

Mrmoriale Sacrae Casarie Majestati pro servitore Domini Edmmeli Ducio Suftolchia.

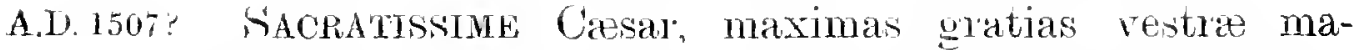
jestati humiliter refero pro favore vestro mihi diversimode dato; in guo hmmiliter supplico nt vestra majestas ex gratia vestra perseverare relit, quia mea firlelitis vestre majestati unon latet, et in qua conditione modo pro eadem existo vestra majestas melius wit frum egomet scio. In qua causa humiliter supplico, ut ex gratia vestra milni esse velitis bonus et gratiosus dominus.

Renindiog Invictissime Cresar, cum post deljberationem dicti the Em of a domini ducis in manus regis Henrici veniebam vestra promise to majestati, me benigne et gratiose accepistis, et mihi procure the diceluatis quod causa et liberatio domini mei de carof De la ceribus erant firmatre in manibus vestre majestatis, Pole. et quod videbatis in me quod ego nolebam dimittere hanc rem quousque finalem conchsionem vestre majestatis inter regem $\boldsymbol{H}$. et entem ducem vidissem, et quod vestra majestas in hac parte talem rospectum wihi habere vellet of po me sic tactaret per fuod regotium haberen honum et honestatem.

Qnamvis, sacratissime Ciesai, cum eran in Fulsamn, habeban de restra majestate alind responsmun, rnor! ommibns consideratis nolo, nee alias yuam bene accipere pussum, serl quod erga me geretis bonam gratiam vestram, quamvis non vultis quod ommes hoc sciant. Et ad finem ruod restura majestas virlebit fircta mea, et quod non sum, nee volo in loce magno of arduo negotio esse levis, vestra majestati certifico, fluor no servitio dicti ducis pariter rm servitio vestræe majestatis veni in hanc civitaten Constantiæ propter 
hoe quod mihi aperuistis vestran homan voluntatem A.D.1507? versus domimum memi: et a de causa puod hene seio ynod vestra majestats un boure vestru et serenissimi regis filii vestrj defuncti el conscientiis utrorumque, lictum lnoom et liberationem suan de carceribus in intimm, rovele recommendatum habetis.

Et yunad intentionen regis Henrici versus me, et Though macticats suas al finem quod veniren in regnum king Anglie, lation bangere non indigeo; sed vastran majes-deavours to bati dico et certifien, facietis de me quidengute volu-win him

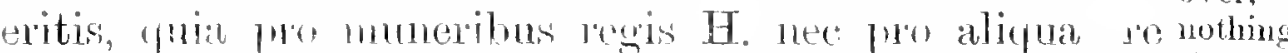
muli nom dimittam dictum ducem in sul maxim shall in necessitate, ef alias non faciam quam decent bonum et writer to ficlelem servitorem. Fit hoc vestra majestas vidit sem- master in per in ne et videbitis. Et si sit placitum vestrece adversity. majestatis, me in lac parte cum adjutorio vestro sic tencan sub tuitione et defensione vestrie majestatis. ${ }^{1}$

Et, sacratissime Cresar, si sit placitum et voluntas vestra majestatis quod in his partibus expectabo, supplico ae peto humiliter yuod vestra majestas oculis gratio me aspicere velit quod possum vivere et necessaria haliere et una pensione " et loco conveniente ubi seenre stare potuero" assignatis, taliter fanam quon vestra majestas de me erit contenta. Et in conclusime stero pro porkm allutorio vestra majestas magnum bahelit homorem. Wt quicpuin sure his erit voluntas vestrat majestation, inmiliter smplioo qund illam soive possum.

Et si placot vestrae majostati, limniliter peto quod possum intelligere quomodo predictus dux et causa sua se habent.

Expecto respousum Domini c'cesaris

Wolumelum in lene written wn the sic. margin in another hand. 
A.D. 1507?

LV.

[MS. in Record Office.]

Memoriale Sacre Cæesariæ Majestati pro parte servitoris Domini ${ }^{1}$ Edmundi Ducis Suffochix de Anglia.

SACratissime Cresar. liumiliter supplico vestræ majestati quod vestra majestas ex gratia vestra velit mihi esse bonus et gratiosus dominus, et quod possum habere favorem et gratiam vestre majestatis tanto citius pro meo fideli servitio predicto domino duci.

The Em- Et quoad fidelitatem meam dicto domino duci, me peror remitto vestræ sacræ majestati, quia hoc bene probavi hnows how coram vestra sacra majestate per vj. annos integros, to Suffolk et modo sum in septimo anno; et sub correctione has been tried for six years. vestre majestatis, est probatio sufficiens pro uno homine; et dictum dominum ducem servivi per $\mathrm{xx}$. annos, quod non est parvim tempus.

Et pro servitio dicti domini ducis, dimisi uxorem, amicos et bona mea, quæ me minime, quamvis est res innaturalis, gravent; sed mala fortuna prædicti domini ducis me intime et maxime graviter. Humiliter supplicamus vestræe majestati quod velitis esse bonus dominus predicto domino duci, et pro honore vestrae majestatis et serenissimi regis filii vestri ${ }^{2}$ defuncti ponere manus vestras in sum adjutorium et libertatem.

Reminds him of his promises in behalf of Suffolk and his brother Etiam, sacratissime Cresar, supplico humiliter ut velitis vestrae memoria nobilissimæ reducere quod ego veni vestræe majestati ea de causa quod pro adjutorio picharda flate sus taliter tractaretis quod dominus liichard. Richardus frater suns, qui modo est in Hungaria, non veniret ad manus Francorum, sed quando tempus esset

\footnotetext{
Domimii, MS.

'Philip archduke of Austria 1506.
} 
conveniens potuit esse ad voluntatem vestræe majes- A.D. 1507? tatis. In quo negotio vestra majestas dedit mihi valde bonum responsum, et quod vestra majestas voluit facere diligentiam vestram pro adjutorio domini mei in manibus regis Angliae existentis.

Et quoad iter meum in Hungariam, non recedissem The writer ibidem nisi ad rogatum Roderici van Riet, etc. (ves- would not træe majestati veraciter dico); et post reveni in toHungary Constanciam vestræ majestati per mandatum preedicti but at the domini Richardi in Hungaria existentis. ${ }^{1}$

Sacratissime Cæsar, maximas gratias vestræe majes. Roderick tati refero pro omnibus quae vestra majestas ex gratia vestra pro me fecit; pro quibus, sicut teneor, sum, et vita durante ero, servitor vestrie sacre majestatis, etc., ut latius patet in articulis vestre majestati deliberatis per dominum cancellarium Sarentiner.

\section{De sequentibus humiliter peto responsum de Casaria, Majestate.}

Primo, supplico domino Casari quod sua majestils ex gratia sua velit milhi plane dicere quomodo dominus meus se habet, et in qua conditione estis cum rege Henrico pro causa sua et libertate.

Secundo, quod possum scire responsum vestre: Ciesariae majestatis de et super articulis pro me vestro cancellario deliberatis et quid placitum vestre majestatis erit quod ego faciam.

Tertio, quod possum scire voluntatem vestre sacre majestatis tangentem hune militem de Anglia qui tantum desiderat mili alloqui.

Quarto, et pro finali conclusione, humiliter supplico vestre majestati quod velitis ex gratia vestra esse milii bonus et generosus dominus, et quod possum scire voluntatem vestre majestatis in omnibus requestis meis. Et si placet vestræe majestati me inter- 
A.D. 150r? tenere, libentissime et paratissinse ero ad mandatum vestrce majestatis, et ero vester servitor.

Copia Articulormm Domino Cusmi doliberatorum

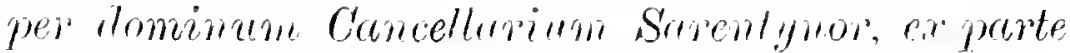
sevitoris domini Edmundi Ducis Sufiolchire.

Sacratissime Cesar, maximas gattias vestre majestati refero pro onnihus que vestra majestas es gratia restra pro ne fecit; pro quibus, sicnt teneor, sum et ru servitor vestra majestatis, sperans, si dominu: mens per adjutorium vestrie majestatis ar suam libertabem perveniet, ex parte mea lu'o eisdem tales reddat sratias vestro majestati quod eadem vestra [majestas"] rit bene contenti.

Verum est, benignissime C'rsar, quod primo et principaliter patior de mea necessitate pro servitio dicti domini ducis jam in manibus regis Anglize existentis. Quia, si vellem relinquere dominum meum et me submittere regi Henrico, libenter me acciperet in gratiam, et mihi redderet mea et amplius, ut non dubito ante hoc tempus vestra majestas bene intellexit.

Tertio, uhi vestra majestas petiit de me si vellem fationtian sustincre quousque vestra majestas, potuerit rum rege Henrico finalem conclusionem po dicto Homino Ance tractare, vestra majestati responsum dedi ynow ita. Puare humiliter supplico, si placet vestro majestati, fuod possum scire quomodo dominus meus ot cansa sua se habent.

Secundo, sacratissime Ciesar, culi servitio dicti domini ducis, de bona fide vestrac majestati veraciter dico quod, sicut teneor, patior etiam in promissis pro honore et relvitio vestran silla majestatis; ad quod? smpplicn hmmiliter ut resjectum habere velitis.

$1 \mathrm{Om}$. in MS.

2 quid, MS. 
Et ubi, sacratissime Cresar po vestris magnis et A.D. 1507? arduis causis, pou puesenti, forsan, non potestis finire causam domini mei, sed oportet quod vestra majestas seruetur mentem segis Henrici, supplico homiliter grod interim ex gratia vestra velit mihi ditre mam provisionem in Parlihus Inferiorihus prod possum me intertener.' ' viver, ete.

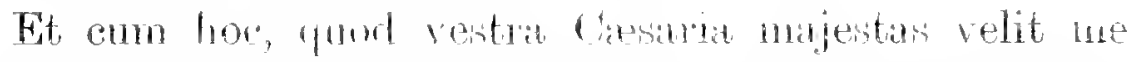

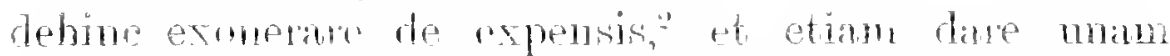

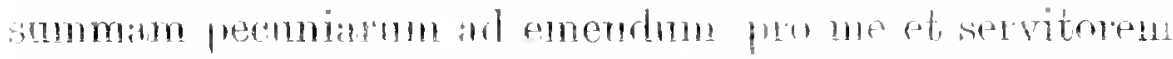

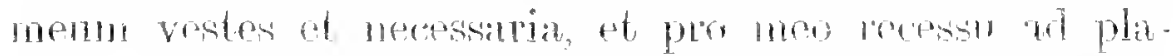

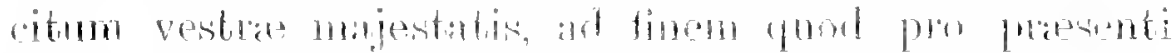

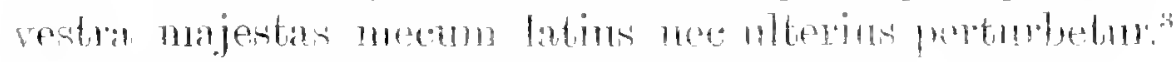
guis sub ista forma non porsum vivere.

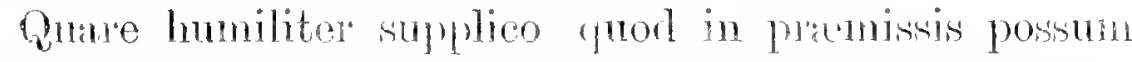
intelligere integram volunbatem vestrat majestatis et semper ero servitor eidem vestra majestati.

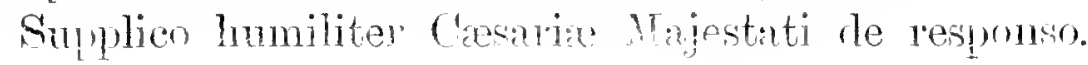

\section{LVT}

[MS. in Resend OHtere]

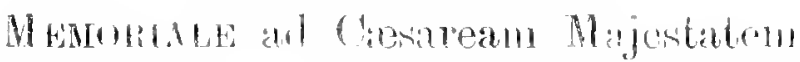

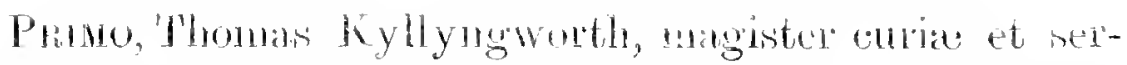

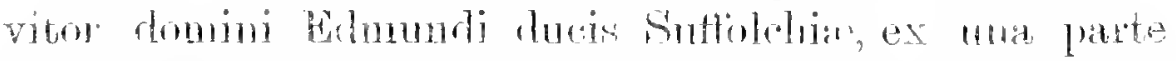

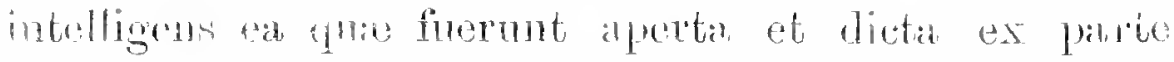
manni concilit moliamenti Parsiensis, sectete in Agricgrann et in Colonia per mmm militem nuncupatum

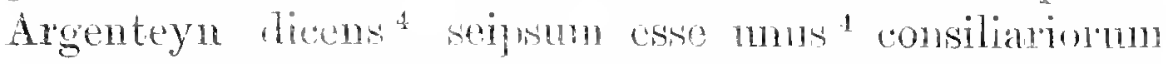
et camerarion peris Froborum, tangentia domionm Ricardum fratrem predicti dmoni Edmundi ducis;

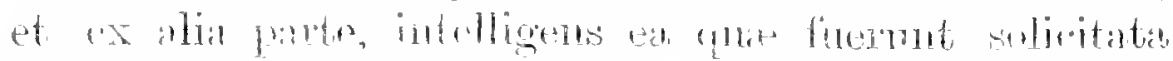

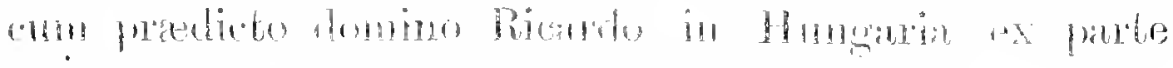

1 intertensin, its

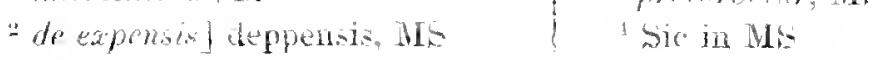


A.D.1507? ejusdem regis Francorum per oratores suos ibidem existentes circa mortem reginre ibidem nuper defunctre : prædicto Thome videbatur quod nihil boni, nisi periIt would be cula, et de malo in pejus, potuit sequi, prædicto dofor Ed- mino Edmundo existente in manibus regis Angliæ, si mund De dominus Ricardus esset in Francia vel ad mandatum la Pole, who is in the hands of the king of England, if his brother Richard were in France. Francorum. Et sic, propter servitium et honorem Caesaris in hoc negotio, sicut tenetur, videns quod materia ista tangit honorem suæ majestatis, et propter bonum et servitium predictorum dominorum Edmundi et Ricardi, dictus Thomas veniebat ad presentiam Cresaris, et supplicavit Cresari ut sua majestas vellet esse bonus et gratiosus dominus predicto domino duci Edmundo. Et super hoc idem Thomas, intelligens honorabilem mentem Caesariae Majestatis versus dominum magistrum suum et suam causam, predicta requesta regis et regni Francire idem Thomas ${ }^{2}$ Cresari plane aperuit, et etiam dixit Cresari se iturum versus dominum Ricardum in Hungariam.

Super quo Ceesar tunc respondebat et dixit, "Unus servitor ${ }^{3}$ domini Ricardi fuit mecum, et breve per cum intellexi de istis negotiis, et misi eum domino Ricardo, et expecto responsum," etc. Et sna majestas ordinavit dictum Thomam eundum versus Brabantiam ibidem standum quousque adventum Coesaris; quia sua majestas tunc dixit se breviter ibidem venturum, ad finem quod idem Thomas csset ibidem paratus sollicitandum in causa domini Edmundi ducis tali modo sicut per Ceesarem esset ordinatus.

Tamen, propter duas causas Casari declaratas, idem Thomas proponebat tenere iter sum versus Hungariam. Et etiam sic contingebat (et si Cresar hoc intellexit vel nou, sibi latet) prope Olmes. Predictus scrvitor Domini Ricardi veniens de Hungaria cum responso

'Anne, queen of IIungary.

2 sic. A repetition. 
Cresari et dictus Thomas insimul labuerunt obviam, et A.D.150z? steterunt in Olmes per duos dies, et ibidem uterque Killingeorum aperuit alteri in hoc negotio intentionem suam. worth's Et super hoc idem Thomas proposuit dimittere iter Richard in suum versus Hungarian et perimplere mandatum Cresaris. $^{1} \quad$ Sed predictus servitor domini Ricardi tantum rogavit dictum Thomam quod omnino iret in Hungariam et quod staret ibidem quousque medium quadragesima, ad finem, si aliqui venirent de Francia domino Ricardo, quod dominns Ricardus cum eis non intromitteret, et quod per illum diem idem servitor vellet in Hungariam esse reversurus. Et super hoc idem Thomas recessit versus Hungariam et ibidem stetit a prima die Martii usque xviij. diem Aprilis jam ultimo preterito, per mandatum domini Ricardi, attendens quotidie adventum servitoris priedicti, ut plenius apparet in literis ejusdem domini Ricardi regia majestati missis. Qua de causa, et ad perimplendum dictum mandatum, et ordinationem solicitandam pro clomino duce Edmundo, dominus Ricardus me misit Cresari cum predictis literis et etiam cum ma credentia, et etiam ad intentionem quod Caesar expediret plus citius dictum servitorem summ; qui quidem servitor fuit expeditus ante adventum pradicti Thomae.

Et cum Cesaria majestas cogitavit super dictam $\Lambda$ nasylum credentiam, quod si rex Francorum practicaret cum for Richard rege Hungarice pro domino Ricardo, quod bene conduce- in Anstria. ret dominum Ricardum per medium [aliquormm amicol'um regis in Hungaria ad locum securum, \&c. si necesse fuerit, quoad hoc dictus Thomas dixit suam opinionem domino doctori Heydon $]^{2}$ domini Cardinalis de Stra-

'et. . . Casaris]. Corr. from "et ire versus partes Inferiores, " sicut ordinatio regiæe majestatis " erat."

2 The words printed within brack- ets are interlined in the MS., apparently as a substitute for the rest of the paragraph, whicl, however, has been left uncancelled. 
1.1\%.150: bugen. et per fratren mims Pumen hic existentem, qui sunt secrete amiri prosis, he illis partions usque ad nnum custrum existan in Nustria pertinens regia majestati et in gubernation fratris predicti Boemen; et ea intentione quod Cixir vellet dictum Boemum breviter expedire com litteris suis domino Cardinali et fratri sno, ac etiam scribere litteras credentiales domino Ricardo, et quod ego seriberem etiam domino Ricardo in hac causa, ad finem yuod dominus Ricardus daret meliorem et firmam fidem predicto Boemmo.

(bjectims Qno ad hoc, serenissine rex, scio veraciter quod hoe "in it. proponitis de bona mente; quanvis supplico humiliter ut vestra majestas velit mihi parcere, quorl ego tam plam respondeo. Vestra majestas luene! vidit malan fortunam domini ducis Edmundi fratris sui, et bene scio quod super onmes principes hmjus mundi, dominus Ricardus dat et dabit vestre majestati fidem. Tamen 2 pro firmo audeo dicere, frod in castrum nullins viventis dominus Ricardus tamen ${ }^{3}$ in tali forma personam suam, quousque dominus fater sus erit per medium vestra majestatis ad libertatem snam. Et si dominus Ricardus ad hoc vellet consentive, scio yrod servitores de consilio suo hoc non permitterent. et vestra majestas bene cognoscit istos Hungarios et Boemmos, non wit fides adhibenda eis. Et sut correctione vestra majestrutis, mihi videtur quod si dominus Ricardus conx sentiret ad hoc proprositmm, si casus necessitatis hon requiret, forsan vestra majestas ot ijrsi possimnt exse drepti. Et ulterius, sernissime rex, si rgo aperiren hane inaterian domino Ricurdo, vel per sciptmm meum, crerlo firmiter quod nec ipse nee sui consilianii, essent de hoc mecum contenti, nes omming consentirent, ser forsan tenerent me value suspectum, et sine causa. Quare humiliter supplico vestra: majestati ut mihi parcere relitis, quia in hos negotio me non intromittam.

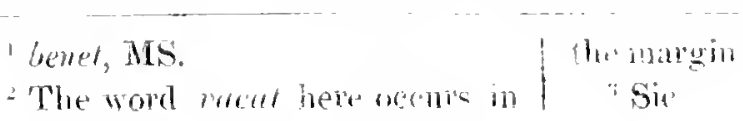


Et si placet Cresari tenere sum propositum pro an- A.0.1507: jntorio domini Edmundi dueis, non dubito quin hoe to the king bene facietis ad honoren sue majestatis, et ald tran- of Tingland quillitatem et bonum totius regni Anglia. Sed mora Bdmud trahit periculum, quia nou latet Carsari debilitas re- and many gis Anglice; et si contingat emm breviter mori, credatis wonld he firmiter ex una parte dominus dux Fdmundus erit in in danger; maximo periculo, et forsan multi alii nobiles; et ex alia parte sic casus potest evenire quod forkun filius regis Anglice potest post mortem regis patris sui esse perhap. in consimili periculo; et iden wo ntraque parte fimalis also the et honesta conclusio esset bona; et hoc tanto' citius tanto melins. Fit si aliquid mali evenimet domino mer; (quor absit), bene seio quod essets in maximum clis." placitum Cresaris.

Quare, mo servitio Casaris, et pro bono et securitate dominorum meorum Edmundi et Ricardi in hac cansa, et ad finem quod dominus Ricardus potest esse ad mandatum Ciusaris pro honore Ciesaris, et pro adjutorio domini fiatris sui, et nullo modo esse ad mandatum regis Francorum, si placet Casari, et sub correctione suce majestatis, mihi videtur, hoc erit bonum et optimum medium; quod doninus Ricardus potest esse conductus extra patriam Hungaria et ire in unum locum secretum infra obedientian Sacri Im. perii, ubi stabit secrete sub salvo conductu Casaris et principis illius patria; et, conclusione facta per Ciesarem inter regem Anglia et predictum dominum ducem, ipso duce Edmundo et etiam iraticto Ricardo: istente ad libertatem smam, dominus Ricardus erit immediate al voluntatem Ciesaris comductus ad presentiam sur najestatis. Et si sit volmatas Casar.i. ponere manus suas ad hanc rem et debursare conve

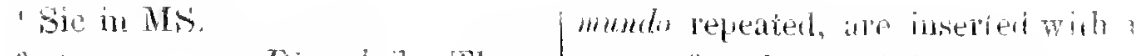

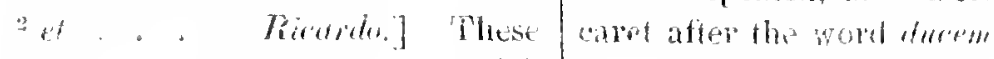
words, preceded by the word Ed-
} 
A.D. 1507? nientem summam pecuniarum secrete pro intertentione domini Ricardi et famulorum suorum, concordia facta, dicta summa pecuniarum et iterum erit satisfacta Caesari. Et etiam dictus Thomas cum uno servitore domini regis hic existente qui vocatur le Bastard van Oysekerke, vadat, si placet Casari, in Hungariam pro hoc negotio. Et ad finem quod Crsar semper erit securus, cum tempus veniet opportunum, de domino Ricardo, dictus Bastardus semper permanebit cum domino Ricardo; et servitor domini Ricardi qui nuper fuit cum Cresare et dictus Thomas revenient insimul Cresari, et, si placet sure majestati, stabunt cum sua mijestate pro parte domini Ricardi, quod sua dominatio perimpleat hanc rem ut predictum est.

Et predictus Thomas supplicat Cæsari quod sua majestas reducere velit suæ memoriæ quod idem Thomas dimisit parentes suos et bona et Anglia ${ }^{1}$ pro servitio lominorum predictorum et ea ratione nihil habet unde vivere possit. Cresar est princeps cum quo idem Thomas stetit per longum tempus pro parte domini magistri sui, et satis vidit et intellexit de fidelitate ejusdem Thome in causa domini sui. Quare insimul supplicat Cesari quorl ex gratia sua pro predicto suo fideli sermone sua majestas admirare velit in hac sua maxima necessitate; et etiam quod Cresaria majestas intertenere velit predictum Thomam cum suo servitore quousque per Ceesariam majestatem finalis concordia et conclusio fieri potest inter regem Angliæe et predictos principes.

1 Sic in MIS. 


\section{LVII.}

\section{[Kilingworth] to Maximilian.}

[MS. in Reeord Offiee.]

A.D. 1507?

SACRatissne Cresar, humiliter supplico vestrie sa- Has been crae majestati quod vestrae memoriae nobilissima redigere awaiting velitis, quod ego hic per xxx. septimanas steti ad man-peror's datum, voluntatem, et placitum vestræe sacrie majestatis. pleasure Et ego rogavi Bastardum Doysekerke quod vellet ex weeks. parte meal sollicitare vestræe majestati. Et ille stetit cum vustra majestate per novem septimanas et amplius; et de eo in hunc diem habui nulla nova, nec aliquod responsum. Etian, sacratissime Cresar, ego hic sum in Is in debt debito hospitis mei lij. Horenorum et aliis xij flor. et to his host. sum in infirmitate et in maxima necessitate et miseria, non habens aliquod, nec scio ubi habere relevamen, nisi de vestra sacra majestate; et quie humiliter supplico ut labere velitis respectum.

Saclatissime Cresar, premissis humiliter supplico vestrie sacro majestati ut velitis mihi esse bonus et gratiosus dominus, et quod ex gratia vestra, vestra majestar literas vestras scribere velit dominis financiarum vestrarum ad exonerandum me de ista civitate, et nilhi dare aliquam pecuniam pro recessu meo, ad placitum vestrae majestatis; et durante vita mea ego ero vester fidelis servitor, et orabo Deum pro conservatione, vestr: saere majestatis.

Ulterius, sacratissime Rex, intelligo quod dominus Fdwardus Wyngfeld ex Anglia miles est cum vestra sacra majestate pro prasente ex parte domini Regis Anglie. Et si idem dominus Edwardus habet onus communicandi cum vestra sacra majestate pro causa domini magistri mei existente in Anglia, si placot 
A.D.1507? vestrie majestati, essset bonum quod ego venirem ${ }^{1}$ vestre majestati, secrete vel alias, sicut virletur majestati, ad declarandum vestrie majestati aliquas magnas causas hoe negotium tangentes. Humiliter supplicans quod in eodem negotio vestra majestas velit mihi habere respectum, et me non ponere in oblivionem.

A.D. $150 \%$

\section{LVIII.}

\section{[Kilingatorth] to "Dominus Dionysius."}

[MS. in Record Office.]

Rogo declaretis tenorem ${ }^{2}$ presentium domino Cresari de verbo in verbum, vel faciatis quod dominus Cresar potest semel legere.

Domine Dyonise, rogo quod ex parte mea detis maximas gratias domino Cæesari pro omnibus qua sua Cæsarea majestas ante hæe tempora, et specialiter ad presens tempus, mili fecit; pro quibas sum et ero, vita mea durante, in omnibus causis ad voluntatem sure Ciesariae majestatis.

The writer Et cum non est in me Casaria majestati predictie hopes the desservire, non dubito, si per medium domini Ceesaris will pro- dominus dux Suffulchice veniet ad suam libertatem, vide for
him, seeing ipse dabit pro his Caesari tales gratias pro parte that he suf-mea quod dominus Ciesar erit bene contentus. Et ferspoverty for his spero quod Cresil bene cognoseit et accepit quod ea

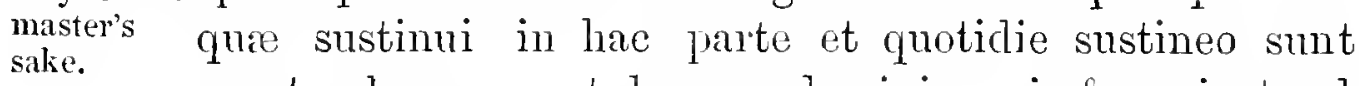
propter honorem et bonum domini mei, de., sicut ad largum domino Ciesari declaravi. Quia si vellem hane rem dimittere non indigeo presentem paupertatem ${ }^{3}$ nee necessitatem habere.

\footnotetext{
'renirem] interlined in place of

the words possem loqui, struck out. "palpertatem, MS.
} 
Super quo, pro finali conclusione in hac re, humiliter A.D. 1507 ? supplico domino Cresari quod sua majestas ex gratia sua nobilissima pro me providere velit, quod possum secrete de sua majestate habere in Partibus Inferioribus unam honestam intertentationem quousque sua majestas potest facere unam finalem conclusionem inter regem Anglire et dominum meum, et dominum fratrem suum in Hungaria existentem.

Et interim, cum favore Domini Casaris, stabo, et Meanwhile expectabo in Aquis-grano, et qualiscumque solicitatio l he will remihi erit facta pro parte regis Angliae, non dubitat Aix. Cresarea majestas quin de tempore in tempus, si casus sic advenerit, certificabo domino Caesari de omnibus.

Et super præemissa humiliter peto responsum domini Cæsaris, et quod per votum, domine Dionesie, illud responsum potest mihi conduci per Bastardum de Oysekerke cum omni conveniente diligentia.

Supplico domino Cresari quod potest super me taliter aspicere oculis gratia quod possum vivere et haberem ? victum et ${ }^{3}$ vestitum.

\section{LIX.}

[Addit. MS. 21,382. Brit. Mus. f. 17.]

Breve Summarium eorum QUe Dicta sunt oratoribus Serenissimi Regis Anglie ex parte Sacratissine Majestatis Cesarem.

Primo, qualiter Majestas Cresarea citra quatuor aut The Emquinque dies continue laboraverit cum illustrissima personal domina Domina Margareta Austrix et Burgundiæ, suæ conferences majestatis filia carissima, et singulis diebus intraverit with Mar 
A.D. 1507? cum ea personalem conferentiam super matrimonio jamdays on the pridem concepto et concluso per quondam bonse me-
proposed marriage morice $\mathrm{Ph}$ [ilippum] Regem Castella, inter serenissibetween and mum ac potentissimum Angliae Regem et eandem Henry VII., illustrissiman dominam.

Ad quod sua Majestas Cresarea mirum in modum fuit et est inclinata, tam propter singularem amorem quem habet ad selenissimum Regem Anglix, tum quia alias sua Majestas in hoc matrimonium consensit et desuper literas tradiderit, tum etiam quia omnes sure Majestatis consiliarii ipsum matrimonium maxime suadent, cupiunt et desiderant.

which he Et ut sua Majestas Cresarea illustrissimam dominam recon- ad loned by atrimonium facilius inclinaret, demonstravit many argu-multis rationibus et argumentis illud matrimonium ments. non solum esse honorificum atque utile sure Majestati, ipsi Domina illustrissimie, atque domibus Austrix et Burgundire, sed etiam non mediocriter necessarium.

Honestum seu honorificum, quia serenissimus Rex Anglia rex est dignissimus, prudentissimus, potentissimus, atque omnium virtutum cumulatissimus, cui merito conjungi debeat uxor seu conthoralis omnium nobilissima ac prudentissima qualis ipsa est.

Utile, propter regnorum et patriarum vicinitatem, propter mercatorum et subditorum utriusque regni continuam frequentationem et mercium commutationem, propter harum provinciarum tranquillitatem.

Necessarium, propter pacis cum Gallis observationem, propter future Hispanica successionis securitatem, propter pacis Gheldrensis conservationem, propter singulorum negotiorum Ciesarere Majestatis, necnon hujus inclytæe domus Burgundiae dilectionem.

Quad si forte hoe matrimonimn, quod absit, non perficiatur, timendum est quod ipse serenissinus Anglix Rex aliam ducet uxorem ex alia familia et gente, forte Ciesireat Iirijestati et suie domui non amica, unde plurima inroummola his patriis et provincis 
possent imminere, adeo quod affinitas nuper facta inter A.D. 150\%? illustrissimum dominum Archiducem et dominam Mariam parve erit utilitatis.

His rationibus et aliis quamplurimis sapius prudentissime repetitis per Cresaream Ilajestatem ore proprio, ac etiam aliquando per organum alterius in prasentia sue Majestatis et nonnullorum suæe Majestatis consiliariorum ipsa illustrissima domina semper rerpoudit in hunc qui sequitur modum.

"Quod ipsal ilhustrissima domina multum est devinctal Her repur. et multa debet serenissimo Regi Anglise, qui, cum sit omnium regum ac principum hujus nostre retatis prurentissimus ac virtuosissimus, velit et cupiat eam habere in uxorem et conthoralem.

"Quod si aliquando ipsa illustrissima domina maritum superducere vellet ipsa non posset digniorem optare, sed illum serenissimum Regem Anglie creteris principibus et regibus or his anteferet.

Having been di-

"Verum, cum jium trina vice jussu ac mandato sacla- voreed by tissime Ciesarea Majestatis nupta fucrit et tres maritos her first habuerit, quorum primus eam repudiaverit, et alii duo and having in jurenili atate et immature obierunt. Tantum in- lost two fortunium passa et experta, timet in illud reincidere; their youth quare decrevit apud se nunquam quartum maritum she is deque viduitate permanere. superducere, sed in sua vidutate permanere. widow.

"Præterea, cum matrimonia communiter fiat ad prolem Fidow. suscitandam, timet illustrissima domina ne al hoc would have sit minus apta ; quod si ita esset, serenissimo Regi Anglice noclildren. aliquando displicere posset.

"Item, dos promissa per matrimonium supradictum thinks the est adeo immensa quod sine magna lasione illustrissimi dowry too Domini Archiducis, sororum et patriarum suarum non poterit persolvi.

"Item, facit illustrissima domina sibi aliquam consci- and the entiam quod tanta bona extraliantur ex domo Burgun- terms too die et remaneant in Anglia, ex quibus suce neptes foEngland. poterunt maritari. 
A.D. 1507? "Item, quantum ad necessitatem allegatam, dixit quod illa cessat cum jarn sit pax facta et conclusa cum Gallis, et etiam in Gheldria, cum etiam serenissimus rex Arragonum cupiat et prosequatur amicitiam Cresarese majestatis, et quod non sit verisimile quod illustrissimo domino archiduci suo nepoti velit nocere aut juri suo in aliquo derogare, cum nemo umquam carnem suam odio habeat; quibus attentis non esset verisimile quod matrimonium quod poterit facere rex Anglia debeat huic domui esse damnosum.

"Maxime cum jam affinitas facta sit et contracta inter" ipsum illustrissimum dominum archiducem et filiam regis Anglire, quare non solum ipse rex Angliæe sed etiam regnum ipsum est aliqualiter obligatum ad amicitian cum iis patriis et provinciis."

Videns sacratissima Cesarea majestas quod nihil posset apud præfatam illustrissimam dominam per se et consiliarios aliquos suæ majestatis proficere nec inducere eandem dominam ad consentiendum huic matrimonio, Cresarea majestas fecit vocari illustrissimum dominum archiducem et totum consilium; in quorum et suæ majestatis presentia iterato dicta sunt ad longum illustrissimæ dominæ ea quæ superius scripta sunt et multa alia ad hoc convenientia, ad finem ut co facilius inclinaretur ad consentiendum. Quibus non obstantibus illustrissima domina firma permansit in suo proposito superius declarato, nec aliud responsum potuit Cæsarea majestas obtinere.

Ex quibus patet quantam operam, solicitudinen, ac diligentiam Cresarea majestas sacratissima adhibuerit eirca hoc matrimonium; verum cum ilhstrissima domina vidua sit nec jure possit ant debeat ulterius cogi ant premi, cupit sua Cæesarea majestas ut ea omnia bono modo et ordine regire celsitudini Anglize referentur ad eum finem ut intelligat Casaream majestatem omnem diligentiam possibilem adhibuisse, neque aliquid prætermisisse quod ad inducendam filiam ad hoc matrimonium 
conferre visum est. Et si videatur dominis oratoribus A.D. 1507? quod Cesarea majestas debeat aliquid amplins facere in hac causa pro contentatione strenuissimi regis Anglie vellet sua majestas hoc intelligere et perficere.

Endorsed: Anglia.

\section{LX.}

Henry VII. to Margaret of Sayoy.
A.1). 1507 .

May.

[From a contemporary copy. MS. Cott, Calignia, D.vi. f. 72. ]

Treshnulte et excellente princesse, nostre treschere Margaret et tresamee bonne cousine, a vous tresaffectueusement requires et de bon cueur nous recommandons. Receu avons glish merles bonnes et cordialles lettres que vous nous avez chantsshall derienier frequent derrenierement escriptes de Bruxelles, en date du viije the Low de ce present mois de May, responsives aux nostres in Countries derrenieres; par lesquelles entendons le vouloir, desir, ance with et grant affection que vous avez que la communiqu the treaty cion, hantize et frequentacion puisse estre entre noz Philip of sulggetz marchans et ceulx depardela, sur lentrecours parcidevant fait et conch par le feu sienr de Beures, Messire Paule de Baenst et aultres lor's ad ce commis et ordomnez delajart de feu prince de bonne memoire

\section{Translation}

Most high and excellent princess, our most dear and well leloved good consin, we commend ourselves to you most atlectionately. We have received the good and cordial letters which you last wrote to us from Brussels, dated the Sth of this present month of May in answer to our last; whereby we understand the will, desire, and great affection that you have that communication and intercourse should exist between merchants who are our subjects and those of your countries, arcording to the treaty formerly made and concluded by the late lord de Benres, Messire Paul de Baenst and others at that time commissioned and ordained thereto on the part of the late prince of good memory, 
A.D. 1507. nostre cousin le roy de Castille vostre trere (a lame Nay. duquel Dieu par sa saincte grace face mercy) et ceulx par nous commis et depputez, nous requerant de en faveur de vous permectre ladite communiquacion et hantize selon ledit entrecours, lequel en ce cas ferez observer et entretenir par ceulx depardela, jusques a ce que par nostre bonfrere le roy vostre pere et nous en soit aultrement ordonne; offrant den faire despescher telles et semblables lectres que nous mesmes adviserons et que de nostre part en vouldrons domner.

Treshaulte et tresexcellente princesse, nostre treschere et tresamee bonne cousine, veritablement nous ne desirons pas seullement en ce vous complaire, mais en toutes aultres choses que bonnement faire pourrions; hien rous voullons advertir que neust este les nouveaulx tonnelieux, exactions, et imposicions que lon mist pardela sur nosdits subgetz et leurs marchandises apres avoir prins et conclu ledit entrecours, ilz ne se feussent point absentez hors des pais depardeia, mais eust este ledit entrecours de duree jusques a present. Et com-

our cousin the king of Castile your brother (on whose soul God of His holy grace have merey) and those commissioned and deputed by us, reruesting ns in yom farour to allow the said communication and interceurse according to the said treaty, which you will in that case canse to be obscrved and kept hy those on your side, until it shall be otherwise arranged by our good brother the king your father and us; offering to despatch such and like letters thereof, as we ourselves shatl think proper and shall he willing to give on our part.

Most high, \&e, truly we desire to please you not only in this, but in all other things that we reasonably can ; nerertheless we wish to apprice you that had it not been for the new tolls, exactions, and imporitions levied there upon onr said subjects and their gools after the said treaty was taken :mit concluded, they wonld not have absented themedves from those comtries, but the said treaty woulh have endured 
bien que ou temps et du vivant du roy votredit feu A.D. 1507. fiere nous luy en escripvismes par reiterees foiz le May. desirant, de on ensuyvaut le traicte de lentrecours quil It was to clesirant, de on ensuyvant le traiete de lentrecours, quil avoid new voulsist faire abolir lesdites nouvelles imposicions et tolls, contonnelieux, en luy signiffiant quelles estoient directement that treaty, contrevenir a icelluy traicte dentrecours, toutefoiz pour that they quelque rescripcion que nous luy en feismes, riens liberty to nen fut fait ny refourme. A ceste cause nosdits sub- market at getz marchans nous supplierent et requirent en toute Calais.

lumilite que nous leur voulsissions permectre de tenir doresenavant leurs foires et marehetz dedens nostre ville de Calais, ce que par bon advis et deliberacion de conseil, considere ce que dit est, ne leur povyons bounement reffuser.

Neantmoins encoires dempuis ce, a este fait, conclu, et passe ung nouveau entrecoms entre les commis et depputez du feu roy vostredit frere et les nostres, chacun en vertu de leurs commissions et povoirs, le jour et terme ordonne et appoinete pour lentreschange des lettres patentes de confirmac[ion] et ratifficacion dune-

ill now. And although in the time and during the life of the king your said late brother we repeatedly wrote to him desiring him, according to the treaty of intercourse, to abolish the said new impositions and tolls, intimating to him that they were in direct opposition to the treaty of intercourse; nevertheless for all the remonstrances that we wrote to him, nothing was done ol reformed. For this reason our sairt subjects merelants have requested us in all hmmility to permit them to hold henceforward their frirs and makets in our town of Calais, which by good antvice and deliberation of conncil, these things considered, we conld not well refuse them.

Nevertheless, amain there has since been made, concluded. and passed, it new treaty between the commissioners and deputies of the late king your said brother and our own, anch by virtue of their commissions and powers, the daly and term ordained and appointed for the exchange of the 
A.D. 150\%. part et daultre; encoires de laparte de dela riens na May. cste tenu, fourny, ne accomply, ja soit ceque dela nostre, nous avons este tousjours prestz de fournir ace que nous avyons promis et aceorde, ainsi que le vous avons signiffie par aultres noz lettres.

Neverthe- Et combien que nosdits marchans avoient fait desja less, out of publier leurs foires en nostredite ville de Calais et Margaret, fait leurs preparatifs pour tenir aceste faicte dela penthe King thecouste leurs foires en icelle; ce non obstant, pour called his le desir et affection que nous avous de vous complaire et licenee and satisfaire a vostredite requeste, et singulierement pour
ordered them to re- honneur et amour de vo[us], entant que sest la premiere pair to the requeste que rous nous avez faicte, suysmes contens tries. [de] consentir et accorder que les subgetz dune part et daultre, voisent, hantent et co[mmuniquent] ensemble, en vertu dudit premier traicte prins avecque ledit feu Sieur de Beures; ce [que nosdits] marchans feroient bien enviz et a tresgrande difficulte, nestoit lordonnance [et] commandement que nous leur avons

lefters patent of confirmation and ratifieation on cither side; again, on your side nothing has been kept, done, nor accomplisted; although on our sile we have been always leasly to do that whieh we have promised and granted as we have signified to you by other our letters.

And although ou and merehants lamb alrearly camberl

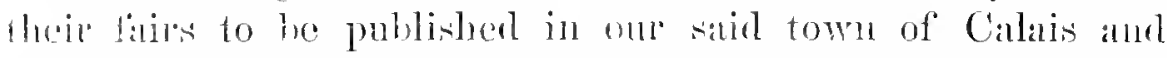
manc their preparations to hold them therein this feast of Penterent, this notwithstanding, for the desire and affection we have to please you and satisty gour said request, and cepecially for the honor and love of you, inamueh as it is the first request you have made to us, we are content to nolee and grant that the snbjects on either side visit, frequent, and [communicate] together hy virtue of the said dirst traty taken with the sairl late lord de Benres, [which our sidid] merchants woukd do rery unwillingly and with rery great difficulty, but for the order and commandment we 
donne pource faire. Et leur avons exp[ressement en- $\Lambda . D .1507$. jo]incts de laisser leursdits preparatifz daller a Calais May. et deulx preparer . . . . . . desmaintenant es pais de nostredit cousin, vostre nepveu. A quoy congnoissan . . . . . . nostre plaisir et intencion, sont prestz a y obeir, et espoirent destre prestz a par[tir dedans] quinze jours. Et pour le bien et scenrte de nosdits marchans et de leursdites ma[rchandises] en ladvenir, nous avons, par ladvis de nostre conseil, conceu et devise en ensuy[vant leur] desir, une mynute, telle quil nous semble estre raisonnable pour la sceurte [deulxet] de leursdites marchandises, laquelle vous envoyons. Et si vostre plaisir est de ende[dens] quinze jours, les nous envoyer expediees et seellees ainsi quil appartient, vous . . . . . de tant plus meilleur vouloir et comraige a nosdits subgetz marchans daller $\mathrm{p}$ [our] y contynuer et resider. Et icelles par nous recenes vous envoyerons les nostre[s au mesme] effect, ayans bon et ferme espoir que ferez doresenavant

have given them to do so. And we have [expressly ordered] them to leave off their sairl preparations for going to Calais, and to prepare themselves [to repair] from this time to the countries of our said consin, your nephew. Whereto, knowing [that such is] our pleasure and intention, they are ready to obey, and hope to be ready to leave [within] 15 days. And for the good and surety of our sairl merchants and their said merchandises in future, we have, by the andice of our conncil, conceived and devised according to their clevire a minute, such as appears to us to be reasonable for the security [of them and] of their said merchandises; which we send to you. And if it the you pleasure within fifteen days to send them (letters patent) despatched and seated as it behoves, you [will canse] so mnch the better will and disposition in our merchants to go thither to remain and reside. And the same being by us received we will send our own [of like] effect, having good 
A.I. 1507. bien et favourable[ment] traicter nosdits subgetz, comme May, de nostrepart nous avons fait et avons intencion. . - les subgetz depardela.

Touchant la priere et requeste que nous faictes davoir regart aux traictez, a[mities], et alliances faictes et conclutes pour nous et noz successeurs, et le roy vostredit fe[u frere] et les siens, et que en acquietant les promesses et obligacions esquelles nou[s sommes] temuz et astrainct par icelles, de accorder aide et secours pour garder et def[fendre] nostre cousin, vostre nepveu, ses pais et subgetz, oueas quilz feussent par voie de - . opprimez par nostre frere et cousin le Roy Loys de France;-

Inenry uses Treshaulte et excellente princesse, nostre tresehere et to protect tresamee bonne cousine, . . . . faisons doubte que Countries from invasion. ne soiez bien advertie, et comme il est a ung chacun tout $m$. . . et magnifeste que pour la bonne amour et affection que nous portons a [nostre] fiere le roy, vostredit pere, et portions aussi au roy vostredit feu frere, nous nous s[ummes] effectuellement emploiez

and firm hope that you will cause henceforward our said subjects to be treated well and favourably, as on our part we have done and intend to do the subjects of those parts.

As to the prayer and recuest that you make to us to have regard to the treaties, [amities], and alliances made and conchuled for us and our successors, and the king your sairl late mother and his, and in fulfilment of the promises and obligations, in which we are bonnd by the same, to grant aid and succour, to keep and defend our cousin, your nephew, his countries and subjects, in case they be oppressed by way of . . . . . l,y our lirother and cousin king Lewis of France:-

Most high, \&c., we make [no] doubt but that you are well informed, and as it is quite . . . . and manifest to every one, that for the good lore and affection which we bear to [our $]$ brother the king, your said lather, and bore also to the king your said late brother, we have offec- 
a hreserver, garder, et derrendre ses pais et subge[tz A.D. 150\%. quand] ilz estoient en voie destre subjuguez par leurs ennemys et adversialires, t[ant en] temps de sa mynorite que aultrement et aussi dempuis en lannee passee [au] fait de Gueldres. Et pour vous en par- Which ler plainement et alavraye verit[e, les] choses ont last year in este aucunesfoiz pardelia petitement recongnues et con- the affair sidelees. . ce que nous avons pource faire eu le to incur. maulgre de nostredit fiere et cousin, [le roy] Loys de the ill-will France, et daultres princes noz confederez et alliez.

Et quant ace que nous requerez vouloir avoir regart aux traictez et a[mities] faitz entre nous et le roy vosiredit feu fiere; tresliaulte et excellente [princesse,] nostre treschere et tresamee bonne cousine, nous vous voullons bien adve[rtir que] tous les traictez et amytiez que nous avons prins et faitz avecque ice[lluy vostre] feu frere, et avec quelzconques aultres princes que ce soient, nous [avons] jusques a ce jourdhuy bien entierement entretenuz et gardez, s[ans] jamais y avoir fait aucune faulte, ne les enfraindre, mais vi[ai est quil y eult]

tually lahomed to preserve, keep, and defend his comntries and sulgects [when] they were in the way to be sublued by their enemies and adversaries, both in time of his mimority and otherwise, and also last year [in the] affair of Gmeldres. And to tell you plainly the very truth, things have been sometimes little anknowledged and considered on your side . . . . . that we have to do this incurred the illwill of om said brother and cousin king Lewis of France, and of other princes our confederates and allies.

And whereas you request us to have regard to the treaties and [amities] made between us and your said late hrother ; most high, \&c., we desire to inform you that all the treaties and amities which we made with the same your late lnother, and with any other princes whomsoever, wo have this day fully kept without ever having made therein any fiult or infringed them; Imt 
A.D. 1507 . certains traictez faitez et concluz entre nous et le roy May. vostredit [feu frere, entre] lesquelz y eult ung traicte damytie qui fut fait en noz personnes, luy estant en nostre royaulme. Et oultre icelluy y avoit deux aultres traictez prins ct concluz entre ses commis et les nostres. It si sest cestuy traicte damytie par lequel vous nous voullez obliger et astraincter, le conseil depardela vous deussent avoir advertie, comme dedens lung desdits aultres cleux traictez est expressement dit et declaire, que le roy vostredit feu frere ne feroit pas seullement imnover ledit traicte danytie, mais aussi confermer lesdits aultres traictez, et le tout endedens certains jours et termes pource ordonnez et appoinctez les nous envoyer. Ce que na este fait ne accomply clelapart de dela. Parquoy les choses a la verite bien et deuement considerees, nous ne suysmes, comme les gens de nostre conseil nous ont dit et remonstre, par ledit traicte damytie, aucunement chargez, astrainctz ne obligez, mais suysmes de nostrepart a nostre liberte; et ne sauroit ou

certain treaties marle and conelnded between $n \mathrm{~s}$ and the king yom said [late brother, among] which there was a treaty of amity which was made in onr persons when he was in our realm. And besides this there were two other treaties taken and concluded between his commissioners and ours. And if it be that treaty of amity by which you wish to bind us, the council there ought to have informed yon, that in one of the said other two treaties it is expressly said and declared, that the king your said late brother would not only cause to be renewed the said treaty of amity, but also confirm the said other treaties, and all within certain days and terms ordained and appointed for the same to be sent to ns, which has not leen done or performed on that side. Wherefore, these things being a truth well and dnly considered we are not, as the gentlemen of our council have shown to us, by the said treaty of amity in anywise burdened, hound. or tied, but are on our side at our liberty, and no one 
pourroit lon par icelluy par voie dobligacion ou promesse A.D. 1507. aucune chose nous demander jusques ace que limnova- May. cion deladicte amytie et confirmacion des aultres traictez soient faitz, delivrez, et entreschangez dunepart et daultre; lesquelz comme entendons sont entre vos mains, et de cenlx dudit conseil depardela. Et ce fait et accomply nous ne fauldrons point de fommir ace que nous estions tenuz; et obligez et plus singulicrement en faveur, honneur, et amour de vous, et pour la bonne affection que nous portons a nostredit consin vostre nepveu.

Et dabuudant, veu et considere que le roy vostredit the feu frere qui estoit lun cles traictans, est alle de vie at $\begin{gathered}\text { treaties } \\ \text { between }\end{gathered}$ trespas, et que nostredit cousin son filz est encoires en Henry and mynorite, il feust bien seant et convenable que tous ${ }_{\text {ought to be }}^{\text {Philip }}$ lesdits traictez feussent confermez, tant par nostredit confirmed. bon frere le roy vostre pere comme mainbounie de nostredit cousin vostre nepveu que par icelluy vostre nepve u.

Pryant ausurplus Nostre Signeur quil vous ait, treshaulte et excellente princesse, nostre treschere et

can by it demand of $n$ s anything by way of obligation or promise until the renewal of the said amity and confirmation of the other treaties be made, delivered, and exchanged on both sides; which, as we mderstand, are in your hands, and those of the comeil there. And this done and areonplished we shall not fail to fulfil all that we are bound to do ; and more especially in fivour, lonour, and love for you, and for the good affection that we bear to our said cousin your nephew.

And, moreover, ennsidering that the king your said late brother, who was one of the contracting partier, is deceased, and that our said eonsin his son is still in minority, it wonld be very meet and befitting that all the said treaties were confirmed, both by our said good brother the king your fither as guardian of our said cousin your nephew, and by the same your nephew.

Praying, moreover, our Lord to have yon, most high, \&c.. 
A.D. inat tresamee bonne eousine, en sa tressainete et digne Mry. garde, et vous doint laccomplissement de vor bons desirs. Escript en nostre manoir de Grenewyche, le * * ${ }^{1}$ jour dudit mois de May, lan $\mathrm{xv}^{\mathrm{c}}$ et sept.

\section{LXI.}

Henry VII. to the lord Bergies.

[From the same MS. eopy subjoined to the preceding.]

Has an- Tresciner et tresame cousin, nous avons recen les swered the lettres que nostre bonne cousine la duchesse douagiere Savoy's de Savoye nous a eseriptes, et les vostres pareillem[ent, letter. le contenu de toutes lesquelles nous avons bien an long entendu. E[t pour] la bonne amour et affection que luy portons, et pour satisfaire a s . . . nous luy faisons de present telle responee que nous no roubtons point sera a son] contentement. Et pource

in Itis most holy and worthy keeping, and to give you the arcomplishment of your good desires.

Written at our manol of Greenwiel $\mathrm{l}_{1}$ the * * laty of the saich nontle of May, the year 1507 .

Most dear and well heloved consin, we have received the lefter's that our good cousin the duchess dowager of Saroy has written to us, and likewise yours ; the contents of all which we have muderstood at length. And for the good love and anfection which we hear her, and to satisfy . . . . . we now make to her snch answer as we doubt not [ Hall] be to her] contentment. And hecause we believe that the things

'Blank in MS. 
que nous croyons que les choses viendront a [vostre] A.D. 1507. congnoissance, nous delaissons a ceste cause de vous May. en faire par cestes [aucun] recit. En vous advisant que des quelle nous aura envoye les lettres qu[elle] advise estre necessaires pour la sceurte de noz marchans et de leur[s dites] marchandises en ladvenir, expediees et seelees ainsi quil appartient, [nous] hy envoyerons les nostres de pareil effect; aiant bon et ferme espoir [que] nostredite bonne consine, vous, et ceulx du con-Hopes the seil depardela, ferez doresena[vant] bien et favourable- English ment traicter nosdits subgetz marchans, affin quilz will hencea[uront] meilleur vouloir et couraige dy contynuer et forth be resider ou temps adve[nir]. Et atant vous disons adieu treated. qui, trescher et tresame cousin, vous [ait] en sa bonne garde. Escript en nostre manoir de Grenewiche, le * * [jour] de May, lan xv'. et sept.

will come to your knowledge, we refrain on that account from making any recital of them to you by these. Informing you that as soon as she shall have sent us the letters which she considers necessary for the security of our merchants and of their said merchandizes in future, despatched and sealed as it behoves, we shall send her ours of like effect; having good and firm lope that our said good consin, you and those of the conncil there will canse henceforward onr said subjects merchants to be well and fuvorably treated, in order that they may have better will and disposition to remain and reside there in time to come. And so we commend you to God, who, most dear and well beloved cousin, have you in His good keeping. Written in our manor of Greenwich, the * * 1 day of May, 1507.

1 Blank in MS. 
A.D. 1507 . 3 Sept.

\section{LXII}

\section{Henrix VII. to Almaçan.}

[MS. Egerton 616, No. 24.]
Was rejoiced to receive

Ferdinand's lettel on his return to Spain.
Henricus Dei gratia Rex Angliæe et Francia ac Dominus Hibernia, nobili atque egregio viro, domino Michaeli Almazano, serenissimi regis Aragonum et utriusque Sicilie ac Hierusalem secretario, amico nostro carissimo, salutem. Accepimus nuper literas serenissimi fratris nostri, regis vestri, $\mathrm{xx}^{0}$ die Julii ex Valentia ad nos datas, quibus cognovimus qualiter eo die illue sospes et incolumis cum sua classe trireminm applicuisset, qua quidem re cognita non facile diceremus quanto gavdio affecti sumus; quod, scilicet, omnes suos prosperos successus, proprios nostros reputemus; unde agimus in præsentiar'um ingentes gratias suæ majestati literis nostris, quod de sua prospera navigatione, suoque adventu ad alia sua dominia nos certiores per: suas literas facere voluerit. Nec minus etiam laudamus plurimum et extollimus vestram diligentian in ipsis literis scribendis et co adventu nobis intimando adhibitam; ex qua re manifeste intelligimus optimum vestrum animum quem habetis ad nobis gratificandum et de nobis bene merendum. De quo, certe, plurimas habemus vobis gratias, et in posterum magis ac magis sumus habituri, vos rogantes quatenus in hoc vestro tam bono proposito erga nos velitis perseverare, et de his quie occurrunt quandoque ad nobis scribere, quod sane nobis est futurum quam gratissimum. Ceterum habnimus et adhuc habemus oratores nostros paratos ad serenissimum fratrem nostrum mittendos, nil aliud expectantes nisi ut postquam filiam suam illustrissimam principem habuerit communicatam super causis prius pro majori vinculo inter nos contrahendo motis, suam prius menten et animum super ea re clare intelligamus. Præterea scribimus eidem serenissimo 
fratri nostro, respondentes super nonnullis rebus quas A.D. 1507. per dominum Doctorem de Puebla suum oratorem 3 Sept. fecerat nobis demonstrari. Et quia non dubitamus quin ipsæe nostræ literæ ad vestras manus sint venturæ, idcireo non erimus in præsentiarum longiores. Hoc tantum vobis dicimus, quod sua majestas in omnibus rebus quibus gratificari sibi poterimus, nos suum verum intimum et cordialem fratrem est semper habitura. Ex manerio nostro de Woodstoke, die tertio Septembris m.d.vij ${ }^{\circ}$.

Scripseramus autem prius hasce literas, sed ob pericula que in longo itinere quandoque contingunt, jussimus illas reiterari.

\section{Henricus R.}

Addressed: Nobili atque egregio viro, domino Michaeli Almazano, serenissimi Regis Aragonum et utriusque Sicilize ac Hierusalem secretario, amico nostro charissimo.

Endorsed in two places. Amj. Del Rey de Inglaterra de iij. de Setiembre de D.vij.

\section{LXIII.}

A.D. $150 \%$. 29 Sept.

Henry VII. to Ferdinand Il.

[MS. Egerton 616, No. 25.]

Serenissimo ac potentissimo principi, Domino Ferdi- ConcernNANDO, Dei gratia Aragonum et utrinsque Sicilie ac portant Hierusalem Regi, fratri, consanguineo, et amico nostro commischarissimo, Henricus eadem gratia Rex Angliee et to him by Francie ac Dominus Hiberniæe, salutem et prosperorum De Puebla. successuum incrementa. Scripsimus paulo antea vestre majestati cum ejus tabellario nomnulla tuue temporis 
A.D. 1507. occurrentia, quæ ob pericula et impedimenta sæepe in 29 Sept. longo itinere contingentia per presentium latorem reiteranda, et denuo scribenda duximus. Cæeterum posteaquam ea scripsissemis, venit ad nos clarissimus orator vester Doctor de Puebla, qui licet non satis se bene ad sui corporis salutem habeat, nunquam tamen desistit in his quæ ad servitium vestræ majestatis pertinent, apud nos intercedere et instare, et officium boni oratoris ac servitoris facere; communicavitque nobiscum nonnulla non parvæ importantiæ, quæ audivimus perlibenter, et super quibus nostrum illi dedimus responsum, non dubitantes quin veram de ipsis rebus sic nobiscum per se communicatis sit vestræe majestati ficturus relationem. Quæe postquam illi fuerint cognita putamus congruum fore ut quid super his sentiat quam primum nobis significet. Quam magnopere rogamus ut quanto citius fieri poterit, suam nobis superinde mentem aperiat. Non dubitamus autem quin, si ea negotia ad effectum deducantur, quamplurima exinde bona ad Omnipotentis Dei lauden, et totius Christiane religionis nostrorumque utrinque statuum et regnorum augmentum, subditorumque line inde nostrorum commodum, sint secutura. Ex manerio nostro de Woodstoke, die xxviiij. Septembris, x.D.VI⿰

Vostre bon fiere,

HesRY R.

Athliessed : Serenissimo ac potentissimo principi Domino Ferdinando Dei gratia Aragonum et utriusque Sicilice ac Hierusalem regi, fratri, consanguineo et amico nostro charissimo.

Enlorsed. A su al. Del Rey de Inglaterra xxviiij. de Setiembre de D.vij. 


\section{LXIV.}

James IV. to Henry VII.

A.D. 1508. March.

[Orig. in Record Office.]

RICHT excellent, right hie and michti prince, and Requesting our derrest fadre. We commend us unto sou in our a safe conmast h[erty wise], praying 3 ou effectuisly to graunt at the bishop this oure request zour lettres of sauf conduct in dew form to ane Reveren[d fader in] God, and our richt trast counsalour Andreu bischop of Mfurray, commendatare of Pettinweme, \&c.; and with him t[o the number] of fourty personis or within, his servauntis or utheris, saufly and seuerly to cum within sour realme of [Ingland by sey] or laund, on hors or on fute, with thare horssis, harnessis, bulgeis, males, money, conzeit and uneonzeit 1 . . . and all utheris thare lefull gudes; and to pas and repas throw zour saide realme for fulfilling of $\mathrm{h}$. . . . doing of his uther lefull eraundes at the court of Rome and utheris partes beyond sey, without , . . . port or passage of ;our saide realm. And als with ane schip or schippis of the birth of ane hu[ndred . . . ] chargeit with ony lefull gudes with ane mastir, twa factours, ane skippar, ane sterisman, . . . . . . . within. And for sic space as the peax requiris to endure. Richt excellent, right hie and michti [Prince and our] deriest fader, we pray God have you in his keping. Geven undre our signet at Edinburgh [the . . day of] March.

3 our Son, JAMES R.

Addressed: To the rucht excellent, richt hie and michti Prince, and oure derrest fadre the King of Ingland, \&e. 
A.D. 1508 . 14 June.

LXV.

\section{The Provost of Cassel to Margaret of SAVOY.}

[Iolograph, Addit, MS., Brit. Mus., 21,382. f. 23 ]

Ma tresredoubtee dame. Je me recommande treshumblement a votre benigne grace. Madame, je voz ay escript nagheres, faisant responce a voz lettres du vije de ce mois. Et a voz en dire franchement la verite, javoye bien eu espoir de mienlx. Car a ee quil ma peu samble, je nay point trouve les courages si adonnez et enelins comme par si devant. Je ne say sylz se sont refroidez, ne pour quelle cause; mais je say bien de vray que en bien peu de tempz la pension de France se doit payer, ${ }^{1}$ car les quitances sont signees. Il me samble que aulcquns pensent que noz les mesteryons volentiers en gheere alencontre des Francois, a quoy ilz ne sont enclins; ear ung des grands me dit, en demandant, quil oiseroit conseillier au Roy soy bouter en telle mer, avee aultres choses, et que ce seroit

\section{Transhation.}

MY most dread lady, I commend myself humbly to your benign grace. Madam, I have written to you lately in answer to your letters of the 7th of this month. And to tell you frankly the truth, I had hoped for better things; for, as it appear's to me, I lave not found men's minds so favourable and well disposed as hitherto, I know not if they be chilled, or for what reason ; but I know well of a truth that in very short time the pension of France is to be paid, for the acquitances are signed. It strikes me that some think we want to get them into a war with the French, to which they are not disposed; for one of the grandees said on asking [me about it] that he dared [not] comsel the king to embark on such a sea, with other things, and that

${ }^{1}$ se doit payer.] Corr, from est arivec. 
grand despens denvoyer les Angloix pardela. Toutes- A.D. 1508. fois en tant quil touche a les $\mathrm{e}^{\mathrm{ml}}$ escus, mais que les 14 June. obligations soyent pardeca, me fut dit quil ny auroit point de difficulte.

Madame, voz me povez croire que je nay rien laisse Had rea dire quil me sambloit servir a propos. Mesmement $\frac{\text { minded the }}{\text { Council }}$ leur ay remante les bonnes lettres que le roy avoit they were escript, tant a voz, madame, comme a cheulx des assist to estas, par les quelles yl promest toute assistence, etc. Low alencontre de cheulx qui vouldroyent envahir mon- Countries seigneur ou ses pays, etc. A quoy me dirent que le aggression roy de France nentendoit point envahir lesdits pays, of France. mais seulement secourir le duc de Gheldres. Madame, soyez asseuree que sur ce point fust bien respondu. Et leur demanday par la meilleur doulceur que je povoy que chose estoit envahir, et se meurdre, occision, ardre, brusler, destruire, et desoler, tout nestoit point envahir? avec tant daultrechose. Mais, comme je vous ay dit ilz demourerent assez froitz reserve que pour

it would be a great expense to send the English thither. Nevertheless, as regards the 100,000 crowns, provided the ohligations be here, I was told there would be no difficulty.

Madam. you may believe me that I have left nothing unsaid, which it scemed to me might be of service. I likewise reminded them of the good letters the king had written, both to you, madam, and to those of the estates, by which he promises every assistance, \&ce, against those who would invade my lord or his comntries, \&c. On which they said that the king of France did not mean to invade the said comntries, but only to succoum the duke of Gueldres. Madim, be assured they were well answered npon this point. And I asked them in the gentlest manuer. I could what was invading, and if muder, killing, buning, destroying, and wasting did not amomit to invasion? with many other things. But, as I have silid, they remaned rery cold except 
A.D. 1508. tout resolution me dirent que le roy en eseriroit vo14 June. lentiers au roy de France, et en froit parler a Dorisole. Et peu apres lung de eulx me dit a part que en vj. ou vij. jours je parleroy mesmes au roy.

Madame, je voz supplye que tont ce soit tenu seeret, car yl y a tant de rapporteurs par le monde que lon noise aulcqune fois escriere le tout. Aussi voz supplye que ne me veulliez rien escriere que bien en voz lettres et laultre par billietz.

$\mathrm{Au}$ cas que les Francois et Messire Robert' viengnent, a votre tresnoble correction, je froy esmouvoir tout le pays par son de cloce et toute aultre maniere du monde, et froy prescher par toutes les villes et villages loultragieuse oppression desdits Francois. Quant a moy, se je y estoye joseroye bien par votre charge et commandement remonstrer au peuple de Gand ce que la conscience men juge et par avanture voz y froye aussi bon service que par deca.

that they gave me as all their answer that the king would willingly write about it to the king of France and would cause Dorisole to be spoken to. And shortly afterwards one of them fold me apart that in six or seven days I shonld speak to the king himself.

Markm, I beg that all this may be kept secret, for there are so many talebearer's in the workl that one sometimes lare not write everything. Also I beg of you that you will write to me nothing lint good in your letters, and anything dise by private notes.

In case the French and Messire Robert' come, [subject] to your most noble correction, I would raise the whole country with alarm-bells and in every possible manner, and canse the ontrageous oppression of the French to be preached through all the towns and villages. As for myself, if I were there I would ventme by your command to show the people of Ghent what in my conscience I think of it, and perhajs I could do you there as good service as here.

'Robert De la Marck, duke of Botillon, "the Boar of Ardennes." 
Madame, je voz supplye tout jour's me pardonner A.1. 1508 . que jescris si privement. Il vault mieulx estre reprins 14 June. de rudesse que daultre chose. Et pour finallement voz advertir de tout lextreme secret que je pomray jamais savoir, je ne say se chascun vouldroit que noz eussions tout le pays de Gheldres; et samble que noz serions trop couragieux et ne fryons point si grand estime de noz voisins, par quoy aulcquns peuvent estre bien contens se noz sommes bridez par ce bout, affin que soyons toutjours suppliantz. Et se quelque jour je me treuve devers voz, je voz en diray plus avant.

Mais, madame, pour lhonneur de Dieu, tenez le secret, et soyez toute asseuree que quelque part que je soye, soit ycy ou par dela, je monstreray se je suis leal soubget ou non. Et de tant plus, puis quil voz plait estre contente et prendre en bonne part mon povre service, jamais temps sera que je ne penseray a desservir, syl mest possible, si grand honneur. Et aftin, madame, que je ne voz celle rien, je croy que a la fin

Madam, I request you still to pardon me that I virite so familiarly. It is hetter to be reproved for bluntness than for other things. And to tell you the upshot of the whole secret as far as I conld learn it, I know not if every one woukl be satistied that we should have the whole country of Gueldres. It seems that we should be too overbearing and not make so great accomt of our neighbours, so that some may be very well pleased if we are hemmed in on that side, in order that we may be always suppliants. If any day I find myself in your presenee I will tell you of this more openly.

But, madam, for the honour of God keep it seeret, and be fully assured that whaterer part I take, either here or there, I will slow if I be a loyal subject or 110 ; and all the more because it pleases you to take in good part my poor services, there shall never be a time that I do not endeavour to deserve if possible so great an honour. And Madam, that I may conceal nothing from you, I think that 
A.D. 1508. ancoirez voz ourez parler du mariage de monseignieur 14 June. le prince de Galles, et de madame Lyonoire, ${ }^{1}$ quelque chose que je voz en ay escript parcidevant; toutesfois de cy a ung mois je voz en escriray plus certainement que je ne sauroye faire maintenant. Tant y a que pour maintenant je say de vray et le commandeur de Haro la dit publiquement, que le roy de France comme vray allie et ami du roy Darragon a puis nagheres escript an roy Dangleterre, le pryant bien acertes pour laccomplissement du mariage de madame Katherine Despangne, avec monseignieur le prince de Galles, etc. Et ma on dit que le roy Dangleterre na point este fort content que le roy de France sen mesle si avant. Et que plus est, lon dit que mondit sieur le prince ny est gheres enclin. Toutesfois, madame, en peu de temps lon en saura plus.

Ledit de Haro a bruyt destre fort Francois, et je le croy, car yl se declaire aulcqune fois trop quant

in the end you will yet hear of the marriage of my lord the Prince of Wales and madam Eleanor, ${ }^{1}$ whatever I may have written to yon of it heretofore; nevertheless, a month hence I will write to yon with greater certainty than I can do at present. Thus much I know for trutl: and the commander de Haro has said publicly, that the king of Franee as true ally and friend of the ling of Arragon has lately written to the king of England urging him very earnestly for the accomplishment of the marriage of the lady Fatherine of Spain with my lord the Prince of Wales, \&e. And I have been told the king of England was not very well pleased at the ling of France interfering in the matter so far. Horeorer they saly my said lord the Prince is hardly much inclined to it. Nevertheless, madam, in a short time we shall know more.

The said de Haro is reported to be rery French, and I helieve it, for it appears too arident sometimes when any news

\footnotetext{
'Eleanor, daughter of the late archduke Philip King of Castile, and
} sister of Charles, afterwards Charles V. 
aulequnes nouvelles viengnent. Mais il lui fait a par- A.D. 1508. donner ; car son maistre est tel. Mais se Dieu donne 14 June. sa grace touchant Gheldres, madame, voz cognoisterez grandz choses et toutz les amys de fortune demanderont votre ayde et assistence. Dieu voz en doint la grace, comme jespoire fermement quil fra; mais yl est mestier que chascun se mette maintenant en oeuvre plus que jamais a rebouter les Francois si viengnent.

$\mathrm{Ne}$ pensez point, madame, que au cas que les If things affaires se portent bien en Gheldres, il ny aura roy de do well in France ne Dangleterre quil ne voz estime plus que Lady Marnulle aultre princesse, et le roy Darragon avecques. be highly Mais principalement le roy Dangleterre; car jamais si esteemed; dingne et profitable pour lui alliance ne pourra avoir en ce monde, comme quelque jour, quant yl voz plaira que je soy retourne, voz diray bien an long. Parquoy en bonne raison il pouroit avoir noz affaires pour recommandees; mesmement considere lestat ou quel chenlx de but they Gheldres sont maintenant, au fort yl noz fault ayder $\begin{gathered}\text { must help } \\ \text { themselves. }\end{gathered}$ noz mesmes, dumoingz durant ses trois on quatre mois.

arrive. But it may be pardoned in him, for his master is so. But if God grant us his grace tonching Gueldres, madam, you will knew great things, and all the friends of fortune will seek your aid and assistance. Grod give you such grace, as I firmly trust he will; but it is needful every one now should bestir himself more than ever to repel the French if they come.

Doubt not, madam, but that if affairs go well in Gneldres, the kings, both of France and England, will esteem you more than any other princess, and the king of $\mathrm{Ar}$ lagon also ; but chiefly the king of England, for never could he have in this world an alliance more worthy and profitahle for him, as some day I will tell you more at length, if it please you that I be recalled. So that with good reason he may be interested in our affairs; especially cousidering the state in which those of Gueldres are at present, it is particularly necessary that we should help ourselves, at least during these three or four months. 
1.1).1508. Madame, comme je voz ay escript pluseures fois que 14 June. le delay de la venue de messieurs les ambassadeurs nest cy non pour entretempz veoir ou la Fortune favorisera, et selle est bonne pour lempereur et votre maison voz aurez des grandz offies de plaisirs et services.

Il y a ung astrologue par deca quil ma dit que des le xxiie. ou xxiiie. de ce mois la fortune de lempereur sera si grande et si bonne plus que jamais. Dieu le face ainsi. Je ny adjouste nulle foy; mais neantmoingz sy fault yl que chascun sy employe a son extreme possible a la conservation de la juste querele, mesurement de celle de Gheldres, ainsi que jay remonstre par deca si a plain que nul nen pouroit dire au contraire.

Madame, je voz pouroy tesner de voz escriere si longlie histoire, mais beauc[ou]p de chose ne se peult mestre en peu de langage. Voz pardonnercz a la simplesse.

Et a tant, ma tresredoubtee dame, yl voz plaira me

Madam, as I have written to you several times, the delay of the coming of the ambassadors is only to see which side fortune will favour, and if it be good for the Emperor and your house, you will have great offer's of pleasures and services.

There is an astrologer here who has told me that from the 22 nd or $23 \mathrm{rd}$ of this month the fortune of the emperor will be greater and better than ever. God make it so; I give no credit thereto; but nevertheless, it is necessary that every one set himself to do his ntmost to maintain the just canse, especially that of Gueldres, as I have explained here so finly that no one had anything to say to the eontrary.

Madam, I may weary you by writing you so long a story, but much matter will not go into few words. You will forgive plainness.

And, thus fir, my most dread lady, it will please you to 
commander voz tresnobles plaisirs pour selon icenlx me $\Lambda . D .1508$. conduire. A layde de Nostre Seigneur au quel prye voz donner que plus desirez. A Londres, le xiiije. de Juing.

Madame, se le roy Dangleterre se peult apercevoir que voz escris telles choses yl me tiendra pour ung espye, et par avanture me vouldroit nuyre. Dieu sait de quelle foy et lealte je $y$ procede. Parquoy, Madame, voz prye de deschirer ses lettres quant voz aurez le tout [b]ien entendu.

Votre treshumble et tresobeissant serviteur,

G. De Theimse[ke].

Addressed: [A ma] tresredoubtee Dame, de.

instruct me of your most noble pleasme that I may conduct myself accordingly, by the help of our Lord, whom I pray to give you what you most desire. At London, the 14th of June.

Madam, if the king of England find out that I write such things to you he will hold ne for a spy, and perhaps he would do me harm. God knows with what faith and honesty I act. Therefore, mad:m, I beg of you to teal' II) these letters when you shall have fully muderstood the whole.

Your most hmmble and obedient servant, (. De Tulimseke.

To my most chead lady, \&ce 
A.D. 1508 . LXVI.

\section{'The Provost of Cassel to Margaret of Savoy.}

[Holograph $\Lambda$ ddit. MS., Brit. Mus., 21,382. f. 25.]

MA trespedonbtee dame, je me recommande treshumblement a votre bomne grace.

Reporting an inter-

Madame, jespere que voz aurez receu mes lettres du view with the King. xiiije de ce mois par les quelles entre aultres choses voz ay escript que le roy vouloit parler a moy. Madame, je fuz hier mande vers lui, et eux audience bien trois heures, devisant seul avec lui en ung giardin ou yl estoit a cheval, et me ordonna prendre ma mule et deviser ainsi ensamble.

Madame, je vouldroy que jeusse la memoire si grande pour savoir bien raconter le tout, mais au mieulx que pourlay voz escripray les principaulx pointz.

1. On the

Le primier diceulx, apres avoir mande des nouvelles subject of Gueldres. et samblables communes devises, estoit touchant Gheldres, comment, en ensuiant certaine ouverture ja pieca faicte par moy sur laffaire dudit Gheldres, il y avoit

\section{Tizanstation.}

MY most dread lady, I commend myself most humbly to your good grace.

Madam, I lope that you have received my letters of the 14 th of this month, by which, among others, I wote to you that the king desired to speak with me. Madam, I was yesterday sent for to him and had audience full three lours conrersing alone with him in a garden, where he was on horseback, and ordered me to take my mule and converse thus together.

Madam, I would that I had a good enough memory to relate the whole, but to the best of my power I will write to you the principal points.

'The first of them, aftel haring talked of news and like ordinary conversation, was touching Gueldres; how according to a certain overture made long since by me on the matter of Gueldres, he had thought over it at great length, and 
pense bien au long et par pluseures fois consulte envers A.D. 1508 . soy mesmes, comment lon y pouroit mestre ugne bonne ${ }^{20} \mathrm{June}$. fin. Et pour sa finale resolution ne trouvoit moyen Henry rene expedient plus convenable que de faire ungne treve commends pour certain tempz, chascun retenant ce quil a, pendant la quelle treve lon determineroit du principal par voye arbitrale; assavoir que de nostre coste lon compromettera en lui comme arbitre on arbitrateur, on amiable compositeur. Et sait bien que du coste de Messire Charles Degmonde lon se comprometteroit au roy de France en pareille facon, et eux deux en certain tempz que a ce seroit ordonne wideroyent le different.

Madame, sur ce point, devant tout oeuvre, je remerciay treshumblement le roy de ce quiluy avoit pleu avoir si bonne souvenance des affaires de Monseigneur, et mesmement tonchant icelle affaire de Gheldres, la quelle estoit telle et de si grande importance que selle estoit bien wydee a son honneur toute la reste de ses aultres affaires se porteroit assez bien. Par quoy, voz,

several times deliberated with himself how at good end could be put to it. And for his final resolution he found no mean nor expedient more suitable than to make a truce for a certain time, each retaining what he has, during which truce a settlement should be made of the priucipal thing by arbitration; to wit, that on our side it should be referred to him as judge or arbitrator or friendly composer of differences. And he knows well that on the side of Messire Charles D'Egmont, they will remit themselves to the king of Frauce in like fashion ; and they two within a certain time, which should be appointed, would adjust the difference.

Madam, on this point, before proceeding to business, I thanked the king most humbly that he had been pleased to have such good remembrance of the affairs of my lord, and likewise touching that matter of Gucldres which was such and of so great importance that if it was well disposed of to his houour all the rest of his affilirs would go on well enough. Wherefore you, madam, knowing truly 
A.D. 1508. Madame, congnoissant de vray quil estoit le prince du 20 June. monde qui mieulx, tant par sa tresgrande auctorite, reputation, et estime, que par le bon amour et affection patemelle quil avoit et portoit envers mondit seigreur, povoit regarir ceste playe, voz maviez charge et commande bien acertes de entendre son tresnoble plaisir touchant ledit Gheldres. Neant moingz, et a sa correction, je desiray bien lui remonstrer ung peu comment de prime face yl povoit sambler que pour le Which the tempz present, consideree lextreme indigence en la writer objected to, quelle les Gheldrois sont maintenant, ceste treve ne as the ad- seroit ne honorable ne proufitable, mais an contraire vantage fort prejudiciable a mondit sieur. Car par le moyen all on the dicelle les dits Gheldrois se renforcerient de rechief, side of
Gueldres. ravitailleryent et se reserryent entierement on mainteugne bonne adresche, secours et auyde pour en avoir la raison a toutjours; la quelle raison se noz povyons obtenir par son bon advis, conseil, et moyen, mondit sieur, voz, Madame, et tout les pays de pardela seroyent

that he was the prinec of all the world, who, both by his very great anthority, reputation and esteem, and by the good love and paternal affection which he had and bores towards my said lord, best could heal this wound, had very carnestly charged and commanded me to learn his most nohle pleasure touching the said Gueldres. Nevertheless, and moler his correction, I desired to shew him a little how it might appear prime fracie that for the present time, considering the extreme indigence in which the Gueldrians now are, this truce would neither be honorable nor profitable, bnt, on the contrary, very prejudicial to my said lord. Becanse, by means of it the said Gueldrians would reinforce themselves again, revictual, and draw together entirely where now they are so very much reduced that it needs but good address, wnecons, and aid to keep them in suljection for ever; which, if we conld ohtain by his good arlviec, comnsel, and means, my sait lord. yon. madam. 
a jamais de tant plus tenuz et obligez vers lui. En A.D. 1508. oultre lui dis que par icelle treve les dits Gheldrois 20 June. seroyent relevez de toutz frais, missions et despens, et de nostre couste rien; car aussi bien fauldroit yl maintenir les garnisons a grandz despens comme selle nestoit point. Et qui est tout le pys, que ungne annee de telle treve seroit assez pour les Gheldrois pour apres noz faire de rechief plus forte gheere, ainsi que par lespace de si long tempz lexperience la monstre; avec pluseures aultres grandes devises, dtc., lui suppliant que au lieu de telle treve yl noz voulsist plus to adrescher pour en avoir la fin finale du tont desmaintenant faire ungne bonne ferme paix, a lhonneur et utilite de mondit sieur ungne fois pour toute.

Madame, je ne say se jay bien dit ou non; car mes instructions ne se extendent point si avant. Toutesfois, a vostre correction, il me sambloit quil ny povoit avoir reprinse. Et le roy me donna si bonne audience quil me sambloit estre heure entendre de lui

and all those countries would always be under so much the greater obligations to him. Besides, I said to him that by this truce the said Gneldrians wonld be relieved of all costs and expenses, and on our side nothing; for it would be equally necessary to keep up the garrisons at great expenses as if it was not made. And what is still worse, a single year of such truce would be enongh for the Gucldrians to make again more vigorous war, as experience has shown during such a long space of time; with a great deal of other conversation, \&c., begging that in place of such a truce he would rather show us how to bring the thing to a conclusion by making, once for all, a good firm peace to the honour and utility of my said lord.

Madam, I know not if I have said well or not, for my instruetions do not extend so far. Nevertheless, under your correction, it appeared to me that there could not have been any oljection. And the king gave me such good audience that it seence to me to be time to lenen from him 
A.D. 1508. sa derniere volente, comme yl me samble qe jay en20 June. tendu au mieulx que jay pen, ainsi que voz coingnoistrez.

The king's Ma dame, a ses devises le roy se tent pour quelque advice
touching Gueldres. gre de parler ainsi francement, et quil vit bien que javoy grand desir de bien servir mon maistre. Aussi de son coste yl le vouloit adrescher le plus a bonne seurte que possible lui seroit, et me diroit aussi francement son avis et les raisons qui lesmovoyent. Et pour lentree me dit quil ne savoit croire que lesdits Gheldrois estoyent si bas et si pres prins comme lon dit; car yl sait de vray que le roy de France jamais ne les lauroit tumber en telle necessite et indigence, et que plus to yl y mesteroit toute sa coroune devant que cela adviengne, quelque chose que lon dye au contraire, dont, madame, yl voz asseure pour vray. Dit que icellui roy de France est riche, puissant de gens et de bien, et que davoir la ghere a lui il ne le con-

his latest will, which I think I have learned to the best of my power, even as you will understand.

Madam, after this eonversation the king kept silence for some little time, and afterwards said to me, smiling, that he liked my talking in this frank fashion, and that lie saw well that I was very anxious to serve my master well. He also on his side desired to induce him to the course whieh was the best possible for his secmrity, and would tell me as frankly his opinion and the reasons which influeneed him. And in the first plaee he said to me he could not believe that the said Gueldrians were so low and so nearly taken as was alleged, for he knows of a truth that the king of France would never have let them fall into suel neeessity and indigenee, and that sooner than that should happen he would risk his erown, whatever is said to the contrary; which, madam, he assures you to be true. He says that the same king of France is rich, powerful in men and money, and that he would never eounsel 
seilleroit jamais. Dit aussi quil a entendu que les A.D. 1508. affaires de lempereur ne sont point si bien adreschees 20 June. alencontre de ses ennemys que le roy de France aye grand peur de lui. Et mesmement quil a entendu puis na gheres que cheulx de lempire lui font bien petit secours, dont yl a grand regret. Aussi a bien entendu que les Venetians ont gagne sur lui grand pays, et journellement sefforcent de lui faire le plus grand grief quilz pouront; qui est bien mauvaise chose avoir a faire en tant de lieux si longtains sans prosperer; ce que lui a fait si grand mal quil lui a grandement retarde sa sainte. Car; quant sa fortune eust este meillieure seust este ugne grand joye pour lui et tontz ses alliez et eust on bien sceu mieulx conduire beaucop de chose que lon ne sanroit faire maintenant. Par quoy, ses choses considerees, yl se arreste a son advis; car, quant a lui, et au regard du secours quil pouroit de son coste envoyer en Ghildres, dit que en ce faisant yl se mestroit en ghere ouverte

the making war on him. He said also, that he understood the affairs of the emperor are not so well disposed against his enemies that the king of France should have great fear of him ; and likewise that he understood of late those of the empire give him very little aid, which he greatly regrets. And he has learned that the Venetians have gained much territory from him, and daily strive to do him the greatest injury they can. It is an ill thing to have to act in so many and so distant places without prospering, which has cansed lim so much annoyance that it has seriously retarded his health. For if his fortune had been better it wouk have been a great joy for him and all his allies, and one would have known better low to conduct many things than one can do now. Wherefore, these things considered, he remains in his opinion; for as to himself and the succours he might for his part send into Gueldres, he says that in so doing he should set him- 
A.D. 1508. arec les Francois, ce que cheulx de son reaulme nelui 20 June. conseillent point, ne yl nest point aussi de tel advis. The king's Car puis quil peult vivre en bonne seure paix, jamais touching nentreprendra la ghere, mesmement ancoires pour chose Gueldres. que ne lui touche, du moingz si pres que il sen devroit mestre en telz dangiers et inconveniens. Dit oultre que lui donne grand merveillic que lempereur mesmes a qui la chose touche, trop plus ny mest ugne bonne fin au cas que la necessite y est si grande, avec tant daultres grandes raisons que certes, madame, il ne seroit point possible les toutz escriere, toutjours persistant en son premier advis.

A ce que par la treve les Gheldrois seroyent plus advantages que noz, et que ce seroit pour de rechief noz faire plus forte gheere, dit que ladvantage seroit tant pour lung que pour laultre ; car yl entent que durant la treve nul nentreprenảra sur laultre, et au cas que aultrement se faisoit, yl se joindroit a lencontre de celui qui auroit encommence et auroit rompu ladite treve, et pareille-

self at open war with the French, which those of his realm do not counsel, nor is he himself in favour of such a policy. For since he can live in good sure peace he will never undertake war, at all events for a thing which by no means concerns him so nearly that he ought to put himself in such dangers and inconveniences ou account of it. He said besides that he was much surprised that the emperor himself, whom it concerns far more nearly, does not put a good end to it, if the necessity be so great, with many other great reasons, which assuredly, madam, it would not be possible fully to recount, always persisting in his first opinion.

As to the Gueldrians being more benefited by the truce than ourselves, and that it would be an opportunity for making more vigorous war against us, he said the advantage would be equally great to the one as to the other; for he means that during the truce neither shall attempt anything against the other, and if it happened otherwise he would join against the party which had commenced and 
ment froit le samblable quant la paix seroit faite. Car A.D. 1508. en ce, veu quil sen auroit mesle si avant pour le bien 20 June. de paix, il pouroit abonne cause et juste querelle ayder et porter celle part qui auroit tenu et garde les dites treves et paix alencontre de laultre qui les auroit enfrainct. Ainsi que en foy et parolle de roy yl ma dit quil froit.

Madame, comme je voz ay escrit derrenierement, les matieres me sont trop pesantes, mais je roz escris le tout au plus pres que je puis. Et mesmement pour ce que je persistay fort de plus to avoir ungne bonne, vraye, et ferme paix que telle treve, me dit que toutz les sages de France et de Flandres ne saroyent faire ungne paix, les choses estantz ainsi quelles sont, que preallablement lon cessa de faire la ghere, et treve precedente. Sur quoy, madame, apres avoir ung peu cesse de devises, et en se promesnant a cheval par ledit giardin il me dit quil me clonnoit le plus seur conseil pour entretempz maintenir monseigneur en bonne paix

had broken the said truee, and he would likewise do the same if peace should be made. For in this, considering that he would have interfered so far for the good of peace, he might with good causo and just quarrel, aid and support that party which should have kept the said truce and peace against the other which should have violated them. 'Thus he deelared to me that he would do, on the faith and word of a king.

Madam, as I last wrote to you, the matters are too weighty for me, but I write you the whole as nearly as I ean. And likewise, because I insisted strongly on having a good, true, and firm peace, rather than such a truce, he told me that all the wise men of France and of Flanders could not make a peace, affairs being in such condition is they are, unless previously there were a truee and cessation of hostilities. Whereupon, madam, after a pause, taking a turn on horseback about the said garden, he told mo he gave me the surest counsel to keep my lord meanwhile in good peace 
A.D. 1508. avec ses voisins et aussi avec ses propres soubgetz. 20 June. Car yl est possible que sesdits soubgetz quelque jour se The king's tenneront de contribuer et donner les aydes et aultres advice touching Gueldres. subsides. Avec ce me dit quil congnoit plus quil nest mestier de clire, et que paravanture tout le monde nest pas si enclin pardela et si resolu comme yl pouroit bien estre, et que de tant que yl y pense plus il sarreste de plus a son premier advis; me disant oultre quil avoit bien grand piete de voz, car, consideree la grandeur des affaires, yl estoit bien force que aulcqune fois voz estiez en grandz regretz et perplexitez, des quelles voz sortiriez par ce bout, \&tc.

Madame, en ses devises le roy vit bien de quel ceur je lui parlay, et en la plus grande reverence que faire savoye, lui regrestant toutesfois que ung prince de si grande extraction questoit monseigneur ne povoit consuir son droit et patrimoisne, ne par voye de justice ne aultrement; et mesmement considere que le roy de France par les traictez de Blaitz et de Trente avoit jure sur le Sainct Sacrament consacre par evesque, sur

with his neighbours, and also with his own subjects; for it is possible that his said subjects one day may weary of contributing aids and subsidies. In addition to this, he told me that he knew more than it was necessary to say, and that perhaps everybody is not so well disposed and resolute there als he might well be, and that the more he think: of it the more he adheres to his first opinion; saying hesides, that he had great pity for you, for considering the greatness of the affairs, it was impossible but that sometimes you must be in great troubles and perplexities, from which you might eseape by this means, \&c.

Madam, in these conversations the king saw well with what conrage I spoke to him, and with the greatest reverence I could; regretting, nevertheless, that a prince of such great extraction as my lord could not pursue his right and patrimony either by way of justice or otherwise, especially considering that the king of France by the treaties of Blois and Trent had sworn upon the Holy Sacrament consecrated by a bishop, 
le Saint Canon, sur les Sainctes Evangiles, de [ne] se A.D. 1508. point mesler des fiefz imperiaulx, tant hors des Ytales que dedans; en lui disant que Dieu quelque jour sen mesleroit pour conforter le bon droit, \&c.

En effect, madame, tout ce que jamais nay sceu penser je le remonstray a ma povre simplesse au mieulx que je puis. Car javoy si tresbonne audience que yl me samble que jamais nen auray meillieure. Mais, madame, chascun ne fait pas tontjours ce quil froit volentiers. Tant y a que envers Dien et tout le monde je cuide avoit satisfait a mon serment. Et finablement je ne me sceus tenir de dire que qui auroit espoir. dobtenir par ung moyen ou aultre les villes et fors qui povoyent le plus grever et nuyre au pays de monseigneur. Ancoires seroit ce bonne chose, mais je craindoy que jamais les Francois ny entendryent; car ylz ne veullient cy non noz grever et confundre se ylz povoyeut, \&c., avec tant claultres choses que il nest possible descriere.

upon the Holy Canon, upon the IIoly Gospels, not to interfere with the imperial fiefs, either without or within Italy; saying to him that God would one day interfere to strengthen the just right, \&c.

In short, madam, everything that I conld ever think of I represented to him in my poor simplicity, to the best of my power ; for I had such excellent audience that it appear's to me I shall never have better. But, madam, every one does not always do what he would wish to do. At all events, towards God and everybody, I think I have fulfilled my oath. And, finally, I conld not refrain from saying that whoever should have hope of obtaining by one means or another the towns and forts which could do most injury in the country of my lord, this, again, would be a good thing; but I feared the French would not listen to it, for they only wished to molest and confuse us if they could, \&ce, with many other things which it is impossible to relate. 
A.D. 1508. Le roy veant que je persistoye fort changa propos; 20 June. toutesfois sy me fist yl quelque responce ace dernier mot, disant que en toute chose yl y a ordre, et de maintenant parler de cela nestoit ancoires heure. Mais fauldroit premierement wyder ce quil avoit conseillie par avant, et apres lon se mestroit en devoir du remenant. Et atant commenca a parler dungne aultre matiere aussi pesante que ceste.

2. of A savoir, madame, des affaires Despangne et du roy Spain. Darragon. Et me demanda premierement se je nen savoye aulcqunes nouvelles. A quoy lui respondis que non. Et lors me dit quil ny avoit homme a Parys Henry says plus Francois que ledict sieur roy Darragon, et savoit tell the em- bien quil namoit point lempereur. Mais se lempereur peror how ini vouloit croire il lui donroit tel advis, conduite, adresthe entiin che, moyens, et advertissementz que ledict Darragon administra- nauroit plus que faire en Castillie, et le tout se con-

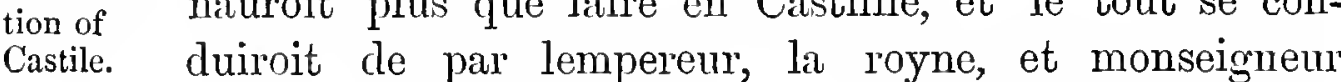
comme prince et heretier. Dit quil nest pas homme

The king pereeiving that I insisted strongly on this, changed the subject, but nerertheless made me some answer on the last point, saying that there should be order in everything, and that it was not yet time to talk of that. But it would be necessary first to settle the matter which he had previously advised, and afterwards the rest would be taken into consideration. And then he began to talk of another matter as weighty as that.

That is to say, madam, of the affairs of Spain and of the king of Arragon. And he asked me in the first place if I knew of any news on the subject, to which I replied, No. He then said to me there was not a man in Paris more French than the king of Arragon, and he knew well that he did not love the emperor. But if the emperor wonld believe him he would give him such advice, guidance, means and intelligence that the said king of Arragon should no longer have anything to do in Castile, and everything should be conducted by the emperor, the queen, and my lord as prince and heir of the kingdom. He said he was not a man of two words, and 
de deux parolles, et ce quil dit yl le tiendra. Dit oul- A.D. 1508. tre que le fait de Castillie est de si grande importance 20 June. que se lempereur y avoit le main souveraine il froit trambler toutz ses ennemys. Disoit ancoires tant daultre chose a cell fin que en effect, madame, soyez toute asseuree quil y est enclin tout oultre. Et pource que jeusse volentiers entendu quelque chose plus avant, il medit que jamais ne me diroit les moyens; mais se jamais lempereur et lui se povoyent trouver ensamble il lui donroit a congnoistre le plus secret touchant ceste affaire qui est possible. Dit oultre que quant lempereur auroit le reaulme de Castillie que le fait de Gheldres se wideroit de soy mesmes, et, par consequent, toutes les pesantes matieres que lempereur pomroit avoir. Dit que il vouldroit que jamais lempereur ne fit entreprinses cy non celles qui seroyent bien deliberees par meur advis et conseil, des quelles yl pouroit avoir gloire et renon, comme seroit ceste sye. Non pas que pourtant yl y deut mesmes aller, cy non apres, quant toutes

that which he says he will keep. He said besides that the affiur of Castile is of such great importance, that if the emperor had sovereign authority there he would make all his enemies tremble. He said besides so many other things to the same effect that in short, madam, you may be fully assured he is thoroughly inclined that way. And because I would gladly have heard something further, he said he should never tell me the means, bnt if ever the emperor and he could meet he would give him the most seeret knowledge possible touching this affail. He said besides, that when the emperor should have the kingdom of Castile, that the affair of Gueldres would settle itself, and consequently all the weighty matters that the emperor might have. He said he would the emperor never made expeaitions except such as should be well weighed by mature advice and council, from which he might have glory and renown, as would be the ease in this. Not, however, that he should go thither himself, except after- 
A.D. 1508. choses seroyent paraschevees, se son plaisir estoit tel. 20 June. Dont yl na doubte nul que tout seroit a lui, et par ceste affaire yl seroit le plus grand qui fut en long tempz. Disoit aussi que il ne se deffye de rien de lempereur; aussi yl croit fermement que lempereur ne se deffye de lui, et le parlement de eulx deux ne greveroit ne a lung ne a laultre.

Madame, ce sy nest pas petite matiere et la fault tenir aussi secrete que la confession; aultrement, \&c.

Madame, je lui demanday se son plaisir estoit bien que je voz en advertisse. Il y pensa ung peu et apres me dit quil en estoit bien content. Par quoy, madame, je men descharge. Neantmoingz syl voz plait que je lentretiengne en ce propos, ordonnes moy par voz premieres lettres que je le remerchye de cestui advertissement.

3. Of the Le tiers point du quel yl me parla estoit de la venue coming of
theFlemish ambassa- est ancoires bien debile, toutesfois il est bien content dors.

wards when everything luad been aceomplished, if such were his pleasure. He has no doubt that everything would turn out favorable to him, and by this affair he would be much greater than he has been for a long time. He said also that he in no wise distrusts the emperor; he also believes firmly that the emperor does not distrust lim, and the interview between them would not be injurions to either.

Madim, this is no small matter, and it must be kept ats secret as the confession, otherwise, \&c.

Madam, I asked him if it was his pleasure that I should inform you of it. He considered for a short time and afterwards told me that he was content; wherefore, madim, I deliver myself of it. Nevertheless if you wish me to keep him to this intention, give me directions by your first letters to thank him for this information.

The third point on which he spoke to me was of the coming of the ambassadors, and in effect, although he is still very weak, yet he is content that they shall come at the end 
quilz viengnent a la fin du moys de jullet prochain, et A.D. 1508 . leur fra la meillieure chiere et expedition quil poura 20 June. Par quoy, madame, voz frez merveilleusement bien de les despecher, affin quilz soyent y chy au tour du dernier jour de jullet. Yl ma aussi dit quil desire bien de savoir les personages quil viendront pour les faire logir et recevoir. Par quoy, madame, il ma ordonne den voz escriere; se vostre plaisir est voz men advertirez, car yl desire de le savoir.

Et finablement me dit comment passe vj. ou vij. jours 4 . Of ceryl avoit ordonne a messieurs de son conseil me parler ${ }_{\text {glish rebel }}^{\text {tain }}$ daulequns ses rebelles soubgetz et aultres qui journele- in the Low ment lui font blasme et deshonneur, dont me fut donne Countries. certain billiet, lequel voz ay envoye.

Madame, je ne voz sauroye point escriere comment yl a celle matiere a ceur et entend que lon envoye les contenuz audit billiet toutz prisoniers pardeca pour en faire la raison; aultrement yl ma dit quil nen sera point content, du moingz de cheulx qui sont ses soub-

of the month of July next, and will give them the best cheer and expedition he can. So that, madan, you will do marvellously well to despateh them so that they may be here about the last day of July. He also told me he desires much to know the personages who shall come, in order to make arrangements for their lodging and reception. Wherefore, madam, he ordered me to write to you of it; if it be your pleasure you will apprise me, for he wishes to know.

And finally he told me how, six or seven days ago, he had "ordered the lords of his council to speak to me of some of his rebel subjects and other's who daily do hin blame and dishonour, of whom a list was given me which I send you.

Madam, I could not write to you how he has this matter at heart and desires to have those contained in the said list all here as prisoners that justice may be done on them; otherwise, he said to me, he shall not be satisfied, at least as to those who are his subjects; and on the others he 
A.D. 1508. getz, et des aultres entend que lon en face pareillie raisor 20 June par dela sans dissimulation ne advertissement pour eulx povoir saulver.

Madame, je neusse jamais cuide quil eut eu la chose tant a ceur. Dieu sait quelle honte que jen ay eu, et quelle chose il men a dit; et certes je vouldroye estre aillieur se je me devoye gheere mesler de telle chose. Car rien ne fut prys en gre de tout ce que je lui savoye dire. Il me doit souffire voz en avoir adverti par deux fois. Aussi de la part du roy, il peult bien penser que je suis homme desglise, \&c.

Madame, jay le ceur trop pesant a voz en escriere ce que jay ouy, par quoy en fray fin.

Ma tresredoubtee dame, je prye a Nostre Seigneur voz donner que plus desirez. A Londres, le $\mathrm{xx}$. de Juing.

Vostre treshumble et tresobeissant serviteur, G. DE Theimseke.

Addressed: [A ma t]resredoubtee Dame, \&c.

means that like justice should be done there without dissimulation, or warning by which they might save themselves.

Madam, I should never have imagined he had the matter so much at heart. God knows how much I was ashamed, and what things he said to me about it, and certainly, I should like to be elsewhere if ever I were to meddle much with such a thing; for nothing of all I could say to him was taken in good part. It ouglit to be enough for me to have given you notice of it twice. As for the king, he may well consider that I am a churchman, \&c.

Madam, I have too heavy a leart to write to you what I have heard, so I shall make an end.

My most dread lady, I pray our Lord to give you what you most desire. At London, the 20th of June.

Your very humble and obedient servant, G. de 'Theimseke.

'To my most dread Lady, \&c. 


\section{LXVII.}

\section{Thef Provost of Casser to Lady Margaret. ${ }^{1}$}

[Holograph, Addit. MS., Brit. Mus., 21,382. f. 29.]:

Ma tresredoubtee dame, je me recommande treshumblement a votre beningne grace, Ma dame, pour ce que pas les deux derrenieres bougettes monsieur lambassadeur de Burgho ne moy avons receu aulcqunes lettres de voz, noz en sumes estez fort maris et perplex, et mesmement que entendons assez le retardement des ambassadeurs.

Ma dame, voz savez ce que ycellui seigneur de Fears a Burgho et moy voz en avons escript, et en effect je combinacrains que le roy Dengleterre se joindra avec le roy tween Ende France entierement a notre destruction. Comme je grand and voz ay escript par tant de fois, le roy Dengleterre a

\section{Translation.}

Mr most dread lady, I commend myself most humbly to your benign grace. Madam, as by the last two budgets neither my lord ambassador De Burgo nor I lave received any letters from you, we have been much grieved and perplexed, especially because we are well aware of the delay of the ambassadors.

Madam, you know that this seigneur de Burgo and I have written to you of it, and in short I fear that the king of England will join the king of France, to our entire destruction. As I have written to you so many times, the

1 The words in italies are written in eipher. $\Lambda$ eontemporary decipher is interlined. 
A.D. 1508. toutjours espie la Fortune et ne vouldroit que eussions 29 July. le pays de Gheldres. A ceste fin yl fait les difficultez touchant argent et le prest.

Ma dame, au cas que le roy Dengleterre soit entierement avec le roy de France comme il fait a craindre, sans doubte se les ambassadeur's ne viegnent, tout se pouroit perdre. Voz en saurez bien user.

Ma tresredoubtee dame, je prye a Notre Seigneur voz donner que plus desirez. A Londres le xxix. jour de Jullet, apres soupe.

Votre treshumble et tres obeissant serviteur,

$$
\text { G. De Theimseke. }
$$

Addressed: [A ma] tresredoubtee Dame, \&c.

king of England has always favored the winning side and would not that we should have the country of Gueldres. To this end he makes difficulties touching money and the loan.

Madam, in case the king of England be entirely with the king of France, as is to be feared, doubtless if the ambassadors do not eome all might be lost. You will know how to act.

My most dread lady, I pray our Lord to give you what you most desire. At London, the 29th day of July, after supper.

Your most humble and obedient servant, G. De Themiseke.

To my most dread Lady, \&c. 


\section{LXVIII.}

A.D. 3508 .

23 Aug.

\section{Henry VII. to the Bishop of Gurk.}

[From the original Addit. MS. 19,398, Brit. Mus.]

Henricus Dei gratia Rex Angliæe et Franciæ ac Sending dominus Hibernix, reverendo in Christo patri, domino him a mesMatthæo episcopo Gurcensi, archidiacono de Surrey, hear what sacratissimæ Cæesaria majestatis secretario et consiliario, he has to amico nostro charissimo, salutem. Accepimus jamdudum cate. ex relatu domini Andrea de Burgo vestram reverendam dominationem cupidam esse ut unum ex nostris fidum ac circumspectum ad vos destinaremus, cui vestram erga nos singularem affectionem ac cordis arcana acsi coram essemus, sinceriter aperire pollicemini. Proinde votis vestris satisfacere cupientes, præesentium latorem ad vestram reverendam dominationem destinamus, candem rogantes ut non modo eidem plenam ac indubiam fidem adhibere sicuti nobis ipsis velit, verum singula nobis significanda eidem aperire fidenter poterit, quod magnopere cupimus et ex corde rogamus. Datum apud Berwike die xxiij. mensis Augusti, anno Domini millesimo quingentesimo octavo et regni nostri vicesimo quarto.

HenRy R. 


\section{LXIX.}

\section{A.D. 1508. The Flemish Ambassadors to the LadY
7 Dec. Margaret.}

[Orig. Addit. MS., Brit. Mus., 21,382. f. 19.]

MadAME, tant et leplus humblement que povons nous nous recommandons a vostre bonne grace.

Madame, nous avons desavant hier v[eille] de Saint Nicolay aux Champs entre Dartford et ceste ville recen voz lettres de Cambray du second de ce mois; dont assez humblement ne vous saurions mercyer, car vous nous avez par icelles et par les bonnes et joyeuses nouvelles y contenues tant confortez et resjoys que ne le vous saurions escripre. Prians Dieu nostre Createm vous par . . ster jusques a lexecucion des matieres conceues, ainsi quil a fait jusques ores, et espero[ns] infailliblement quil fera enoultre jusques a la fin. Nous vous supplions aussi en toute humilite que en ensuyvant ce que de vostre grace vous a pleu nous escripre par vosdites lettres nous vouloir signifier de la con-

\section{Translation.}

Maday, in as humble manner as we can we recommend ourselves to your good grace.

Madam, the day before yesterday, the eve of St. Nicholas, in the fields between Dartford and this town, we received your lettel's from Cambray, of the second of this month, for which we cannot sufficiently thank you; for you have by them and by the good news contained in them, given us such consolation and joy as we camnot describe to you. Praying God our Creator to . . . you until the execution of the matters projected, as he has done to this time, and we hope, withont doubt, he will do henceforth, even to the end. We also request in all humility that according to what of your grace it has pleased you to write to us in your said letters, you will give us notice of the conclusion of the said matter's when 

clusion desdites matieres quant elle se fera pour icelle $\underset{7 \text { Der. }}{\text { D. } 1508 .}$ nostre joye confirmer et radoubler.

Quant a noz nouvelles, madame, depuis que dernierc- Relatiug ment vous avons escript nostre arrivec a Douvres, ney from sommes le lendenain " de la Saint Andrieu partiz dudit loover to lieu de Douvres, accompaigniez du gra[n]t prieur de Canturbery, de messieurs Eduart de Pouninghe et Gilbert de Talbot d[e]pute de Calays, chevalier de lordre, et allez le[dit] jour angiste audit Canturberey en labbaye illec. A notre entree devant ladite abbaye furent audevant de nous [t]ous les officiers principauls et gens de la ley de ladite ville en grant nombre, qui nous bienviengnerent et feirent tant bon recueil avec offre et presentacion de tout plaisir et service de si bonne sorte que riens plus. Et le soir nous vindrent faire presens de vin, cyre, espices, et pluiseurs autres choses, selon la coustume du pays, en grant quantito et bien $\mathrm{h}[\mathrm{o}]$ norablement.

it shall take place, that our joy may be confirmed and dontled.

As for our news, malam, since we last wrote to you of our arrival at Dover, we left that place on the morrow' of St. Andrew, accompanied by the grand prior of Canterbury, Sir Edward Poynings and Sir Gilbert Tilbot, deputy of Calais, knight of the order, and lodged that night at Canterbury, in the abbcy. At our entry there were before us, in front of the said abbey, all the principal officers and men of the law in he said town in great numbers, who welcomed us and gave us such a good reception, with offer's and presentation of every pleasure and service, that nothing could exceed it. And in the evening they came to make presents of wine, wax, spices, and several other things, according to the custom of the country, in great quintity and in very honomible fishion.

1 Dee. 
A.D. 1508. Le Samedy partismes, et venismes au giste a Setim7 Dec. borch, ung village a dix milles plusavant, dont aussi nous partismes le lendemain, qui fut Dimence, apres la messe, et venismes au giste a Rochestres. Dudit Rochestres feismes une antre journee, qui fut le Lundy, jusques a Dartfort, a douze miles pres de ceste cite. Et partout estions recueillez et tant bien venuz que merveilles. Jusques aupres dudit lieu de Dartfort nous convoyerent et conduirent tousjours le grant prieur de Canturbery et Messire Eduart de Pouninghe, qui furent a nous recevoir au descendre des navires audit Douvres, avec aussi le depute de Calays, et illec print congie de inous ledit sieur prieur et retourna en son eglise.

Lesdits depute et de Pouninghe nous ont tousjours accompaignic jus[qu]es icy. Et derant h[ie]r Mardy en deslogeant dudit Dartfort a demye lyeue pres dillec, trouvasmes au devant de nous aux champs messicurs levesque de Woucestre, ${ }^{1}$ le conte de Serosbery, grant

On Saturday we left, and came to rest at Sittingburn, a village ten miles further on, whence we again set out next lay, which was Sunday, after mass, and lodged at Rochester. From Rochester we made another day's jommey on Monday to Dartford, twelve miles from this city; and every where we were marvellously well received and welcomed. As far ats to the neighbourhood of Dartford we were conducted by the grand prior of Canterbury and Sir Edward Poynings, who were at the receiving of us when we disembarked at Dover, allong with the deputy of Calais; and there the said lord prior took leave of us and returned to his church.

The said deputy and Poynings have accompanied us all the way hither. And on Tuesday [the day] before yesterday, in our way from Dartford, at half a league from that place, we found before us in the fields my lord the hishop of Worcester,' the earl of shrewsloury, grand master of England, 
maistre Dengleterre, le commandeur de Saint Jehan, A.D. 1508. messire Eduart Brandon, chevalier de lordre, et le doctor West, avec grant multitude de gens de bien en nombre de cent et cinquante chevaulx ou plus ; lesquelz avec aussi lesdits depute de Calays et le sieur Pouninghe nous conduirent jusques en notre logiz. A lentre de la ville trouvasmes nouvelle compaignie de gentilz hommes de lostel du roy et autres, bien accoustrez et montez. Le soir nous vint on semblablement faire des presens de par Ia ville, non moindres, ains plusgrans que jusques ores lon avoit fait, tousjours en accroissant.

Hier, le jour Saint Nicolay, entre une et deux heures apres midy vindrent devers nous en notredit logis messieurs larchevesque de Canturberey et le conte Doxenfort, ung des grans, et, comme lon nous dit, le principal personnaige de ce royaulme. Apres la congratulacion faicte de notre bien joyeuse et desiree venue, qui seroit trop longue a escripre, nous dirent que le roy estoit prest de nous recevoir et donner audience

the commander of St. John, Sir Edward Brandon, knight of the order, and Dr. West, with a great multitude of wealthy people, in number about 150 horse or more, who, with the said deputy of Calais and Sir Edward Poynings conducted us to our lodging. On entering the town we found a new company of gentlemen of the king's household, and other's well accoutred and mounted. In the evening, likewise, people came to us to make presents on behalf of the town, not less but greater than ever, always increasing.

Yesterday, the day of St. Nicolas, between one and two o'clock after noon, eame to us in our said lodging, my lord the archbishop of Canterbury and the earl of Oxford, one of the great, and, as we are told, the prineipal personage of this kingdom. After congratulations on our joyful and wished-for arrival, which would be too long to write, they wold us that the king was rearly to receive and give us atudience when ve would; and on our iclling them we vere 
A.D. 1508. quant nous vouldrions, et en leur disant que nous estions 7 Dee. prestz quant il plairoit a sa majeste, nous consignerent heure ce jourdhuy devers luy en sa court de Grunevuyse, hors de ceste ville, a unze heures devant midy. Et pour y aller nous envoya sa barge avec aussi les scigneurs et personnaiges dessus nommez.

Audience Madame, nous y sommes allez a lheure assignee. given to Illec venuz avons trouve ledit sieur roy accompaignie
them at Greenwich. de monseigneur le prince de Gales, son filz, de lambassadeur ${ }^{1}$ du roy Darragon, de douze ou treize evesques, et de pluiseurs et la pluspart des princes et grans maistres de son royaulme. De vous escripre lonneur et le recueil quil nous feist et demonstra, ce seroit chose trop longue, et ne saurions. Il seroit impossible de meilleur.

Apres la presentacion et visitacion de noz lettres de credence, et lexposicion de notre clarge, et responce de par luy surce faicte par la bonche de monseigneur de Canturbery, ${ }^{2}$ son chancellier, nous dit ct repeta a di-

rearly when it should please his Majesty, they appointed us an hour this day [to be] before him in his court of Greenwich, ont of this town at eleren o'elock before noon. And to go thither he sent his barge with the lords and personiges above named.

Madam, we went thither at the hour appointed. Arrived there we found the said lord king accompanied by ny lord the prince of Wales, his son, the ambassador ' of the king of Arragon, twelve or thirteen bishops, and the greater part of the princes and leading men of the kingdom. To describe to you the honour and the reception which he gare us wonld be too long, and we conld not do it. Nothing conld have been better.

After the presentation and reading of our letters of credence, and the declaration of our charge, and answer thereupon made on his part by the month of my lord of Cinterbury,"

'Guttierc Gomez de Fuensalida. I " William Warham. 
verses fois et de tant bonne affection quil estoit pos- A.D. 1508. sible, que nous luy estions les tresbien venuz. Il nous 7 Dec. dit aussi que vray estoit quil avoit en quelque regret et anvy a notre retardement et longue demeure; mais notredite venue, congnoissant par icelle la bonne et entiere affection le lempereur et de vous, madame, pour laccomplissement des choses faictes et traictees a Calays, luy fait oblier le tout.

Apres, pour la presse qui estoit en la salle ou il nous avoit recen, nous mena en sa chambre, et illec se devisa longuement et priveement de sa grace avec moy, de Berghes, et me dit tout plain de bonnes choses. En effeet, pour demonstrer quil a aussi grant desir a laccomplissement des choses traictees, et a nostre despesche comme nous meismes, nous dit que demain envoyera dever's nous ses deputez pour veoir et visiter les lettres, tant dun coste que dautre, et apres adviser et conchre du jour de la solempnisacion des fianchailles et des choses qui en deppendent, tellement que esperons

his chancellor, he said and repeated to us diver's times, with as much affection as possible, that we were exceedingly welcome. He told us also that it was true that he had felt some unpleasantness at our long delay; but our said coming, as he knew thereby the good and entire affection of the emperor and you, madan, for the accomplishment of the things done and treated at Calais, causes him to forget everything.

Afterwards, on account of the crowd in the room where he received us he took us into his chamber, and there of his grace, conferred long and privately with me, De Berghes, and said to mo all sorts of fine things. Indeed to show that he has as great desire for the accomplishment of the things treated of, and for our despateh as ourselves, he said to us that to-morrow he will send to us his deputies to view and examine the letters on both sides, and afterwards advise and conclude touching the day for the solemuization of the betrothal and the things depending on it, so that we hope 
A.D. 1508. bien brief avoir bonne ${ }^{1}$ expedicion du tout. Alayde 7 Dec. du benoit Filz de Dieu, anquel prions, madame, vous donner bonne vie et longue, avec lentier accomplissement de voz tresnobles et tresvertneulx desirs. Escript a Londres le vije de Decembre, $\mathrm{xv}^{\mathrm{c}}$ huyt.

Voz treshumbles et tresobeissans serviteurs,

$$
\begin{gathered}
\text { J. de Berghez, } \\
\text { Sigismunde, } \\
\text { Andere de Da Borgo, } \\
\text { G. De Theimiseke. }
\end{gathered}
$$

A Madame.

very shortly to have good despatch of everything by the aid of the Blessed Son of God, whom we pray, madam, to give you good life, and long, with the entire accomplishment of your most noble and virtuous desires. Written at Loudon, the 7 th of December, 1508.

Your most humble and obedient servants,

$$
\begin{gathered}
\text { J. de Bergiez, De Gorretod, } \\
\text { Sigisilunde, } \\
\text { Andrea da Borgo, } \\
\text { G. De Tileiniseke. }
\end{gathered}
$$

To Madam.

1 bonne repeated in MS. 
$\Lambda$ P PEN II X. 



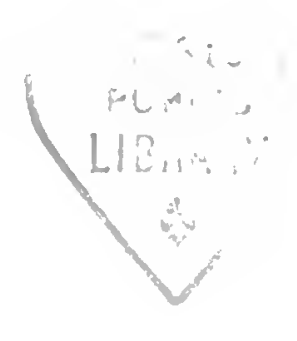

\section{APPENDIX A.-SUPPLEMENTARY PAPERS.}

\section{I.-Tite Lords of Ireland to Henry VII.}

[Orig. in Record Ollice.]

This letter is mentioned by Ware in his Amnals of Treland, and is attributed by him to the year 1486, to which date it appeared not mmatural to refer it. Taken, however, in comnection with the two doeuments which follow, (and which have been erronenusly attributed to the reign of Henry VIII.,) it appears that the date must be between 1489 and 1493.

\section{To The King OUR SOVErayne LIEge LORD.}

Moost excellent Cristen kyng and our moost redoulted soverayne liege lord, in the lumblest wise that eny subjettes kan or may, we recommaund us unto your moost noble grace. Please it the same that our right gode lord Gerald erle of Kyldare your 'the earl of depute lientenaunt of this your land of Irland hath Kildare is shewed unto us your graciouse lettrez dated at your by the maner of Grenewich, the xxviij. day of July last King to passed, wherby we have well understannd your graciouse mynd in the same that ye wold have our said gode lord to your noble presence, to thentent that he myght knowe therby your graciouse mynde, and that your highnes myght have plenar communicacion with hym in all such thinges as myght concerne the wele of this your said land and for the reducyng therof and your subjettes of the same to a gode and lawefull ordre and obeisaunce, to the pleaser of God and the 
wele and profit of your said subjettes and land, as in your said lettre more amplier it dothe appere. Graciouse lord, and it like your highnes, we understand that he is bounden and sworne to be your trewe and feithfull subjet and liegeman as straitly and as sure as ever was eny subjet to his prince; the which othe and assuraunce our said gode lord hath wele and truly kept and observed contynuelly to this tyme, and undoubted will kepe during his lyve, and never will degresse from the said othe and assurannce. And, graciouse lord, forasmoche as we understand the great

IIis presence in Ireland is essential to the safety of the country. daungiers and emynent periles that shold falle yif he shold depart owt of this your land, aswell by your Irishe enemys as otherwise; for when our said gode lord was seke, wher of we certified your highnes but late, it was playnl[y] and openly reported that our said gorle lord was in grete joperdy of his lyve, by reason wherof diverse of the myghtiest of your Irish enemys confedered to gedir ymagyned and noysed a division $t$. . . . betwene them of your landes in this parties, yif God had don the will of our said gode lord. And in his said sekenes ther were diverse of your subjettes robbed, spoyled and taken prisoners and meny [othe]r grete hurtes done. And by the oothes that we have don to your highnes that is true withowte feynyng. Wherfor we in our moost liumble and obeysant maner beseche your excellent grace to be his gode and graciouse lorde, and to have hym in your moost tendre favour, and that he may liave your graciouse license at this tyme to abicle at home for the defense and saufgard of us and others your feithfull subjettes, for diverse and meny urgent causes and greate daungiers, which we knowe rightwell shold fall in his absence yif he shold departe. And, graciouse lord, we beseche your highnes that what soever accusementes be made unto your grace on our said lord that therbe no credence takyn therto tyll his reson- 
able excuses be had in the same. Moost excellent Cristen kyng and our moost redoubted soverayne liege lord, the Blessid Trinite graunte you meny prosperouse yeres to reigne upon us, with victory of your enemys. Yoven at your Cite of Divelyn in playne parlement undre the oone part of your grete seall of this your said land, the iiij. day of Juny.

Walterus Dublin.

Per Armacanum, manu propria.

Johannes Midensis.

Johannes Abbas Sancti Thomæ Martyris.

Valterius Abbas domus Sancte Mariæ Virginis.

Johannes Abbas Mellofontis.

Henricus Abbas domus Beatæe Mario de Vallosalutis

Nicholaus prior de Conall.

Rabart Preston Vicount of Gormanstoun.

Janes Fleming Baron of Slane.

Richard Nugent Baron of Delvyn.

Edmund Plunket lord of Kyllene.

Nycolas de Sancto Lawrentio lord of Houthe.

Cristoforus Barnewelde Dominus de TrymletysTON.

John Plunket lord of Dunsany.

By your true and feithfull subjectes the lordes spirituels and temporels and your Counseillours of your land of Irlaud in playne parlement ther assembled.

Addressed :-To the Kyng our Soverayne liege Lord. 


\section{II.-Gerald Earl of Kildonre to Henry VII.}

[Orig. in Record Oflice.]

Mooss excellent Christen kyng, and my moost redoubted soveraine liege lord, in as humble and obeysannt maner as cny subject can or may doo to his soveraine, I recommannd me to your moost noble and benyng grace. Pleassed the same to be

IIas reeeived the King's letter desiring his presence in England ;

but has re. mained to arljust a difference between

Desmond and the lord Bourk of Connaught. accrted that I hare receyred your gracions lettres myssives dated at your mancre of Grenewich the xxviij. day of Jullii ' passed, wher by I have wele understand your gracions mynd that ye wold have me to your moste noble presennec that I monght ther by knowc your gracions mynd, and that ye monght have plenary communicacion with me in alle suche thynges as monght concerne the wele of this your said land, and that your subjectes of the same may be redneed to a good and lafull ordyr and obeisannce to the plesyr of Godd, wele and profite of the same your lind, as in your said lettres it doth appier more at large.

Gracions lord, I, accordyng to your highe commaundement, was in full mynd and purpose to have accomplisshed and performed your moost noble plesyr in the same, settyng apart alle exseuses, till I was desyred by your true and feithfull sub. jectes of this your land, and my consynes in especiall, therle of Dessemond and the lord Bourk of Comnght, that I shold not depart, but to abjide for their defennce, and to apece such variemce as is dependyng betwix the said erle and lord Bourk, and that they wold take on them to write onto your highnes that your grace shold take noo displesyr with me herin, as it shall appier to your grace by their lettres and sealles more at large; the whiche I in my moost humble maner beseche your moost benyng grace to accepte and reputte for myn exscuse without cny displesyr to be had by your highnes herin with me, for I am and shalbe glade to see your highnes. And I beseche lumbley your noble grace to be my gracions lord, for I am and shalbe duryng my lywe your true knyght, and never shalbe

' Sie, apparently written Junii at $\mid$ of looped heads to the two minums first and corrected by the addition $\mid$ of the $n$. 
proved otheirwise. And what suerte or band other then I have made convenyently for the same may be had, I shall bynd me therto. And ower that, if it pleas your highnes to send a servannt of yours, such as shall like you, into this your said land, I shall cause my said consyn therle of Dessemond, and all the lordes spirituelles and temporelx of Monnester, the lord Bourk of Connaght, and all the lordes of the same contre, to be bonden as sure and as largely onto your grace as I am in presennec of your said servannt, with diverse others whose ancesters was never bonden to noon of your progenytours kynges of England befor this tyme; soo that ye shall have noo canse of mystrust to be had ne understannd in me. And God knowethe whate liboure and peyn I have susteigned and daily doth susteigno to sett your said subjectes in easse, to my gret charge and coste. And by the othe that I have doo onto your highnes, ther shold nothyng be to me soo grett a plesyr, as oonly it mought be perfitly understaund to your grace what I have done for your honor and the wele of your subjectes of this your land.

Moost excellent Christen kyng and my moost redonbted soveraine liege lord, the Blessed Trinyte preserve your moost noble grace to reigne moost roially, and of your enymies and rebelles to have the victory. Written at your cite of Divelin the $\mathrm{v}^{\text {te }}$ day of Junii,

By your true and feithfull suljoct,

Gemot Erle on Kildare.

Addressed: To the Kyng, my soverayne liege Lord.

11L.-The Elill of Desmond and otuers to Hexhy VII.

[Orig, in Recoril Office.]

Mooste execllent Christen king, and oure mooste goode and gracions lord, in the mooste humble wise that we cane we recomaund ns to your goode grace. Pleasid youre highnes that we ben enformyd that youre grace wold have our right goode lord therle of Kildare to your highness in to youre realme of Ingland for diverse causis considerid by your grace. Gracious lord, we know right well that his veray mynd and entent was to For the lave perfornyd your noble plesire in that behalve; and we, protection undirstinclyng that the mooste part of this lond, and in especiale of the 
North the North Parties and alle suche land as he have of late enhabit, against the the which was many ; eris afor in the possession of your Irische Irish, enemice, schold have ben distruid in his absens, and also fering the grete danger and perelis that might fortume hyme by the se, as wel in his goyng as returuyng, and also for the grete trowbill, variens, and discencion that dependith be thwene us and for the and the lord Bourke of Connaght and other lordis in that parties pacification taking his parti, by reison wherof ther is like to be mortale of feuds, werre and grete soheding of Cristyn blode by thwyxe us, which can in no wise be endid ne pesid with out our said goode lord be personaly with ns, for we ben bound and swom to abide his rule and jugement in this wariens aforsaid; for we the said erle of Desemond and the said lord Bourke, and the substance of us all, bene the nexte of oure said goode lorde blode in Irland, and ther is none can end our trowbill and wariens but onely hym silffe; and suche direceion and ordir as it shal like his lordisehipe to take be thwene us we must and wil olsey it, for we must be rulid by his consaile and he must be rnlid by ouris.

they have Wherfor we have caused hyme to change his mynde and to abide persuaded at home for the causes forsaid, trusting in Crod that your higherildare to nes wold take no displesire with hym ne with us, the said causis Ireland. by you graciusly considerid. And, gracions lord, we undirstand that he is bound and sworn to be your trew feithfull suljet and ligisman as straitly as eny Cristin man may be; wich othe and band he haith kept and performyd truly to youre highenes syn the said othe and band unto this tyme. And thoght the said othe be a sufficient band for every Cristin man, ;et we your subjectis for the contynuannce and more largir assurans of the same, promit and bind $\mathrm{ns}$ by this onr writing and selis, that our said good lord shall truly kepe and obserre the said othe during his live. Wherfor, gracions lord, we bescehe your highenes to be his goode and gracions lord at this onr lonly peticionis, and that he may be pardonid to abide at home with owt youre displesire. And, mooste excellent Cristyn king, and onr gode and gracions lord, the Holy Trinite preserve yone to reigne in prosperite on us youre subjectis, and of your cnemice to have rictori. Writtin at Lymrek the $x$ day of Juyll.

\section{Morice Erlie of Dessemont. Pers Butteler therle of} ORMOND is deppute.

MLR. LORD Rocire. JAMNES LORD CURSY.

With four seals pendent, in bad condition. 
iV.--Ogtavin de Palatio, Archbishop of Armagh.

[See page 95.]

A letter of this prelate is mentioned in Harris' Ware, vol. I. p. 88 , in which the writer not only disclicims complicity in Simnel's rebellion, but declares himself to have been the only one who opposed it. The following transcript has been kindly communicated to me hy Mr. Hardinge of the Landed Estates Record Office, Dublin, from the MS. referred to, which is a seventeenth century copy in Marsh's library. 'The letter was probably addressed either to Cardinal Morton or to Fox, then bishop of Exeter.

Veneradilis in Christo pater, congrua commendatione promissa, paternitatem restram non celamus, quod profano coronationis pueri in Hibernia secleri, me solo execpto, nullus obstitit manifeste; qua in re mo maximis subjeci periculis vitæ, cum Lincolniensis comes, mihi tune raljiosa invidia invidens, comitem Kildariensem inordinata adiens iracundia, potestatem quæsivit pariter et licentiam jura regalia in contradicentibus actui hujusmodi realiter exequendi. Attamen, quamquam dictns comes Kildariensis quod dietus Lincolniensis desideravit in ea parte co instante abmit, benevolentiam supradicti Kildariensis et aliorum procerum et primorum, cum eodem in actu hujnsmodi profine participantium, cordialcm me adipisci hactenus non sensi, imo in ambignitatis amissionis bonorum et temporalinm meortum perplexitate in dies permanere compellor. Et licet prefatus Kildar. et alii quirlam magnates et primores Hibernia strenuo viro Richardo Eggecombe, militi, screnissimi domini nostri regis Hemrici invictissimi in hac parte commissionario, muper in Hiberniam destinato, nomine dicti domini regis homagium et fidelitatis juramentum prestiterint, nilhilominus antiqui livoris fiecem in eis contra me reminere conspicio. Nim milite pradicto, nt opinor,

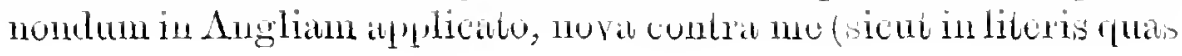


prasentibus interclusas volis transmitto latins eontinetur) incitamenta moverunt, instigante (ut wstimo) venerabili fratre meo, fratre Joame Midensi episcopo, meo suffraganco, qui in ambatiatorem dieti Kildar. atqne magnatum ad regem mittendus est festinanter; materiem quippe hujusmodi novorum incitamentorum vestrw predictæ paternitati me convenit explanare.

Post pradictam coronationem de facto celelsatam, pranominatus comes Kildar. quoddam nomine dicti coronati magnum tenuit concilinm, in quo Domini Spirituales in eodem coneilio comparentes, me tamen absente, personaliter conscientiar'um suar'um morsibus vulnerati, quoddam subsidium ad sacrosanctam Sedem Apostolicam pro absolutione a sententiis et censuris quas forsan novos tumultus contra regem prodictum suscitantes incurrerunt, obtinenda, destinandum concessermut super Hibernix clero. Et postquam serenissimus dominus noster rex ex sua benignitatis gratia generalem absolutionem expensis suis propriis obtinuit in ea parte petentibus, dictus comes Kildar., nitens subsidium hujusmodi contra formam conccssionis ejusdem in proprios usus et utilitatem, pro suis apnd regem expediendis hac vice negotiis, convertere, mihi reclamanti et alleganti quod cessante causa cessare debet et effectus, volenticune clero meo defendere pro posse, noviter nocere demolitur, asserens me semper sibi et toti corpori terræ contrarium fore. Et scio pro certo quod si contingat dictmm comitem Kildar. regimen Hibernire regia anthoritate obtinere, ac cancellarium Hibernia ad nutum summ ordinare, spes non est mibi quietis in Hibernia. Et tunc infideles domino nostro gandebunt, et ego pro fidelitatis mea bravio opprobrimm atque dispendium invidi rancoris reportabo. Si tamen predictus serenissimus dominus noster rex mo de cancellariatus officio Hibernice providere dignaretur, tanta columna snffultus partem dieti domini mei regis contra suos adversarios fortius possem sustentare, et dictum comitem et alios mihi et dicto domino meo contrarios minus ponderare. Quamolurem vestræ pra. dicte paternitati precibus ruibus possum supplico instantissimis, quatenus dicto domino regi promissa suggerentes, mex quieti in dicto cancellariatns officio mihi obtinendo adminiculnm adhibeatis, et, si paternitas vestra me consulerit, ad Angliam personaliter accedam. Quicquid vero paternitas vestra viderit faciendum in promissis me cum latore prosentium literatorie dignetur celeriter certificare, \&c. 


\section{V.-Agreement of Henry VII. with the EarL of Angus. ${ }^{1}$}

[MS. in Record Office, among the Seottish documents formerly at the Chapter IIouse.]

Memorandur. . . . this writing endented the xv[j] A.D. 1491. $d[a y]$ of [November, in the year] of our Lord [God $16 \mathrm{Nor}$. m.]cccelx[xxxj., the vijth of] the reigne of King Henry the vijth, that it is agreed and con[co]rded [be]twixt [Sir John Cheyney and Sir Thomas Tiler knights on behalf of the king] their souverain lorde [on] that oon partie, and Archibald e[arl of] Anguyssh [on that other. . . . . . . . . . . . . ] forme that folowithe :First, the said erle bindeth hym . . . . . . . . . . . . . . . . . to hym possible to moove t[he] king of Scottes.

. unto the sayd king of England, and to take and kepe ferm $\mathrm{p}$. . . . . . . . . . . . . . isshed beiwix both the roialmes. . - . both the sayd kinges. And if he may not atteigne his purpose. . . . behalve bot that [wer] re be betwix the said linges and roialmes, the said e[rle and his son] shal [endeavour] theym to thuttermost of theire powers to make playn werre. Scot. . . . that was contrary to their desire ${ }^{2}$ and purpose, as touchyng the said amytie and peas. And if the case so fall

1 The doenment is very much mutilated and defaced. The words in italies are illegible, but are supplied from an original draft signed by Angus, which is also very badly mutilated, in the Cottonian MS. Calig. D. II. f. 14. The bracketed words are illegible in both MSS., and are supplied to suit the context.

2 After the word werre, the Cottonian draft reads "upon all thoos "within [t] he roialme of Scotland "that wilbe contrary to ther de" sire." 
A.D. 1491. that the said erle and his son by the might of their 16 Nov. enemyes, as God defend, be put to that extremytic that they may not by the eyde and supportacion of the said kinges highnes of England broke or rejoyse theyr landes and revenues witlin the roialme of Scotland ne make their partie good, that they shall del[yv]er unto the kinges highnes of Englond, or to such persones subjettes of the said linges, as his highnes pleas to assigne, the castell, callicl the Hermitage, with all the lordships and landes belonging to the same. And for the more suretie of the premisses the said erle is aggreed to delyver the said George, his eldest son, orells his own person to the said Sir John, to he conveyd unto the kinges highnes, or wher his grace pleas to assigne or appoynt him to be. And also in like wise Robert Elwolde, son to Robert Elwold of the Hermitage, yonger, whiche late deceassid, to be delivered with the said erles son, for the same or with hym self. And also to bynde hym self and his said son and heir to the same by their writinge under their seales. And over that to labour and requyre other of his frendes in Scotlond, as feere as he godly may, to be bounden for hym in like wise. For the which is also agreed that the kinges highnes of Englond, nor his commissioners nowe being upon the bordores, or any other commissioners hereafter shall conclude noe peas nor trienx with the Scottes comissioners, but that the said erl shalbe comprised . . . and give his advice to the same. And if it come to that poynte, that the said erle delyvere the said castell of Thermytage into the linges handes, as afore is said, than his highnes shall, according to his honor, helpe, soccor, and relief the said erle with landes and goodes within Englond, at the lest of as grete value and substance as the said castell, landes, or lordstips to the same belonging be worth, and of yerely value. And also the said erle nor his said son shall in noo wise after this day make poynteyment 
for them self, nor $f[o r$ any] of their frendes with the A.D. 1491. said k[ing] of Scotland, nor of him receive pardone 16 Nor. . . land or goodes within th[at realm without the] counsaill of the said king of Englond. And if the seid trieux be not had according to $\mathrm{t}$ [he] premisses, than [the s]aid Sir John a[nd Sir] William shall, for the wele of the said erle and his [said son], at, their resonable request and desire, move prov . . . . . . . . the borders . . . Englond to make sharpe warre upon the Scottes, and specially suche as be enemyes and adversaries to the said . . . . . . . . . to favor their frendes and lovers. And for the more suretie of the premisses the said Sir John and Sir Will[iam . . . . . . ] theyr writing on the king their soverain lordes behalve, that his highmes shall ratifie and conferme th. . . . . writing. . . . . . . . said erle undre his grete seale by the fest of Saint Hillary next comyng after the date of thies presentes. In witnesse wherof to the toon partie of this indentures remaynyng with [t]he said Sir John [and Sir Wi]lliam the said erle and George his son have set their seales. And to the other partie of the same indentures remayning [with] the said erle and George, the said Sr John and $\mathrm{S}^{\mathrm{r}}$ William have set their seales. Yeven the day and yere above said.

$$
\text { (L.S.) }
$$

Endorsed:- $"$ Artieles agreed npon twixt $\mathrm{S}^{\mathrm{r}}$ John Cheyney and $\mathrm{S}^{\mathrm{r}}$ Thomas Tiler, Knightes, on the behalf of the king our soveraign lord on thone parte; and Archibalt Dowglas earle of Angwishe on thother parte."-In a modern hand, "Henr. 7. Dat. 1491, 16 Novembr. Scotia." 


\title{
VI.-The Creation of Henry Duke of York.
}

\author{
[MS. Cott., Julius, B. x1I. f. 91.]
}

A.D. 1494. In the yere of oure Lord a $\mathrm{m}^{1}$ ecce.iij ${ }^{\mathrm{xx}}$, and $x i i \mathrm{j}^{\mathrm{e}}$, the tent $[\mathrm{h}]$ yer of the reigne of onr souverain lord, kyng Henry the VII ${ }^{\text {the }}$ beyng in his manoir of Wodestoke, determyned at Alhalowyn tide then folo[wing] to holde and to kepe roially and solemply, that fest in his palaice o[f] Westmynter, and at that fest to doube his ijde son knyght of the Bath, and after to ereat hym due of Yore; and there apon directed his lettres missives, and allsoo writtes accordyng to the same to divers nobles of this his roianlme to be of his somnis bayne, and to receve thordre of knyghthod, of wiche att his commaundement came xxij., as schall folow after in this booke, and the remanent wer pardoned, or wer at their fynes. Knowlege wel of openly had in his court, iiij. noble men, and as men of great courage, and allsoo willyng and desiryng to homnour the said creacion and fest; and for the pleasir of our sonverain lord, the quenes grace and the ladies, remenbringe theym selff that ameyent custume of thys his noble realme of Englond att suche roiall festes to be great a[nd] notable actis of armes, for the continnance of the wiche, and for the excersice of the same, and lest any oder schuld take that enterprinse beffore them, they besonght the kyngis grace to licens and to permitte them at the said fest to hold and to kepe a justes roiall, and to aunswer all commers of what nacion so crer they bee, as well his subjectes as oder, accordyng to there articles, wiche they besought his grace, his licems ther apon graunted, to command his officiers of armes to puplishe the articles of there armes, as well in lis noble court as in the cite of London. And themne his grace thankkeffully gramted them, and asseigned their articles, and commanded Gartter principal kyng of armes, to assigne off hys compaignie, to proclame the said article $[s]$ in places conrenient for suche actis to be doon ; wiche was furst proclamed in the kyngis great chambre of his maner of Wodestoke, after in the fair off the same towne, and after in London, in maner as folowithe.

Proclama. "Oyez, oyez, oyez. For asmoche as hit is comen to the tion of notice and knowlege of iiij. gentillmen of the kyng our sontourna. verayne lord most roiall and homonrable court, that his highment. ness endendith and purposithe by Goddis grace and sufferans in brief tyme to yeve creacion of duc on to the right high and cxecllent prince my lord Henry, ij som to our sonverayn lord liyng Hen'y the rijhe; and att like tymes it hathe ben used alwey, and accustumed of anneyennyto with in this his most noble 
realme of Englond, for the lawde and lonnour of suche festes, to A.D. 1494. have justis and turney accordyng to their artieles: The kyng our souverain lord, consideryng the noble and eouragieuse desyres of the said iiij. noble men, hathe thankkeffully graunted their peticions in this behalve, and licenced thaym, and all oder gentillmen of his said realme or oder nacions, to accumplishe the articles folowyng, and hoo soo ever justithe best in the justys roiall schall have a ryng of gold, with a ruby of the value of a $\mathrm{m}^{1}$ scuttes or under; and hoo soo ever torneythe best, and fairyst accumplishit his strokkis schall have a ryng of gold, with a diamant of like value."

And after the proctamneion of thes forsaid justys and turney was proclaimed in the kyngis chamlne as above, and to seew dyvers actis and exercises of armes, vj. oder gentillmen presented their articles to the kyngis grace, wiche his grace liberally accordyd, and were proclaymed as the furst artieles wer, and as cnsuyth. "Where it is soo that diver's noble persommes hamne enterprised and undertaked to hold a justis roiall and a turney the iiijthe and the ix. day of Novenbre, at Westmynster, as playnley dothe apere by thair articles; and for as moche ys att so noble fest divers and sundery excersices of armes is used; ther for and to the entent, $y$ f there bee any gentillmen or othre men of armes that present nott theym selff at the said day of justes or turney, there be $\mathrm{vj}$. gentillmen that will make them disport the xij. day of Norenbre, aceordyng to thair articles, $y$ f it schall soo please the kyngis grace and highnes, for whoys pleasir, the quenes grace, and all the ladies the under take the said enterprise, and specially for the pleasir of thair redoubted lady and fairyste yong princesse, the eldest doughter to our souverayn lord the liyng."

And on Simon and Jude eryn, the kyng, the quene, and my ladye the kyngis moder came from Schen to Westmynster to dyner. And on the morne after Simon and Jude the kyng sent to Eltam for to convoye the said lord Henry, wiche, with great honnour, tryhumphe, and of great astates, was convoyed thorongli London, and receved with the maior, the aldermen, and all the crafftys in their liveres, and soo homorably brought to Westmynster. And on the Thursday the xxx. day of Oetobre the said lord Hemry served the kyng of towell, and the lord Haryngton toke to sey, and the lord Clyfford hild the bason, and the lorel Fitz-Waren bere the water, the lord Dacre of the Sow the here the kyngis potage, Mr. Thomas Stanley and the remanent bere dishes at the furst course or the $\mathrm{id}^{\mathrm{de}}$; and theme thes lordes serviturs and the oder nobles, sum dyned in the chamble, and the reminent satt in the hill, sum at my lord stewardis table, ami 
A.D. 1494. sum at master controller table, and after in like wise soo did Ceremony they sope. And when it was nyght, and that their baynes werc of the redy, furst, in the kyngis closett was the lord Henry bayne
Bath. roially dressed, and a riche bed well empairelled; and therll of Oxinford red the advertisement, and then the kyng toke of the water, and putt on his schulder, and made a crosse, and kyst hit; and from thens went in to the qwenes clossct, and like wyse advertised the lord Haryngton and the lord Clifford, and from thens went in to the parlement chambre, where wer $\mathrm{xx}$. baynes, and beddes wiche hadden sparvers, and the best ordred that I have sien, and as folowy th:-Furst, in that chambre was the lord Fitz-Waren, the lord Dacre of the Sowthe, Sir Thomas Stanley, som and heir of the lord Strange, Sir John Arundell, Sir Water Gryffithe, Sir Gervoys of Cliffton, Sir Edmond Traford, Sir Robert Harrecourt, Sir Henry Marney, Sir Roger Neubourgh, Sir Rauff Rider, Sir Thomas Barde, Sir John Speke, Sir Humfrey Fullford, Sir Robert Litton, Sir Piers Eggecombe, Sir Robt. Clere, Sir Thomas Fairfax, Sir Richard Knyghtley, Sir John Chooke: And after that the kyng of his grace and benevolens had riseted them alle in their baynes, he departed into his chambre; and thenne when they wer dry in their beddes they were revested in theyre heremites wede, and soo departed to the ehappell, where they had spices, and their roidie, and the sergent of the confexeionary had of every knyght a noble.

31 Oct. And on the morne erley every man was shreven, and herde theyr messe, doyng all obserrance therto belongyng, retourned to thair beddys, and delivered thair russett gownes to the mynstrells; and it was so well ordred, and the howse soo well voided, and theme kept that they toke good rest. And a non after, as it was day, and that they wor awaked, they well and liberally paid the fee of money to thofficiers of armes; that is to sey, the lord Haryngton, son and heyre of the lord marcuis of Dorsett, 1. s., and every baron above-named, xl. s., and everyche of the remanent $x x$. s. Item, they paid to the sergent of thwry every man xx. s. iiijd. Item, they rewarded the users and the grome porter and there escuiers of homnonr liberally, [an]d content the [se]rgent of the amedry all [hi]s fees, and yet they made a commune purse. When the tyme wos come that it was the kyngis pleasir that they schuld arise, therlle of Oxinford, therlle of Northumberlond, therlle of Essex, the lord Daubeney, with oder whent to the said lord Henry, and from hym to the lord Haryngton; and therll of Oxinford, great chamberlayn of Englond, gave hym hys shertt, and after hym the oder nobles did alsoo gyve them part of theyr abbelementes; and allsoo my lord of Oxinford with the forsaid lords hon- 
nored them with his honde, gevyng them all their sherttes, A.D. 1494. in ordre as above, and after as therc beddes stode in ordre. 31 Oct. And immediately after that they wer redey, they toke thair waye secretly by our ladie of Pien thorough Saint Stephins Chappell on to the steyr foote of the Ster chambre end, whero they toke their horsses, wiche in died wer simple and soo lytill of valeur, and nott to the worshipp of knyghthod. And that the olde ordonance was that thoos hor's empairelled after the custume schuld be fee to the marishallis of England or a c. s., and in his abeense to the marishall of the kyngis hall, consyderyng that thoos hors for the most part wer so simple, and for an ensample that oder her after schuld eome with better hor's and more homorably, for this oons my lord marishall, by thavys of his chiff counceill, toke of every man xl. s. for this time oenly, and pardoned the value of iij. li., and delivered there hor's ageyn. And the lord William Courteney bere the said lord Henry swerde, and spores, the pomel upward; and wen he dicl a light of his hors Sir William Sanddis bere hym to the kyngis presens, and there therlle of Oxinford toke the swerde and spores, and prosented the right spore to the kyng; and the kyng commanded the duc of Bokyngham to putt hit on the right hele of the said lord Itenry, and in like wise the lifft spore to the lord marquis of Dorsett. And thenme the kyng gerd his swerde a bowt hym, and after doubbed him linyght in maner accustnmed, and then sett Prince hym apon the table. In tyme the kyng hade in like fourme Henry donbed the lordis and Sir Thomas Stanley, \&e., themne Sir dubbed William Sandlys bere my lord Henry in to the chappell, and knight, there at the highe aultre offred his swerd, and the lordis after in ofbers. ordre; and after alle the knyghtes as they wer loubed. And when my lord was come out of the (fwere dore, the kjngis maister cooke toke his spores for his fee, and in like wyse of every oder knyght and a nolble. My said lord dined in his owne chambre, and the oder lords and new doubed linyghtes dined in the parlement chambre att a long table all on oon side, and their esquiers of honnour kerved byfore them, and the kyng licensed them to ett their mette (by eause hit was fastyng day), and after diner all thos new made knyghtes went in to a great chambre and did off their mantells, surcottes, gyrdils, and coyffes, and delivered them to thofficiers of armes, never better, and theme clothed thaym in blew gownes with hodes. And immediatly after they went to comnseill, and chase Sir Robert Litton to gyve the kyngis grace thankkynges.

And on the Saturday, Alhalowin day, after the kyng had berd matins and was retournod in to his chambre, and did on his robbes of astat roiall, and, crowned, eame into the parlemont

1 Nov. 
A.D. 1494. chambre, and there stode under his elothe of astate, havyng

1 Nov. many great astates by hym, as the eardinal of Cantmibury and many oder prelatys, the due of Bedford, the dne of Bokyngham, therll of Oxinford, therll of Essex, therll of Kent, therll of Willshir, and the substanee of all the barons of this realme, all in there robbes; and in like wyse the juges, the master of the roullys, ${ }^{1}$ the maior of London ${ }^{2}$ with his bredren the aldremen, and g'reat pres of knyghtes and esquiers and oder nobles; and ont of the eloister a galary att the nether end of that chambre entred divers nobles and offieiers of armes, and proeeded towards the kynges presens; but Gartier, principal king of armes, ${ }^{3}$ presented his patent, and after thre great astates in their robbes, that is to sey, therll of Suffolke, wiche bere a riche swerde, the pomell upward, therll of Northumberlond bere a rod of gold, and therll of Derby the cape of astate furred with ermyn thike poundred, of iiij. renges, and a riehe eoranall there apon; and therell of Shrewsbnry bere the said yong prince. In tyme he entred the parlement chambre dore, and then the marquis of Dorsett and therll of Armdell lede hym to the kyngis presens, all being in theyre robbes of astates, and doyng their obbeissance as aparteynythe. And then the reverent fader in God the lord Oliver Kyng, bishopp of Excestre and the kyngis secretary, red the

Created duke of York. patent of his ereacion presented by G[artier] as before, and soo there the kyng ereatyd him dne of Yore, with the gyfft of a thousand pond by yere; and after all the seremonys there to belongyng was doon, the kyng, being erowned, proceded in to the qwere of his chappell and stode in the denys stall, and taryeng there, ordred the proeession: butt there were doubtes wethre therll of Snfiolke or therll of Kent schuld goo before, and the kyng determined therll of Suffolke. A noder doubte was betwen the lord Grey and the lord Clyfford: the kyng by advys of his lordes ordeyned the lord Grey to goo before the said lord Clyfiord. The qwne, my ladie the kyngis moder, was as yet in her clossett. The eardinal of Canturbmy' ${ }^{4}$ did the devyn service in pontificalibus; alsoo the bishopp of Ely ${ }^{5}$ was gospeler, the bishopp of Excestre ${ }^{6}$ epistoler, the bishopp off Rochestre $^{7}$ croysyer, the bishoppis of Wynchestre, ${ }^{8}$ Dirham, ${ }^{9}$

1 William Warham.

${ }^{2}$ Richard Chawry.

${ }^{3}$ Sir John Wrythe.

* Cardinal Morton.

5 John Alcock.
${ }^{6}$ Oliver King.

"Thomas Savage.

8 'Thomas Langton.

${ }^{9}$ Richard Iox. 
London, ${ }^{1}$ and Salisbury ${ }^{2}$ and of Saynt Asse ${ }^{3}$ [and] cer-A.D. 1494. tain abbotes wer all in pontificaliuns, and tharchebishopp 1 Nov. of Yore ${ }^{4}$ was present but not in pontificulibus. This precession was the best ordred and moost preysed off all the precessions that I have herd of in England, and this was the maner. Furst before the kyng therll of Arundell bere his swerde, and before hym on the right syde therll of Derby, constable of Englond, beryng the staff of his office, the due of Yore on his lifft hand borne by therll of Shrewysbury and his eape, with cornall on his hede, and his verge of gold in his hand. And Sir Joln Digby bere his staff of marehalse by fure hym, and Garter kyng of armes, and the maior of London, before them tharehebishopp of Yorke, and before hym maister Amoner, ${ }^{5}$ the wiche accompened thambassateur of Naples, my lord Steward ${ }^{6}$ and lord Tresorer 7 of Englond before them, and before them the trezorer $\mathrm{Mr}$. Controller, ${ }^{8}$ and before hym the kerver in his robbes, and next before them, on eyther syde the precession, thofficiers of armes, savyng Norrey kyng of armes, wiche aecompened Marehemont herault of Scottland, wiche went be fore my lord Stewart. And after the kyng folowed his unele, the due of Bedford, and the due of Bokyngham, and therll of Northumberlond, and all oder lordes, wiche had robbes, in ordre. After them jnges, then the qwene erowned, my ladie the kyngis moder with a rich eommall; and after folowed ducesses, contesses, baronesses, and oder ladies and gentillwemen. After them folowed all oder lordes and knyghtes that had noo robbes, wiche richely by syen wer that day. After them Sir Charles Somersett with the garde.

The kyng after masse did of his robbes of astate and came in to the great chambre, and there creat an heranld for the marquis of Dorsett, and named hym Dorsett the herauld. 'That doon, weshed and sett to diner, and the cardinal of Canturbury on his right hand, and non oder bodye at the borde that day. After the ijde com's, Garter kynge of armes and the oder officier's of armes gave the kyngis graee thankkynges for liys great liargesse, and allsoo besought his grace to owe thankkynges to the high and myghty prinee, his soon, the due of Yore, for the great and habundant largesse that he had geven them for his sake and for thonnomr of his court. Where for after the kyngis largesse was cryed in bothe stilis aceustumed,

\footnotetext{
1 Riehard Hill.

2 John BIyth.

${ }^{3}$ Richard Redman.

${ }^{6}$ Lord Willoughby de Broke,

* Thomas Scot, alias Rotherham.

${ }^{5}$ Christopher Urswick.

"Sir Richard Guildford, con troller of the flomsehold.
} 
A.D. 1494. he was cryed as folowyth:- "Largesse, \&c., de treshanlt, puis, 9 Nov. sant, et excellent prince, secound filz du roi nostre seigneur, duc de Tore, licutenant-goneral Dirlond, counte marishall, marishall Dengletcre, et gardien de Cing Portz, Largesso par troys fois."

Tourna- And on the ix. day of the said monethe were the jnstys ment at Westminster: roianlx in the kyngis palicice of Westmester; and as hit was prepared and fom nyshed it was the most tryhmphant place that ever. I sayw. Furst, to see the kyngis grace and the qwenys soo richely empairelled, his house and stage convered with riche cloth of Aras blew, emramplished with fleurs de lis of gold, and with in fourthe hangid with riche clothe of Arras of oder ystorys, and $\mathrm{ij}$. clothes of astate, oon for the kyng, a noder for the qwene, and riche coshyns of clothe of gold, accumpened with the substance of the great astatys of this realme, as the duc of Yorc, the duc of Bedford, the duc of Bokynham, and many oder, ellres (sic), barons, baneretes, and knyghtes, and as her after their names in ordre schall apere, \&e. And owt of Westmynster hall came in to the felde the chalengers on helmed, and their hors richely trapped of the kyngis coulours, emamplised with somnettes of silver, and summe whit and summe grene, with oder great gilt belles over the mane and alsoo the croper, with journates of the kyngis conlours. That is to say, therll of Sufiolke, therll of Essex, Sir Robert Curson, Joln Peche, richely accompened with many lordes, lnyglites, and escquicrs, merve. lensly well by seen and with soo great richesses, in cheynys of gold, dyrers mancrs of way borne, bothe in goldsmythis werke and clothe of gold, both in jomrnates, hoquetons, and hors hanneys, and sum hor's harneis of goldsmythis werke furred with ermyn. There schuld yon have syen the good riders, the well doyng horsses, whatt gambadys, the changelyng of Jollis, the glisteryng of spangils, and especialle among oder the lord Bonrgavenny had a small blake hor's wiche in montyng soo high a bove grounde did merveilles, and soo oftyn tyme. And when this noble and tryhmphant eompency had accompened the challengers a bowt the tilt, then and in the yest end thereof, they helmed thaym sellff.

And then out of the Kyngis strete entred the aunswerers, allsoo richely accompened, but they were helmed. There was therll of Shrewysbury and Sir Tohn Cheney, so well horssed and soo richely by seen, that it was a tryhumphant sight to see them, and many oder, and soo in like wise rod a bowt the felde. And theme therll of Suffolke and Sir Edward A Borongh ran the vi. furst courses; and then therll of Essex and Sir Edward Dancll ran vi. the noxt couses; theme Sir Robert

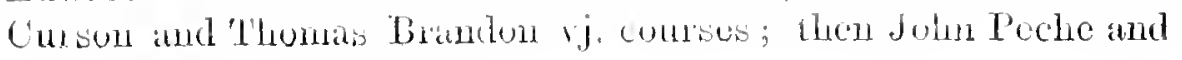


Matew Baker six oder courses. That doon, therll of Suffolko A.D. 1494. ran vj. courses with Guillam De la Rivere, and in like wyse 9 Nor. therll of Essex with Rouland De Veilleville, and Sir Robert Curson with Henry Wynslow, and then John Peche and William Craythorn; bntt the said erll of Essex and Rouland ran at the furst butt $v$. conrses, by cause Rouland hor's wold nott cope. Those conrses accomplished, therll of Suffolke and Sir Edward A. Borough ran oder vj. conrses, and in all that day brake apon Sir Edward ij. speres well brokyn, the iijde better; and the said Sir Edward brake a spere, well brokyn, and gave ij. good atteyintes. Then thorll of Essex lan with Sir Edward Darell, and on his helme brake a spere, by syde a great atteynt; and the said Sir Edward Darell brake ij speres well broken, the iijde better, and ij great atteyntes. Then in like wyse Sir Robert Curson and Thomas Brandon, and bothe conoyted soo moche the hede that they broke fow stavys; butt Sir Robert gave good atteyntes, and Thomas Brandon brake ij. speres and give ij. atteyntes. After them John Peche and Matew Bakel. And John Peche in all that day brake apon the said Matew Baker v. speres well brokyn; and the said Matew Baker broke thre speres and a great atteynt. And then ran efftsonnes therll of Snffolke and Grillam de la Rivere; and therll brake on the said Gnillam oon spere well brokyn, and Gnillam brake on the said erll that day ij. speres well brokyn and oon mnder. Then therll of Essex and Rouland ran oder vj. conrses, butt Ronland hor's wold nott cope. After them Sir Robert Curson and Henry Wynslow, on whom the said Sir Robert brake a spere well brokyn, and gave a good atteynt. And the said IIemry brake ij. sperers well brokyn. After them ran John Peche with William Craithom, wiche Joln Peche brake that day on Craythor'n rj. speres well brokyn, the vij. better, and over that gave a good ateynt; and the said Craythorn brake on the same Peche ij. speres well brokyn. And thenne was cryed a lotell, de.

And after the somper began the daunces; wiche doon, ij. The mize right noble ladies maidyns, that is to say, the ladie Anne given in Persie and the ladie Ame Neryll, presented John Peche Johm to the right high and excellente princesse the ladie Margerete, the kyngis oldeste donghter; wiche by thavys of the kyng, the riwene, my ladie the kyngis moder, and of all the ladies, gave hym the price, that is to sey, a ryng of grolel with a l'uby, as be the proclamacion shall appere. And for asmoche as the wordes in the proclamacion wer" generalle, "Who soo ever justethe hest" and named nother the partie with in nor with owt, where for the price was geren to the partie with in. How be it, hithe hathe nott ben comonly sicn, or clis 
A.D. 1494. Sir Edward Darell schuld have had it for the partie with owt 9 Nov. on that day, for he brake ij. speres well, the iijde better, and soo was alowed iij. speres well brokyn, and gave ij. great atteyntes in rynnyng of xij. courses ; and the said John Peehe in remyng of xxiiij. courses brac xij. stavys, wiche wer alowed xiij. speres well brokyn. And thes armes were accomplished the ix. day of

The obit of Henry VII's father kept on the 4 Nor.

11 Nov. Second day's fournament. Novembre, wichel in maner above said, wiche schuld have ben doon the iiij. day, and wer defered by canse on the forsaid iiijthe day was kept thobitt of the full nolsle memor the kyngis fader, and thos armes of turney that schuld have ben on the ix. were defferred to the xj. day of the said monethe. And thos armes of the oder $v j$. gentillmen wiche schuld have ben doon on the xij. day wcr well and notably accomplished the xiije day, as here after sehall apere.

How the right noble lords therlles of Suffolke and of Essex, Sir Robert Curson, and John Peche, came in to the feld the iide day at the tourney in this maner, every man under his pavilion, and a crest upon hit, with roundelettes of cramoisyn velvet with goldsmythys werke comyng under their chymnys and a bowt their helmes; thior journates of the conleurs of the duc of Yorc, that is to sey, blew and tawny. Allsoo their hors hameys was of blake relvet, bordred and losenged of goldsmythis werke, and on every corner of the said losenges a rounde silver bell, and in the myddys rosses, oon red, a nothre whit, and oon every roos a wafin gilt. And in this fourme eame owt of Westmynstre hall. Therll of Suffolkes pavylion was of red donble sarcenet and his worde writtyn there apon, "For to accumplisshe;" and his crest above was a lion of gold, the taille fourched, sett in maner of a curnalles with plumasses whit and grene, and ramplyshed with spangils. After hym entred therll of Essex under his parylion, the wiche was of a darke tawny sarcenet, and his worde was, "Owr promesse made;" his crest a fawcon fleyng silver with a brused wyng, sett in like maner as therll of Suffolkis. Then entred Sir Robert Curson in his parylion of blake sarcenett, and his crest a red dragons hede sett as above, and his worde was, "There to we be redy." And after hym entred John Peche in his parylion of a light tawny sarcenet, and his worde embrowdered was, "In every thing," and his crest a lions hed of ermyn crowned with gold, sett in like plmmasses as a bove said, and went a bowt the tilt. And when they yssewd owt of their parylions besicn as a bove, and thofficiers of armes toke them for their fee, then entred owt of the torme Sir Edward A Borough with a demy trapper of grene velvet, \&c. enramplished with *

'Sic in MS. $\quad 1 \quad$ Blituk space in original. 
And Sir Edward Darellis hors was empairelled with a demy A.D. 1494. trapper of grey velvet emramplished with * *. Thomas 11 Nov. Brandon hor's was trapped with a demy trapper of gren velvet, as the oder a bove, enramplished with lions heddys rasyd and crowned gold. And then entred Rouland de Veilleville, wiche was trapped with russet sarcenett.

And then tourned furst therll of Suffolke with Sir Edward A Borongh, and therll of Suffolke brake his swerde, and bothe they nobly and couragiensly accumplished their xxiije strokkis. Then tourned therll of Essex and Sir Edward Darell, and therll of Essex brake his swerde, and bothe they fur'yeusly and natably accomplished their strokkis; Jutt the said erll ran soo firsly ayenst the schulder and the sadell of the said Sir Edward that Sir Edwardis hors was in doulte to have fallen. Then Sir Robert Curson and Thomas Brandon furicusly and conragieusly ran to gedres, and after certain strokkis, there swerdes wer cnterclosed with the gamntellet of the said Sir Robert, that Thomas Brandon with the ploke of Sir Robert was sum what meved of his sadell, butt soo well recouverd that the gamntellet with the swerde of Sir Robert felde to the ground, or ells hit was thonght the said Thomas had ben in juberte to have ben on sadeled; but the kyng licenced the said Sir Robert to have his ganntellet a geyn, and theme they bothe tmrned a geyn like ij. champions, and Sir Robert brake his swerde, and Thomas swerde lorake in the hilt, and eyther of them had new swerdes and full valiantly accumplished thair armes. Then entred John Peche and Rouland de Veilleville, bntt Rouland gave good strypis, and the said John Peche dyd full well, and couragensly accumplished their armes. And after that this tourney was soo well and notally accumplished, entred in to the felde to the justes roianlx Sir Edward A Borongh, his hors trapped with clothe of gold, bordred with blake velvet embrawdered with lettres of gold, convered with sarcenet whit and grene voided. And then John Cheney came in to the feld, and his hors trapped with gren velvet and whit dasmaske paly euramplished with red rosses. And owt of Westmester hall came John Nevyll armed and helmed, his hor's trapped with lawnd. And after them entred Rouland de Veilleville, and then they ran round. Sir Edward A Borongh that day ran well and couragiensly, and brake a spere well brokyn, the ijde better, with a teynt. John Cheney brake ij. speres well, the iijde better, and gave a good atteynt. John Nevyll brake i.j. speres well brokyn, and gave a good atteynt. Rouland brake ij. speres well, the iij $^{\text {de }}$. better, with a great atteynt, and fonrnyshed that justys honnorably, \&a. 
A.D. 1494. And after souper the ladies whent to the daunces, wiche doon the 11 Nov. prices wer geren in maner as folowyth. Furst ij. fair and noble ladies, maidyns, that is to sey, the ladie Elizabethe Stafford, suster to the dne of Bokyngham, and the ladie Anne Nevyll, doughter to therll of Westmerlond presented the noble and couragieuse Prize knyght therll of Suffolke to the high and excellente princesses given to the ladie Margarete the kyngis oldeste doughter, wiche by thavys the earl of of the kyng, the qwene, and my ladic the kyngis moder, and of all the ladies, the said princes hathe awarded and geven the price for the partie with in to the forsaid erll of Suffolke, as be the pron clamacion schall appere. "Oyez. The kyng our sonrerain lord and the qwenys grace and in especiall the noble and myghty prince the ijde soon of the kyng our sonverain lord the due of Yore, in the homnour of whoos creacion this nolble justys and tournay hathe ben holden, gerythe thair especiall thankkes to all those noble and honnoraljle gentillmen that hathe at this tyme indevered thaym selff to the homoryng of the said fest of creacion, and in accumplishyng of suche chalenges as the right noble lorddes, therlls of Suffolle and Essex, Sir Robert Curson, John Peche chalenger's hathe homorably accumplished. And where as in tymes past the price hathe ben commenly geven ooenly to the partie with owt, neverthelesse now it is thonght that they that hathe ben chief causers and chalengers of this noble entrepris and actis of armes in thoos justys and tommey hathe deserved especiall thankkess and honmour, where for the right high and excellente princesse above said, by tharys of the kyng, the fwene, my ladie the kyngis moder, and of all the ladies, hathe awarded and gyren the price for the partie within to the right noble lord therll of Suffolke, that is to sey, a lyng of gold with a diamant." And in like fonme the right noble ladies the comntesse of Northumberlond and the ladie Elizabethe Herbert presented the right valiant escuire and to Thomas Brandon to the excellente princesse afore said, to Thomas wom she gave the price for the partic with owt, as schall Brandon. appere by the crie, "Oyez. And for the partic with owt that hathe soo homorably and valiantly acquite them in answering the said tourney, that is to sey, Sir Edward A Borough, Sir Edward Darell, Thomas Brandon, and Rouland de Veilleville, the kyngis grace, the quenes, my ladie the kyngis moder, and the said noble and excellente prince the duc of Yorke, geves them their especiall thankkes, and the right high and excellente princes the ladic Margarete the kyngis oldeste donghter, and by tharys of the kyng, the qwene, my ladie the kyngis moder, and of all the ladies, hathe yeren the price for the partic with owt to the raliant esquier Thomas Braudon, that is to say, a ryng of gold with a rubee."

13 Nov. And on the xiij. day of Norembre, after that the kyng, the 
qwene, \&c. wer entred the felde to their house a fore said, and a A.D. 1494. long space of tyme loked that Thomas Rider and William Trenry schuld have entred, wiche Trenry was deseved of his hed piece for that tyme, then the kyng commanded William Craythor'n and na Henry Wynslow to entre the felde and to ren a conrs oocnly with the spere, and thenne to the swerdes in tyme xviijo stroklis wer accmplished. And the said Craythor'n hor's was cmpairelled in paper in maner of a barde, whitt and red losenged, and soo openly torne in the feld, and sporned with the fett of his owne servantes, butt they wyst full lityll what they dyd their master that wrong. And Henry Wynslow hors was empairelled in like wyse in paper in maner of a demy trapper, ther apon peynted ij. men pleyng at dyse and certain othes writtyn nott wrothey her to be rehearsed. That was doon, as hym sclfe told me, to canse the kyng to langh, and they bothe ran very ner the closer of the feld, but they coped nott with there speres, and Wynslow cansed Craythorn to lecse his swerde, butt get the said Craythorn after his swerde was restored to hym, gare the said Wynslow great strokkis, \&c., and with the pomell of his swerde smot hym on his helme, and hurt sore his honnd, wiche that nott with standyng lett nott to accumplishe his strokkys. That doon, the kyng commanded them bothe to onhelme them selff, and eyther of thaym to take a longe truncliun for to depart them that sculd turnay afterward. Then entered William Trenry owt of Westmynster hall, heined, his hors trappet with a trapper of whitt and grene damaske parted por pate, a bordre chererome of blake satin emramplished with pyme tres of fyno silver in plate and with spangils Joramlyng among: And Thomas Ryder came owt of the towne, and to hym was presented $\mathrm{ij}$. speres with moomes, where of he toke the choise and Treury toke the toder ; and then they ran to gedres, and Thomas Rider gave William Treury a great atteynt, butt he brake nott his spere. Then every of thaym had a swerde and tourned to gedre, butt Thomas Rider cansed the said Treury to lese his swerde, wiche was restored to hym a geyn, and after that, they strakke dyvers strokkys to gedres, Jutt then Thomas Rider sumwhat meved or declyned from the strokkis; wether hit was for the fiult of his sight, or to roide the strokkis I can nott say, butt he was nott preysed for the roidyng. And after that they wer departed ther came owt of Westmynster hall in to the felde, helmed, and their horsses richely trappet, and also rood a bowt the felde, Syr Edward A Borough, Syr Edward Darell, Thomas Brandon, Matew Baker, Rouland de Veilleville; and Guillam de la Rivere came in afterward, by canse he had lent his hedpicce to William Treury. Then ort of the towne came

Third

day's tournament. 
A.D. 1494. iij. gentill, fair and nol,le ladies, maidyns, ledyng iij. knyghtes 13 Nov. and allsoo a noble maide ledyng an esquier, all iiij. in a seute, that is to say, the iiij. forsaid noble ladies, maidyns, and gentillwomen ${ }^{1}$ in oon a sente, and the iiij. gentillmen in a noder. The ladies wer abillide in this maner, everyche of thaym in a gowne of whitt damaske, their slevys of cramoisyn velvet sett to the bodies, and like wyse at thelbous with chenys of gold, and in there her, with riche serkellettes of gold and preciense stomnys a bowt their heddys, with great chenys of gold abont their myddlys, and mervyleuse riche bees a bowt their nekkes, a pon iiij. whit palfereys. The furst was the ladie Elizabethe Stafford, suster to the duc of Bokyngham, and she lade by a riche fanse reigne the hors of therll of Suffolke. The ijde was the ladie Amne Nevyll, donghter of therll of Westmerland, and she lade therll of Essex. The iijde was the ladie Anne Percy, suster to therll of Northumberlond, and she lade Syr Robert Curson. The iiijthe was maistres Saint Liger, doughter of the ducess of Excestre, and she lade John Peche. And after them folowed John Nevyll, broder to the lord Bourgavenny, and John Williams, well horssed. And in especial the foure forsaid gentilmen apon foure balde horsses, well barded and like crestes on theyr heddys as wer on theire tentes stondyng be twen ij. great and high plumashis of whit, the toppis blake spangils, the thirde hangyng doon be hynd.

Then furst by the kyngis commandement and ordonans ran to gederes therlls of Suftolke and of Essex atoons ayenst Sir Edward A Borongh and Syr Edward Darell. And Sir Edward $\Lambda$ Borough at that cours brac his spere well apon therll of Suffolke; and the said erll glissed on the helme of the said Sir Edward, the wiche ran with speres with moornes; after them therll of Essex and Sir Edward Darell, butt they brake $n o o$ spere. That doon, Thomas Brandon and Matew Baker a yenst Syr Robert Curson and John Peche, but the said Thomas and the said Sir Robert brake noo spere, but John Peche hrake his spere apon Mathew Baker. Then ran Gnillam de la Rivere and Ronland de Veilleville a yenst John Neryll and John Villiams, bnt they encomtred nott. Then Sir Edward A Borough and Sir Edward Darell turneyed ayenst therll of Snffolke and therll of Essex, but therll of Suffolke at the ix. stroke gave suche a stroke to Sir Edward A Borough that is swerde was almost owt of his honde and brused his ganntellett. And as the said Sir Edward wolde have holpen hym selff and

${ }^{1}$ And gentillwomen] Crossed in original. 
amended hit with his bridyll hand, his hor's tourned from therll A.D. 1494 and Sir Edwardes bake towardes him, supposyng to moche peple 13 Nov. that the hand of the said Sir Edward had ben stonyed; butt Third when he had sumwhat amended his swerde, he tommed his nament. hors and gave a light strokke over the helme of the said erll. Then therll wold furyensly goon a yenst hym, and soo wer they departed. And Sir Edward Darell and therll of Essex bothe furyensly aceomplished their xij. strokkis largely. Then tommed Thomas Brandon and Mathew Baker a yenst Sir Robert Curson and John Peehe, and there wer great strokkis geven, yett ereryehe of thaym had nott his felow that he supposed to have had. After them Guillam de la Rivere and Rouland de Veilleville a yenst John Neryll and Joln Williams, wiehe well and comragiensly accomplished their strokkis. After that they ran all xij. to gederes and strakke firyensly and great strokkis be twen them. In tyme vj. strokkys wer acemplished, and soo with great homour wer they departed. And at that stomre John Peche acemplished his strokkis a yenst ij., for asmoehe as ij. sundry men strakke at hym, butt nott atoons; and thus with homour every man departed the feld that day, God be thanked and Saint George! And after souper began the damees, wiche doon ij. right noble ladies, the ladie of Northumberland and the ladie Herbert presented the right noble knyght Syr Edward A Borongh to the right high and Prizes excellente princesse the ladie Margerete, oldest doughter to given to the kyng our sonverain lord, to whom sche gave the price Sir Ldward for the partic with in in maner as her after schall folow an Borongh And in like fourme ij. oder noble ladies, the ladie Anne Perey of Essex. and the larlie Ame Neryll, presented to the forsaid excellente prineesse therll of Essex, to whom she gave the price for the partic with owt, as her after schall appere. That doon, Garter kyng of armes, aceumpened with oder kynges of armez, haranldes, and pursuyvantes stondyng on high on a fourme, there declared the prices in maner as folowythe.

"The kyng our" souverayn lord, the qwenys grace, and the right high and excellente prineesse the ladie Margarete, their oldest donghter, for whoos sake and homneur the justes and turney hathe ben thys day entreprised and valiantly and couragiensly doon and accumplished, gyve their entiere and especiall thankkes, mn to Syr Edward A Borongh, Syr Edward Darell, 'Thomas Brandon, Natew Baker, Guillam de la Rirere, Rouland de Veilleville, entreprengneurs of the same justes and turney. And where as in tymes passed the price hathe be commenly geven oenly to the partic with owt, neverthelesse now it is thought that they that hathe ben ehief causers and ehalengers of this noble enterprise and actis of armes in these justes and

$$
\text { C C }
$$


A.D. 1494. tourney hathe deserved special rewarde and honnour. Wherfor the right high and excellente princesse the ladie Margarete the kyngis oldest donghter, wiche by tharys of the kyng, the qwene, my ladye the kyngis moder, and of all the ladies, hathe arvarded and geven the price and laude for the partie with in to the right honnonrable knyght Syr Edward A Borongh, wiche as thus day hathe well and homorably brokyn his spere, and alsoo hathe well beharen hym selff at the tourney, that is to sey, a ryng of gold with a dyamant. And where as the partie with owt, that is to wete the right honnourable and noble lordes therlls of Suffolke and of Essex, Sir Robert Curson, John Peche, John Neryll, John Williams, answerer's to those said justes and turney hathe soo honnorably and ralfantly acquited them in the same, our said sourerayn lord, the qwenys grace, and their oldest donghter the ladie Margerete byfore named, yeven to theym their right enteer thankes; and morover the right high and excellente princesse the same ladie Margarete, by thavys of the kyng, the qwene, wy ladie the kyngis moder, and all the ladyes, hathe awarded and geven the price and lande for the partie with owt to the right noble lord therll of Essex, wiche as this day bathe geren great strokkis in this tom'ney and long contynued in the same, that is to sey, a ryng of gold with an emeranld."

The names of thastates, lordes, banerettes, and knyghtes beyng at thy's fest:-

Fur'st the Kyng

The Qwene

My ladie the King's moder'

'The Due of Yorc

'Thambassateu' of Naples

The Duc of Bedford

The Dnc of Bokyngham

The Marquis of Dorsett

Therlt of Armudell

Ther]l of Oxinford, great cham. berlayn of Englond

Therll of Northumberland

Therll of Derby, eonstable of

Englond and juge ordred a]l

thynges doon in the feld

thos iijd ys.

Therll of Shrenesbury

Therll of Suffolke

Therll of Essex

Therll of Kent

Therll of Wilshir
Therll of Crmond

The Lord Haryngton

The Lord William Courteney

Therll of Kyldare son and heyre

The Lord of Saint Johns

The Lord Grey

The Lord Clyfford

The Lord Bourgamy

The Lord la War

The Lord Scropp

The Lord Giey of 'Wilton

The Lord Fitz Waren

The Lord Zoncbe

The Lord Dacre of the Sow the The Lord Daere of the Northe

'The Lord Dodeley

The Lord Banchamp

The Lord Hastynges

The Lord Dranham

The Lord Dawbeney

The Lord Broke 
The Lord Wylougby

The Lord Hosey

The Lord Bryan

The Lord Hodye

The Lord Bothwell

The Baron of Slane

All the Ladies of the Court in great numbre.

The Ducesse of Bedford

The Marquisse of Dorsett

The Countesse of Kent

The Ladic Burgaremny

The Ladie Dodeley

The Ladie Dynham, and soo many mor in mum. bre, and allsoo I have nott halff their names.

The names of the Prelatys.

The most Reverent Fader in

God, the cardinal of Cantor.. bury

Thareheljishopp of Yor'

The Bishopp of Ely

The Bishopp of Wynchester

The Bishopp of Duresme

The Bishopp of London

The Bishopp of Saleshury

The Bishopp of Excestre

The Bisshopp of Saint Asse

The Bishopp of Rochester, and many oder abbottes, prionrs, doctenrs, and oder clerkes.

Bunerettys and Inyghtes.

Sir John Cheney, baneret and knyght of the garter

Sir Thomas Mongomere, knyght of the garter

Sir John Arundell, baneret, broder to therll of Arnudell

Sir Gillsert Talbot, baneret

Sir Edward Stanley, baneret

Sir John Fortescu, baneret

Sir Humfrey Stinley, baneret

Sir Edmond Berlynfeld, baneret Sir Jobn Sayvell, baneret
Sir Richard de Labere, baneret A.D. 1494 .

Sir James Tyrell, baneret

Sir Christoffor Ward, baneret

Sir Pier's A Ligh, baneret

Sir Thomas Stanley

Sir Charles Somersett

Sir Richard Gilford, countroller of the kyngis house

Sir Dary Owen

Sir Thomas Bonrser of Barnes

Sir Walter Hungerford

Sir Hemry Vernon

Sir Thomas Butteler

Sir Reignold Bray

Sir 'Thomas Lovell

Sir Thomas Darey

Sir. John Arundell of the West contre

Sir John Riseley

Sir Nycholas Vanx

Sir Edward A Borough

Sir Edward Barkeley

Sir John Wyngfeld

Sir Edward Darell

Sir Robert Curson

Sij Roger Nenibourgh

Sir William Knerett

Sir Tilliam Bolen

Sir Mater Browne

Sir Henry Wilonghby

Sir John Gyse

Sir John Hastynges

Sir William Scott

Sir Jolum Sabacottes

Sir Walter Gryffitho

Sir Gervoys Cliffton

Sir Edmond Traford

Sir Ranff Rider

Sir Robert Hareourt

Sir Henry Marney

Sir John Speke

Sir John Turberville

Sir Henry Roos

Sir William Urydall

Sir Piers Eggeeombe

Sir Robert Litton 
A.D. 1494. Sir Robert Clere

Sir Thomas Tirell

Sir Humfrey Fullford

Sir Richard Lews

Sir Thomas Fairfax

Sir Richard Knyghtley

Sir John Chooke

Sir Olyver Mamnyngham

Sir John Mannyugham

Sir Joln Halwell

Sir Robert Pointz

Sir John Norbery

Sir Henry Heydon

Sir Robert Rateliff

Sir John Pikeryng

Sir Edward Wyngfeld

Sir Robert Brandon

Sir Thomas Bawde

Sir Thomas Tempest

Sir William Litillton

Sir Edward Pykeryng

Sir Robert Markam

Sir Gry Fairfax

Sir John Digloy

Sir William Vampaige

Sir William Sanddis
Sir Nicholas Lisle

Sir Thomas Fitz William of York shir.

Sir Thomas Hungerford wiche ther decesed

Sir Sampson Norton

Sir Roger Cotton

Sir Thomas Leighton

Sir Thomas Markenfelde

Sir William Caru

Sir Willian Wilougly

Sir Adam Furneys

Sir John Lovesque

Sir John Browne of London

Sir Fugh Brise

Sir Thomas Fitz William of Lyneolnshir

Sir William Martin

Sir Ranfi Ostrishe, obiit

Sir William Horn

Sir Tohn Perserall

Sir William Capell

Sir Joln Fenkyll

Sir Simon Monfort.

Finis.

\section{VII.-Arrangements for the Reception of Cathe- RINE OF ARRAGON.}

[One seheme of these arrangements has been printed in the Hardwicke State Papers from a modern MS. in the Harlcian Collection. The present differs from it considerably, and is from an original draft by Henry VII.'s Conncil in the Cottonian volume, Vespasian C. XIV. f. 81. An account of her actnal reception will be found in Leland's Collectanca (2nd Edition) vol. V. 352.]

A.D. 1501 .

Oct. barges and great bootes to the said Westminster. And as for the princesse, it is thought that she shuld be with the quenes grace in her Jarge. 
: The charge of warning of all the lordes bothe for the prepay- A.D. 1501. ring and arredieng of thaym self, and warnyng of the tyme of Oct. theyr attendaunce in thayr barges is comitted to my lord chambrelayn. $^{2}$

And besides this provision that the kinges great and litell bootes be purposely prepaired and kept, nott onlie for suche estraungiers as shall come with the said princesse, wherof my lord chambrelain hath taken the charge, butt also for her and the said ambassadours servauntes.

Item, when alle thies barges and bootes of the lordes spirituel and temporall shalbe thus appoynted and redy npon the Thamys to sette forthwardes towardes Westminster, then the said lordes spirituel and temporall hover and attende every man in his barge or bote in the ryver upon the kinges barge. And when the king in his said barge shall sette forth from the said Baynardes Castell, then alle thoder barges and bootes to rowe by the king and about the king as the space of the river with thebbe or flode, and good ordre shall lede theim till the tyme his grace shalbe landed at the great loruge of Westminster, and that the quenes grace and alle the ladies, and certain lordes to be appoynted by the kinges grace to attend npon her, folowe in the company of the king, and when she shall come to the great bruge at Westminster, that then she, her ladies and lordes attending upon her pause and rest in their barges till suche tyme that the king with his company be landed and entred into the palois.

[Memorandum, to appoynt tro fiire and large barges, thoon for" thambassadours of Spayne, and thother for the ambassidours of Scotland, besides the kynges two bootes for thayr servanntes. The Archebishoppe of Cauntreberys barge and the abbott of Westmynster's barge been th[e most] mete and convenient for the said ambassadours. ${ }^{3}$

And esfor justes, torneys and suche other cerymonyes thei be remytted to the said $\mathrm{Mr}_{\mathrm{r}}$. comptroller sergeant of the kinges armoury.

Item, it is thought wele fitting and honorable that every lord spiritucl and temporall, that shall gief their attendaunce at this tyme, kepe his house during the said fest, and till the king departe from Westminster.

Item, that my lord chambrelain send certain of the huisshers of the kinges chambre to take up Herons house within the saintwary, and to serche alle the logingos that be within thabley

\footnotetext{
1 This sentenee is inserted in the handwriting of Ruthal.

"Giles lord Daubeney.
}

${ }^{3}$ 'This paragraph is inserted in Ruthal's hand but seored ont. 
A.D. 1501. and Chanen Rowe, and canse the owners of theim to dresse and Oct. fornyssbe theim with eonvenient stuf, and to make their reaporte of every of the same by writing.

Item, my lord stieward ${ }^{1}$ and the comptroller shall cause vj. of th $[\mathrm{e}]$ best fornysshed loginges, and the towne of Westminster to be reserved and kept for estraungiers.

Item, that Robert Suthwell and Sir William Vampage shall have eithr[e] of theim a hool copy of this boke to thentent thei may often orersee and perfitely peruse the same, and not oonly to advertise every man that hath eny charge to hym to be redy to doo their offices, but also to calle upon theim for thexecucion of the same.

Item, that certain officiers at armes, that is to saie Richemonnt king of [arms], Somerset, Rngedragon heraldes, and Mountorgell pursuyraunt, Conyers, John Craford, Jolm Molle, Cholmeley, sergeantes-at-arms, goo with my said lord steward, and gief their attendaunce, and serve the said princesse as the shalbe commaunded by my said lord steward.

Item, that xij. palfraies and a litter upon Friday the viij. day of Octobre, departe and drawe streight to Honyngton, in Deronshir, and ther tary and aljide the commyng of my said lord stieward, and at his commyng thider go streigh[t] with hym to Excestre, to thentent to serve the said princesse and her ladies, wherof my lord stieward shall gief her knowelege, and canse theim to be ordred and disposed after her pleasure.

17 Oct. And that my said lord steward, with suche as shall attende upon hym loe at Exeestre the Sonday, which shalbe the xrijth day of this moneth of Octobr at the ferrest.

Item, that the Thesday next ensuyng, that is to saie the xixth day of the said moneth, the said princesse accompanyed with alle the nobles of Dexon and Cornwall that brought her to Exeestre, departe thens and the night folowing loge at Honyington.

Item, the Wednesday then next ensuying, which shalbe the xxth day of the said moneth the said prineesse accompanyed with the saich nohles of Deron and Cornewall shall departe from $\mathrm{Ho}$. nyngton, and goo to Crokehorne, and ther loge in the parsonage the night ensuyng.

And ij. or iij. myles hefor the come to Crokehome she shalbe met with Sir Amys Paulet, Sir Hugh Lutterrell, Sir John Speke, Sir William Willonghby, Sir John Wodham, John Sydenham of Brympton, and John Horsey. And soo fourthe attende npon her, and bring her to Shirbourne, and there departe.

'Lord Willoughby de Broke, steward of the king's household. See Leland, Coll, v. 353. 
Item, the Wendisday the xxvijth day of this moneth, the said A.D. 1501. prineesse, aecompanyed with the said Sir Amys Panlet, and thoder, shall disloge fro Crokehorne, and drawe towardes Shirborne, and there loge in thabbey that night and the Friday folowing alle day.

Item, ij. or iij. myles befor the come to Shirborne, to be mette by Sir Thomas Lynde, William Martyne, Sir John 'Turbrevile, Sir Rogier Newburgh, Riehard Willonghby, William Basket, Henry Stanguysshe, and so forth attend upon her, and eonvey her to Shafteshury, and there departe.

Item, the Saterday next ensuyng, which shalbe the xxxth day of Oetolsre, the [said] princesse, accompanyed with the said Sir Thomas Lyude and thoder, shal dis . . from Shirborne, and drawe towardes Shafteslury, in there loge in thabbey that night and the next day folowing. which shalbe the Sonday, and Monday all day, which shalbe all Alon day.

Item, ij or iij myles befor she come to Shaftesbury to be mette with Sir Morys Barowe, John Monpesson, Thomas Long, John York, yong Baynard, Waltier Servington, John Gawen, Richard Clifford, William Lamberd, John Ludlowe, Waltier Bonlam, James Lowder, Waltier Torney, John Burley, William * * 1 Robert Unwyn, and soo forth, to convey her to Ambresbury, and ther departe.

Item, the Tewsday next ensnyng, whiche shalbe the ijd. day of the said moneth, the said princesse, aceompanyed with the said Sir Maurice Barowe and thoder, shall disloge from Shaftesbury, and drawe towardes Ambresbury, and ther loge the next night in thalbbey.

Item, it is appoynted that my lady of Norffolk, with certain ladies awaiting mpon her at the namyng of the quene and my lord tresourer, be at Ambreshury, upon Monday the xxith day of Oetobre, ther and then to mete and receyve the said princesse after the maner folowing, that is to saie, my lord tresonrer, accompanyed with the Bisshops of Bathe and Hereford, thabbots of Abandon and Reding, my lord Dacre of the Sonth, my lord Zonche, Sir Robert Poyntz, Sir William Sandes, Sir John Seymor, Sir Christofer Wroughton, Sir John Brereton, and Sir John Chok, to mete her iij. or iiij. myles befor she come to Ambresbury. And the said duchesse of Norfolk, to receyve her after her offring in som convenient place betrix that and her loging, at which tyme William Hollybrand, which shall awaite npon her', shall in the Spanysshe toug, in the name of the said duchesse welcome the said princesse with suche wordes

${ }^{1}$ Blank in MS 
A:D. 1501, as be delyrered to hym in writing. And that the said duchesse 2 Nov. have warnyng hereof by $*$ * and the said Hollybrand by my lord chambrelain.

Item, that there be a chare redy at Ambresbury the same tyme, for the said princesse to put her in the next day, or at cny other tyme when it shall please her, wherof the charge apperteigneth to ${ }^{1} *$ *

3 Nov. Item, the Wensday next folowing, which shalbe the iijd. day of the said moneth, the said princesse, accompanyed with the said duchesse and tresourer, and the nobles that attended upon theim, and in the said chare, if it shal soo please her, shall disloge from Ambresbury, and drawe towardes Andoror, and ther loge the night ensuyng in the inne of Thaungell.

4 Nov. Item, the Thursday next ensuyng, which shalbe the iiijth day of the said moneth, the said princesse, accompanyed as above, shall disloge fro Andoror, and drawe towardes Basingstoke, and ther the next night loge in Kingesmelles hous.

5 Nov. Item, the Friday next ensuyng, which shalbe the $\mathrm{r}^{\text {th }}$. day of the same moneth, the said prineesse, accompanyed as afor shall disloge fro Basing Stoke, and drawe torardes Dogmersfeld, and ther loge in my lord of Bathes place that night, and the next day folowing, which shalbe the Saturday the $\mathrm{vj}^{\text {th }}$ day ${ }^{2}$ of the said moneth.

6 Nov. Item, the Saterday next ensuyng, which shalbe the vith. day of the said moneth, the said princesse, accompanyed as afor, shall disloge from Dogmersfeld, and drawe towardes Chertesey, and ther in thabbey loge the night folowing, and the Sonday and Monday next ensuyng.

8 Nor. Item, the Monday next ensuyng, which shalbe viij. day of November, the said princesse shall disloge from Chertesey, and drawe towardes Croydon, and ther in tharchebisshops place loge the next night ensuyng, and the Thesday next day folowing.

And botwix Chertesey and Croydon, at the fote of Banstede Downe the said princesse shall be met with the personages folowing, that is to say, my lord of Buk, therle of Kent, my lord Fitzwarren, my lord Saintmond, the lord Ston'ton, my lord Dudley, thabbotes of Bury and * *, ${ }^{1}$ Sir Waltier Hungerford, Sir Edward Darell, Sir Robert Hareconrt, Sir Rogier Lewkenor, Sir Giles Bruges, Sir John Guys, Sir Joln Longford, Sir John Hnddelstone, Sir Alexandre Bayneham, Sir John Rodney, and Sir Edmond Gorge, wherof thei shall have waruyng by my lord chimbrelain.

\footnotetext{
I Bank in MS.

"Sidurlu!y the vith] Friluy the with eontemporary alterations in wath in the text, corrected as the dates throughout.
} 
Item, the 'Tewsday, which shalbe the $x^{\text {th }}{ }^{1}$ day of Novembre, A.D. 1501. and it be a fayer day, and elles upon the Friday $\mathrm{v}^{\text {th }}{ }^{2}$ day of the 10 Nov. same moneth, the said princesse shall departe fro Croydon towardes London, and ther make her entre, and loge in the Bisshops palois.

Item, it is to be remembred that the lordes and other nobles that shal mete and receyve the said princesse at eny tyme, loe alwaies redy with their attendaunce at every disloging, and departe not till she be logied, and in good and lonorable maner and ordre, contynuelly kepe hor company betwix loging and loging till she come to London. And that no per. sone commyng with theim in their companyes, except he be a necessary oflicier, ride befor out of the company of the said princesse, but alwaies in journeyng the gentilmen to ride befor her and the yeomen behynde, for the better ordre and the more honour. And that the said lordes and nobles be advertised hereof by my lord stieward and officer's of armes. And the same officiers and som of the servanntes of my lord sticward to be by hym commannded to see that this ordenaunes be duly kept and observed. And that noon of the said lordes ner noon othre persone attending upon the said princesse, take their loginges at their owne handes, or be their owne herbegers, lut alwaies resorte unto the kinges herbegers, to take their loginges by their assignement.

Item, after her departing fro Croydon, she shalbe conveied to my lord of Rochestre is place besides Lamhithe, and ther loge that nyght, and hir ladyes; thareheljisshop, the bisshop, therle, and the remenamt of her compaignye to loge in the towne of Lambythe. And the 'Thursday, if it be a fayre daye, or ellys the Fridaye, by $x$. of the clok byfor none, to be receyred into a ${ }^{3}$ richer litter then thoder, and in the same to make her entre into London; and that the same lytter be at the said place of ny lord of Rochestre orer eren, or at good hour in the mornyng.

Item, that iij. henshmen, in side sadeles and hernes alle of oon sute, be arredicd by the maister of the quenes horses, to folowe next mito the said prineesse lytter, and that thei be at the said place orer even, or erly in the mornyng.

Item, that a palfray with a pylion richely arraied, and led in hand, be then at the said place for the said princesse, and doo folowe next nuto the said hensmen.

1 The words Trusday and $x$ th are a correction from Thursiley and iijth; lut the corrector has forizot to make corresponding alterations.

- See preceding note 3into $a]$. After the words "my " lort of Rochestre," this passage is an interlincation in the hand of bishop fox, in place of two lines scored out. 
A.D. 1501. Item, that xix. palfraies, alle of oon sute, be then in the said Nov. place, redy ordeyned for suche ladics as shall folowe next unto the said pylyon.

Item, that $\mathrm{v}$ chares diversely apparaled be then redy in the said place, wher of oon of the chief most be richely apparaled and garnysshed for the said princesse, and thoder iiij. to serve suche ladies as shalbe appoynted by the quenes ehambrelain. And that the same folowe in suche ordre as the same chambrelain shall appoynte.

Item, that betwix every of the said chares ther be v. or vj. palfraies with suche ladies and gentilwomen as shall come to the fest for attendannce gyring upon the quenes graee.

Item, the same chambrelain hath also the ordering of the said palfraies, as well as the chares. And if there fortune eny more ehares to eome then is above assigned, then the same to be ordered by the said chambrelain.

Item, the said princesse shall in saynt George is felde be mette with my lord of York, the kinges second son, attended upon with the lordes folowing, that is to saie, tharchebisshop of York, the bisshop of Winton, therle of Essex, the lord Harrington, the lord Strannge, the lord of Bergevemuy, the lord Willonghby, the lord William of Deron, the lord William of Suffolk, thalbotes of Westminster and Saint Albane, Sir Gilbert Talbot, Sir Fdward Ponynges, Sir Edward Stanley, Sir John Risley, Sir Nicholas Vaux, Sir Thomas Cheyne, Sir Mathene Broune, Sir Thomas Grene, Sir William Tyrwit, Sir John Longvile, Sir Marmadne Connestable, Sir John Sayvile, Sir William Gascoigne, Sir John Huse, Sir Henry Heydon, Sir William Bolloigne, Sir Robert Broughton, Sir William Seot, Sir Hugh Conwey, Sir John Raynesford, Sir Henry Mcrney, Sir Richard Lewes, Sir Thomas Tyrell, Sir John Pastone, Sir Philip) Calthorp, Sir Robert Brandon, Sir Thomas Wortley, Sir George Maners, Sir George Teere, Sir Robert Tyrell, Sir Rogier IVentworth. Sir John Ferrys, Sir Thomas Rotheram, Sir John Audcley of Suffulk, Sir Edward Ranghlegh, Sir John Verney, Sir John Digly. Sir Robert Clere, Sir Henry Willongbby, Sir Edward Stanhop, Sir John Wynfeld, and Sir Robert Peyton. And to calle alle thics to guyders, and to gief theim warnyng herof, the Bisshop of Winton, and Sir John Risley, have the rharge.

Item, ${ }^{1}$ itt is appoynted thatt att entring into the citie the archebischoppe of Yorke shall kepe emmpenie with the ar'chebischoppe of Spayne, ${ }^{2}$ and the duke of Bukkyngham with the erle of Cabra,

\footnotetext{
The whole of this paragraph is inserted in the margin in Ruthal's handwriting.

2 Alonso de Fonseca, Archbishop of Saut Jage.
} 
the bischopp of Winchestre with the bischoppe of Mayorke, A.D. 1501. and with thoder lordes and nobles of Spayne ecrtayn lordes and Oct. nobles to be appoyntid after the diseresions of the lord tresourer, and the said bischoppe of Winchestre.

Item, that the maire, citezens, and craftes of London attende upon the said princesse, at the crosse in the Chepe, ayenst her commyng to the eitie, in suche maner and such solempnitie, and with suche pagentes and cerymonye as thei have devised for thonor of the citie, and of the fest, wherof they shalbe advertised by the lord Bergerenny.

Item, that the said princesse be conveied thorongh Sonthwerk, streight ove[1] London Bruge, and soo thorongh the Brugo strete to Greschurch strete, streight to Leden Halle corner, and then into Connell, and fromthens through Chepe, and then entre into Panles Churehe yerd by the gate that is against Saint Michell Churehe, and then out at thoder gate, streight south against that gate, and soo into the brode strete to the west dore of the churche, where she shathe receyred with procession by tharehebisshop of Canterlury in pontificalibus, aceompanyed with suche bisshops and abbotes as be commaunded to come to the feste aud not appoynted to be at cuy of the said motinges, and suche other wherof the names folowe; that is to saie, the bisshops of Ely, Lincoln, Rouchestre, Landaff, and Bangore; thabottes of Stratford, Barmondesey, and Towre Hill, all and every of theim being in pontificulibes, and fio the said churche dore with the quere of the churche processionally, to bring her to the high aultier, and there to do snche cerymonyes as in suche case is accustumed. And after her olfring to be conveied to the litell dore ayenst the consistory that ledeth into the palis, and soo forth brought to her chambre within the said palois; and for her long travaill and labour it is thought that she shall tary within the said palois oon day at the leest before the day of her mariage, and more as the case shall require, and as it shall please the king, and to lede and conrey the said eompany thorough the stretes above named to the said west door of Paules, and to see good ordre kept in riding. And that there be nouther to great hast ner tomoche tarying by the way my lord Bergerenny hath the charge, wherof my said lord stieward shall gief to hym adver. tisement. ${ }^{1}$

\footnotetext{
'Added in Fox's hand, but afterwards scored out:--" and that "tharchiebisshop of York lepe " compaignye, with tharchiebisshop " of Spaigne, my lord of Buk with "therle and therle (sic) of Wynches-

"tre with the bisshop; and with " other lords and nobles of Spaigne, "lords and nobles after the discre" cion of my lord tresorer and my " lord previseale."
} 
A.D. 1501. Item, that tharchebisshop, the bisshop, therle, and the ladies Nov. and gentilwomen that come out of Spayne, be logied in the dean and chanons loginges and other lonest houses adjoynyng ${ }^{1}$ to the said palois by Whiting [and 'Trefrye] ${ }^{1}$ gentilmen huissher [s]' by the oversight and ordering of my lord chambrelain, and that a consideracion be had that thei be logied after their honour and degrees.

Item, it is appoynted that at the after noon of the day next ensuing the day that the said princesse shall come to the palois, the same princesse in her lytter, accompanyed with the duchesso of Norfolk in her litter, and certain ladies, som of the quenes, and some of the said princesse at the quenes nominacion, and suche lordes and nobles as be appoynted for thattendannce gyving upon the lordes of Spayne, shalbe conveied by Panles Chene, downe Lamberdes Hill to the quene being at Baynardes Castell. And that the quenes chambrelain recerre her at the fote of the grece that goth up to the quenes chambre, and goo before her to the quenes great chambre. And after she bath seen the quene, and made a certain panse, she shall retour'ne to the palois.

Item, that Lamberdes Hille be sanded by the maire of London by the same tyme; and that the sergeant porter be warned that no maner persone en [tre] the gate but oonly the said princesse, and her lords and ladys, and such as accompaigne them.

Item, as for the day of mariage. It is thonght that, for the more solempuitie of the fest, it shuld be upon the Sonday or som holy day, and that the said princesse be going out of her chambre towardes the church, somwhat before ix. of the clok.

Item, it is ordeyned that the bisshops of Excestre, Herford, Bath, Lincoln, Sarnm, Chestre, Ponchestre, and Norwich, and thablotes of Westminster, Bury, Saint Albane, Glastonbury, Abendon, and Reding, alle in pondificulitus gief theire attendannee, the day of the said mariage, upon tharchebisshop Cauntirbery, executor of the said mariage.

And asfor the princes commyng to the citie, it is thonght that he shuld be there a day or ij. before the eommyng of the said princesse to the palais, and that he shnld loge in the Warderobe, ${ }^{2}$ and the day of mariage to make his dutie into the churche somwhat before the princesse commyng thither, which entre is

1 Crossed out.

a Irurderobe.] This word is interlined by Ruthal in place of " bis"shop of sarum place," which originally stood in the text, witl these words added: "till the night
" next before the day of the ma-

"riage, and that night for his more

"redynesse for the busynesse of the

"next day, to loge in the Warde"robe." 
devised to be at the south doore, next westward to our Lady of A.D. 1501. Grace in the body of the churche, and the princes houshold serNov. vauntes to gief their attendaunce, and convey hym to the haulto place to be made before the consistory in the said body of the churche somwhat before her commyng thider.

Item, the said princesse, accompanyed with the grettest estates of the lordes and ladie[s to] goo ont of the palois at the grent gate and entre by the west dore of said church, and soo to goo to the same mantle place, led by my lord of York.

Item, for the more easy commyng of the said princesse it is devised that barres shalbe made from the said palois gate unto the said great west doore of the church, and soo from thens to the fote of the galory.

And as for the hanlte place, it is devised to be set in the nary and body of the churche, even arempst the consistory, to thentent that the king and quene may secretly goo out of the bisshop's palois into the same consistory, and ther to here and see the cerymonyes of the mariage at their pleasure. And for this canse a bak doore most be made in the same consistory, wherof maister comptroller and Sir Charles Somrerset have the charge.

Item, the faction of this hanlte place is devised to be made like mnto the hanlte place at the cristernyng of the kinges childern, with brode and large greces and steppes, and with a good large space, alle on high on loft to thentent that executor of thoffice of the mariage, and the ministres of the church necessary for to doo that acte, and the prince and the princesse, may be tognyder, and no 11100 above in the said space, alle on high then be necessary. And the bisshops, abbotes, and other prelates and other officers may stande lower upon the said steppes and the haulte place, soo as therby growe noon impedyment to the sight of the people. And that fio the said haulte place to the quere dore there be a stage of $\mathrm{v}$. fote high, with a raile upon either side; and Sir Charles Somerset and the comptroller of the kinges house have take upon theim that the said work shalbe made sure and sustanciall.

Item, that the chureh of Paules be hanged with aras soo high that the lowes[t] parte therof be vij. or viij. fote from the ground, and my lord chambrelain bath taken the charge of this matier upon hym.

Item, that the trompettes stande alofte orer the same west door, and blowe contynuelly after the furst commyng out of the said princesse of the great gate of the said palois, till the tyme she be in the churche upon the baulte place; and then furthwith when she shalbe there the trompettes to ceasse, and thordering, and guyding of the said trompettes and ministrelles for the tyme 
A.D. 1501. of the fest is committed to Thomas Lovell, yeoman huissher of Nov. the kinges chambre.

[And when the said prince and princesse shalbe on the said haulte place on loft, and the banes asked, than that Mr. Secretary objecte openly in Laten ayenst the said mariage, allegging that the same mariage cannot be laufull for suche reasons as he shall exhibite there, supposed to be grounded in the lawes of Cristes Churche; whereunto Mrr. Doctor Bernes ' shal replie and declare solemply in like wise in Laten the said mariage to be good and effectuell in the lawe of Cristes Churebe by vertu of a dispensacion which he shall have there redy openly to be redde, and therupon furthwith to delyver to thexecntor officii, and the same executor to commanude his chauncellor to rede it, the same objections made or eny other to be made ayenst the same notwithstanding. $]^{2}$

And when the said princesse schalbe on the sayd haulte place on lofte, than schall the kynges secretarie purpose the proposition for the lawde and prayse of the matrimonie, whiche he hath for that intent devised; whiche thinge doone the banys shalbe solempnelie askyd, and thexecutor oficii schall farther procede to the solempnizing of the same matrimonie.

Item, ${ }^{3}$ itt is requisite that the count, according to the custume and maner of Ingland, geve and deliver the said mincesse to the executour of the office.

Item, when alle shalbe fynysshed that is to be doon, the said lavulte place for the matrymony, then shall the prince and princesse goo togruder upon the said lerye hand in hand all along the body of the said ehurche, streight aforehed up to the rquere, and thorough the quere torardes the high antier, to theire places appoynted there.

Item, assone as the prince and princesse shall begynne to departe from the said haulte place, then shall alle the ministrelles, erery man after his facultic, oon after another, being' alle on high in the rawtes of the churehe, doo theire partes in musik contyunelly, as shall come to their course, till the prinee and princesse shalbe before the high aultiel, and then alle the ministrelles to ceassc.

And to thentent that the prince and princesse may have som place secretly to resorte unto for suche casualties as may falle

\footnotetext{
1 Willian Barons, afterwards master of the rolls and bishop of London.

${ }^{2}$ This paragraph is cancelled and

that which follows substituted for it in the margin in Ruthal's hand.

${ }^{3}$ This paragraph is interlined by Ruthal in place of one struck ont.
} 
during the high masse. It is to be forseen that the prince shall A.D. 1501 . have a traverse seled, made, and sette on the north side the Nov. quere nere the high aultier, in place convenient, with a rennyng curteyn to serve, when nede slalbe, soo as the ministres abont the high aultier ner those in the vawtes shall not mowe see what shalbe doon in the said traverse. And semblably an other traverse to be made in likewise, and to be set on the south side of the quere, also in place convenient for the said princesse to resorte unto, if eny occasion soo demaunde; and my lord chambrelain hath take npon hym the provision and making of thies traverses.

Item, asfor the careclothes, it shallue of white bawdekyn, and provided by my lord chambrelain, and by hym delyvered to the princes chambrelain, and the spices and rynes to be provided by my lord stieward, and delyvered to the princes chambrelain and his efficer's, thei to have the ordering of the same; and that and that the carecloth be holden by two barous, to be assigned by my lord chambrelain.

Item, after this solempnitie of matrymony shalbe fully doon the prince shall furst, and before the princesse, departe with his company down alle aloug the hawt place, and goo thorowt the consistorie in to his chambre, to thentent he may be redie in the same palois to receyve the said princesse at her chambre dore at her enmmyng.

Item, the said princesse, soone after the departing of the said prince, ledde by my lord of York, shall retemrne the same way she went; that is to saie, thorough the qwere down upon the said levye alle along the bedy of the church, ont at the great west doore of the same, and in at the great gate of the bisshops palois; and soo to her great chambre, where at the dore therof, the prince shall receyve her as the custmme of England is.

Item, that furst the ministrelles, and after the trompettes, every man after his course and facultie, doo their partes when the princesse shall retomrne towardes the palois of the bisshop, as thei did at her commyng from the same.

Item, it is thought good that somwhat besides the great west dore of the ehurche, on the south side therof, there shalbe a solempne conduyte rele and pompousely divised for to reme diverse sortes of good wynes, and the said conduyte to begyme to reme assone as the princesse shall be entred into the said palois, and soo contynuelly to remne alle that day, and parte to reme alle that night folowing.

Item, it is thought convenient that suche hede officers as shal have charge of the fest day of the said mariage, doo provide among other thinges, that the halle of the bisshop of London palois, aswele in enhawnsing of the boordes, tables, and fomrmes 
A.D. 1501. therof, and in hanginges of the house, as in making of cupOct. bordes, as wele in the chambre where the said princesse shall dyne as also in the halle, and otherwise thought necessary, but weale and honorably garnysshed and dressed, soo as it shalloe best divised for thonour of the said fest. 'The charge of the hanging of the said paloys is committed to my lord chambreleign.

Item, asto the fest, that matier is remytted unto the stieward, comptroller, and hede officers of the kinges most honorable houshold.

Item, that the iijde day next after the day of the mariage the said prince and princesse shall departe fro the said palois towardes Baynardes castell to goo to Westminster with the kinges grace, and that the said princesse soo departing shall ride in her lytter, or npon her spare horse, with the pylion behynde, a lord to be named by the ling, and xj. ladies upon palfraies after her. And that a certain convenient nombre of the said lordes and nobles be named, and wamed by my lord chambrelain, then also awaite upon her on horsbak, with the same nombre of their servantes with theim upon fote, that thei had betwix the Towre and the chureh of Panles, keping company with the lordes of Spayne, as thei did before, taccompany the said princesse to Baynardes castell, where the ling and the quene shalbe, and soo forth to goo to Westminster with the king by watier. And for this to be weale doon, two thinges be behorefull. Thoon is that the stretes from Paules ehene, down Lamberdes Hille, betwene therle of Derbys Place on thonside and the undertreasonres loging, to the said Baynardes castell be weale gravaled and substancially cast with sand, by the maire of Imndon, for the horses, more surcly to kepe theim silf uprigh in the great discent of the hille forsaich. Thcier is that the said princesse disloge the said ijje day from the said bisshops palois, at suche good houre as she may come to the king and quene to departe, if the king soo be pleased, the same day at tyme convenient from the said Baynardes castell to the linges palois of IVestminster.

If that the great bruge at Westminster be amended by the treionrer of England, and the kinges beestes and armes be renned and newe peynted.

Item, that the florth of Westminster Halle be new dressed, and the wyndowes of the same glased, whereof Mr. comptroller, and Worley have taken charge.

Item, that the Wollebruge at the said Westminster be also new repaired at the king [es] cost.

And for the more roialtie of the going of the king and the quene, of the prince and of the princesse, nnto Westminster by water, it is according that the ling and quene, and the prince have 
their barges apart, weale and pomponsly rigged and ad- A.1). 1501 . dressed.

Oct.

Item, that in. likewise alle the lordes spiritnall and temporall, that have yeven their attendaunee at this fest, accompany the king in theire ${ }^{1}$

Item, that the barges of tharehebisshoppe of Canntirbery, and thabat of Westmynstyr be appoyntyd, prepaired, and arredied for the ambassatoures of Spayne and Scotland.

\section{VIII-Norroy's Instructions. See page 222.}

[From a modern copy in Anstis' MS. Collections relating to the Officers of Arms, Heralus' College.]

A Remembrance given by the King's highness mnto Norroy A.D. 1503. King at Arms, shewing how he shall order himself with the King of Romans in such matters as be committed unto him by the King's said highness.

First, he shall address himself to the Cambremaister of the To comsaid king of Romans, and follow his advice, direction and municate eonnsel, as well in the time and manner of presentation of the with Maxiking's letters, the delivery of the George, mantle, collar', garter', chamberand other things concerning the Order of the Garter to be by lain him presented and delivered nnto the said king, as also in as to the soliciting for the proclamations and banishments to be made time and soliciting for the proclamations and banishments to be made mamner of by the commandment of the said king of Romans in those parts delivering after the form hereafter ensuing.

Also the said Norroy, at snch convenient time as shall be limited and assigned unto him by the said Cambremaister, shall resort mito the presence of the said king of Romms, to whom he shall on the king's behalf make dne recommendations and reverently deliver his letters as it appertaineth, desiring at his good pleasure and leisure to have answer upon the same.

And at a convenient time after the presentation of the king's said letters, when the said Norroy shall have perfect knowledge by the said Cambremaister or otherwise, that the king of Romans woll be contented and ag'eeable to aceept and receive the ornaments of the foresaid Order of the Garter, then he, nsing the adrice of the said Cambremaister, shall, in good, discreet and honest manner deliver the same ornaments to the said king, using such kind, loving, and substantial words at the deliverance of the same as the said king thereby may well perceive the

'Here the original text of the fragment ends, the item below being one of Ruthal's insertions at the bottom of the page. 
A.D. 1503, inward love, zeal, and affection that the king's highness per-

To note

well the manner in which it is received,

and whether Maximilian wears it.

To be present along with an officer of Maximilian at the proclamation of the peace and banishment of the re els. severantly beareth unto him. Ant the said Norroy shall well note the manner and words that the said king shall nse and speak at the acceptation thereof, witl every circumstance of the same, as near as he shall mowe, and advertise the ling's highness thereof at length by his writings.

Item, the said Norroy shall, dning his abode in the said king's conrt, daily note and well regard, whether the king of Romans at any time wear and unse the said ornaments of the Garter, or any of them, and how often, and advertise the king's highness in the specialty there of by his writing.

Item, at time convenient by the advice and comnsel of the said Cambremaister, he shall shew that the king's highness hath sent him thither to be prescnt with some other officer at arms, to be deputed and assigned by the said king of Romans in such cities and places where the proclamations of the peace and amity, the proscriptions and banishments of the king's rebels, shall be made, desiring the said king to cansc his said writings and mandenents to be made in dine and effectual form for the same proclamations and banishments, in snch form and mamer, and within the cities and towns specified in the copies of the said proclamations delivered mito the sald Norroy, which forms have been derised and commnned betwixt the king's highness and the ambassandors of the said king of Romans, as it appeareth by the letter's of recesse resting in the hands of the said ambassador's.

And for the olstaining of the said proclannations to be made in the best and most offectnal form and manner as they be now devised, the said Norroy shall, by the advice of the said Cambremaister, insist and endearonr himself in his best manner.

Ilow he

shall

answer, if

the addi-

tions made

to the proclamations be objected

to.
And if any difficnlty be made therein becanse of the additions new made and set to the said proclamations, he shall in cold and sober manner, sherw that forasmuch as the other form of proclanation was in so general mamer devised and made that by the same no specialty was expressed whereby the said ling's suljects monght have notice or knowledge of the eonelnsions or articles contained in the said peace and annity, by reason wherof they might pretend ignorance therein, and so not observe the same; to the intent therefore that some partienlar linowledge and specialty of the said treaty might be declired and shewed nuto the said king's suljects, it was thonght right, convenaljle, and expedient that those small additions, which in substance compriseth no more but the effect of one article of the said peace and amity, shonld of congrinenee be put thereunto. And inasmuch as the king's highness hath cansed the said peace and anity and every article of the same, wholly, entirely, and 
particularly to be proclaimed and published in the principal A.D. 1503. cities and towns of his realm, it is thonght to his grace and his council that no difficulty should be made in this form of proelamation with the small additions, which neither containeth the tenor of all the articles, nor yet wholly the effect of one of the same, but shortly and summarily toucheth part thereof.

And in case the said Norroy may perceive that the said king If insisted and his conncil will in nowise be agreeable to have the pro. on, these clamations made in any other form than in the general manner additions by them first devised, the copy whereof the said Norroy hath abandoned. also now with him, then he shall, without further difficulty making therein, be agrecalsle therennto, and desire the king's writings, mandements and his officer at arms, for the same to be made as well within the town of Achon, as in all the other cities mentioned in the form of the said proclamation, and with the same officer personally to be present and see the saic proclamations effectually to be done in all the places therefor appointed and assigned, as solemnly as he may obtain it to be done, and to endeavour himself to canse the officers of all the cities and towns, when the said proclamations shall be made, to be present at the making of the same.

Item, the said Norroy shall take with him the king's poursuivant Rongedragon, to the intent that he may not only convey unto the king's grace such writings as the said Norroy shall send unto his highness concenning his expedition in all the premises, but also advertise the Cambremaister thereof to the intent that if the said king of Romans or the Cambremaister woll write any thing unto his said grace, the said Rougedragon shall be redy to bring the same with all speedy diligence.

H. R.

\section{IX..-LeTter to KildiNGWORTH.}

[From a copy in Killingw orth's hand, in the Record Office.]

MaIsTER Steward, to write our povertie hyt nedeth A.D. 1505. not, for alle the worlde knoweth hyt wel ynough. But where hit is soo that ye desire to knowe my mynd, hit is soo that I spake not with my lord our maister sythen the xvij. day of October, and al by the meanes of that false errant traytor, the mynyster of Hownsloo, that utterly hath conspired the destruction of my lord oure maister and me. Yet neverthalas, I shall doo to you as a true man aughte to doo with 
A.D. 1505. his maister, and with suche as have been to hym as Jan. ye have been. This it is. The man that ye knowe of, spake with our maister on Sonday last past, at $\mathrm{xj}^{\text {th }}$ of the clok in the nighte, and was with him iij. howres and more; and I truste of suretie, and also I perceive by certain signes bytwix our maister and me, that good direction is taken bytwixt theym for his synglier welthe and owres, and shortely I truste it shal comme to passe of this secret practise; alle the world knoweth it not but they ij. and oon more whiche under jurgo confessionis hath shewed it to me. This kepe to your sylf as your lyf, and utter hit not to noo creature as ye love your maister. Pauca sapienti. Provyd for your silf a litle while, and lette. me knowe where ye bee, and as I am true servant to God and to our maister, as the matier werketh soo shal ye knowe hyt, in that I can or maye. I hope to God he shalbe shortely hable to have you with hym and al his true servantes, and I doubte not the matier is concluded. Nowe, maister stewerd, I committe this secretnesse to your wisdam; and concernyng the cause, write not nor clo no maner thing that shal discontent the parties; and advise other men to suffire, and to bee ware of great wordes, for a lytle thing maye hurte where muche cannot helpe. Geve your good counsaill to theym soo to doo, and bee wel ware of any comfort that ye have. Hyde this in your her' and bremne this letter. There is noo man lyving knoweth this. Departe secretly and sende me worde by this bringer where I shal fynde yowe, and noo more a doo. Within xiiij. daies I truste ye shal here other thinges.

${ }^{1}$ Recepi hane literam $\mathrm{v}^{\text {ta }}$ die Januarii, die Dominica, vigilia Epiphanize. In claustro prope Zwolle appunctuavi obviam cum 'Thoma.'

'Added by Killingworth. $\quad$ I Tho', MIS. 


\section{APPENDLX 3.-HUTLATHE PLERS AND ABSTRLITS.}

I.

\section{Oration to the Pope after Henry Vil.'s Marriage.}

IN the Cottonian MS., Cleopatra E. IIr. f. 123, is the rough draft of an oration intended to be delivered to the Pope and Cardinals by an ambassador of Henry VII., shortly after his marriage with Elizabeth of York. This speech is alluded to in Bacon's History of Henry VII. It is quite an unfinished composition. The substance is as follows:-

At the commencement the pope is complimented as one who hatd led a celestial life from his earliest years on earth, who nad endured great labours in the canse of religion, in many jouncys through many countries, and whose breast might be called the home of all liberal arts and sciences. The ling of England, who had been tossed on the wares and exposed to immmeralle dangers, like another Eneas, having been nearly fifteen years an exile, acknowledged that it was by dirine aid and beyond all human expectation that he had recovered in so brief a space the throne of his ancestors. To put an end to civil war, he had, at the request of all the lords of the kingdom, consented to marry Elizabeth, danghter of Edward IV., though he was free to hare made a profitable foreign alliance. Of her it is said, "Hujus plane forina pudicitiaque tanta est, " nt neque Lucretia neque Diana ipsa vel speciosior vel casta

" magis fuerat unquan. Tanta deinde est ei virtus ae morum " elegantia, ut certe nutu quodam divino ab ipsa sua nativi-

" tate ad hac usque tempora sili consors et regina reservata

" esse videatur."

The pope, it is added, had opportunely sent a legate to celeJrate the nuptials, at a time when the kingdom again appeared to be in the greatest danger from the fraudnlent machinations of certain persons. Following the example of Theodosius and Constantine, Henry desired to acknowledge his subjection to the Church, \&e. 
II.

\section{Blyth's Oration at Cajibridge.}

Is the Bodleian Library, MS. 13, formerly 2,357, is an elegantly written copy of an oration delivered in the presence of Henry VII., his mother the Countess of Richmond, and Prince Arthur, at Cambridge. It bears internal evidence of having been composed by John Blyth, bishop of Salisbury, who was chancellor of the University between the years 1493 and 1495 . The following is a brief outline of its substance, which is in many respects remarkable:-

After comparing the king to Moses, on account of the dangers escaped in infancy from the hands of his perseentors. - "Sed

"quorsum ista? Nimirum, ut intelligamns quanta sit mag" nitudo tua, rex illustrissime, qui tam mirabiliter natus es, " atque in lucem editus a nobilissinna principe genitrice tua

" unue præsenti, que tum anmum non implevit quartum.

" decimum, rarus profecto partus et insolitus, ipsaque (ut

" cernimus) non magna stature fomina est; et multo tune

" (ut asseritur) minoris fuit, adeo ut miraculum cunctis vide-

"batur in illis amuis, et in illa corporis parritate guatum

" alifuem, maxime tam procerum, tam elegantem edidisse.

". . . . . . . . Nam et dum in ntero por-

" turet te mater, vix discrimen pestis evasisti quæ teneriores

"foctus facile consuevit interimere, de qua ct pater tuns

" princeps illustris interiit. Mater deincle viro orbata te

"peperit orphanum, ${ }^{3}$ a cujus ubcribus mox abstrac tus,

"illorum custodia traditus fueras qui bellis assiduis im-

" plicabantur. Castelhum in quo tenebaris obsessum in manus

" inimicornm tnorum renit; (pui tamen, Deo ita providente,

" te (ut preclarmm sanguine deceret) edncaverunt egregie.

"Inde rumsitus ad neeem, patriam descrens, ulsi ad cognatum

" tuum regem Francolum ire destinaveras, in Minoris Britan-

" nix ducem utilius ineidisti, quamruam ab eo rursum tan-

" quam captivus detincbare. Sed, pace eum eo facta, quum in

'When the editor called attention | Preface), he was not aware that to this fact in Memorials of Hem!y 171. (sere note at parce xxiv of the than the Inquisitions post mortem. 
" patriam redire statuisti, tanto ventormm impetu elassis tua jac" tabatur nt vi compulsus retro retulisti pedem, Deo rem ita dis" ponente, ne forte in manus inimicorum tnorum venisses qui " tune insidias pararant tibi. Post hae Britanni te venalem. " offerebant eapitalibus inimicis tnis, nihil majus quam tumm " sanguinem sitientiluts. Quid multis? Convenit inter eos de " pecuniar; sed tu interea, Deo mirabiliter subveniente, cum " tuis omnibus effugisti salvus in Galliam. Unde quum

" denno temptirres venire in patrian, dirigente tune trum iter.

" et prosperante Deo, parva mam ingressus hoc tunm regumm,

" regem qui tune fuit cum universo ijssins exercitu fudisti

" "quamprimum. In solio demum confirmatus (me Jesu) quot

" adversie fortune machinatas insidias? puot proditiones clan-

" culum excogitatas? quot murmura et rebelliones nefiriorum?

" quot formidanda ols eventum maxime incipitem prolia (qux

" nos ommes recenti adhue memoria tenemus) tu ad tuan in"gentem glorian, non nisi divinitus, superasti semper." The orator went on to say, that he need not recount Henry's descent from so many most holy ("sanctissimis") kings, nor his many personal and mental qualities (which, however, aro fully emmerated). He begged him to take compassion on that ancient university, which had been in existence certuinly long before Honorins I., who was 160 years before Charlemagne, the fomder of the miversity of Paris. Donbtless the latter miversity took its origin from theirs, viz., from Alenin, Joamnes and Rabanns, whom even Gagnin admitted to have been alummi of Cambrilge.

They had been endowed by varions kings._-" Henricus tertius " has ipsas redes in quibus nunc sumus a fundamentis " erexit." Henry VII. had already shown a disposition to enconrage learning, as no one conld better witness than the orator": "Me ipsum (incuam) gnem incredibile cunctis fuit ad "episcopatum tam repente promoveri; quippe rui pancos " amos habnerin, qui nuuquam in curia obsequium prastite" rim, rai mullis ante dotatus bencficis. Et quamobrem ego "ad epriscopatum assumerer? Quid tuam ad hoc admirabilom " sapientiam movelat? Nihil prolecto alind nisi ut studiosis, " omnilus licpido constaret illorum cansa id factum esse." 'The king had done it quite unsolicited by man or woman, to enconrage rirtue and learning. To show his regard for scholars"Anno superiori cum ad nos venisti, dignatus es disceptationi" bus interesse, atque id per omninm Facnltatum sclolas.

"Postridie eum hae nudicris ingentem auri sumnam cum "magno ferarum nummo in puliliam compotationem uni"versis seholasticio maxina tuli liberalitate conbulisti," \&e. 
III.

\section{Norroy's Mission to JAMES IV.}

Arout the begnning of the year 1498, Norroy King of Arms was sent by Henry VII. to James IV. His instructions signed by the king are contained in MS. Cott., Vespasian, C. xvi. f. 115, and are to the following effect:-

1. 'To thank James for his kind and loving letter's sent by Lyon King at Arms, expressing his desire to observe the amity. The king had received the letters patent confirming the treaty made by the English and Scotch commissioners. (Sce Rymer xii. 673.) The declaration made by James in the th article appeared musatisfactory, as it only ratified by an inspeximus in laee vorlue the conventions made by the com. missioners of both princes.

2. To explain that the words ad nocendum alteri are omitted in the new letters patent sent by Henry to "his said consin," because each prince was bound to refuse aid or succour to the rebels of the other, and these words might afford a pretext for erasion. Either prince might refuse to give up rebels, salying he would keep them so strictly that they should have $n$ no power al nocendum alteri.

3. That the words sulvis conductibus, ete are also omitted, becanse James's chicf reason for inserting them was the safe conduct he had given to Perkin, who was now in the king's keeping, and would never again be in a position to benefit thereloy.

4. The king thinks that James, out of his desire for the dne punishment of murders and robberies, will be satisfied with these alterations and deliver letter's patent of like effect.

5. But if be camot be induced to consent, Norroy is to deliver Henry's ratifieation mnder the Great Seal, of the same tenor as that of James. 


\section{IV.}

Commerce with the Low Countries.

Some very mutilated dispatches of the bishop of Rochester (Fitzjames), Warhaun and Sir Richard Hatton, written from Calais in March 1499, exist in the Cottonian MS., Galba B. II. 46. They relate to the negociations with the commissioners of the archduke Philip, for a commercial treaty having special relation to the export of wool. A letter sent to them by the king in answer dated Greenwich, the . . A Aril, $^{-}$ follows at f. $49 \mathrm{~b}$. The contents of the papers are of no great value.

V.

Instructions to Richiond, King of ARms.

In the same very mutilated volume, Galba B. II., ff. 108,109 , is contained a copy of instructions to [Richmond, king of] arms, of Clarencieux, [sent to the king of the Romans and his] son the archduke of Austria. They commence on the reverse of f. 109, and appear to have reference to the proposed marriage of Henry duke of York with Philip's daughter, referred to at p. 167 , ante.

\section{VI.}

\section{Wolsey's Negociations in Flanders.}

Tirese interesting papers relating to the services in which Wolsey was engaged in the year 1508, with reference to the two projected marriages; first, between Henry VII. and Margaret of Savoy; and, second, between Charles prince of Castile and the princess Mary, have unfortmately suffered most severely in the Cottonian fire. Those which are in Wolsey's own handwriting, being rough drafts very much corrected, are

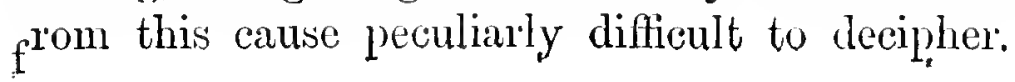




\title{
I.-The King's Instructions to Wolsey.
}

\author{
[MS. Cott. Galba B. II., f, 134.]
}

H.R. [Instructiones da]tæ $\mathrm{p}[\mathrm{er}$ re]giam maje[statem] fideli [et dilecto] capellano suo domino Thome Wolseye, \&c.

INPRIMIs, post commendationes regias idem capellanus dicet quod post reditum summ in Angliam, cum sacra regia majestati ea omnia $\mathrm{p}[\mathrm{er}]$ ordinem retulisset quæ A. sibi dcclaravit regixe majestati aperienda, admodum grata atque accepta sure celsitudini singnla fuermut. Ex his denique sna celsitudo plane intellexit, quod sibi semper antea persuasum habebat, illum, scilicet, intimum amorem, sinceram mentem, et cordialem affectionem, qure idem A. crga eum hacten[us] gessit et indics magis ac magis gerit atrue ostendit.

Et quamris celsitudo sua hec omnia antehac evidentissimis atque apert[issimis] argumentis, demonstrationilons et experimentis penes se te. . . atque ob id singularem et precipnam suam confidenciam in code[m posuerit] et locaverit, sicuti tam ex literis suis antehac eidem srepius [ostensis] guam etiam ex his quæ sibi referenda domino Edwardo Wy [ngfeld] oratori suo istic commisit, intelligere potnit, tamen . . . . qua inter dictum A., et eundem capellanum communi[cata fuerunt], et quæ serenitati suæ per ordinem fideliter accurate at[que] . . . recitarit, oculata quorlammodo fide et luce clariu[s inmotescere] re ipsa comprobavit dictum A. enm virum esse qui . . . exaltationem sure majestatis felices atque prosperos success[us omninm] negotiormm suorum summopere cupit atque exoptat; quibus [ . . . . . . s]ua serenitas jam rehementius accenditur atque cxcitatur $[$. - . i]mpellitur nt $n$ mon modo cundem A. amore ma[ . . . - . sed] etiam nt de eodem A. tancjnam de pracipuo suo [apud Cresaream] majestatem amico confidat et tanquam de sua majestate op . . . . . . crbis se memorem reddat.

The king desires the continuance of A.'s. good offices,
[A] git igitur imprimis sua sacra majestas eidem $A$. . . - [gratias] illas quas potest maximas pro hac sua precipna erga e[um] dilectione, gratitudine et observantia, proque maximis labori[bus] curis et solicitudinibus circa cansarnm et negotiorum suorum felicem cxpeditionem habitis et impensis; rogatque et ex corde prec[atur] nt quemadmodum idem A. hactemus humanissime cœpit, ita posthac velit pergere et perseverare, sibique persubdeat celsitudinem regiam se tam gratum tamque munifieun principem erga enndem exhibiturum. officiorumrque et meritorum suorum o[am] condignim rationem 
habiturum ut in gratum atque munificen[tem] principem obsequium collatum sentict et experietur, et ita tractabit eundem A. quod liquido constabit Cresari, domine ducissa ae omnibus aliis, eum esse in pracipua gratia et anctori[tate] ae multum valere apud majestatem suam.

Et, ut reipsa potins quam verbis id comprobetur, id [em] capel- and hopes lanus dicet, quod saera regia majestas sibi injum[xerit, quod] eun- by his dem A. certiorem reddat, quod pro memoriale ${ }^{1}$... . suo- means the rum meritorum in snam majestatem aliquale (licet non co[gatur two mar. ] m riages may pro] retributione et pro futura sua in causis et negoti[is agendis] take effect, fide, solicitudine, observantia, gratitudine atcue di[ligentia], viz., l, et ut majestas sua plene de co tanguan de precipuo [et] fidis-between et ut majestas sua plene de to tanquan de precipto [et] fidis- Henry VII. simo suo amico confirlere, et suis operibus sieut . . . . and Marconsiliarii sui uti poterit, si mediis, prudentia. . . dex-garet of teritate sua he affinitates inter Cesarea[m majestatem e]t colsi- Savoy, tudinem regian tractate et inceptre and, 2 , duobus contractubus matrimouialibus inter [ recem et] ducissam between Sabaudie, principen Castelle [et] clarissimam filiam suam Castile and dominam Marian, [enm omnibus et] singulis conditionibus et the prindependentiis super eisdem, ad honorem, contentationem et eomcess Mary. placentiam sure celsitudinis perficiantur et ad optatum finem dedueantur; ae quod in hac conventione sive dieta inter ducissam Sabaudice et legatum Francia in tractatu pac is] inter Casaream majestatem et regem Lodwienm Francise habenda et fienda, nihil fiat ant conchudatur quod in dispendium regii honor[is] aut in damnum sive prajudicium dictarum duarum affinitatum quovismod[o] cedere possit, sua serenitas providelit eidem $A$. infra regnum suum in spiritualibus promotionibus ad bonum valorem.

Et quamvis majestas regia speret et firmiter confidat quod The king infr $[$ a breve $]$ tempons eidem A. providebitur in hujusmodi pro- will give motionilus . . . . interim, et quoadusque idem A. per suan him a penmajostatem sirc ] promotus fuerit, eelsitudo sua siu- sion and gulis anuis cidem A. . . . solvet mille nobitia An- new beneglicama, angelettes vulga[riter dieta], preter et ultra exitus, England, redditus et proventus benefieiorum [qua] jam babet in regno Angliae, ad duos ammi terminos, [quorum primus] terminus incipiet in festo Pasche proximo futuro et se[cundus in festo Saneti] Michaelis Archangeli tune proximo et immediate sequente, et sic [de anno in] ammum quonsrine de dictis promotionibus ecclesiasticis per" $\mathrm{r}^{2}$ [egiam majestatem] sibi provideatur, dummodo premissa per eundem A. con[ficiendatur e]t ad optatum finem deducantur, de quibus sua majestas partes suas effeetnaliter interponere volnerit. 
and if the $\quad[\mathrm{E}] \mathrm{t}$ præter ac ultra præmissa, si, matrimonio inter s[uam marriage majestatem re]giam et ducissam Sabaudia contracto, aliqua take wil $[$. . . an] ctoritas in regimine sive administratione ipsa-

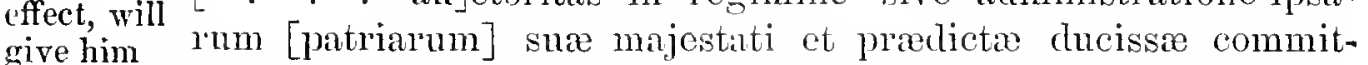
the chief tatur, regia majestas ob illum precipum amorem et singurule in the larem fiduciam cuam erga pradictum A. habet, non modo Low Coun- procurabit et faciet regi[men] ipsarnm patriarnm ciden A. sub tries. se committi, postpositis aliis omnilus et penitns semotis, sed etiam, si promotio aliqua honorifica in partiluns illis pro temporce quo anctoritas predicta crit penes suam majestatem et dictam ducissam vacare contigerit, illam pro viribus suis sibi concedi curabit, et [pro] posse suo eundem. A., auctoritatemque et potestatem sibi in ea parte concedendam manutenebit et plenam fide $[\mathrm{m}]$ et confidenciam in co tanquam in amico sno præcipuo et carissimo locabit.

Quæ omnia et singnla regia majestas cum effectu fa[cict] si promissa per eundem A. debite impleantur, prout s[ua] majestas $110 n$ diffidit quin perficientur si partes snas . . efficaciter interponere voluerit.

Praterea significarit idem capellanus regia m[ajestati quod] pradictus A. retulit silji de domino Bergensi v . . . . . iu omni tractatu et communicatione quos m[utuo sunt] habituri de matrimonio suo cum domino Bergensi f . . . . regia ad contentationem dicti Bergensis.

Et quoniam hace rerba adeo gencralia atque . . . . ut regia majestas aperte nequit perpe . . . . super lis cidem domino Bergensi ad animi s . . . respondere possit; ideireo sua celsitudo eundem A. rogatum habet ut clure et specifice velit eidem capellano suo declarare mentem et intentionem suam in ea re, et consilinm summ super eadem significare.

The king Et quia non dubitat regia majestas quin ommes difficnltates desires to tractatus matrimonialis inter suam majestatem et ducissam know from him wherein the Fmperor's diffeulties consist. Sabandia (si que fuerint) eidem A. hene cognitas esse; ideirco precatur regia majestas ut d[e his] et aliis in quibus Cesarea majestas judicat regiam majestatem $\mathrm{k}[\mathrm{am}]$ duriter et modo mercatorio potius quim regio incede[re], neenon quo tendant illa verba, "Venient oratores [Cesaris] principaliter ad exsequendum " ca que erant conclus[a, ete.] cum model'amine domini Andrew " de Burgo," idem A. [regiam] celsitudinem per capellanum snum predictum certio[rem fateiat].

Cumque idem A. dixerit mam difficultatem esse. . . . tractatu matrimoniali eo ruod clomina non revertetur [ad partes] illas, dignetur etiam idem significare utrum men[s et intentio] Gasaris et domine sit quod expresse per articulum in tra[ctatu] 
matrimoniali cavcatur ut domina dncissa Sabandiæ [post] matrimonium solemuisatum vivente rege poss[it ad] rotum summ, quandocumque ci libncrit et placnerit, revert[i ad partes i]llas; qua res si ita procederet, tenderet in [dispendimm re]gii honoris et maxime dicte domina ducissa et no[n decet] quod illud petant ant petere velint; idcirco arbitratur regia majestas quod dictus capellanus eundem A. in ea re clare non intellexcrit.

His difficultatibus intellectis, et consilio dicti A. super eisdem cognitis, majestas sua eidem domino Buigensi respons[a] congrua aptare poterit, et certe persuadeat sibi dictum A. regiam majestatem ol, illas preclaras et egregias virtutes qu[ibus] ipsam dominam ducissam Sabandia abunde refertam [esse] audivit. obque illas miximas gratitudines signaque et. . . . amoris sua majestati ampliter ct continne ostensa ita affi[ci] eidem domine ut ad contrahendum cum ea matrimonimm [pro] cateris aliis principibus optime disponatur, adeo nt [melius] disponi non possit; omniarque majestas regii pro part[e sna] ficiet qua honorifica et rationabilia videbuntur, [et quas] commode fieri poterint, nee per onm stabit quomi[nus illud] matrimonium debitum sortietnr effectmm; que o[muia] bona oppor'tunitate regia majestas cupit ut id[em A.] significet eidem domina ducissa

Prrterea, cum idem A. proniserit dicto capella[no se] missurum exemplar instructionum oratorum Ce[saris a]d celsitudinem regiam, dignabitur igitur e[asdem i]nstructiones jam mittere, et, si commode fieri [poterit, co]pias etiam instruetionum quas domina ducis[sa se]cm habebit in hae conventione cum legat[o Francice]; in quo rem supra quam dici potest gratam sua majestati faciet.

Cupit preterea atque exoptat majestas regia de his ommibus quae, vel in hac conventione inter dominam ducissam Sabandiae ct legatum Francia vel alibi, suam celsitudinem ant honore[m] suum quomodolibet tangentibus, tractabuntur, per prodictum A. certio[rem] fieri nune et posthac de tempore in tempus, per se vel alium, sicnti dicto capellano promisit; et propterea majestas regia [eundem] A. rogatum habet nt non modo super præmissis omnibus et si[ugulis] mentem, consilium, et intentioncm suam eidem capella[no] quantocins commode poterit aperiat et declaret, sed etia[m si] aliqua alia nova istic contigerint ex quo dictus $\mathrm{C}[$ æasar] hine discessit, vel si aliquid a domino Andrea de Bu[r'go audierit] ex Hispania, ant quidquam actum vel dictum fuerit ci[rea mutnum] Caesaris et regis conventum, et ntrum aliquid Cosar[ia majestatis] oratoribus superinde eommittetur, dignetur suam [majestaten superinde] per capellanum pradictum certiorem redderc. [Quæ] adeo 
secrete servabuntur ac si in armariolo pect[oris sui] recondita essent, et non mims honorem smm [majestas r] egia commendatum habebit quam proprium.

$[I]$ nsuper capellanus predictus significabit eidem A. q[uod rex i]nstruxit et expedivit oratores suos ad Crsarem et [sunt in itinere ve]rsus Casaream majestatem, atque eo citius sua inajestas eosdem s[uos oratores] expedivit et destinarit quo istic esse possent cum Crosare prinsquam domina dncissa et dictus A. discedant et proficiscantur versus hanc conven[tionem] sive dietam cum legato Francia habendam, nommlla Casarix [majestati] significaturi que sibi grata et accepta erunt et qua prædictæ con[rentioni] utilia esse possunt.

The rule of Significabit praterea dietns capellanus eidem A. quo[modo] res Ferdinand et negotia regni Castella consistunt, dicetque quod jamdud[um] is conrecepit regia majestas literas recentissimas in zifris scriptas sidered a per $q\left[\right.$ nendam] servitorem sunm ${ }^{1}$ istuc moram trahentem, ex usurpation. quibus plane perpend[it quod] tam dux de Nagera et marchio de Plego qnametiam Gundisa[lyus] Fernandus magnus capitanens, nuacum omnibus aliis dom[inis et] nobilibus dicti regui agre ferunt hane nsurpationem regimin[is regis] Aragonum in dicto legno Castellw ac pessime contentantur cum [jurisdictione] sua in eodem, quxentes occasionem et modum quomodo ip [smm regem] a regno Castellie expellere jossint, qui plurima enor$m[$ ia et] exorbitantia istic facit in prejndicinm juris et titnli lri[ncipis], et pejora timendar sunt si non oecurratur hujusmodi c[onvenienti] tempore. Quod si predicti domini haberent aliquim spem sub[sidii et] relevaminis a Casare, sive per oratores snos in regnum [Castella] mittendos sen alirno alio nodo, non sinerent dictum rege[m Aragonum] dintius regere in ipso regno. Nam nt publice ibidem asseritur, [conatur] exhereditare principem Castella et preficere fratrem . . . . . Fernandum in regem, (pood dicti domini mullo pacto pati . . . . . quam ob alia exorbitantia et justitice atcue rationi dissona a $[$. . . . . . ] vellent enm expellere a regno si alifpum spem sulsidii [haberent. Expedit] ergo ut Ciesarea majestas suos oratores in dictum regnum [mittat ad] confirmandum et animandum eosdem dominos in hoc propo[sito contra] regem Aragonum pro conservatione juris et tituli pradicti princip[is... ] timendum est ne deteriora succedant et sequantur. proind $[\mathrm{e}]$. . . occurrendum et subveniendum est hoc magno malo.

\section{H. $[\text { R. }]^{2}$}

${ }^{1}$ Donbtless John Stile.

2 Only the beginning of the $I I$ of the king's signature is visible. 


\section{II.-Articles to be communicated to A, on the patit of HENRY VII.}

[Draft in Wolsey's hand.-MIS. Galba B. II. 127.]

Quod mediis et dex[terita]te vestra he duw affinitates inter Cresaream [majestatem] et celsitudinem regiam cum omnibus et singulis conditionibus et dependentiis [super] eisclem, ad honorem, contentationem et complacentiam snæ celsitudinis p[erficientur], et quod in hac dieta inter ducissam Sabaudia et legatum. Flandrix nihil f[iat ant] concludatur cinod in dispendium regii honoris ant in dammum sive [prajudicium] dietarum d[uar'um] affinitatum quovismodo cedere possit.

Deelaret vestra dominatio specifice intentionem et consilium summ quid . . . . . ad domini Bergensis animi satisfiuctionem regia majestas res[poncleat].

Qno tendantilla verba, "Venient oratores Casaris principaliter" "ad [exsequendum ea] quæ erant conchusa Calisiis quo ad " solemnitatem matrimonii eum moderamine domini Andrea " [de Burgo]"?

Quæ sunt illa in tractatu matrimoniali quæ majestas [Casarea vult] mitigari, et in quibus judicat regem tam duriter et m[odo mercatorio] potius quam regio incedere?

[Utrum] mens et intentio Casaris sit quod expresse per articulum [in traetatu matrimo]niali eaveatur nt domina dueissi perfecto matrimonio [possit, vivente rege, ad] votum summ, quandocunque ei libnerit, reverti ad partes [Flandriæ]?

[Quid int]elligat Casar per illa verba "non revertetur ad "p[artes illas]?"

[Ro]gat regia majestas quatenus dignemini mittere co[pias instructionum orat] ormm Casaris et etiam eopias instrnetionum domine [ducissa Sabaudia super] hac eonventione cum legato Francic, ete.

[C]upit rex certior fieri de omnibus que tractabuntur, vel in hae [eonventione inter dominam et lega]tum Franeiæ, vel alibi suam eelsitudinem [ant honorem summ tangentibus, nume et post]hac de tempore in tempus.

*[Utrum a]liq[u]a nova [istie contigerint ex quo Cesar hine [*f. 12: diseessit], vel si aliquid a domino A[ndrea] de Burgo audierit ex Hispania?

Utrum quiequam actum vel dictum fuerit circa mutnum Cassaris et Regis conventum?

Utrum aliquid Casaria majestatis oratoribus superinde committetur?

Et majestas regia vestram reverendam dominationem rog[atam] habet ut mentem, consilinm et intentionem suam su[per'] 
promissis omnibus et singulis quantocius commode poterit aperi[et] et declaret; in quo rem supra cuam dici potest gratam [suæ] majestati freiet.

Ea que sunt dicenter domines ex parte Reg[is].

[De adve]ntu oratorum suorum et quod jam sunt in itinere versns Casa[rem, quos eo citius] mittit, gnod istic esse possint cum Cresare prinsquam donina d[ncissa et $A$. discedant versus hanc] conventionem, et quod sint nommlla Cosari significat[uri cure precticta conventioni] ntilia esse possint.

$\left[\begin{array}{lll}\text { In } & \text { qno } & \text { s}\end{array}\right]$ tatu res et negrotia regni Castella consistmit, et quod d[omini istins regni agre fermut usurpationem] regiminis regis Aragomm in dieto regno, ac p[essime contentantur cum jurisdicti]one sua in dieto regno, querentes modnm quo. . . . . . . . . modo idem rex exhareditare conatur prineipem C[astelle . . . . . . . . . ]; quw omnia domini ipsins regni multum agre fer[unt . . . . . . . . ] et rationi et justitic dissoni rellent . . . . . . - . . subsidii haberent. Expedit ergo ut [Casarea majestas mittat] snos oratores in dietum regnum ad animandum [eosdem dominos in] hoc proposito contra pradictum regem ne deter[iora snccedant].

[*f. 128. *Et quod dominatio [restra] . . . . tate dicat do[mina dneisse] quod sua majestas ob praclaras et egregias virtutes quilus ipsam dominam a[bmic] refertam andivit, obque illas maximas gratitudines, si[gnaque] et officia amoris sure majestati ampliter et contimne ostensa, ita affiei [eiclem] domine ut ad contrahendum cum ea matrimoninm prae cateris aliis prineipibus . . . disponatur, adeo nt melins disponi non possit; omuiaqne sua majestas [pro parte] ejus facict qua honorifica et rationabilia videbuntur et quæ commod[e facere] poterint, nee per enm stabit quominns illnd matrimonium debitum sort[ietnr effectum].

\section{III.-Answer to the Precedixg.}

[Draft in Wolsey's hand.-MIS. Galba B. Ir. 199.]

A. pro.

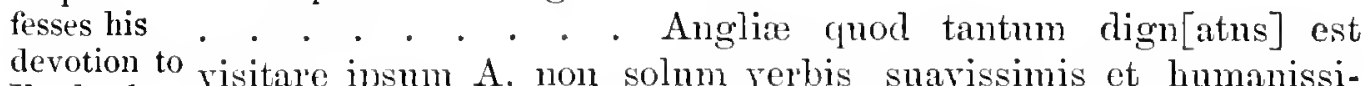

Is primis A. ag. . . . . . . . . . . . . . . . England, mis, sed etiam rebus amplissimis, et crnod sincere et aperte [de] omnibus secum dignatur lorni, et de eo tanqnam suo fidcli servitori $s$. . . et confidere, pro quiluns idem $A$. promittit se fideliter et diligenter i[nservire] sure majestati, 
et sataget pro posse suo quod omnia sna negotia hic [perficiantur] ad honorem, exaltationem, et complacentiam suam, et quod post Crasarem et dominam et . . . . . cum quibus a teneris fuit educatus, sibi inserviet ante omnes [principes] mundi; et istud firmiter credat et speret rex Angliæ, et quod iste A. . . . . .non inservient A. pro promotionibus ecclesiasticis aut spe alicujus muneris, sed plus pro amore quem habet [erga] ipsum et quod in eo confidat et quanto magis amaverit . . . . . melius si fieri poterit illi inservire studebit prædictis . . . .

Et quantum ad istas dnas affinitates inter regem [Angliae et and lis deCresaream] majestatem, mediantibus his duobus contractibus sire to promatrimoni[alibus inter regem] Anglia et ducissam Sabandia, mote the principem Castelle et [dominam Mariam . . . . ]s ances. pradict., dicit A. istud esse fundamentum totins. . . . . . . . semper intelligens quam conjuncta sunt iste dno patr[ia . . . . . . . i]sta patria et quam ntilis sit una alteri, semper [. . . . . . . uti]litate istarum patriarum, studuit modum et viam quomodo ista [dnæ patria esscnt conjun]cta per muam strictam amicitiam et confoederationem [inter Casarean majesta]tem et regem Anglie ad predictam confoed[erationem . . . . . . ]s dedit operam suam et post hac prast[abit] . . . . suo nec constabit cum omni effectn [ . . . . . . d] na affinitates inter Casarem et regem Ang[lia cum singulis conditionibus et depe]ndentiis super eisdem ad honorem, contenta[tionem, et complacentiam regis] Angliæ perficiantur et optatam finem dedu[cantur].

* [Et dicit A. quod nihil fiat in hac dieta qnod in damnmm sive [*f. $129 \mathrm{~b}$. præjudicium] regis Anglia ve[l] dictarum duarnm affinitatum quovismodo c[edere possit, sed] sciet majestas regis Anglia quod re et non verbis sibi fidelissime inservict, et istnd fideliter pro [se] promittit quantum in eo erit.

Et quantum ad consilium ipsius A. super istis verbis, "Faciet "rex ad cont[entationem] domini Bergensis," consilinm ipsins A. super hac re est quod rex Anglia faciet bonum . . . . pro matrimonio domina cum domino Bergensi et gubernatore, quoniam non decet quod ips . . . iant hujnsmodi communicandi, et ideo non habebunt anctoritatcm incipiendi, sed [postquam] inceperit rex Angliæ tunc habebunt anctoritatem 1[oqnendi et - . Isionandi cum dicto rege super eodem matrimonio et super articnl[is ejusdem].

[. . . a a riculo dotis ubi est provisum quod rex haberet $^{1} \operatorname{tr}[$. . flore $]$ norum et quod centum millia solvantur

${ }^{1}$ An Arabic numeral 3 is here struck ont. 
quando erit d . . . cunod animus Cresaris erit quod mi-

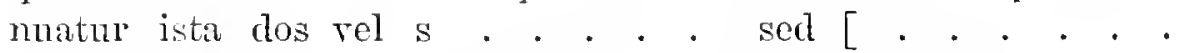
Bu]rgundian ex dono Cesaris cujus anmuus [valor est] . . - florenorum vel plus: ideo dominus Bergensis et G[ubernator volunt disp] utare cum rege super en re et querere ac int . . . . . . . . estri super ea rec quid et quantum velit babere . . . facient Cresarem ecrtiorem, in qua re et s . . imperator faciet quod videbitur consonum ratio[ni]. [*f. 130. *Sunt dno alii artienli qui videntur Cresari valde duri; Objections primus, vide[licet,] rnod mortuo rege Anglia domina relinof the En- queret dotem et medietate[m] jocalium, et sic mortuo rege peror. rediret ad patrias istas quasi ancilla regis . . . et per enm esset depanperata. Non ita fuit actum cum illa, neg[ue de] Hispania neque Sabandia, sed, mortuis principe Hispaniæe et d[ucissa] Sabandia, rediit ${ }^{1}$ ad patrias istas eum dote et jocalibus . . . contra dote; et si vivente rege Anglize illa obiret diem summum quod . . . . nihil disponeret de jocalibus et bonis suis q . . alibi perquisivit cederet in dammum domus Burgundie . . . . ista videntur mims dura et non . - . Cesaris quod nihil horum fiet neque quod hæe totaliter abolentur sed ratione mitigant[ur], quia jam erit desponsata . . . . . et potenti principi. Igitur in omnibus istis erit tractatus. . . . gubernatorem et majestatem regis Anglia ad rect. . . . . . [ar]ticulos secundum rationem et honestatem pro utroque . . . .

[Artien]lus tractatus qui videtur durus ruod. . . . [rex A]ngliae, domina, Cassar, et tota ista patria oblig.... . [omne]s et singulas conventiones in predicto tractatn . . . . . . censuris ceclesiasticis iste modus non videtur . . - . . s sed minus servilis, sed domina et imperator . . . . rex Anglia haberet per perimpletionem omnium . . . . . . mo omnem seeuritatem rationabilem et hon . . . . . . et rex Angliae cum domino B[ergensi] . . . . . rationabili et honesto q . . ipsi facient. . . . . i et super easclem imperator scribet eis . . . . . . . tis oratoribus regis Angliae dabit eis a[uctoritatem ad conc]ludendum super ommibus et singulis præmissis.

$\left[{ }^{*}\right.$ f. 130 b.

*. . . . . . . . . . . . . . . . sua majestas . . toto isto tractatr ma[jestas . . . . . . . . . ] A. interponet part[es] suas pro toto suo posse cuod id fiet ad beneplacitum summ.

Quantum ad articnlum illum quod domina non revertatur ad patrias istas, et cuod astringatur quod nullomodo vivente rege possit reverti ad patrias is [tas], est nimis" durum, et pro altera

rediis, MS.

1 :minus, MS. 
parte quod poterit libere reverti quando volner[it], est inhonestum; sed mens Casaris est quod singulis annis aliqua parte - . . ri beneplacito regis Anglia una cum rege si velit vel si[ne eo domin]a poterit descendere ad visitandum et attendendum gubernationem prædictarum pa[triarum. Nam] Casar est totaliter resolutus committere regimen istarum patri[arum prædictæ] domine et nulli de hac patria, et videtmr A. quod iste . . placebit regi Anglia.

[Inten]tio istorum verborum "Venient Oratores ad exequen"dum e[a . . . . Ca]lisiis enm moderamine domini An"dreæ de Burgo". . . . . . . . quendum ea qua erant conclusa Calisiis sol . . . . . . bi conclusum cum moderamine domini Andrea de B[urgo . . . . . ]lia ratione mutui impignorandi jocalia sicut . . . . . . . . . de Burgo.

[Quantum] ad copias instructionum cogitarit A. quid facere . . . . videtur sibi quod cum honore suo non potest mittere h. . . . quod si mitteret quamris rex Anglia ill . . . . . geret illum et pro centum mille ducatis . . . . . . . . . . rex Anglie quod non est aliquid . . . . . . [ruam quod] predictum est et quantum ad . . . . . . . non est aliquid in illis instructionibus quod.. - . . . . ere possit regi Anglie vel cedere n . . . . nec fict dummodo A. ${ }^{1}$ impedire pote

$*$ Et

vel alibi sua

tempus ego promitto

Et quantum ad dominum Andream de Burgo, nihil alind audivi ab [eo quam] quod rex Aragonum est totus malus et non vult permittere enm intrare [regnum] Castella, et sic credit ipse quod redibit.

Et quantum ad adventum oratorum regis vestri, domina multum . . . de adventu eorum, et quod velit ad $\mathrm{x}$. dies diffe[r're] profectionem ejus ad dietan expectando eor'um adventum . . desiderat andire ea qua sunt dicturi ex parte regis v[estri].

$[\mathrm{E}] \mathrm{t}$ quantum ad regem Aragonum et negotia regni [sui. - . re] Aragonum non comprehendatur in ista intelligen$\mathrm{t}[\mathrm{ia} . . . \quad \mathrm{pl}] \mathrm{acent}$ ea qua dicuntur per regem et etiam orato[res] . . . . videtur multum bene quod oratores regis restri. . . te regis vestri in ea re sic quod illi et no[bis] . . . . . ure unde bonmm. . .

[Et o]blata bona opportunitate, ego domina dicam singula illa - . $t$ me dicere pro parte sna domine sicnt semper dixi.

'A.] first writen eyo, then corrected. 
[Et q] uantum ad regimen istarum patriarum si videbitur . . - . . ego potero cis aliquid inservire in ea re et a. . . . . . . ero ad aliquod tempus contentus hie St. . . . . . . . ter aut quater, quod post decessum s . . . . . . . . re, quia uullus est preter me eni committ . . . . . am sub quodammodo officia dueatus . . . . . [qui]a non potest din et pro semper abesse.

- tria habeat sub eis regimen ne fort . . . . $\left\lceil{ }^{*}\right.$ f. 131 b.

. . . [G]allorum ad quas modo snnt multum inel[inati].

. . . . . . [dominus B]ergensis convalu[it] quia est pomposu[s] . . . . . . . . facere apud regem et ridit quod non sunt plura predict . . . commissa, ideo redit jam se difficile et cupit expeetare adventum Casa[ris] quatenus possit habere majores commissiones, sed seiat pro vero [quod nullas] habebit alias commissiones; et ideo seripsi Casari quod imperaret il . . pergat de incontinenti et absque mora, et si moram fecerit inveniemus aiium modum quo fiet nolens rolens etsi ille imperator . . fiet; et igitur firmiter creclat rex Anglia guod de incontinenti ven[iet].

[Si aliq]uid actum vel dictum sit circa mutumm regum conventum et utrum .... eodem, oratoribus suis eomittatur.

[*f. 132. *Quantum ad . . . . . . . . . . . . . . . . . . . . duæ patria et quod . . . . . alteri . . [pro ho]nore Casaris et utili[tate] . . . . studuit modum et riam quo ista dua patrix essent similiter eonjuncta per unam [strictam] anieitiam et confoderationem et quinetiam ipse $A$. vidit Casarem et re[gem] meum optime etiam ad illam dispositos hactenus studuit et dede . . . et posthae præstabit et faciet pro toto posse suo quod ha dua affinitates in[ter] Cæsarem et regem Ang[liæ] ad honorem, eontentationem, et complacentiam regis Anglia perficiant[ur et ad] optatum finem declneantur cum singnlis eonditionibus et dependent[iis super] cisdem. Et promittit idem A. quod nihil fiet in hae dieta quod in da[mnum sen] prejudicinm regis vel dictarum duarum affinitatum quovismodo [cedere possit,] sed seiet majestas regis Anglia quod re et non rerbis sibi [fidelissime] serviet; et hoe fideliter promittit quantum in eo erit.

Consilium A. quantum ad seeundum artienlum est quod rex Anglie [faciet . . . . .] super matrimonio domine enm domino Bergensi et gubernatore . . . . . . . anctoritatem incipiendi, sed postquam rex inceperit [habebunt auctori-

'One entire line lost. 
tatem lo]quendi et ratiocinandi cum dicto rege super codem ma[ritagio].

- . . dote quæ extendit ad tria millia florenorum non cred[it A. . . ] quod minnatur dos sed quia domina habebit . . . . . nos, ideo dominus Bergensis debet disputare . . . . . . gere animum l'egis quid et quantum amplius vel. . . . . . certiorem. In qua re et singulis aliis . . . [responsum] detur consonum rationi. ${ }^{1}$

*. . . . . . . . . . . . . . . . . . ietate [*f. $132 \mathrm{~b}$

. . . . . . [in Hispani]a neque in Sabau[dia]. . quod vivente rege . . . . eret de . . omnibus istis erit tract . . . Bergensem et gubernatorem ad rectifieandum istos articulos ad rationum et $\mathrm{h}[$ onorem] pro utraque parte.

Quod omnes tractatus istius matrimonii serventur sub ponis et censuris ecelesiasticis videtur tollere libertatem et quodanmodo facere dominam servam et quod iste . . . . videtur regius, sed domina et imperator erunt contenti quod habeat omnem securitate $[\mathrm{m}]$ rationabilem et honestam ; in quibus omnibus disputet cum domino Berge[nsi et] gubcrnatore super rationabili et honesto quin ipsi facient creditum [ . . . . Cæ] $]$ sari et super cadem imperator seribet eis animum sum et forte - . . bus vestris dabit eis anctoritatem ad tractandum et concludend $[\mathrm{um}$. . . . . . $]$ majestas sua A. quid velit rationabiliter fieri et ipse. . . . . nas pro posse.

[Quod domina a]stringatur quod nullo modo possit reverti vivente rege $[$. . . . . . a]liqua parte anni cum beneplacito regis ma cum rege. . . . sola ad visitandum et attendendum ${ }^{2}$ gubernatorem.

*. . . . . . . . . . . . . . quod . . . . . . . plementum . . . . . . . . . . . . comitatu Burg[undir] ad terminum vite sure cujus anmuus valor extendit, ut Casar predicto A. sign[ifieavit], circa $\mathrm{xx}$. mille florenos . . . communiter voeatos lienyche gylders ad er- . . . quod eum centum mille coronis quas dictum sperat A. pradieta domina habe . . . . supra Burgundiam et eum ipso amuo valore pradicte Burgundia rex . . . . habere in effectu et aquivalentia pradietam integram dotem trecen[tarum] millium coronarum, et eredit A. si Casar et rex Anglix in aliis poterunt cont[entari] in articulo dotis non erit magnia difficultas. Sed Cesarea majestas [est cont]enta quod

Underneath in the margin at mere memoranda. Among these the bottom of $f$. 132, some words are scrawled by Wolsey, apparently as $\because$ attendendum] attentendum, MS. 
pradietus rex Anglia labeat pro tirma et secura solu[tione] - . . dietre dotis omnem seemitatem rationabilem et bonestam, verum . . . . . . non est dum plene resolutus ruo modo et sub qua forma et sp . . . . . . habebit prædictum eomitatum, sed hoc fiet per disputationes cum o[ratoribus regis] Anglia quia oratores Cresaris, puta Bergensem et Gubern[atorem . . . . . . ] habebunt anetoritatem tractandi et ratioeinand [i, tam super] dotem [quam super] alios articulos duros, sicut speravit et credidit A., sed totam hoe lie $[\mathrm{t}$. . . . . ]estres.

\section{De Oratoribus Coesaris.}

. . . dieit A. quod oratores Casaris qui venient ad regem . . . . . de articulis, videlicet, dotis et aliis, nec $\mathrm{h}[$ abebut auctoritat $]$ em pro matrimonio dominæ nisi solus gubernator ad e[ . . . . . . r]egis, et quem animum et affectionem rex gerit erga prad[ict . . . . . . .] faciet reditum domina. . . . . et tantum ad solemnizandum matrimonium con . . . . . . . pecuniarum eo modo sicut prædictum est.

\section{IV.-WOLSEY to HeNRY VII.}

[From a corrected draft in Wolsey's own hand.-MS. Cott. Galba B. 11. f. 138.]

Aftrli most humble eomendacions. Pleasyt your nobyll srace to undyrstand [that the] iiij $^{\text {th }}$ day of thys present moneth in the towne of Meclyne, I kam to the presen[ce of] A., wher aftyr your rygth herty comendacions and overture of myn inst[ruccions] at the leynth, wych the seyd $A$. was nat only dlissyrous to know but [also] gave to them rygth good andyens and attent he-

The lorde Bergen corettyng to appere to yowr grace that he war in gre[at ancto]ryte and credens with the Emperor, and the lady, hath ${ }^{1}$ selaeky[d his] komyng ${ }^{2}$ and desyryng to have a large commission, . . . as wel to komyn as to conclude the ladis maryage wyeh in [no] wyse sche wold he sehuld have.

[The] lord Bergensis [is] nat contentyd that ys hys commissyon.

$1 /$ ath repeated in MS.

2komyng repeated in MS. 
. . . he by the slacknes and ontowardes of the lord Ber[gensis . . . . con]tentyd with hys comissyon, bn dissyryng to have $\mathrm{yt}$. . $^{\circ}$. . . . . . . anctoryte to . . . . ferther then ys seyd in the liady . . . . . - . sche in no wyso contentyd he ${ }^{1}-$

[The lord] Bergensis somewhat purpose dissyryng to be sen . . . . . that he war of gret anctoryte with the emp[eror] . . . . . . hys comyng forward dyssyryng. . . . . afore hys departing, trustyng that yf he so dyd he shuld have. . . . . to intreate and conclnde of the ladys maryage, wyche . . . . . . ld he shnld hare, and so . . . . . . at mydnygt he reparyd to the emperor . . . . . . . . haryng knowleg preventyd seme dyss . . . . . . vyse as yet he geve hym ferther commission . . . . . . . yn that owt any ferther delay he $d . . .+. .3$. so that $\Lambda$. dowth nat that within vj. day . . . . . . forth komyng for both the lady and . . . . . . . . eontent with for hys long delay.

\section{V.-Wolsey to Henry VII.}

[From a colrected draft in Wolsey's own hand.-IIS. Galba B. IJ. f. 139.]

Pleasyt your nobyl [grace to understand that since the writing of $\mathrm{m}$ ] y laste letters scnt [nnto your grace] datyd the $\mathrm{x}^{\text {th }}$ day of [this month I have 1] ernyd $n[0$ th] yng of importanee to be [written] to your graee, but only that $\mathrm{A}$. the $\mathrm{x}^{\text {th }}$ day of the seyd moneth, havyng word [that the] ambassadors wer kom to Andwerp, departyd from Meelyn to the emperor . . - in Holand in distans from thens xviij. Duche mylys, wyllyng me to m[ake my] abood style at Mechlyn, promysyng within rj. days at the most . . . Howbeyt as yet we have no sner knowleg of hys komyng thethe[r] nor [yet of] the emperors. Ther ys liere so myche ineonstance, mutabilte, and lytyl re[gard of] promysys and canses, that in ther appoyments ther ys lytyl [trust] or suerte; for thyngs snerly determyd to be downe on d[ay are] changyd and alteryd the next, and as fast as on set forward another, ${ }^{2}$ wher with, as I undyrstand, the lady ys nat a lytyl dys[pleasyd] and abashyd, feryng that every thyng thyng shal folow and insue

\footnotetext{
${ }^{1}$ Sic, apparently an unfinished | 2 another] Sic, the clause is intersentence lined and left incomplete.
} 
ac[cording to] suche wryityng as she have sent to yow, the forseyd $x j^{\text {th }}$ day . . . . . . [d]epartyng sheuyd how that the day before the lady had $v$ [ery loving l]etters from your grace wryttyn with yowr awne hands, wych w[ere . . - p]lesant and joyfull, but also she mervelyd to se how wys. . . . . . . . . encyously they wer conceyvyd, and the wordes of . . . . . . . . . ther, affermyng that by them ye apperyd how gret an . . . . . . . . . . . . . grace had nat content with onys or twys redyng of them . . . . . . . . . . . . de them, and the oftymer she so dyd the more she d . . . . . . . . . be hold the said A. was very glade nat. . . . . . . . . yrly fyxyd hyr hert and mynd on yow and every th . . . . . . . . . . . grace wold resanably dyssyre. And in cas ye wold folow . . . . . . . -. . he shuld shen to yow mervelos conclusyons $t$. . . . . . . . . . . lower contreys.

[The $x$ ] ij. day of the seyd moneth the lord Bergens ka[me] . . . . . . . . . . . . at whos kommyng yt was suerly appoyntyd that. . . . . . . . . re set for'ward. Howbeyt that appoyntment ys chang[ed . . . . . . . . . instr. $]$ nccions and ratyfycacion ys in doctor Fluc hand . . . . . . . . . . . . . . . . yse to the hands of the lord Bergens with . . . . . . . . [1]eter from the emperor for hys dyscharge and th . . . .

. . . . them wol in no wyse set forward, seying that . . . . . . . $[\mathrm{com}]$ mysyon. $^{1}$

. . . . . . . . . . . . . wardes on to suche tyme . instru[ccions and ratifica]cion be in hys hand. . . . . . ythe doctor Flucke wyl nat delyv . . . to hym without specyall [warrant a] nd dyschard from the emperor, so that ther ys stryf betwen them tweyn w[hether o]f them shulde bryng the seyd wryttyng. The other cause ys the emperor [hath ha]d of the marchant Fokers l. thousand crownys, leyng to them in pleg for [the p]ayment ther of certayne juelles, wyche the seyd merchant Fokers be content to d[eliver at] Kales, ther to be leyd in gange for suche money as the emperor [shall bor]row of your grace, so that they may [he repa]yd of the sume wych the... . . Iy promysyd to do. And for the assuryd performans ther of the seyd . . . standyth bownd to the seyd mer-

1 The lattel part of this paragraph is scored through with the pen. 
chant Fokers. Wher for on to su[ch time as the] emperor send to hym a letter to save hym harmeles . . . . . . [ind]empnyte he wol nat set forwards. Thys letter ys every da[y expected, but a]s yet yt komyth nat; yt shalnat, they sey.. . . . . after they wyl set forwardes myche of the fawte why . . . . . be so long taryd ys imputyd to the by . . . . . . . in trowth all ther prevy dryftes be to be sen to do . . . . . . and to get thanekes of your grace wych your grace [shall better unde]rstand at ther fom$y^{\prime} g^{\prime}$ than I can wryt, perceyv[ing that there is none] here that regardyth or hedyth ther masters ho[nor, but only their own particu]ler profygt and avantage.

. . . . iij. of the seyd moneth master Wyngfyl and I dynyd with . . . parte of the seyd dyner talkyd of your graee preysy[ng . . . . . ]ng these words: Rex Anglice vester et mens non . . . . . . [Ce]sar neque potest tan sero et mane comedere sicut Ca[sar] . . . . . . . subtilem et clarum et qucedam . . . . . . . emperor and this contrey seye non . . . . . ra nisi ista poma et dominum.

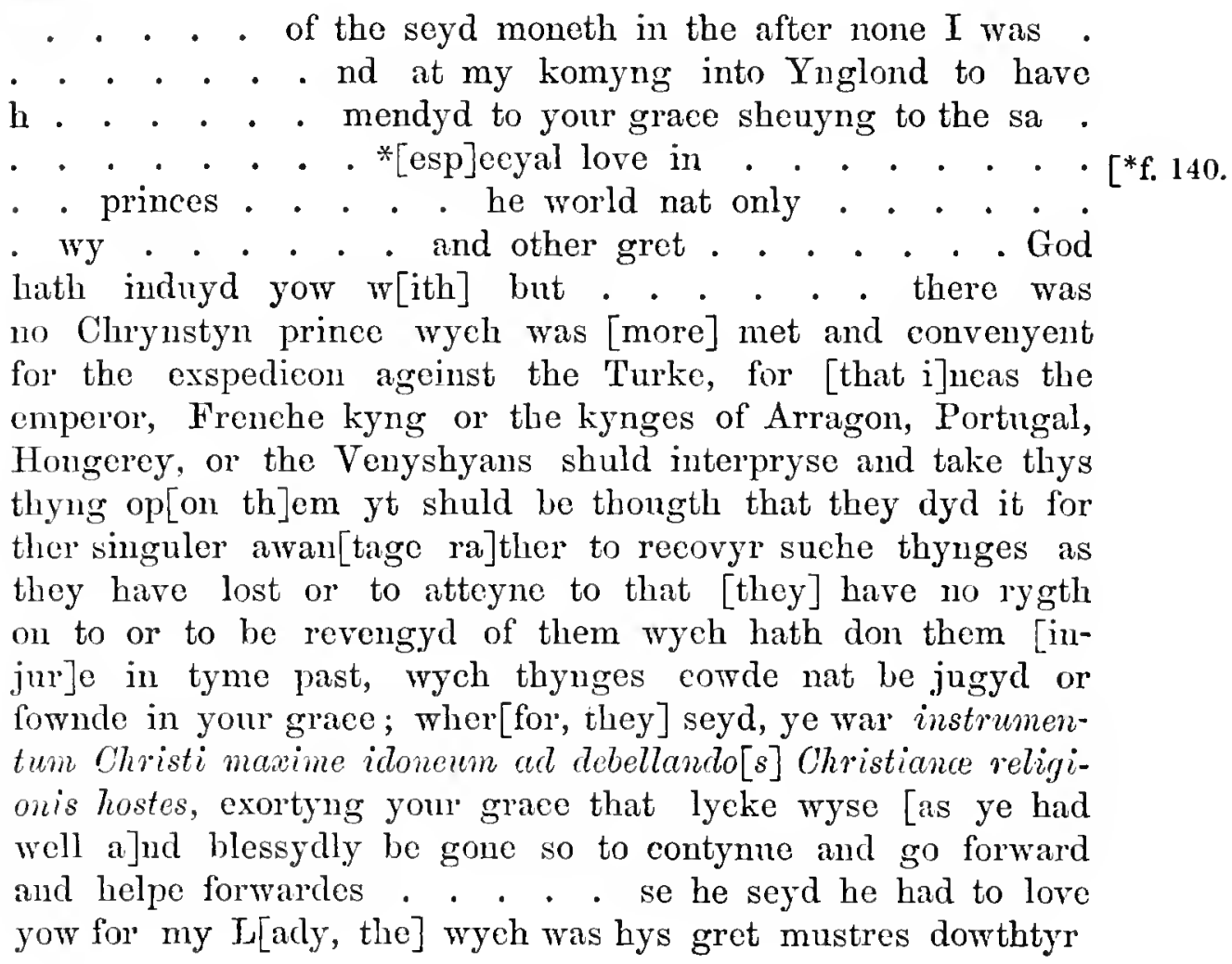

${ }^{3}$ The words in italics here are scored through with the pen. 
and also hys . . . . . . . d most specyaly for the yong prince of Castell, wych ys b . . . . . . re and lord, so that thes forseyd thynges movyd hym [to love you more than] other princes. Wherfor from tyme to tyme he wold put . . . . . aid and assystans to the furtherans of al su[ch matters and] causes as your grace had to be donne in the cour[t] . . . . hys lyf to declare and specke your vertuys your nam[e . . . . . . . ot $]$ her good wordes of semblale eff [ect].

Tonchyng your ambassadors [to] wards the court of Rome, the xxv. day of thys mo[neth $\left.{ }^{1}\right]$ they ly as yet . . . . - . yng wher or when they shal repare to the $\mathrm{E}[\mathrm{mper}$. - . t]hys moneth the lady sent to them the kapteyn. . - . [willing th]em to make ther abode styl at Andwerp [till such time as s]he shal asserteyne them of the emperors

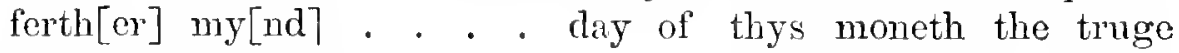
begenyth bet[wene . . . . . F]renche kyng. Other neuys [have I none.]

And thus Jesu prescre your grace your $\mathrm{m}$. . . . . Wryttyn at Mechlyne, the xxiij. day of $\mathrm{O}$ [ctober by] yowr humble servant.

$[*$ f. 140 .

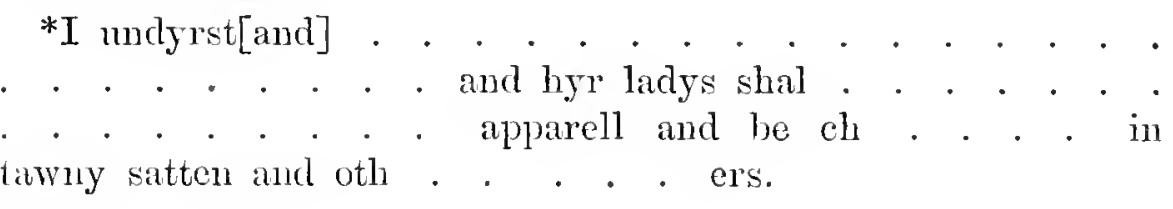

\section{VI.-Wolsey to Henry VII.}

[NIS. Galba D. 1I. f. 141.]

Pleasyt yowr grace . . . . . Octolyr . . . e towne of Anclwerp at $\mathrm{v}$ [of] the clocke at nygth, I [resay]vycl your most honorabyl letteres datyd at Gre[enwich], the xxij. day of the seyd moneth, with certayne instruccions in Lattyn to [have] disclosyd on to $A$., by the contyune whereof I perceyve that your hygnes a[nd your] most honorabyl consell juggyth on artycle wych I wrot to yowr grace [in the] Ynglyche tonge consernyng the dote shuld implie contradiccion, mervelyng $\mathbf{t}$ [hat there] was mad no mensyon in the artycle in

\footnotetext{
${ }^{3}$ towards-moneth] These words are an interline ation.
} 
Latyn of suche words as war . . . . in Ynglyshe tong, neyther of rebuttyng any part of the seyd dote and appese wych shuld be betwyx your grace and the lordes Bergensis and Governer, nor yet that the assignacion . . . . comte of Burgon to the lady shuld be for terme of hyr lyf as. - . nat presumyng to defend the contrary parte of yowr hy juggement, but to decl[are my poor] mynde and what I perceyve in that behalf, wyeh I beseche yowr [grace] hmmble to accept in god parte. Wher I seyd that the emperors m . . . . he dote of thre hunderyth thousan . . shonld nat be mynishyd or browt to any lower sume, I undyr . . - . have the seyd integyr dote in effect and equyvalen . . . . . . . e Lady shuld have the county of Burgone $\mathrm{t}$ [he ammual value wh]er of extendyth to $\mathrm{xx}^{\mathrm{ti}}$ thonsand florens and above to. . . . . . tayne other sums such as shuld be appeysyd and thowth r. . . . . e and the lordes Bergensis and Governer . . . . . . he words as yt ys implyd in . . . . . . mum leabelit Burgundian ex dono Casaris, eujus an[nuns valor extendit all] wex millica florenorum vel plus. Idleo dominus Bergensis . . . . . . - . $t$ disputare cum rege super ea re et querere ac intelligere - . . . . [qu]antum velit habere supra illan summam . . . etc. . . . . d bes sume what that obs.. . . . of the seyd A. overtures be for a snerte al . - . . gth, nor as yet he, as I thynk, hath not groundly oversen . . . . ymony concludyd betwyx kyng Phylyp an . . . . esolnte mynde of the emperor's in the seyd . . . . . rest opon, for 1 suppose the emperor as yet k. . . . . apon he wyl rest.

*Wherfor in the se... . . . . . . . . . . [*f. $141 \mathrm{~b}$. entent that suche articles as I have sent to your hygnes . . . . shuld nat be thougth . . words, but the playne overture of A., I have sent to your grace with thes my letteres a boke of the seyd articlys by hys awne hand correctyd, with hys interliniacion in such places as he thowthe be of importance; prayng fowr [grace] that the same may be sent to me ageyne, for he hath oftyn tymys askyd the delyvery therof, howbeyt I have by as good [means] as I kan nse pot of the deleverans of $y t$ and shal do [ if it] may be withont hys displesure or myscontentacion. Wher also I seyd the lady shnld have the seyd counte of Burgon dur[ing. her] lyf, makyng no mencion ther of in the artycle of Lattyn, veryl[y the $]$ seyd $A$. so seyd to me and the duches. And why that was nat commyttyd to . . . yng as the residue yowr grace shal know at my commyng to the $s$ [ame]. 
In that hys seyng I have musyd low yt mygth b . . . e - duches shuld have the seyd conte duryng hyr lyf, seyng that $y[t$ is part of $]$ the yong princes ${ }^{1}$ inherytans. Wherfor I shal by a[ll mamner $m]$ eanys and wys that I kan use, accordyng [to your graces] commande to know for how long she shal have the . . . . . . . the very value ther of of hys and what and nat. . . . . other thynges, to the intent at my komyng I may . . . . . . declare to yowr grace as fere as shalbe lem . . . every poynt.

. . . . . . day of the forseyd mone at $\mathrm{rj}$. of the cloke in the . . . . . . d leysor shenyd to him my instruccions with suche oth[er things]. . . the same thyngs as your grace wold I shuld $d$. . . . . cansyd hym as of my owne hed with owt comande . . . . . . instruccions. Wher with he was wel contentyd . . . . . . [su]bstancyally to be rememberyd in the seyd........ or his departyng to the dyet pleynly to ass . . . . . . all thynges. At that tyme he shou[yd to me that Andreas de] Burgo was arreyvyd latly agen in to $y$. . . . . yn letters he shuld be arryvyd un to yn . . . . . . ${ }^{2}$

. . . . seyd A. shenyd to me that the Lady shulk $\mathrm{h}$ [ive the county of Burgundy] wher of I have myche musyd, seyng that [it is part of the prince] of Castellys inherytans. The cause why yt was na[t . . . . . your grace

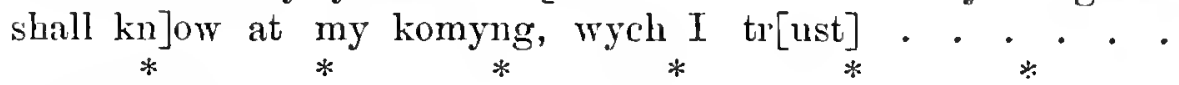

[*f. 142. *furryd with s . . . . . . . . . . . . . . . . havyng on hys hed [a] cap of scarlet. . . . . . . . . . . whyt heres.

The last day of [October] in the towne of Andwerp betwen $v$. and $\mathrm{vj}$. [of the] clocke at nygth yowr ambasador's accompanyd with the byshop of $\mathrm{A}$. the emper . mky and A. B. and C. kam to the emperors presens, wych ware resseyvyd undyr [form] folowyng. The emperor with the yong prince of Castell on hys rygth $\mathrm{h}$ [and] with man[y] . . . . . stod at the npper part of the chambyr. Unto hom your ambassadors enteryng . . . . the same made thrys . . conrenyent gemufleccions; and at ther komyng to hys presen[ce ${ }^{3}$ his majesty] toke my lord Treserer ${ }^{4}$ by

1 "Dukys" eorrected.

2 'These lines struek out.

${ }^{3}$ psen . . ., MS., the latter

part of the word burnt away.

4 'Thomas earl of Surrey. 
the hand, and lycke wyse the master of the [rolls ${ }^{1}$, nat avalyng hys bonet to them. Mastyr Wyngfyld for as myche as he [thought] hym nat on aqueyntyd with the emperor pressyd nat hymsylf to tak . . . . . by the hand; wych the emperor perceyvyn[g] . . . . to hym with lauthyng cowntenans seyng "I wyl tak . . . . . by the hand." Thys done, my lord of Surrey with the residue on their k[nees, after $]$ makyng yowr commendacions, delyvery [d your letter $]^{2}$ to the emperor, wych as sone as my lord namyd . . . . - hys bonet eftsonys my seyd lord tresorer on hys kneys $\operatorname{mad}[\mathrm{e}$ your commen]dacions and delyveryd your letters. . . . . . . ygt boldly and quycly or that my lord tresurer had endyd . . . . . . Frenche tonge how that your grace faryd. Wher at the .. . . . . . . hertly. Thys done the emperors sceretary red such letter[s] . . - . hyn and the yong prince of Castyl that he had herd . . . . . . and glad was he to here what they had . . . . - . the emperor set hym sylf dome undyr the clothe of . . . . [prin]ce of Castell on hys rygth syd and a lytyl lower on that syd ther . . . . . [Co]unt Palantyne the markes of Brandloorow and other . . . . . er sate the byshops of Turnocke and Gurcen with the . . . . . . ayenst the emperror. Your orator's wer . . . . - [the master of t]he Rolls began hys oracion wyeh was nttered and $p[$ ronounced very] wel and dystynctly with good spryt and bol[ness] . . . . . . . . to the contentacion of them that wer present, the sume wher of I wryt nat yowr graee for . . . . . . . . osse the same nat on knowyn . . . . . . . s mad by the byshop of Gureen wych thow . . . . . . . . best pronowncyd, nor the Latyn ther of most . . . . . . . was very good and furnyshyd with many a . . . frendly . . . . . . thys.

*The emperor and the yong prince of Castylle... . . [ ${ }^{*} \mathrm{f}_{0} 142 \mathrm{~b}$. ornat oracion, gretly . . . . . that yt had pleasyd the kyng of Ynglond hys . . . . . and the seyd princes father to send to them so gret and honorabyl men of suche gravyte . . . . hym wher in he sheuyd hys fraternall and fatherly love gret and . . . . . wher of the emperor and yong prince hath ben allweys desyros..

' Dr. Young. He was sent to the Emperor in July 1508. See Memorials of Henry VII. 125.
2 These words appear on a previous line, crossed out with the pen. 
. . . . suche gret effectes and comodytes as may aryse ther of to the gret honor . . . . . . acion and suerete of yow both and gret prosperyte of yowr reamy[s] and subgettes, and to redounde to the singulare name and fa. . . throwth a . . . . Wherfor the emperor nat only to geve consell on the yong prince of Castell. . . . . . that intent that suche amyte as had ben begon betwyx hym and your [grace shou]ld be knyt perpetuo quodam feedere et newu indissolubili hath des

- . kom doune to thys contreys. In seconde parte of hys answer he sheny[d . . . . . . . ]orys that allweys the hows of Borgon had ben allyd and . . . . [ky]nges of Ynglond wych hath proceyd of very good reason for [that those count]rys be so nere and ther condicions so lyeke . . . . . . . . . . . . the emperor had appoyntyd men of gret sadnes and honor . . . . . . . . good brother to fynyshe the nygt affynyte wyche . . . . . . . . . . And that ther shuld be no let but profygt indevo . . . . . . . [ [a]myte confederaacion and shuld suerly be made betw . . . . . . . . . . . . indure, ne nevyr to be brockyn to the gret he . . . . . . . . . both your chyldern, yshu and succecion, ream[is] . . . . . . . . . . . subjects for eryr maye. And thus . . . . . . . clon the emperor rosse up and yowr orators . . . . . . . . lynn secret comynycacion.

$\left[{ }^{*}\right.$ f. 143. * ${ }^{*}$ In the se . . . . . . . . . . . . . . . . . . . . . . . that the . . . . . . . . meyne . . . singuler w . . the how[se] of Burgone hath . . . . singuler . . . to be allyed with kynges of Ynglond a fore other princes, wych ys very agrealyyl to reason, seyng thes ij countreys so nygth and condicions of the inhabitantes in them so lycke; the wych thyn[g the] emperor substancyally consyderyng hathe begone and contractyd s[uch] a amyte with hys brother the kyng of Ynglond, [for the] acomplyshment wherof he hath appoyntyd men of gret honor to be sent in legacye [to his] seyd brother, and that ther shuld be in hym no stop [nor] let but perfygt indever that suche a anyte and confederacon s[hould be made] suerly betwyx them wyeh shal erer indure nevyr to be brokyn to the . . honor, weil, and suerte of them, [their] chyldern, ishu a[nd successors], and the prosperite of your suljects, reamys, londes and . . . . and to yowr inestymabyl renown, glory, and $\mathrm{s} . . .2$. . all the world evyr to indure. And thus he mad a ende; a[nd this] downe, the emperror ros up, kalling yowr orator's to hym. 
. . . . to them in Almayne tonge, afterward declaryd to them [by the bishop] of Gurce in Latyn hys excuse why they had $b[e e n]$. . . . . . hys presens praying them not to be myscontentyd ther . . . . . . . . . . h[e] demandyd whetther they had commyssyon [or licence] to be at the commynycation of peax with the . . . . . . [a]nswerd Nay. Than the emperor prayd them to wryt by p[ost to your grace for t]he seyd lycens, for he was very desyros that [they should be present a]t the seyd dyet and to have yowr ad[vice mpon] all suche thyngs as shuld be concludyd ther. [Wherenpon they au] swerd that they wold wryt to yowr grace sheu[ing]. . . . . the cmperors request and desyre, nat dowttyng . . . . . . . grante and assent to the same. Thys done . . . . . . . . . . . . . . of the byshop of Grucen causyd all yowr . . . . . . . let in to the chamber, takyng every on of the . . . . . . . . . wer talmen and by lyclyod good . . . . . . . . ittare vobiscum. Thys don the Emperor b . . . . . . . . . . . r orators departyd to their loggyn, accompanyd . . . . . . . . . . . ch browt them to hys presens.

*. . . . me day in the towne of Andwerp betw . . [*f. 144 . . . . . . . . clocke at nygth yowr ambasadors accompany . . . . . . . . nd the lord Chevers and Mons . . kam to the

*The fyrst day of . . . . . . moneth . . . of [*f. 145. the clocke in the mornyng shenyd to me that $y[$ onr $]$ grace had wryttyn to hym a mervelos god let . . . wher by he was gretly movyd and provokyd and . . . . to apply all hys wyt and power to se that all yowr c[auses] and matters shuld be browt to good effect yowr complacens a . . . . . . . purposse. I have also for my parte metly wel . . . . . . . . so that yf he performe hys seyng and promyse, by hys polytyce meany[s your] mynd shalbe in al thyngs fulfyllyd. Over thys he shen[yd] me that the emperor thowth yt kam of a singuler god mynde towardes [him] and hys that ye had sent to hym so honorabyl ambasyat [being] men of suche gravyte and personages whom he was gretly desyrous t[o be] present at the commynycacion of peax be twyxt hym and the s . . . . . to the yntent he mygth have yowr consell and thers [in] what maner of wyse he shuld conchnde with the seyd Frenche k[ing, whom] the emperor and A. in no wyse loryd but accomptyd . . . . . . . suttell, and fayne wold the emperror be to take suche weys as . . . . . the lessyng and mynishing of the seyd Frenche kyng . . . . . was so am- 
byshyous that he nat content . . . . . . desyryd to have all. To thys I answeryd seyng . . . . . . . [F]renche kyng lowe and that hys power shuld be $\mathrm{m}[\mathrm{in}$ ished] substancyally constantly and fr . . . . . . . - joyne hymsylf with the kyng my master . . . . . . - . . . nat to be dowyt the Frenche kynges power shal nat . . . . To thys A. answerryd that the emperor was . . . . . thus to fast. And suerly to adyoyn hym self . . . grace. Wherfor he advysyd the same to be cont[ent . . . . . . a $]$ mbassador's shuld acconpagne the b . . . . . . . . . et for the causes above rehersyd. And that . . . . . . . no tyme shuld be sclackyd or lost . . . . . ys contenttyd to geve hym anctoryte to komyn with yowr [grace touching] all the artyelys of the seyd matrimony . . . . . . ys as he wyl use yowr grace shal have your ples[ure].

[*f. 145 b. *And to jntent that $\mathrm{y}$. . $^{2}$. . . . . . . . . d thys auctoryte [for] yowr ambasadors thus to be present at [the said] dyet the emperor [hath] wryttyn to hys ambasador ther to move your grace in [that] behalf to assent to hys forseyd desyre and petycion. And the seyd . . . wold I shuld writ to yowr grace' with al sped in the same. Wherfor [for] lacke of tyme I beseche yowr grace of pardon yf I wryt nat so $\mathrm{p} \mathrm{.} \mathrm{.} \mathrm{.} \mathrm{.} \mathrm{in} \mathrm{every} \mathrm{thyng} \mathrm{as} \mathrm{I} \mathrm{shuld} \mathrm{do.}$ Thys day A. sheuyd to me that . . . ambasadors aftyr dynuer shuld be [with] the emperor agayn, and that they shuld be present with hym also [at] evyn songe. How he intreattyth them then I shal asserteyn yowr grace [in] my next letters.

[A]s for the komyng of the ambasadors towards your grace A. seyth [tha]t incontymently they shal kom withont ferther delay, and that thy . . . . . . . d hath nat ben by the emperor but by the lord Bergensis . . . . . of pompe and serymonys, desyrous to have gret . . . . . . . . . . . . have the ratyficacion with other wryttyng in hys handes... . . . . . . [t]he emperor ys very yl contentyd with hym, w . . . . . . . . . have in commyssyon. Or yf the emperor . . . . . . . . . . d yowr orators wyl change or alter any thy[ng] . . . . . ch was to fore commyttyd to them, the seyd A. . . . . . . . . . yowr grace by me ther.

1 Scored out. 
last nygt the emperor send by . . . . . to kom to Necklyne, ther to here and specke [with him]. And thus Jesu preserve your grace. From Andw[erp], the fyrst day of [Novem] ber by the ban] des of your humble servant.

\section{VII.-HeNRY VII. to WOLSEY.}

[MS. Galba I., 11. F, 146.]

H. R.

By the king:

Trusty and well-beloved, we grete you well, and have receyred [your] lettre dated at Mechlyno the xxij daye of Octol»re, by the con[tinue] wherof amonges other thinges we pereevve what commnnycarion $[\mathrm{A}$.$] hath had with you for onr mariage$ with the dnchesse of Sav[oy,] not doubting but every thing shuld comme to passe as we [wonld] reasonably desire; and showing furthermor that in ca[se we] wold sumwhat folowe his mynde and counsaill he [would shew] unto us mervelons conchisions tonching the rule and [governance] of these Lowe partics.

As unto that matier, forasmoche as those wordes [ ] o of great] substannee waight and importannee and tha[t knowledge] of his further entent therin is necessary . . . . [we] wol that ye eftsones entre communicacion . . . - And to thentent the said A. shuld elere[ly show and] deelare his full entent and mynde unto $y$ [on therein] wo have now directed to hym our lettres [desiring him to] yeve unto you ferme credence.

And therfor in theritring of this matier ye may [say that ye by] youre writing have made reapport unto us . . . . . . . concernyng the rule and gouvernance of th[ose comntries], and that we bee not oonly greately desirous to [understand] his mynde and opinion therin, but also sha[11 eonform] ourself to his advise and counsaill in th[e same. Ye may] further saye that a better acte or dede c[ould not be for] the honor, weale and suertie of the yong [prince of Castile, his] euntreys and the conservacion of his. . . . elles where, then to bring the governa[unce into our] handes during the minorite of the said $y[o m g$ prinee. And the] mariage oones concluded betwist ns [and the said duchess] of Savoye, and the rule and governaunce being committed to us and the said duchesse, we cowde bee contented to make onr abode in the said cuntreys by a good space and season every yere for the quiete and restfull ordre and governamee of the same. And wolle assmred maye they hee that, the said 
rule resting in oure anctoritic, and wo being in thoes parties, there is noon ontward prince that wold attempt or doo any thing to their inquictacion or trowleke, and snche as nowe attempteth against the yonge prinecs inheritance elleswhere wold soone forlocre soo to doo, or clles by meanes and porvair of themperor of us and of those cuntreys, they shuld bee [e]nforced to desist, whether they wold or not. Soo that by [m]eames therof aswell this and manye other notaljle effectes and [com]modities shuld and monght ensue to the snertie and weale of [the] said yonge prince, his reames, cuntreys and subgiettes. [And] if they wold not bee contented to committe the said anctorite [to us a] nd hir joynctely; we cowde not oonly bee contented [rather.] than to finyle, that she shuld have the rule therof [her] self and aloon, but also that she slunld reasort [unto those co]nutreys for the better ordre and governamee of theym [as shall he con] renient and at her pleasure. Howe bee it more . . . . . . it were that the said anctorities were committed to us [and her j] oynctely; and therfor ye shall on our behalf make . . . . unto the said A. for the knowlenge of his furth [er mind, ad $]$ vise and connsaille in that matier, and to put th[e same in] writing, cxtending it at good length, to thente[nt wo may] clerely and openly bee instructed upom the same. [And the same] knowen we shall declare muto hym onr adri[se and gice] unto bym suche amswer as he shatbe right w[ell content]. For in caas the said A. by his wisedome . . . . . . in and wol rednce and bring the anctorite rul[e and gorernanc]e of the said contrayes to us, and the said [duchess of] Savoye, or to the said duchesse oonly if it ma[y not otherwis]e be gotyn, than she being maried to us. . . maye hee well assured that it is and shalbe our lole mynde and will that the said A. shall nat oonly have under us and lier the hool rule and sovernanuce of the said cuntreys and noon other. but also we shall in suche thankful maner rememlne his kindenesse, and geve unto lym a farre better remembrance than we willed you to offre unto hym by our last instruccions, as he shallave good canse to hee contented. And orer [this,] seing the great honor, prouffit and promocion that he shall mowe have therby, we thinke that of his g[reat] wisedome he shuld bee gladde to bring the said a[uctorite] into our and the said duchesse hands, and und[er us] to take the sime uppon hym.

And ye ma[y further] saye that these matiers brought into sood e[ffect and] parfaite conclusion he shall assuredly trust [that we shall] always entende the furtherame of bis . . . snche thinges as for the tyme shall for [tume to be] voide in those parties, prefering hym . . . . Willing you sub- 
stancially to note an! . . . [his] annswer therin, to thentent ye maye . . . . . . ascertaigne us therof. And in ca[se it shall] fortune you before the receipt of these o[ur letter's to be] in your reatorne towardes us and thon. -. . . in your jomney towardes us als farre a[s] . . . neverthelas we wol ye reatorne and l'. . . . said A. for the declaracion of the [premises and for] knorlenge of his perfitte mynde npon [the same; which] had, we can bee contented ye reatorne. [And for'] youre costs and charges to be susteigned [in this behalf] we shall soo see mito you therin at yo[ur return that] ye shall have cause to be contented.

Orer this, alle it that ye by your sundery lettres and instruccions hertofore sent mito us have declared and shewid on the bchalf of $A$. that the lorde Barges shuld bee anctorised to treat and commune with us of and npon oure mariage with the dichesse of suroye, exhorting and comsailling us therefor to take a speciall regarde mo the said lord Barges, who shuld tale ou mynde upon suche diffienties as bee made there in the treate of onr said mariage, and therupon make relacion unto themperor; yit nererthelas we have been nowe of late ereclibly enformed that the said lord Balges as yit hath not, nor as it is supposed shalhave, any mance of commission or anctorite geren to hym to treate with ns of any thing conccinyng [on]re said maringe, wherof we greately mervaile [con] sidering the sundry writinges diverse tymes [heret]ofore by you sent unto us, wherin ye declared [exp]resscly that metorite shuldbe yeven to the s[aid lord] Barges at his commyug unto us in that boh[alf: Exp]edient therfor it is that Je shewe the premisse[s unto t] he said $A$. desiring lyym not oonly to shewe [unto] you the verrarye certainte where any snche [eomm]ission be geven to the said lord Barges for o[ur said] mariage, or in cats be have noon siche ancto[rite, what] is the occaeion and canse therof, but also . . . . . the said A. to enderor hymself that comm[ission may] bee yeven to the said lord Berges or [to some other] as it shall please themperor for the declar[ation of his] mynde therin. For remembring the l[ore and lindness] that have been used in the tracting of [our said m] ariage hitherto, if they have noo commiss [ion at] this tyme it is noo signe of any towardnes that they have to the spedy accomplisshement therof. For we entend nat to bee delayed or abused in this matier any further, but loke to have a fynall aunswere at thi[s] tyme without any further delayes.

Fynally, for your good deroir in ascertaignyng us aswe of the premisses as also of the ordre d maner of that. court, of the canses of the retardacion of their ambassad $[e, 7$ 
and of such communyeacion as the legate there h[ad] with you, we can you right good thanke. Yeve[n nnder] our signet at onr manoir of Grenewiche the v[ . day $]$ of Novembre.

H.R.

Addressed: To our trusty and welbeloved clerc and chapelain Maister Thomas Wolcey. 


\section{LIST O F W O R K S}

PCBLISHED

By the late Record and State Paper Commissioners, or under the Direction of the Right Hon. the Naster of the Rolls, which may be had of Messrs. Longman and Co.

\section{PUBLIC RECORDS AND STATE PAPERS.}

Rotulorum Originalium in Curia Scaccaril Abereviatio. Hemry III.-Edward III. Edited by ILnRy Plarrond, Esq. 2 vols. folio (1805-1810). Price, boards, 12s. 6d. each, or 25s.

Calendariun Inquisitionum post Mortma sive Escaetarum. Henry III.-Richard III. Edited by JoIn Caley AND J. Bayler, Esqus. 4 vols. folio (1806-1808 ; 1821-1828), boards: vols. 2 and 3 , separately, price, boards, each $21 s$; vol. 4 , boards, $24 s$.

Libroruit Manuscriptorum Biblothecas Harleiana Catalogus. Vol. 4. Edited by The Rer. T. H. Honve, (1812) folio, boards. Pricc $18 s$.

Aberevintio Pracitonum, Richand I.-Edward II. Edited by The Right Hon. George Rose, and W. Illingwortil, Esq. 1 vol. folio (1811), hoards. Price $18 s$.

Libri Censunus rocati Donespay-Book, Indices. Edited by Sir Henry Eldis. Small folio (1816), boards (Domesday-Book, rol. 3). Price $21 s$.

Libri Cexsualis rocati Domesday, Adpitanevta ex Conic. AntiQuiss. Edited by Sir Henry Eliss. Small folio (1816), boards (Domesday-Book, vol. 4). Price $21 s$. 
Statutes of the Realy, in very large folio. Vols. 1 to 11 (except vols. 5 and 6), including 2 vols. of Indices (1810-1828). Edited by Sir 'T. E. 'Tombins, Jomn Raitmey, Jomn Caley, and War. Elliote, Esqrs. Price 31s. 6d. each.

*** The Alphabetical and Chronological Indices may be had separately, price 30 s. each.

Valor Ecchesiasticus, temp. Henry VIII., Auctoritate Regia institutus. Edited by JoHn Caler, Esq., and the Rev. JosepiI Hunter. Vols. 4 to 6 , folio (1810, \&c.), boards. Price $25 s$. eich. ** 'The Introduction is also published in Svo., cloth. Price $2 s .6 d$.

Rotuli Scotia in Turri Londinexsi et in Domo Capitulari WestMonasteriensi asservati. 19 Edward I.-Henry VII. Edited by Dayid Macpherson, John Calex, and W. Illingwortil, Escrs., and the Rev. T. H. Horne. 2 vols. folio (1814-1819), boards. Price $42 s$.

"Fadera, Conventiones, Littera," \&c. ; or', Rymer's Fodera, A.D. 1066-1391. New Edition, Vol. 2, Part 2, and Vol. 3, Parts 1 and 2, folio (1821-1830). Edited by JoIn CALEY and Fred. Holbroore, Esqrs. Price 21s. each Part.

Ducatus Lancastria Camendarium Inguistigaum post Mortem, \&e. Part 3, Ducatus Lancastria. Calendar to the Pleadings, \& Henry VII.-Ph. and MI. ; and Culendar to Pleadings, 1-18 Elizabeth. Part 4, Calendar to Pleadings to end of Elizabetl. Edited by R. J. Harper, Jonn Caler, and Wh. Minchin, Esqrs. Part 3 (or Vol. 2) (1827-1831), price 31s. 6d.; and Part 4 (or Vol. 3), boards, folio, price $21 \mathrm{~s}$.

Calendars of the Proceedings in Chancery in time Reign of Queen Enzabeth, to which are prefixed exmuples of carlier. procecedings in that Court from Richard II. to Elizabeth, from the originals in tive 'Tower. Editcd by Jonn Barler, Eeq. Vols. 2 and 3 (1830-1832), hoards, each, folio, price $21 s$.

Parlinmentary Writs and Writs of Military Summons, together with the Records and Muniments relating to the Suit and Service due and performed to the King's High Court of Parliament and the Councils of the Realm. Edward I., II. Edited by Sir Francis Palgrate. (1830-1834). Vol. 2, Division 1, Edward II., 21s. ; Vol. 2, Division 2, 21s.; Vol. 2, Division 3, folio, boards, price 42.

Rotul Litterarum Claugarui ix Turia Londinensi asservati. 2 vols. folio $(1833-18 \pm 4$ ). 'The first rolume commences A.D. 1204 to 1224. The second volume 1224-1227. Edited by Timonas Durfus IIardy, Esq. 'Together, price 81 s. cloth ; or the volumes may he had separately. Vol. 1, price 63s. clotli; Vol. 2, cloth, price $18 s$. 
Time Great Rolls of the Pipe fole the Second, Third, and Fourti Years of the Reign of King IIenty tile Second, 115j-1158. Edited by the Rev. Josep'I Hunter. 1 vol. roya? 8vo. (1844), clotl. Price $4 s .6 d$.

The Great Roll of the Pite for the First Year of tile Reign of King Richard tie First, 1189-1190. Edited by the Rev. Josepit Hunter. I vol. royal 8vo. (1844), clotl. Price 6s.

Proceedings and Ordinances of the Privy Council of EngLand, commencing 10 Richard II.-33 Henry VIII. Edited by Sir N. IIARris Nicolas. 7 vols. royal 8vo. (1834-1837), cloth 98 s.; or any of the volumes may be had separately, clotlı. Price $14 s$, each.

Rotuli Litterarum Patentium in Turri Londinensi asservati, A.D. 1201 to 1216. Edited by Thomas Duffus Hardy, Esq. 1 rol. folio (1835), cloth. Price 31s. 6d.

** The Introduction is also published in 8ro, clotl. Price $9 s$.

Rotuli Curia Regis. Rolls and Records of the Court held before the King's Justiciar's or Justices. 6 Richard I.-1 John. Edited by Sir Francrs Palgrave, 2 vols. royal 8ro. (1835), clotl. Price 28 s.

Rotuli Normannie in 'Turli Londinensi asservati, A.d. 12001205. Also from 1417 to 1418. Edited by Tilomas Dufrus Hardy, Esq. 1 rol. royal 8vo. (1835), clotl. Price 12s.6d.

Rotuli de Oblatis et Finibus in 'Turi Londnensi asservati, tempore Regis Johannis. Edited by Thomas Duffus Hardr, Esco. 1 vol. royal 8ro. (1835), clotl. Price 18 s.

Excerpta a Rotuis Finfum in Turri Londinensi asservatis. IIen'y III., 1216-1272. Editcd by Cinarles Roberts, Eeq. 2 vols. royal 8 vo. (1835, 1836), cloth, price $32 s$.; or the volumes may be hiad separately, Vol. 1, price 14s.; Vol. 2, eloth, price 18 s.

Fines sive Pedes Fineum sive Finales Concordia in Curia Domni Regis. 7 Richard I.-16John (1195-1214). Edited by the Rev. Joseph Hunter. In Counties. 2 vols. royal 8 vo. (1835-1844), together, cloth, pricc $11 s$.; or the volumes may be liad separately, Vol. 1, price 8s. 6d.; Vol. 2, cloth, price 2s. $6 d$.

Ancient Kalendars and Inventories (The) of the Treasury of His Majesty's Exchequer ; together with Documents illustrating the History of that Repository. Edited by Sir Francis Palgrave. 3 vols. royal 8vo. (1836), cloth. Price 42s.

Documents And Records illustrating the History of Scotland, and the Transactions between the Crowns of Scotland and England ; preserved in the 'Treasilly of Her Mijesty's Exchequer. Edited by Sir Findis Palgrave. 1 vol. royal Svo. (1837), cloth, Price 18s, 
Rotuli Cimartarum in Tuliri Londinensi asservati, a.d. $1199-$ 1216. Edited by Thomas Dufrus Hardy, Esq. 1 vol. folio (1837), cloth. Price 30s.

Registrum vulgariter nuncupatum "The Record of Caemarvon," e codice MS. Harleiano, 696, descriptum. Edited by Sir Henry Eutis. 1 vol. folio (1838), cloth. Priee 31 s. 6d.

Ancient Laws and Institutes of England; comprising Laws enacted under the Anglo-Saxon Kings, from Ethelbirht to Cnut, with an English 'Translation of the Saxon; the Laws called Edward the Confessor's ; the Laws of William the Conqueror, and those ascribed to Henry the First ; also, Monumenta Ecclesiastica Anglicana, from the 7th to the 10th century; and the Ancient Latin Version of the Anglo-Saxon Laws; with a compendious Glossary, \&e. Edited by Benjanin Thorpe, Esq. 1 vol. folio (1840), clotl. Price 40s.

2 vols. royal 8vo. cloth. Priec $30 s$.

Ancient Laifs and Institutes of Wales; comprising Laws supposed to be enacted by Howel the Good ; modified by subsequent Regulations under the Native Princes, prior to the Conquest by Edward the First ; and anomalous Laws, consisting principally of Institutions which, by the Statute of Ruddlan, were admitted to continue in force. With an English Translation of the Welsh Text. To which are added a few Latin Transcripts, containing Digests of the Welsh Laws, principally of the Dimetian Code. Witl Indices and Glossary. Edited by Axeurin Ower, Esq. 1 vol. folio (1841), cloth. Price $44 s$.

2 vols. royal 8ro. clotl. Price $36 s$.

Roteli de Linerate ac de Misis et Prestitis, Regnante Johamne. Edited by Tilomas Duffus Hardr, Esq. 1 vol. royal 8vo. (1844), cloth. Price 6s.

Documents Illustrative of Exglisin History in the 13th and 14th centuries, selected from the Records in the Exchequer. Edited by Hunry Cole, Esq. 1 vol. fep. folio (1844), clotl. Priee $45 s .6 d$.

Modus 'Tenend Pirlinmentum. An Ancient Treatiso on the Mode of holding the Parliament in England. Edited by Thonas Durrus Ilardi, Esq. 1 vol. Sro. (1846), cloth. Price $2 s .6 d$.

Reponts on time Procendngs of tue Recond Commissioners, 1800 to 1819,2 vols., folio, boards. Price 5l. 5s. From 1819 to 1831 their proceedings have not been printed. $\Lambda$ third volume of Reports of their Proceedings, 1831 to 1837, folio, boards, 8s. 3 vols. together, boards. Price 5l. $13 s$. 
The Acts od tile Parlianents of Scotinnd. Il vols. folio (18141844). Vol. I. Editcd by Thomas Thomson and Cosmo Innes, Esqrs. Price $42 s$.

$$
\text { ** Also, Vols. 4, 7, 8, 9, 10, 11, 10s. 6d. each Vol. }
$$

The Acts of the Lords of Council in Civil Causes. A.D. 1478 1495. Edited by Timomas Tinomson, Esq. Folio (1839). Price $10 s .6 d$.

The Acts of the Lords Auditors of Causes and Complaints. A.D. 1466-1494. Edited by Tromas 'Tromson, Esq. Folio (1839). Price 10s. 6d.

Registrum Magni Sighlat Regur Scotorum in Archivis Publicis asservatum. A.D. 1306-1424. Edited by 'Thomas 'Thomson, Esq. Folio (181t). Price 15s.

Issce Roll of Thomas de Brantingham, Bishop of Exeter, Lord High Treasurer of England, containing Payments out. of His Majesty's Revenue, 44 Edward III., 1370. Edited by Frederick Devon, Esq. 1 vol. 4to. (1835), cloth. Price 35s.

- Royal 8vo. cloth. Price 25s.

Issues of The Exchequen, contrining similar matter to the above, temp. Jac. I., extracted from the Pell Records. Edited by Frederick Devon, Esq. I vol. 4to. (1836), cloth. Price 30 s.

- Royal 8vo. cloth. Price $21 s$.

Issues of the Exchequer, containing like mattel to the above, extracted from the Pell Records; Henry III. to Henry VI. inclusive. Edited by Frenerick Devon, Esq. 1 vol. 4to. (1837), cloth. Price $40 s$.

Royal 8vo. cloth. Price 30s.

Liber Munerum Publiconum Hibernie, ab an. 1152 usque ad 1827 ; or, 'The Establishments of Ireland from the 19th of King Stephen to the 7th of George IV., during a period of 675 years ; being the Report of Rowley Lascelles, of the Middle Temple, Barrister-at-Law. Extracted from the Records and other authorities, by Special Command, pursuant to an Address, an. 1810, of the Commons of the United Kingdom. With Introductory Observations by F. S. Thomas, Esq. (1852.) 2 vols. folio. Price 42s.

Notes of Materials for tile Histony of Public Departuents. By F. S. Thomas, Esq. Demy folio (1846). Price $10 s$.

Handbook to the Public Reconds. By F. S. Thomas, Esq. Royal 8vo. (1853.) Price 12s. 
State Papers during tue Reign of Henry the Eightil. 11 vols. 4to. (1830-1852) completing the work in its present form, with Indices of Persons and Places to the whole. Price 5l. 15s.6d.

Vol. I. contains Domestic Correspondence.

Vols. II. \& III._Correspondence relating to Ireland.

Vols. IV. \& V.-Correspondence relating to Scotland.

Vols. VI. to XI.-Correspondence hetween England and Foreign Courts.

* Any Volume may be purchased separately, wrice $10 \mathrm{~s} .6 \mathrm{~d}$.

Morumenta Historica Britanica, or, Materials for the History of Britain from the earliest period. Vol. l, extending to the Norman Conquest. Prepared, and illustrated with Notes, by the late Menry Petrie, Esq., F.S.A., Keeper of the Recolds in the Tower of London, assisted by the Rev. Johr Sinnpe, Rector of Castic Eaton, Wilts. Finally completed for publication, and with an Introduction, by Thomas Duffus Hamor, Esq., Assistant Keeper of Records. (Printed by command of Her Majesty.) Folio (1848). Price 42s.

Histonicar Notes relative to the History of England ; enlbracing the Period from the Accession of King Fiemy VIII. to the Deatlı of Queen Anne inclusive (1509 to 1714). Designed as a Book of instant Reference for the purpose of ascertaining the Dates of Events mentioned in IIistory and in Manuscripts. The Name of every Person and Event mentioned in History within the above period placed in Alphabetical and Chronological Order, and the Authority from whence taken is given in each case, whether from Printed History or fiom Manuscripts. By E.S. 'Tnomas, Eeq., Secretary of the Public Record Office. 3 vols. 8 vo, (1556.) Price $40 s$. 


\title{
CALENDARS OF STATE PAPERS.
}

\author{
[Imperial 8vo. Price $15 s$, each Volume.]
}

Calendar of State Papers, Domestic Series, of the Reigns of Enwalid VI., Mary, Etrzaneti, 1547-1580, preserved in tho State Paper Department of Her Majesty's Public Record Offiec. Edited by Ronert Lemon, Eeq., F.S.A. 1856.

Calendar of State Paperis, Domestic Series, of the Reign of Jayes I., preserved in the State Paper Department of Her Majesty's Public Record Ofice. Edited by MarY Lxwe EvenetT Grees. 1857-1859.

Vol. I.-1603-1610.

Vol. II.-1611-1618.

Vol. III.-1619-1623.

Vol. IV.-1623-1625, with Addendia.

Chlendar of State Papers, Domestic Seremes, of the Relin of Cinarles I., preserved in the State Paper Department of Her Majesty's Public Record Oflice. Edited by Jomn Bruce, Esq., V.P.S.A. 1858-1859.

Vol. I.-1625-1626.

Vol. II.-1627-1628.

Vol. III.1628-1629.

Vol. IV.-1629-1631.

Calendere of State Papres, Domestic Series, of the Reign of Cnalues II., preserved in the state Paper Departinent of IIeI Majesty's Public Liecord Once. Erlited by Mary Arne Everett Green. 1860-1861.

Vol. I.-1660-1661.

Vol. II._-1661-1662.

Calendar of State Papers relating to Scothand, preserved in the State Paper Department of Her Majesty's Public Record Office. Edited by Mankman Johr ThonPe, Esq., of St. Edmund Hall, Oxford. 1858.

Vol. I., the Scottish Series, of the Reigns of Henry VIII., Edward VI., Mary, Elizabeth, 1509-1589.

Vol. II., the Scottish Series, of the Reign of Queen Elizabeth, 1589-1603; an Appendix to the Seottish Series, 15431592 ; and the State Papers relating to Mary Queen of Scotsduring lier Detention in England, 1568-1587.

Calendar of State Papers relating to Ireland, 1509-1573, preserved in the State Paper Deparment of Her Majesty's Public Record Office. Edited by H. C. Hamiton, Esq. 1860. Vol. I. 
Calnendr of State Papres, Colonial Series, preserved in the State Paper Department of IIer Majesty's Pablic Record Ofilee. Edited by W. Nö̈l SAmsinur, Eeq. 1860.

Vol. I. -157t-1660.

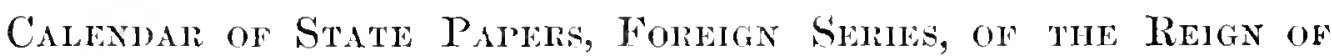
Eowani VI. Edited by W. B. 'Tunveula, Esq., of Jincoln's Im, Barrister-at-Law, and Correspondant du Comité Impérial des 'Travanx Historiques et des Sociétés Sarants de France. 1861.

Calmondr of State Papers, Foreigy series, of the Reign of

Marr. Edited by W. B. 'Tumisulu, Esq., of Lincoln's Inn, Barrister-at-Law, and Correspondant du Comité Impérial des Travaux Historiques et des Sociétés Savints de France. 1861.

\section{In the Press.}

Chlenima of State Papers melating to Ireland, preserved in the State Paper Department of Her Majesty's Public Record Office. Edited by II. C. Hammoton, Esq. Vol. Iİ.

Calendar of State Papers of the Reign of Henti Vili. Edited by the Rev. J. S. Brewer, M.A., Professor of English Literature, King's College, London, and Render at the Rolls.

Calendar of State Papers, Colonial Semes, prescrved in the State Paper Department of Her Majesty's Public Record Office. Edited by W. Nö̈L Samsecri, Esq. Vol. II.

Calendar of State Papeis, Domestic Series, of the Reign of Chamess I., preserved in the State Paper Department of Her Majesty's Publie Record Office. Edited by Jomn Bruce, Esq., V.I.S.A. Vol. V.

Calenidr of State Papers, Donestic Series, of time Reign of Cinares 1I., preserved in the State Paper Department of IIer Majesty's Public Record Office. Edited by Mari Anve Everett Green. Vol. III.

Calfendar of State Papeis, Domestic Series, of tile Reign of Elizabetil, preserved in the State Paper Department of Her Majesty's Public Record Office. Edited by Robert Lenon, Esq., F.S.A. 


\title{
THE CHRONICLES AND MEMORIALS OF GREAT BRITAIN AND IRELAND DURING THE MIDDLE AGES.
}

\author{
[Royat 8vo. Price 8s. 6d. each Volume.]
}

1. Time Cimonicle of Evgland, ly Jom Capgrave. Edited by the Rev. F. C. IIngeston, M.A., of Exeter College, Oxfori.

2. Curonicon Monasterit de Aminguon. Vols. I. and II. Edited by the Rev. J. Stevexsox, M.A., of University College, Durham, and Vicar of Leighton Buzzard.

3. Lives of Edwari tim Confessor. I.-La Estoire de Seint Aedward le Rei. H.- Vita Beati Edvarti Regis et Confessoris. III.-Vita Edunardi Tregis qui apud Westmonasterium requieseit. Edited by II. R. Luand, M.A., Fellow and Assistant 'T'utor of 'Trinity College, Cambridge.

4. Monumenta Franciscana; seilicet, T.-Thomas de Eccleston de Adventu Fratrum Minorum in Angliam. II.-Ade de Marisco Epistole. III.-Regristrum F'atrun Minorum Londonia. Edited by the Rev. J. S. Brewer, M.A., Professor of English Literature, King's College, Lonton, and Reader at the Rolls.

5. Fascicula Zizanionum Magistri Jomannis Wrolif cum 'Tritico. Ascribed to 'Thomas Netter, of Waldex, Provincial of the Carmelite Order in England, and Confessor to King Henry the Fifth. Edited by the Rer. W. W. Sinncer, M.A., Tutor and late Fellow of Wadham College, Oxford.

6. Tine Bum of trie Cronichis of Scothand; or, $A$ Metrical Version of the History of Hector Boece; by Willidal Stewart. Vols. I., II., and III. Edited by W. B. Tumsiuld, Esq., of Lincoln's Inn, Barrister-at-Law.

7. Johannis Capgrave Liber de Imaustribus Henricis. Edited by the Rer. F. C. Inngrastox, M.A., of Exeter College, Oxford.

8. Historia Monasteriu S. Augustini Cantuniensis, by Thomas of Elmund formerly Monk and Treasurer of that Foundation. Edited by C. Handwick, M.A., Fellow of St. Catharine's Irall, and Christian Adrocate in the University of Cambridge.

9. Eulogium (Histominum sive Tmipoms), Chronicon ab Orbe condito usque ad Annum Donini 1366; a Monacho quodam Malneshiriensi exaratmm. Vols. I. and II. Edited by F. S. HaYion, Essy., T.A. 
10. Menromals of King Henry time Seventu: Bermardi Andrea 'Tholosatis de Vita Regis IIcnrici Septimi IIstoria; necnon alia quedam ad eundem Reecm spectentia. Edited by J. Gairdater, Esq.

11. Memorials of Hexry the Fiftm. I.-Vita Hemrici Quinti, Roberto Redmanno auctore. II.-Versus Rhythmici in laudem Regis Hemrici Quinti. III.-Elmhami Liber Metricus de Henrico V. Edited by C. A. Cole, Esc.

12. Munmexta Gilphalla Landonexsis; Liber Albus, Liber Custumarum, et Liber Horn, in archivis Gildhalla asservati. Vol. I., Liber Albus. Vol. II. (in Two Parts), Liber Custumarum. Edited by II. T. Riter, Escl., M.A., Barrister-at-Law.

13. Cimonica Jomdnnis di Oxenedes. Edited by Sir H. Ellis, K.H.

14. 1 Collection of Political Poens from time Accession of Eowhrd III. to tife Reign of IIexry TII. Vols. I. and II. Edited by T. Wrigrit, Esq., M.A.

15. The "Opes Tertiun" and "Opes Mines" of Roger Bacon. Edited by the Rev. J. S. Brewer, M.A., Piofescor of English Literature, King's College, London, and Reader at the Rolls.

16. Bartholohat de Cotton, Moxachi Norwicexsis, Historia Anglicana (A.D. 449-1298). Edited by H. R. Luard, M.A., Follow and Assistant Tutor of 'Trinity College, Cambridge.

17. The Brut r Trwrsogrox, or, The Chronicle of the Princes of Wales. Edited by the Rer. J. Hildmais an Itmel.

18. A Collection of Royal and Historical Letters during the Reigx of Hexry IV. Vol. I. Edited by the Rev. F. C. Hingestox, M.A., of Excter College, Oxford.

19. The Repressor of oter nuch Blamifr of time Clergy. By Regralad Proock, sometime Bishop of Chichester. Vols. I. and II. Edited by C. Babingtox, B.D., Fellow of St. John's College, Cambridge.

20. Tine Axrales Camirie. Edited by the Rev. J. Willadis ab ITHEL.

21. Tue Works of Giramdes Camprexiss. Vol. I. Edited by the Rev. J. S. Brewer, M.A., Professor of English Literature, King's College, London, and Reader at the Rolls.

22. Letters and Papers illestrateve of the Wars of the Exglisil in France indrixg the Reigx of Hexpy time Sixtit, King of Exgiand. Vol. I. Edited by the Rev. J. Stevenson, M.A., of University College, Durham, and Vieal of Leighton Buzzard. 
28. The Angro-Saxon Chroniche, accordng to the several Original Autionties. Vol, I., Origimal Texts. Vol. II., 'Translation. Erzited ly, B. 'Tronpe, Esq., Member' of the Royal Academy of Sciences at Munich, and of the Soeiety of Netherlandish Literature at Leyden.

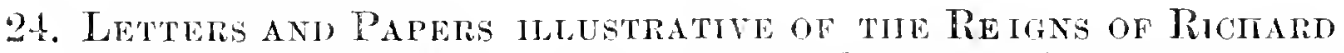
III. and IIenry VII. Vol. I. Edited by Jahes Gairdner, Esq.

\section{In the Press.}

Richroi de Cirefoestria Speculum Mistoriale de Gestis Regum ANGitzs. (A.I). 4t7-1066.) Edited b!y J. E. B. Mayon, M.A., Fellow and Assistant 'Tutor' of St. John's College, Cambridge.

Le Livers me Reis de Brittanie. Edited by J. Glover, M.A., Chaplain of 'Trinity College, Cambridge.

Recuela des Croniques et axcinennes Istories de ia Grant Bretaigee a present romale Exgleterie, par Jeilan de Waurin. Edited by W. Hardi, Esq.

'Tine Wars of tue Danes in Iremand : written in the Irish language. Edited by the Rer. Dr. 'Tuov, Librarian of the University of' Dublin.

A Collection of Sagas and otifer IIsstorical Documents relating to the Settlements and Descents of the Northmen on the Britisl Isles. Edited by George W. Dasent, Esq., D.C.L. Oxon.

A Collection of Royal and IIistorical Letters during the Reign or Henry IV. Vol. II. Edited by the Rev. F. C. Hingeston, M.A., of Exeter College, Oxford.

Munmenta Gildinlate Lonbonensis; Liber Albis, Liber Custumarm, et Liber Horn, in archivis Gildhalla asservati. Vol. III. Translations from the Anglo-Norman portions of the Liber Allus; Appendix ; Glossaries ; and Index. Edited by H. T. Rner, Esq., M.A., Barrister-at-Law.

Eulogium (Historiarum sive Temporis), Chronicon ab Orbe condito usque ad Ammun Domini 1366; a Monacho quodam Malmesbiriensi exaratum. Vol. III. Edited by F. S. Hardon, Esq., B.A.

Letters and Treatises of Bismor Grossetete, illustrative of the Social Condition of his 'Time. Edited by the Rev. H. R. Luard, M.A., Fellow and Assistant Tutor of Trinity College, Canbridge. 
Tine Works of Giraldus Cambrensis. Vol. II. Edited by the Rev. J. S. Brewer, M.A., Professor of Englisl Literature, King's Collegre, London, and Reader at the Rolls.

Letters and Papers illustrative of tire Wars of the Exglish in France durixg time Reigx of Henry the Sixtm, King of England. Vol. II. Edited by the Rev. J. Stevenson, M.A., of 'University College, Durham, and Vical of Leighton Buzzard.

Chronicon Ambatie Evesmanensis, Auctormus Domrnco Priore Eveshamis ex Thoma de Marleberge Abbate, a Fundatione ad Annum 1213, una cum Continuatione ad Annum 1418. Edited by the Rev. IV. D. Macrar, M.A., Bodleian Library, Oxford.

Polycironicon Ravulmin Higdexi, with Trevisa's Translation. Edited by C. B.ibington, B.D., Fellow of St. John's College, Cambridge.

Letters and Parers illustrative of time Reigse of Richard III. and Henry VII. Vol. II. Edited by Janes Gairdner, Esq.

Descriptrye Catalogue of Manuscripts relatixg to the Early Iistory of Great Britain. Edited by T. Duffus Harin, Esq.

\section{In Progress.}

Historia Minor Matthei Paris. Edited by Sir F. Madden, K.H., Chief of the MS. Department of the British Museum.

A Roll of tile Irisit Privy Counchr of the 16til Year of the Reicin of Richard II. Edited by the Rev. James Graves.

July 1861. 


Tairaner, James, ed.

\section{5}

Gairdner, James, ed. Letters and papers illustrative of the reigns of Richard III and Honry VII.

$$
13(12,29)
$$


